\title{
Kvensk grammatikk
}

Eira Söderholm

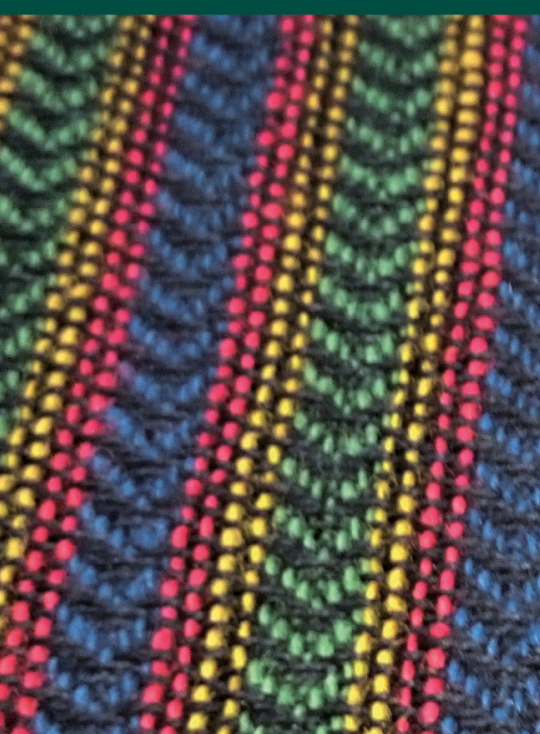

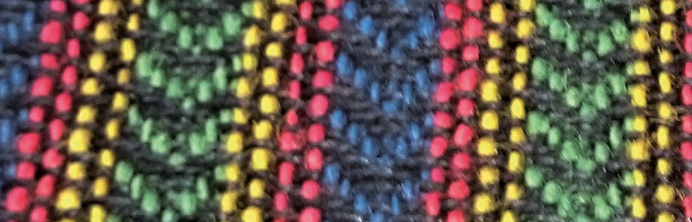

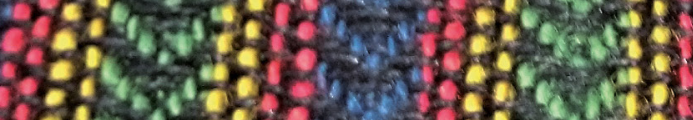

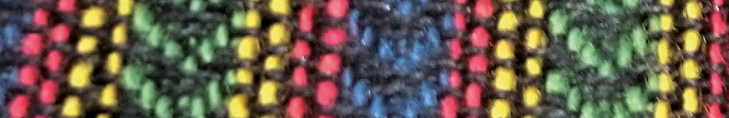

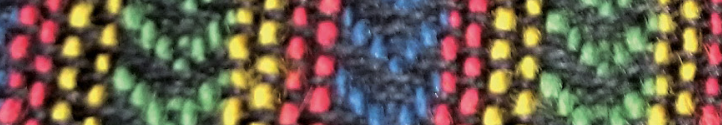
chas Wof

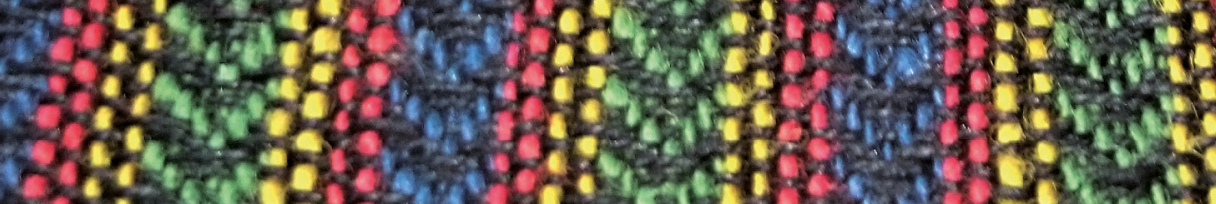

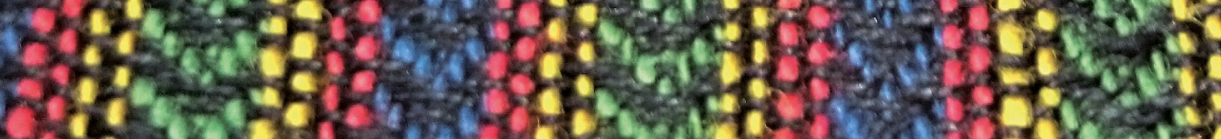
8

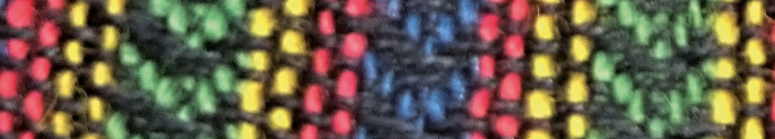

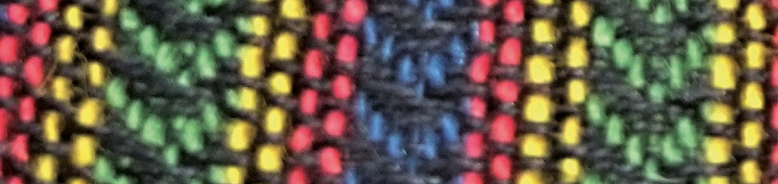

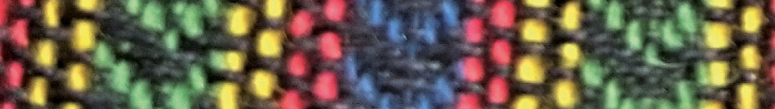
60785005

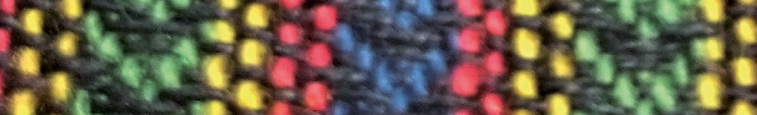


Kvensk grammatikk 

Eira Söderholm

\section{Kvensk grammatikk}

Oversatt fra kvensk av Philipp Conzett 
Dette verket omfattes av bestemmelsene i Lov om opphavsretten til åndsverk m.v. av 1961. Verket utgis Open Access under betingelsene i Creative Commons-lisensen CC-BY 4.0 (http:// creativecommons.org/licenses/by/4.o/). Denne tillater tredjepart å kopiere, distribuere og spre verket i hvilket som helst medium eller format, og å remikse, endre, og bygge videre på materialet til et hvilket som helst formål, inkludert kommersielle, under betingelse av at korrekt kreditering og en lenke til lisensen er oppgitt, og at man indikerer om endringer er blitt gjort. Tredjepart kan gjøre dette på enhver rimelig måte, men uten at det kan forstås slik at lisensgiver bifaller tredjepart eller tredjeparts bruk av verket.

Originalens tittel: Kainun kielen grammatikki

(c) Eira Söderholm 2014

Utgitt av Suomalaisen Kirjallisuuden Seura

Dette er en vitenskapelig monografi. Eira Söderholm og Philipp Conzett er begge tilknyttet UiT Norges arktiske universitet.

Følgende institusjoner har gitt finansiell støtte til revisjonen, oversettelsen og utgivelsen av verket:

Institutt for språk og kultur, UiT Norges arktiske universitet

Kainun institutti - Kvensk institutt

Kulturdepartementet

Norges forskningsråd

Publiseringsfondet ved UiT Norges arktiske universitet

ISBN: 978-82-02-56965-5

DOI: https://doi.org/10.23865/noasp.24

Sats: Datapage India (Pvt.) Ltd.

Omslagsdesign: Cappelen Damm

Omslagsfoto: Charlotte Engstad

Cappelen Damm Akademisk/NOASP

noasp@cappelendamm.no 


\section{Forord av lederen i Kvensk språkting}

Da Eira Söderholms kvenske grammatikk ble lansert i Tromsø vinteren 2014, var det en stor begivenhet for kvensk språk, for kvensk kultur, ja, for kvenene. Det var også en stor begivenhet for Norge, fordi man fikk en grammatikk for språket til en av de nasjonale minoritetene våre. Grammatikken kom ut på kvensk, men vi var da enige om at den også skulle komme ut på norsk.

Kvensk språkting er derfor glad for at man nå også kan gi ut den norske utgaven av kvensk grammatikk. Eiras grammatikk er av avgjørende betydning for at man har fått etablert kvensk som eget skriftspråk. Før grammatikken kom ut, hørte man ofte at før man kan gjøre noe som helst med kvensk språk, så må man først få en grammatikk. Arbeidet med grammatikken skjedde i nær kontakt mellom Eira og kvensk språkting, og man hadde mange gode og nødvendige diskusjoner om en rekke grammatiske problemstillinger.

Da boka kom, fikk man et konkret verktøy for å systematisere og videreutvikle det kvenske språket. Boka ble også et symbol for kvensk språk og for kvensk kultur. Boka brukes i alle sammenhenger der kvensk språk er viktig; innenfor utdanning på alle nivåer, den brukes i forskningssammenheng, og den brukes flittig som oppslagsverk.

Kvensk grammatikk ville sannsynligvis ikke blitt realisert uten Eiras ståpåvilje, og det var derfor vel fortjent at hun sammen med Agnes Eriksen fikk den første kvenske språkprisen tidligere i år.

Vi håper at grammatikken også kan skape diskusjoner. Kvensk språk har mange dialektvarianter, og det blir interessant å se om brukerne kjenner seg igjen i de geografiske variasjonene. 
Når vi nå får grammatikken i norsk utgave, vil den kunne brukes av mange flere, og den vil dermed bidra til revitalisering av kvensk språk. Kanskje vi kan berge språket?

Vestre Jakobselv / Annijoki den 28. mai 2017 Trygg Jakola leder i Kvensk språkting 


\section{Forord av forfatteren}

Dette er en revidert og oversatt versjon av Kainun kielen grammatikki, som blei utgitt på kvensk av Suomalaisen Kirjallisuuden Seura i 2014. I innleiinga er den største endringa gjort i det første avsnittet, 1.1 Mikä oon kielen nimi? ('Hva heter språket'), som nå har fått nytt navn, Hva heter språket og folket?, og greier ut om både navnet på språket og folkegruppa. Nytt her er forklaringa av navnet lantalainen ('kven').

Når det gjelder sjølve grammatikken, handler de største endringene og tillegga om syntaks. Jeg har lagt til et nytt avsnitt om setningsfragment (2.4.9). I kapittel 4 Syntaks har jeg for eksempel lagt til to nye setningstyper, EKSISTENSENDRING og INTRANSITIV EIERSKAPSENDRING. Ellers er det i syntakskapitlet føyd til utgreiinger om mindre fenomen som mangla i førsteutgaven.

Avsnittet om vokalharmoni er flytta fra kapittel 2.3, som handler om ordbygning, til kapittel 3.1, som handler om morfofonologiske vekslinger.

Den største endringa i morfologidelen er at i bøyinga av tredje person flertall av verb er såkalt egentlig tredje person flertall i Porsanger-varieteten nå jamstilt med bøyinga som er identisk med passivformene (avsnitt 6.3.3 og tabell 6.4).

Som et hjelpemiddel til brukeren har jeg til den norske utgaven utarbeidd ei definisjonsliste, der en lett kan sjekke hvordan de forskjellige grammatiske begrepa blir brukt i boka.

Grammatikken mangla opprinnelig ei litteraturliste. Denne mangelen har Philipp Conzett bøtt på i denne norskspråklige versjonen. Han har også lagt til et stikkordregister heilt til slutt i boka.

De øvrige endringene er bare presiseringer og rettinger av den opprinnelige utgaven.

Til slutt vil jeg gjerne takke min kollega Leena Niiranen, som har lest grundig gjennom det kvenske originalmanuskriptet og gitt meg nyttig 
tilbakemelding. Jeg vil også takke fagfellene som har vurdert og kommentert originalmanuskriptet og det oversatte manuskriptet. Jeg skylder også en spesiell takk til Kainun kieliraati - Kvensk språkråd og Kainun kielitinka - Kvensk språkting for trivelig, godt og berikende samarbeid.

Vehmaa, august 2017

Eira Söderholm 


\section{Innholdsliste}

Forkortelser og tegnbruk

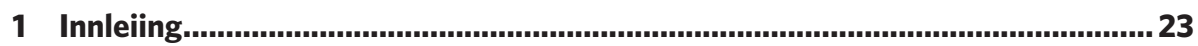

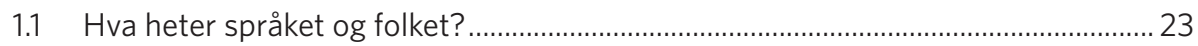

1.2 Hvor finner vi informasjon om kvensk språkstruktur? ................................................. 28

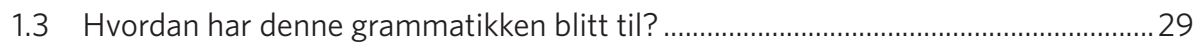

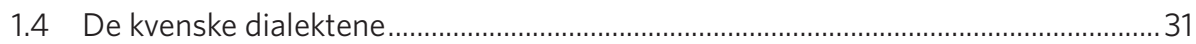

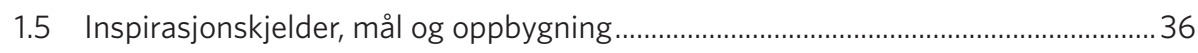

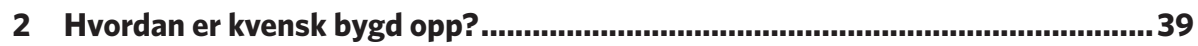

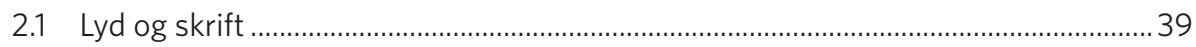

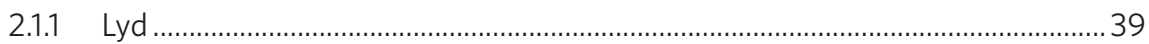

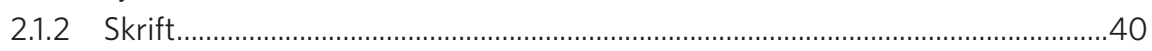

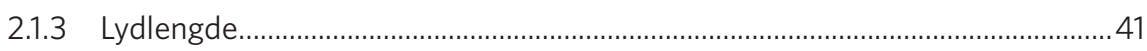

2.1.4 Diftonger og deres plassering i ordet ................................................................. 41

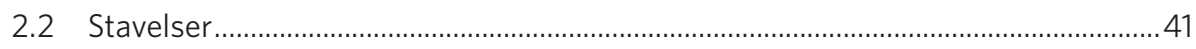

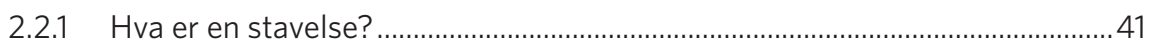

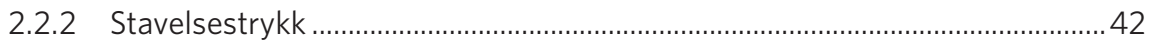

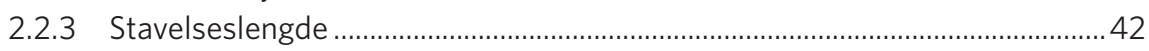

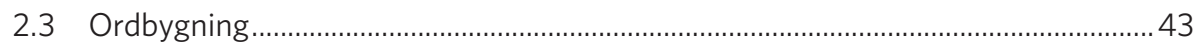

2.3.1 Konsonanter i ordbegynnelse, -kjerne og -slutt ................................................ 43

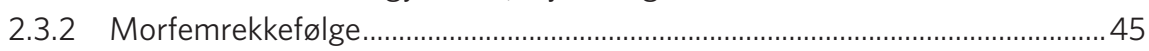

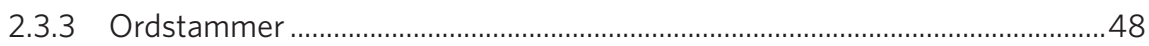

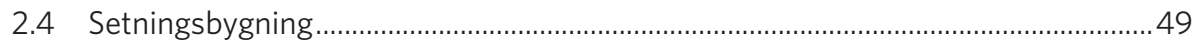

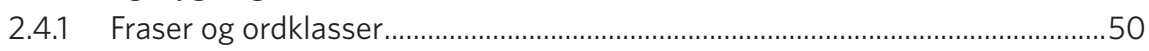

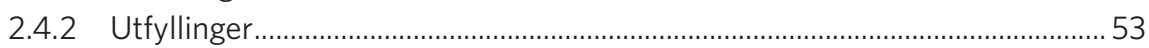

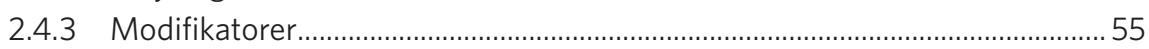

2.4.4 Korrelat og ankerord................................................................................................. 58

2.4.5 Subjektlause setninger: passive og upersonlige konstruksjoner .....................59

2.4.6 Setningstyper: fortellende setninger, spørresetninger og bydesetninger ......61

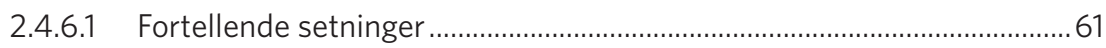

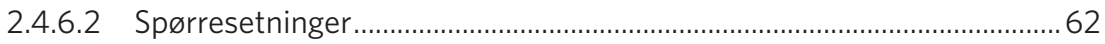

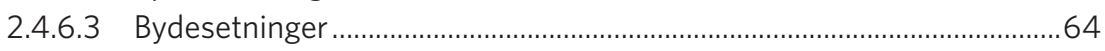

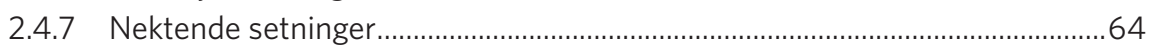




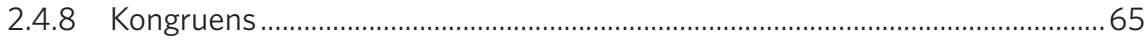

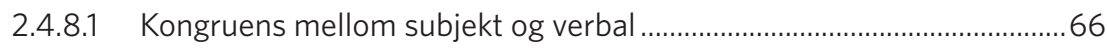

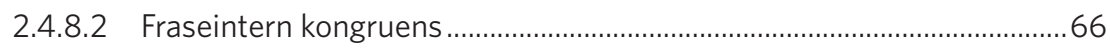

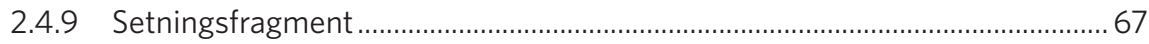

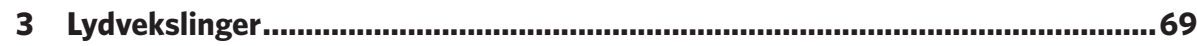

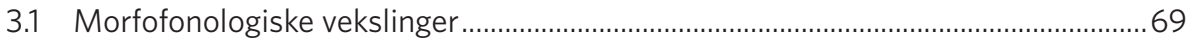

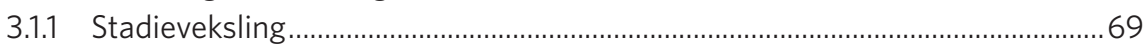

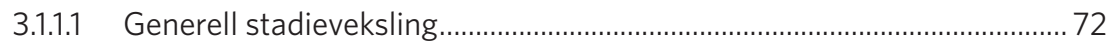

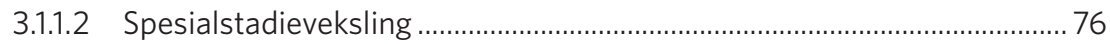

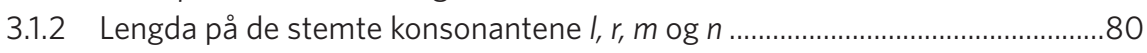

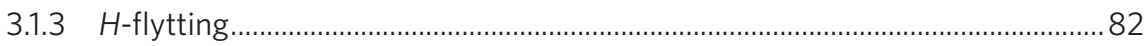

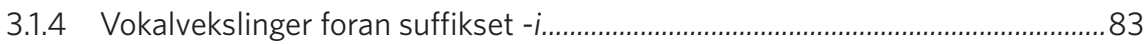

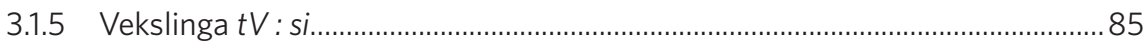

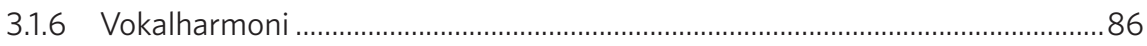

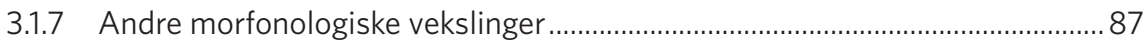

3.2 Lydvekslinger mellom de kvenske skriftspråksvarietetene ........................................... 88

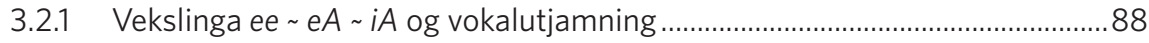

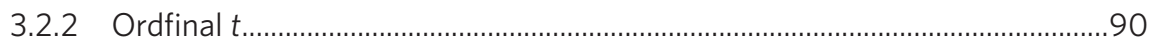

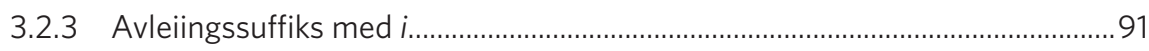

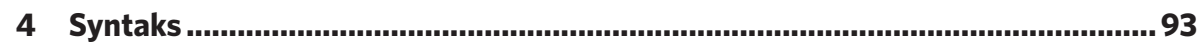

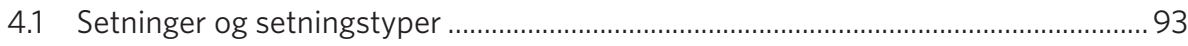

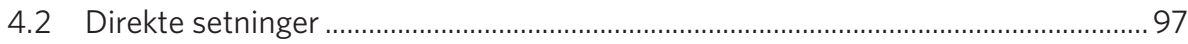

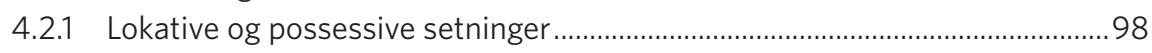

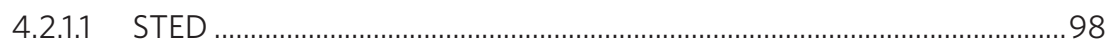

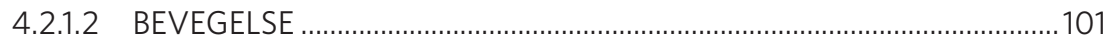

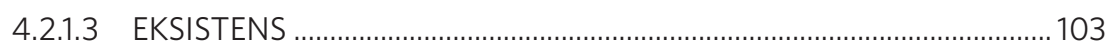

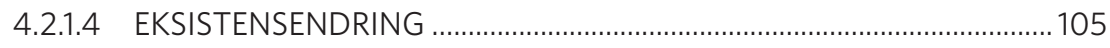

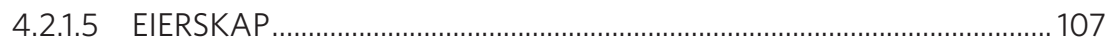

4.2.1.6 INTRANSITIV EIERSKAPSENDRING ...................................................... 109

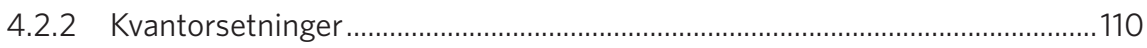

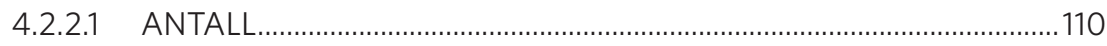

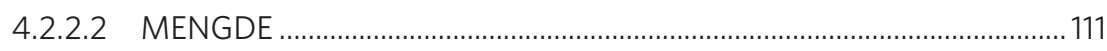

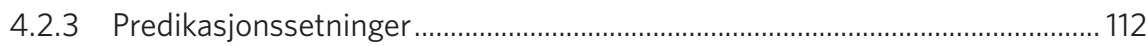

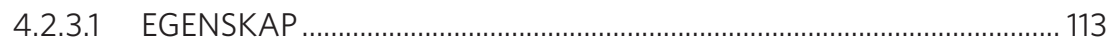

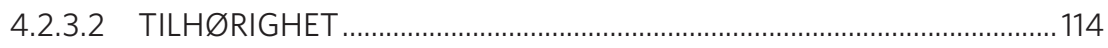

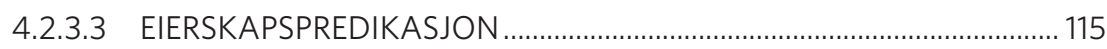

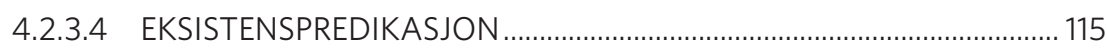

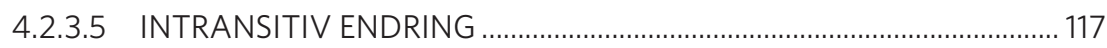

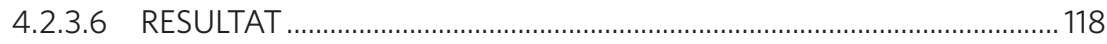

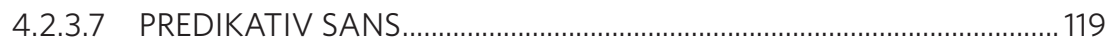

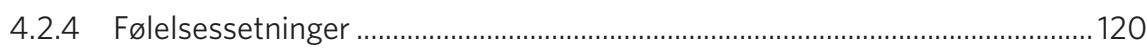




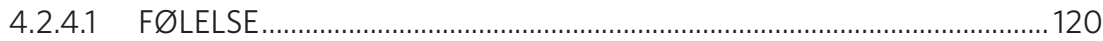

4.2.4.2 KAUSATIV FØLELSE............................................................................. 121

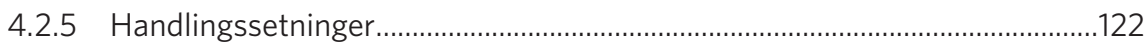

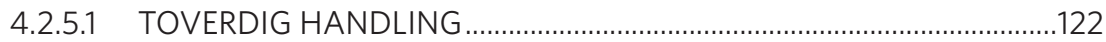

4.2.5.2 TRANSITIV ENDRING ........................................................................ 124

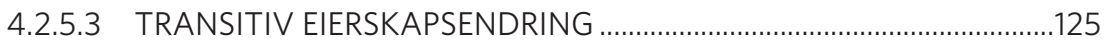

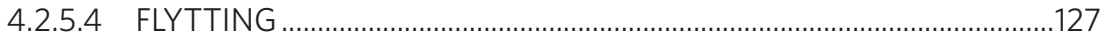

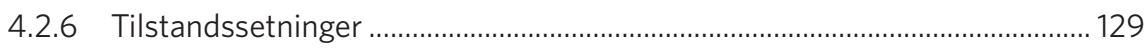

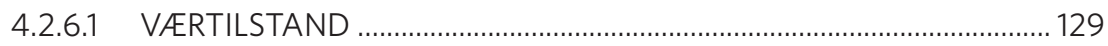

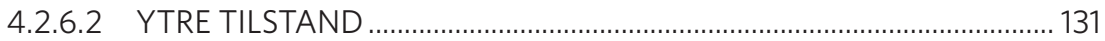

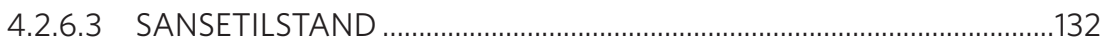

4.2.6.4 INDRE TILSTAND …............................................................................

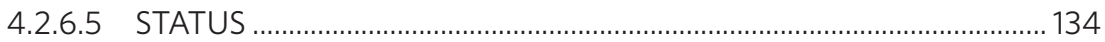

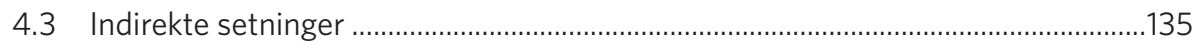

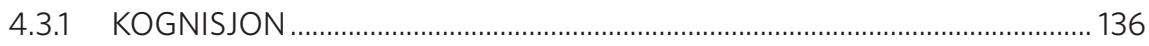

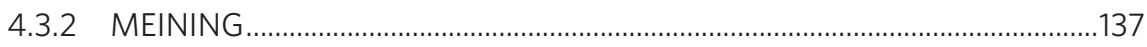

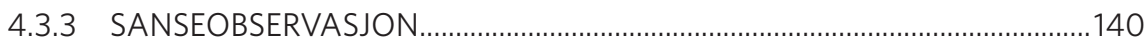

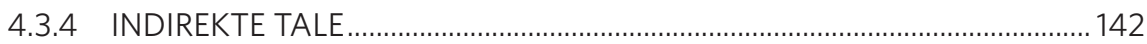

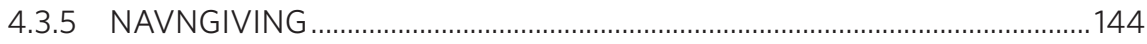

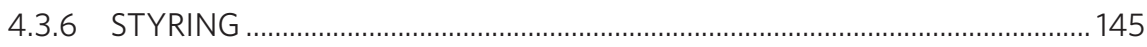

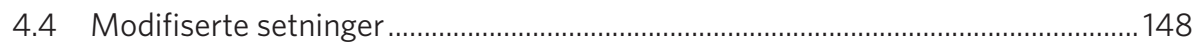

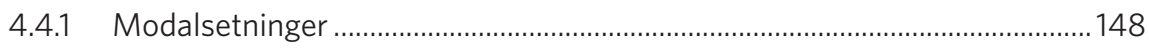

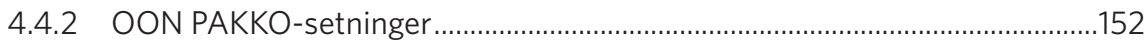

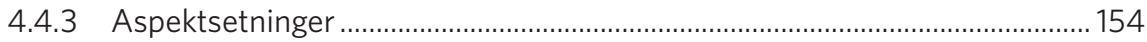

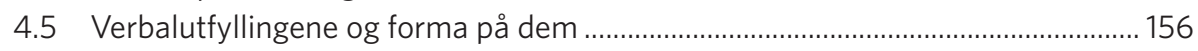

4.5.1 Kongruens mellom subjekt og verbal, og subjektskasus ................................ 156

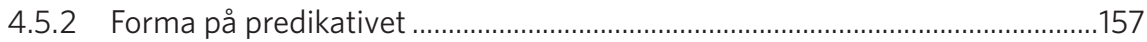

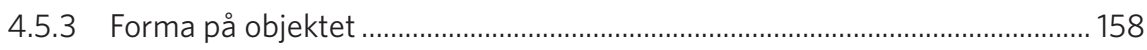

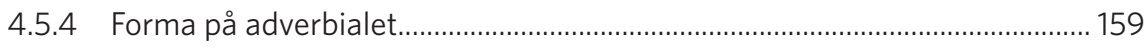

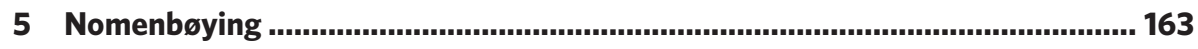

5.1 Nominale stammetyper og bøyingsklasser .......................................................... 164

5.1.1 Nomen med tostava vokalstamme på kort vokal (type 1) ................................ 166

5.1.1.1 Enstamma nomen med tostava vokalstamme på kort vokal (type 1.1) ............................................................................. 166

5.1.1.2 Tostamma nomen med vokalstamme på kort vokal (type 1.2) ................................................................................167

5.1.2 Nomen med flerstava vokalstamme på kort vokal (type 2)............................168

5.1.2.1 Enstamma nomen med flerstava vokalstamme på

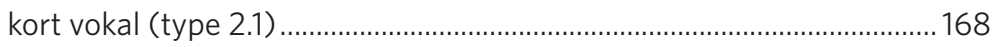

5.1.2.2 Tostamma nomen med flerstava vokalstamme på kort vokal (type 2.2)

5.1.3 Nomen med vokalstamme på lang vokal (type 3) ...........................................172 
5.1.3.1 Enstamma nomen med vokalstamme på lang vokal (type 3.1) ..............172

5.1.3.2 Tostamma nomen med vokalstamme på lang vokal (type 3.2) .............173

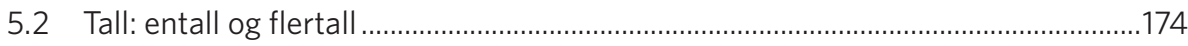

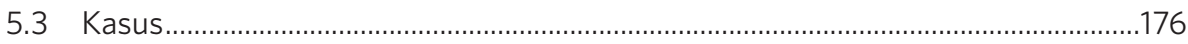

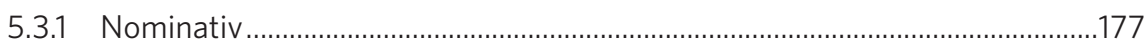

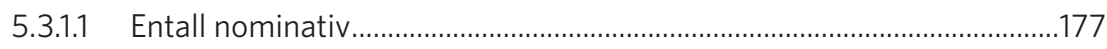

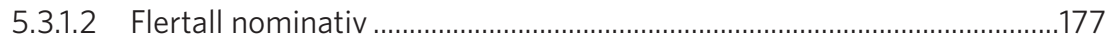

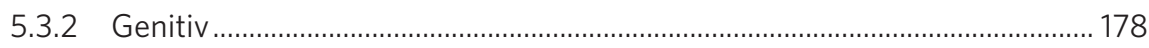

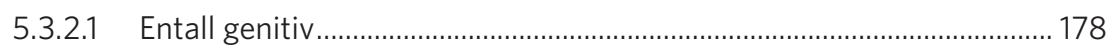

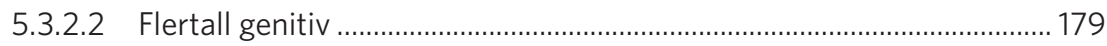

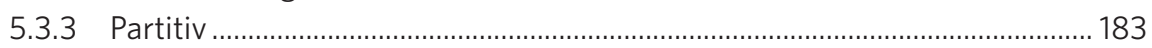

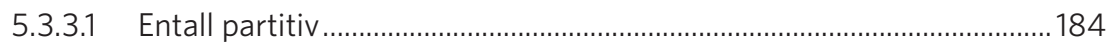

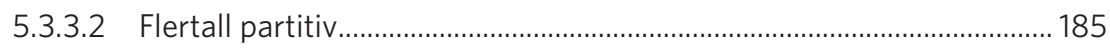

5.3.4 Predikerende kasus: essiv og translativ ...................................................... 189

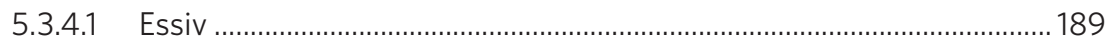

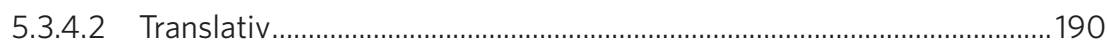

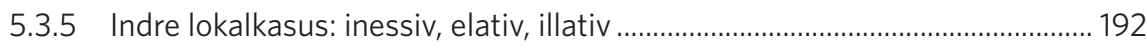

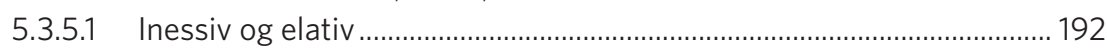

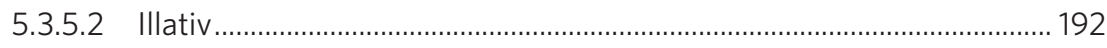

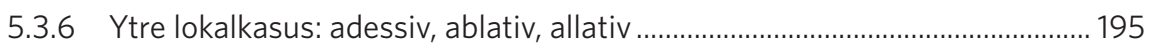

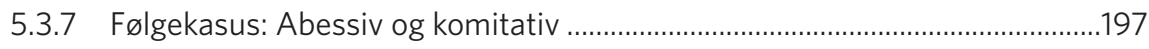

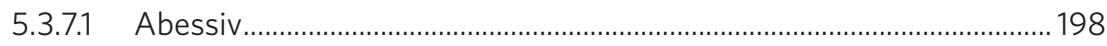

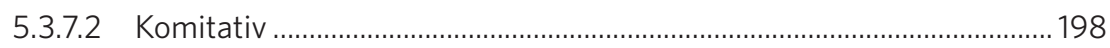

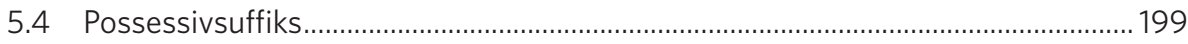

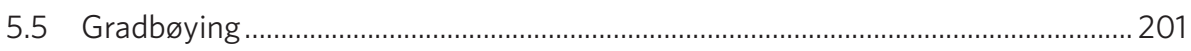

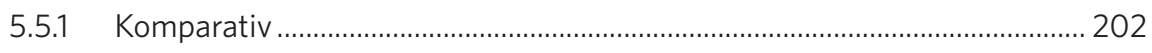

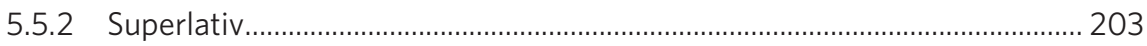

5.5.3 Bruk av komparativ og superlativ ..................................................................... 207

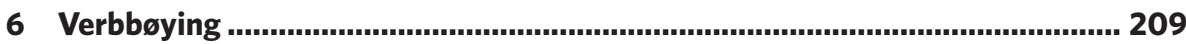

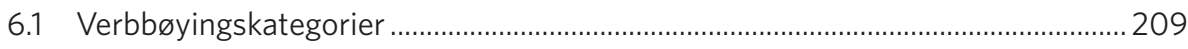

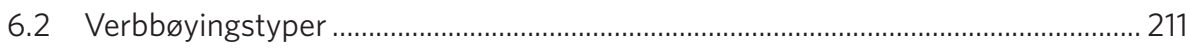

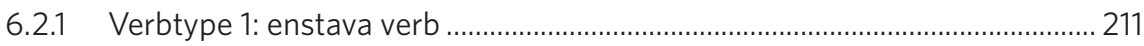

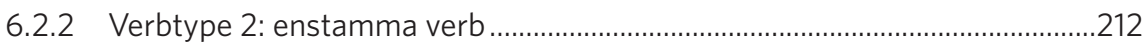

6.2.3 Verbtype 3: verb med konsonantstamme........................................................213

6.2.4 Verbtype 4: verb med to vokalstammer.....................................................213

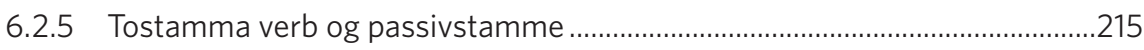

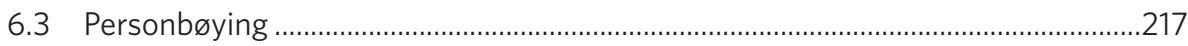

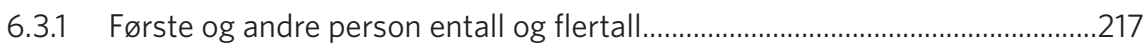

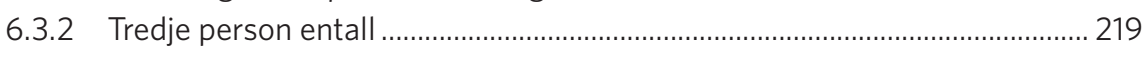

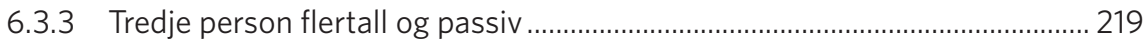

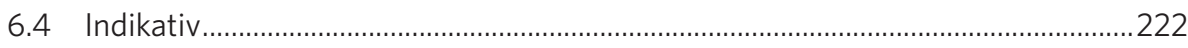

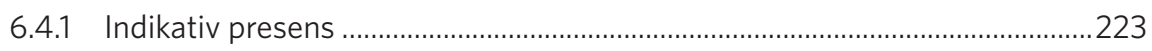




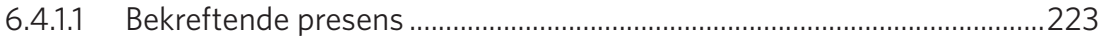

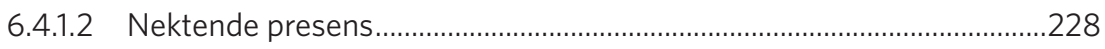

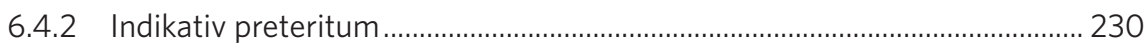

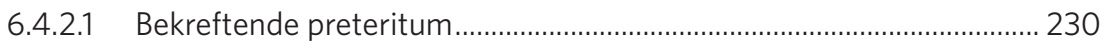

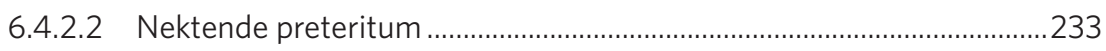

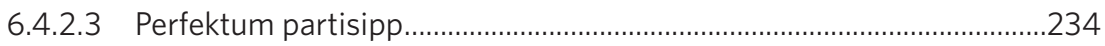

6.4.3 Indikativ presens perfektum og preteritum perfektum .................................238

6.4.3.1 Bekreftende presens perfektum og preteritum

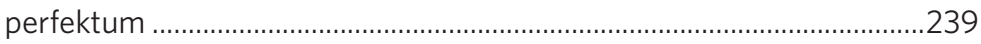

6.4.3.2 Nektende presens perfektum og preteritum perfektum........................239

6.4.4 Perfektum partisipp i sammensatte verbalformer...................................... 240

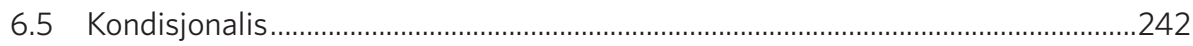

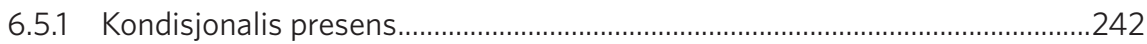

6.5.1.1 Bekreftende kondisjonalis presens..................................................243

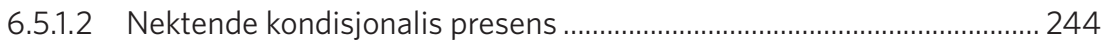

6.5.2 Kondisjonalis presens perfektum .................................................................... 246

6.5.2.1 Bekreftende kondisjonalis presens perfektum ..................................... 246

6.5.2.2 Nektende kondisjonalis presens perfektum...........................................24

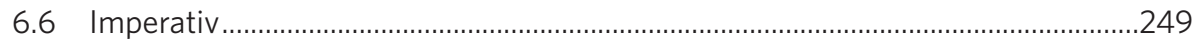

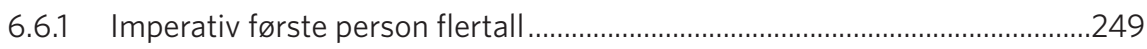

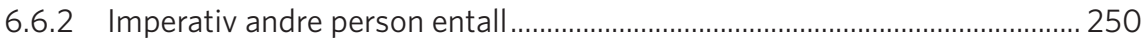

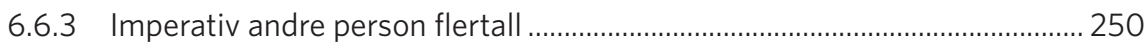

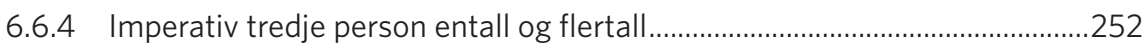

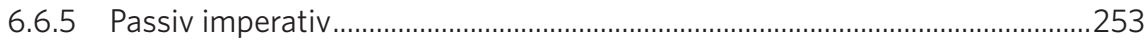

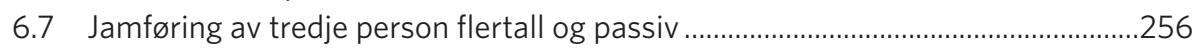

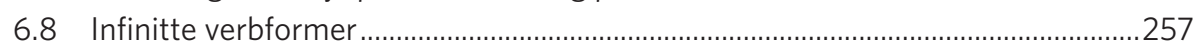

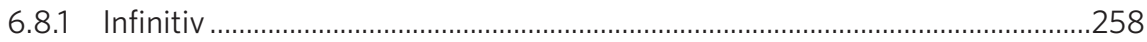

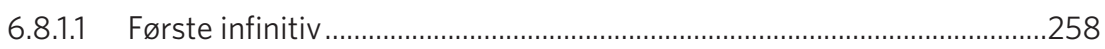

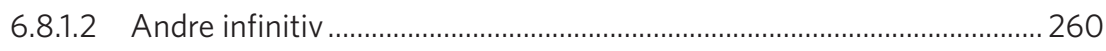

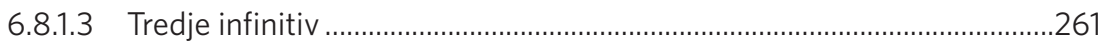

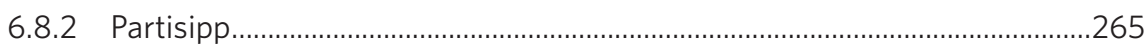

6.8.2.1 Bruk av presens partisipp og perfektum partisipp ................................265

6.8.2.2 Danning av perfektum partisipp ............................................................26

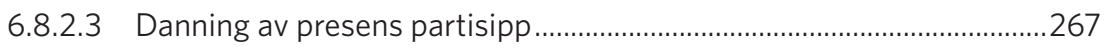

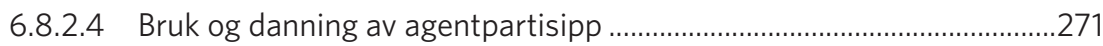

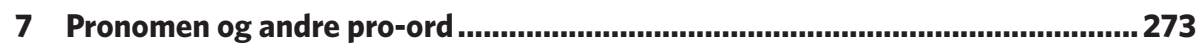

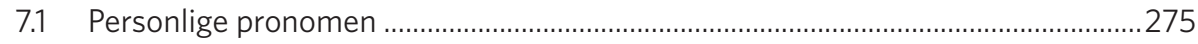

7.2 Demonstrative pronomen og andre demonstrative pro-ord...................................277

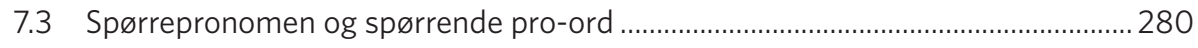

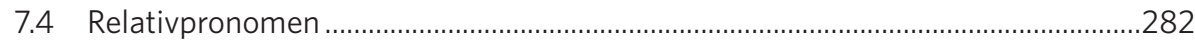

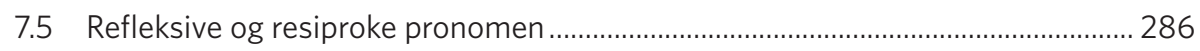




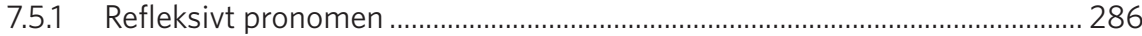

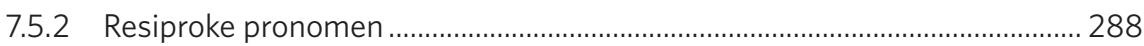

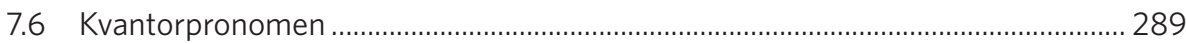

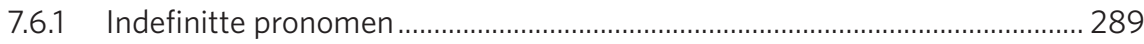

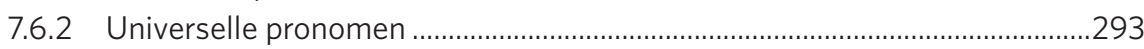

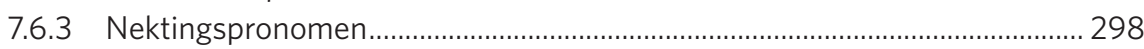

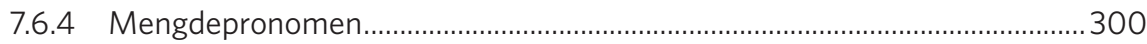

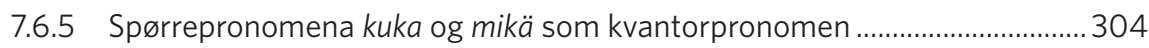

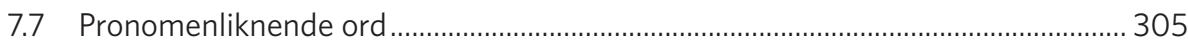

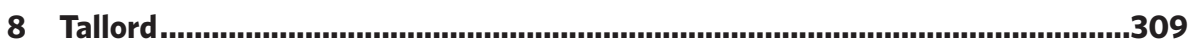

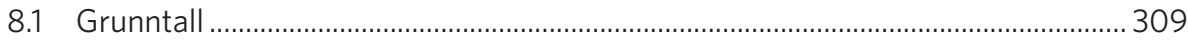

8.1.1 Grunntall som setnings- og fraseelement...........................................................313

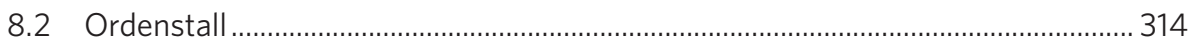

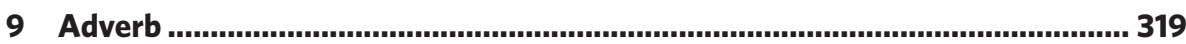

9.1 Generelt om adverb.................................................................................................. 319

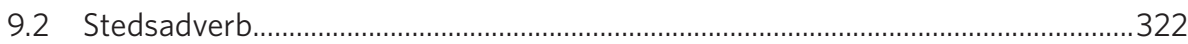

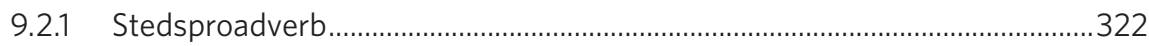

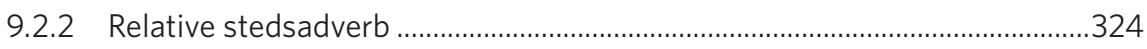

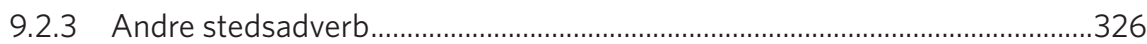

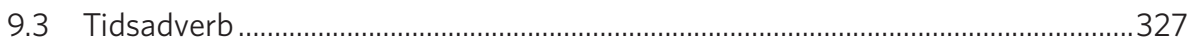

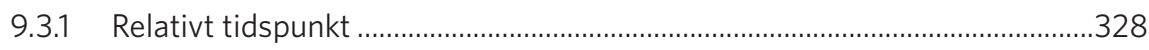

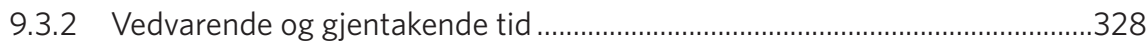

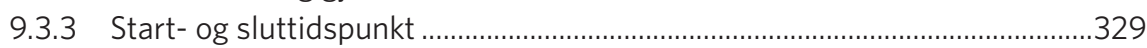

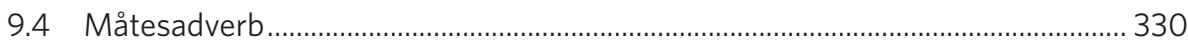

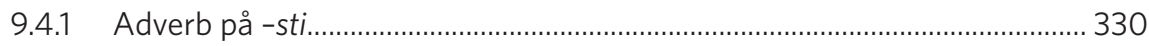

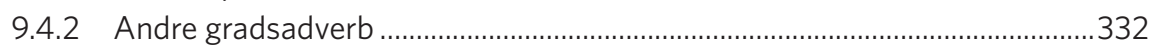

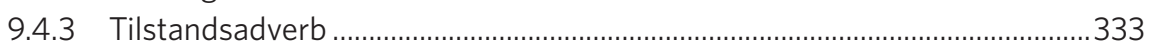

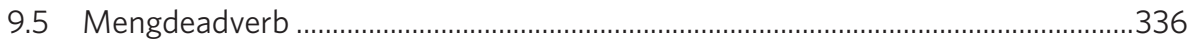

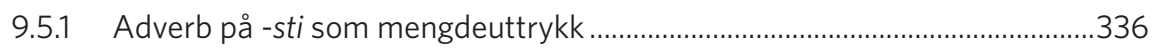

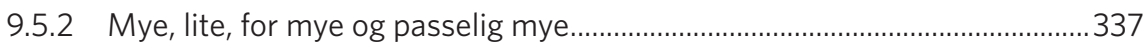

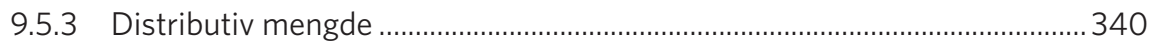

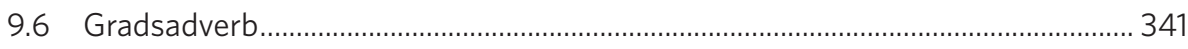

9.6.1 De adjektiviske adverba som uttrykker grad av egenskap............................. 341

9.6.2 Andre adverb som uttrykker grad av egenskap...........................................342

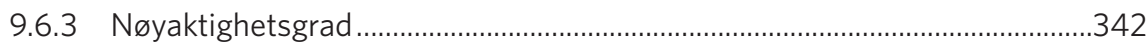

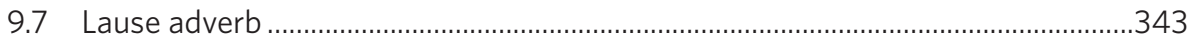

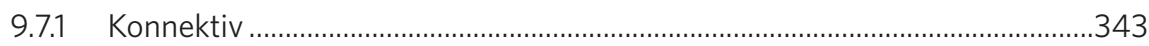

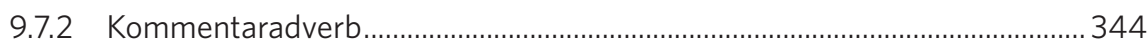




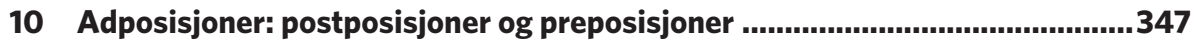

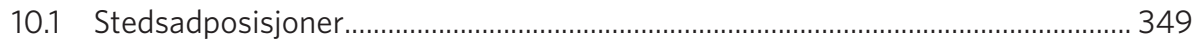

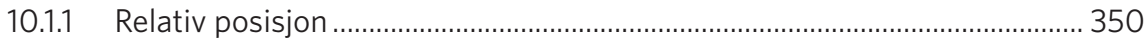

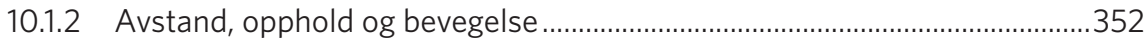

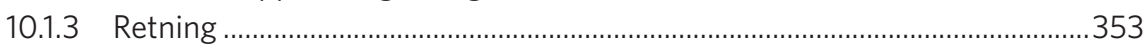

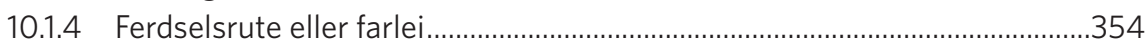

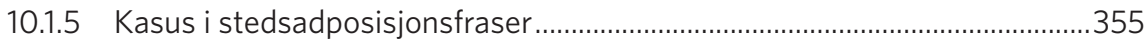

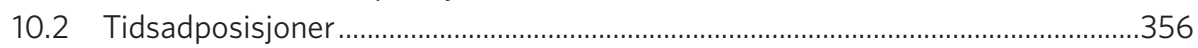

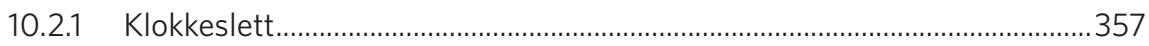

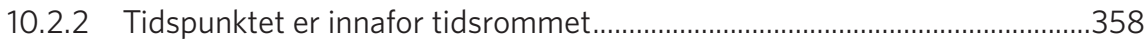

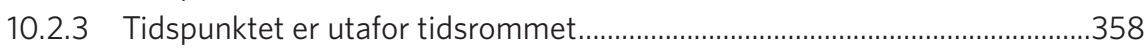

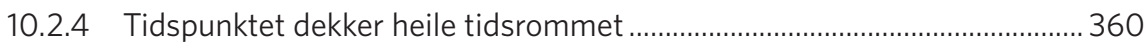

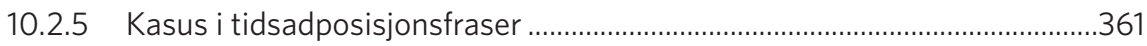

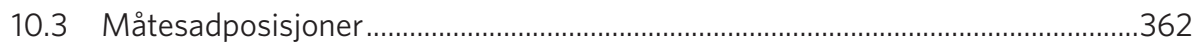

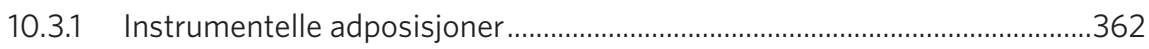

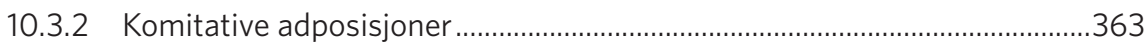

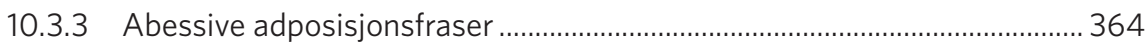

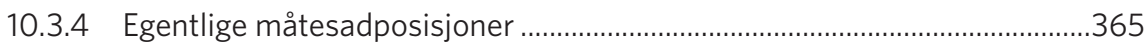

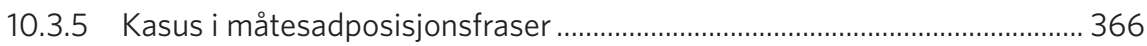

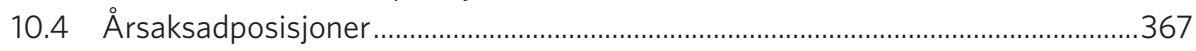

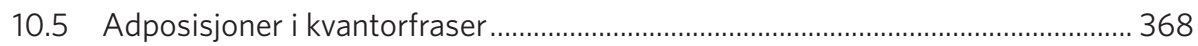

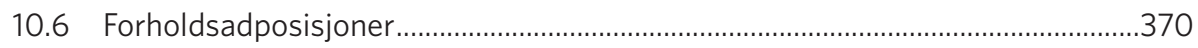

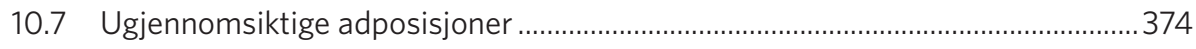

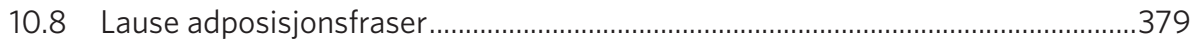

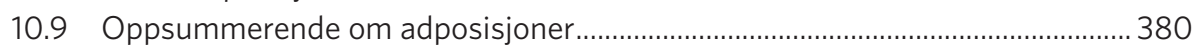

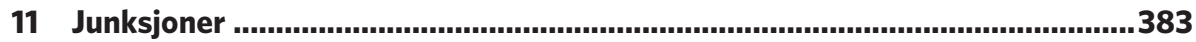

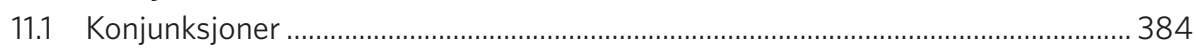

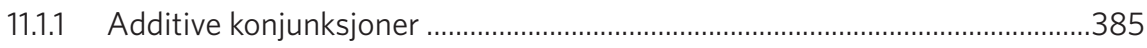

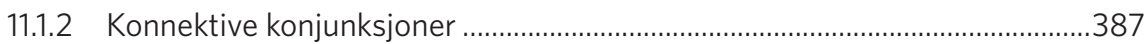

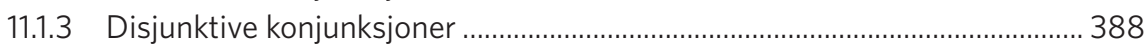

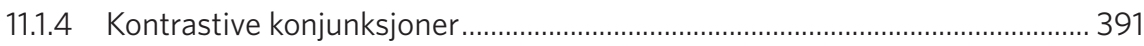

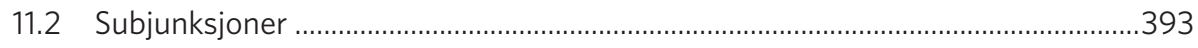

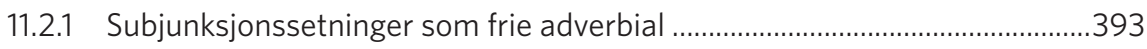

11.2.1.1 Temporale subjunksjoner ....................................................................... 394

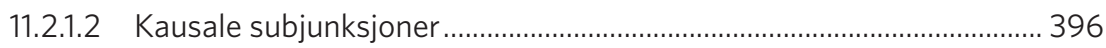

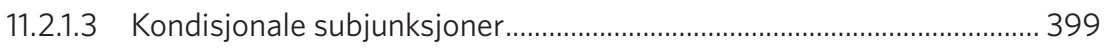

11.2.1.4 Konsessive subjunksjoner ......................................................................400

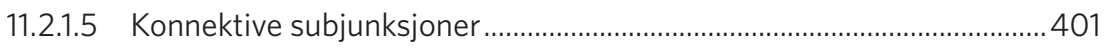

11.2.2 Subjunksjonssetninger som verbalutfyllinger .............................................403

11.2.2.1 Subjunksjonssetninger som subjekt................................................... 403 
11.2.2.2 Subjunksjonssetninger som objekt....................................................... 405

11.2.2.3 Subjunksjonssetninger som predikativ................................................... 407

11.2.2.4 Subjunksjonssetninger som adverbialutfylling .................................... 407

11.2.3 Subjunksjonssetninger som modifikatorer .................................................... 408

11.2.3.1 Subjunksjonssetninger som modifikator til adverb og adjektiv .........408

11.2.3.2 Subjunksjonssetninger som modifikator til substantiv ...................... 409

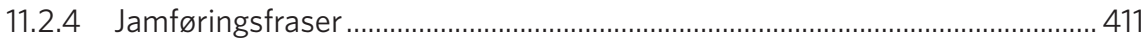

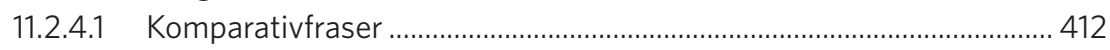

11.2.4.2 Ekvivalente forhold ........................................................................... 413

11.2.4.3 Illustrerende forhold............................................................................... 414

11.2.5 Oppsummerende om subjunksjoner ............................................................... 417

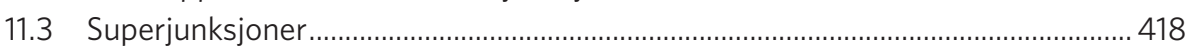

Litteraturliste ..................................................................................................... 421

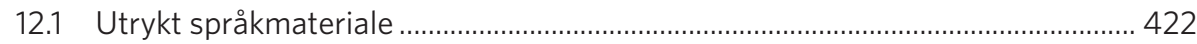

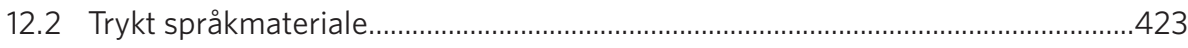

Definisjoner av fagtermer .............................................................................425

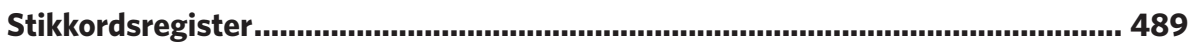

\section{Kart}

1.1 Tradisjonelle bruksområder for kvensk og viktigste kommuner ............................... 32

\section{Tabeller}

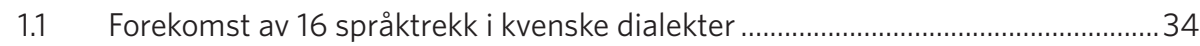

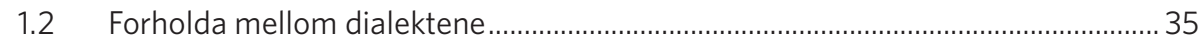

$2.1 \quad$ Kjernekonsonantkombinasjoner av to konsonanter ................................................4 44

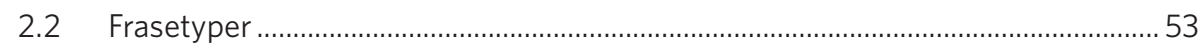

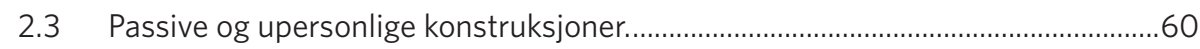

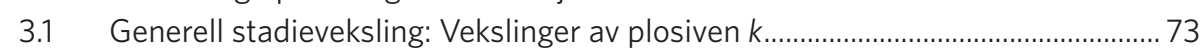

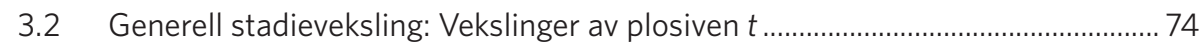

3.3 Generell stadieveksling: Vekslinger av plosiven $p$..................................................... 75

3.4 Generell stadieveksling: Vekslinger av andre konsonanter ....................................... 76

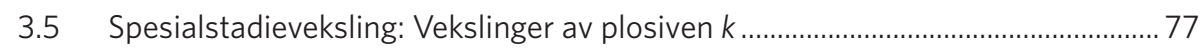

3.6 Spesialstadieveksling: Vekslinger av plosiven $t$.............................................................. 78

3.7 Spesialstadieveksling: Vekslinger av plosiven $p$...................................................... 79

3.8 Spesialstadieveksling: Vekslinger av konsonanten $s$.................................................. 79

3.9 Spesialstadieveksling: Vekslinger av konsonantene $h, j, l, m, n, r$ og $v$...................80

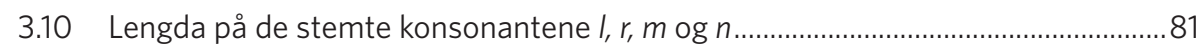

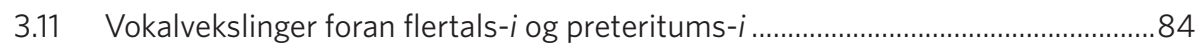

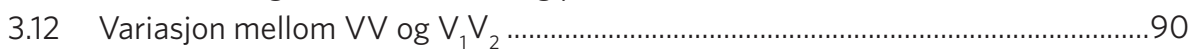




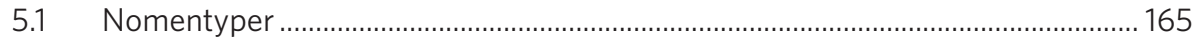

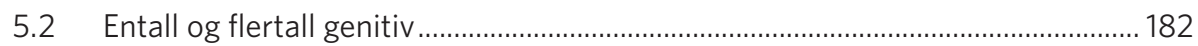

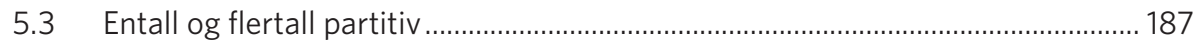

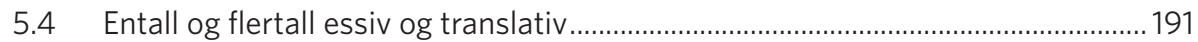

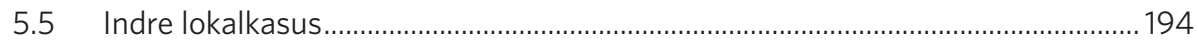

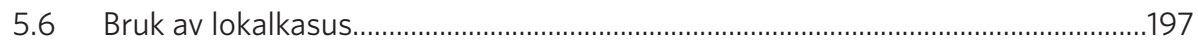

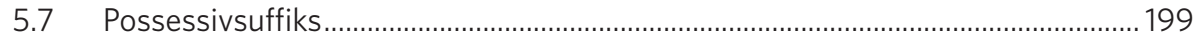

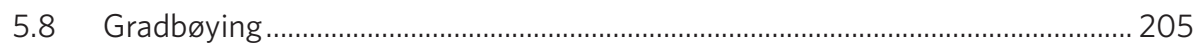

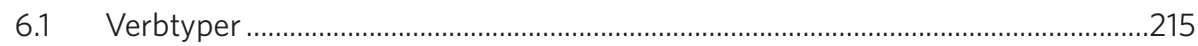

6.2 Personsuffiks i første og andre person entall og flertall ......................................... 218

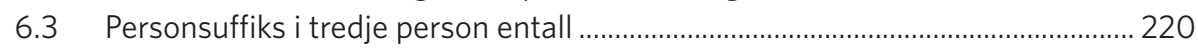

6.4 Personsuffiks i tredje person flertall og i passiv .........................................................222

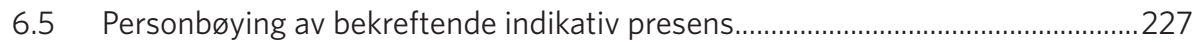

6.6 Personbøying av bekreftende indikativ preteritum ...............................................231

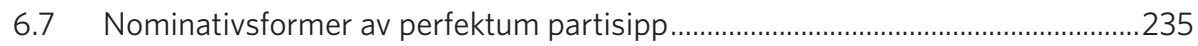

6.8 Sammensatte verbalformer med perfektum partisipp...........................................241

6.9 Bekreftende og nektende kondisjonalis presens.....................................................245

6.10 Bekreftende og nektende kondisjonalis presens perfektum ................................. 248

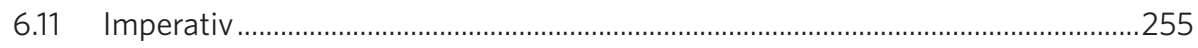

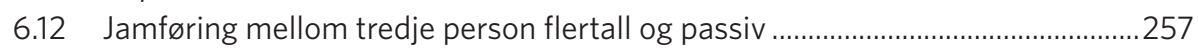

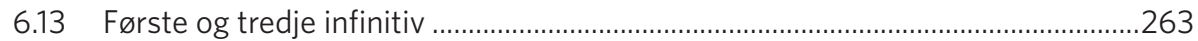

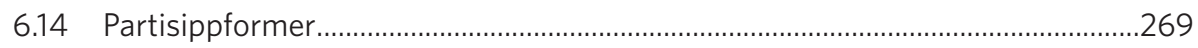

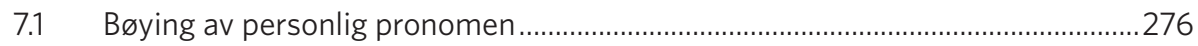

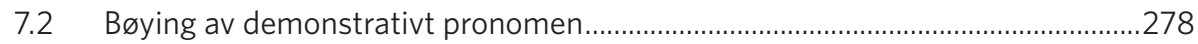

7.3 Demonstrative proadjektiv og -adverb ...........................................................279

7.4 Bøying av spørrepronmena kuka og mikä.......................................................... 280

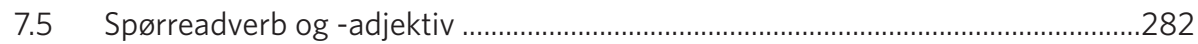

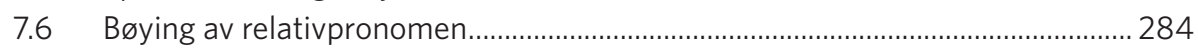

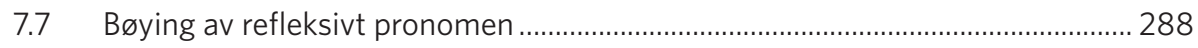

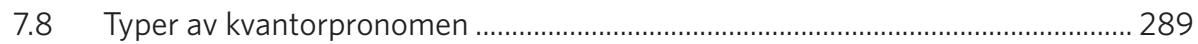

7.9 Bøying av pronomena joku og jompikumpi ..............................................................292

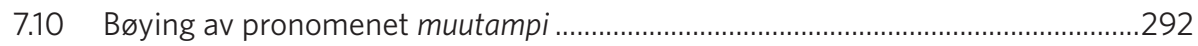

7.11 Bøying av pronomenet molemat ................................................................................ 294

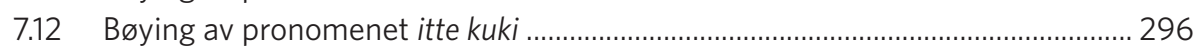

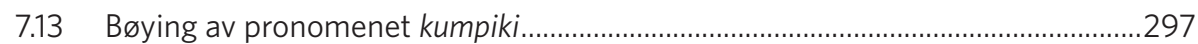

7.14 Bøying av pronomena kukhaan og mikhään .............................................................. 299

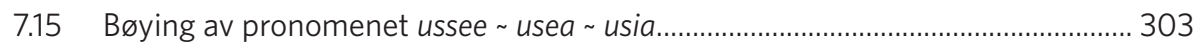

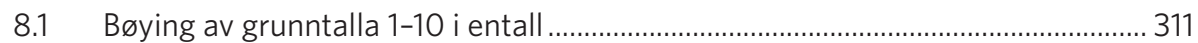

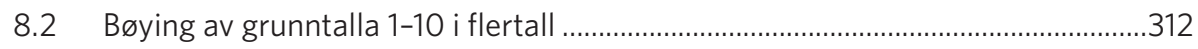

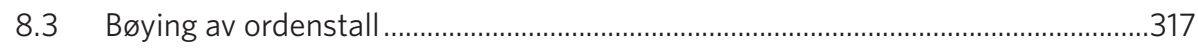

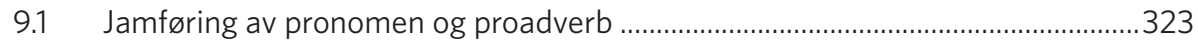

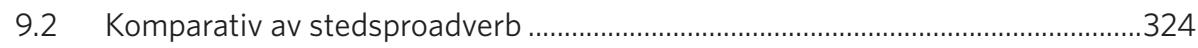




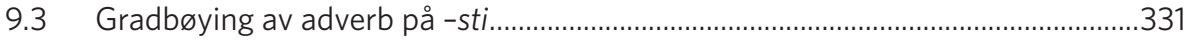

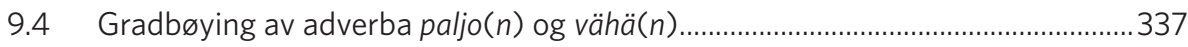

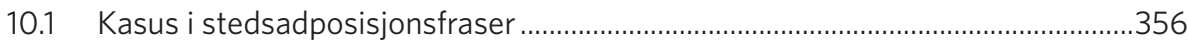

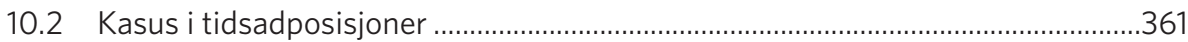

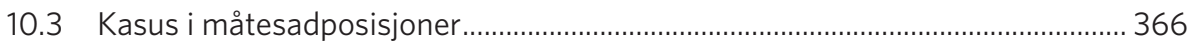

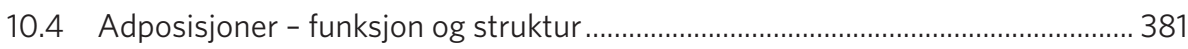

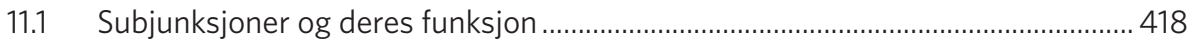




\section{Forkortelser og tegnbruk}

\section{Forkortelser}

\begin{tabular}{|c|c|c|}
\hline 1. pl. & $=$ & første person flertall \\
\hline 1. sg. & $=$ & første person entall \\
\hline 2. pl. & $=$ & andre person flertall \\
\hline 2. sg. & $=$ & andre person entall \\
\hline 3. pl. & $=$ & tredje person flertall \\
\hline 3. sg. & $=$ & tredje person entall \\
\hline A & $=$ & adjektiv \\
\hline abess. & $=$ & abessiv \\
\hline abl. & $=$ & ablativ \\
\hline adess. & $=$ & adessiv \\
\hline Adv & $=$ & adverb \\
\hline $\mathrm{ADV}$ & $=$ & adverbial \\
\hline AdvP & $=$ & adverbfrase \\
\hline akk. & $=$ & akkusativ \\
\hline akt. & $=$ & aktiv \\
\hline all. & $=$ & allativ \\
\hline $\mathrm{AP}$ & $=$ & adjektivfrase \\
\hline dvs. & $=$ & det vil si \\
\hline elat. & $=$ & elativ \\
\hline ess. & $=$ & essiv \\
\hline F-ADV & $=$ & fritt adverbial \\
\hline gen. & $=$ & genitiv \\
\hline ill. & $=$ & illativ \\
\hline imp. & $=$ & imperativ \\
\hline
\end{tabular}




\begin{tabular}{|c|c|c|}
\hline ind. & $=$ & indikativ \\
\hline iness. & $=$ & inessiv \\
\hline jf. & $=$ & jamfør \\
\hline kond. & $=$ & kondisjonalis \\
\hline konj. & $=$ & konjunksjon \\
\hline KvaP & $=$ & kvantorfrase \\
\hline mod. & $=$ & modifikator \\
\hline $\mathrm{N}$ & $=$ & substantiv \\
\hline nekt. & $=$ & nektende \\
\hline nom. & $=$ & nominativ \\
\hline NP & $=$ & substantivfrase \\
\hline OBJ & $=$ & objekt \\
\hline OBJ-ADV & $=$ & objektsadverbial \\
\hline osv. & $=$ & og så videre \\
\hline part. & $=$ & partitiv \\
\hline pass. & $=$ & passiv \\
\hline perf. & $=$ & perfekt \\
\hline pers. & $=$ & person \\
\hline pers. suff. & $=$ & personsuffiks \\
\hline pl. & $=$ & pluralis, flertall \\
\hline $\mathrm{PP}$ & $=$ & adposisjonsfrase \\
\hline PRED & $=$ & predikativ \\
\hline pres. & $=$ & presens \\
\hline pres. perf. & $=$ & presens perfektum \\
\hline pret. & $=$ & preteritum \\
\hline pret. perf. & $=$ & preteritum perfektum \\
\hline Pron & $=$ & pronomen \\
\hline pts. & $=$ & partisipp \\
\hline S & $=$ & subjekt \\
\hline SETN & $=$ & leddsetning \\
\hline sg. & $=$ & singularis, entall \\
\hline transl. & $=$ & translativ \\
\hline UTF & $=$ & utfylling \\
\hline $\mathrm{V}$ & $=$ & verb; verbal \\
\hline VP & $=$ & infinitt verbfrase \\
\hline
\end{tabular}




\section{Tegnbruk}

$? .$.

$>$

SUBJEKT,

EIERSKAP

VOKAL

$[\ldots]$

/

/... /
= Spørsmålstegn framfor et språklig uttrykk markerer at det er usikkert om det er grammatisk korrekt/akseptabelt, for eksempel ? Viisasko se poika oli? ('Var det klok den gutten var?').

$=$ Er-større-symbolet markerer at ei ordform blir endra til eller utvikler seg til noe. For eksempel $a+$ $i>$ oi betyr at vokalen a etterfulgt av vokalen $i$ blir til diftongen oi (i tostava nomenstammer).

$=$ Pil markerer at ordet til høgre for pila er avleid av ordet til venstre for pila. For eksempel markerer $(k o l m e \rightarrow)$ kolma/s at ordet kolmas ('tredje') er avleid av ordet kolme ('tre').

$=$ Versaler brukes (1) i navn på setningsfunksjoner, for eksempel SUBJEKT, og (2) i navn på setningstyper, for eksempel EIERSKAP.

= Kapiteler markerer fagtermer når de forekommer første gangen i teksten, eller når de forklares, for eksempel voKAL. Forklaringene er også samla i ei eiga definisjonsliste og oppført i stikkordregisteret.

$=$ Hakeparenteser markerer frasegrense, jamfør for eksempel substantivfrasen [Pieni vihrinen mies]. De brukes også for å markere morfologiske trekk i setningsanalyser, for eksempel V[3. sg.], som betyr at verbalet står i tredje person entall.

= Skråstrek markerer morfemgrense, som for eksempel i tule/n (av tulla 'komme'), der grensa går mellom ordstammen og personsuffikset i første person entall.

To skråstreker markerer uttale, som i /kenkä/ (kenkä 'sko'). 
/jo.en/

Punktum i uttale markerer stavelsesgrense, som i / jo.en/ (av joki 'elv').

$=$ Kolon mellom to ordformer markerer at de begge hører til samme bøyingsmønster. For eksempel tule/ $n$ : tulle/e, som er henholdsvis første og tredje person aktiv indikativ presens av verbet tulla ('komme').

$=$ Tegnet $\sim$ mellom to eller flere ordformer eller uttrykk betyr at de alle er gangbare, og at det er snakk om likestilte varianter av ei og samme ordform eller ett og samme uttrykk. For eksempel er første infinitivsformene kulkke/et $\sim$ kulke/a $(t) \sim$ kulki/a ('gå, ferdes') alle like gangbare i kvensk, men den første varianten er brukt i Porsanger (og Nordreisa), den andre er en såkalt elvedalsvariant (Tana, Alta, Kvalsund, Hammerfest og Storfjord samt Kvænangen og Kåfjord), og den tredje er en Varanger-variant (Sør-Varanger, Vadsø og Vardø).

itte

$=$ Senka bokstaver etter ordformer markerer at de har samme referent. For eksempel i setninga Is $\ddot{a}_{i}$ oon itte $_{i}$ kutonu tuon tröijyn ('Far har strikka denne trøya sjøl') viser isä ('far') og itte ('sjøl') til samme person. 


\section{1 \\ Innleiing}

Innleiingsvis skal jeg her kort greie ut om navnet på språket som er gjenstand for denne grammatikken, og hvor vi finner informasjon om kvensk språkstruktur. Videre skal jeg fortelle om bakgrunnen for denne grammatikken og om de kvenske dialektene. Til slutt i innleiinga skal jeg si noe om hva slags inspirasjonskjelder jeg har hatt, hva som er målet med grammatikken, og hvordan den er bygd opp.

\subsection{Hva heter språket og folket?}

Nordmenn har kjent til det finskætta folket som har bodd nordpå og gått under navnet kvon(er), i hvert fall fra sagatida. For nordmenn har det også vært klart hva slags språk disse «kvænene» har snakka: Det var «kvænsk» eller - etter dagens ortografi - kvensk. Det var derfor naturlig da kvenene i 1998 av den norske staten blei tilkjent status som nasjonal minoritet, at de blei omtalt som nettopp kvener i offisielle dokument. På samme måte blei også kvensk valgt som navn på språket da det i 2005 blei anerkjent som eige nasjonalt minoritetsspråk uavhengig av finsk.

Derimot står det ingenting i offentlige dokument om hvilke navn som hadde passa best på kvenene og språket deres på deres eige språk. Og det er heller ikke lett å avgjøre disse spørsmåla. Som kjent har kjært barn mange navn, og det gjelder også kvenene og språket deres. Jeg skal derfor her innleiingsvis drøfte disse spørsmåla litt nærmere.

Ordet suomalainen ('finlender; finsk') har fra gammalt av vært kjent i kvensk. Men det har nesten ikke vært brukt som inngruppenavn, det vil si av folk som bodde i Norge. Det har vanligvis betegna folk som bor i Finland, men ofte også eigne forfedre, som kom fra Finland. Men når folk omtaler seg sjøl, så har jeg hørt at de sier «Mie olen suomen lähtöö» eller om så «suomalaislähtöö» ('Jeg er finskætta'), men neppe «Mie olen suomalainen» ('Jeg er finlender/finsk'). I 
Finland har man rett nok ofte snakka om Ruijan suomalaiset ('Finlendere i Nord-Norge') i spørsmål om kvener. Denne betegnelsen kom særlig i bruk i finsk litteratur da nasjonalismen kom på moten i begynnelsen av 1900-tallet, og i de første tiåra av det sjølstendige Finland.

I nyere tid bruker folk som meiner at språket deres er finsk og ikke kvensk, ordet suomalainen også om seg sjøl: De er norskfinner.

Det eldste belegget på hvordan kvenene betegna seg sjøl, er et dokument som er bevart i arkivet til Lyngen sokneprestembete for åra 1769 og 1770. Der berettes det om «Qvænerne» at «fra Tornaa Lapmark ere fast alle de Qvæner her findes. Jkkun een Kone fra Finland, som kom hid i aar 1741». Og så følger merknaden: «Qvænerne fra 1 ste sted kalde Sig Selv Landa=laizet fra sidste Sted Suoma=laizet.» På 1700-tallet ser det i hvert fall i Nord-Troms ut til at de folka som hadde sine røtter i Tornedalen og i svensk lappmark, kalte seg sjøl for lantalaiset, og de som var fra de administrative områda som på den tida blei kalt for Finland, og som bare strakte seg til litt nord for Kemi, kalte seg for suomalaiset.

Det neste belegget er fra fortellingene fra kvener i Nord-Troms i 1890-åra som Just Qvigstad ga ut i 1921 (Qvigstad 1925). Der brukes vanligvis begrepet lantalainen om kvener. Også Johan Beronka (1885-1965), som var prest i Vadsø og andregenerasjons kven, kaller alltid kvener for lantalaiset i sine fortellinger (1921). I det upubliserte og udaterte finskspråklige artikkelmanuskriptet «Norjan suomalaiset» ('Norges finlendere') skriver han om den betegnelsen kvenene brukte om seg sjøl, at «He kutsuvat itseänsä yleensä lantalaisiksi» ('De kaller seg sjøl vanligvis for lantalaiset').

Så kanskje lantalainen ville vært et høvelig inngruppenavn?

Lantalainen var da også en vanlig betegnelse som hørtes mye blant kvener enda den gangen jeg flytta til Nord-Norge i 1979. Av en eller annen grunn ser det likevel ikke ut til at det har vært noe særlig populært navn, og at i hvert fall folk fra Finland ikke likte det. Det skyldes nok at ordet lanta i dagens finsk betyr 'gjødsel, møkk', og noen har meint at betegnelsen lantalainen kom derifra. Men et slikt ord er ikke kjent i kvensk. Ordet for 'møkk' heiter sonta, og 'gjødsel' er (maan)höystö på kvensk. Det er på det reine at ordet lantalainen ikke har noe med møkk å gjøre. Likevel har kvenene blitt gjort narr av (også) for dette ordet. Det er kanskje derfor ordet lantalainen ikke forekommer i dagens kvenlitteratur. (Om etnonymet lantalainen se også Ryymin 2007.) 
Men hva med navnet på språket? Hva har kvenene brukt å kalle språket sitt for, og hvilket navn bruker de i dag?

Det synes å ha vært vanlig at kvenene har kalt språket sitt for suomen kieli ('finsk'). Noe anna navn har jeg ikke hørt folk bruke før i de aller siste tiåra, og jeg har heller ikke funnet det i gamle intervjuopptak, dokument eller i litteraturen. Kvensktalende har tenkt at språket deres er en finsk dialekt. Det er ikke noe rart med det i det heile tatt, i og med at det har mange fellestrekk med dialektene på finsk side av grensa og med de austersjøfinske dialektene på svensk side av grensa, det vil si med meänkieli ('vårt språk') eller tornedalsfinsk.

Om dialektene på norsk side er det også blitt sagt at de er gammaldags finsk, og derfor har noen meint at vanhaasuomi ('gammalfinsk') ville ha vært et passende navn for dem. Men det blir ikke helt rett. I disse dialektene fins det rett nok gamle trekk som dialektene på finsk side har mista eller holder på å miste, men de kvenske dialektene oppviser også særegne nye trekk. Dessuten bidrar adjektivet gammal neppe til økt status for et språk som skal revitaliseres. Et språk bør være moderne for å bli tatt i bruk i dagens samfunn.

I finsk litteratur har man fra begynnelsen av 1900-tallet brukt ordet Ruijan suomi eller ruijansuomi ('Ruija-finsk'), og med det meinte man den finsken som blei snakka i det området som finlendere har omtalt som Ruija, det vil si Nord-Norge. I Norge betydde Ruija fra gammalt av det samme som det norske ordet Norge, og norsk språk har alltid blitt kalt for ruijan kieli, og nordmenn for ruijalaiset. I stedet for Ruijan suomi kunne man altså også ha brukt Norjan suomi. Det er litt som når den svensken som snakkes i Finland, kalles for finlandssvensk, og når den finsken som den finske immigrantgenerasjonen fra 1900-tallet snakker i Sverige, kalles for sverigefinsk. Men det er likevel slik at talerne på norsk side sjøl aldri har brukt betegnelsen ruijansuomi om sitt eige språk. Enda rarere ville det ha vært for dem å omtale sitt eige språk som ruijan murtheet ('norske dialekter'; jf. det finske ordet Ruijan murteet 'Ruijadialekter'). Det ville ha sikta til de norske dialektene, som bergens- eller oslodialekten. Også av en annen grunn lar navnet seg vanskelig sammenlikne med verken sverigefinsk eller finlandssvensk. De to sistnevnte er nemlig ikke eigne språk, men VARIETETER av henholdsvis finsk og svensk.

Etter at språket i Norge offisielt fikk status som eige språk i 2005, kan det ikke lenger betraktes som finsk varietet. Derfor passer ikke navna ovafor, som tar utgangspunkt i ordet suomi ('finsk'). De impliserer at språket er en dialekt 
eller varietet av finsk. Nå når språket gjennom eiga språkplanlegging er blitt til et utbyggingsspråk med en grammatikk og et ordforråd som bygges på eigen grunn, så bør det få et eige navn.

Ei mulig løysing kunne være å kalle språket for meiđänkieli eller meänkieli ('vårt språk'). Språket ville da hatt samme navn som nærspråket som snakkes i Tornedalen og andre steder i Nord-Sverige. Noen har også foreslått dette navnet, og det brukes ofte i talespråket - på samme måte som talere av mange språk eller dialekter ofte omtaler sin eigen språkvariant som 'vårt språk'. Men sjøl om språket som snakkes på svensk side, likner svært mye på språket som snakkes i Nord-Norge, anses de å være to eigne språk. Navnet me(id)änkieli ville ha blanda de to språka i hop og er derfor et dårlig alternativ.

Kvensk språkting bestemte i 2009 at språket skulle hete kväänin kieli. I talemålsopptaka fra 200o-åra i Ruija-korpuset («Ruija-korpuset» 2016) er ordet kvääni svært vanlig, men ofte høres også ordet kvääna/kväänä. Her bør det legges til at intervjueren i det nye Ruija-korpuset er fra Finland, og i finsk tale er det forma kveeni som er mest brukt nå til dags. Orda kvääni og kväänal

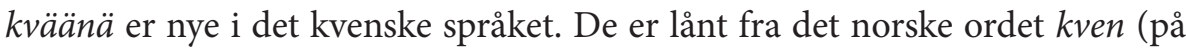
nordnorsk ofte uttalt /kvæ:n/). At kvenske ord som er laga etter mønster av det norske ordet kven, er av nyere dato, det indikerer det faktum at orda kvääni, kvääna/kväänä eller kveeni ikke er belagt en eneste gang i de over 500 sidene med talespråktekst som jeg har brukt i tillegg til Ruija-korpuset. Tekstene representerer eldre talemål, det vil si fra 1960- og 1970-åra, og de er transkribert fra lydopptaka som Finska bandarkivets stipendiater har gjort i NordNorge (Suomen kielen nauhoitearkisto).

Mange språkbrukere føler seg utilpass med kvääni-ordet. Det skyldes at minoriteten har hatt låg status i Norge, og at det norske ordet kven er blitt brukt som nedsettende skjellsord. Eller det var i hvert fall slik mange i minoritetsgruppa opplevde det. Mange meiner derfor også at det innlånte ordet kvääni er nedsettende. Men etter som kven-begrepet har fått stadig mer positiv valør, så vil kanskje ordet kvääni heller ikke oppleves som like ubehagelig lenger.

Derimot er ordet kvääni problematisk også strukturelt sett, for konsonantklynga $k v$ - hører ikke heime i språket. Vi finner denne kombinasjonen ellers bare i ett litt eldre lånord, nemlig ordet kvartti ('kvarter'). Men også det opptrer vanligvis i forma vartti. Ordet kvääni er også uheldig i og med at det ikke er laga vanlige nasjonalitetsbetegnelser basert på ordet. Slike finner vi for alle 
nabofolk. Vi har altså orda ruottalaiset ('svensker'), ruijalaiset ('nordmenn'), norjalaiset ('nordmenn'), saamelaiset ('samer'), lappalaiset ('samer') og suomalaiset ('finlendere'), men ordet ${ }^{*} k v a ̈ a ̈ n i l a ̈ i n e n ~ m a n g l e r$.

Ordet kvään passer derfor dårlig inn i språket. Og ettersom det også ellers er uvanlig at en minoritet bruker navn fra majoritetsspråket om seg sjøl og om språket sitt, så har jeg ikke ønska å bruke det i den kvenskspråklige originalutgava av denne grammatikken.

Etter å ha fundert på dette spørsmålet lenge har jeg bestemt meg for å bruke navnet kainun kieli ('kvensk språk') i den kvenske utgava av denne grammatikken. Om folk som tradisjonelt har snakka språket eller har forfedre som har brukt det, bruker jeg navnet kainulainen ('kvener').

I finsk litteratur på 1800-tallet var ordet kainulainen vanlig som motsvar til det norske ordet kven. Det kommer trulig av at den etymologiske forskninga på 1700-tallet hadde begynt å kople sammen det norske ordet kvoen og den eldgamle betegnelsen kainulainen, som i finske dialekter bruktes om beboerne i Bottenvika (jf. Julku 1986, s. 13-24). Man meiner altså, og meiner fortsatt, at kven og kainu er samme ord, og at det er blitt lånt mellom de to språka. Hvilket av de to språka som er långiver, og hvilket som er låntaker, er forskerne fortsatt uenige om (jf. Andreassen 2016).

Seinere har ordet kainulainen nesten blitt borte i finsk litteratur. Men ordet blei på nytt lansert av «skriftkvenskens far», Terje Aronsen, til bruk for kvenskspråklige (jf. Aronsen 2001). ${ }^{1}$ Samtidig begynte han å kalle språket for kainun kieli. Navnevalget bygde han på muntlige opplysninger han sjøl hadde fått om at gamle folk fortsatt huska ordet kainunlainen som inngruppenavn, sjøl om det allerede hadde forsvunnet fra dagligtalen. I dag brukes orda kainulainen og kainun kieli blant anna i undervisningsmateriell på Universitetet $\mathrm{i}$ Tromsø og $\mathrm{i}$ lærebøker for barneskolen.

Det er uansett bare tida som vil vise hvilke navn som kommer til å feste seg, og hvilke som kommer til å falle bort. I dag er det fortsatt flere navn som er i bruk, og kanskje er det slik at et språk kan ha flere navn som brukes parallelt, og ikke bare ett navn. Kvensk har jo faktisk også to navn på majoritetsspråket her i landet, ruija og norja!

$1 \quad$ Sjøl foreslo jeg allerede i 1996 ordet kainhun kieli som navn på et felles skriftspråk for folk på norsk og svensk side av grensa. Men Terje Aronsen hadde allerede den gangen fått samme idé. 


\subsection{Hvor finner vi informasjon om kvensk språkstruktur?}

Kvensk språkstruktur er lite utforska. De mest omfattende arbeida er Johan Beronkas framstillinger av syntaksen og orddannelsen i dialektene i Porsanger og Vadsø (Beronka 1922; Beronka 1925) og Anna-Riitta Lindgrens doktoravhandling om endringer i verbbøyinga i dialektene i Nordreisa, Børselv og Vestre Jakobselv (Lindgren 1990). Her kan vi også nevne flere større eller mindre studentoppgaver: Marjut Aikio har undersøkt variasjonen i nominale vokal- og konsonantstammer i Nordreisa-dialektene (Aikio 1981), Trond Trosterud bindingsrelasjoner i dialektene i Pasvik og Børselv (Trosterud 1990), Klaus Skoge variasjonen i illativsformer av fjerde infinitiv i dialektene i Nordreisa, Børselv og Vestre Jakobselv (Skoge 1998), Maarit Soukka kongruens mellom subjekt og predikat i Alf Nilsen-Børsskogs roman Kuosuvaaran takana (Soukka 2006) og Mihail Voronov predikatfunksjoner i samme romanen (Voronov 2006). Av eldre framstillinger kan vi også nevne Martti Rapolas lydhistoriske eksempelsamling fra Lyngen-dialekten (Rapola 1939).

Så langt fins det svært lite skriftlig materiale på kvensk, og det meste av det er skrevet av folk fra Porsanger, først og fremst av Alf Nilsen-Børsskog, som ga ut tre romaner (Nilsen-Børsskog 2004; Nilsen-Børsskog 2007; Nilsen-Børsskog 2011) og flere diktsamlinger (Nilsen-Børsskog 2008; Nilsen-Børsskog 2010a; Nilsen-Børsskog 201ob; Nilsen-Børsskog 2010c; Nilsen-Børsskog 2013). Agnes Eriksen har gitt ut kvenske regler (Eriksen 2003) og eventyr (Eriksen 2011a; Eriksen 2011b). Hun har også skrevet lærebøker i kvensk for barneskolen. Terje Aronsen har særlig bidratt som oversetter fra kvensk til norsk. Han har oversatt offisielle skriv, religiøse tekster, vitenskapelige framstillinger og tegneserier, og han har vært så vennlig å gi meg tilgang til disse oversettelsene i digital form. Pasvikdølen Olav Beddari skreiv også fortellinger på sin eigen dialekt, som han sjøl rett nok så på som finsk dialekt (Beddari 1987). I tillegg har vi de nesten hundre år gamle fortellingene fra Kvænangen og Nordreisa ført i pennen av Just Qvigstad (Qvigstad 1925), og Johan Beronkas fortellinger, som er med i hans Syntaktiske iagttagelser fra de finske dialekter $i$ Vadsø og Porsanger (Beronka 1922).

Det er likevel samla inn en god del kvensk dialektmateriale som er oppbevart i arkiv. Viktigst for studiet av grammatikken har Finska bandarkivet vært, hvor det fins 419 timer med kvenske dialektopptak (Suomen kielen nauhoitearkisto). 
Materialet spenner fra Storfjord i vest til Sør-Varanger i aust. Av betydning er også materialet i Ruija-korpuset, som er tilgjengelig på nettet («Ruija-korpuset» 2016). Der fins først og fremst digitaliserte opptak fra Porsanger og Varanger. Til hjelp har også Arkivet för morfologi i finska dialekter vært, hvor det fins materiale fra Nordreisa og Aust-Finnmark («Arkivet för morfologi i finska dialekter (Muoto-opin arkisto)»).

Men ettersom det i liten grad fins spesifikk forskning om emnet, så har det vært et stort nybrottsarbeid å få skrevet denne grammatikken. Basert på de nevnte tekstkjeldene har de strukturelle egenskapene ved språket blitt forsøkt beskrevet, og deretter har det blitt lagt fram forslag for Språktinget om hvordan kvensk skriftspråk bør skrives i lærebøker.

\subsection{Hvordan har denne grammatikken blitt til?}

Opptakten til denne grammatikken går tilbake til 2006, da jeg begynte å undervise i kvensk språk ved Universitetet i Tromsø. Den gangen fans det ikke noen kvensk grammatikk, og jeg så meg derfor nødt til å sette i gang arbeidet med å lage en slik. Som grunnlag for den første versjonen av grammatikken valgte jeg porsanger- og da spesielt børselvsdialektenvarieteten. Det var der jeg fant mest skriftlig materiale som kunne danne utgangspunkt for en grammatisk beskrivelse av det kvenske språket. Den viktigste enkeltkjelda var Alf Nilsen-Børsskogs roman Kuosuvaaran takana (Nilsen-Børsskog 2004), som nettopp var kommet ut da arbeidet med grammatikken tok til.

Like etter begynte også det offisielle planleggingsarbeidet for kvensk. I statsbudsjettet for 2006 satte Stortinget av midler til standardisering av kvensk, og Kvensk institutt fikk ansvaret for dette arbeidet. I 2007 blei Kvensk språkråd etablert, og i 2008 Språktinget.

Mandatet til Språktinget var å standardisere kvensk språk. Standarden skulle tjene som mal for hvordan kvensk bør skrives i lærebøker. Men til å begynne med var det ikke klart for Språktinget hvordan en skulle ta fatt på utforminga av en slik standard.

Språk er alltid prega av variasjon mellom ulike dialekter, og slik er det også i kvensk. Når man nå skulle ta i bruk kvensk som skriftspråk, så gjaldt det å bestemme seg for hvilke prinsipper man ville følge. Ett mulig prinsipp går ut på å inngå kompromisser mellom de ulike dialektene. Til en viss grad er det slik man på 1800-tallet bygde for eksempel det finske skriftspråket, som 
inneholder strukturelle trekk og ord både fra de austlige og de vestlige dialektene. Derimot fikk ikke nordlige dialekttrekk innpass i skriftspråket.

En annen modell for å lage et skriftspråk er å ta utgangspunkt i den dialekten som er mest brukt, og som det fins mest skriftlig materiale ifra. Det har som regel vært administrasjonsspråket. Det var slik for eksempel det svenske og det franske skriftspråket så dagens lys. Etter en slik modell burde en uten tvil ha valgt porsangerdialekten og forfatterne derifra som normeringsgrunnlag for kvensk: Så langt er nesten alt av skriftlig kvensk skrevet på denne varieteten. Det var da også opprinnelig denne strategien jeg la meg på, da jeg begynte å skrive på grammatikken.

Begge strategiene har sine fordeler og ulemper. Når man bygger et kompromisspråk, risikerer man at språkbrukerne har vanskelig for å identifisere seg med språket. Det kjennes litt fremmed for alle. Når man derimot baserer seg på kun én dialekt, så kjenner de som snakker en annen dialekt, seg ikke igjen i språket og syns det er feil.

En kan også velge enda en annen strategi, som går ut på å tillate variasjon. Det vil si at man ikke etablerer noen mal for hvordan man skal skrive, men overlater til hver enkelt å skrive på sin eigen dialekt og etter eige ønske. En slik modell er nok gangbar for skjønnlitterære tekster, men den er utilstrekkelig i de tilfeller der språket skal læres bort til barn og folk som ikke kan det fra før.

En annen måte å godta variasjon i skriftspråk på er å åpne for bruk av to eller flere varianter av ett og samme grammatiske trekk.

Ei slik løysing falt også Språktinget ned på. Det har bestemt at variasjon og parallelle former skal være tillatt når det dreier seg om slike markører som heilt klart skiller dialektene fra hverandre, og som språkbrukere og språkmiljøer der språket fortsatt er i aktiv bruk, anser som viktige. Dette prinsippet gir seg i denne grammatikken utslag $i$ at det for ett og samme grammatiske trekk til dels er satt opp to eller tre mønster for hvordan det kan skrives. Som oftest er det likevel bare snakk om én variant i og med at det er mange likhetstrekk og bare få markante forskjeller mellom de kvenske dialektene (se Söderholm 2008).

Språktinget har også fulgt et anna viktig prinsipp: I skriftspråket er det bare tatt med slike trekk som fins i kvenske dialekter. Da de ulike formene og språkstrukturene blei vedtatt, blei det tatt hensyn til alle kvenske dialekter fra Lyngen til Pasvik, men ikke til språk eller dialekter utafor Norge. En annen strategi ville ha vært å inngå kompromisser med meänkieli eller det finske skriftspråket, men det gjorde man ikke. 
Arbeidsfordelinga mellom Språkrådet og Språktinget var til å begynne med tenkt slik at Språkrådet skulle legge fram forslag for Språktinget, som så skulle fatte vedtak basert på forslaga. Mens man utpekte språkforskere til å sitte i Språkrådet, så blei medlemmene av Språktinget valgt blant språkbrukere som representerer ulike dialekter. Språkrådet besto av Irene Andreassen, Terje Aronsen, Pia Lane, Anna-Riitta Lindgren og forfatteren av denne grammatikken. Som medlemmer i Språktinget fungerte Trygg Jakola, Oddgeir Johansen, Dagny Olsen, Henry Osima og Leena Pedersen. Oddgeir Johansen blei seinere avløyst av Kyrre Isaksen.

Arbeidsfordelinga mellom Språkrådet og Språktinget varierte likevel noe, og Språkrådet blei lagt ned da mandatperioden gikk ut våren 2010. I løpet av mandatperioden rakk Språkrådet å behandle ortografisk, fonologisk og morfologisk variasjon, verb- og nomenbøying og nesten også syntaksen. Som diskusjonsgrunnlag brukte vi grammatikken som jeg hadde laga for studentene mine. Språkrådet gjorde vedtak om hva slags type variasjon som skulle innlemmes i læreboknormalen. Mest sentralt i arbeidet var verb- og nomenbøyinga. Anna-Ritta Lindgren utreda variasjonen i verbbøyinga, mens jeg tok meg av variasjonen i nomenbøyinga. Etter at Språkrådet var lagt ned, var det jeg som hadde hovedansvaret for å legge fram forslag for Språktinget. Innimellom kom også medlemmer av Språktinget sjøl med forslag, som da enten blei godkjent eller avvist.

Den foreliggende grammatikken bygger på de vedtaka som Språktinget har gjort. Grunnstammen i framstillinga er likevel den grammatikken som jeg i begynnelsen laga basert på Porsanger-varieteten, og jeg står også ansvarlig for den teoretiske ramma rundt verket.

Eksempelsetningene som er brukt i grammatikken, er først og fremst på Porsanger-varieteten, men også andre varieteter er representert der. De norske oversettelsene av setningene følger originalen så tett som mulig, noe som i noen tilfeller har resultert i mindre elegante formuleringer. Når det gjelder bøying, så viser eksempelorda alltid heile variasjonsbredden mellom de ulike varietetene som rommes innafor vedtaka til Språktinget.

\subsection{De kvenske dialektene}

Kvenske dialekter har fra gammalt av vært snakka i Troms og Finnmark. I dag er de like mye brukt i store byer, som Oslo og Tromsø. Men problemet 


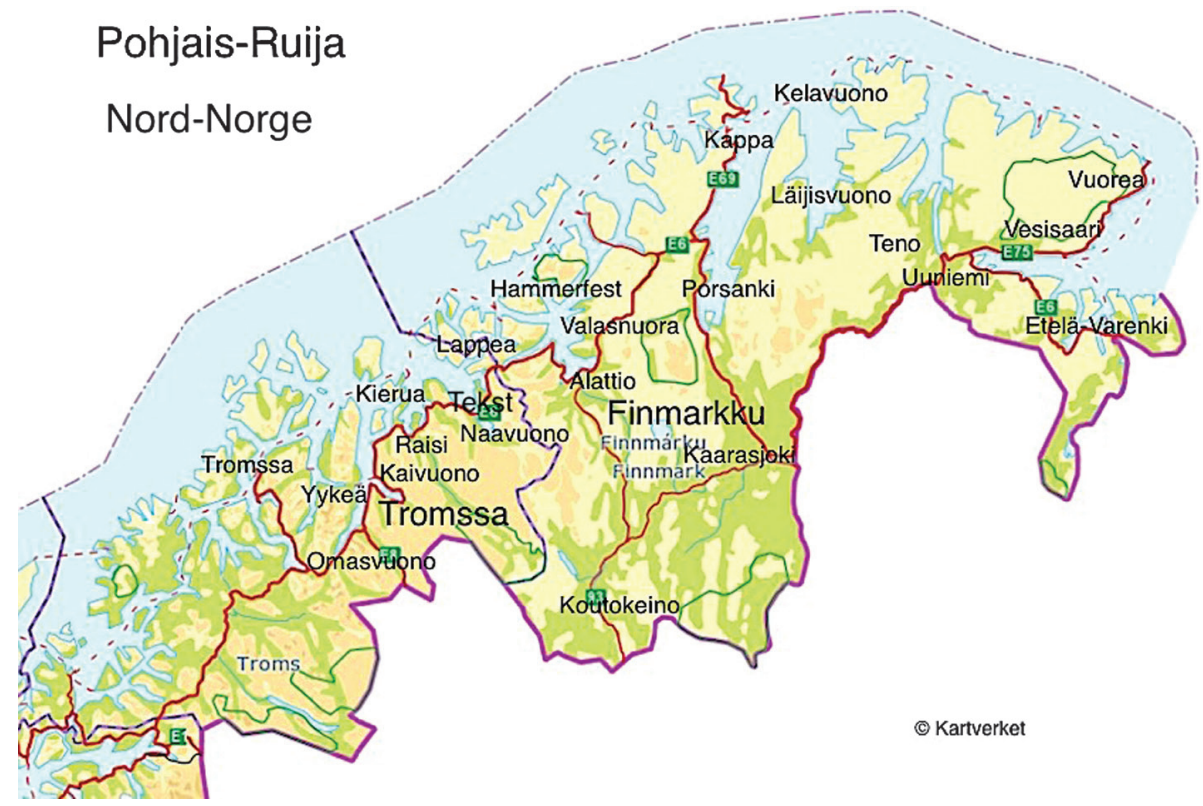

Kart 1.1 Tradisjonelle bruksområder for kvensk og viktigste kommuner (Kjelde: Norgeskart. De kvenske stedsnavna er lagt til av Eira Söderholm.) De norske navna er: Alattio = Alta, Etelä-Varenki = Sør-Varanger, Finmarkku $=$ Finnmark, Kaarasjoki $=$ Karasjok, Kaivuono $=$ Kåfjord, Kappa $=$ Nordkapp, Kelavuono $=$ Kjøllefjord, Kierua $=$ Skjervøy, Koutokeino $=$ Kautokeino, Lappea $=$ Loppa, Läijisvuono $=$ Laksefjord, Naavuono $=$ Kvænangen, Omasvuono $=$ Storfjord, Porsanki $=$ Porsanger, Raisi $=$ Nordreisa, Teno $=$ Tana, Tromssa $=$ Troms $\varnothing$, Troms, Uuniemi $=$ Nesseby, Valasnuora $=$ Kvalsund, Vesisaari $=$ Vads $\varnothing$, Vuorea $=$ Vardø, Yykeä = Lyngen

er overalt at det blir færre og færre som snakker språket, og at aldersstrukturen blant talerne er skeiv: Mens vi finner en god del språkbrukere blant de eldste generasjonene, så er det nesten ingen unge som behersker språket. De viktigste tradisjonelle bruksområda for kvensk er merka av på kart 1.1.

Ut fra en tradisjonell strukturlingvistisk synsvinkel regnes de kvenske dialektene til de nordfinske dialektene. I tillegg til kvensk består denne gruppa av dialektene på finsk side fra Kemi og nordover og alle de austersjøfinske dialektene på svensk side. Nå når kvensk og meänkieli har fått status som eigne språk, omtaler vi dem ikke lenger som dialekter. Om slike språk som likner svært mye på hverandre, har jeg begynt å bruke begrepet norspråk (på finsk og kvensk likikielet) (jf. for eksempel Söderholm 2001). Eksempler på nærspråk er kvensk, meänkieli og finsk. I en annen 
sammenheng har jeg satt opp en «nærspråksindeks» for disse tre språka (Söderholm 2010). Indeksen er regna ut basert på de 61 av Lauri Kettunens dialektkart som inneholder nok informasjon om kvenske dialekter og meänkielidialekter (Kettunen 1969). Karta gir en oversikt over tradisjonelle finske dialektmerker. Indeksen måler hvor like de tre nærspråka er jamført med hverandre. Dersom to språk deler et dialektmerke, så er likhetsverdien 1, ellers o. Gjennomsnittet av alle verdiene utgjør da likhetsindeksen mellom de to språka. Resultatet blir da slikt:

Kvensk versus meänkieli: 0,87

Kvensk versus finsk skriftspråk: 0,53

Meänkieli versus finsk skriftspråk: 0,52

Vi ser at målt på disse trekka står meänkielidialekter og kvenske dialekter svært nær hverandre. Hadde vi sett bort fra variasjonen og bare undersøkt om vi finner de samme formene på kartet, så ville likhetsverdien ha vært 1.

Men hvordan ser bildet ut om vi sammenlikner de kvenske dialektene med hverandre? Jeg har forsøkt å tallfeste variasjonen mellom kvenske dialekter ved å kartlegge forekomsten av 16 språktrekk. Det er for det meste trekk som Språktinget i begynnelsen av arbeidet sitt brukte som kriterier når det forsøkte å ta stilling til om man i standardiseringa av kvensk muligens skulle sikte seg inn mot nærspråka meänkieli eller kanskje finsk skriftspråk. I undersøkelsen har jeg brukt det samme materialet som jeg brukte som grunnlag for forslaga jeg utarbeida for Språktinget (se 1.2 ovafor). Framstillinga er ganske summarisk, og den er ikke gitt ut annetsteds.

Resultata er oppsummert i tabell 1.1. Der er dialektene rangert fra aust til vest med disse forkortelsene: $\mathrm{S}=$ Sør-Varanger, $\mathrm{V}=$ Vadsø, $\mathrm{T}=$ Tana, $\mathrm{P}=$ Porsanger, $\mathrm{A}=$ Alta, $\mathrm{Kv}=$ Kvænangen, $\mathrm{N}=$ Nordreisa, $\mathrm{K}=$ Kåford, $\mathrm{St}$ = Storfjord (Lyngen). Siste kolonnen viser forekomsten av trekka i Alf NilsenBørsskogs bøker (AB). Symbolene som er brukt i radene, betyr følgende: - = trekket forekommer (nesten) ikke, $(-)=$ ganske sjelden, $+/-=$ verken vanlig eller uvanlig, $(+)=$ ganske vanlig, $+=$ svært vanlig. Det må understrekes at vurderinga ikke er absolutt: For eksempel er første og andre persons personlige pronomen belagt som mie og sie i heile området, men hvor vanlige formene $m i$ og si er, varierer fra dialekt til dialekt. 
Tabell 1.1 Forekomst av 16 språktrekk i kvenske dialekter

\begin{tabular}{|c|c|c|c|c|c|c|c|c|c|c|}
\hline & S & v & $\mathrm{T}$ & $P$ & A & $\mathrm{Kv}$ & N & K & St & $A B$ \\
\hline $\begin{array}{l}\text { 1. H-flytting, for eksempel kouhluun } \\
\text { vs. koulhuun }\end{array}$ & + & + & $(-)$ & $(-)$ & - & + & $(-)$ & $(-)$ & $(-)$ & - \\
\hline $\begin{array}{l}\text { 2. Perfektum partisipp på - } t \text {, for } \\
\text { eksempel tullut vs. tullu }\end{array}$ & - & - & $(-)$ & - & $(-)$ & $+/-$ & - & - & - & - \\
\hline 3. Personlige pronomen mi og si & - & - & $(-)$ & $(-)$ & + & + & $+/-$ & + & $+/-$ & - \\
\hline $\begin{array}{l}\text { 4. Kongruens i flertall presens tredje } \\
\text { person, for eksempel het ova( }(t) \text { } \\
\text { ouva(t) vs. het oon }\end{array}$ & - & $(-)$ & - & - & - & $+/-$ & - & $+/-$ & - & - \\
\hline $\begin{array}{l}\text { 5. đs som 0-stadium av } t \text { vs. } j, v, h \text { eller } \\
\text { ingenting, for eksempel kota vs. kođan }\end{array}$ & - & - & - & $+/-$ & - & - & - & - & - & + \\
\hline $\begin{array}{l}\text { 6. Bortfall av -i i preteritum tredje } \\
\text { person, for eksempel löyty vs. löytyi }\end{array}$ & + & + & $(+)$ & - & $+/-$ & $(-)$ & $(-)$ & - & $(-)$ & - \\
\hline $\begin{array}{l}\text { 7. Preteritum tredje person flertall } \\
\text { identisk med andre person entall eller } \\
\text { med passiv, for eksempel het tulit vs. } \\
\text { het tulthiin }\end{array}$ & + & + & + & - & + & - & - & - & + & - \\
\hline $\begin{array}{l}\text { 8. Presens tredje person flertall på } \\
\text {-vA(t) vs. passivform, for eksempel } \\
\text { het tul(le) va( } t) \text { vs. het tulhaan }\end{array}$ & + & + & + & $+/-$ & + & + & $(+)$ & + & + & $+/-$ \\
\hline $\begin{array}{l}\text { 9. Spesialgeminering vs. } \\
\text { allmenngeminering, for eksempel } \\
\text { aikkaa vs. aikaa }\end{array}$ & - & - & - & $(+)$ & - & $(-)$ & $+/-$ & - & - & + \\
\hline $\begin{array}{l}\text { 10. Monoftongering av sluttvokalisme, } \\
\text { for eksempel pimmee vs. pimeä pimiä, } \\
\text { laattii vs. laattia, porstuu vs. porstua }\end{array}$ & - & - & $(-)$ & $(+)$ & - & $(-)$ & $(+)$ & - & - & + \\
\hline $\begin{array}{l}\text { 11. iA- vs. eA-kombinasjon ( ee), for } \\
\text { eksempel kauhia vs. kauhea kauhee }\end{array}$ & + & + & $(-)$ & $(-)$ & - & - & - & $+/-$ & $(-)$ & - \\
\hline $\begin{array}{l}\text { 12. Realisering av - } t \text { i former som } \\
\text { ajjaat vs. ajjaa, venet vs. vene, kaikilet } \\
\text { vs. kaikile, sinnet vs. sinne, läpit vs. } \\
\text { läpi }\end{array}$ & - & - & - & $+/-$ & $(+)$ & + & $(-)$ & $+/-$ & + & $+/-$ \\
\hline $\begin{array}{l}\text { 13. Bortfall av -a i partitiv flertall, for } \\
\text { eksempel marjoi vs. marjoja }\end{array}$ & - & - & - & $(-)$ & - & $(-)$ & $(-)$ & - & $(-)$ & + \\
\hline $\begin{array}{l}\text { 14. Illativ av 3. infinitiv på - } h \text { An vs. } \\
\text {-mhA(A)n, for eksempel tulehan vs. } \\
\text { tulemhaan }\end{array}$ & - & - & - & $(+)$ & - & - & $+/-$ & - & - & + \\
\hline $\begin{array}{l}\text { 15. UA-vs. OA-kombinasjon, for } \\
\text { eksempel maitua vs. matoa }{ }^{2}\end{array}$ & $(-)$ & $(-)$ & - & - & - & $(+)$ & - & $(+)$ & - & - \\
\hline $\begin{array}{l}\text { 16. Assimilasjon av -si verbstamme og } \\
\text { - } t \text { i ending, for eksempel pessä vs. pestä }\end{array}$ & + & + & $(-)$ & - & - & + & $(-)$ & + & - & - \\
\hline
\end{tabular}

2 I Kvænangen og Kåfjord blir $O$-endinga som regel til - $U$, og kombinasjonen $O A$ er derfor svært sjelden. 
Jeg har regna ut avstanden mellom dialektene ved at jeg for hvert trekk sammenlikna hver dialekt med seg sjøl og alle de andre dialektene og tallfesta likheta med distanseverdier fra 1 til o med mellomtrinna $0,75,0,5$ og 0,25 . Deretter har jeg regna ut den gjennomsnittlige distanseverdien for alle trekka mellom alle para av sammenlikna dialekter. Gjennomsnittet viser avstanden fra en bestemt dialekt til de andre dialektene. Jo nærmere 1 verdien er, jo likere er de to dialektene. Resultata er framstilt i tabell 1.2.

Ifølge tabellen ligger Sør-Varanger-dialekten nærmest Vadsø-dialekten $(0,98)$, Tana-dialekten nærmest Storfjord-dialekten $(0,83)$, som igjen ligger nærmest Alta-dialekten $(0,88)$. Porsanger-dialekten likner mest på Nordreisadialekten $(0,84)$, og kvænangsdialekten likner mest på Kåfjord-dialekten $(0,80)$. Språket til Alf Nilsen-Børsskog ligger ikke overraskende nærmest Porsanger-dialekten, men mens språket til Alf nesten er gjennomført konsekvent, så fins det variasjon i dialekten. Avstandsverdien blir derfor 0,83 .

En annen ting vi kan lese ut av tabellen, er at de kvenske dialektene ikke utgjør et dialektkontinuum hvor nabodialekter ligger hverandre nærmest. Unntaket er Varanger-dialektene, det vil si Sør-Varanger og Vadsø, som er svært like. Derfor blir det etter mitt syn ikke rett å dele dialektene inn i austlige og vestlige dialekter. Ei inndeling i fire grupper ser ut til å gi en mer treffende beskrivelse: (1) Varanger, (2) Tana, Alta og Storfjord, (3) Porsanger og Nordreisa, og (4) Kvænangen og Kåfjord. Det er mulig at utfallet blir et anna

Tabell 1.2 Forholda mellom dialektene

\begin{tabular}{|l|c|c|c|c|c|c|c|c|c|c|}
\hline & $S$ & $V$ & $T$ & $P$ & $A$ & $K v$ & $N$ & $K$ & $S t$ & $A B$ \\
\hline$S=1$ & 1 & 0,98 & 0,78 & 0,44 & 0,64 & 0,56 & 0,53 & 0,64 & 0,67 & 0,30 \\
\hline $\mathrm{V}=1$ & 0,98 & 1 & 0,77 & 0,42 & 0,63 & 0,58 & 0,52 & 0,66 & 0,66 & 0,28 \\
\hline $\mathrm{T}=1$ & 0,78 & 0,77 & 1 & 0,63 & 0,83 & 0,56 & 0,72 & 0,64 & 0,83 & 0,45 \\
\hline $\mathrm{P}=1$ & 0,44 & 0,42 & 0,63 & 1 & 0,58 & 0,50 & 0,84 & 0,58 & 0,67 & 0,83 \\
\hline $\mathrm{A}=1$ & 0,64 & 0,63 & 0,83 & 0,58 & 1 & 0,64 & 0,67 & 0,69 & 0,88 & 0,47 \\
\hline $\mathrm{K} v=1$ & 0,56 & 0,58 & 0,56 & 0,50 & 0,64 & 1 & 0,63 & 0,80 & 0,64 & 0,36 \\
\hline $\mathrm{N}=1$ & 0,53 & 0,52 & 0,72 & 0,84 & 0,67 & 0,63 & 1 & 0,64 & 0,73 & 0,70 \\
\hline $\mathrm{K}=1$ & 0,64 & 0,66 & 0,64 & 0,58 & 0,69 & 0,80 & 0,64 & 1 & 0,69 & 0,41 \\
\hline $\mathrm{St}=1$ & 0,67 & 0,66 & 0,83 & 0,67 & 0,88 & 0,64 & 0,73 & 0,69 & 1 & 0,50 \\
\hline $\mathrm{AB}=1$ & 0,30 & 0,28 & 0,45 & 0,83 & 0,47 & 0,36 & 0,70 & 0,41 & 0,50 & 1 \\
\hline
\end{tabular}


dersom noen av trekka i sammenlikninga byttes ut med andre trekk. Og vi kan også tenke oss at en grundigere analyse basert på et større materiale kan få fram andre forekomstverdier for de ulike trekka. Et anna problematisk aspekt ved den foreliggende undersøkelsen er at trekka er vekta likt. Men det er også slik at for eksempel gemineringsforskjeller veier tyngre enn forskjeller av typen pessä vs. pestä. Alt i alt er det like fullt grunn til å hevde at dialektisoglossene går på kryss og tvers av det kvenske språket. I denne grammatikken opererer jeg derfor ikke med noen bestemt dialektinndeling ved å sette opp formvarianter for ulike dialektgrupper. Men når det for én og samme kategori fins to eller flere godkjente varianter, så nevner jeg som regel hvilken variant som høver best med hvilken dialekt, for eksempel Porsanger (og Nordreisa) eller Varanger. Av og til snakker jeg også om Nord-Troms-dialekter. Men en mer spesifikk dialektinndeling har det verken vært ønskelig eller mulig å gjennomføre.

En stor del av dem som leser og lærer seg kvensk, kan i utgangspunktet ikke språket. I den praktiske språkundervisninga har jeg derfor brukt å dele grammatiske trekk inn i tre grupper, som jeg har kalt for varieteter. Det er (1) Porsanger og Nordreisa-varieteten, (2) Varanger-varieteten og (3) den såkalte elvedalsvarieteten, som høver for språkinnlærere fra alle de andre dialektområda. I den grad det fins variasjon mellom de ulike varietetene, så er språkeksempla i denne grammatikken alltid ordna på den måten at Porsanger og Nordreisa-varianten er oppført først, så kommer elvedalsvarianten, og til slutt står Varanger-varianten. Når det bare er to varianter, så er den første fra Porsanger og Nordreisa-varieteten, mens den andre representerer de andre varietetene.

Leseren som har kunnskap om sin eigen dialekt, står sjølsagt fritt til å kombinere dialekttrekk ut fra systemet i sitt eige talemål.

\subsection{Inspirasjonskjelder, mål og oppbygning}

Som jeg var inne på i avsnitt 1.2 ovafor, så kan vi regne Johan Beronkas framstillinger av dialektene i Porsanger og Vadsø som den første kvenske grammatikken (Beronka 1922; Beronka 1925). Men den foreliggende grammatikken er den første som gir ei samla framstilling av kvensk skriftspråk. Slik sett har den ikke hatt noe bestemt forbilde å bygge på. Jeg har likevel fått inspirasjon fra flere beskrivelser av finsk grammatikk. I mindre grad har jeg også konsultert samiske og norske grammatikker. 
Av de viktigste inspirasjonskjeldene kan følgende nevnes: Iso suomen kielioppi (Hakulinen mfl. 2004), Maria Vilkunas Suomen lauseopin perusteet (Vilkuna 1996), Anneli Pajunens Suomen verbirektiosta (Pajunen 1999) og Argumenttirakenne (Pajunen 2001), Klaus Peter Nickels Samisk grammatikk (Nickel 1994), og Norsk referansegrammatikk (Faarlund, Lie, og Vannebo 1997).

Ved å tilpasse disse framstillingene, forenkle dem, og kombinere dem på ulike plan har jeg utarbeida en modell som jeg i denne grammatikken bruker for å beskrive det kvenske språket. Det er likevel ikke lingvistisk teoriutvikling denne grammatikken sikter mot. Det primære målet med grammatikken er heller å presentere læreboknormalen som Språktinget har vedtatt, og på den måten være et hjelpemiddel for språkbrukere og de som ønsker å lære seg språket. Slik håper jeg at grammatikken kan komme til nytte både som oppslagsverk og som lærebok.

Boka er disponert slik: Først prøver jeg å gi et overordna bilde av hvordan det kvenske språket er bygd opp, og så følger en beskrivelse av morfofonologiske vekslinger og lydvariasjonen mellom dialektene. Deretter kommer et større kapittel om syntaks. Jeg syns det er enklere å lære seg de ulike bøyingsformene når en først har lært seg hvilke syntaktiske rammer de kan opptre i. Etter syntakskapitlet går vi i detalj gjennom nomen- og verbmorfologien. For hver kategori er det også kort oppgitt hvilke syntaktiske omgivelser den brukes i. Deretter presenterer jeg i tur og orden ordklassene pronomen, tallord, adverb, adposisjoner (preposisjoner og postposisjoner), og til slutt junksjoner, det vil si konjunksjoner og subjunksjoner. De siste tre ordklassene er beskrevet fra en semantisk-syntaktisk synsvinkel.

Orddannelse er ikke omtalt i denne grammatikken. Temaet er nesten ikke forska på, og Språktinget har ikke behandla det enda. Beronkas Iagttagelser fra orddannelses- og formloeren gir blant anna en oversikt over en god del avleiingssuffikser og bruken av dem (Beronka 1925). 



\section{2 \\ Hvordan er kvensk bygd opp?}

Vi skal først bli kjent med grunnstrukturen i det kvenske språket. Vi ser på hva slags lyder som fins i språket, hvordan disse kommer til uttrykk i skrift, hvilke element ord er bygd opp av, og hva slags grunnregler som gjelder for hvordan ord kombineres til setninger.

\subsection{Lyd og skrift}

Hovedprinsippet mellom uttale og skrift er at én og samme bokstav bestandig svarer til én og samme lyd. Også lengda på lydene markeres på en entydig måte. Slik sett er kvensk lett å lese og skrive.

\subsubsection{Lyd}

Lydinventaret i kvensk består av disse LYDENE: /a $\delta$ e f h i j k l m n n o p r s t u v y ä ö/. Av disse er /a e i o u y ä ö/ vOKALER, resten er KONSONANTER. I lånord forekommer også konsonantene /b d g/, og i stedsnavn som er lånt fra samisk, finner vi konsonanten $/ \mathrm{J} /$, som uttales på samme måte som $s h$ i engelsk, det vil si som vislelyd. Når det i denne grammatikken er tale om en hvilken som helst konsonant, så er den symbolisert med stor K. Vokalene /o u ö y/ er labiale eller runda vokaler. Det vil si at leppene er runda når vi uttaler dem. De andre vokalene er urunda, det vil si at munnvikene er dratt litt ut til sidene. Vokaler er alltid sтемте, og luftkanalen er åpen når de uttales. Videre deler vi vokaler inn i to grupper basert på om tunga er plassert bak eller foran i munnhula når vi uttaler dem. BAKRE VOKALER er /a o u/, FREMRE VOKALER er /ä ö y i e/. I suffikser forekommer det veksling mellom de bakre vokalene /a o u/ og de fremre vokalene /ä ö y/, og som fellesbetegnelse for slike vokalvekselpar bruker 
vi A for /a/ eller /ä/, O for /o/ eller /ö/, og U for /u/ eller /y/. En hvilken som helst vokal symboliserer vi med stor $\mathrm{V}$.

Konsonantene /f h k p s t/ er USTEMTE, det vil si at stemmebanda ikke vibrerer når vi uttaler dem. Derimot er det vibrasjon i stemmebanda når vi uttaler de stemte konsonantene $/ \delta \mathrm{j} \mathrm{m} \mathrm{n} \mathrm{n} \mathrm{r} /$. Konsonanten $/ \delta /$ forekommer bare i stadieveksling sammen med $/ \mathrm{t} /$. Det vil si at dersom ei ordform inneholder $/ \delta /$, så finner vi alltid også /t/ i ei anna form av det samme ordet. Uttalen av / $\delta /$ er som den første lyden i det engelske ordet there. I dagens kvensk høres denne lyden bare i Porsanger, de andre varietetene har mista den.

Konsonantene / $\mathrm{k} \mathrm{t}$ / kalles for PLOSIVER. I norsk er de aspirerte, det vil si at man hører en tydelig $h$-lyd når lufta blir sluppet ut etter at luftkanalen blir åpna igjen. I kvensk blir de uttalt uten aspirasjon. Derfor høres de i norske ører ofte ut som $/ \mathrm{g} \mathrm{b} \mathrm{d/.} \mathrm{Men} \mathrm{de} \mathrm{er} \mathrm{likevel} \mathrm{ustemte,} \mathrm{som} \mathrm{i} \mathrm{norsk.}$

Lyden /f/ finner vi stort sett bare i lånord. Men den forekommer også i andre ord, nemlig i bøyingsformer når /v/ havner ved sida av /h/. Da blir den uttalt som /ff/. Vi ser det for eksempel i sg. nom. og sg. gen. av ordet taivas ('himmel'), taivas : taivhaan. Den siste forma blir av mange morsmålsbrukere av kvensk uttalt som /taiffān/, men man kan også høre uttalen /taivhān/.

\subsubsection{Skrift}

I kvensk gjelder det samme ortofone hovedprinsippet som i finsk om at én lyd svarer til én bokstav. Det eneste større unntaket er skrivemåten av /y/-lyden. Lyden forekommer bare som kort variant $(/ \mathrm{h} /)$ foran $/ \mathrm{k} /$, og som lang variant (/ny/ i stadievekslingspar sammen med /nk/. Eksempler er /kenkä ('sko') :

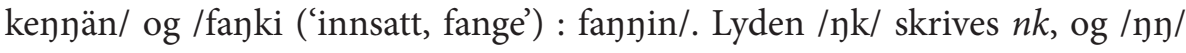
skrives ng. Eksemplene blir da kenkä : kengän, fanki : fangin. Det andre unntaket er at $v h$ ofte blir uttalt /ff/ (se avsnitt 2.1.1 ovafor).

Bokstaver i kvensk:

$a, b, d, d, e, f, g, h, i, j, k, l, m, n, o, p, r, s, \check{s}, t, u, v, y, \ddot{a}, \ddot{o}$.

Ellers kan vi nevne her at $/ \delta /$ skrives som $\hbar$, og at $/ \delta /$ skrives som š. Blant vokalene kan vi legge merke til følgende forskjeller fra norsk: Bokstaven $o$ uttales som norsk $\stackrel{a}{a}, u$ uttales som norsk $o$, og $y$ uttales som norsk $u$. I visse lånord eller sitat får man også bruke bokstavene $c, q, w, x, z$, å etter mønster av kjeldespråket. 


\subsubsection{Lydlengde}

Kvenske lyder kan være korte eller lange. Lengdeopposisjonen blir uttrykt i skrift på følgende måte: Når lyden er kort, skrives den med bare enkelt bokstav, når lyden er lang, skrives den med to bokstaver. Eksempler: tuli /tuli/ ('han kom'), tuuli /tu:li/ ('vind'), tulli /tul:i/, tullii /tul:i:/ ('toll').

\subsubsection{Diftonger og deres plassering i ordet}

Diftonger er vokalkombinasjoner som uttales som enhet innafor én og samme stavelse. I kvensk finner vi følgende diftonger i første ordstavelse:

Diftonger på -i: ai, ei, oi, ui, yi, öi. Eksempler: laina ('lån'), keino ('retning, veg'), koira ('hund'), kuiva ('tørr'), plyijy ('bly'), tröijy ('trøye').

Diftonger på -o og -ö: uo, yö. Eksempler: huoli ('bekymring'), työ ('arbeid').

Diftonger på -u og -y: au, eu, ou, äy, öy. Eksempler: sauna ('bad, badstue'), neula ('nål'), koulu ('skole'), häyttyy ('må), köyhä ('fattig').

I bøyingsformer av pronomenet nuot ('de der') finner vi også triftonger: nuoilta, nuoitten osv. I dialektene forekommer også andre typer triftonger.

I andre ordstavelser enn i første stavelsen finner vi kun diftonger på - $i$, som for eksempel i havaita ('legge merke til'), taloissa ('i husa'), aurinkoinen ('solrik'). Andre vokalkombinasjoner blir delt opp i stavelser. For eksempel deles ordet kaota ('forsvinne') opp i stavelsene ka-o-ta, og ordet taphaus ('hendelse') i tap-ha-us.

\subsection{Stavelser}

Kvenske ord består av én eller flere stavelser. En stavelse kan igjen bestå av én eller flere lyder. Reglene for stavelsesgrense er enkle, og det samme gjelder stavelsestrykket. Vi ser her nærmere på disse stavelsesegenskapene.

\subsubsection{Hva er en stavelse?}

Ord er satt sammen av stavelser, som igjen er satt sammen av lyder. For eksempel er ordet kai-nu-lai-sis-ta ('fra/om kvener/kvenene') satt sammen av fem stavelser. Hovedregelen for stavelsesdeling er at det går ei stavelsesgrense foran hver kombinasjon av konsonant og vokal. 
Noen ganger går stavelsesgrensa også mellom to vokaler, som i ordet $A$-latti-o ('Alta'). Men det er ikke vanlig ettersom to vokaler som følger etter hverandre, vanligvis blir realisert som diftong, og da hører de til samme stavelse.

Når to etterfølgende vokaler hører til hver sin stavelse, merker vi av stavelsesgrensa med', som i (sata 'hundre' $\rightarrow$ ) sa'as ('hundrede'), (hauki 'gjedde':) hau'issa ('i gjedda'). Merket er likevel bare brukt dersom ordet ellers kan leses feil. Vi skriver altså for eksempel (tieto 'opplysning; kunnskap' :) tieot, (joki 'elv' :) joen og (lauta 'fjøl, bord' :) lauan. Kvensk har ikke diftongene eo, oe eller ua, og derfor veit vi at stavelsesgrensene i disse orda går slik: tie-ot, jo-en og lau-an. (Om diftonger se avsnitt 2.1.4 ovafor.)

\subsubsection{Stavelsestrykk}

Kvensk har klare regler for STAVELSESTRYKK. Det fins tre typer stavelsestrykk: Hovedtrykk (eller mest trykk), вІтRYкк (eller mindre trykk) og тRYKкSVAKE stavelser (enda mindre trykk eller nesten ingen trykk). Regelen for hvor disse tre typene opptrer, er enkel. Første stavelsen har alltid hovedtrykk. Deretter er annenhver stavelse trykksvak, og annenhver har bitrykk. Den siste stavelsen er alltid trykksvak.

I ordet kai-nu-lai-ses-sa-ki ('også i/hos kvenen/kvensk') for eksempel har første stavelsen kai hovedtrykk, andre stavelsen $n u$ er trykksvak, tredje stavelsen lai har bitrykk, fjerde stavelsen ses er trykksvak, femte stavelsen $s a$ har bitrykk, og sjette og siste stavelsen ki er trykksvak. Stavelser som har hovedtrykk eller bitrykk, kaller vi for TRYKKSTERKE stavelser.

\subsubsection{Stavelseslengde}

I kvensk er stavelseslengda uavhengig av stavelsestrykket. Her skiller kvensk seg fra for eksempel norsk. Derimot har det noe å si for stavelseslengda om ordet gjennomgår stadieveksling og i så fall hva slags type stadieveksling (om stadieveksling se avsnitt 3.1.1 nedafor).

Det fins to typer stavelseslengder: KorTe STAVELSER og LANGe STAVELSER. En kort stavelse slutter på kort vokal, og en lang stavelse slutter på lang vokal eller diftong, eller på konsonant. For eksempel består ordet ko-ta ('gamme, koie') av to stavelser, som begge er korte. Også ordet pie-ni ('liten') er satt sammen av to stavelser, men her er den første lang og den andre kort. Ordet 
A-lat-ti-o ('Alta') har fire stavelser, hvorav den andre er lang og alle de andre korte. I ordet kai-nu-lai-ses-ta ('fra/om kvenen/kvensk') er den første stavelsen $k a i$, den tredje stavelsen lai, og den fjerde stavelsen ses lange, mens den andre stavelsen $n u$ og den siste stavelsen ta er korte.

\subsection{Ordbygning}

I utgreiinga vår om hvordan kvensk er bygd opp, skal vi nå flytte oss fra stavelsesnivået til ordnivået. Vi skal her ta for oss ordbygginga, det vil si hvordan lyder og stavelser blir kombinert til ord, hvilken rekkefølge morfem står i, samt hva slags stammer ord bygges på.

\subsubsection{Konsonanter i ordbegynnelse, -kjerne og -slutt}

Arveorda i kvensk har tradisjonelt vært tostava, og noen pronomen også enstava, og de har hatt strukturen $(K) V(V) K(K) V$. Eksempler er pata ('gryte'), kukka ('blomst'), paska ('skit'), pieni ('liten'), ääni ('stemme; lyd'). I dagens kvensk fins det også enstava ord som työ ('arbeid'), tie ('veg'), juo- ('drikk!'), vie- ('bring!'). Ord med flere enn to stavelser er avleid av tostava ord, eller så er de lånord. Lån har også ført til andre endringer i språket. I dagens kvensk kan konsontantstrukturen i ord beskrives slik:

- I begynnelsen av et ord kan det være en hvilken som helst lang eller kort vokal eller diftong eller en enkelt konsonant, bortsett fra $d$. I lånord finner vi også konsonantkombinasjoner ordinitialt. Vanlige konsonantkombinasjoner er:

På -l: $f l, k l, p l, s l$. Eksempler: fläkki ('flekk'), flasku ('flaske'), klasi ('glass'), kläppi ('barn'), plassi ('plass'), plokata ('plukke'), sliipata ('kvesse'), sluuka ('sluk').

På -r: fr, kr, pr, tr. Eksempler: frahti ('frakt'), frouva ('frue'), kravata ('skrape'), kraatari ('skredder'), pruuni ('brun'), pruukata ('bruke'), trappu ('trapp'), trolli ('troll').

kn: For eksempel knappi ('knapp'), knuppi ('knott, knapp'), knippu ('knippe').

De fleste slike ord er gamle lån fra svensk, og de fins også i de fleste finske dialekter og i meänkieli i Sverige. 
Andre ordinitiale konsonantklynger er $k v, s k r, s k$, sp og str. Eksempler: kvartti ('kvarter'), kvääni ('kven'), skruvi ('skrue'), skarffa ('skarv'), spiuni ('spion'), staara ('tare'), strenka ('streng'). Slike ord er som regel nyere lån fra norsk eller samisk.

- Rundt første stavelsesgrensa i ordet kan det forekomme én eller ingen konsonant, som for eksempel i joki ('elv') : joen/jo.en/ joven. Slike kaller vi for KJERNEKONSONANTER eller KJERNEKONSONANTKOMBINASJONER, dersom det er snakk om to eller flere ulike slike konsonanter. Hvilken som helst konsonant kan fungere som kjernekonsonant, også i lang versjon, som for eksempel i orda pannu ('panne') og koukku ('krok'). Tabell 2.1 gir en oversikt over mulige kjernekonsonantkombinasjoner av to konsonanter.

Tabell 2.1 Kjernekonsonantkombinasjoner av to konsonanter

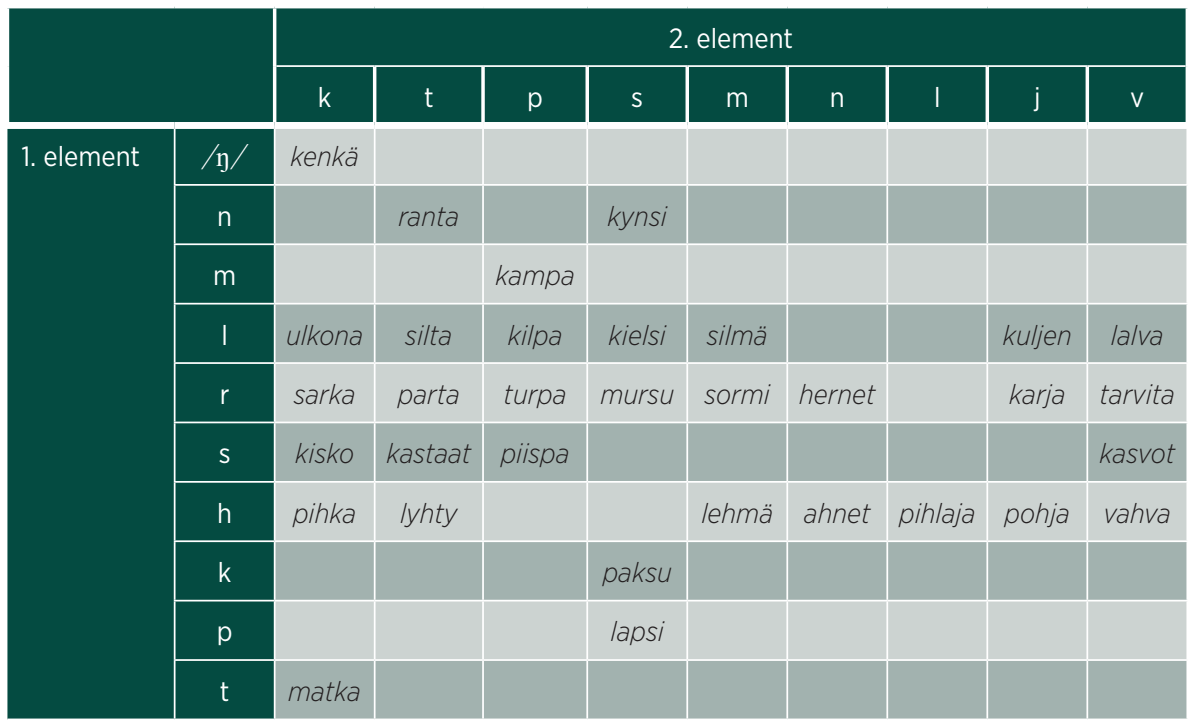

Er første elementet en stemt konsonant (/n n m l r/), så kan andre elementet være en lang ustemt konsonant (/k t p s/), for eksempel pankku ('bank'), kynttilä ('talglys'), purssuut ('renne over'), lamppu ('lampe'), hirttäät ('henge').

Særlig i nyere lånord finner vi også andre konsonantkombinasjoner. Eksempler er linja ('linje'), räknätä ('regne'), traktori ('traktor'), autsi ('trang dal').

Også kombinasjoner av tre forskjellige konsonanter er mulig. I slike tilfeller hører de to første til første stavelsen, og den tredje til andre stavelsen. Slike kombinasjoner er likevel sjeldne, bortsett fra $r s t$ og $r s k$, som er ganske vanlige. 
Eksempler på sistnevnte er: pyrstö ('spord'), hurskas ('from'), porstua ('bårstue, gang'), myrsky ('uvær, storm'), hersku ('godbit'), turska ('torsk'), tirskuttellee ('fnise'). Eksempler på de andre, svært sjeldne kombinasjonene finner vi bare i lånord: pukstaavi ('bokstav'), hanska ('hanske'), sentrumi ('sentrum'), engelska ('engelsk'), spanska ('spansk'), altso ('altså), kräntsi ('grense'), vekslata ('veksle penger'), intressi ('interesse'), kontrakti ('kontrakt'), astma ('astma').

- I posisjoner lenger ute i ordet er det enda færre konsonantkombinasjoner som er mulige. Da er det som regel snakk om at sluttkonsonanten i den delen av ordet som suffiks er føyd til, blir stående ved sida av første konsonanten i suffikset, eller så er det en kombinasjon av konsonanter inni suffikset (om suffikser se avsnitt 2.3.2 nedafor). Vanligst er kombinasjoner på - $t$ $(n t, l t, r t, s t, h t)$, på - $k(n k, l k, r k, s k)$, på -s $(n s, l s, r s, k s)$ og $m p$. Eksempler er: parantunnu ('blitt bedre'), puhaltannu ('blåst'), kumartui ('bøyde (seg) framover'), kalastaat ('fiske'), tapahtuut ('hende'), aurinko ('sol'), voitanko ('vinner jeg?'), ajatelkaa ('tenk!'), ymmyrkäinen ('rund'), äitinsä ('mor si'), puhalsin ('jeg blåste’), kumarsin ('jeg bukka'), kysymykset ('spørsmål'), parempi ('bedre'). I Porsanger-varieteten finner vi i stedet for $h t$ som regel $t$, for eksempel tapattuut ('hende').

Såkalt flytte- $h$ kan stå sammen med hvilken som helst konsonant. Eksempler er (sg. nom. : sg. ill.) suku ('slekt') : sukhuun, pörsi ('pengepung') : pörshiin, myrsky ('uvær, storm') : myrskhyyn, (1. inf. : 3. inf. ill.) jakkaat ('dele') : jakamhaan, maata ('ligge') : makkaamhaan, (sg. nom. : pl. nom.) venet ('båt') : venheet, kirkas ('lys, klar') : kirkkhaat. (H-flytting er forklart nærmere i avsnitt 3.1.3 nedafor.)

- Ord kan også slutte på konsonant, men bare på enkelt konsonant. Unntak er ord som er blitt forkorta, for eksempel kans < kansa ('med'). Ordfinalt forekommer konsonantene $n, l, r, s$ og $t$. Eksempler er: paimen ('gjeter'), kyynel ('tåre'), sisar ('søster'), kirkas ('lys, klar'), venet ('båt').

\subsubsection{Morfemrekkefølge}

Kvensk er et såkalt AGGLUTINERENDE språk. Det betyr at ord er satt sammen av morfem som legges til etter hverandre, og som hvert endrer litt på ordets betydning og funksjon. I kvensk finner vi også MORFOFONOLOGISKE VEKSLINGER på innsida av ord, men uten at de påvirker ordbetydninga eller funksjonen. Vi skiller mellom følgende morfemtyper: 
- Rotmorfem, som er ordets minste deler med eiga, sjølvstendig betydning;

- AVLEIINGSMORFEM, som brukes til å avleie nye ord;

- BØyingsmorfeM, som uttrykker tall (entall eller flertall), tempus (= tid), modus (= måte) osv., eller med andre ord hva slags funksjon ordet har i setninga.

Avleiings- og bøyingsmorfem legges alltid til etter rota i ordet, og begge typene kan derfor kalles for suFFIKs. I tillegg fins det

- ENKLitika (sg. enklitikon), som egentlig ikke er del av ordet, men som forteller hvordan ordet forholder seg til andre ord eller også andre setninger. I kvensk skrives enklitika som en del av ordet, og de blir lagt til heilt til slutt i ordet. Gruppa av enklitika i kvensk består av sPøRREENKLITIKONET $k O(1)$, enklitikonet $k i(1,4,5,6)$, som betyr det samme som kans ('også), enklitikonet $k h A A n(2,3)$, som i nektende setninger brukes som motstykke til $k i$, og de modifiserende enklitikaene $h A n(4), p A(2,5)$ og $p A s(6)$.

Når spørreenklitikonet $k O$ og det modifiserende enklitikonet $h A n$ legges til samme ord, så smelter de gjerne i hop til khOOn (7). Videre kan vi merke oss at når enklitika som begynner på $k$, legges til ordformer som slutter på $t$, så blir denne $t$-en i talespråket som regel assimilert av $k$-en (1).

1. Meinaatko [meinaakko] sieki tulla myötä, vaikka pojatki [pojakki] tulhaan? 'Vil også du bli med, sjøl om også guttene kommer?'

2. Miepä en kyllä lähđe teiđän myötä, eikä kyllä Pekkakhaan.

'Jeg blir nok ikke med dere, og heller ikke med Peder.'

3. Äläkä luulekhaan, ette mie annan sulle rahhaa!

'Ikke tru engang at jeg skal gi deg penger!'

4. Olishan sitä sullaki rahhaa, jos olisit vähäsen säästäny.

'Også du ville ha hatt penger om du hadde spart litt.'

5. Olipa tietenki ennenki kummituksii.

'Det fantes sjølsagt spøkelser også før i tida.'

6. Tulepas sieki myötä!

'Bli (nå) med, du òg!'

7. Lähtiskhöön sitä vielä tääpänä pyythöön?

'Mon tru om vi skal dra ut på fiske enda i dag?' 
Nomen og verb har i prinsippet samme oppbygning sjøl om de bruker forskjellige avleiings- og bøyingssuffikser.

- Oppbygning av nomen: rot (+ avleiingssuffiks + avleiingssuffiks ...) (+ tall) (+ kasus) (+ enklitika)

For eksempel er substantivforma kainulaisilaki ('også hos kvenene') (av substantivet kainulainen ('kven'), som er avleid av substantivet kainu ('kvensk')) bygd opp slik:

kainu + lais $+\quad i+\quad l a+\quad k i$

rot avleiingssuffiks tall kasus enklitikon

Substantivforma opettajastako ('om/fra læreren?') (av substantivet opettaja ('lærer'), som er avleid av verbet opetta/a( $t$ ) ('undervise'), som igjen er avleid av verbet oppi/it oppi/a(t) ('lære')) er bygd opp slik:

ope $+\quad \mathrm{tta}+\mathrm{ja}+\quad$ sta $+\quad k o$

rot avleiingssuffiks avleiingssuffiks kasus enklitikon

- Oppbygning av finitte verb: rot (+ avleiingssuffiks + avleiingssuffiks ...) (+ tempus/modus) + personsuffiks (+ enklitika)

For eksempel er verbforma muistelimmako ('fortalte vi?') (av verbet muistela ('fortelle'), som er avleid av verbet muista/a(t) ('huske')), bygd opp slik:

$\begin{array}{lllll}\text { muist }+ & e l+ & i+ & m m a+ & k o \\ \operatorname{rot} & \text { avleiingssuffiks } & \text { tempus } & \text { personsuffiks } & \text { enklitikon }\end{array}$

Verbforma ajelisittepa ('bare dere kjører nå litt') (av verbet ajel/a ('småkjøre'), som er avleid av verbet ajja/a(t) ('småkjøre, kjøre rundt')) er bygd opp slik:

$\begin{array}{lllll}a j+ & e l+ & i s i+ & \text { tte }+ & p a \\ \text { rot } & \text { avleiingssuffiks } & \text { modus } & \text { personsuffiks } & \text { enklitikon }\end{array}$

Infinitte verbformer er bygd opp på tilsvarende måte. Hovedpoenget her er at det første morfemet i ordet er rota, så kommer avleiingssuffiks, deretter bøyingssuffiks, og til slutt eventuelle enklitika.

Det fins likevel ett unntak fra det som er sagt ovafor. Kvensk har også et såkalt privativt PREFIKS, nemlig epä-, som blir lagt til i begynnelsen av ordet, altså framfor rota. Prefikset legges til adjektiv og til dels også substantiv for å lage nye adjektiv og substantiv. Det avleide ordet uttrykker da som regel det 
motsatte av grunnordet, eller fravær av det grunnordet står for (jf. prefikset $u$ - i norsk). Eksempler er epätavalinen ('uvanlig'), epäselvä ('uklar'), epäjumala ('avgud').

I denne grammatikken markerer vi morfemgrenser med skråstreker, som for eksempel i kainu/lais/i/la ('hos kvenene'), anne/tta/is ('skulle gi'), hyppää/ $m \ddot{a} / s s a ̈$ ('holder på med å hoppe'). Når vi bare behandler bøyingsmorfologi, skiller vi ikke mellom avleiingssuffiks, og den første skråstreken markerer da grensa mellom ordstamme og bøyingssuffiks, som for eksempel i suomalaise/t ('finner'), og eventuelle følgende skråstreker markerer grensa mellom bøyingssuffiks, som for eksempel i paijuko/i/ssa ('i vierkrattene') og matkust/i/mma ('vi reiste').

\subsubsection{Ordstammer}

Den delen av ordet som bøyingsmorfem legges til, kaller vi her for STAMME. Stammen består av rotmorfemet og, dersom ordet er avleid, i tillegg av ett eller flere avleiingsmorfem.

Et og samme ord kan ha flere ulike stammer. De to hovedtypene er VOKALSTAMMER og KONSONANTSTAMMER. Vokalstammer slutter på vokal, og konsonantstammer slutter på konsonant. For eksempel bøyes verbet tulla ('komme') slik (1. inf. : akt. ind. pres. 1. sg. : akt. ind. pres. 3. sg.): tul/la : tule/n : tulle/e. Stammen i 1. infinitiv er da tul-, og det er verbets konsonantstamme, mens tulle- og tule- er verbets vokalstammer. Når det gjelder bøyingsmønstre som for eksempel i adjektivet (sg. nom. : sg. gen. : sg. part. : pl. iness.) pieni ('liten') : pieni:piene/n:pien/tä:pien/i/ssä, så sier vi at det bare er i entall partitiv, pien/ tä, vi har med konsonantstamme å gjøre. Flertallsforma i inessiv, pien/i/ssä, analyserer slik at det er lagt til en flertalls- $i$ til vokalstammen piene-, og at sluttvokalen $e$ har falt bort foran $-i$. Altså på denne måten:

$$
\begin{aligned}
& \text { pien }+ \text { tä }>\text { pien } / \text { tä } \\
& \text { piene }+i+\text { ssä }>\text { pien } / i / s s \ddot{a}
\end{aligned}
$$

Med andre ord finner vi konsonantstammer bare foran suffiks som sjøl også begynner på konsonant. Ellers har vi med vokalstammer å gjøre.

Alle ord har vokalstamme, mens konsonantstamme finner vi bare hos ord av bestemte bøyingstyper. Ord som bare har vokalstamme, kaller vi for ENSTAMMA ord, og slike som har både vokal- og konsonantstamme, kaller vi 
for tOstamma ord. Noen Verb har to typer vokAlstammer, en kort og en lang, og slike verb kaller vi for verb med to vOKALSTAMMER. Siste lyden i stammen kaller vi for henholdsvis STAMMEVOKAL og STAMMEKONSONANT.

Hos nomen kan stammen være identisk med nominativsforma i entall, som også er oppslagsforma som er brukt i ordbøker og ordlister. Det gjelder enstava ord som for eksempel (sg. nom. : sg. gen. : sg. part.) maa ('jord, land’) : maa/n : maa/ta og lengre ord som slutter på $-A(=\mathrm{a} / \mathrm{a}),-O(=o / \ddot{o}),-U(=u / y)$ eller $-V i$, som for eksempel (sg. nom. : sg. gen. : sg. part.) matka ('reise') : matka/na : matka/a, juoppo ('fyllik') : juoppo/na: juoppo/o, fyyry ('fyr') : fyyry/nä:fyyry/y, maanantai ('mandag') : maanantai/na : maanantai/ta. Også stammen i noen av orda på -Ki er identisk med nominativsforma, som for eksempel takki ('jakke; kofte') : taki/n, äiti ('mor’) : äiti/n. Ofte må vi likevel ty til andre bøyingsformer for å identifisere ordstammen. I de følgende orda går stammen fram av entallsformene i genitiv og partitiv: (sg. nom. : sg. gen. : sg. part.) pieni ('liten') : piene/n : pien/tä, kainulainen ('kven; kvensk') : kainulaise/n : kainulais/ta. I orda (sg. nom. : sg. gen. : sg. part.) ty(t)är ('datter; jente') : tyttäre/n : tytär/tä og rakas ('kjære') : rakkhaa/n : rakas/ta er konsonantstammen identisk med nominativsforma, men vokalstammen finner vi i genitiv.

Hos verb er stammen aldri identisk med oppslagsforma. Som oppslagsform brukes 1. infinitiv, for eksempel lähtelet lähtelä lähti/ä ('dra av gårde'), kulkkelet $\sim$ kulkela kulkila ('vandre, gå), kirjoitta/a(t) ('skrive'), tul/la ('komme'), men/nä ('gå), kiusa/ta ('plage'), som dannes med hjelp av suffiks. For å få fram verbstammen må vi altså ta bort bøyingssuffiksa.

Ordet stamme bruker vi også om ordformer som inneholder bøyingssuffiks. Vi snakker for eksempel om FLERTALLSSTAMME, som inkluderer flertallssuffikset $-i$, og om PASSIVSTAMME, som er den verbstammen som passivsuffikset festes til.

Vi deler orda inn i ulike bøyingsklasser basert på hva slags stammer de har. De ulike bøyingsklassene og stammene blir diskutert nærmere når vi tar for oss verb- og nomenbøyinga (jf. kap. 5 og 6).

\subsection{Setningsbygning}

Begrepet SETNING er her brukt om enheter som inneholder ei finitt verbform som knytter til seg andre aktører eller komplement, for eksempel subjekt, objekt, adverbial eller predikativ. Ei finitt verbform har personbøying og fungerer som VERBAL i setninga. I funksjonsanalyser forkorter vi verbalet med V. 


\subsubsection{Fraser og ordklasser}

Setninger er satt sammen av FRASER eller ordgrupper som hører sammen. Ordene i en frase kan ikke skilles fra hverandre, og de må flyttes i lag dersom vi skal bevare innholdet i setninga. Vi kan også si at faser fungerer som SETNINGSLedd. Setninga Pieni vihrinen mies syö mielelä ruijalaista kallaa, mitä myyähään Marsin torila ('Den lille grønne mannen spiser gjerne norsk fisk som selges på torget på Mars') kan vi forkorte til Mies syö kallaa ('Mannen spiser fisk') uten å endre på grunnstrukturen i setninga. Hvert ord som står igjen i denne siste setninga, kan altså representere hver sin frase i den første, uforkorta setninga. Vi sier at slike ord utgjør KJERNEN i frasen de inngår i. Ord som står i tillegg til kjernen, men som kan tas bort uten at grunnstrukturen i setninga blir endra, kaller vi for MODIFIKATORER i frasen.

Når vi analyserer setningsstrukturen, markerer vi frasegrensene med hakeparenteser ([...]), som i (1)-(3) nedafor:

1. [Pieni vihrinen mies] syö [mielelä] [ruijalaista kallaa, mitä myyđhään Marsin torila].

'Den lille grønne mannen spiser gjerne norsk fisk som selges på torget på Mars.'

2. [Viisi tytärtä] seisoi [torin vieressä] [kattomassa häntä].

'Fem jenter sitter på torget og ser på han.'

3. [Het] nähthiin [hänen syövän paljon kallaa].

'De ser han spise mye fisk.'

Frasene kan videre deles opp i fraser, og vi får da en analyse som i (1)-(3):

1. [[Pieni] [vihrinen] mies] syö [mielelä] [[ruijalaista] kallaa, [[mitä] myyđhään [[Marsin] torila]]].

2. [Viisi [tytärtä]] seisoi [[torin] vieressä] [kattomassa [häntä]].

3. [Het] nähthiin [[hänen] syövän [paljon [kallaa]]].

Består en frase av kun ett ord, kan vi også sløyfe hakeparentesene.

Frasene får navn etter ORDKLASSEN til frasekjernen. I denne grammatikken opererer vi med disse ordklassene: VERB, SUBSTANTIV, ADJEKTIV, PRONOMEN, TALLORD, ADVERB, ADPOSISJONER Og JUNKSJONER.

Verb er ord som bøyes i PERson, og som fungerer som setningskjerne. Vi sier likevel ikke at den finitte verbforma utgjør en verbfrase, ettersom verbet 
som regel er hovedelementet i heile setninga og det ikke gir meining å bruke samme termen om en frase som om heile setninga. Men verb opptrer også i INFINITTE former, nærmere bestemt INFINITIVER OG PARTISIPP, og disse danner verbfraser, nærmere bestemt INFINITIVSFRASER Og PARTISIPPFRASER. Verbfraser forkorter vi med VP (jf. engelsk Verb Phrase). I setninga Liisa kävi ostamassa sykkelin ('Lisa gikk og kjøpte en sykkel') er [ostamassa sykkelin] en verbfrase, og kjernen i den er 3. infinitivsforma ostamassa.

Om substantiv, ADJEKTIV, PRONOMEN og TALLORD brukes også fellesbetegnelsen nomen. De har til felles at de bøyes i kasus og tall. Størst likhet er det mellom substantiv og adjektiv: De har samme type kasus- og tallbøying. Ofte er det også slik at det samme ordet kan fungere både som substantiv og som adjektiv. For eksempel fungerer ordet valkkee som substantiv i setninga Valkkee levis koko metthään ('Ilden spredde seg gjennom heile skogen'), men i setninga Matti osti valkkeen piilin ('Mats kjøpte en lys bil') fungerer det som adjektiv. Når et ord fungerer som substantiv i ei setning, så danner det en SUBSTANTIVFRASE (= NP; jf. engelsk Noun Phrase), når det fungerer som adjektiv, danner det en ADjektivfrase (= AP; jf. engelsk Adjective Phrase).

Som navnet tilsier, så står PRONOMEN i stedet for andre ord i setninga. Vi bruker ikke termen pronomenfrase, men kaller frasen etter ordklassen til det ordet som pronomenet står i stedet for i setninga. Vanligvis representerer et pronomen et substantiv eller et adjektiv i setninga, og ett og samme pronomen kan da ha begge funksjonene. For eksempel fungerer ordet tämä som substantiv i setninga Tämä oon oikhein hyvä grammatikki ('Dette er en svært god grammatikk'), og det danner en substantivfrase. Men i setninga Tämä grammatikki oon oikhein hyvä ('Denne grammatikken er svært god') fungerer tämä som adjektiv, og det danner en adjektivfrase. Et pronomen kan også fungere som KVANTOR, det vil si uttrykke mengde, og da danner det en KVANTORFRASE (= KvaP). For eksempel fungerer pronomenet jokhainen som kvantor i setninga Jokhainen meistä halluu oppiit kainun kieltä ('Hver av oss ønsker å lære seg kvensk'), og frasen jokhainen meistä danner en kvantorfrase.

TALLORD fordeler seg på to grupper: GRUNNTALL og ORDENSTALL. Grunntall angir antall, og de fungerer enten som kvantorer i kvantorfraser eller som adjektiv. Kvantorfraser opptrer i to ulike mønstre. I det første mønsteret står grunntallet i entall nominativ, og det andre elementet i frasen står i partitiv. Et eksempel på en slik kvantorfrase er kaksi tytärtä ('to jenter'). I det andre mønsteret står det andre elementet i frasen i elativ, og grunntallet kan stå i hvilken 
som helst kasus i entall. En slik kvantorfrase er for eksempel kahđela tyttäristä ('på/om to jenter'). Ellers fungerer grunntall som adjektiv, og de danner da adjektivfraser. Et eksempel på det er setninga Kahđela ämmälä olthiin samat vaattheet kaikissa kolmissa häissä ('De to konene hadde de samme klærne på seg i alle tre bryllupa'). Her fungerer kahđela og kolmissa som adjektiv, og de danner hver sin adjektivfrase.

Ordenstall er avleid av grunntall, og de angir plass i ei rekke. De har samme funksjon i setninga som adjektiv og danner derfor adjektivfraser. I setninga Neljensissä häissä heilä olthiin uudet vaattheet ('I det fjerde bryllupet hadde de nye klær på seg') kan vi bytte ut ordenstallet neljensissä med for eksempel adjektivforma iloisissa ('glad') uten å endre på setningsstrukturen.

Med andre ord danner ikke tallord noen eigen frasetype, men de opptrer enten som kvantorfrase eller som adjektivfrase, alt etter hvilken funksjon de har i setninga.

Adverb og Adposisjoner har det til felles at det i begge klassene fins ord som har en slags kasusbøying, mens andre mangler det. Det er likevel ingen av dem som har fullstendige bøyingsmønstre. Noen ord kan fungere både som adverb og som adposisjon. Det gjelder særlig STEDS- og TIDSADVERB. I setningene Pekka istuu klassissa takana ('Peder sitter bak i klassen') og Pekka tuli meile monta kerttaa jälkhiin ('Peder kom til oss mange ganger etterpå) fungerer orda takana ('bak') og jälkhiin ('etterpå') som adverb, men i setningene Pekka istuu koulun takana ('Peder sitter bak skolen') og Pekka siirtyi meile kesän jälkhiin ('Peder flytta til oss etter sommeren') fungerer de samme orda som adposisjoner. Dersom ordet opptrer sammen med en NP som står i genitiv eller partitiv, så regner vi det som adposisjon, ellers som adverb. Noen adverb kan også inngå i kvantorfraser. Et eksempel på det er adverbet paljon ('mye'), som i kvantorfrasen paljon tyttäriitä ('mange jenter').

Adposisjoner danner ADPOSISJONSFRASER (= PP; jf. engelsk Preposition Phrase) sammen med nomena de styrer. Også adverb kan sammen med en modifikator danne en ADVERBFrASE (= AdvP), men det er aldri snakk om et obligatorisk element, for adverb kan alltid også opptre aleine. I denne grammatikken bruker vi termen adverb også om ord som ikke kan opptre sammen med andre ord $\mathrm{i}$ en frase, men som alltid danner en frase aleine, som for eksempel silloin ('da'), avain ('aldeles; bare'), piian ('kanskje').

Den siste ordklassen er JUNKSJONER. Det er ord som brukes for å begynne ei setning eller en frase, eller som fungerer som bindeledd mellom fraser og 
Tabell 2.2 Frasetyper

\begin{tabular}{|c|c|c|}
\hline Forkortelse & Navn & Eksempel \\
\hline NP & SUBSTANTIVFRASE & $\begin{array}{l}{[[\text { vihrinen }] \text { mies }]} \\
{[[\text { Marsin }] \text { torila }]}\end{array}$ \\
\hline AP & ADJEKTIVFRASE & [pieni] [vihrinen] \\
\hline PP & ADPOSISJONSFRASE & [[torin] vieressä] \\
\hline AdvP & ADVERBFRASE & [mielelä] \\
\hline KvaP & KVANTORFRASE & [viisi [tytärtä]], [paljon [kallaa]] \\
\hline $\begin{array}{l}\text { VP (= infinitivsfraser og } \\
\text { partisippfraser) }\end{array}$ & VERBFRASE & $\begin{array}{l}\text { [kattomassa [häntä]] } \\
{[\text { [hänen] syövän] }}\end{array}$ \\
\hline
\end{tabular}

setninger. Junksjoner deles inn i to hovedgrupper, KONJUNKSJONER og SUBJUNKSJONER. Mens konjunksjoner binder sammen setninger eller fraser som er på samme nivå, så viser vi med hjelp av subjunksjoner hvilken funksjon ei setning har i forhold til ei anna setning. Inga av gruppene har i seg sjøl noen eigen funksjon i setninga, og de danner derfor ikke noen eigen frasetype. Derimot snakker vi om JUNKSJONSSETNINGER når en junksjon viser til forholdet mellom setninger. Et eksempel på ei slik junksjonssetning er ette-setninga i Pekka tiesi, ette Liisa lähtee pois ('Peder visste at Lisa skulle dra bort').

I setningene i (1)-(2) ovafor er alle frasetyper representert, og vi kan oppsummere dem i tabell 2.2 .

\subsubsection{Utfyllinger}

Ei setning kan bestå av én eller flere fraser. Fraser har forskjellige funksjoner i setninga, for eksempel subJeKt, овJEKT, PREDiKativ og ADVERbial. Sjøl om rekkefølgen mellom frasene er mye mindre fast enn for eksempel i norsk, så kan vi likevel si at kvensk i likhet med norsk er et såkalt SVO-språk. Det betyr at i ei vanlig setning så står subjektet først, så kommer verbalet, og til slutt følger objektet $(1,3)$, adverbialet $(2,3)$ eller predikativet $(4)$, som illustrert nedafor:

$\begin{array}{lll}\text { 1. } & \text { Matti } \quad \text { söi } & \text { kallaa. } \\ \text { S } & \text { V } & \text { O-UTFYLLING } \\ \text { 'Mats spiser fisk.' } & \end{array}$


2. Nilla assuu Alattiossa.

$\begin{array}{lll}\mathrm{S} & \mathrm{V} & \text { ADV-UTFYLLING }\end{array}$

'Nils bor i Alta'.

3. Nilla vei preivin kuninkhaale.

$\mathrm{S} \quad \mathrm{V}$ O-UTFYLLING ADV-UTFYLLING

'Nils tok med brevet til kongen.'

4. Nilla oli kainulainen.

S V PRED-UTFYLLING

'Nils var kven(sk)'.

Men i noen setninger er adverbialet plassert først (5):

5. Meressä oon kallaa.

ADV $\mathrm{V} \quad \mathrm{S}$

'I havet er det fisk'.

I setningene ovafor er alle frasene eller ledda obligatoriske, uten dem ville ikke setningene ha vært fullstendige. Slike obligatoriske setningsledd kalles for UTFYLLINGER (UTF) til verbalet. Det er verbalet som styrer utfyllingene. Den viktigste utfyllinga og den som ofte står først i setninga, kaller vi for HOVEDUTFYLLING. Det er oftest subjektet i setninga.

De ulike utfyllingene er altså subjektet $(\mathrm{S})$, objektet $(\mathrm{O})$, predikativet (PRED) og adverbialet (ADV). Men det fins enda en syntaktisk funksjon, som likner på både adverbial og objekt, som illustrert i (6)-(10):

6. Mie kävelin [kilometrin].

'Jeg gikk en kilometer'.

7. Lohi painoi [kymenen killoo].

'Laksen veide ti kilo.'

8. Piili maksoi [miljoonan].

'Bilen kosta en million.'

9. Mie en jaksa kävelä ennää [metriikhään].

'Jeg orker ikke å gå en meter lenger'.

10. Porot kiikuthiin [vaaran laittaa].

'Reinsdyra klatra opp fjellsida.' 
Slike fraser står i objektskasus, men de har ingen typisk objektsfunksjon. De er likevel utfyllinger i og med at setningene er ufullstendige uten dem. Vi skal kalle slike setningsledd for oвjeKTSADVERbial (O-ADV). Når det dreier seg om kvantorfraser (6-9), så kaller vi dem bare for kvantorfraser i funksjonsanalysen også.

Verbalet med sine utfyllinger kaller vi for KJERNESETNING. Hvor mange utfyllinger ei kjernesetning trenger å ha for å være fullstendig, varierer fra setningstype til setningstype. På samme måte varierer også forma på utfyllingene. Slike forhold blir behandla i kapittel 4 .

I likhet med verb må også adposisjoner knytte til seg ord for at frasen skal være fullstendig. Det ser vi i setning (11) og setning (12) nedafor:

11. ${ }^{\star}$ Liisa tuli kautta.

'Lisa kom via.'

12. ${ }^{*}$ Alf muisteli ympäri.

'Alf fortalte om.'

Setningene er ufullstendige slik de er nå, men dersom vi legger til ord som i (13) og (14)

13. Liisa tuli [Suolovuoman kautta].

'Lisa kom via Suolovuoma'

14. Alf muisteli [pyssyjokilaisten ympäri].

'Alf fortalte om folk fra Børselv'

så blir de fullstendige. Vi ser altså at adposisjoner kun fungerer som fraser sammen med utfyllinger. Adposisjonen er kjernen i frasen ettersom den styrer hvilken form utfyllinga skal stå i. Adposisjonsfraser diskuteres nærmere i kapittel 10.

\subsubsection{Modifikatorer}

Ei setning kan også inneholde ledd som ikke er obligatoriske, det vil si at setninga er fullstendig også uten dem. Vi kaller slike element for MODIFIKATORER til forskjell fra utfylling. Det fins to hovedtyper modifikatorer:

- Den første hovedtypen er slike som modifiserer verbalet eller heile setninga. Tallet eller forma på disse retter seg ikke etter verbalet eller setninga som de modifiserer. Slike ledd kaller vi her for frie ADVERBIAL (F-ADV). 
Blant dem finner vi for det første RAMmeadverbial, som setter en slags ramme rundt kjernesetninga, som i (1) og (2) nedafor:

1. [Raavhaana]

RAMMEADVERBIAL

'Som voksen bodde Nils i Alta.'

2. Nilla vei preivin kuninkhaale kjernesetning

'Nils tok med seg brevet til kongen i april'.

Andre typer modifikatorer er KOMMENTARADVERBIAL, som på en måte kommenterer sannhetsgehalten i setninga (3), og KONNEKTIVER, som knytter sammen setninger eller setningsdeler (4), som illustrert nedafor:

3. Piian

KOMMENTARADV

[met lähđemä Alattihoon].

'Kanskje vi drar til Alta'.

4. Ensistä

[met lähđemä sitte

[met käymä

\section{Alattihoon],}

KONNEKTIV kjernesetning KONNEKTIV

Porsangissa]

'Først drar vi til Alta, så drar vi til Porsanger.'

Men også objektsadverbial (se avsnitt 2.4.2) kan fungere som rammeadverbial i setninga (5):

5. Pekka asui Milanossa [koko viikon]. kjernesetning O-ADV

Med andre ord kan objektsadverbial både fungere som modifikator og som utfylling. Det er ingen vasstette skott mellom de to funksjonene.

- Den andre hovedtypen modifikatorer er element som vi finner i fraser som fungerer som subjekt, objekt, adverbialutfyllinger og frie adverbial. Slike ledd er som regel ikke obligatoriske, men de gir tilleggsinformasjon om eller modifiserer frasekjernen, og vi kaller dem derfor bare for MODIFIKATORER. I eksempla (6)-(12) nedafor er MODIFIKATORENE kursiverte.

6. [Viisas poika] lukkee [kaikki läksyt] [oikhein hyvin].

'Den kloke gutten gjør alle leksene svært bra.' 
7. [Meiđän Liisa] lähti [kovala hopula] [Koutokeinhoon, missähänen tytär assuu]. 'Vår Lisa dro i all hast til Kautokeino, hvor dattera hennes bor.'

8. [Matka tänne] oli pitkä.

'Reisa hit var lang.'

9. [Tie Koutokeinhoon] oli raskas.

'Vegen til Kautokeino var tung.'

10. Kirjassa oon [muistelus Kippaisen Sammelin ympäri].

'I boka var det ei fortelling om Samuel Kippainen.'

11. Se oon [soma oppiit kainun kieltä].

'Det er artig å læres seg kvensk'.

12. Ollilta sain kuula [semmoisen huhun, ette sie olet nainu].

'Fra Olli fikk jeg høre (et slikt) rykte om at du er gift.'

Av eksempla ser vi at modifikatorer kan stå både før og etter frasekjernen. Slike som står før kjernen, kaller vi for PREMODIFIKATORER, og slike som står etter, kaller vi for POsTMODIFIKATORER. Med utgangspunkt i ordklassen til modifikatoren kan vi også snakke om ADJEKTIVMODIFIKATORER, SUBSTANTIVMODIFIKATORER, ADVERBMODIFIKATORER Og INFINITIVSMODIFIKATORER. I tilfeller hvor ei heil setning modifiserer et ledd i ei anna setning, så kaller vi modifikatoren for SETNINGSMODIFIKATOR. Basert på kasusen modifikatoren står i, kan vi også bruke termene GENITIVSMODIFIKATOR, ILLATIVSMODIFIKATOR Osv.

- Til slutt fins det en type frie ledd som vi kaller for APPOSISJONER. Det er forklarende, laust tilknytta ledd som har samme funksjon som et anna ledd i setninga, som illustrert i (13) og (14) nedafor (apposisjonene er kursiverte):

13. [Frederik V, Tanmarkun ja Ruijan kuningas], luki [Talmulahđen papin, Johan Falchin,] preivin.

'Frederik V, Danmark og Norges konge, leste brevet fra presten fra Talvik, Johan Falch'

14. [Met] laskima hevoiset ulos kevväilä juoksemhaan[, sekä mie ette kranni]. 'Om våren slapp vi hestene ut på beite, både jeg og naboen.'

Modifikatorer blir ikke behandla særskilt i denne grammatikken, men vi kommer til å lese mer om dem for eksempel når vi diskuterer adverb og 
subjunksjoner. Nominale modifikatorer er lista opp i begynnelsen av kapittel 5. Adjektivmodifikatorer som står til substantiv, og kongruensen mellom dem er behandla i kapittel 2.4.8.2.

\subsubsection{Korrelat og ankerord}

Forholdet mellom to ledd i ei setning kan også være på den måten at det ene leddet forklarer nærmere eller forteller noe om egenskapene til det andre leddet, eller at det refererer til det andre leddet. Det leddet som blir forklart eller referert til på den måten, betegner vi her som KORRELATET til det andre leddet. Det er likevel ikke slik at korrelatet styrer det forklarende eller refererende leddet i den forstand at det bestemmer forma på det andre leddet, eller at det andre leddet trenger å være del av den samme frasen som korrelatet. Eksempler på slike forhold er framstilt i (1) og (2) nedafor:

1. Nilla oli kainulainen.

'Nils var kvensk'.

2. Lohi painoi [kymmenen killoo].

'Laksen veide ti kilo.'

I setning (1) er Nilla korrelatet til adjektivet kainulainen, på samme måte som ordet lohi i setning (2) er korrelatet til kvantorfrasen kymmenen killoo.

Som korrelat omtaler vi også nomenfraser som blir referert til av pronomen, som i (3) og (4) nedafor:

3. Kissa söi kalan, minkä Pekka oli jättäny pöyđäle.

'Katten spiste fisken som Peder hadde levna på bordet.'

4. Maija osti ittelensä piilin.

'Maija kjøpte bil til seg sjøl.'

I setning (3) er kalan korrelatet til relativpronomenet minkä, og relativsetninga som heilhet forteller noe om sjølve korrelatet. I setning (4) refererer refleksivpronomenet ittelensä til subjektet i setninga, Maija, som er korrelatet til refleksivpronomenet. Setningene i (5)-(7) illustrerer samme type forhold:

5. Tääpänä näyttää siltä, ette sikkaristi tullee sađet.

'I dag ser det ut til at det kommer regn.' 
6. Se oon kumma, ette sieki minnuu rakastat.

'Det er rart at også du elsker meg.'

7. Silloin, ko mie lapsena asuin Talmulahessa, sielä vielä puhuthiin kainua.

'Den gangen jeg som barn bodde i Talvik, så blei det fortsatt snakka kvensk.'

I disse setningene er orda siltä, se og silloin semantisk tomme, og de har bare en syntaktisk funksjon i den overordna setninga (oversetninga). Slike semantisk tomme ledd i oversetninga kaller vi for ANKERORD, fordi de på en måte fungerer som ankerfeste for leddsetninga. Ankerord kan ofte også sløyfes, men som regel er de likevel med for å klargjøre strukturen i oversetninga og gjøre den syntaktisk komplett.

\subsubsection{Subjektlause setninger: passive og upersonlige konstruksjoner}

Sjøl om subjektet er den vanligste utfyllinga til verbet, så fins det i kvensk også setninger som mangler heilt subjekt. Det er for det første PASSIVKONSTRUKSJONER $(1,2)$, som aldri har subjekt. Den andre typen er såkalte GENERISKE, UPERSONLIGE KONSTRUKSJONER $(3,4)$, hvor verbet står i tredje person entall, og som ofte svarer til man-setninger i norsk. I begge typene kan vi tenke oss et subjekt, men det kommer altså ikke fram i setninga. Subjektet har som regel rolla AGENS, eller vi kan i hvert fall forestille oss det som handlende aktør.

Passive og upersonlige konstruksjoner har hver sine bruksområder: Upersonlige konstruksjoner uttrykker noe som er generelt og/eller sant, mens passivkonstruksjoner beskriver mer spesifikke hendelser eller tilstander. Vi kan si at agens i upersonlige konstruksjoner er hvem som helst, mens agens i passivkonstruksjoner er én eller flere bestemte aktører. Forskjellen er illustrert i tabell 2.3.

Vi ser at passivkonstruksjonen har flertallsbetydning ettersom predikatet står i flertall (2), mens den upersonlige konstruksjonen har entallsbetydning ettersom predikatet står i entall (4). Det blir enda klarere når vi sammenlikner passivkonstruksjonen med tilsvarende aktivkonstruksjon: Formene til passiv og tredje person flertall er i de fleste tilfella identiske, og ofte er det ikke lett å avgjøre hvilken av de to konstruksjonstypene vi har å gjøre med. I upersonlige konstruksjoner derimot står verbet i tredje person entall. 
Tabell 2.3 Passive og upersonlige konstruksjoner.

\begin{tabular}{|c|c|c|}
\hline \multicolumn{2}{|c|}{ Subjektlause setninger: } & Setninger med subjekt: \\
\hline Passiv & $\begin{array}{l}\text { 1. Aavasta pyyđethiin kallaa. } \\
\text { F-ADV V[passiv] O } \\
\text { 'I havet blei det fanga fisk.' } \\
\text { 2. Kirkossa olthiin finit. } \\
\text { F-ADV V[passiv] PRED } \\
\text { 'I kirka var folk fint kledd.' }\end{array}$ & $\begin{array}{lll}\text { Het } & \text { pyyđethiin } & \text { kallaa. } \\
\text { S } & \text { V[3. pl.] } & \text { O } \\
\text { 'De fanga fisk i havet.' } & \\
\text { lhmiset } & \text { olthiin } & \text { fiinit. } \\
\text { S } & \text { V[3. pl.] } & \text { PRED } \\
\text { 'Folk var fint kledd.' } & \end{array}$ \\
\hline Upersonlig & $\begin{array}{lll}\text { 3. } & \text { Kainuu oppii } & \text { hopusti. } \\
\text { O } & \text { V[3. sg.] } & \text { F-ADV } \\
\text { 'Kvensk lærer man seg fort.' } \\
\text { 4. } & \text { Kirkossa piti } \quad \text { olla fiini. } \\
\text { F-ADV V[3. sg.] } & \text { VP[V + PRED] } \\
\text { 'I kirka bør man være fint kledd.' }\end{array}$ & $\begin{array}{lll}\text { Pekka } & \text { oppii } & \text { kainuu. } \\
\text { S } & \text { V[3. sg.] } & \text { O } \\
\text { 'Peder } & \text { lærer seg kvensk.' } \\
\text { Vaimo } & \text { piti } & \text { olla fiini. } \\
\text { S } & \text { V[3. sg.] } & \text { VP[V + PRED }] \\
\text { 'Ei kone } & \text { måtte være fint kledd.' }\end{array}$ \\
\hline
\end{tabular}

Det som karakteriserer verbalet i slike passive og upersonlige konstruksjoner, er at de mangler nettopp subjekt, som i vanlige, aktive setninger er den viktigste utfyllinga til verbalet. Ettersom subjektet mangler, prøver man å flytte et anna ledd til subjektsposisjonen slik at verbet ikke blir stående først i setninga (jf. 1 - 4 ovafor). I passivkonstruksjoner finner vi setningsinitialt ofte også det semantisk tomme ordet sitä $(5,6)$ :

5. Sitä pyyđethään paljon kallaa aavasta.

'Det blei fanga mye fisk i havet.'

6. Sitä olthiin tasan fiinit kirkossa.

'Man var alltid fint kledd i kirka.'

Upersonlige konstruksjoner kan begynne med ordet se dersom verbalet består av et modalverb $(7,8)$ :

7. Se piti olla paljon ihmistä turvethommassa.

'Det må være mye folk som jobber med torv'

8. Ei se auta itkeet tyyhää.

'Det nytter ikke å gråte for ingenting.'

Slike tilleggssubjekt som ikke har noe semantisk innhold, men bare syntaktisk funksjon, kaller vi for TOMME SUBJEKT (jf. termene KORRELAT og ANKERORD i avsnitt 2.4.4 ovafor).

Det fins flere setningstyper som mangler subjekt. Uten subjekt er RESULTAT (se 4.2.3.6), KAUSATIV FØLELSE (se 4.2.4.2) og en del av tilstandssetningene 
(se 4.2.6). Disse skiller seg likevel fra de subjektlause setningstypene ovafor ved at verbalet i disse konstruksjonene knytter til seg et anna ledd som hovedutfylling enn subjektet. Det er altså ikke plass til noe subjekt i disse konstruksjonene.

\subsubsection{Setningstyper: fortellende setninger, spørresetninger og bydesetninger}

Setninger kan deles inn i tre hovedgrupper etter hva slags talehandling de blir brukt til. Vi skiller mellom fortellende setninger, spørresetninger og bydesetninger. De tre typene har hver si typiske oppbygning.

\subsubsection{Fortellende setninger}

FoRTELLENDE SETNINGER sier noe om hvordan ting er, eller hvordan vi trur eller antar at ting er $(1,2)$, og utgjør dermed den vanligste setningstypen i kvensk. Leddstillinga i slike setninger er normalt subjekt + verbal + utfylling (1). Dersom subjektet mangler, er det et anna ledd som blir flytta til subjektsposisjonen (se (2) og avsnitt 2.4.5 ovafor).

1. Nilla pyyttää kallaa Alattionjovesta.

$\begin{array}{llll}S & \mathrm{~V} & \mathrm{O} & \mathrm{F}-\mathrm{ADV}\end{array}$

'Nils fanger fisk i Altaelva.'

2. Alattionjovesta pyyđethään lohta.

F-ADV V O

'I Altaelva fanges det fisk.'

Men leddstillinga i kvensk er ikke så fast som for eksempel i norsk. Setninga i

(3) nedafor betyr nesten det samme som setninga i (1).

3. Nilla pyyttää Alattionjovesta kallaa.

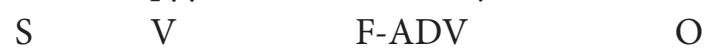

Eller med andre ord kan objektet og adverbialet relativt fritt bytte plass i ei fortellende setning. Men for eksempel i setningene i (4) og (5) er søkelyset satt på andre ledd enn i (1)-(3).

4. Lohta Alattionjovesta pyyđethään.

O F-ADV V

'Det er laks som fanges i Altaelva.' 
$\begin{array}{llll}\text { 5. Pyyttää } & \text { Nilla } & \text { Alattionjovesta kallaa. } \\ \text { V } & \text { S } & \text { F-ADV } & \text { O }\end{array}$

'Visst fanger Nils fisk i Altaelva'

I setning (4) er det lagt vekt på at det er nettopp laks som blir fiska i Altaelva, og ikke for eksempel ørret. Talehandlinga i setning (5) er en påstand: Visst er det slik at Nils fanger fisk i Altaelva, om enn noen hevder det motsatte. Setninger av typen (4) og (5) finner vi mest i muntlige replikker. Leddet som er flytta først i setninga, får da mer trykk enn i setninger med vanlig leddstilling.

Når vi seinere, i kapittel 4, skal presentere ulike setningsmønster, så bruker vi nesten bare eksempelsetninger med vanlig leddstilling. Men det er viktig å huske at andre leddstillingsmønster også er mulige.

\subsubsection{Spørresetninger}

SPøRRESETNINGER bruker vi til å spørre om noe. Spørresetninger kan formes på to hovedmåter: med hjelp av spørreord eller ved å hekte $k O$-enklitikonet på ett av ledda.

- På et spørsmål som begynner med et spørreord, kan man svare på hvilken som helst måte; svaret er fritt. Det er illustrert i spørsmåla og svara i (1)-(3):

1. Missä Nilla assuu? Alattiossa. / Ruottissa. / Tornionväylän varressa. 'Hvor bor Nils? I Alta. / I Sverige. / I Tornedalen.'

2. Kuka pyyttää Alattionjovesta? Nilla. / Kainulaiset. / Englanin herrat. / Fiskuseura. / Ei kukhaan.

'Hvem fisker i Altaelva? Nils. / Kvenene. / Engelske stormenn. / Fiskeforeninga. / Ingen.'

3. Mitä sie pölkkäät? Hukkaa. / Pappii. / Kuningasta. / Emänttää. / Tauttii. / En mithään.

'Hva er du redd for? Ulv. / Presten. / Kongen. / Kona. / Sjukdommer. / Ingenting.'

Som vi ser, kommer verbalet før subjektet i spørreordsetninger. Bortsett fra at det leddet som uttrykker det som spørres om, blir flytta først i setninga, er leddstillinga som i fortellende setninger.

- På spørsmål som er laga med hjelp av $-k O$, må svaret være bekreftende eller nektende. Også her står det leddet som uttrykker det som spørres om, først i setninga, og i tillegg får det enklitikonet -kO hekta på seg; se (4)-(11) nedafor. 
Hvilket som helst setningsledd kan være gjenstand for spørsmål. Oftest er det verbalet $(4,5)$, men det kan også være subjekt $(6)$, objekt $(7)$, adverbial (8) eller modifikator $(9,10)$. Derimot fungerer predikativ dårlig som gjenstand for spørsmål (11). Svaret består av det samme ordet som vi spør om, eller dersom svaret er negativt, så bruker vi nektingsverbet $e i$ og eventuelt også hovedverbet (om nektingskonstruksjoner se avsnitt 2.4.7 nedafor). Spør vi etter ulike alternativ, kan svaret også inneholde andre ord enn ordet som er gjenstand for spørsmålet. Setningene i (4)-(11) illustrerer de ulike typene:

4. Assuuko Nilla Alattiossa? Assuu. / Ei (asu).

'Bor Nils i Alta? Ja. / Nei'.

5. Pölkkäätkö sie hukkaa? Pölkkään. / En (pölkkää).

'Er du redd for ulv? Ja. / Nei'.

6. Nillako se assuu Alattiossa? Nilla. / Ei (Nilla, mutta Nillan sisar).

'Er det Nils som bor i Alta? Ja. / Nei(, ikke Nils, men søstera hans)'.

7. Hukkaako sie pölkkäät? Hukkaa. / En (hukkaa, mutta karhuuta).

'Er det ulv du er redd for? Ja. / Nei(, ikke ulv, men bjørn).'

8. Alattiossako se Nilla assuu? Alattiossa. / Ei (Alattiossa, mutta Koutokeinossa).

'Er det i Alta Nils bor? Ja. / Nei(, ikke i Alta, men i Kautokeino).'

9. Hetikö sie halluut sen ruvan? Heti. / En (heti, mutta vähäsen hiljemin).

'Er det med en gang du vil ha mat? Ja. / Nei(, ikke med en gang, men litt seinere).'

10. Tämänkö hamheen sie ostit Milanosta? Tämän. / En (tätä, mutta sen vihrisen).

'Er det det her skjørtet du kjøpte i Milano? Ja. / Nei(, ikke det her, men det der grønne).'

11. ?Viisasko se poika oli?

'Var det klok den gutten var?'

I bekreftende svar kan vi også bruke orda joo ('ja, jo') og kyllä ('ja, jo (visst)'). På spørsmålet Pyyttääkö Nilla Alattionjovesta? ('Fisker Nils i Altaelva?) kan vi svare med Joo, pyyttää ('Ja, det gjør han') eller Kyllä hän pyyttää ('Ja visst gjør han det').

Som i norsk kan åpne spørsmål også lages med hjelp av en fokuseringskonstruksjon, det vil si at det leddet som er gjenstand for spørsmålet, flyttes til ei eiga oversetning, og resten av setninga legges til som leddsetning til slutt, som i (12)-(14) nedafor: 
12. Oonko se Nilla, joka assuu Alattiossa?

'Er det Nils som bor i Alta?'

13. Oonko se Alattiossa, ette Nilla assuu?

'Er det i Alta Nils bor?'

14. Oonko se hukka, mitä sie pölkkäät?

'Er det ulv du er redd for?'

Spørsmålskonstruksjoner finner vi også i leddsetninger (15-17):

15. Mie kysyin, koska mie pääsen kothiin.

'Jeg spurte når jeg kunne dra heim.'

16. Pekka ei tieđä, oonko hän jo taivhaassa.

'Peder veit ikke om han allerede er i himmelen.'

17. Mie en muista, kuka ei ole saanu käyđä kouluu.

'Jeg husker ikke hvem som ikke fikk gå på skole.'

Leddstillinga i slike leddsetninger er den samme som i tilsvarende spørrekonstruksjoner i hovedsetninger.

\subsubsection{Bydesetninger}

Talehandlinga i ei ByDEsETNING er ikke bare befaling, men det kan også være ei oppfordring eller et forslag. Bydesetninger skiller seg fra fortellende setninger ved at verbalet flyttes til begynnelsen av setninga, og at subjektet er utelatt. I tillegg står verbet i bydeform eller imperativ. Eksempler på bydesetninger ser vi i (1)-(4) nedafor:

1. Mene kothiin! ('Gå heim!')

2. Luje preivin! ('Les brevet!')

3. Menkkää kothiin! ('Gå heim, dere!')

4. Lukekkaa preivin! ('Les brevet, dere!')

Imperativformer er nærmere behandla i avsnitt 6.6.

\subsubsection{Nektende setninger}

Nekting i kvensk er litt spesielt i og med at det skjer med hjelp av det såkalte NeKTINGSVERbet ei. Dette verbet bøyes i person, men ikke i tid eller modus. Nektingsverbet står som regel foran hovedverbet, og til sammen utgjør 
de nektingskonstruksjonen. Dersom tidsforma for nektingskonstruksjonen er presens, så har hovedverbet såkalt NEKTINGSFORM (NEG). Ved alle andre tidsformer i nektingskonstruksjonen brukes perfektum partisipp av hovedverbet. Setningene i (1)-(6) viser ulike eksempler på nektingskonstruksjoner:

1. Met

asuma

Alattiossa.

S[1.pl.]

$\mathrm{V}$ [1.pl.]

ADV

'Vi bor i Alta.'

2. Met

$$
\text { [emmä }
$$

asu]

Alattiossa.

S[1.pl.]

ikke[1.pl.]

$\mathrm{V}$ [nekt.]

ADV

'Vi bor ikke i Alta.'

3. Heikka pölkkää

S[3.sg.]

$\mathrm{V}$ [3.sg.]

hukkaa.

'Henry er redd for ulv'

4. Kaisa

[ei pölkkää]

hukkaa.

S[3. sg.]

ikke[3. sg.]

$\mathrm{V}$ [nekt.]

$\mathrm{O}$

'Kaisa er ikke redd for ulv'

5. Sie

$$
\text { kirjoitit }
$$

preivin.

S[2.sg.]

$\mathrm{V}$ [2. sg.]

$\mathrm{O}$

'Du skreiv brevet.'

6. Sie [et kirjoittannu] preivii.

S[2.sg.]

ikke-[2. sg.]

V[perf. pts.]

$\mathrm{O}$

'Du skreiv ikke brevet. / Du skreiv ikke noe brev'

Bøying av nektingsverbet og nektingsform av hovedverbet er behandla i avsnitta 6.4.1.2, 6.4.2.2 og 6.4.2.3.

\subsubsection{Kongruens}

Med KONGRUENs eller samsvarsbøying sikter vi til det fenomenet at bøyinga av et ledd i ei setning er styrt av forma på et anna ledd i setninga. I kvensk fins det to typer kongruens: kongruens mellom subjekt og verbal, og fraseintern kongruens. Som tredje type har vi tallkongruens mellom predikativ og korrelat (se avsnitt 4.5.1). 


\subsubsection{Kongruens mellom subjekt og verbal}

Mellom subjekt og verbal er det TALL- og PERSONKONGRUENS. Det betyr at viss subjektet for eksempel står i første person flertall, så skal verbet også ha samme person og tall. Noen eksempler er gitt i (1)-(6) nedafor:

1. Mie lujen kirjaa.

S[1.sg. $\quad \mathrm{V}$ [1.sg.] $\mathrm{O}$

('Jeg leser i ei bok.')

2. Sie lujet kirjaa.

S[2.sg.] V[2.sg.] O

('Du leser i ei bok.')

3. Hän/Se/Pekka lukkee kirjaa.

S[3.sg.] V[3.sg.] O

('Han/hun/Peder leser i ei bok.')

4. Met lujema kirjaa.

S[1.pl.] V[1.pl.] O

('Vi leser i ei bok.')

5. Tet lujetta kirjaa.

S[2.pl.] V[2. pl.] O

('Dere leser i ei bok.')

6. Het/Net/Tyttäret lujethaan kirjaa.

S[3.pl.] $\quad \mathrm{V}[3 \cdot \mathrm{pl}$. $] \quad \mathrm{O}$

('De/jentene leser i ei bok.')

Det fins også setninger hvor det ikke er kongruens mellom subjekt og verbal.

De blir behandla sammen med andre setningstyper i syntakskapitlet (kap. 4).

\subsubsection{Fraseintern kongruens}

Fraseintern kongruens går ut på at modifikatoren (MOD), det vil si adjektivet eller pronomenet, i en nomenfrase står i samme tall og kasus som frasekjernen, som oftest er et substantiv. Eksempler på det ser vi i (1) og (2) nedafor:

1. Siljola oon [iso huonet]

ADV V MOD[sg. nom.] KJERNE[sg. nom.]

'På gårdsplassen står et stort hus.' 

2. [Isossa huonheessa] oon [seppii tyttäriitä]. MOD[sg. iness.] KJERNE[sg. iness.] V MOD[pl.pts.] KJERNE [pl. pts.]

'I det store huset er det flinke jenter.'

Noen få adjektiv og pronomen bøyes ikke, og da viser de heller ikke kongruens med frasekjernen. Slike ubøyelige ord er for eksempel adjektivet pikku ('liten') og pronomenet joka ('hver'), som illustrert i (3) og (4):

3. Met istuma [pikku [sg. nom.] lomassa [sg. iness.]].

'Vi sitter i et lite rom.'

4. Se tukkii ittensä [joka [sg. nom.] paikkhaan [sg. ill.]].

'Det presser på fra alle kanter.'

\subsubsection{Setningsfragment}

Særlig i muntlig språkbruk finner vi ord og fraser som ikke er del av en annen frase eller setning, men som heller ikke danner ei eiga setning. Slike ytringselement kaller vi her for SETNINGSFRAGMENT. Det viktigste kjennetegnet til setningsfragment er at de mangler finitt verb.

Det fins mange typer setningsfragment. Vanligst er FRIE og FASTE SETNINGSFRAGMENT, og INTERJEKSJONER. Frie og faste setningsfragment er satt sammen av nomen, og de kan også inneholde ord av andre ordklasser (se avsnitt 2.4.1). Interjeksjoner danner en eigen ordklasse og opptrer som regel bare som setningsfragment.

FRIE SETNINGSFRAGMENT er syntaktiske element som ikke har noen fast oppbygning eller inneholder bestemte ord. Vi sier gjerne at de er laust tilknytta tekstelement, for eksempel overskrifter (jf. Setningsfragment ovafor), men også tekstinterne element som lause kommentarer eller utrop. Eksempler på frie setningsfragment er:

1. Mutta mitä se ihmisen luppaus on? Ei paljoksi mithään!

'Men hva slags utsikter har mennesket? Så godt som ingen!'

2. Aamhuun asti hän nukkui lapsen vijatonta unta. Niin tehthiin toisetki. Tällä kerttaaa.

'Han sov som et uskyldig barn heilt til morgenkvisten. Det samme gjorde de andre. Denne gangen.' 
3. Ja Ylijoki oli kaunis. Kaunis. Kaunis!

'Og Ylijoki [= den øverste delen av Børselva] var vakker. Vakker. Vakker!'

(Eksempla ovafor er henta fra Alf Nilsen-Børsskogs roman Kuosuvaaran takana (Nilsen-Børsskog 2004).)

Vi kan også bruke frie setningsfragment som svar på åpne spørsmål (se mer om spørresetninger i avsnitt 2.4.6.2 ovafor):

1. Mihin sie nyt aijot lähteet? Alattiohoon.

'Hvor har du tenkt å dra nå? Til Alta.'

2. Kuka lähtee minun myötä Alattihoon? Pekka.

'Hvem blir med meg til Alta? Peder.'

Som FASTE SETNINGSFRAGMENT regner vi her faste hilsener, lykkønskninger og andre høflighetsfraser, innbydingsfraser, oppmerksomhetsfraser, følelsesuttrykk, skjellsuttrykk og uttrykk for undring. Eksempler på faste setningsfragment er:

Päivää! ('God dag!'), Hyvvää ilttaa! ('God kveld!), Aamuu! ('God morgen!'), Hyvästi! ('Ha det bra!'), Terve(t)tulemaa! ('Velkommen!'), Hyvvää matkaa! ('God tur!'), Onnee! ('Gratulerer!'), Onnee päiväle! ('Gratulerer med dagen!'), Kiitos! ('Takk!'), Kiitoksii paljon! ('Mange takk!'), Kiitos/Kiitoksii osasta! ('Takk sjøl!'), Antheeksi! ('Unnskyld!'), Turpa kiini! ('Hold kjeft!'), Jumalan kiitos! ('Gud skje lov!'), Sillä hyvä! ('Det var da enda godt!'), Sillä selvä! ('Dermed basta!'), Herraton aika! ('Herregud!'), Perkele(t)! ('Fan!').

Eksempler på INTERJEKSJONER er hilsningsuttrykk som Hei! ('Hei!'), Mooraa! Moro! ('God morgen/morn!'). Videre har vi ei gruppe med affektive utrop, for eksempel Oi! Voi! Ai! Hah! De brukes også sammen med andre fragment, for eksempel i Voi hyvä(i)nen aika! ('Du store tid!'), Voi helvetti! ('For helvete!'), Voi riivattu/taavetti/tontta/tomppeli (senthään)! ('Helsike!'), Oi oi oi, sitä onnee! ('For ei lykke! / For et lykketreff!').

Interjeksjonen senki ('for en/ei/et ...') brukes også sammen med skjellsord: Senki ruokopää/tomppeli/pöllö/pöllöpää/toljana/kälmi/konna! ('For en tosk/ luring!).

En annen type interjeksjoner er vanlige samtalepartikler som joo ('ja, jo’), kyllä ('ja visst'), jaa (niin) ('ja'), jo vain ('ja da'), no ('nå), na ('nja’), spørrende täh og häh ('hva, hæ') og nektende hui hai. (Mer om svar på spørresetninger i avsnitt 2.4.6.2 ovafor.) 


\section{3}

\section{Lydvekslinger}

I dette kapitlet skal vi se nærmere på to typer LYdveKslinger. Den første typen er såkalte MORFOFONOLOGISKE VEKSLINGER, som går ut på at ett og samme morfem - ordstamme eller suffiks - opptrer i ulike former avhengig av hvilken bøyingsform ordet har, hvilken lydomgivelse morfemet opptrer i, eller hvilken stammetype det hører til. Til denne typen vekslinger hører stadieveksling, vekslinger i lengda på konsonantene $l, r, m$ og $n, h$-flytting, vekslinga $t i$ : $s i$, og endringer av stammesluttvokal $+i$.

Den andre typen er lydforskjeller mellom de ulike kvenske skriftspråksvarietetene, det vil si det at visse ord og ordformer skrives på ulike måter i de ulike varietetene. Til denne gruppa hører veksling mellom $e e \sim i A \sim e A$ og veksling mellom $t$-ending og bortfall av $-t$. Her finner vi også forskjeller innafor stadievekslingssystemet mellom spesialstadieveksling og generell stadieveksling, og for eksempel om o-stadium av $t$ blir realisert som $₫$ eller ved bortfall, som markeres her med $\varnothing$.

\subsection{Morfofonologiske vekslinger}

Vi skal først se på MORFOFONOLOGISKE VEKSLINGER. Her skal vi bare diskutere vekslinger som kommer til uttrykk i ordstammen. Morfofonologiske vekslinger som viser seg i suffiks, blir behandla i seinere kapitler sammen med de ulike suffiksa.

\subsubsection{Stadieveksling}

Konsonanter i kvenske ordformer kan endre seg etter hvilket stadium de er på, og dette fenomenet kalles for STADIEveKsLING. Stadievekslinga kan være kvantitativ og innebærer da at konsonantlengda i et ord veksler, som for eksempel $k$ i ordet (sg. nom. : sg. gen.) kukka ('blomst') : kuka/n eller $n$ i ordet (sg. nom. : sg. part.) sana ('ord') : sanna/a. Men vekslinga kan også være kvalitativ, 
og da blir en stammekonsonant bytta ut med en annen konsonant eller faller bort heilt. Et eksempel på det ser vi i verbet (1. inf. : pres. 1. sg) lukke/et luke/a(t) luki/a ('lese') : lu(j)e/n.

En konsonant eller konsonantkombinasjon som befinner seg i en posisjon i ordet hvor vekslinger forekommer eller kan forekomme, kaller vi for STAMMEKONSONANT. Slike finner vi oftest mellom første og andre stavelse, og det gjelder da kjernekonsonanter som i eksempla ovafor. Men stadieveksling opptrer også i lengre ord. I ordet ajatella ('tenke') for eksempel forekommer to stadievekslinger, mellom $t$ og $t t$ og mellom $l$ og $l l$ : (1. inf. : akt. pres. 1. sg : akt. pres. 3. sg.) ajatel/la : ajattele/n : ajattelle/e.

Derimot kaller vi kvalitative vekslinger mellom sluttkonsonanten i konsonantstammen og siste konsonanten i vokalstammen ikke for stadieveksling, men for STAMMEVEKSLING. Vekslinga $s$ : $k s$ i ordet (sg. nom. : sg. gen.) vares ('kråke') : varekse/n er altså ikke eksempel på stadieveksling, men på stammeveksling.

Alle konsonanter kan inngå i stadieveksling bortsett fra heilt nye konsonanter som $b, d \operatorname{og} g$, som bare fins i nye lånord. Vi skriver for eksempel (sg. nom. : sg./pl. part.) verbi ('verb') : verbii, og ikkje *verbbii. Bokstaven $g$ fins rett nok også i kvenske arveord, men da bare foran $n$, og kombinasjonen får da nasal uttale / $\mathrm{h} /$ (se avsnitt 2.1.2).

Som nevnt tidligere finner vi de følgende konsonantene i kvensk: $d, f, h, j, k, l$, $m, n, p, r, s, t \operatorname{og} v$. Av disse forekommer $f$ bare i posisjoner hvor det er uaktuelt med stadieveksling. Konsonantene $k, t$ og $p$ har tre ulike vekslingsstadier, de andre konsonantene bare to. Her er det viktig å være klar over at én og samme verb- eller nomenstamme kan forekomme på alle tre stadier, avhengig av hvilken bøyingsform den opptrer i. Konsonanten $d$ forekommer bare i Porsangervarieteten, og også der bare i stadieveksling på o-stadiet av $t$ (se avsnitt 3.1.1.2).

Også konsonantkombinasjoner som slutter på $k, t, p$, kan inngå i stadieveksling, men da må første komponenten i kombinasjonen være en av de stemte konsonantene $l, m, n$ eller $r$. Også kort $k$ og $t$ veksler når de står etter $h$. Andre ustemte konsonantkombinasjoner, for eksempel $k s$, ps eller $k s$, inngår ikke i vekslinger. Eksempler: (sg. nom. : sg. gen. : sg. part.) ranta ('strand') : rannan : ranttaa og tuhka ('sot, aske') : tuhan, men lapsi ('unge, barn') : lapsen og maksa ('lever') : maksan.

Det fins altså tre stadier: II, I og o. Med sTADIUM I og II meiner vi her stadier som har samme konsonanter, men på stadium I er den kort, og på stadium II er den lang, for eksempel $k: k k, t: t t, p: p p, s: s s$ osv. På sTADIUM o finner vi en 
annen konsonant enn på stadium I og II, eller så mangler stadium o konsonant i det heile tatt. I sistnevnte tilfelle har vi med bortfall å gjøre, som vi merker av med $\varnothing$. For eksempel veksler $t$ på stadium I med $₫$ på stadium o i Porsanger, og med $\varnothing \mathrm{i}$ de andre varietetene, og $k$ på stadium I veksler med $j, v$ eller $\varnothing$ på stadium o. Eksempler: For eksempel (II : I : o) jakkaa(t) ('dele') : jakanu : jajan $\sim$ jaan, lattoo ( latoa) ('stable') : lato : lađon $\sim$ laon .

Ikke alle ord gjennomgår stadieveksling i kvensk. Uten stadieveksling er for eksempel ord med stammekonsonantene $f, h, l, m, n, r, s$ eller $v$ på stadium II i alle bøyingsformene, som for eksempel i (sg. nom. : sg. gen.) kumma : kumma/n ('rar'), Tromssa ('Tromsø') : Tromssa/n, herra ('herre') : herra/n, kaffi ('kaffe') : kaffin. Og så har vi også ei gruppe med ord med stammekonsonant $t$ som står ved lag i alle bøyingsformene, for eksempel (1. inf. : pres. 3. sg : pres. 1. sg) katto/ot ('se') : katto/o: katto/n, nukattalat ('sovne av') : nukatta/a: nukatta/n. I det første eksemplet har vi å gjøre med en opprinnelig konsonantkombinasjon ${ }^{\star} t s$, som i finsk skriftspråk fortsatt skrives som $t s$, men som i kvensk (og flere finske dialekter) er blitt assimilert til $t$. Konsonanten i det andre eksemplet går tilbake på et opprinnelig ${ }^{\star} h t$-samband, som i Porsanger har blitt assimilert til $t$ t. I de andre varietetene skrives det $h t$, som i finsk skriftspråk. I verb med to vokalstammer (verbtype $4.1 \mathrm{og}$ 4.2) er $t t$ alltid utafor stadieveksling. Den lange vokalstammen i slike verb slutter på -itte, som for eksempel i (1. inf. : pres. 3. sg : pres. 1. sg) kyyti/tä kyytittelä(t) ('skysse'): kyytittele : kyytitte/n, piikaroi/ta piikaroittela $(t)$ ('spikre') : piikaroittele : piikaroitte/n.

Når det i diskusjonen av ordbøying nedafor snakkes om stadieveksling i de ulike stammene, så siktes det sjølsagt bare til tilfeller som har stadieveksling, og hvor det omtalte stadiet forekommer.

Hvilket stadium som er aktuelt, er avhengig av hvilken bøyingstype og bøyingsform det er snakk om. Reglene for dette blir presentert når vi går igjennom de ulike bøyingskategoriene.

Vi kan likevel allerede her gi disse generelle reglene for stadieveksling:

Generelle regler for stadieveksling:

Når stammekonsonanten står etter lang vokal (og stundom også etter diftong), så er den på stadium II. Når det etter stammekonsonanten står en kort vokal og stavelsen slutter på konsonant, så er stammekonsonanten på lågere stadium, det vil si stadium o i vekslingstypene II : I : o og I : o, og stadium I i vekslingstypen II : I. 
Det fins to typer stadieveksling i kvensk, og skriftspråksbrukeren får sjøl velge hvilken type som passer best til sin varietet. Vi kaller de to typene her for SPESIALSTADIEVEKSLING og GENERELL STADIEVEKSLING. Spesialstadieveksling finner vi i varietetene i Porsanger og Nordreisa, de andre varietetene følger som regel generell stadieveksling. Det gjelder ulike regler for de to typene, og de hører egentlig heime i avsnittet om lydforskjeller mellom varietetene (se 3.2). Men ettersom de samtidig presenterer vanlige morfofonologiske vekslinger, så blir de likevel behandla her.

Videre er det også ord som gjennomgår lydvekslinger av mer uregelmessig karakter. Eksempler på det er ordet (sg. nom. : pl. nom.) vapaa ('fri') : vaphaat, hvor vi ville ha forventa lang $p p$ etter første stavelse, og bøyinga av ordet poika ('gutt'): (sg. nom. : sg. gen.) poika : pojan mot forventa poika : ${ }^{*}$ poijan.

Ei anna uregelmessighet er forskjeller i spesialstadieveksling som for eksempel mellom sannoi, som er flertall partitiv av substantivet sana ('ord'), og sanoi, som er tredje person entall preteritum indikativ av verbet sannoot ('si').

Vi skal først ta for oss den generelle stadievekslinga.

\subsubsection{Generell stadieveksling}

Generell stadieveksling av konsonanter er brukt i kvenske varieteter utenom Porsanger og Nordreisa.

Vi ser først på vekslinger av plosivene $k, t$ og $p$.

GENERELl STADIEVEKSLING:

I den generelle stadievekslinga kan plosivene $k, t \operatorname{og} p$ opptre på i alt tre forskjellige stadier (II : I : o) i samme ord dersom den foregående stavelsen er trykksterk og inneholder kort vokal. Ellers veksler plosivene enten mellom stadium II og I, eller mellom I og o. Konsonantklynger som slutter på $k, t$ eller $p$, veksler bare mellom to stadier, enten II : I eller I : o. Andre konsonanter veksler bare mellom stadium II og I, og bare etter kort trykksterk vokal.

I den generelle stadievekslinga veksler konsonantsambandet $n k$ bare mellom første og andre stavelse, ellers er det uendra. Vi skriver altså aurinko ('sol'): aurinkon, kuninkas ('konge') : kuninkhaan.

Konsonantene $h, j, l, m, n, r, v$ og $s$ fins bare på to stadier (II : I), og de veksler etter kort, trykksvak stavelse. Ellers opptrer de alltid enten bare på stadium II eller bare på stadium I $\mathrm{i}$ alle ordformer.

Vi ser at vekslingene av andre konsonanter enn plosiver og $s$ er identiske i spesialstadievekslinga og i den generelle stadievekslinga. 
Tabell 3.1 Generell stadieveksling: Vekslinger av plosiven $k$

\begin{tabular}{|c|c|c|c|c|c|c|}
\hline Veksling & Stadium II & Bøyingsform & Stadium I & Bøyingsform & Stadium 0 & Bøyingsform \\
\hline \multirow{4}{*}{$\begin{array}{l}\mathrm{kk}: \mathrm{k}: \\
\varnothing, \mathrm{h}\end{array}$} & \multirow{4}{*}{$\begin{array}{l}\text { makkaa } \\
\text { räkkää } \\
\text { lukkee } \\
\text { tekkee }\end{array}$} & pres. 3. sg. & makas & pret. 3. sg. & maata & 1. inf. \\
\hline & & sg. part. & räkä & sg. nom. & räät & pl. nom. \\
\hline & & pres. 3. sg. & luki & pret. 3. sg. & luen & pres. 1. sg. \\
\hline & & pres. 3. sg. & teki & pret. 3. sg. & tehen & pres. 1. sg. \\
\hline \multirow[t]{6}{*}{$\mathrm{k}: \varnothing, \mathrm{v}$} & \multirow{6}{*}{\multicolumn{2}{|c|}{ Stadium II fins ikke. }} & $\begin{array}{l}\text { laki : lakea } \\
\text { lakia }\end{array}$ & $\begin{array}{l}\text { sg. nom. : } \\
\text { sg. part. }\end{array}$ & laen & sg. gen. \\
\hline & & & koko: kokoa & $\begin{array}{l}\text { sg. nom. : } \\
\text { sg. part. }\end{array}$ & koot & pl. nom. \\
\hline & & & rukhiit & pl. nom. & ruis & sg. nom. \\
\hline & & & aika : aikaa & $\begin{array}{l}\text { sg. nom. : } \\
\text { sg. part. }\end{array}$ & aiat & pl. nom. \\
\hline & & & puku : pukua & $\begin{array}{l}\text { sg. nom. : } \\
\text { sg. part. }\end{array}$ & puvut & pl. nom. \\
\hline & & & $\begin{array}{l}\text { poika: } \\
\text { poikaa }\end{array}$ & $\begin{array}{l}\text { sg. nom. : } \\
\text { sg. part. }\end{array}$ & pojat & pl. nom. \\
\hline \multirow[t]{2}{*}{$k \mathrm{k}: \mathrm{k}$} & $a k k a$ & sg. nom. & akat & pl. nom. & \multirow{2}{*}{\multicolumn{2}{|c|}{ Stadium 0 fins ikke. }} \\
\hline & rikkhaat & pl. nom. & rikas & sg. nom. & & \\
\hline \multirow[t]{2}{*}{ nk: ng } & \multirow{2}{*}{\multicolumn{2}{|c|}{ Stadium II fins ikke. }} & $\begin{array}{l}\text { kenkä: } \\
\text { kenkää }\end{array}$ & $\begin{array}{l}\text { sg. nom. : } \\
\text { sg. part. }\end{array}$ & kengät & pl. nom. \\
\hline & & & $\begin{array}{l}\text { lankeaa } \\
\text { lankiaa }\end{array}$ & pres. 3. sg. & langeta & 1. inf. \\
\hline \multirow[t]{3}{*}{ nkk : nk } & vankka & sg. nom. & vankat & pl. nom. & \multirow{3}{*}{\multicolumn{2}{|c|}{ Stadium 0 fins ikke. }} \\
\hline & krenkku & sg. nom. & krenkut & pl. nom. & & \\
\hline & tankkaa & pres. 3. sg. & tankata & 1. inf. & & \\
\hline \multirow[t]{4}{*}{$r k: r, r j$} & \multirow{4}{*}{\multicolumn{2}{|c|}{ Stadium II fins ikke. }} & varkhaat & pl. nom. & varas & sg. nom. \\
\hline & & & parkua(t) & 1. inf. & parun & pres. 1. sg. \\
\hline & & & $\begin{array}{l}\text { märkä: } \\
\text { märkää }\end{array}$ & $\begin{array}{l}\text { sg. nom. : } \\
\text { sg. part. }\end{array}$ & märjät & pl. nom. \\
\hline & & & $\begin{array}{l}\text { särkeä(t) } \\
\text { särkiä }\end{array}$ & 1. inf. : & $\begin{array}{l}\text { särjen: } \\
\text { särjin }\end{array}$ & $\begin{array}{l}\text { pres. 1. sg. : } \\
\text { pret. 1. sg. }\end{array}$ \\
\hline \multirow[t]{2}{*}{ rkk: rk } & $\begin{array}{l}\text { tarkka: } \\
\text { tarkkaa }\end{array}$ & $\begin{array}{l}\text { sg. nom. : } \\
\text { sg. part. }\end{array}$ & tarkat & pl. nom. & \multicolumn{2}{|c|}{ Stadium 0 fins ikke. } \\
\hline & värkkää & pres. 3. sg. & värkätä & 1. inf. & & \\
\hline \multirow[t]{4}{*}{$\mathrm{lk}: \varnothing, \mathrm{lj}$} & \multirow{4}{*}{\multicolumn{2}{|c|}{ Stadium II fins ikke. }} & jalka & sg. nom. & jalat & pl. nom. \\
\hline & & & nälkyä(t) & 1. inf. & nälyn & pres. 1. sg. \\
\hline & & & $\begin{array}{l}\text { kulkea }(t) \text { } \\
\text { kulkia }\end{array}$ & 1. inf. & $\begin{array}{l}\text { kuljen: } \\
\text { kuljin }\end{array}$ & $\begin{array}{l}\text { pres. 1. sg. : } \\
\text { pret. 1. sg. }\end{array}$ \\
\hline & & & pölkää & pres. 3. sg. & pöljätä & 1. inf. \\
\hline Ikk: Ik & $\begin{array}{l}\text { pulkka: } \\
\text { pulkkaa }\end{array}$ & $\begin{array}{l}\text { sg. nom. : } \\
\text { sg. part. }\end{array}$ & pulkat & pl. nom. & \multicolumn{2}{|c|}{ Stadium 0 fins ikke. } \\
\hline \multirow[t]{2}{*}{ hk : h, hj } & \multirow{2}{*}{\multicolumn{2}{|c|}{ Stadium II fins ikke. }} & tuhka & sg. nom. & tuhat & pl. nom. \\
\hline & & & pohkheet & pl. nom. & pohje(t) & sg. nom. \\
\hline
\end{tabular}


Tabell 3.2 Generell stadieveksling: Vekslinger av plosiven $t$

\begin{tabular}{|c|c|c|c|c|c|c|}
\hline Veksling & Stadium II & Bøyingsform & Stadium I & Bøyingsform & Stadium 0 & Bøyingsform \\
\hline \multirow[t]{2}{*}{$\mathrm{tt}: \mathrm{t}: \varnothing$} & pattaa & sg. part. & pata & sg. nom. & paat & pl. nom. \\
\hline & ittää(t) & 1. inf. & itäny & $\begin{array}{l}\text { perf. pts. } \\
\text { sg. nom. }\end{array}$ & ietty & $\begin{array}{l}\text { pass. perf. } \\
\text { pts. }\end{array}$ \\
\hline \multirow[t]{3}{*}{$\mathrm{t}: \varnothing$} & \multirow{3}{*}{\multicolumn{2}{|c|}{ Stadium II fins ikke. }} & $\begin{array}{l}\text { tietää }(t): \\
\text { tietäny }\end{array}$ & $\begin{array}{l}\text { 1. inf : } \\
\text { perf. pts. } \\
\text { sg. nom. }\end{array}$ & tiiän (sic!) & pres. 1. sg. \\
\hline & & & $\begin{array}{l}\text { pato: } \\
\text { patoa }\end{array}$ & $\begin{array}{l}\text { sg. nom. : sg. } \\
\text { part. }\end{array}$ & paot & pl. nom. \\
\hline & & & $\begin{array}{l}\text { katoaa: } \\
\text { katos }\end{array}$ & $\begin{array}{l}\text { pres. 3. sg. : } \\
\text { pret. 3. sg. }\end{array}$ & kaota & 1. inf. \\
\hline \multirow[t]{2}{*}{$\mathrm{tt}: \mathrm{t}$} & $\begin{array}{l}\text { katto: } \\
\text { kattoa }\end{array}$ & $\begin{array}{l}\text { sg. nom. : } \\
\text { sg. part. }\end{array}$ & katot & pl. nom. & \multirow{2}{*}{\multicolumn{2}{|c|}{ Stadium 0 fins ikke. }} \\
\hline & keittää(t) & 1. inf. & keitän & pres. 1. sg. & & \\
\hline \multirow[t]{3}{*}{$n t: n(n)$} & \multirow{3}{*}{\multicolumn{2}{|c|}{ Stadium II fins ikke. }} & $\begin{array}{l}\text { ranta: } \\
\text { rantaa }\end{array}$ & $\begin{array}{l}\text { sg. nom. : } \\
\text { sg. part. }\end{array}$ & rannan & sg. gen. \\
\hline & & & $\begin{array}{l}\text { emäntä : } \\
\text { emäntää }\end{array}$ & $\begin{array}{l}\text { sg. nom. : sg. } \\
\text { part. }\end{array}$ & emänän & sg. gen. \\
\hline & & & $\begin{array}{l}\text { lentää(t): } \\
\text { lentäny }\end{array}$ & $\begin{array}{l}\text { 1. inf. : perf. pts. } \\
\text { sg. nom. }\end{array}$ & lennän & pres. 1. sg. \\
\hline $\mathrm{ntt}: \mathrm{nt}$ & $\begin{array}{l}\text { kontti : } \\
\text { konttia }\end{array}$ & $\begin{array}{l}\text { sg. nom.: } \\
\text { sg./pl. part. }\end{array}$ & kontit & pl. nom. & \multicolumn{2}{|c|}{ Stadium 0 fins ikke. } \\
\hline \multirow[t]{2}{*}{$r t: r(r)$} & \multirow{2}{*}{\multicolumn{2}{|c|}{ Stadium II fins ikke. }} & $\begin{array}{l}\text { siirtyä(t): } \\
\text { siirtyny }\end{array}$ & 1. inf. : perf. pts. & siiryn & pres. 1. sg. \\
\hline & & & $\begin{array}{l}\text { parta: } \\
\text { partaa }\end{array}$ & $\begin{array}{l}\text { sg. nom. : sg. } \\
\text { part. }\end{array}$ & parran & sg. gen. \\
\hline $\mathrm{rtt}: \mathrm{rt}$ & $\begin{array}{l}\text { hurtta: } \\
\text { hurttaa }\end{array}$ & $\begin{array}{l}\text { sg. nom. : } \\
\text { sg. part. }\end{array}$ & hurtan & sg. gen. & \multicolumn{2}{|c|}{ Stadium 0 fins ikke. } \\
\hline \multirow[t]{2}{*}{ It : I(I) } & \multirow{2}{*}{\multicolumn{2}{|c|}{ Stadium II fins ikke. }} & ilta : iltaa & $\begin{array}{l}\text { sg. nom. : sg. } \\
\text { part. }\end{array}$ & illan & sg. gen. \\
\hline & & & kieltää(t) & 1. inf. & kielän & pres. 1. sg. \\
\hline Itt : It & $\begin{array}{l}\text { polttaa }(t): \\
\text { polttanu }\end{array}$ & $\begin{array}{l}\text { 1. inf. : } \\
\text { perf. pts. } \\
\text { sg. nom. }\end{array}$ & poltan & pres. 1. sg. & Stadium 0 & ins ikke. \\
\hline \multirow[t]{2}{*}{ ht : h } & \multirow{2}{*}{\multicolumn{2}{|c|}{ Stadium II fins ikke. }} & $\begin{array}{l}\text { lähteä(t) } \\
\text { lähtiä }\end{array}$ & 1. inf. & lähen & pres. 1. sg. \\
\hline & & & $\begin{array}{l}\text { lehti : } \\
\text { lehtiä }\end{array}$ & $\begin{array}{l}\text { sg. nom. : sg. } \\
\text { part. }\end{array}$ & lehen & sg. gen. \\
\hline
\end{tabular}


Tabell 3.3 Generell stadieveksling: Vekslinger av plosiven $p$

\begin{tabular}{|c|c|c|c|c|c|c|}
\hline Veksling & Stadium II & Bøyingsform & Stadium I & Bøyingsform & Stadium 0 & Bøyingsform \\
\hline \multirow[t]{2}{*}{$p p: p: v$} & tuppaa & sg. part. & tupa & sg. nom. & tuvassa & sg. iness. \\
\hline & leppää & pres. 3. sg. & lepäs & pret. 3. sg. & levätä & 1. inf. \\
\hline \multirow[t]{3}{*}{$p: v$} & \multirow{3}{*}{\multicolumn{2}{|c|}{ Stadium II fins ikke. }} & apu : apua & $\begin{array}{l}\text { sg. nom. : } \\
\text { sg. part. }\end{array}$ & avut & pl. nom. \\
\hline & & & leipä : leipää & $\begin{array}{l}\text { sg. nom. : } \\
\text { sg. part. }\end{array}$ & leivät & pl. nom. \\
\hline & & & $\begin{array}{l}\text { repeää } \\
\text { repiäää }\end{array}$ & pres. 3. sg. & revetä & 1. inf. \\
\hline \multirow[t]{3}{*}{$p p: p$} & $\begin{array}{l}\text { leppä : } \\
\text { leppää }\end{array}$ & $\begin{array}{l}\text { sg. nom. : } \\
\text { sg. part. }\end{array}$ & lepän & sg. gen. & \multirow{3}{*}{\multicolumn{2}{|c|}{ Stadium 0 fins ikke. }} \\
\hline & $\begin{array}{l}\text { pappi: } \\
\text { pappia }\end{array}$ & $\begin{array}{l}\text { sg. nom. : } \\
\text { sg./pl. part. }\end{array}$ & papin & sg. gen. & & \\
\hline & $\begin{array}{l}\text { kuoppa: } \\
\text { kuoppaa }\end{array}$ & $\begin{array}{l}\text { sg. nom. : } \\
\text { sg./pl. part. }\end{array}$ & kuopan & sg. gen. & & \\
\hline \multirow[t]{3}{*}{$\begin{array}{l}m p: \\
m(m)\end{array}$} & \multirow{3}{*}{\multicolumn{2}{|c|}{ Stadium II fins ikke. }} & $\begin{array}{l}\text { tempaa: } \\
\text { tempas }\end{array}$ & $\begin{array}{l}\text { pres. 3. sg. : } \\
\text { pret. 3. sg. }\end{array}$ & temmata & 1. inf. \\
\hline & & & $\begin{array}{l}\text { ampua: } \\
\text { ampui }\end{array}$ & $\begin{array}{l}\text { 1. inf. : pret. } \\
\text { 3. sg. }\end{array}$ & ammun & pres. 1. sg. \\
\hline & & & $\begin{array}{l}\text { kumpi : } \\
\text { kumpaa }\end{array}$ & $\begin{array}{l}\text { sg. nom. : } \\
\text { sg. part. }\end{array}$ & kummat & pl. nom. \\
\hline $\begin{array}{l}\mathrm{mpp}: \\
\mathrm{mp}\end{array}$ & tumppu & sg. nom. & tumput & pl. nom. & \multicolumn{2}{|c|}{ Stadium 0 fins ikke. } \\
\hline \multirow[t]{3}{*}{$r p: r v$} & \multirow{3}{*}{\multicolumn{2}{|c|}{ Stadium II fins ikke. }} & $\begin{array}{l}\text { arpa: } \\
\text { arpaa }\end{array}$ & $\begin{array}{l}\text { sg. nom. : } \\
\text { sg. part. }\end{array}$ & arvat & pl. nom. \\
\hline & & & turpheet & pl. nom. & $\operatorname{turve}(t)$ & sg. nom. \\
\hline & & & varphaat & pl. nom. & varvas & sg. nom. \\
\hline$r p p: r p$ & korppi & sg. nom. & korpit & pl. nom. & \multicolumn{2}{|c|}{ Stadium 0 fins ikke. } \\
\hline \multirow[t]{2}{*}{ Ip : Iv } & \multirow{2}{*}{\multicolumn{2}{|c|}{ Stadium II fins ikke. }} & kelpaa & pres. 3. sg. & kelvata & 1. inf. \\
\hline & & & $\begin{array}{l}\text { halpa: } \\
\text { halpaa }\end{array}$ & $\begin{array}{l}\text { sg. nom. : } \\
\text { sg. part. }\end{array}$ & halvat & pl. nom. \\
\hline Ipp : Ip & helppo & sg. nom. & helpot & pl. nom. & \multicolumn{2}{|c|}{ Stadium 0 fins ikke. } \\
\hline
\end{tabular}


Tabell 3.4 Generell stadieveksling: Vekslinger av andre konsonanter

\begin{tabular}{|c|c|c|c|c|}
\hline Veksling & Stadium II & Bøyingsform & Stadium I & Bøyingsform \\
\hline $\mathrm{hh}: \mathrm{h}$ & $\begin{array}{l}\text { lihhaa } \\
\text { sahhaa }\end{array}$ & $\begin{array}{l}\text { pres. 3. sg. } \\
\text { sg. part. } \\
\text { pres. 3. sg. }\end{array}$ & $\begin{array}{l}\text { puhun } \\
\text { liha } \\
\text { sahata }\end{array}$ & $\begin{array}{l}\text { pres. 1. sg. } \\
\text { sg. nom. } \\
\text { 1. inf. }\end{array}$ \\
\hline $\mathrm{jj}: \mathrm{j}$ & $\begin{array}{l}\text { ajjaa(t) } \\
\text { rajjaa }\end{array}$ & $\begin{array}{l}\text { 1. inf. } \\
\text { sg. part. }\end{array}$ & $\begin{array}{l}\text { ajan } \\
\text { raja }\end{array}$ & $\begin{array}{l}\text { pres. 1. sg. } \\
\text { sg. nom. }\end{array}$ \\
\hline II : I & $\begin{array}{l}\text { kallaa } \\
\text { sullaa }\end{array}$ & $\begin{array}{l}\text { sg. part. } \\
\text { pres. 3. sg. }\end{array}$ & $\begin{array}{l}\text { kala } \\
\text { sulata }\end{array}$ & $\begin{array}{l}\text { sg. nom. } \\
\text { 1. inf. }\end{array}$ \\
\hline $\mathrm{mm}: \mathrm{m}$ & rummaa & sg. part. & ruma & sg. nom. \\
\hline $\mathrm{nn}: \mathrm{n}$ & $\begin{array}{l}\text { sannoo } \\
\text { sannaa }\end{array}$ & $\begin{array}{l}\text { pres. 3. sg. } \\
\text { sg. part. }\end{array}$ & $\begin{array}{l}\text { sanoa(t) } \\
\text { sana }\end{array}$ & $\begin{array}{l}\text { 1. inf. } \\
\text { sg. nom. }\end{array}$ \\
\hline$r r: r$ & $\begin{array}{l}\text { herrää } \\
\text { porraa }\end{array}$ & $\begin{array}{l}\text { pres. 3. sg. } \\
\text { sg. part. }\end{array}$ & $\begin{array}{l}\text { herätä } \\
\text { pora }\end{array}$ & $\begin{array}{l}\text { 1. inf. } \\
\text { sg. nom. }\end{array}$ \\
\hline SS : s & $\begin{array}{l}\text { ossaa } \\
\text { ossaa }\end{array}$ & $\begin{array}{l}\text { pres. 3. sg. } \\
\text { sg. part. }\end{array}$ & $\begin{array}{l}\text { osata } \\
\text { osa }\end{array}$ & $\begin{array}{l}\text { 1. inf. } \\
\text { sg. nom. }\end{array}$ \\
\hline $\mathrm{VV}: \mathrm{v}$ & $\begin{array}{l}\text { hyvvää } \\
\text { kuvvaa }\end{array}$ & $\begin{array}{l}\text { sg. part. } \\
\text { pres. 3. sg. }\end{array}$ & $\begin{array}{l}\text { hyvä } \\
\text { kuvata }\end{array}$ & $\begin{array}{l}\text { sg. nom. } \\
\text { 1. inf. }\end{array}$ \\
\hline
\end{tabular}

\subsubsection{Spesialstadieveksling}

Den generelle regelen for spesialstadieveksling er slik:

SPESIALSTADIEVEKSLING:

I spesialstadievekslinga kan plosivene $k, t$ og $p$ opptre på i alt tre forskjellige stadier i samme ord uavhengig av hva slags struktur den foregående stavelsen har. Den kan være trykksterk eller trykksvak, lang eller kort. Konsonanten $s$ har bare to stadier (II : I), men også denne vekslinga skjer uavhengig av strukturen i den foregående stavelsen. De andre konsonantene veksler bare etter kort, trykksterk vokal.

Tabellene nedafor gir en oversikt over hvilke typer spesialstadieveksling de ulike konsonantene inngår i.

Ønsker en å skrive på den skriftspråksvarianten som ligger nærmest Nordreisadialekten, kan en i vekslinger av plosiven $k$ sløyfe $j$ og $v$ på o-stadiet. Ordformene blir da for eksempel räät i stedet for räjät ('snørr'), jaan i stedet for jajan ('(jeg) deler'), koota i stedet for kovota ('plukke, samle'), paeta i stedet for pajeta ('rømme'), ruis i stedet for ruvis ('rug'), og parun i stedet for parvun ('(jeg) gråter').

Konsonantene $h, j, l, m, n, r$ og $v$ veksler bare når de følger etter trykksterk, kort stavelse. I alle andre tilfeller opptrer de alltid enten bare på stadium II eller bare på stadium I i alle bøyingsformer. Disse konsonantene veksler med andre ord etter de samme reglene som gjelder for generell stadieveksling (se nedafor). 
Tabell 3.5 Spesialstadieveksling: Vekslinger av plosiven $k$

\begin{tabular}{|c|c|c|c|c|c|c|}
\hline Veksling & Stadium II & Bøyingsform & Stadium I & Bøyingsform & Stadium 0 & Bøyingsform \\
\hline $\begin{array}{l}\mathrm{kk}: \mathrm{k}: \mathrm{j}, \mathrm{v}, \mathrm{h}, \\
\varnothing\end{array}$ & $\begin{array}{l}\text { aikkaa } \\
\text { räkkää } \\
\text { jakkaat } \\
\text { kokkoo } \\
\text { pukkuu } \\
\text { makkaa } \\
\text { tekkee } \\
\text { poikkaa } \\
\text { lakkii }\end{array}$ & $\begin{array}{l}\text { sg. part. } \\
\text { sg. part. } \\
\text { 1. inf. } \\
\text { pres. 3. sg. } \\
\text { sg. part. } \\
\text { pres. 3. sg. } \\
\text { pres. 3. sg. } \\
\text { sg. part. } \\
\text { sg. part. }\end{array}$ & $\begin{array}{l}\text { aika } \\
\text { räkä } \\
\text { jakanu } \\
\text { kokosin } \\
\text { puku } \\
\text { makas } \\
\text { teki } \\
\text { poika } \\
\text { laki }\end{array}$ & $\begin{array}{l}\text { sg. nom. } \\
\text { sg. nom. } \\
\text { perf. pts. } \\
\text { pret. 1. sg. } \\
\text { sg. nom. } \\
\text { pret. 3. sg. } \\
\text { pret. 3. sg. } \\
\text { sg. nom. } \\
\text { sg. nom. }\end{array}$ & $\begin{array}{l}\text { aijat } \\
\text { räjät } \\
\text { jajan } \\
\text { kovota } \\
\text { puvut } \\
\text { maata } \\
\text { tehen } \\
\text { pojat } \\
\text { lait }\end{array}$ & $\begin{array}{l}\text { pl. nom. } \\
\text { pl. nom. } \\
\text { pres. 1. sg. } \\
\text { 1. inf. } \\
\text { pl. nom. } \\
\text { 1. inf. } \\
\text { pres. 1. sg. } \\
\text { pl. nom. } \\
\text { pl. nom. }\end{array}$ \\
\hline$k: j, v$ & \multicolumn{2}{|c|}{ Stadium II fins ikke. } & $\begin{array}{l}\text { pakenee } \\
\text { rukhiit }\end{array}$ & $\begin{array}{l}\text { pres. 3. sg. } \\
\text { pl. nom. }\end{array}$ & $\begin{array}{l}\text { pajeta } \\
\text { ruvis }\end{array}$ & $\begin{array}{l}\text { 1. inf. } \\
\text { sg. nom. }\end{array}$ \\
\hline$k \mathrm{k}: \mathrm{k}$ & $\begin{array}{l}\text { akka: } \\
\text { akkaa } \\
\text { rikkhaat } \\
\text { lykkään }\end{array}$ & $\begin{array}{l}\text { sg. nom. : } \\
\text { sg. part. } \\
\text { pl. nom. } \\
\text { pres. 1. sg. }\end{array}$ & $\begin{array}{l}\text { akat } \\
\text { rikas } \\
\text { lykätä }\end{array}$ & $\begin{array}{l}\text { pl. nom. } \\
\text { sg. nom. } \\
\text { 1. inf. }\end{array}$ & \multicolumn{2}{|c|}{ Stadium 0 fins ikke. } \\
\hline nkk: nk: ng & $\begin{array}{l}\text { aurinkkoo } \\
\text { kenkkää } \\
\text { lankkee }\end{array}$ & $\begin{array}{l}\text { sg. part. } \\
\text { sg. part. } \\
\text { pres. 3. sg. }\end{array}$ & $\begin{array}{l}\text { aurinko } \\
\text { kenkä } \\
\text { lankes }\end{array}$ & $\begin{array}{l}\text { sg. nom. } \\
\text { sg. nom. } \\
\text { pret. 3. sg. }\end{array}$ & $\begin{array}{l}\text { auringon } \\
\text { kengät } \\
\text { langeta }\end{array}$ & $\begin{array}{l}\text { sg. gen. } \\
\text { pl. nom. } \\
\text { 1. inf. }\end{array}$ \\
\hline nk: ng & \multicolumn{2}{|c|}{ Stadium II fins ikke. } & kuninkhaat & pl. nom. & kuningas & sg. nom. \\
\hline$n k k: n k$ & $\begin{array}{l}\text { vankka: } \\
\text { vankkaa }\end{array}$ & $\begin{array}{l}\text { sg. nom. : } \\
\text { sg. part. }\end{array}$ & vankat & pl. nom. & \multicolumn{2}{|c|}{ Stadium 0 fins ikke. } \\
\hline $\begin{array}{l}\text { rkk : rk: r, rj, } \\
\text { rv }\end{array}$ & $\begin{array}{l}\text { märkkää } \\
\text { särkkeet } \\
\text { parkkuut } \\
\text { kerkkii } \\
\text { kerkkee }\end{array}$ & $\begin{array}{l}\text { sg. part. } \\
\text { 1. inf. } \\
\text { 1. inf. } \\
\text { pres. 3. sg. } \\
\text { pres. 3. sg. }\end{array}$ & $\begin{array}{l}\text { märkä } \\
\text { särkeny } \\
\text { parkunu } \\
\text { kerkis } \\
\text { kerkes }\end{array}$ & $\begin{array}{l}\text { sg. nom. } \\
\text { perf. pts. } \\
\text { sg. nom. } \\
\text { perf. pts. } \\
\text { pret. 3. sg. } \\
\text { pret. 3. sg. }\end{array}$ & $\begin{array}{l}\text { märät } \\
\text { särjen } \\
\text { parvun } \\
\text { keritä } \\
\text { kerjetä }\end{array}$ & $\begin{array}{l}\text { pl. nom. } \\
\text { pres. 1. sg. } \\
\text { pres. 1. sg. } \\
\text { 1. inf. } \\
\text { 1. inf. }\end{array}$ \\
\hline rk: $r$ & \multicolumn{2}{|c|}{ Stadium II fins ikke. } & varkhaat & pl. nom. & varas & sg. nom. \\
\hline rkk: rk & $\begin{array}{l}\text { tarkka: } \\
\text { tarkkaa }\end{array}$ & $\begin{array}{l}\text { sg. nom. : } \\
\text { sg. part. }\end{array}$ & tarkat & pl. nom. & \multirow{2}{*}{\multicolumn{2}{|c|}{ Stadium 0 fins ikke. }} \\
\hline & kirkkhaat & pl. nom. & kirkas & sg. nom. & & \\
\hline \multirow{5}{*}{$\begin{array}{l}\text { Ikk : Ik : I, lj, } \\
\text { lv }\end{array}$} & pölkkää & 3. $\mathrm{sg}$. & pölkäs & pret. 3. sg. & pölätä & 1. inf. \\
\hline & jälkkee & sg. part. & jälki & sg. nom. & jäljet & pl. nom. \\
\hline & kulkkeet & 1. inf. & kulki & pret. 3. sg. & $\begin{array}{l}\text { kuljen } \\
\text { kuljin }\end{array}$ & $\begin{array}{l}\text { pres. 1. sg. : } \\
\text { pret. 1. sg. }\end{array}$ \\
\hline & jalkkaa & sg. part. & jalka & sg. nom. & jalvoissa & pl. iness. \\
\hline & nälkkyyt & 1. inf. & nälkyi & pret. 3. sg. & nälvyn & pres. 1. sg. \\
\hline \multirow[t]{2}{*}{$\mathrm{Ik}: \mathrm{lj}$} & \multirow{2}{*}{\multicolumn{2}{|c|}{$\begin{array}{l}\text { Stadium II fins ikke. } \\
\text { valkenee }\end{array}$}} & palkheet & pl. nom. & paljet & sg. nom. \\
\hline & & & pres. 3. sg. & valjeta & 1. inf. & \\
\hline Ikk: Ik & $\begin{array}{l}\text { pulkka: } \\
\text { pulkkaa }\end{array}$ & $\begin{array}{l}\text { sg. nom. : } \\
\text { sg. part. }\end{array}$ & pulkat & pl. nom. & \multicolumn{2}{|c|}{ Stadium 0 fins ikke. } \\
\hline hk: h & \multicolumn{2}{|c|}{ Stadium II fins ikke. } & $\begin{array}{l}\text { pahka } \\
\text { tuhka } \\
\text { pohkheet } \\
\text { puhkee }\end{array}$ & $\begin{array}{l}\text { sg. nom. } \\
\text { sg. nom. } \\
\text { pl. nom. } \\
\text { pres. 3. sg. }\end{array}$ & $\begin{array}{l}\text { pahat } \\
\text { tuhat } \\
\text { pohet } \\
\text { puheta }\end{array}$ & $\begin{array}{l}\text { pl. nom. } \\
\text { pl. nom. } \\
\text { sg. nom. } \\
\text { 1. inf. }\end{array}$ \\
\hline
\end{tabular}


Tabell 3.6 Spesialstadieveksling: Vekslinger av plosiven $t$

\begin{tabular}{|c|c|c|c|c|c|c|}
\hline Veksling & Stadium II & Bøyingsform & Stadium I & Bøyingsform & Stadium 0 & Bøyingsform \\
\hline \multirow[t]{3}{*}{$\begin{array}{l}\mathrm{tt}: \mathrm{t}:{ }^{\circ} \sim \\
\varnothing\end{array}$} & tiettäät & 1. inf. & tietäny & $\begin{array}{l}\text { perf. pts. } \\
\text { sg. nom. }\end{array}$ & ti(eđ)än & pres. 1. sg. \\
\hline & pattoo & sg. part. & pato & sg. nom. & $p a(d) o t$ & pl. nom. \\
\hline & kattoo & pres. 3. sg. & katos & pret. 3. sg. & ka(d)ota & 1. inf. \\
\hline $\mathrm{t}: ₫ \sim \varnothing$ & \multicolumn{2}{|c|}{ Stadium II fins ikke. } & puthaat & pl. nom. & pu(d)as & sg. nom. \\
\hline \multirow[t]{2}{*}{$\mathrm{tt}: \mathrm{t}$} & ratthaat & pl. nom. & ratas & sg. nom. & \multirow{2}{*}{\multicolumn{2}{|c|}{ Stadium 0 fins ikke. }} \\
\hline & katto: kattoo & $\begin{array}{l}\text { sg. nom. : sg. } \\
\text { part. }\end{array}$ & katot & pl. nom. & & \\
\hline \multirow{3}{*}{$\begin{array}{l}\text { ntt : nt: } \\
n(n)\end{array}$} & ranttaa & sg. part. & ranta & sg. nom. & rannan & sg. gen. \\
\hline & emänttää & sg. part. & emäntä & sg. nom. & emänän & sg. gen. \\
\hline & lenttäät & 1. inf. & lentäny & $\begin{array}{l}\text { perf. pts. } \\
\text { sg. nom. }\end{array}$ & lennän & pres. 1. sg. \\
\hline $\mathrm{nt}: \mathrm{nn}$ & \multicolumn{2}{|c|}{ Stadium II fins ikke. } & kinthaat & pl. nom. & kinnas & sg. nom. \\
\hline \multirow[t]{2}{*}{$\mathrm{ntt}: \mathrm{nt}$} & kontti & sg. nom. & kontit & pl. nom. & \multicolumn{2}{|c|}{ Stadium 0 fins ikke. } \\
\hline & ranttheet & pl. nom. & rantet & sg. nom. & & \\
\hline \multirow{3}{*}{$\begin{array}{l}r t t: r t: \\
r(r)\end{array}$} & parttaa & sg. part. & parta & sg. nom. & parran & sg. gen. \\
\hline & siirttyyt & 1. inf. & siirtyny & $\begin{array}{l}\text { perf. pts. } \\
\text { sg. nom. }\end{array}$ & siiryn & pres. 1. sg. \\
\hline & kuurttoo & pres. 3. sg. & kuurtosin & pret. 1. sg. & kuurota & 1. inf. \\
\hline$r t: r r$ & \multicolumn{2}{|c|}{ Stadium II fins ikke. } & harthaat & pl. nom. & harras & sg. nom. \\
\hline$r t t: r t$ & $\begin{array}{l}\text { hurtta: } \\
\text { hurttaa }\end{array}$ & $\begin{array}{l}\text { sg. nom. : sg. } \\
\text { part. }\end{array}$ & hurtan & sg. gen. & \multicolumn{2}{|c|}{ Stadium 0 fins ikke. } \\
\hline \multirow[t]{2}{*}{ Itt : It : I(I) } & ilttaa & sg. part. & ilta & sg. nom. & illan & nom. gen. \\
\hline & palelttuut & 1. inf. & paleltunnu & $\begin{array}{l}\text { perf. pts. } \\
\text { sg. nom. }\end{array}$ & palelun & pres. 1. sg. \\
\hline It : II & \multicolumn{2}{|c|}{ Stadium II fins ikke. } & mallas & sg. nom. & malthaat & pl. nom. \\
\hline Itt : It & $\begin{array}{l}\text { polttaat: } \\
\text { polttanu }\end{array}$ & $\begin{array}{l}\text { 1. inf. : perf. } \\
\text { pts. } \\
\text { sg. nom. }\end{array}$ & poltan & pres. 1. sg. & \multicolumn{2}{|c|}{ Stadium 0 fins ikke. } \\
\hline \multirow[t]{3}{*}{ ht : hđ h } & \multirow{3}{*}{\multicolumn{2}{|c|}{ Stadium II fins ikke. }} & lähteet & 1. inf. & läh(đ)en & pres. 1. sg. \\
\hline & & & lehti : lehtee & $\begin{array}{l}\text { sg. nom. : sg. } \\
\text { part. }\end{array}$ & leh(đ)en & sg. gen. \\
\hline & & & puhthaat & pl. nom. & puh(d)as & sg. nom. \\
\hline
\end{tabular}


Tabell 3.7 Spesialstadieveksling: Vekslinger av plosiven $p$

\begin{tabular}{|c|c|c|c|c|c|c|}
\hline Veksling & Stadium II & Bøyingsform & Stadium I & Bøyingsform & Stadium 0 & Bøyingsform \\
\hline \multirow{3}{*}{$p p: p: v$} & аррии & sg. part. & apu & sg. nom. & avut & pl. nom. \\
\hline & leippää & sg. part. & leipä & sg. nom. & leivät & pl. nom. \\
\hline & leppää & pres. 3. sg. & lepäs & pret. 3. sg. & levätä & 1. inf. \\
\hline \multirow[t]{3}{*}{$\mathrm{pp}: \mathrm{p}$} & $\begin{array}{l}\text { leppä : } \\
\text { leppää }\end{array}$ & $\begin{array}{l}\text { sg. nom. : } \\
\text { sg. part. }\end{array}$ & lepän & sg. gen. & \multirow{3}{*}{\multicolumn{2}{|c|}{ Stadium 0 fins ikke. }} \\
\hline & $\begin{array}{l}\text { pappi : } \\
\text { pappii }\end{array}$ & $\begin{array}{l}\text { sg. nom. : } \\
\text { sg. part. }\end{array}$ & papin & sg. gen. & & \\
\hline & saapphaat & pl. nom. & saapas & sg. nom. & & \\
\hline \multirow{3}{*}{$\begin{array}{l}\text { mpp : mp: } \\
m(m)\end{array}$} & amppuut & 1. inf. & ampui & pret. 3. sg. & ammun & pres. 1. sg. \\
\hline & temppaa & pres. 3. sg. & tempas & pret. 3. sg. & temmata & 1. inf. \\
\hline & kumppaa & sg. part. & kumpi & sg. nom. & kummat & pl. nom. \\
\hline $\mathrm{mpp}: \mathrm{mp}$ & tumppu & sg. nom. & tumput & pl. nom. & \multicolumn{2}{|c|}{ Stadium 0 fins ikke. } \\
\hline rpp : rp : rv & turppaa & sg. part. & turpa & sg. nom. & turvat & pl. nom. \\
\hline \multirow[t]{2}{*}{$r p: r v$} & \multirow{2}{*}{\multicolumn{2}{|c|}{ Stadium II fins ikke. }} & turpheet & pl. nom. & turvet & sg. nom. \\
\hline & & & varphaat & pl. nom. & varvas & sg. nom. \\
\hline rpp : rp & korppi & sg. nom. & korpit & pl. nom. & \multicolumn{2}{|c|}{ Stadium 0 fins ikke. } \\
\hline \multirow[t]{2}{*}{ Ipp : Ip : Iv } & kelppaa & pres. 3. sg. & kelpas & pret. 3. sg. & kelvata & 1. inf. \\
\hline & halppaa & sg. part. & halpa & sg. nom. & halvat & pl. nom. \\
\hline Ip : IV & \multicolumn{2}{|c|}{ Stadium II fins ikke. } & helpheet & pl. nom. & helvet & sg. nom. \\
\hline \multirow[t]{2}{*}{ Ipp : Ip } & valpphaat & pl. nom. & valpas & sg. nom. & \multirow{2}{*}{\multicolumn{2}{|c|}{ Stadium 0 fins ikke. }} \\
\hline & helppo & sg. nom. & helpot & pl. nom. & & \\
\hline
\end{tabular}

Tabell 3.8 Spesialstadieveksling: Vekslinger av konsonanten $s$

\begin{tabular}{|c|c|c|c|c|}
\hline Veksling & Stadium II & Bøyingsform & Stadium I & Bøyingsform \\
\hline \multirow[t]{9}{*}{ ss : s } & kiussaa & pres. 3. sg. & kiusata & 1. inf. \\
\hline & kiussaa & sg. part. & kiusa & sg. nom. \\
\hline & ossaa & pres. 3. sg. & osata & 1. inf. \\
\hline & ossaa & sg. part. & osa & sg. nom. \\
\hline & tylssää & sg. part. & tylsä & sg. nom. \\
\hline & kanssaa & sg. part. & kansa & sg. nom. \\
\hline & anssoot & 1. inf. & ansoi & pret. 3. sg. \\
\hline & kärssiit & 1. inf. & kärsin & pres./pret. 1. sg. \\
\hline & karsshaat & pl. nom. & karsas & sg. nom. \\
\hline
\end{tabular}


Tabell 3.9 Spesialstadieveksling: Vekslinger av konsonantene $h, j, l, m, n, r$ og $v$

\begin{tabular}{|c|c|c|c|c|}
\hline Veksling & Stadium II & Bøyingsform & Stadium I & Bøygingsform \\
\hline \multirow[t]{3}{*}{$\mathrm{hh}: \mathrm{h}$} & puhhuut & 1. inf. & puhun & pres. 1. sg. \\
\hline & lihhaa & sg. part. & liha & sg. nom. \\
\hline & sahhaa & pres. 3. sg. & sahata & 1. inf. \\
\hline \multirow[t]{3}{*}{$\mathrm{jj}: \mathrm{j}$} & ajjaat & 1. inf. & ajan & pres. 1. sg. \\
\hline & rajjaa & sg. part. & raja & sg. nom. \\
\hline & vajjoo & pres. 3. sg. & vajota & 1. inf. \\
\hline \multirow[t]{3}{*}{$\|: \mid$} & kallaa & sg. part. & kala & sg. nom. \\
\hline & sullaa & pres. 3. sg. & sulata & 1. inf. \\
\hline & pillaa & pres. 3. sg. & pilata & 1. inf. \\
\hline \multirow[t]{2}{*}{$\mathrm{mm}: \mathrm{m}$} & rummaa & sg. part. & ruma & sg. nom. \\
\hline & kummoo & pres. 3. sg. & kumota & 1. inf. \\
\hline \multirow[t]{3}{*}{$\mathrm{nn}: \mathrm{n}$} & ennoo & sg. part. & eno & sg. nom. \\
\hline & sannoot & 1. inf. & sanoi & pret. 3. sg. \\
\hline & sannaa : sannoi & sg. part. : pl. part. & sana & sg. nom. \\
\hline \multirow[t]{3}{*}{$r r: r$} & kirroo & pres. 3. sg. & kirota & 1. inf. \\
\hline & herrää & pres. 3. sg. & herätä & 1. inf. \\
\hline & pirruu & sg. part. & piru & sg. nom. \\
\hline \multirow[t]{2}{*}{$\mathrm{VV}: \mathrm{v}$} & hyvvää & sg. part. & hyvä & sg. nom. \\
\hline & levvii & pres. 3. sg. & levitä & 1. inf. \\
\hline
\end{tabular}

\subsubsection{Lengda på de stemte konsonantene $I, r, m$ og $n$}

De stemte konsonantene $l, r, m$ og $n$ opptrer også i andre vekslinger enn stadieveksling. I kvensk er det slik at lang eller geminert $l l, r r, m m$ og $n n$ blir forkorta i noen omgivelser, mens den står ved lag i andre. Regelen for lengda på disse konsonantene er enkel:

LENGDA PÅ DE STEMTE KONSONANTENE $1, \mathrm{r}, \mathrm{m}$ OG n:

Etter lang trykksterk eller trykksvak vokal og etter kort trykksvak vokal følger kort $l, r, m$ og $n$, ellers følger lang $l l, r r, m m$ og $n n$. 
Tabell 3.10 Lengda på de stemte konsonantene $l, r, m$ og $n$

\begin{tabular}{|c|c|c|c|c|c|c|}
\hline & $\begin{array}{l}\text { Etter lang } \\
\text { vokal med } \\
\text { hovedtrykk } \\
\rightarrow I, r, m, n\end{array}$ & $\begin{array}{l}\text { Etter lang } \\
\text { vokal med } \\
\text { bitrykk } \rightarrow I, r \text {, } \\
m, n\end{array}$ & $\begin{array}{l}\text { Etter lang, } \\
\text { trykksvak } \\
\text { vokal } \rightarrow l \text {, } \\
r, m, n\end{array}$ & $\begin{array}{l}\text { Etter kort, } \\
\text { trykksvak } \\
\text { vokal } \rightarrow I, r \text {, } \\
m, n\end{array}$ & $\begin{array}{l}\text { Etter kort } \\
\text { vokal med } \\
\text { hovedtrykk } \\
\rightarrow I I, r r, m m \\
n n\end{array}$ & $\begin{array}{l}\text { Etter kort } \\
\text { vokal med } \\
\text { bitrykk } \rightarrow \text { II, } \\
r r, m m, n n\end{array}$ \\
\hline $\begin{array}{l}\text { Pl. 1. pers. } \\
\text { suff. } \\
m m A \text { / } \\
m A\end{array}$ & $\begin{array}{l}\text { saa/ma } \\
\text { sai/ma } \\
\text { juo/ma } \\
\text { joi/ma }\end{array}$ & $\begin{array}{l}\text { piikaroi/ma } \\
\text { haravoi/ma }\end{array}$ & $\begin{array}{l}\text { sanoi/ma } \\
\text { puhui/ma } \\
\text { halluu/ma } \\
\text { pölkkää/ } \\
\text { mä }\end{array}$ & $\begin{array}{l}\text { lähđe/mä } \\
\text { lähđi/mä } \\
\text { kirjoittele/ } \\
\text { ma } \\
\text { kirjoitteli/ } \\
\text { ma }\end{array}$ & $\mathrm{e} / \mathrm{mmä}$ & $\begin{array}{l}\text { kirjoita/ } \\
\text { mma } \\
\text { kirjoiti/ } \\
\text { mma } \\
\text { puhele/ } \\
\text { mma } \\
\text { puheli/ } \\
\text { mma }\end{array}$ \\
\hline $\begin{array}{l}\text { Perf. pts. } \\
n n U / n U \\
I / I U / I U\end{array}$ & $\begin{array}{l}\text { saa/nu } \\
\text { juo/nu } \\
\mathrm{maa} / \mathrm{nu} \\
\mathrm{kuul} / \mathrm{u}\end{array}$ & $\begin{array}{l}\text { piikaroi/nu } \\
\text { haravoi/nu }\end{array}$ & $\begin{array}{l}\text { havai/nu } \\
\text { kirroil/u }\end{array}$ & $\begin{array}{l}\text { lähte/ny } \\
\text { kirjoitutta/ } \\
\text { nu } \\
\text { puhel/u }\end{array}$ & $\begin{array}{l}\text { men/ny } \\
\text { ol/lu } \\
\text { tul/lu }\end{array}$ & $\begin{array}{l}\text { kirjoitta/ } \\
\text { nnu } \\
\text { ajatel/lu }\end{array}$ \\
\hline $\begin{array}{l}\text { 1. inf. } \\
\text { I/IA / I/A }\end{array}$ & $\begin{array}{l}\mathrm{kuul} / \mathrm{a} \\
\text { luul/a }\end{array}$ & & kirroil/a & $\begin{array}{l}\text { puhel/a } \\
\text { muistel/a }\end{array}$ & tul/la & $\begin{array}{l}\text { kohđatel/la } \\
\text { kylästel/lä }\end{array}$ \\
\hline $\begin{array}{l}\text { Ess. nnA / } \\
n A\end{array}$ & $\begin{array}{l}\text { yö/nä } \\
\text { pää/nä }\end{array}$ & $\begin{array}{l}\text { kuninkhaa/na } \\
\text { praatikkhaa/ } \\
\text { na }\end{array}$ & $\begin{array}{l}\text { rikkhaa/na } \\
\text { vaphaa/na }\end{array}$ & $\begin{array}{l}\text { poika/na } \\
\text { ruijalaise/na }\end{array}$ & $\begin{array}{l}\text { [Sic! si/nä } \\
\text { tä/nä] }\end{array}$ & $\begin{array}{l}\text { kaupunki/ } \\
\text { nna } \\
\text { tyttäre/nnä }\end{array}$ \\
\hline $\begin{array}{l}\text { Adess. } \\
\text { IIA / IA }\end{array}$ & $\begin{array}{l}\text { jää/lä } \\
\text { tuo/la }\end{array}$ & $\begin{array}{l}\text { kiikarii/la } \\
\text { kantelhee/la }\end{array}$ & $\begin{array}{l}\text { faarii/la } \\
\text { valkkee/la } \\
\text { varkhaa/la }\end{array}$ & $\begin{array}{l}\text { siljo/la } \\
\text { kainulaise/la }\end{array}$ & $\begin{array}{l}\text { jo/lla } \\
\text { si/llä }\end{array}$ & $\begin{array}{l}\text { hevose/lla } \\
\text { amtmani/lla } \\
\text { harav/i/Ila }\end{array}$ \\
\hline $\begin{array}{l}\text { All. } \\
\| l e(t) / \\
l e(t)\end{array}$ & $\begin{array}{l}\text { tei/le } \\
\text { mui/le }\end{array}$ & $\begin{array}{l}\text { kiikarii/le } \\
\text { kantelhee/le } \\
\text { kuninkhaa/le }\end{array}$ & $\begin{array}{l}\text { faarii/le } \\
\text { valkkee/le } \\
\text { varkhaa/ } \\
\text { le }\end{array}$ & $\begin{array}{l}\text { matka/le } \\
\text { minu/le }\end{array}$ & $\begin{array}{l}\text { si/lle } \\
\text { tä/lle }\end{array}$ & $\begin{array}{l}\text { hevose/lle } \\
\text { amtmani/ } \\
\text { lle } \\
\text { harav/i/Ile }\end{array}$ \\
\hline
\end{tabular}

Denne lengdevekslinga overstyrer stadieveksling. Sjøl om reglene for spesialstadieveksling (se 3.1.1.2 ovenfor) tilsier at for eksempel presens tredje person entall av verbet ajela ('kjøre, småkjøre') er *ajellee (stammekonsonanten er her etterfulgt av lang vokal), så blir $l l$ her likevel forkorta, det vil si at vi skriver ajelee. Derimot har vi lang $l l$ i forma ajattellee, som er presens tredje person av verbet ajatella, igjen etter lengderegelen for stemt $l, r$, $m$ og $n$. Lengderegelen kommer også til uttrykk i vekslinga av ulike suffiks:

Vekslinger i konsonantlengde av denne typen finner vi også på innsida av stammen og i avleiingssuffiks, for eksempel kuunel/a ('høre på) : kuuntele/e vs. 
kannel/a ('bære') : kantele/e, tavalinen ('vanlig') vs. tynnyrillinen ('fat'). Etter kort, trykksterk stavelse følger stammekonsonanten likevel ikke denne lengderegelen. Det ser vi for eksempel i nomenformer som pala ('stykke, bit'), tora ('krangel'), nenä ('nese'), tuli ('glød, ild'), ajattelu ('tenking') (og ikke *palla, ${ }^{*}$ torra, ${ }^{\star}$ nennä, ${ }^{\star}$ tulli, ${ }^{\star}$ ajattellu) og i verbformer som mene ('kom!'), puri ('beit'), tuli ('kom'), kirota ('sverge, banne'), haluta ('ha lyst til'), ajattelen ('jeg tenker') (og ikke ${ }^{\star}$ menne, ${ }^{\star}$ purri, ${ }^{\star}$ tulli, ${ }^{\star} k i r r o t a,{ }^{\star}$ halluta, ${ }^{\star}$ ajattellen). Men konsonanten i slike omgivelser kan sjølsagt forlenges etter reglene for stadieveksling. Eksempler på det ser vi i (sg. nom. : sg. part.) pala : pallaa, tora : torraa, nenä: nennää, ajattelu : ajattelluu, (imp. 2. sg. : pres. 3. sg.) mene: mennee, pure: purree, tule: tullee, kirota: kirroo, ajattele : ajattellee.

\subsubsection{H-flytting}

I visse kvenske ord fins det en $h$ som opprinnelig har stått mellom vokaler, men som i visse ordformer opptrer lenger bak i ordet. Dette fenomenet kaller vi her for $h$-flytting, og $h$-en som blir flytta, kaller vi for flytte- $h$. I dialektene fins det variasjon i hvor langt bak $h$-en kan opptre, men i skriftspråket flytter den likevel aldri mer enn ett hakk. ${ }^{1}$ La oss se nærmere på de ulike tilfellene av $h$-flytting:

- Illativformer av nomen: VhVn > hVVn. Eksempler: sauna ('badstue') + $\mathrm{hVn}>$ saun/haan, koivukko ('bjørkeskog') $+\mathrm{hVn}>$ koivukk/hoon, (vares :) varekse- ('kråke') + hVn > vareks/heen, Alattio + hVn ('Alta') > Alatti/hoon, (hevo(i)nen :) hevo(i)se- ('hest') $+\mathrm{hVn}>$ hevo(i)s/heen.

- Illativformer av 3. infinitiv: $\mathrm{mA}+\mathrm{hVn}>$ mhAAn. Eksempler: (syö/đä :) syö/ $m \ddot{a}$ - ('spise') + hVn > syö/m/hään, (ajja/at :) aja/ma- ('kjøre') + hVn > aja/m/ haan, (räknä/tä :) räknää/mä- ('regne, telle') + hVn > räknää/m/hään.

- Tostamma nomen med stammer på -Vs : -hVV. Eksempler: rikas ('rik') : rikkhaa/n, lammas ('sau') : lamphaa/t, kuningas kuninkas ('konge') : kuninkhaa/n.

- Tostamma nomen med stammer på -e(t) : -hee. Eksempler: vene( $t$ ) ('båt') : venhee/t, liike $(t)$ ('bevegelse') : liikkhee/t, vastale( $t$ ) ('motbakke') : vastalhee/t.

1 Jeg tar her ikke stilling til det språkhistoriske spørsmålet om hvordan $h$-en har havna i disse posisjonene, det vil si om det er $h$-en som har flytta på seg sammen med vokalen, eller om vokalen har falt bort foran $h$-en. 
- Nomen som er avleid med suffikset hinen. Eksempler: jokhainen ('hver'), ikhäinen ('gammal'), joukhainen ('svane'), alhainen ('grei, kjekk'), munhainen ('nyre'), muurhainen ('maur'), melkheinen ('anselig'), yhtheinen ('felles'), ylheinen ('allmenn'), mielhuinen ('kjærkommen').

Vi ser at flytte- $h$ kan endre morfemgrensa, slik at stammevokalen havner i suffikset. Det er for eksempel tilfellet i illativ.

\subsubsection{Vokalvekslinger foran suffikset - $i$}

Kvensk har flere suffiks som begynner på vokalen $i$, eller som består utelukkende av denne vokalen. Foran slike suffiks skjer det ofte ei endring i sluttvokalen i stammen. De to viktigste suffiksa i denne gruppa er FLERTALLssuffikset - $i$ og PRETERITUMssuffikset $-i$. Tabell 3.11 viser hvordan sluttvokalen i stammen endrer seg foran disse to suffiksa.

Vi finner følgende vokalvekslinger foran flertalls- og preteritums- $i$ :

(1) Når stammen slutter på lang vokal, så blir denne forkorta foran flertallsog preteritums-i. (2) Når stammen slutter på diftong, så faller den første vokalen i diftongen bort, og $i$-en opptrer som andre vokal i den nye diftongen $\left(V_{2} i\right)$. (3) Dersom den andre vokalen i den opprinnelige diftongen er $i$, så faller den alltid bort. (4) De enkle vokalene $o, \ddot{o}, u$ og $y$ står alltid ved lag i stammeutlyd foran suffikset $-i$, mens sluttvokalen $e$ alltid faller bort. (6) Når stammevokalen er $i$, så får vi et skille mellom nomen og verb i Porsanger-varieteten: $i$-en står ved lag foran flertalls-i, men ikke foran preteritums-i. I de andre varietetene faller $i$ i stammeutlyd alltid bort foran $i$-suffikset.

(7) I tostava stammer på $a$ gjelder $a+i>i$ dersom vokalen i første stavelse er $o$ eller $u$ (det vil si runda vokal) (7.1), ellers gjelder $a+i>$ oi (7.2). (8) Stammesluttvokal $\ddot{a}$ faller alltid bort i tostava stammer foran flertalls- og preteritums-i. Det er vanskelig å gi klare regler for flerstava stammer som slutter på $a$ eller $\ddot{a}$ (7.3 og 8.2). Én ting er likevel klart: Når stammen slutter på va eller $v \ddot{a}$, så er resultatet alltid $v i$. I flerstava verbstammer faller $a / \ddot{a}$ alltid bort foran preteritums- $i$ (8.2).

Vi kan altså konstatere at det i de fleste tilfeller gjelder de samme reglene for vokalvekslinger mellom stammesluttvokal i nomen og flertalls- $i$ som mellom stammesluttvokal i verb og preteritums- $i$.

Nomenstammen som slutter på flertalls- $i$, kaller vi for FLERTALLSSTAMME, og verbstammen som slutter på preteritums-i, kaller vi for PRETERITUMSSTAMME. 
Tabell 3.11 Vokalvekslinger foran flertals- $i$ og preteritums- $i$

\begin{tabular}{|c|c|c|}
\hline Stammesluttvokal & $\begin{array}{l}\text { Flertals-i (sg. nom. : [sg. ess. :] } \\
\text { pl. ess.) }\end{array}$ & $\begin{array}{l}\text { Preteritums-i (1. inf. : [pres. } \\
\text { 3. sg. :] pret. 3. sg.) }\end{array}$ \\
\hline $1 V_{1} V_{1}+i>V_{1} i$ & $\begin{array}{l}\text { pää : pä/i/nä } \\
\text { korkkee : korkke/i/na }\end{array}$ & 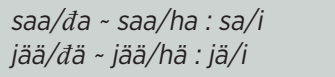 \\
\hline $2 V_{1} V_{2}+i>V_{2} i$ & $\begin{array}{l}\text { tie : te/i/nä } \\
\text { työ : tö/i/nä }\end{array}$ & $\begin{array}{l}\text { vie/dä vii/ä : vie : ve/i } \\
\text { syö/đä syy/ä : syö : sö/i }\end{array}$ \\
\hline $3 V i+i>V i$ & $\begin{array}{l}\text { täi : täi/nä : tä/i/nä } \\
\text { maanantai : maananta/i/na }\end{array}$ & ui/(d)a : ui : u/i \\
\hline $4 O, U+i>O i, U i$ & $\begin{array}{l}\text { poro : poro/i/na } \\
\text { koivu : koivu/i/na }\end{array}$ & $\begin{array}{l}\text { usko/ot usko/a(t): usko/i } \\
\text { häytty/yt häyty/ä(t): } \\
\text { häyty/i }\end{array}$ \\
\hline $5 e+i>i$ & $\begin{array}{l}\text { pieni : piene/nä : pien/i/nä } \\
\text { kainulainen : kainulaise/na : } \\
\text { kainulais/i/na }\end{array}$ & $\begin{array}{l}\text { tul/la : tulle/e : tul/i } \\
\text { kuunel/a : kuuntele/e : } \\
\text { kuuntel/i }\end{array}$ \\
\hline $\begin{array}{l}6 i+i>(i \text { nomen }) \\
\text { Porsanger: } i \text {, ellers: } i \\
>(i \text { verb) } i\end{array}$ & $\begin{array}{l}\text { pappi : pappi/na : pappi/i/na } \\
\text { papp/i/na } \\
\text { kläppi : kläppi/nä : kläppi/i/nä } \\
\text { kläpp/i/nä } \\
\text { tunturi : tunturi/i/na tuntur/i/ } \\
\text { nna }\end{array}$ & $\begin{array}{l}\text { soppi/i(t) sopi/a/(t): } \\
\text { sop/i } \\
\text { purjetti/i(t) purjehti/a(t): } \\
\text { purjett/i purjeht/i }\end{array}$ \\
\hline $\begin{array}{l}\text { 7.1 Tostava stammer } a+i>i \\
\text { (første vokal i første stavelse o } \\
\text { eller } u \text { ) }\end{array}$ & $\begin{array}{l}\text { poika : poik/i/na } \\
\text { hukka : hukk/i/na }\end{array}$ & $\begin{array}{l}\text { otta/a(t) : ott/i } \\
j u t t a / a(t): j u t / i\end{array}$ \\
\hline $\begin{array}{l}\text { 7.2 Tostava stammer } a+i>o i \\
\text { (første vokal i første stavelse ikke } \\
\text { o eller } u \text { ) }\end{array}$ & $\begin{array}{l}\text { ranta : ranto/i/na } \\
\text { kelkka : kelkko/i/na } \\
\text { kaula : kaulo/i/na }\end{array}$ & $\begin{array}{l}\text { saatta/a(t) : saatto/i } \\
\text { laula/a(t): laulo/i }\end{array}$ \\
\hline $\begin{array}{l}7.3 \text { Flerstava stammer } a+i \\
>i \text { (i verb og deler av nomen) }\end{array}$ & $\begin{array}{l}\text { saarnaaja : saarnaaj/i/nna } \\
\text { jout(ta)ava : jout(ta)av/i/nna } \\
\text { korkea korkia : korke/i/na }\end{array}$ & $\begin{array}{l}\text { upotta/a(t) : upott/i } \\
\text { rakasta/a(t) : rakast/i }\end{array}$ \\
\hline > Oi (i deler av nomen) & $\begin{array}{l}\text { kulk(ki)ija : kulk(ki)ijo/i/na } \\
\text { nutukka : nutuko/i/na } \\
\text { makkara : makkaro/i/na }\end{array}$ & \\
\hline $\begin{array}{l}\text { 8.1 Tostava stammer } a ̈+i>i \\
\text { (nomen og verb) }\end{array}$ & $\begin{array}{l}\text { lehmä : lehm/i/nä } \\
\text { tyhmä : tyhm/i/nä }\end{array}$ & 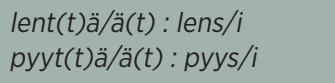 \\
\hline $\begin{array}{l}\text { 8.2 Flerstava stammer } a ̈+i>i(i \\
\text { verb og deler av nomen) }\end{array}$ & $\begin{array}{l}\text { näppärä : näppär/i/nnä } \\
\text { terävä : teräv/i/nnä }\end{array}$ & $\begin{array}{l}\text { lähättä/ä(t) : lähätt/i } \\
\text { vähent(t)ä/ä(t) : vähens/i }\end{array}$ \\
\hline > öi (deler av nomen) & penikkä : penikö/i/nä & \\
\hline
\end{tabular}




\subsubsection{Vekslinga $t V:$ si}

Tidligere har vi sett at plosiven $t$ i stadieveksling kan opptre på tre stadier: $t t: t$ : $\downarrow \sim \varnothing$. I en del ganske frekvente ord ser derimot $t$-en ut til å veksle med $s$. Eksempler på slike ord er (verb: 1. inf. : perf. pts. : pres. 1. sg. : pret. 3. sg. : pret.

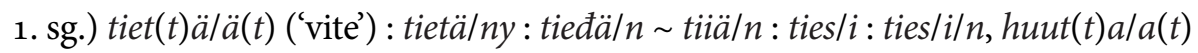
('skrike') : huuta/nu: huu(đ)a/n : huus/i : huus/i/n, ymmärt(t)ä/ä(t)) ('forstå) : ymmärtä/nny : ymmärä/n : ymmärs/i : ymmärs/i/n; (nomen: sg. nom. : sg. ess. : sg. part. : pl. nom. : pl. part.) vuosi ('år') : vuote/na : vuot/ta : vuo(d)e/t:vuoss/i/i $\sim$ vuos/i/a, uusi ('ny') : uute/na: uut/ta: uu(đ)elt: uuss/i/i uus/i/a, hirsi ('tømmer') : hirte/nä : hirt/tä : hirre/t: hirss/i/i hirs/i/ä.

Denne $t V: s i$-vekslinga finner vi i ord hvor stammesluttvokalen $e$ eller $A$ faller bort foran flertalls- eller preteritums- $i$ :

- I tostava preteritumsstammer av verb som har lang førstestavelse, og som gjennomgår spesialstadieveksling av typen II : I : o og generell stadieveksling av typen I : o. Eksempler er (1. inf. : perf. pts. : pres. 1. sg. : pret. 3. sg.) tunt $(t) e / e(t)$ ('kjenne') : tunte/nu : tunne/n : tunsi, lent $(t) \ddot{a} / \ddot{a}(t)$ ('fly') : lentä/ny : lennä/n : lens $/$, huut $(t)$ a/a(t) ('skrike') : huuta/nu : huu(đ)a/n : huus/i, pyyt(t)ä/ä(t) ('be (om); fange') :

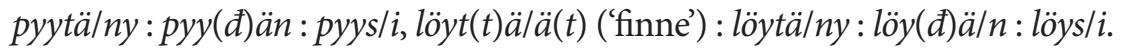

- I flerstava ord forekommer vekslinga regelmessig i verb med $r t A$-, ltA- og $n t A$-stammer. Eksempler er (1. inf. : perf. pts. : pres. 1. sg. : pret. 3. sg.) puhalt $(t)$ a/a(t) ('blåse') : puhalta/nnu : puhala/n : puhals/i, ymmärt $(t) \ddot{a} /(\ddot{a}) t$ ('forstå) : ymmärtä/nny : ymmärä/n : ymmärs/i, vai(j)ent $(t) a / a(t)$ ('få til å tie') $: \operatorname{vai}(j)$ enta/nnu:vai(j)ena/n $:$ vai(j)ens/i.

- Verb med $t V$ : si-veksling hører alle til verbtype 2 (se 6.2.2).

- Vekslinga er også heilt regelmessig i nomen som i nominativ slutter på - $i$, og som har vokalstamme på -e. Eksempler er (sg. nom. : sg. ess. : sg. part. : pl. iness.) käsi ('hand') : käte/nä : kät/tä : käs/i/ssä, viisi ('fem') : viite/nä : viit/tä : viis/i/ssä. Disse er alle såkalte tostamma nomen (nomentype 1.2, se 5.1.1.2).

- I ordenstall veksler nte i entallsstammen med $n s i$ i flertallsstammen, som for eksempel i (sg. nom. : sg. ess. : pl. iness.) kolmas ('tredje') : kolmante/nna : kolmans/i/ssa. Mer om det i avsnitt 8.2.

Vekslinga $t V: s i$ :

Foran $i$ veksler $t$ ofte med $s$. Men slik $t V: s i$-veksling forekommer derimot aldri i ord som gjennomgår stadieveksling av typen II : I. 


\subsubsection{Vokalharmoni}

Et fenomen som er felles for alle varietetene av kvensk, er såkalt vokalharmoni. Det innebærer at vokalkvaliteten i rota på et ord, det vil si om rotvokalen(e) er bakre eller fremre, påvirker vokalkvaliteten i suffikset som følger etter. Vi ser det for eksempel i disse substantivformene: joki ('elv') : jove/ssa, huonet ('hus') : huonhee/ssa : huonet/ta, kota ('gamme') : kođa/ssa koa/ssa, men niemi ('odde, nes') : nieme/ssä, elämä ('liv') : elämä/ssä : elämä/ä, meri ('hav') : mere/ ssä : mer/tä, og i disse verbformene: lukke/et ('telle; lese') : luje/ma : luke/nu, men lähte/et ('dra av gårde’) : lähđe/mä : lähte/ny.

Vokalharmoni kommer også til uttrykk i avleiingssuffiks. Eksempler på det er sammu/ut ('slokne') $\rightarrow$ sammu/tta/at ('slukke'), men lähte/et ('dra av gårde') $\rightarrow$ lähälttälät ('sende'), kuol/a ('dø') $\rightarrow$ kuole/ma ('død'), men ellälät ('leve') $\rightarrow$ eläl mä ('liv').

Enkelt sagt går vokalharmoni ut på følgende:

Vokalharmoni:

Når rota inneholder minst én bakre vokal, så brukes bakre vokalvarianter også i suffikset. Ellers brukes det fremre vokalvarianter.

Bakre vokaler, eller vokaler som uttales bak i munnhula, er $a$, $o$ og $u$. Alle de andre vokalene i kvensk er fremre vokaler, altså $e, i, \ddot{a}, \ddot{o}$ og $y$. Vokalene grupperes i par, slik at den fremre varianten av $a$ er $\ddot{a}$, den fremre varianten av $o$ er $\ddot{o}$, og den fremre varianten av $u$ er $y$.

De fremre vokalene $e$ og $i$ er nøytrale på den måten at de i rota kan opptre sammen med bakre vokaler. For eksempel finner vi både vika ('skade, feil') og ikä ('alder'), kesä ('sommer') og velka ('gjeld'). Legg også merke til (sg. nom. : sg. part.) virsi ('salme') : virt/tä, men (sg. nom.) virsta ('urin').

I denne grammatikken bruker vi stor bokstav som felles symbol for den bakre og fremre vokalvarianten i suffiks, det vil si at

$$
\begin{aligned}
& a \sim \ddot{a} \text { skrives } \operatorname{som} A, \\
& o \sim \ddot{o} \text { skrives som } O \text { og } \\
& u \sim y \text { skrives som } U .
\end{aligned}
$$

En hvilken som helst vokal skrives med V. To like vokaler som følger etter hverandre, skrives som VV, og dersom det er ulike vokaler, skriver vi $\mathrm{V}_{1} \mathrm{~V}_{2}$. 


\subsubsection{Andre morfonologiske vekslinger}

I kvensk fins det ganske strenge regler for hvilke konsonanter som kan følge etter hverandre (se avsnitt 2.3.1). Disse fonotaktiske reglene resulterer også $\mathrm{i}$ en del morfofonologiske vekslinger. Vi skal her ta for oss de viktigste.

- I mange tilfeller veksler en $n$ i slutten av et ord med en $m$ i inni ordet. Det har sin grunn $\mathrm{i}$ at et ord aldri får slutte på $m \mathrm{i}$ kvensk. Eksempler på slik veksling er:

Redskapsord som er avleid av verb med hjelp av suffikset -in. Eksempler: (sg. nom. : sg. part. : pl. nom.) (avata ('åpne') $\rightarrow$ ) avvain ('nøkkel') : avvain/ta : avvaime/t, (istuut ('sitte') $\rightarrow$ ) istuin ('sete') : istuin/ta : istuime/t, (luistaat ('gå på skøyter') $\rightarrow$ ) luistin ('skøyte') : luistin/ta : luistime/t.

Andre ord. Eksempler: (sg. nom. : sg. part. : pl. nom.) elläin ('dyr') : elläin/tä : elläime/t, höyhen ('fjær, dun') : höyhen/tä : höyheme/t, lai(đ)u(i)n ('beite') : lai(d)u(i)n/ta : laitu(i)me/t, morssiin morsian ('brud') : morssiin/ta morsian/ta : morssiime/t $\sim$ morsiamet, vaa(đ) in ('simle') : vaa(d) in/ta : vaatimelt, $s y(đ) \ddot{a} n$ ('hjerte') : sy(đ)än/tä:sy(đ)äme/t.

Vanligere er likevel at - $n$ i ord på -en står ved lag også i vokalstammen. Eksempler: ahven ('uer; abbor'): ahvene/t,jäsen ('medlem'): jäsene/t, paimen ('gjeter'): paimene/t, siemen ('frø') : siemene/t. Vekslinga $n: m$ fins heller ikke i nomen på ( $i$ )nen.

Her kan vi også nevne superlativformer, hvor konsonantstammen på (i)in veksler med suffiksa (i)impA :-(i)imA i vokalstammen. Eksempler: vanhiin ('eldst') : vanhiin/ta : vanhiimp/haan : vanhiima/t, issoin ('størst') : issoin/ta : issoimp/haan : issoima/t (se nærmere om superlativ i avsnitt 5.5.2).

- I kvensk fins det også en tendens til at konsonanter som følger etter hverandre, bør være homorganiske, det vil si at de har omtrent samme artikulasjonssted i munnhula. Det er grunnen til at stammekonsonanten i visse ord retter seg etter konsonanten i suffikset. Eksempler: lumi ('snø') : lume/n : lun/ta, liemi ('kjøttkraft') : lieme/n: lien/tä, niemi ('odde, nes') : nieme/n : nien/tä; yksi ('én') : yh/tä, kaksi ('to') : $k a h / t a$. (Samme homorganiske tendens ser vi i gamle lånord hvor $k t$ blir til $h t$, som i lyhty $(<$ lykt), rehtori (<rektor), tohtori (<doktor), tirehtööri $(<$ direktör $)$.)

- I ordslutt er det kun tillatt med én konsonant. På samme måte fins det begrensninger for hvilke konsonantkombinasjoner som er tillatt. Vi får derfor vekslinger som i varis $\sim$ vares ('kråke') $:$ varikse/t $\sim$ varekse/t $:$ varis/ta $\sim$ vares/ ta, ajos ('betennelse') : ajokse/t : ajos/ta, hiilos ('glo') : hiilokse/t: hiilos/ta, sormus ('ring') : sormukse/t : sormus/ta, selitys ('forklaring') : selitykse/t : selitys/tä; 
rakkhaus ('kjærlighet') : (rakkhaude/t : rakkhaut/ta :) rakkhauks/i/ssa, tottuus ('sannhet') : (tottuuude/t : tottuut/ta :) tottuuks/i/ssa; lapsi ('unge, barn') : lapse/ $n$ : las/ta, juos/ta ('springe') : jukse/ $n$.

Som morfonologisk kan vi også regne vekslinga vi har i visse verb mellom to vokalstammer av ulik lengde (for eksempel pime/tä ('mørkne') : pimene/e, hypä/tä ('hoppe') : hyppää), det at avleiingssuffikset i nomen på -(i)nen går tilbake på et anna suffiks enn i de andre kasusene (for eksempel i puna(i) nen ('rød') : puna(i)se/t: puna(i)s/ta), og det at sluttkonsonanten i konsonantstammen og i entall nominativ av en del nomen faller bort og blir erstatta av flytte- $h$ (for eksempel i pallas ('kveite') : palthaa/t : pallas/ta, vene( $t$ ) ('båt') : venhee/ $t$ : venhet/tä). Slike eksempler skal vi se nærmere på når vi behandler de ulike stammetypene hos nomen (se 5.1) og verb (se 6.2).

\subsection{Lydvekslinger mellom de kvenske skriftspråksvarietetene}

Ovenfor har vi diskutert ordinterne lydvekslinger. Her skal vi ta for oss lydvekslinger som viser forskjeller mellom de ulike varietetene av kvensk skriftspråk. Stadieveksling hører egentlig også til denne gruppa ettersom reglene for stadieveksling varierer mellom varietetene. Stadieveksling er likevel behandla sammen med de andre morfonologiske vekslingene ovenfor (se 3.1.1).

Dersom ei ordform har ulike varianter i de ulike skriftspråksvarietetene, så er variantene atskilt med tilde $(\sim)$ i denne grammatikken. Har ei ordform tre varianter, så er Porsanger- (og Nordreisa-) varianten satt opp først og Varangervarianten sist, mens den mellomste varianten kan brukes i de andre varietetene. Dersom det bare fins to varianter, gjelder den første Porsanger og den andre de andre varietetene. Ofte er variantene uttrykt med hjelp av parenteser. For eksempel betyr markeringa i puna(i)nen ('rød') at ordet har to varianter, punainen og punanen. Med hjelp av grammatikken skal det være mulig å finne ut hvilken varietet de ulike variantene hører heime i.

\subsubsection{Vekslinga ee eA iA og vokalutjamning}

Vekslinga $e e \sim e A \sim i A$ er ved sida av stadieveksling den lydvekslinga som skaper det tydeligste skillet mellom de ulike varietetene av kvensk. Vekslinga innebærer at en i den ene varieteten skriver ee, mens de andre 
varietetene har tilsvarende $e A$ eller $i A$. Vekslinga gjelder bare i visse kategorier:

- I såkalte $e A$-nomen ${ }^{2}$. Det er mest adjektiv, men også substantiv og pronomen hører til denne gruppa. Eksempler er korkkee korkea korkia ('høg'), valkkee valkea valkia ('ild; kvit'), hoppee hopea hopia ('sølv'), ussee usea usia ('flere'). Legg merke til at varianten $i A$ gjennomgår morfofonologisk veksling mellom entall og flertall, slik at entall $i A+$ flertalls- $i>e i$, som i (sg. nom. : sg. gen. : pl. iness.) korkia : korkia/n : korke/i/ssa.

- I entall partitiv av enstamma nomen med stamme på e. Eksempler er (sg. nom. : sg. gen. : sg. part.) järvi ('innsjø’) : järve/n : järvele järve/ä järvi/ä, salmi ('sund') : salme/ $n:$ salme/e $\sim$ salme/a salmi/a.

- I 1. infinitiv av enstamma verb med stamme på e. Eksempler er lähtelet lähtelä $(t) \sim$ lähti/ä ('dra av gårde'), lukkelet lukela(t) luki/a ('regne; lese').

- I den lange stammen av såkalte kontrakte verb: (1. inf. : pres. 3. sg.) langel ta ('snuble') : lankkee lankea/a lankia/a, ilje/tä ('tørre, våge, få seg til') : ilkkee ilkeä/ä ilkiälä, halje/ta : halkkee halkea/a halkia/a ('sprekke').

Fordelinga av disse variantene mellom de ulike varietetene er slik at ee-varianten er mest brukt i Porsanger og Nordreisa, $i A$-varianten i Varanger, og $e A$ varianten i de andre varietetene. Vokalene i disse vokalkombinasjonene hører til hver sin stavelse, og i Porsanger og Nordreisa er de blitt utjamna til én lang vokal (ee).

På tilsvarende måte er i Porsanger og Nordreisa-varietetene også andre vokaler som opprinnelig hørte til hver sin stavelse, blitt utjamna til lang vokal. Denne endringa har resultert i følgende variasjon i kvensk:

- I nomenstammer: laattii laattia ('golv'), astii astia ('kar'), kalttii kaltio ('kjelde'), rauttii rautio ('smed'), porstuu porstua ('bårstue').

- I entall partitiv: (sg. nom. : sg. part.) pappi ('prest') : pappi/i pappi/a, ukko ('gubbe') : ukko/o ukko/a.

- I 1. infinitiv: soppi/it sopi/a(t) ('passe'), usko/ot usko/a(t) ('tru'), kyssyl $y t \sim k y s y / \ddot{a}(t)$ ('spørre').

- I den lange stammen av kontrakte verb: (1. inf. : pres. 3. sg.) keri/tä ('rekke, nå) : kerkkii kerkiä/ä, halu/ta ('ha lyst til') : halluu halua/a.

2 Som $e A$-nomen regner vi her nomen som opprinnelig var avleid med suffikset $-e A$. 
Tabell 3.12 Variasjon mellom $\mathrm{V} V$ og $\mathrm{V}_{1} \mathrm{~V}_{2}$

\begin{tabular}{|l|l|l|l|}
\hline & $\begin{array}{l}\text { Porsanger og } \\
\text { Nordreisa: ee, ii, oO, } \\
\text { UU }\end{array}$ & $\begin{array}{l}\text { Varanger: iA, OA, UA, } \\
i O\end{array}$ & Andre: eA, iA, OA, UA \\
\hline eA-, iA- og iO-nomen & valkkee, laattii, kurkkii & valkia, laattia, kurkkio & valkea, laattia, kurkkio \\
\hline Sg. partitiv & $\begin{array}{l}\text { lehte/e, ukko/o, } \\
\text { syksy/y }\end{array}$ & $\begin{array}{l}\text { lehti/ä, ukko/a, } \\
\text { syksy/ä }\end{array}$ & $\begin{array}{l}\text { lehte/ä, ukko/a } \\
\text { syksy/ä }\end{array}$ \\
\hline 1. infinitiv & $\begin{array}{l}\text { lähte/et, usko/ot, } \\
\text { kyssy/yt }\end{array}$ & lähti/ä, usko/a, kysy/ä & $\begin{array}{l}\text { lähte/ä(t), usko/a(t), } \\
\text { kysy/ä(t) }\end{array}$ \\
\hline Kontrakte verb & $\begin{array}{l}\text { lankkee, kerkkii, } \\
\text { puttoo, halluu }\end{array}$ & $\begin{array}{l}\text { lankia/a, kerkiä/ä, } \\
\text { putoa/a, halua/a }\end{array}$ & $\begin{array}{l}\text { lankea/a, kerkiä/ä, } \\
\text { putoa/a, halua/a }\end{array}$ \\
\hline
\end{tabular}

Denne typen veksling er viktig på flere måter: Den virker ofte inn på stadieveksling, og den kan også føre til forskjeller i ordbøying mellom varietetene. Eksempler på det siste ser vi i (sg. nom. : sg. ill.) laattii laattia ('golv') : laattii/sseen laattil haan, valkkee valkea valkia ('ild; kvit') : valkkee/sseen valke/haan: valki/haan.

Tabell 3.12 oppsummerer de viktigste kategoriene hvor variasjonen mellom $V V$ og $V_{1} V_{2}$ kommer til uttrykk i kvensk.

\subsubsection{Ordfinal $t$}

Et anna trekk som danner et skille mellom de kvenske varietetene, er i hvilke kategorier en opprinnelig ordfinal $t$ er bevart eller ikke. Det er særlig følgende kategorier som er aktuelle:

- Nomen som slutter på et $\sim e$ i entall nominativ. Eksempler: venet vene ('båt'), myötälet myötäle ('nedoverbakke'). I de andre bøyingsformene er det ingen forskjeller mellom varietetene.

- Suffikset $V t \sim V$ i 1. infinitiv av enstamma verb (verbtype 2). Eksempler: jakkalat jakkala ('dele'), puhhu/ut puhu/a(t) ('snakke'), ymmärttä/ä(t)

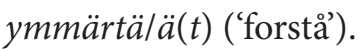

- Allativsuffisket (l)le (l)let. Eksempler: (äiti ('mor') :) äiti/le äiti/let, (tytär tyär ('jente; datter'):) tyttäre/lle tyttäre/llet.

- Adverb og adposisjoner, for eksempel läpi läpit ('gjennom'), sinne sinnet ('dit'), asti astit ('inntil, til'), pääle päälet ('opp på').

Slike ord slutter ikke på $t \mathrm{i}$ Varanger-varieteten. Ordfinal $t$ i slike ord er også sjelden i Tana-varieteten, og svært sjelden i Nordreisa. I Porsanger-varieteten er ordfinal $t$ vanlig i de to første gruppene ovafor, men ikke i de to siste. I de 
andre varietetene er ordfinal $t$ vanlig i alle gruppene ovafor, men den kan også sløyfes.

- Variasjon mellom former med og uten ordfinal $t$ finner vi også i entall av perfektum partisipp. Eksempler: syö/ny syö/nyt ('spist'), lähte/ny lähte/nyt ('dratt av gårde'), halu/nu halu/nut ('ønska'). Formene uten $t$ er vanligst, og det enkleste er å sløyfe $\mathrm{t}$ i alle varietetene.

- På samme måte kan ordfinal $t$ være med eller ikke i vekslinga $v A \sim v A t \mathrm{i}$ tredje person flertall av presens indikativ. Eksempler: syö/vä syö/vät ('(de) spiser'), lähte/vä lähte/vät ('(de) drar av gårde’), likene/vä likene/vät ('(de) nærme seg'). Formene uten $t$ er identiske med entallsformene i presens partisipp.

\subsubsection{Avleiingssuffiks med $i$}

Det fins ei gruppe avleiingssuffiks som opprinnelig inneholdt en $i$, som seinere i dialektene ofte har blitt borte ifra andre stavelsen. Slike suffiks kan i kvensk skrives med eller uten $i$, men det er bare i Porsanger-varieteten at former med $i$ er i vanlig bruk. Slike suffiks finner vi i følgende grupper:

- Nomen på inen nen. Eksempler: (adjektiv:) puna/inen puna/nen ('rød'), keltalinen kelta/nen ('gul'), näkö/inen näkö/nen ('lys'), ikhu/inen ikhul nen ('evig'); (substantiv:) hevo/inen hevo/nen ('hest'), kukka/inen kukkal nen ('blomst'), kylä/inen kylä/nen ('lita bygd'); (pronomen:) jokha/inen jokha/nen ('hver').

- Verb på OittA OttA. Eksempler: kirj/oitta/a(t) kirj/otta/a(t) ('skrive'), var/oitta/a $(t) \sim$ var/otta/a( $t$ ) ('advare'), miin/oitta/a( $t) \sim$ miin/otta/a $(t)$ ('minelegge'). Verbalsubstantiv avleid av slike verb: kirjoitus kirjotus ('skriving; skrift'), varoitus varotus ('advarsel'), miinoitus miinotus ('minelegging').

- Verb på Aise Ase. Eksempler: auk/ais/ta auk/as/ta ('åpne'), halk/ais/ta $\sim$ halk/as/ta ('kløyve'), ratk/ais/ta ratk/as/ta ('løyse'), sylk/äis/tä sylk/äs/tä ('spytte'). Verbalsubstantiv avleid av slike verb: aukaisu aukasu ('åpning’), halkaisu halkasu ('kløyving'), ratkaisu ratkasu ('løysing'), sylkäisy sylkäsy ('spytting').

Bortsett ifra når den opptrer $\mathrm{i}$ andre stavelsen er $i$-en alltid med i avleiingssuffiksa i gruppene ovafor. Eksempler er toinen ('andre'), puinen ('av tre, tre-'), aurinkoinen ('solrik'), kunnioittaa(t) ('verdsette'). 



\section{4 \\ Syntaks}

Den grunnleggende setningsbygninga i kvensk er framstilt i avsnitt 2.4 ovafor. I dette kapitlet skal vi ta for oss hvordan ledd kombineres til setninger. Vi ser på hvilke setningstyper som fins i kvensk, og hvilken bøyingsform de ulike ledda har i de ulike setningstypene.

\subsection{Setninger og setningstyper}

Med SETNING meiner vi her en konstruksjon som har et finitt verb som kjerne. For eksempel danner utsagna Met lähđemä aikamatkale ('Vi drar på tidsreise') og Nilla antoi preivin kuninkhaale ('Nils ga brevet til kongen') begge to hver si setning. I begge er det ett finitt verb, det vil si et verb med personbøying. I den første setninga er det lähđemä, og i den andre antoi.

Setninger kan også bestå av to eller flere setninger som er satt sammen til ei større enhet. To eksempler på slike KOMPLEKSE SETNINGer er (1) Met lähđemä aikamatkale ja tulema heti takaisin ('Vi drar på tidsreise og kommer snart tilbake') og (2) Nilla sanoi emänälle, ette hän oon kauheen vaipunu ('Nils sa til kona at han var fryktelig trøtt'). Begge inneholder to setninger. Men de skiller seg fra hverandre ved at den komplekse setninga (1) er satt sammen av to SIDEORDNA SETNINGER på samme nivå: Begge er HOVEDSETNINGER. I den komplekse setninga (2) er den første delsetninga ei hovedsetning, og den andre er ei LEDDSETNING, som blir styrt av hovedsetninga (1). Ei setning som styrer ei anna setning på denne måten, kaller vi for overordna SETNING eller OVERSETNING.

Leddsetninger kan også stå parallelt til hverandre. For eksempel er det to fordi-setninger i den komplekse setninga Mie en tahđo lähteet koulhuun, ko mie olen kippee ja ko ei Liisakhaan lähđe ('Jeg vil ikke gå på skolen, fordi jeg er sjuk, og fordi Lisa heller ikke går'), som begge er leddsetninger styrt av 
oversetninga Mie en tahđo lähteet koulhuun, og de er parallelle i forhold til hverandre. Men ei leddsetning kan også inneholde ei anna leddsetning, som for eksempel i den komplekse setninga Mie en pölkkää hukkaa, ko mie en usko, ette se oon vaaralinen ('Jeg er ikke redd for ulv, for jeg trur ikke at den er farlig'). Her er leddsetninga ko mie en usko oversetninga til leddsetninga ette se oon vaaralinen.

Verbalet er det mest sentrale og styrende elementet i enhver setning. Det knytter til seg andre obligatoriske ledd eller UTFYLLINGER, og det er subjekt, objekt, predikativ og adverbial. Basert på hvor mange utfyllinger et verbal tar, skiller vi mellom NULLVERDIGE, ENVERDIGE, TOVERDIGE Og TREVERDIGE verb. Vi kaller denne egenskapen for VALENSEN til verbet.

- Nullverdige verb er ofte verb som uttrykker ulike typer værfenomen, såkalte værverb, for eksempel sattaat ('regne'), tuula ('blåse') og tuiskuut ('fyke'). Verbformer som Sattaa ('Det regner'), Tuulee ('Det blåser') og Tuiskuu ('Det fyker') danner med andre ord fullstendige setninger.

- Enverdige verb krever vanligvis et subjekt og bare det. For eksempel er Matti yksii ('Mats hoster') og Matti sairastaa ('Mats er sjuk') fullstendige setninger.

- Toverdige verb krever i tillegg til subjekt et objekt, predikativ, adverbial eller et objektsadverbial. I sjeldne tilfeller er den første utfyllinga ikke subjekt, men en av de andre leddtypene. Eksempler på setninger med toverdige verb med subjekt er: Nilla hakkas mettää ('Nils hogger skog'; den andre utfyllinga er objekt), Nilla oli kainulainen ('Nils var kven/kvensk'; den andre utfyllinga er predikativ), Nilla kävi Kööpenhaminassa ('Nils dro til København'; den andre utfyllinga er adverbial) og Met kiikuima vaaran laittaa ('Vi klatrer opp fjellsida'; den andre utfyllinga er objektsadverbial).

- Treverdige verb krever i tillegg til subjekt et objekt og et adverbial. Eksempler er: Mie ostan sinule piilin ('Jeg kjøper bil til deg') og Liisa viskas kiven merheen. ('Lisa heiv steinen i sjøen'). Den tredje utfyllinga kan også være predikativ, som for eksempel i setninga Joonas käski valasta kalaksi ('Jonas kalte kvalen for fisk').

I passive og upersonlige setninger er subjektsplassen tom (se avsnitt 2.4.5). Til slike verbalhandlinger er det likevel mulig å forestille seg en aktør sjøl om den tilsvarende subjektsplassen i setninga er tom. Vi sier derfor at hovedutfyllinga mangler i slike setninger. Subjektet mangler også i bydesetninger 
(se avsnitt 2.4.6.3). Aktøren kommer ikke til uttrykk i imperativforma av verbet, og subjektplassen er dermed tom også i slike setninger sjøl om subjektet ville ha vært hovedutfylling i tilsvarende fortellende setninger eller spørresetninger. Sjøl om subjektsplassen i slike setninger er tom, så er valensen til verbet den samme. Valensen gjelder altså verbtypen, og ikke hvordan utfyllingene kommer til uttrykk i de ulike setningsmønstra.

Verb som krever objekt, eller som valgfritt kan knytte til seg objekt, kaller vi for transitive Verb. Som regel er disse toverdige eller treverdige verb. Men transitive verb kan også opptre uten objekt, som for eksempel verbet laulaat ('synge'). Setninga Terje laulaa ('Terje synger') er fullstendig uten objekt, men vi kan legge til et objekt, som i setninga Terje laulaa virttä ('Terje synger en salme'). Vi ser altså at sjøl om objektet vanligvis er ei obligatorisk utfylling til verbet, så kan det stundom mangle i transitive setninger uten at de dermed bli ufullstendige.

I motsetning til transitive verb kaller vi verb som ikke kan ta objekt, for INTRANSITIVE VERB. Intransitive verb som ikke krever andre utfyllinger, er nullverdige, som for eksempel tuula i setninga Tuulee ('Det blåser'). Ellers er transitive verb en- eller toverdige, men aldri treverdige.

Vi skal her se nærmere på hva slags verbal som fins i setninger, og hvilke setningstyper de ulike verba opptrer i. Disse to forholda styrer også hvilken bøyingsform de andre ledda i setninga har, det vil si subjekt, objekt og andre utfyllinger.

Basert på det som blir uttrykt eller framstilt med hjelp av ei setning, deler vi setninger $\mathrm{i}$ to hovedtyper, DIREKTE SETNINGER og INDIREKTE SETNINGER. Direkte setninger gjengir et saksforhold direkte (1-5), mens indirekte setninger viser til noe andre har sagt, eller gjengir tanker eller sanseinntrykk (6-8). Eksempler er:

1. Mie lähđen Alattihoon. 'Jeg drar til Alta.'

2. Mistä sie olet pois?

'Hvor er du fra?'

3. Pappi kirjoitti preivin.

'Presten skreiv et brev/brevet.'

4. Nilla vihas amtmanii.

'Nils hata amtmannen.' 
5. Tullee sađet.

'Det blir regn.'

6. Kreeta näki, ette Nuutti tuli takaisin.

'Greta så at Knut kom tilbake.'

7. Kuningas ajatteli, ette kainulaiset oon sepät ihmiset.

'Kongen syntes at kvenene var dyktige folk'.

8. Mie luulen, ette nyt tullee sađet.

'Jeg trur (at) det blir regn nå.'

En viktig strukturell forskjell mellom direkte og indirekte setninger er at verb som typisk opptrer i direkte setninger, vanligvis ikke kan ha at-setninger eller andre leddsetninger eller verbfraser som utfylling. Derimot er slike leddsetninger og verbfraser vanlige utfyllinger til verb i indirekte setninger.

Det fins også verb som fungerer som verbal i både direkte og indirekte setninger, for eksempel verba puhhuut ('snakke'), kirjoittaat ('skrive'), lukkeet ('lese') og tutkiit ('studere, undersøke'). Det kommer fram når vi jamfører den direkte setninga i (3) ovafor med den indirekte setninga i (9) nedafor. På samme måte opptrer ett og samme verb i ei direkte setning i (10), men i ei indirekte setning i (11).

9. Pappi kirjoitti, ette amtmani kiussaa kainulaissii.

'Presten skreiv at amtmannen plaga kvenene.'

10. Äiji luki aviissii.

'Bestefar leste i avisa.'

11. Äiji luki aviisista, ette huomena tullee kova sää.

'Bestefar leste i avisa at det skulle bli dårlig vær i morgen.'

Det fins enda en tredje setningstype, såkalt modifiserte setninger, der verbalet verken gjengir noe saksforhold eller viser til utsagn, tanker eller noe anna. Slike setninger modifiserer bare det som blir framstilt i setninga, eller bestemmer hvilket tidspunkt som gjelder for handlinga eller hendelsen som framstilles.

Denne grammatikken tar ikke mål av seg til å presentere alle mulige setningstyper i kvensk, men konsentrerer seg om de viktigste og mest vanlige. Av setningsledda skal vi først og fremst diskutere verbal og utfyllinger til verbal, 
mens vi bare i liten grad skal ta opp frie adverbial som rammeadverbial, konnektiver og kommentaradverbial. Disse får likevel noe omtale i avsnitta om adverb og junksjoner. På samme måte kommer vi heller nesten ikke inn på fraseinterne ledd eller modifikatorer.

Det er bare små syntaktiske forskjeller mellom de kvenske varietetene, og syntaktisk variasjon er derfor ikke gjenstand for denne grammatikken. De syntaktiske eksempla er først og fremst gjengitt i den morfologiske og fonologiske forma som gjelder for Porsanger-varieteten, men de kan sjølsagt lett overføres til de andre varietetene etter de morfologiske og fonologiske reglene som er presentert i denne grammatikken.

\subsection{Direkte setninger}

DiREKTE SETNINGER gjengir et saksforhold slik som det er, og viser ikke til noe noen har sagt eller skrevet, eller til tanker og sanseinntrykk. Det som avgjør om vi har med ei direkte setning å gjøre, er hva slags verb der er som utgjør verbalet, ikke hvilken bøyingsform verbet har. Til direkte setninger regner vi derfor også alle bydesetninger og spørsmålssetninger hvor verbalet for eksempel er et BEVEGELSES- eller TILSTANDSVERB. Setningene i (1) og (2) har et bevegelsesverb som verbal og er altså direkte, sjøl om de ikke uttrykker noe faktisk forhold, men befaler at et slikt forhold bør bli sant (1), eller spør om et slikt forhold er tilfellet (2).

1. Lähđe kothiin!

'Dra heim!'

2. Lähteekö Matti kothiin?

'Drar Mats heim?'

Her og de andre kapitla som handler om setningstyper, er eksempla satt opp på følgende måte: Først er setninga gjengitt slik som den skrives (linje 1). Under setninga følger en morfologisk analyse (ordklasse og bøyingsform) og ofte også en fraseanalyse (linje 2). Så kommer en syntaktisk funksjonsanalyse (linje 3). Og til slutt følger ei norsk oversetning av setninga (linje 4).

Grammatisk informasjon som står innom hakeparenteser [], hører til samme frase.

Vi deler direkte setninger inn i seks undergrupper, som igjen har sine eigne undergrupper. 


\subsubsection{Lokative og possessive setninger}

LOKATIVE SETNINGER forteller noe om at noen eller noe er relatert til et sted. Possessive SETninger forteller noe om at noen eller noe har eller eier noe eller noen. I dette avsnittet ser vi kun på toverdige setninger. Treverdige lokative og possessive setninger diskuterer vi i avsnittet om handlingssetninger (se avsnitt 4.2.5).

\subsubsection{STED}

STEDssetninger er lokative setninger som forteller at noen eller noe er på et sted. Det vanligste verbet i slike setninger er olla ('være'), men også andre tilstandsverb er mulige, for eksempel seissoot $\sim \operatorname{seisoa(}(t)$ ('stå), istuut $\sim$ istua $(t)$ ('sitte'), maata ('ligge'), assuut asua( $t$ ) ('bo') og ellää( $t$ ) ('leve'). Eksempler er:

1. Met olema siinä lomassa].

Pron[1.pl., nom.] V[olla, 1.pl.] N[sg. iness.]

S $\mathrm{V}$ ADV

'Vi er på dette rommet.'

2. Het seisothaan [vaaran laiđala].

Pron[3. pl, nom.] V[seissoot, 3. pl.] N[sg. adess.]

S $\mathrm{V}$ ADV

'De står i fjellia.'

3. [Kainun institutti] oon Pyssyjovessa.

$\mathrm{N}$ [sg. nom.] $\quad \mathrm{V}$ [olla, 3. sg.] $\mathrm{N}$ [sg. iness.]

S $\mathrm{V}$ ADV

'Kvensk institutt er i Børselv.'

4. Trygg assuu Annijoela.

$\mathrm{N}$ [sg. nom.] $\quad \mathrm{V}$ [assuut, 3. sg.] $\quad \mathrm{N}$ [sg. adess.]

S $\mathrm{V}$ ADV

'Trygg bor i Vestre Jakobselv.'

5. Aaroni assuu [vaaran takana].

$\mathrm{N}$ [sg. nom.] $\quad \mathrm{V}$ [assuut, 3. sg. $\quad \mathrm{PP}[\mathrm{N}+$ adposisjon $]$

S $\mathrm{V}$ ADV

'Aron bor bak fjellet.' 

6. Mie istun täälä.
Pron[1. sg., nom.] V[istuut, 1. sg.] Adv
S $\mathrm{V}$ ADV
'Jeg sitter her.'

Til STEDssetninger regner vi her også setninger som forteller at noe hender på et sted. Hendelsesverb er for eksempel työtelä ('arbeide, jobbe'), kuola ('dø') og synttyyt syntyä( $($ ) ('bli født'), som i setningene i (7-9):
7. Hilde
työtelee
[Kainun institutissa].
$\mathrm{N}[$ sg. nom.]
V[työtelä, 3. sg.]
$\mathrm{N}[$ sg. iness.
$S$
$\mathrm{V}$
ADV

'Hilde arbeider på Kvensk institutt.'
8. Aapo-faari
syntyi
Alattiossa.
$\mathrm{N}$ [sg. nom.]
$\mathrm{V}[$ synttyyt, 3. sg.]
$\mathrm{N}$ [sg. iness.]
$\mathrm{S}$
$\mathrm{V}$
ADV

'Bestefar Aapo blei født i Alta'

9. Hän

kuoli

kotona.

$\mathrm{N}$ [pron.3.sg.]

$\mathrm{V}[$ kuola, 3. sg. $]$

Adv

$\mathrm{S}$

$\mathrm{V}$

ADV

'Han døde heime.'

Når bevegelser kan forstås som hendelser og ikke uttrykker at noen eller noen beveger seg fra eller til et sted, så kan også bevegelsesverb (se avsnitt 4.2.1.2) fungere som verbal i STEDssetninger; jf. setningene i (10) og (11):

10. Iisakki

naakkii

klasin takana.

$\mathrm{N}[$ sg. nom.

$\mathrm{V}[$ naakkiit, 3. sg. $]$

$\mathrm{PP}[\mathrm{N}+$ adposisjon $]$

$S$

$\mathrm{V}$

ADV

'Isak sniker seg bak vinduet.'

11. Eira

uipi

lantossa.

$\mathrm{N}$ [sg. nom.]

$\mathrm{V}[$ uida, 3. sg.]

$\mathrm{N}$ [sg. iness.]

SUBJ

$\mathrm{V}$

ADV

'Eira svømmer i tjernet.'

Vi ser at subjektet (S) står først i STEDssetninger, så kommer verbalet (V), og til slutt adverbialet (ADV), som forteller hvor subjektet er. Subjektet i 
setninga står i nominativ, og verbet og subjektet kongruerer i tall og person. Adverbialet er et nomen som står i lokalkasus, det vil si inessiv $(1,3,7,8)$ eller adessiv $(2,4)$, eller det er en adposisjonsfrase (PP; 5,10$)$ eller et stedsadverb (Adv; 6, 9).

Når vi skal fortelle hvor noe eller noen er, så bøyes stedsnavnet som regel i indre lokalkasus, og stedssetninga står i inessiv $(3,8)$. Men visse stedsnavn står vanligvis i ytre lokalkasus (4). Man bør alltid undersøke hvilken kasus folk som bor på stedet, bruker, og så skrive deretter. Men dersom man ikke veit hvilken kasus som er brukt lokalt, så er det best å bruke indre lokalkasus.

STEDssetninger er altså av denne typen:

\section{STED:}

$\mathrm{S}[\mathrm{NP}[$ nom. $]]+\mathrm{V}[$ tilstandsverb, subjektskongruens $]+\mathrm{ADV}[\mathrm{NP}[$ iness./adess. $] / \mathrm{PP} /$ AdvP]

Samme mønster har også setninger med tilstandsverb som verbal og hvor den andre utfyllinga er et adverbial i 3. infinitiv inessiv (12):
12. Perunka
istui
[lukemassa Bibliaa].
$\mathrm{N}$ [sg. nom.]
$\mathrm{V}[$ istuut, 3. sg. $]$
$\mathrm{VP}[3$. inf. iness. $+\mathrm{N}]$
$\mathrm{S}$
$\mathrm{V}$
$\mathrm{ADV}[\mathrm{V}+\mathrm{OBJ}]$

'Beronka satt og leste i Bibelen.'

Også setninger med bevegelsesverb kan ha en slik struktur (13):
13. Lantalaiset kulkivat [nuottimassa Varenkinvuonossa].
$\mathrm{N}[$ pl. nom. $\quad \mathrm{V}[$ kulkia, 3. pl.] $\quad \mathrm{VP}[$ 3. inf. iness. $+\mathrm{N}]$
$\mathrm{S} \quad \mathrm{V} \quad \mathrm{ADV}[\mathrm{V}+\mathrm{ADV}]$

'Kvenene brukte å dra på garnfiske i Varangerfjorden.'

Slike setninger likner på aspektsetninger (se avsnitt 4.4.3).

Et spesielt unntak er tilstandsverbet jääđä jäähä ('bli (igjen)'), som alltid tar stedsutfylling i tilstedskasus (14):

$\begin{array}{lll}\text { 14. Muori } & \text { jäi } & \text { tunturhiin. } \\ \text { N[sg. nom.] } & \text { V[jääđä, 3. sg.] } & \text { N[sg. ill.] } \\ \text { S } & \text { V } & \text { ADV }\end{array}$

'Bestemor blei igjen på fjellet.' 


\subsubsection{BEVEGELSE}

Ei BEVEGELSEssetning er ei lokativ setning som forteller at noen eller noe beveger seg fra et sted eller til et sted. Som kjerne i slike setninger kan vi ha hvilket som helst BEVEGELSESVERB, det vil si et verb som uttrykker at noen eller noe flytter på seg. Vanlige eksempler er tulla ('komme'), mennä ('gå; dra') og lähteet lähteä $(t) \sim$ lähtiä ('dra av gårde'). I tillegg til subjekt har verbet i slike setninger som regel et adverbial som utfylling, og det forteller da hvor subjektet beveger seg fra eller til. Også tilstandsverb kan stundom opptre i BEVEGELSEssetninger, som for eksempel verbet istuut istua(t) ('sitte') i (5) nedenfor.

1. Met menemä Tromsshaan.

Pron[1. pl., nom.]

$\mathrm{V}[$ mennä, 1.pl.]

$\mathrm{N}$ [sg. ill.]

$\mathrm{S}$ $\mathrm{V}$

ADV

'Vi drar til Tromsø.'

2. Met

lähđemä

rannale.

Pron[1.pl., nom.]

V[lähteet, 1.pl.]

$\mathrm{N}$ [sg. all.]

$\mathrm{S}$ V

ADV

'Vi drar på stranda.'

3. Nilla

likeni

Aaronniemestä.

$\mathrm{N}$ [sg. nom.]

$\mathrm{V}[$ lijetä, 3. sg.

$\mathrm{N}$ [sg. elat.]

S $\mathrm{V}$

ADV

'Nils nærma seg fra Aronnes.'

4. Nilla hihtas [Alattiosta Kööpenhaminhaan].

'Nils gikk på ski fra Alta til København.'

5. Ville istui [Stiinan Leenan vierheen].

'Ville satt seg ved sida av Lena.'

6. Studentit kiikuthiin [vaaran pääle].

'Studentene klatra opp på fjellet.'

7. Kreetta laukkoi tänne.

'Greta sprang hit.'

Subjektet i slike setninger står alltid i nominativ, og det kongruerer med verbet. Etter bevegelsesverbet følger et adverbial som vanligvis består av en 
nomenfrase i TILSTEDSKasus $(1,2,4)$ eller FRASTEDSKAsus $(3,4)$, et adverb (7), eller en adposisjonsfrase $(5,6)$.

Til BEVEGELSEsetninger regner vi også setninger hvor verbet forteller at noen eller noe forsvinner, eller at noen eller noe kommer til syne. Adverbialet i slike setninger forteller hvor noe forsvinner ifra, eller hvor det dukker opp. Typiske verb i slike setninger er for eksempel hävitä ('forsvinne, bli borte'), ka(d)ota ('forsvinne'), jaukkuut jaukkua(t) ('forsvinne'), jää(đ) ä ('bli igjen'), ilmestyyt ilmestyä( $t$ ) ('dukke opp'), ittää(t) ('komme til syne') (8-11), og også alk(k)aa(t) ('begynne') og loppuut loppua $(t)$ ('slutte'), som brukes når man vil fortelle hvor noe begynner ifra, eller hvor det slutter (12).

8.

$\begin{array}{lll}\text { Matti } & \text { katos } & \text { tunturhiin. } \\ \mathrm{N} \text { [sg. nom.] } & \mathrm{V} \text { [kađota, 3. sg.] } & \mathrm{N} \text { [sg. illat.] } \\ \mathrm{S} & \mathrm{V} & \mathrm{ADV}\end{array}$

'Mats forsvant på fjellet.'

9. Kaikki linnut jaukuthiin pois.

$\mathrm{N}$ [sg. nom.] V[jaukkuut, 3. pl.] N[adv.]

$\begin{array}{lll}\mathrm{S} & \mathrm{V} & \mathrm{ADV}\end{array}$

'Alle fuglene blei borte.'

10. Muori jäi tunturhiin.

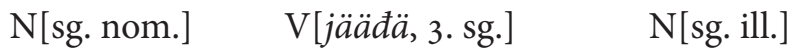

$\begin{array}{lll}S & \mathrm{~V} & \mathrm{ADV}\end{array}$

'Bestemor blei igjen på fjellet.'

11. Aaro [ei ollu itäny] kođale.

'Aaro har ikke dukka opp ved gammen.'

12. Tie alkoi Yykeänperästä ja loppui Palovaarhaan.

'Vegen begynte i Skibotn og slutta i Palovaara.'

BEVEGELSEssetninger har altså følgende mønster:

BEVEGELSE:

$\mathrm{S}[\mathrm{NP}[$ nom. $]]+\mathrm{V}[$ bevegelsesverb, subjektkongruens $]+\mathrm{ADV}[\mathrm{NP}[$ elat./ill./ablat./ all.]/PP/AdvP] 
Verbet käyđä käyvä ('dra (en tur)') er også brukt i bevegelsesetninger, men det skiller seg fra andre bevegelsesverb ved at adverbialet alltid står i PÅsTEDSKASUS (13), enten $\mathrm{i}$ inessiv eller adessiv:
13. Tet
käyttä
Alattiossa.
Pron[2.pl, nom.]
V[käyđä, 2.pl.]
$\mathrm{N}$ [sg. iness.]
$S$ $\mathrm{V}$
ADV
'Dere drar (en tur) til Alta.'

Når noen flytter seg inn i noe eller ut av noe, så bruker vi INDRE LOKALKASUS $(1,3,4,10,12)$, mens når noen beveger seg fra eller til overflata eller utsida av noe, så bruker vi YTRE LOKALKAsus $(2,11)$. Ved stedsnavn bruker man vanligvis indre lokalkasus $(1,3,4,12,13$; les mer om det $\mathrm{i}$ avsnitt 4.2.1.1 ovafor).

Også verbfraser kan fungere som adverbial utfylling i BEVEGELSEssetninger (14-16). Slike setninger likner på aspektsetninger (se avsnitt 4.4.3).

14. Met lähđemä [hihtaamhaan vaarhaan].

'Vi drar på skitur til fjells.'

15. Tyttäret käythiin [kävelemässä tunturissa].

'Jentene gikk en tur på fjellet.'

16. Tet tulitta [syömästä].

'Dere kom fra å ha spist.'
Jamfør: Met lähđemä vaarhaan. 'Vi drar til fjells.'

Jamfør: Tyttäret käythiin tunturissa.

'Jentene gikk på fjellet.'

Jamfør: Tet tulitta Vesisaaresta. 'Dere kom fra Vadsø.'

Vi ser at verbfrasen med 3. infinitiv (for eksempel kävelemässä) har sammekasus som en tilsvarende nomenfrase ville ha hatt. Det brukes alltid indre lokalkasus i slike konstruksjoner, det vil si elativ (16) eller illativ (14), og med käyđäkäyvä-verbet er det inessiv som er brukt (15).

\subsubsection{EKSISTENS}

Ei EKSISTENSsetning er ei lokativ setning som forteller at noen eller noe fins et sted. De to vanligste verba i EKSISTENSsetninger er olla ('være') og löyttyyt löytyä $(t)$ ('finnes'). Men også andre verb er mulig, for eksempel alle tilstandsverb, slik som maata ('ligge'), seissoot seisoa( $t$ ) ('stå), istuut istua( $t$ ) ('sitte') og pyssyyt $\sim$ pysyä $(t)$ ('bli værende'): 
1. Talossa oon [kaksi lommaa].

$\mathrm{N}$ [sg. iness.] $\quad \mathrm{V}$ [olla, 3. sg.] KvaP[grunntall[sg. nom.] + N[sg. part.]]

ADV $\mathrm{V} \quad \mathrm{S}$

'Det er to rom i huset.'

2. Jovessa kallaa.

$N$ [sg. iness.] $\quad \mathrm{V}[$ olla,3.sg.] $\quad \mathrm{N}[$ sg. part.]

ADV V S

'Det er fisk i elva'.

3. Lomassa istuu [studenttiita, tyttäriitä ja poikkii].

$N$ [sg. iness.] $\quad \mathrm{V}$ [istuut, 3. sg.] $\mathrm{N}[$ pl. part.]

ADV V S

'Det sitter studenter, jenter og gutter på rommet.'

4. Kentälä seisoi [paljon ihmissii/ihmistä].

$\mathrm{N}$ [sg. adess.] $\mathrm{V}[$ seissoot, 3. sg. $] \mathrm{KvaP}[\mathrm{Adv}+\mathrm{N}[$ pl. part./sg. part.]]

ADV $\quad \mathrm{S}$

'Det står mye folk på sletta'.

5. [Huonheen takana] makkaa studenttijoukko.

'Det ligger en gjeng med studenter bak huset.'

6. Tässä istuthaan [studentit, tyttäret ja pojat].

'Her sitter studenter, jenter og gutter.'

Også verb av typen kasuta ('vokse') kan brukes som verbal i EKSISTENSsetninger, og de fungerer da mer som tilstandsverb enn som endringsverb:

7. Laksossa kassuu [koivuu, pihlajaa, paivuu ja katajaa].

'Det vokser bjørk, rogn, selje og einer i dalen.'

Vi ser at subjektet kommer sist i EKSISTENSsetninger. Først i setninga står adverbialet, som forteller hvor subjektet er. Adverbialet består av en nomenfrase i påstedskasus $(1-4,7)$, eller så er det en adposisjonsfrase (5) eller en adverbfrase (6).

Subjektet er ofte en nomenfrase som står enten i nominativ $(5,6)$ eller i partitiv $(2,3)$. Når subjektet står i partitiv, er det ikke kongruens mellom subjekt og verbal, men verbet står da alltid i tredje person entall. Derimot gjelder det vanlig subjektskongruens når subjektet står i nominativ. Forskjellen kommer tydelig fram om vi jamfører setning (3) med (6), der subjektet betyr det samme. 
En annen vanlig subjektstype er fraser hvor et mengdeord, for eksempel paljon ('mye') eller vähän ('lite'), eller et tallord, for eksempel kaksi ('to'), viisi ('fem') eller tuhat ('tusen'), står sammen med et nomen. Subjektet i slike setninger ( 1 , 4) består med andre ord av en kvantorfrase (KvaP), og verbet står også her i tredje person entall.

Subjektskasusen i nektende setninger er alltid partitiv $(8,9)$ :

8. Talossa [ei ole] porstuuta.

'Det er inga bårstue i huset.'

9. Lomassa [ei istu] studenttiita, ei tyttäriitä eikä poikkii.

'Det sitter ingen studenter på rommet, verken jenter eller gutter.'

Mønsteret for EKSISTENSsetninger er slikt:

EKSISTENS:

$\mathrm{ADV}[\mathrm{NP}[$ iness./adess.]/PP/AdvP $]+\mathrm{V}[$ tilstandsverb, 3. sg. $]+\mathrm{S}[\mathrm{NP}[$ part. $] /$ kvantorfrase]

eller

ADV[NP[iness./adess.]/PP/AdvP] + V[tilstandsverb, subjektskongruens $]+$ SUB[NP[nom.]]

Verbet löyttyyt löytyä(t) ('finnes') avviker fra dette mønsteret ved at det tar utfylling i frastedskasus elativ eller ablativ $(10,11)$.

10. Huonheesta löytyi [kymmenen tytärtä].

'Det fantes ti jenter i huset'.

11. Laattiilta löyttyy kuolut kissa.

'Det fins en død katt på golvet'.

\subsubsection{EKSISTENSENDRING}

EKSISTENSENDRINGSsetninger er lokative setninger som forteller at noen eller noe oppstår et sted, eller at noen eller noe forsvinner eller blir mindre av et sted. Som verb opptrer for eksempel syttyy(t) ('dukke opp; tennes'), sammuut sammua( $t$ ) ('slokne'), tulla ('komme'), ittää( $t$ ) ('komme til syne'), ilmestyyt ilmestyä $(t)$ ('dukke opp'), hävitä ('forsvinne'), tippuut tippua( $t$ ) ('dryppe, falle'), pudota ('dette'): 
1. Taivhaale

syttyi tähti.

$\mathrm{N}$ [sg. allat.]

$\mathrm{V}[$ syttyyt, 3. sg. $\quad \mathrm{N}[\mathrm{pl}$. nom.]

ADV

$\mathrm{V}$

S

'Ei stjerne tentes / dukka opp på himmelen.'

2. Särmile $\mathrm{N}$ [sg. allat.]

ilmestyi

[tyttäriitä ja poikkii].

ADV

$\mathrm{V}[$ ilmestyyt, 3. sg]

$\mathrm{N}$ [pl. part.]

'Det dukker opp jenter og gutter på skjermen.'

3. Kođan suuhun

iti

[kaksi miestä].

$\mathrm{NP}[\mathrm{N}[$ sg. gen. $]+\mathrm{N}[$ sg. illat. $]$

$\mathrm{V}[$ ittäät, 3. sg.]

KvaP[kardinaali[sg. nom.] + N[sg. part.]]

ADV

V

S

'To menn kom til syne i gammeåpninga.'

4. Puitten oksilta

$\mathrm{NP}[\mathrm{N}[$ pl. gen. $]+\mathrm{N}[$ sg. ablat. $]]$

ADV

tippuu

vettä.

$\mathrm{V}$ [tippuut, 3.sg.] N[sg. part.]

'Det drypper vatn fra greinene på trærne.'

5. Arinasta sammui valkkee.

'Ilden slokna i ildstedet.'

6. Pörsistä hävis rahhaa.

'Det forvant penger fra lommeboka'

7. Talhoon tuli uusi emäntä.

'Det kom ei ny husmor til gården.'

8. Talhoon tulthiin [uuđet ihmiset].

'Det kom nye folk til gården'.

Strukturelt likner slike setninger på eksistenssetninger: Leddrekkefølgen er den samme, subjektet står i nominativ $(1,5,7,8)$ eller partitiv $(2,4,6)$, eller er en kvantorfrase (3), og setninga mangler subjektskongruens når subjektet står i partitiv (2) eller når det er en kvantorfrase (3). 
EKSISTENSENDRINGSsetninger har følgende mønster:

EKSISTENSENDRING:

$\mathrm{ADV}[\mathrm{NP}[$ elat./ill./ablat./all.]/PP/AdvP] + V[3. sg.] + S[NP[part.]/kvantorfrase] eller

ADV[NP[elat./ill./ablat./all.]/PP/AdvP] + V[subjektskongruens $]+\mathrm{S}[\mathrm{NP}[$ nom.] ]

Verbet loppuut loppua(t) ('slutte') er spesielt ved at det alltid står i nominativ

(9) når det opptrer som verbal i eksistensendringssetninger:

9. Vuonosta loppui kala.

'Fisken tok slutt i fjorden.'

Også i denne setningstypen er subjektet i nektende setninger alltid i partitiv (10):

10. Talhoon [ei tullu] [uutta emänttää].

'Det kom inga ny husmor til gården.'

\subsubsection{EIERSKAP}

Ei EIERSKAPssetning forteller at noen har eller eier noe(n), eller at noen bestemmer over noe(n). Det er alltid verbet olla ('være') som er brukt i EIERSKAPssetninger. Eksempler er:

1. Hänelä

Pron[3. sg., adess.]

ADV

'Han/hun har stor mage.'

2. Heilä

Pron[3. pl., adess.]

ADV

'De har barn.'

3. Ämmilä

$\mathrm{N}$ [sg. adess.

ADV oon

$\mathrm{V}$ [olla, 3.sg. $]$

$\mathrm{V}$

oon

$\mathrm{V}$ [olla, 3. sg. $]$

$\mathrm{V}$

oli

V[olla, 3. sg. $]$

$\mathrm{V}$ [iso vatta].

$\mathrm{N}$ [sg. nom.]

$\mathrm{S}$

lapsii.

N[pl. part.]

$\mathrm{S}$

[viisi lasta].

Kva P [talord [sg. nom] $+\mathrm{N}$ [sg. part.]]

$\mathrm{S}$

'Bestemor hadde fem barn.' 
4. Nillala olthiin/oli sivakat myötä.

'Nils hadde med seg skia.'

5. Meilä oon [vanhaat vaattheet].

'Vi har gamle klær'.

6. Nillala [ei ollu] sivakoita myötä.

'Nils hadde ikke med seg skia.'

7. Hänelä [ei ole] [issoo vattaa].

'Han/hun har ikke stor mage'

Oppbygninga til EIERSKAPssetninger er nesten den samme som i EKSISTENSsetninger (se 4.2.1.3 ovafor). Også EIERSKAPssetninger begynner med adverbialet, som står i adessiv. Adverbialet forteller hvem som har eller bestemmer over noe(n). Så følger verbalet med verbet olla, som kongruerer med subjektet etter de samme reglene som i EKSISTENSsetninger. Etter verbalet kommer subjektet, som forteller hva eller hvem som eies eller blir bestemt over. Subjektet står i nominativ $(1,4,5)$ eller partitiv (2), og ofte kan det også være en kvantorfrase (3). I likhet med EKSISTENSsetninger står subjektet i nektende setninger i partitiv $(6,7)$.

Men til forskjell fra EKSISTENSsetniger kan verbet i EIERSKAPssetninger stå i tredje person entall også når subjektet er i flertall nominativ (4). I presens er det uansett ingen forskjell mellom tredje person entall og 3 . flertall av verbet olla (5).

Vi ser at EIERSKAP blir uttrykt på en heilt annen måte enn på norsk: I kvensk kommer eieren til uttrykk gjennom et adverbial, og det som eies, er subjekt. På norsk er det eieren som er subjekt, mens det som eies, er objekt.

En annen forskjell mellom kvensk og norsk er illustrert i $(8,9)$ :

8. Piilissä oon [neljä pyörää].

'Bilen har fire hjul'.

9. Talossa [ei ole] porstuuta.

'Huset har inga bårstue.'

Dersom det som har noe, er ikke-levende, så bruker vi EKSISTENSsetninger og ikke EIERSKAPssetninger. I likhet med EIERSKAPssetninger svarer denne typen EKSISTENSsetninger til ha-setninger i norsk. 
EIERSKAPssetninger følger dette mønsteret:

\section{EIERSKAP:}

ADV[NP[levende[adess.] $]]+\mathrm{V}[$ olla, 3. sg. $]+\mathrm{S}[\mathrm{NP}[$ nom./part. $] / \mathrm{KvaP}]$

eller

ADV[NP[levende[adess. $]]]+\mathrm{V}[$ olla, subjektskongruens/3. sg. $]+\mathrm{S}[\mathrm{NP}[$ nom. $]]$

Samme mønster følger EIERSKAPSsetninger som i stedet for olla ('være') bruker vailuut vailua( $t$ ) ('mangle') eller puuttuu( $t) \sim$ puuttua $(t)$ ('mangle') som verbal $(10,11)$. Med disse to verba uttrykker vi at noen mangler noe(n), og setningene har samme form som de egentlige EIERSKAPSsetningene med olla.

10. Minula vailuu rahhaa.

'Jeg mangler penger.'

11. Muorila vailuu mies.

'Mor mangler en mann.'

\subsubsection{INTRANSITIV EIERSKAPSENDRING}

Ei INTRANSITIV EIERSKAPSENDRINGssetning forteller at noen mister noe, eller at noen får noe nytt. Som verbal i slike setninger fungerer for eksempel synttyyt, syntyä( $t$ ) ('føde; bli født; oppstå), kuola ('dø'), loppuut loppua(t) ('ta slutt'), tulla ('komme'), mennä ('gå), hävitä ('forsvinne'), kasuta ('vokse'). Denne setningstypen har samme oppbygning som EIERSKAPssetninger (se 4.2.1.5), men her står adverbialet, som uttrykker den som mister noe, i ablativ, og den som får noe, står i allativ. Eksempler er:

1. Multa

Pron[1. sg., ablat.]

ADV

'Jeg mista sønnen / en sønn.'

2. Liisale

$\mathrm{N}$ [sg. allat.]

ADV

'Lisa fikk mange barn' kuoli

$\mathrm{V}[$ kuola, 3. sg. $]$

$\mathrm{V}$

syntyi

$\mathrm{V}[$ synttyyt, 3. sg.]

$\mathrm{V}$ poika.

$\mathrm{N}$ [sg. nom.]

$\mathrm{S}$

[paljon lapsii].

$\mathrm{N}$ [KvaP]

S 
3. Muorile $\mathrm{N}$ [sg. allat.]

ADV

'Mor fikk en svær mage.'

4. Faarile

$\mathrm{N}$ [sg. allat.]

ADV kasus

V[kasuta, 3. sg.]

$\mathrm{V}$

tullee

V[tulla, 3. sg. $]$

$\mathrm{V}$ hirmunen vatta.

$\mathrm{N}$ [sg. nom.]

$\mathrm{S}$

'Far får gjester på besøk.'

5. Heiltä meni talot ja tavarat.

'De mista husa og tinga sine.'

6. Maijalta loputhiin rahat.

'Maja gikk tom for penger.'

7. Muorile [ei kasunu] [hirmuista vattaa].

'Mor fikk ikke noen svær mage.'

Som det går fram, kan disse setningene ha subjektskongruens etter samme mønster som EIERSKAPssetninger, og da står subjektet i nominativ (6). I nektende setninger står subjektet alltid i partitiv (7).

INTRANSITIVE EIERSKAPSENDRINGssetninger har følgende mønster:

INTRANSITIV EIERSKAPSENDRING:

ADV[NP[levende[adess.]]] + V[3.sg.] + S[NP[nom./part.]/KvaP] eller

ADV[NP[levende[adess.]]] + V[subjektskongruens/3. sg.] + S[NP[nom.]]

\subsubsection{Kvantorsetninger}

Den andre utfyllinga i ei KVANTORSETNING er en frase som verken kan klassifiseres som objekt, predikativ eler adverbial. Vi kaller den derfor bare for KVANTORFRASE. Det fins to typer av kvantorsetninger.

\subsubsection{ANTALL}

Den første kvantorsetningstypen er ANTALL, som uttrykker hvor mange eller hvor mye det er av noen eller noe. Som verbal brukes alltid verbet olla ('være'), som står i tredje person entall. Subjektet i setninga er et nomen i partitiv, enten et substantiv $(1,3)$ eller et pronomen $(2)$, og den andre utfyllinga er en kvantorfrase: 
1. Studenttiita

N[pl. part.]

$S$

'Det var femten studenter.'

2. Meitä

Pron[1. pl., part.]

S

'Vi var ti barn.'

3. Kallaa

$\mathrm{N}$ [sg. part.]

$\mathrm{S}$

'Det er mye fisk.' oli

V[olla, 3. sg.]

$\mathrm{V}$

oli

V[olla, 3. sg.]

V

oon

V[olla, 3. sg.]

$\mathrm{V}$ viisitoista.

Kva[grunntall[sg. nom.]]

KvaP kymmenen lasta.

KvaP[grunntall[sg. nom.] $+\mathrm{N}$ [sg. part.]]

$\mathrm{KvaP}$

I setninger der kvantorfrasen inneholder et grunntall, kan subjektet også stå i nominativ, og det kongruerer da med verbet $(4,5)$ :

4. Studentit olthiin viisitoista.

'Det var femten studenter.'

5. Met olima kymmenen lasta.

'Vi var ti barn.'

Det anbefales likevel også i slike setninger å bruke partitivsubjekt etter reglene som er framstilt ovafor.

Mønsteret for EKSISTENSMENGDEsetninger er slikt:

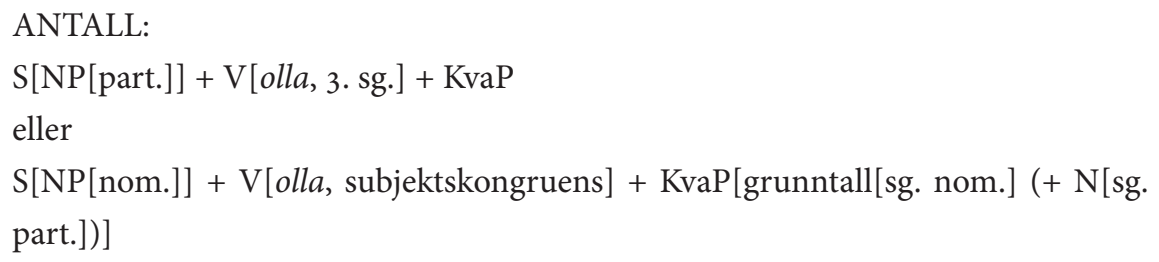

\subsubsection{MENGDE}

Den andre typen kvantorsetning forteller hvor mye noe koster eller veier (1-6), eller hvor mange år noen fyller (7). Vi kaller slike setninger for MENGDEsetninger. Subjektet er som vanlig i nominativ, og verbalet består av 
et såkalt KVANTORVERB, eksempel maksaa( $t$ ) ('koste'), tehđä tehhä ('utgjøre'), tienata ('tjene'), painaa ( $t$ ) ('veie'), täyttää( $t$ ) ('fylle'). Den andre utfyllinga er en kvantorfrase:

1. Karittat painethiin [viisitoista killoo]

$\mathrm{N}[$ pl. nom. $\quad \mathrm{V}[$ painaat, 3. pl.] $\quad \mathrm{KvaP}[$ kardinaali[sg. nom.] + N[sg. part.]] S $\quad \mathrm{V} \quad \mathrm{KvaP}$

'Lamma veide femten kilo'

2. Kengät maksethiin [liian paljon].

N[pl. nom.] V[maksaat, 3.pl.] AdvP

S $\quad \mathrm{V} \quad \mathrm{KvaP}$

'Skoa kosta for mye.'

3. Turska maksaa [100 kruunuu (= sata kruunuu)] kilo.

'Torsken koster 100 kroner kiloen.'

4. Meiđän venet maksoi [hirmuisen paljon].

'Båten vår kosta vanvittig mye.'

5. Poika painoi [kolme ja puoli killoo].

'Gutten veide tre og et halvt kilo.'

6. Yhtheensä se tekkee [1000 kruunuu (= tuhat/tuhanen kruunuu)].

'Til sammen blir det 1000 kroner.'

7. Pekka täyttää heti [10o vuotta (= sata vuotta)], mutta Maija täyttää vasta [50 vuotta (= viisikymmentä vuotta)].

'Peder fyller snart 100 år, men Maja fyller bare 50 år.'

MENGDEsetninger følger dette mønsteret:

MENGDE:

$\mathrm{S}[\mathrm{NP}[$ nom. $]]+\mathrm{V}[$ kvanttorverb, subjektskongruens $]+\mathrm{KvaP}$

\subsubsection{Predikasjonssetninger}

I PREDIKASJONSSETNINGER korrelerer subjektet - og stundom også andre medlemmer - med predikativet, som forteller noe om egenskapene til subjektet som det hører til, hvilken gruppe det hører til, eller om noe anna som kjennetegner subjektet. Verbet i predikasjonssetninger er alltid intransitivt, og det 
betyr at det ikke er mulig å legge til noe objekt i setninga. Det fins flere typer predikasjonssetninger, og vi skal diskutere dem i tur og orden.

\subsubsection{EGENSKAP}

EGENSKAPssetninger forteller om hvilke(n) egenskap(er) subjektet har, eller av hvilket slag eller type det er. Som verb i slike setninger bruker vi alltid olla ('være').

1. Ragnhild

$$
\begin{array}{ll}
\text { oon } & \text { ruijalainen. } \\
\mathrm{V} \text { [olla, 3. sg. }] & \text { A[sg. nom.] } \\
\mathrm{V} & \text { PRED }
\end{array}
$$

N[sg. nom.]

S

'Ragnhild er norsk.'

2. Kalat

olthiin [aivan verekset].

$\mathrm{N}$ [pl. nom.]

$\mathrm{V}[$ olla, 3. pl. $]$

A[pl. nom.]

S

PRED

'Fiskene var heilt ferske.'

3. Matkustaminen oon jännittäävä.

$\mathrm{N}$ [sg. nom.] V[olla, 3. sg. $\quad$ A[sg. nom.]

$\begin{array}{lll}S & V & \text { PRED }\end{array}$

'Reising er spennende.'

4. Kaffi

oon makkee.

$\mathrm{N}$ [sg. nom.]

V[olla, 3.sg.]

A[sg. nom.]

$S$

$\mathrm{V}$

PRED

'Kaffen er god./Kaffe er godt.'

5. Het oon [kovin iloiset].

'De er svært glade.'

6. Mie olen [Maijan Kreeta].

'Jeg er Maja si Greta.'

7. Tet oletta [somat ihmiset].

'Dere er artige folk.'

Korrelatet i ei egenskapssetning er et subjekt som står i nominativ, og det er det setninga forteller noe om. Det andre leddet er verbalet, som består av verbet olla, som kongruerer med subjektet. Og til slutt har vi predikativet (PRED), 
som kan være adjektiv (1-5) eller substantiv $(6,7)$. Også predikativet kongruerer med subjektet i tall, det vil si når subjektet er i entall, så er også predikativet $i$ entall $(1,3,4,6)$, mens når subjektet er i flertall, så er også predikativet i flertall $(2,5,7)$. Predikativet står så godt som alltid i nominativ.

EGENSKAPssetninger følger dette mønsteret:

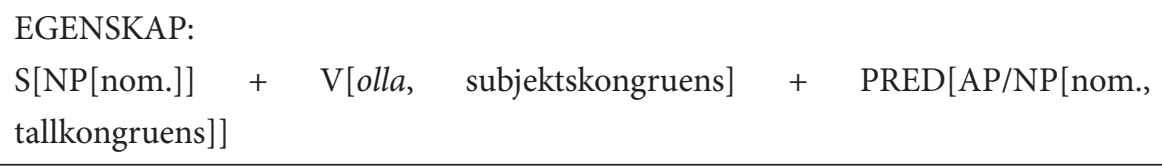

Når korrelatet er delelig eller et stofford i entall, så kan predikativet også stå i partitiv (8).
8. Se
oli
[puhđasta vettä].
Pron[sg. nom.]
$\mathrm{V}[$ olla, 3. sg. $]$
$\mathrm{N}$ [sg. part.]
$S$
$\mathrm{V}$
PRED

'Det var reint vatn'.

\subsubsection{TILHØRIGHET}

Predikasjonssetninger kan også fortelle hvilken gruppe noen eller noe hører eller regnes til, eller hva subjektet er en del av. Det er alltid verbet olla ('være') som fungerer som verbal i slike TILHØRIGHETssetninger, og predikativet står i partitiv. Det er ikke tallkongruens mellom korrelat og predikativ; tallet til predikativet retter seg etter om ordet som uttrykker gruppa eller heilheta, har entallsbetydning (1-3) eller flertallsbetydning (4):

1. [Maija ja Nilla]

oon

[Niilan Oulan issoo sukkuu].

NP[sg. nom.]

V[olla, 3. pl. $]$

NP[sg. part.]

$S$

$\mathrm{V}$

PRED

'Maja og Nils er av den store slekta til Nils sin Olav'.

2. Ryssänmaa

N[sg. nom.]

$\mathrm{S}$

'Russland er en del av Europa.'

3. Tet

Pron[2. pl., nom.]

S

oletta

$\mathrm{V}[$ olla, 2. pl. $]$

$\mathrm{V}$

oon

V [olla, 3. sg. $]$

$\mathrm{V}$

Eurooppaa.

$\mathrm{N}$ [sg. part.]

PRED

'Dere er av mongolsk avstamning.'

mongooliraassii.

$\mathrm{N}$ [sg. part.]

PRED 

4. Aaro oli Jaakkoloita.
$\mathrm{N}$ [sg. nom.] $\quad$ V[olla, 3. sg. $] \quad \mathrm{N}$ [pl. part.]
S $\quad \mathrm{V}$ PRED

'Aaro var en Jaakkola [= en av Jaakkola-familien].'

TILHØRIGHETssetninger følger dette mønsteret:

\section{TILHØRIGHET:}

$\mathrm{S}[\mathrm{NP}[$ nom. $]]+\mathrm{V}$ [olla, subjektskongruens] $+\mathrm{PRED}[\mathrm{NP}[$ part., ingen tallkongruens med korrelatet]]

\subsubsection{EIERSKAPSPREDIKASJON}

Predikativet kan også være et substantiv i genitiv som forteller hvem eller hva som eier det subjektet står for $(1,2)$. Vi kaller slike setninger for EIERSKAPSPREDIKASJONssetninger (til skilnad fra EIERSKAPssetninger; se avsnitt 4.2.1.5).

1. [Net porot] olthiin Liisan.

$\begin{array}{lll}\mathrm{N} \text { [pl. nom.] } & \mathrm{V}[\text { olla, 3. pl.] } & \mathrm{N} \text { [sg. gen.] } \\ \mathrm{S} & \mathrm{V} & \text { PRED }\end{array}$

'De reinene var Lisas.'

2. Lapset [ei ole] meiđän.

'Barna er ikke våre'.

EIERSKAPSPREDIKASJONssetninger har slikt mønster:

EIERSKAPSPREDIKASJON:

$\mathrm{S}[\mathrm{NP}[$ nom. $]]+\mathrm{V}[$ olla, subjektskongruens $]+\operatorname{PRED}[\mathrm{NP}[$ gen. $]]$

\subsubsection{EKSISTENSPREDIKASJON}

Det fins også en predikasjonssetningstype hvor subjektet eller korrelatet til predikativet står i partitiv (1-4). Slike setninger forteller at noen eller noe er av en viss type, og de kalles for EKSISTENSPREDIKASJONssetninger. Som verbal bruker vi enten verbet olla ('være') eller löyttyyt löytyä( $t$ ) ('finnes'), og det står alltid i tredje person entall. Predikativet står i partitiv, og det kongruerer i tall med korrelatet. Eksempler er: 
1. Maittoo oon [tavalista maittoo ja kevveetämaittoo].

$\mathrm{N}$ [sg. part.] $\quad \mathrm{V}$ [olla, 3. sg. $\quad \mathrm{NP}$ [sg. part.]

$\mathrm{S} \quad \mathrm{V} \quad$ PRED

'Det fins vanlig mjølk og lettmjølk'.

2. Ihmissii oon monenlaissii.

$\mathrm{N}$ [pl. part.] $\quad \mathrm{V}[$ olla, 3. sg. $\quad \mathrm{A}[$ pl. part.]

$\mathrm{S} \quad \mathrm{V}$ PRED

'Det fins mange slags folk'.

3. Kukkii oli [keltaissii ja punaissii].

$\mathrm{N}$ [pl. part.] $\quad \mathrm{V}[$ olla, 3. sg. $\quad \mathrm{A}[$ pl. part.]

$\mathrm{S} \quad \mathrm{V} \quad$ PRED

'Det var gule og røde blomster'.

4. Piilii löyttyy [tyyrhiitä ja halppoi].

N[pl. part.] V[löyttyyt, 3.sg.] A[pl. part.]

S V PRED

'Det fins dyre og billige biler.'

EKSISTENSPREDIKASJONssetninger har slikt mønster:

EKSISTENSPREDIKASJON:

$\mathrm{S}[\mathrm{NP}[$ part. $]]+\mathrm{V}[$ olla, löyttyyt, 3. sg. $]+\mathrm{PRED}[\mathrm{AP} / \mathrm{NP}[$ part., tallkongruens $]]$

Setningene ovafor kan også formuleres på en annen måte (5-8):

5. Sitä oon [tavalista maittoo ja kevveetämaittoo].

6. Sitä oon [monenlaissii ihmissii].

7. Sitä oli [keltaissii ja punaissii kukkii].

8. Sitä löyttyy [tyyrhiitä ja halppoi piilii].

Og da representerer de en type EKSISTENSsetninger uten adverbial (se 4.2.1.3).

I begge tilfella kan verbalet bestå av verbsambandet olla olemassa (altså ei bøyd form av verbet olla +3 . infinitiv av verbet olla), og setningene betyr da det samme som setningene i (1-8) ovafor, men de framhever eksistensaspektet $(9,10)$ :

9. Maittoo [oon olemassa] [tavalista maittoo ja kevveetämaittoo].

10. Sitä [oon olemassa] [monenlaissii ihmissii]. 


\subsubsection{INTRANSITIV ENDRING}

En viktig type predikasjonssetning er INTRANSITIVE ENDRINGssetninger. De forteller hva noen eller noe blir til eller blir værende. De vanligste ENDRINGsVERBA er tulla ('komme; bli'), muuttuut muuttua( $t$ ) ('forandre seg'), kasuta ('vokse') og jääđä jäähä ('bli igjen, forbli'). Predikativet i slike setninger står i translativ, og det er oftest et adjektiv (1-3), men det kan også være et substantiv (4) eller et pronomen (5). Eksempler er:

1. Mie tulen hulluksi.

Pron[1.sg., nom. V[tulla, 1. sg.] A[sg. transl.]

$S$ $\mathrm{V}$

PRED

'Jeg blir gal'.

2. Pojat

kasuthiin

isoksi.

$\mathrm{N}$ [pl. nom.]

V[kasuta, 3. pl. $]$

A[sg. transl.]

$\mathrm{S}$

$\mathrm{V}$

PRED

'Guttene vokste seg store.'

3. Saalis jäi pieneksi.

$\mathrm{N}$ [sg. nom.]

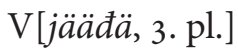
A[sg. transl.]

$S$ $\mathrm{V}$ PRED

'Det blei liten fangst.'

4. Yö muuttui aamuksi.

'Natta blei til dag.'

5. Kaikki muuttuu muuksi.

'Alt blir til noe anna'

Setningene har subjektskongruens. Derimot kongruerer ikke predikativet i tall med korrelatet sitt, men står alltid i entall translativ.

INTRANSITIVE ENDRINGSssetninger følger dette mønsteret:

\section{INTRANSITIV ENDRING:}

$\mathrm{S}[\mathrm{NP}[$ nom. $]]+\mathrm{V}[$ endringsverb, subjektskongruens] + PRED[AP/NP[sg. transl.]]

Til samme type mønster kan vi formelt sett også regne setninger som forteller hva noen eller noe egner seg til $(6,7)$ :

6. Turska passaa keittokalaksi.

'Torsk egner seg bra som kokefisk.' 
7. Koivuhalvot sovithaan poltoksi.

'Bjørkeved egner seg bra som brensel.'

Til forskjell fra typiske INTRANSITIVE ENDRINGssetninger er predikativet i slike setninger alltid et substantiv, og aldri et adjektiv.

\subsubsection{RESULTAT}

RESULTATsetninger er nær beslekta med ENDRINGssetninger. Men mens ENDRINGssetninger fokuserer på sjølve endringsprosessen, så er oppmerksomheta i RESULTATsetninger retta mot sluttproduktet eller resultatet.

Det er to typer RESULTATsetninger: I den ene er predikativet et substantiv, i den andre et adjektiv. Når predikativet er et substantiv, så er korrelatet et adverbial i elativ, og setninga mangler subjekt (1-5). Men når predikativet er et adjektiv, så er korrelatet et subjekt i nominativ $(6,7)$. Predikativet står i begge tilfella i nominativ, og det kongruerer i tall med korrelatet. I RESULTATsetninger bruker vi vanligvis verba tulla ('komme; bli') og kasuta ('vokse'):

1. Mikosta

$\mathrm{N}$ [sg. elat.]

ADV tuli

V[tulla, 3. sg. $]$

$\mathrm{V}$ varas.

A[sg. nom.]

PRED

'Det blei tjuv av Mikkel.'

2. Pojista

kasus

[kommeet miehet].

$\mathrm{N}$ [pl. elat.]

V[kasuta, 3. sg.]

N[pl. nom.]

ADV $\mathrm{V}$

PRED

'Det blei staselige menn av guttene.'

3. Minusta tuli opettaaja.

'Jeg blei lærer.'

4. Meistä tuli krannikset.

'Vi blei naboer.'

5. Porosta tullee [makkee ruoka].

'Det blir lekker mat av reinen.'

6. Housut

tulthiin

[liian lyhykäiset]

$\mathrm{N}$ [pl. nom.]

$\mathrm{V}$ [tulla, 3. pl.]

A[pl. nom.]

$\mathrm{S}$

$\mathrm{V}$

PRED

'Buksene blei for korte.' 
$\begin{array}{lll}\text { 7. Hamet } & \text { ei tullu } & \text { [liian lyhykäinen]. } \\ \mathrm{N} \text { [sg. nom. }] & \mathrm{V} \text { [tulla, nekt. 3. sg. }] & \text { A[sg. nom.] } \\ \mathrm{S} & \mathrm{V} & \text { PRED }\end{array}$

'Skjørtet blei ikke for kort'.

RESULTATsetninger følger slikt mønster:

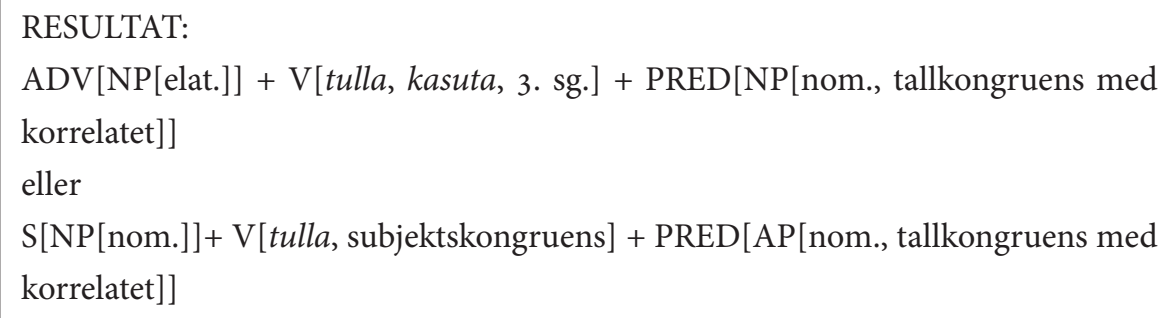

\subsubsection{PREDIKATIV SANS}

Den siste typen predikasjonssetning vi skal ta opp her, er setninger som forteller hvordan noe(n) lukter, smaker, høres, ser ut eller føles. Vi kaller denne setningstypen for PREDIKATIV SANS. I slike setninger bruker vil INTRANSITIVE SANSEVERB som haista ('lukte'), näyttää( $t$ ) ('se ut'), kuuluut kuulua(t) ('høres'), maistuut maistua( $t$ ) ('smake'), tunttuut tuntua( $t$ ) ('kjennes, føles'). Predikativet er som regel et adjektiv som alltid er i entall ablativ (1-4). Men predikativet kan også være et substantiv (5). Eksempler er:

1. Kalat haisthiin pahalta.

$\mathrm{N}$ [pl. nom.] V[haista, 3. pl.] A[sg. abl.] $\mathrm{S}$ $\mathrm{V}$ PRED

'Fiskene lukta vondt.'

2. [Terjen pellaaminen] kuului hyvältä.

'Terjes spell hørtes bra ut.'

3. Sie näytät kaunhiilta.

'Du ser vakker ut.'

4. [Antin kirvaaminen] tuntui pahalta.

'Bannskapen til Anders føltes ille.'

5. Kalat

$\mathrm{N}$ [pl. nom.]

$\mathrm{S}$

'Fiskene så ut som laks.' lohelta.

N[sg. abl.]

PRED 
PREDIKATIV SANS følger dette mønsteret:

PREDIKATIV SANS:

$\mathrm{S}[\mathrm{NP}[$ nom. $]]+\mathrm{V}[$ intransitivt sanseverb, subjektskongruens $]+\operatorname{PRED}[\mathrm{AP} / \mathrm{NP}[\mathrm{sg}$. abl.] $]$

\subsubsection{Følelsessetninger}

Vi skiller mellom to typer følelsessetninger, slike som uttrykker at subjektet føler noe, og slike som uttrykker at objektet føler noe som følge av noe eller noen. Den første typen kaller vi for FØLELSE, og den andre typen kaller vi for KAUSATIV FØLELSE.

\subsubsection{FØLELSE}

Vanlige FØLELSEssetninger forteller hva slags følelse subjektet har. Som verbal i slike setninger fungerer FøLELSESVERB av typen rakastaa(t) ('elske'),

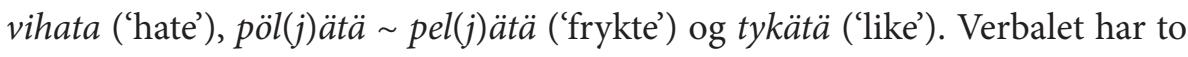
utfyllinger, subjekt og objekt. Eksempler er:

1. Knuutti

$\mathrm{N}$ [sg. nom.]

$\mathrm{S}$

'Knut elsker Greta'

2. Kreeta

$\mathrm{N}$ [sg. nom.]

S

'Greta hater Nils.'

3. Mie

Pron[1.sg., nom.]

S

vihhaa

$\mathrm{V}$ [vihata, 3. sg. $]$

$\mathrm{V}$

rakastaa

Kreettaa.

V [rakastaat, 3. sg.]

$\mathrm{V}$

$\mathrm{N}$ [sg. part.]

$\mathrm{O}$

Nillaa.

$\mathrm{N}$ [sg. part.]

$\mathrm{O}$

ruijalaisista.

tykkään

$\mathrm{N}$ [pl. elat.]

V [tykätä, 1. sg.]

$\mathrm{V}$
$\mathrm{O}$

'Jeg liker nordmenn.'

I slike setninger er subjektet alltid i nominativ, og det kongruerer med verbet. Objektet er vanligvis i partitiv $(1,2)$, men verbet tykätä tar objekt i elativ (3). Det vanlige mønsteret for FØLELSEssetninger er slikt:

FØLELSE:

$\mathrm{S}[\mathrm{N}[$ nom. $]+\mathrm{V}[$ følelsesverb, subjektskongruens $]+\mathrm{O}[\mathrm{N}[$ part. $]]$ 
Når gjenstanden for følelsen er ei handling, så er objektet som regel et verb i 1 . infinitiv $(4,5)$ :

4. Kreeta pölkkää hihđata.

$\mathrm{N}$ [sg. nom.]

$\mathrm{V}[$ pölätä, 3. sg. $]$ $\mathrm{V}$ [1. inf.]

$\mathrm{S}$ $\mathrm{V}$

$\mathrm{O}$

'Greta er redd for å gå på ski.'

5. Mie

tykkäsin

[lypsäät lehmii].

Pron[1. sg.]

$\mathrm{V}$ [tykätä, 1.sg.]

S $\mathrm{V}$

$\mathrm{VP}[\mathrm{V}$ [1. inf.] + N[pl. part.]]

'Jeg likte å mjølke kyr'.

\subsubsection{KAUSATIV FØLELSE}

I KAUSATIVE FØLELSESsetninger er verbalet et KAUSATIVT FøLELSESVERB som forteller hva slags følelse noe(n) forårsaker i objektet (1). Eksempler på slike kausative verb er oksettaa(t) ('gjøre kvalm'), iljettää( $t$ ) ('gjøre kvalm'), hävettää(t) ('skjemmes'), naurattaa(t) ('få til å le'), janottaa $(t)$ ('tørste'). Objektet i slike setninger uttrykker den som kjenner følelsen, og det står alltid i partitiv. Subjektet uttrykker det eller den som forårsaker følelsen. I noen setninger er det en vanlig nomenfrase i nominativ (1):

1. Pekka

iljettää

Stiinaa.

$\mathrm{N}$ [sg. nom.]

V [iljettäät, 3.sg.]

$\mathrm{N}$ [sg. part.]

$\mathrm{S}$

$\mathrm{V}$

$\mathrm{O}$

'Peder får Stina til å føle avsky'.

Et vanligere setningsmønster er likevel at subjektet er et verb i 1. infinitiv $(2,3)$, eller at subjektet mangler heilt $(4,5)$. I subjektlause setninger er verbet alltid i tredje person entall.
2. Liissaa
hävetti
[pierä äänheen].
$\mathrm{N}[$ sg. part. $]$
V[hävettäät, 3. sg.]
$\mathrm{VP}[\mathrm{V}$ [1. inf.] + Adv]
$\mathrm{O}$
$\mathrm{V}$
$\mathrm{S}$

'Lisa skjemtes over å fjerte høgt.' 
3. Minnuu

Pron[1.sg., part.]

V[iljettäät, 3.sg.]

$\mathrm{VP}[\mathrm{V}[$ 1. inf. $]+\mathrm{N}$ [sg. part.] $]$

$\mathrm{O}$

$\mathrm{V}$

S

'Jeg vemmes av å spise lever'.

4. Heikkaa oksetti.

'Henry blei kvalm.'

5. Meitä nauratti.

'Vi måtte le.'

Ei typisk KAUSATIV FØLELSEssetning følger altså dette mønsteret:

KAUSATIV FØLELSE:

$\mathrm{O}[\mathrm{NP}[$ part.] $]+\mathrm{V}[$ kausativt følelsesverb, 3. sg.] (+ S[VP[1. inf.] $])$

\subsubsection{Handlingssetninger}

HANDLINGSSETNinger forteller at subjektet gjør noe eller er årsak til at noe oppstår eller skjer. Subjektet står som regel for en person, men det kan også være et dyr eller hva som helst anna som kan tenkes å fungere som agens, det vil si noen eller noe som utfører ei handling. Det er alltid et transitivt handlingsverb som er verbalet i slike setninger.

Det fins toverdige og treverdige handlingssetninger. I toverdige setninger er det subjekt og objekt som er utfyllinger til verbalet. I treverdige kommer et adverbial i tillegg. Objektet i handlingssetninger har varierende objektskasus (se nedafor).

\subsubsection{TOVERDIG HANDLING}

I ei TOVERDIG HANDLINGssetning er det oftest et objekt som uttrykker det det skjer noe med, det handlinga resulterer i, eller det som er mål for handlinga (1-12). Men dersom det kun er aktiviteten subjektet utfører som står i sentrum, så kan objektet mangle i setninga $(13,14)$. Vi kan likevel alltid forestille oss et objekt også i slike setninger.

1. Pappi

$\mathrm{N}$ [sg. nom.]

$\mathrm{S}$

'Presten skreiv et brev'. kirjoitti

$\mathrm{V}[$ kirjoittaat, 3. sg. $]$

$\mathrm{V}$ preivin.

$\mathrm{N}$ [sg. gen.]

$\mathrm{O}$ 
2. Liisa

$\mathrm{N}$ [sg. nom.]

$\mathrm{S}$

'Lisa slakta reinene'.

3. Polta

V[polttaat, imp. 2.sg.]

$\mathrm{V}$

'Brenn brevet!'

4. Preivin

$\mathrm{N}$ [sg. gen.]

$\mathrm{O}$

'Brevet blei brent.'

5. Matti

$\mathrm{N}$ [sg. nom.]

$\mathrm{S}$

'Mats slakta ikke rein.'

6. Kuningas

$\mathrm{N}$ [sg. nom.]

$\mathrm{S}$

'Kongen (satt og) leste i brevet fra Nils.'

7. Amtmani hävitti mettän.

'Amtmannen ødela skogen.'

8. Amtmani hävitti mettää.

'Amtmannen holdt på å ødelegge skogen. / Amtmannen ødela skog'

9. Mie rakensin huonheen.

'Jeg bygde et hus/huset.'

10. Pekka pyyttää kallaa.

'Peder driver med fiske'.

11. Mie studeeraan [kainun kieltä].

'Jeg studerer kvensk språk.'

12. [Annan Kaisa] puhhuu [kainun kieltä].

'Anna si Kaisa snakker kvensk.' porot.

$\mathrm{N}[\mathrm{pl}$. nom.]

$\mathrm{O}$

poltethiin.

$\mathrm{V}[$ polttaat, passiv $]$

$\mathrm{V}$

ei lahđanu porroi.

V[lahđata, nekt. 3. sg.] N[pl. part.]

$\mathrm{V}$

$\mathrm{O}$

[Nillan preivii].

$\mathrm{N}$ [sg. part.]
$\begin{array}{ll}\mathrm{V} \text { [lukkeet, 3. sg. }] & \mathrm{N} \\ \mathrm{V} & \mathrm{O}\end{array}$ 
13. Terje laulaa.

'Terje synger.'

14. Pojat piirethään.

'Guttene tegner.'

I slike setninger kongruerer verbalet alltid med subjektet, og subjektet er alltid i nominativ. Dersom setninga også har et objekt, så har det OBJEKTSKAsus, det vil si at et entallsobjekt kan stå i genitiv $(1,3,4,7,9)$ og et flertallsobjekt i nominativ (2). Både entallsobjekt og flertallsobjekt kan stå i partitiv $(5,6,8,10-12)$.

Objektet er alltid i partitiv når setninga er nektende, det vil si at den inneholder ei form av nektingsverbet ei (5). Partitiv bruker vi også når handlinga ikke er avslutta, og/eller når den fortsatt pågår $(6,8)$. Vi kan si at objektskasus i kvensk uttrykker ASPEKT, eller om handlinga er AVGRENSA eller UAVGRENSA. Objektet står også i partitiv når det står for noe DELELIG, noe som kan måles, eller når vi kan spørre hvor mye det er av det $(8,10)$. Det fins også verb som allid tar objekt i partitiv, for eksempel studeerata ('studere') (11) og puhhuut ('snakke') (12). Slike handlingssetninger skiller seg ut ved at objektet ikke blir endra eller påvirka av verbalhandlinga.

Vi kan si at vi bruker genitivs- eller nominativsobjekt når handlinga omfatter objektet som heilhet, mens når handlinga ikke påvirker objektet, eller ikke omfatter heile objektet, så bruker vi partitivobjekt. I det første tilfellet snakker vi om TOTALOBJEKT, og i det andre tilfellet om PARTIALOBJEKT.

Personlige pronomen i flertall har ei spesiell objektsform, som også kalles for akkusativ (meiđät meät ('oss'), teiđät teät ('dere'), heiđät heät ('dem')), og som brukes som totalobjektskasus.

TOVERDIGE HANDLINGssetninger følger dette mønsteret:

TOVERDIG HANDLING:

$\mathrm{S}[\mathrm{NP}[$ nom. $]]+\mathrm{V}[$ handlingsverb, subjektskongruens $]+\mathrm{O}[\mathrm{NP}[$ objektskasus $]]$

\subsubsection{TRANSITIV ENDRING}

TRANSITIV ENDRING er en treverdig setningstype som likner på den TOVERDIGE HANDLINGssetningstypen. TRANSITIVE ENDRINGssetninger forteller at noe blir endra på et eller anna vis. Verbalet tar et predikativ som si 
tredje utfylling, og korrelatet til predikativet er objektet i setninga. Verbalet består at et ENDRINGSVERB av typen maalata ('male'), färjätä ('farge') eller muuttaa(t) ('endre').
1. Anni
färjäs
hamheen
vihriseksi.
$\mathrm{N}$ [sg. nom.]
$\mathrm{V}[$ färjätä, 3. sg.]
$\mathrm{N}$ [sg. gen.]
A[sg. transl.]
$\mathrm{S}$
$\mathrm{V}$
$\mathrm{O}$
PRED

'Anni farga skjørtet grønt.'

2. Pekka muutti nimen norjalaiseksi.

'Peder fornorska navnet sitt.'

3. Faari leikkas housunsääret lyhykäisemäksi.

'Far klipte bukseleggene kortere.'

TRANSITIVE ENDRINGSssetninger følger dette mønsteret:

TRANSITIV ENDRING:

$\mathrm{S}[\mathrm{NP}[$ nom.] $]+\mathrm{V}[$ endringsverbi, subjektskongruens $]+\mathrm{O}[\mathrm{NP}[$ objektskasus $]]+$ PRED[AP[sg. trans.]]

\subsubsection{TRANSITIV EIERSKAPSENDRING}

Verbalet i TRANSITIVE EIERSKAPSENDRINGssetninger er et treverdig verb som forteller at noen får eller tar noe(n) fra noen, eller at noen gir, selger eller på anna vis avstår noe til noen. Verba som er brukt i slike setninger, kan vi dele inn i GI-VERB og TA-VERB. Eksempler på gi-verb er ant(t)aa(t) ('gi'), $m y y(d) \ddot{a}$ ('selge'), kenkätä ('gi i gave'), ojent(t)aa(t) ('overrekke') og også ostaa( $t$ ) ('kjøpe (til)'). Eksempler på ta-verb er saađa saaha ('få), ottaa(t) ('ta'], varastaa $(t)$ ('stjele') ja ostaa( $t$ ) ('kjøpe (av)’), Eksempler:
1. Pekka palkinon Kalevalaseuralta.
$\mathrm{N}$ [sg. nom.] $\quad \mathrm{V}$ [saada, 3. sg.] $\quad \mathrm{N}[$ sg. gen.] $\quad \mathrm{N}[$ sg. abl.]

$\begin{array}{llll}\mathrm{S} & \mathrm{V} & \mathrm{O} & \mathrm{ADV}\end{array}$

'Peder fikk en pris fra Kalevala-selskapet / Peder fikk Kalevala-selskapets pris.'
2. Pekka [ei saanu] palkinttoo kruunulta.
$\mathrm{N}$ [sg. nom.] $\quad \mathrm{V}$ [saada, nekt. 3. sg.] N[sg. part.] $\quad \mathrm{N}$ [sg. abl.]
$\begin{array}{llll}\mathrm{S} & \mathrm{V} & \mathrm{O} & \mathrm{ADV}\end{array}$

'Peder fikk ikke noen pris fra kongemakta'. 
3. Aaro varasti minulta syđämen.

'Aaro stjal hjertet mitt [ordrett: fra meg].'

4. Matti [ei ostanu] minulta ruokkaa.

'Mats kjøpte ikke mat av meg.'

5. Stiina kenkkäs

$\mathrm{N}$ [sg. nom.]

$\mathrm{V}[k e n k a ̈ t a ̈, 3 . s g$.

Mikole

piilin.

S $\mathrm{V}$

$\mathrm{N}$ [sg. all.]

$\mathrm{N}$ [sg. gen.]

ADV

$\mathrm{O}$

'Stina ga Mikkel en bil i gave.'

6. Liisale

annethiin

preivit.

$\mathrm{N}$ [sg. all.]

$\mathrm{V}$ [anttaat, passiv.]

$\mathrm{N}$ [pl. nom.]

ADV

$\mathrm{V}$

$\mathrm{O}$

'Breva blei gitt til Lisa'

7. Pekale ojenethiin palkinon.

'Prisen blei overrakt til Peder.'

I TRANSITIVE EIERSKAPSENDRINGssetninger med ta-verb står adverbialet, som uttrykker den eller det som blir tatt fra, i ablativ (1-4), sammen med gi-verb står det i allativ $(5-7)$. Objektet tar objektskasus. Vi ser også at adverbialet og objektet kan bytte plass uten at betydninga blir endra, til forskjell fra norsk, hvor det direkte objektet følger rett etter verbalet.

Ei typisk TRANSITIV EIERSKAPSENDRINGssetning følger dette mønsteret:

TRANSITIV EIERSKAPSENDRING:

$\mathrm{S}[\mathrm{NP}[$ nom. $]]+\mathrm{V}[$ ta- eller gi-verb, subjektskongruens $]+\mathrm{O}[\mathrm{NP}[$ objektskasus $]]+$ ADV[NP[abl./all.]]

Vi kan jamføre denne setningstypen med EIERSKAPssetninger. I EIERSKAPssetninger er det noen som har noe, i ta-setninger er det noen som får eller tar noe fra noen, og i gi-setninger er det noen som gir noe til noen. I alle disse setningstypene står adverbialet i ytre lokalkasus eller l-kasus.

Av eksempla ovafor går det fram at reglene for objektskasus er de samme som i TOVERDIGE HANDLINGssetninger (se avsnitt 4.2.5.1).

Også FLYTTEVERB (se avsnitt 4.2.5.4 nedafor) kan brukes som verbal i TRANSITIVE EIERSKAPSENDRINGssetninger $(8,9)$ : 
8. Kaisa toi minule skenkin.

'Kaisa hadde med seg en gave til meg.'

9. Muori siirsi [minun kontole] rahhaa.

'Mor overførte penger til kontoen min.'

Det fins også ei heil gruppe med verb som brukes i indirekte setninger (se avsnitt 4.3 nedafor), som tar både objekt og adverbial heilt på samme måte som setningene som er presentert ovafor. Eksempler på slike indirekte setninger ser vi i (10-16).

Som verbal i slike setninger opptrer vanligvis verb som pyyt(t)ää(t) ('be om'), puhhuut puhua(t) ('snakke'), kirjo(i)ttaa(t) ('skrive'), näyttää(t) ('vise'), muistela ('fortelle') og opettaa( $t$ ) ('lære, undervise'):

10. Matti pyysi minulta ruokkaa.

'Mats ba meg om mat.'

11. Kaisa sanoi Maijale tottuuđen.

'Kaisa fortalte Maja sannheta'

12. Mie puhuin hänele [kaunhiita sannoi].

'Jeg sa fagre ord til henne.'

13. Stiina [ei muistelu] Mikole tottuutta.

'Stina fortalte ikke sannheta for Mikkel.'

14. Leena näytti studentiile [uussii kuvvii].

'Lene viste nye bilder til studentene.'

15. Oppiijoile opetethiin [suomen kieltä].

'Elevene blei undervist i finsk språk.'

16. Studentiile näytethiin eksaamenitehtävän.

'Studentene fikk se eksamensoppgavene.'

\subsubsection{FLYTTING}

FLYTTINGssetninger er et treverdig verb som kjerne, og de forteller at noen flytter noen eller noe fra et sted til et anna sted. Subjektet i setninga er den eller det som flytter, objektet er det som blir flytta, og adverbialet er stedet som objektet blir flytta fra eller til. Vi kan sammenlikne FLYTTINGssetninger med TRANSITIVE 
EIERSKAPSENDRINGssetninger: I begge er det noe, uttrykt gjennom objektet, som endrer posisjon. I TRANSITIVE EIERSKAPSENDRINGssetninger er det eieren som bytter, mens i FLYTTINGssetninger er det noe som bytter plass fordi noen flytter på det.

Eksempler på fLYTteVerb er siirt(t)ä̈̈(t) ('flytte'), liikuttaa(t) ('røre, bevege'), tuođa tuua ('bringe, ha med seg'), vieđä viiä ('føre, ta med seg'), panna ('legge; sette'), nout(t)aa(t) ('hente'), vettää(t) ('slepe, dra, trekke'). Jamfør disse eksempelsetningene:
1. Einari
toi
piilin
Tyskästä.
$\mathrm{N}$ [sg. nom.] V[tuođa, 3. sg.]
$\mathrm{N}$ [sg. gen.]
$\mathrm{N}$ [sg. elat.]
$S$
$\mathrm{V}$
$\mathrm{O}$
ADV

'Einar hadde med seg en bil / bilen fra Tyskland.'

2. Sie [et pannu] kuppii hyllyle.

Pron[2. sg. V[panna, nekt. 2. sg.] N[sg./pl. part.] $\mathrm{N}$ [sg. all. $]$ $S$ $\mathrm{V}$

$\mathrm{O}$

ADV

'Du satte ikke koppen på hylla.'

3. Miina [oon noutanu]

minun kothiin. N[sg. nom.] V[nouttaat, 3. sg.] Pron[gen.] Adv $\mathrm{S}$ $\mathrm{V}$

$\mathrm{O}$ ADV

'Mina har henta meg heim.'

4. Muori vei pojan lastentarhaasseen.

'Mora leverte gutten/sønnen i barnehagen.'

5. Sisaret [olthiin viemässä] poikkaa lastentarhaasseen.

'Søstrene hadde med seg gutten på veg til barnehagen.'

6. Äiji [ei löytäny] [kuolutta reppoo] siljolta.

'Bestefar fant ikke noen død rev på brua.'

7. Pekka siirsi toolin siljole.

'Peder flytta stolen ut på gårdsplassen.'

8. Pekkaa [ei nouđettu] taivhaasseen.

'Peder blei ikke henta opp til himmelen.'

9. Mettästä löyđethiin [kuolheen revon].

'Det blei funnet en død rev i skogen.' 
10. Kaapista viskathiin [vanhaat ruvat].

'Den gamle maten blei kasta ut av skapet.'

Typiske FLYTTINGssetninger følger dette mønsteret:

\section{FLYTTING:}

$\mathrm{S}[\mathrm{NP}[$ nom. $]]+\mathrm{V}[$ flytteverb, subjektskongruens $]+\mathrm{O}[\mathrm{NP}[$ objektskasus $]]+$ ADV[NP[frastedskasus/tilstedskasus]/PP/AdvP]

Adverbialet står i frasteds- eller tilstedskasus. Reglene for når vi bruker indre eller ytre lokalkasus ( $s$ - eller $l$-kasus), er de samme som vi bruker når noe(n) beveger seg fra eller til et sted (se STED i avsnitt 4.2.1.1 og BEVEGELSE i avsnitt 4.2.1.2 ovafor): Når noe(n) flyttes ut av innsida av noe, så bruker vi indre lokalkasus (3-5, 8-10). Når noe(n) flyttes bort fra utsida av noe, så bruker vi ytre lokalkasus (2, 6, 7). Sammen med stedsnavn bruker vi vanligvis indre lokalkasus (1).

Også TRANSITIVE EIERSKAPSENDRINGsverb kan brukes som verbal i FLYTTINGssetninger $(11,12)$.

11. Lassi osti sykkelin Uslusta.

'Lars kjøpte en sykkel / sykkelen i Oslo.'

12. Mie sain skenkin Suomesta.

'Jeg fikk en gave / gaven fra Finland'

\subsubsection{Tilstandssetninger}

Tilstandssetninger forteller noe om en ytre eller indre tilstand eller tilstandsendring. Det fins flere typer tilstandssetninger.

\subsubsection{VAERTILSTAND}

Den første typen vi skal diskutere her, er VÆRTILSTANDssetninger. Eksempler på VÆrVERB er paistaa( $t$ ) ('skinne'), tuula ('blåse') og sattaa( $t$ ) ('regne'). I noen tilfeller uttrykkes VÆRTILSTAND i ei setning med $\mathrm{S}+\mathrm{V}$-struktur, det vil si at subjektet står først i setninga, og så følger værverbet (1):

1. Aurinko paistaa.

$\mathrm{N}$ [sg. nom.] V[paistaat, 3. sg. $]$

S V

'Sola skinner.' 
Vanligere er likevel at VÆRTILSTAND blir uttrykt med ei setning hvor subjektet mangler heilt (2-4). I slike setninger er det vanligvis et fritt adverbial (F-ADV) som står i begynnelsen av setninga $(3,4)$, ettersom det er et prinsipp i kvensk å unngå at verbet står først i setninga. Verbet sattaat betyr 'komme som nedbør', og nedbørsforma er uttrykt gjennom subjektet, som kommer sist i setninga på samme måte som i EKSISTENSsetninger (5-7). Men på subjektsplass i begynnelsen av setninga kan vi også plassere det tomme subjektet se (8). Alle disse setningene svarer til norske setninger med det formelle subjektet det. Eksempler på VÆRTILSTANDssetninger er:

2. Sattaa ja tuulee.

V[sattaat, 3. sg. $]$

Konj V V tuula, 3.sg.]

$\mathrm{V}$

Konj

$\mathrm{V}$

'Det regner og blåser.'

3. Ulkona

sattaa.

Adv

F-ADV

$\mathrm{V}[$ sattaat, 3. sg. $]$

$\mathrm{V}$

'Det regner ute.'

4. Merelä

tuuli.

$\mathrm{N}$ [sg. adess.]

V[tuula, 3. sg.]

F-ADV

$\mathrm{V}$

'Det blåste på havet.'

5. Tromssassa

$\mathrm{N}$ [sg. iness.]

F-ADV

sattaa

$\mathrm{V}[$ sattaat, 3. sg. $]$

$\mathrm{V}$ vettä.

$\mathrm{N}$ [sg. part.]

S

'Det regner i Tromsø'

6. Tunturissa pani/satoi lunta.

'Det snødde på fjellet.'

7. Pyssyjovessa

sattaa

rakheita.

$\mathrm{N}$ [sg. iness.]

$\mathrm{V}[$ sattaat, 3. sg. $]$

$\mathrm{N}$ [pl. part.]

'Det hagler i Børselv.'

8. Se sattaa ja tuulee.

'Det regner og blåser.'

Som vi ser i (7), så mangler VÆRTILSTANDssetninger subjektskongruens, og setningstypen likner også i så henseende på EKSISTENSsetninger. 
Det vanlige mønsteret for VÆRTILSTANDssetninger er slikt:

VÆRTILSTAND:

(se/F-ADV[NP/PP/AdvP] +) V[værverb, 3. sg.] (+ S[NP[part.]])

\subsubsection{YTRE TILSTAND}

Den andre typen tilstandssetning er YTRE TILSTAND, som forteller om temperaturen eller karakteriserer været på annen måte. Som verbal i slike setninger bruker vi olla ('være') (1-4) eller tulla ('komme') $(5,6)$. Subjektet står sist i setninga, etter verbalet. Særlig når utfyllinga er en adjektivfrase (2), så kan slike setninger analyseres som predikasjonssetninger med predikativ som utfylling.

1. Oli

V[olla, 3.sg.]

$\mathrm{V}$

'Det var dårlig vær/uvær.'

2. Oli

$\mathrm{V}[$ olla, 3. sg. $]$

$\mathrm{V}$

'Det var riktig varmt.'

3. Oon ilta.

'Det er kveld.'

4. Ushein olthiin [pahat ilmat].

'Det var ofte dårlig vær.'

5. Tuli [kaunis syksy].

'Det blei en fin høst.'

6. Huomena tullee [kaunis sää].

'Det blir fint vær i morgen.'

Også her kan vi legge til det tomme subjektet se i begynnelsen av setninga $(7,8)$ :

7. Se oli [kaunis ilta].

'Det var en fin kveld.'

8. Se oli [oikhein lämmin].

'Det var riktig varmt.' [kova sää].

$\mathrm{N}$ [sg. nom.]

S

[oikhein lämmin].

A[sg. nom.]

PRED 
Mønsteret for YTRE TILSTANDssetninger er slikt:

YTRE TILSTAND:

$($ se/F-ADV $[\mathrm{NP} / \mathrm{PP} / \mathrm{AdvP}]+) \mathrm{V}[$ tulla, olla, subjektskongruens + S[NP[nom.]]/ PRED[AP[nom.]

\subsubsection{SANSETILSTAND}

SANSETILSTAND er en type tilstandssetning hvor predikativet står i ablativ, og som forteller hvordan det lukter eller ser ut på et sted. Her bruker vi verba haista ('lukte') og näyttää( $t$ ) ('se ut'). Slike setninger mangler subjekt, men har i stedet et stedsadverbial $(1,2)$. Denne setningstypen ligger nærmest PREDIKATIV SANS, og vi analyserer den andre utfyllinga som predikativ.

1. Saunassa

haissee hyvältä.

$\mathrm{N}$ [sg. iness.]

V[haista, 3. sg.]

A[sg. abl.]

ADV

PRED

'Det lukter godt i badstua.'

2. Sielä

näytti

kaunhiilta.

Adv

V [näyttäät, 3. sg.]

A[sg. abl.]

ADV

$\mathrm{V}$

PRED

'Det så fint ut der.'

I disse setningene er verbalet alltid i tredje person entall. Setningstypen følger dette mønsteret:

\section{SANSETILSTAND:}

$\mathrm{ADV}[\mathrm{NP}[$ tilstandskasus]/PP/AdvP] $+\mathrm{V}[$ haista, näyttäät[3. sg.] $]+\mathrm{PRED}[\mathrm{AP}[\mathrm{sg}$. abl.]]

\subsubsection{INDRE TILSTAND}

Den fjerde tilstandssetningstypen kaller vi for INDRE TILSTAND, og den forteller noe om den indre tilstanden til et levende vesen. Det er verbet olla ('være') som er brukt i slike setninger. Setningstypen minner om EIERSKAPssetninger, men den kan alternativt også fortelle noe om ei tilstandsendring. Da er det tulla ('bli') som er brukt som verb. Utfyllinga som står foran verbalet, er i adessiv når verbet er olla $(1,3,5,7)$, og i allativ når verbet er tulla $(2,4,6)$. Den andre utfyllinga i setninga er en 
tilstandsbeskrivende adjektivfrase $(1,2)$ eller en substantivfrase $(3-7)$. Adjektivfraser likner her mest på predikativ, mens substantivfraser likner mest på subjekt. Vi kaller dem her for enkelthets skyld bare for utfylling.

1. Dagnylä

$$
\begin{array}{ll}
\text { oon } & \text { kylmä. } \\
\text { V }[\text { olla, 3. sg. }] & \text { A[sg. nom.] } \\
\text { V } & \text { UTFYLLING }
\end{array}
$$

$\mathrm{N}$ [sg. adess.]

ADV

'Dagny fryser.'

2. Liisale

tuli

kylmä.

$\mathrm{N}$ [sg. adess.]

V[tulla, 3. sg. $]$

A[sg. nom.]

ADV

$\mathrm{V}$

UTFYLLING

'Lisa blei kald.'

3. Minula

oon

palava.

Pron[1.sg.]

$\mathrm{V}$ [olla, 3.sg.]

$\mathrm{N}$ [sg. nom.]

ADV

$\mathrm{V}$

UTFYLLING

'Jeg er svett.'

4. Kissale tuli [nälkä ja jano].

'Katten blei sulten og tørst.'

5. Kaikila oon hoppu.

'Alle har det travelt.'

6. Äijile tuli [paha mieli].

'Bestefar blei i dårlig humør.'

7. Meilä oli [huono tila] ja [huono sija].

'Vi hadde dårlig tid og dårlig med plass.'

Sjøl om disse setningene minner om EIERSKAPssetninger, så skiller de to typene seg fra hverandre ved at subjektet i nektende EIERSKAPssetninger står i partitiv, mens den tilsvarende utfyllinga i INDRE TILSTANDssetninger alltid står i nominativ $(8-12)$ :

8. Dagnylä [ei ole] kylmä.

'Dagny fryser ikke.'

9. Liisale [ei tullu] kylmä.

'Lisa blei ikke kald.' 
10. Minula [ei ole] palava.

'Jeg er ikke svett.'

11. Heikala [ei ole] koskhaan hoppu.

'Henry har det aldri travelt.'

12. Äijile [ei tullu] [paha mieli].

'Bestefar blei ikke i dårlig humør.'

Mønsteret for INDRE TILSTANDssetninger er slikt:

INDRE TILSTAND:

ADV[NP[adess. $]]+$ V[olla, 3. sg. $]+$ UTFYLLING[NP/AP[sg. nom. $]]$

eller

ADV[NP[all.]] + V[tulla, 3. sg. $]+$ UTFYLLING[NP/AP[sg. nom. $]]$

\subsubsection{STATUS}

Den siste tilstandssetningstypen vi tar opp her, er STATUS. Her korrelerer subjektet med et tilstandsadverb (se avsnitt 9.4.3). Som verb bruker vi olla ('være') $(2,4,5)$ eller mennä ('gå) $(1,4)$, og stundom også tulla (komme; bli')

(6). Eksempler er:

1. Piili

$\mathrm{N}$ [sg. nom.]

$\mathrm{S}$

'Bilen gikk sund.'

2. [Kaikki tiet]

$\mathrm{N}$ [pl. nom.]

$\mathrm{S}$

'Alle veger var stengt.'

3. Talo

$\mathrm{N}$ [sg. nom.]

$\mathrm{S}$

'Huset står på skrå.'

4. Pekka ja Kalla menthiin naimishiin.

'Peder og Kalla gifta seg.'

5. Häävierhaat olthiin päissä.

'Bryllupsgjestene var fulle'. meni

$\mathrm{V}$ [mennä, 3. sg.]

$\mathrm{V}$

olthiin

V[olla, 3. pl. $]$

$\mathrm{V}$

oon

V [olla, 3. sg.]

$\mathrm{V}$ rikki.

Adv

ADV

poikki.

Adv

ADV

kaltossa.

Adv

ADV 
6. Liisaki tuli päihin.

'Også Lisa blei full.'

Sjøl om adverb ikke bøyes, så ser vi her at verba mennä og tulla i slike konstruksjoner tar som utfylling adverb som historisk sett er substantiv i tilstedskasus $(4,6)$, og verbet olla slike som historisk sett er substantiv i påstedskasus $(3,5)$. Adverb av typen rikki(t) ('sund, i stykker'), poikki(t) ('i to'), halki(t) ('i to, tvers igjennom') har bare éi form, som passer med alle verb $(1,2)$.

STATUSsetninger følger dette mønsteret:

STATUS:

$\mathrm{S}[\mathrm{NP}[$ nom. $]+\mathrm{V}[$ olla, mennä,tulla, subjektskongruens $]+\mathrm{ADV}[\mathrm{AdvP}$ [påstedskasus] $]$

\subsection{Indirekte setninger}

Setningstypene vi har diskutert så langt, gjengir direkte et eller anna saksforhold. Nå skal vi ta for oss den andre hovedgruppa av setningstyper, såkalte indirekte setninger.

Som navnet sier, så forteller INDIREKTE SETNINGER bare indirekte om et saksforhold. Subjektet i oversetninga er et ord som betegner et levende vesen. Verbalet i oversetninga forteller hva slags forhold subjektet har til det refererte saksforholdet. Leddsetninga kan være utfylling til verbalet i oversetninga, og i setningsmønster markerer vi slike leddsetninger med SETN. Også en verbfrase (VP) kan være utfylling til verbalet i oversetninga. Verbfrasen kan ha form av infinitiv eller partisipp. Partisippforma verbfraser kan alltid erstattes med en subjunksjonssetning, og derfor skal vi ikke gå nærmere inn på dem her. Men det fins eksempler på slike setninger i avsnittet om partisipp (se 6.8.2.1, eksempler 9-15).

Verbalet $\mathrm{i}$ indirekte setninger kongruerer alltid i tall og person med subjektet. Den andre utfyllinga i indirekte setninger er oftest et objekt. Det er slike vanlige tilfeller som skal diskuteres nedafor. Men det fins også indirekte setninger hvor den andre utfyllinga er et adverbial. For eksempel i setninga Met luotama siihen, ette kainun kieli säilyy ('Vi stoler på at kvensk overlever') er frasen siihen, ette kainun kieli säilyy ('at kvensk overlever') adverbial til verbet luottaa(t) ('stole på). Slike setningstyper skal vi ikke gå inn på her, men vi kommer tilbake til dem for eksempel i avsnittet om junksjoner (se 11.2.2.4). 


\subsubsection{KOGNISJON}

KOGNISJON uttrykker en kognitiv tilstand. Eksempler på KOGNITIVE VERB er muistaa $(t)$ ('huske'), tiet $(t) \ddot{a} a ̈(t)$ ('vite') og ymmärt(t)ää(t) ('forstå). Verbalet har to utfyllinger, subjektet og objektet. Objektet er typisk ikke noen nomenfrase, men en verbfrase $(1,6)$ eller ei leddsetning $(2-5,7-8)$. Leddsetninga er enten ei ette-setning $(2,4,7)$, eller sammen med noen verb, særlig med muistaat og tiettäät i nektende setninger, så kan det også være ei spørresetning (3, 5, 8). Er leddsetninga ei spørresetning, så kan den innleies med subjunksjonen ette, men denne kan også utelates. Eksempler er:
1. Pekka
muisti
[lukkeet preivin].
$\mathrm{N}[$ sg. nom.]
$\mathrm{V}[$ muistaat, 3. sg. $]$ $\mathrm{VP}[$ 1. inf. $+\mathrm{N}[$ sg. gen. $]]$
$\mathrm{S}$ $\mathrm{V}$
$\mathrm{O}$

'Peder huska å lese brevet.'

2. Pekka muisti [ette hän häyttyy lukkeet preivin]. $\mathrm{N}[$ sg. nom. $\mathrm{V}$ [muistaat, 3. sg.] S $\mathrm{V}$

'Peder huska at han måtte lese brevet.'

3. Kuningas [ei muistanu] [(ette) oliko hän lukenu preivin].

$\mathrm{N}$ [sg. nom.] $\quad \mathrm{V}$ [muistaat, nekt. 3. sg.] SETN [(ette +$)$ spørresetning] $\mathrm{S}$ $\mathrm{V}$

\section{$\mathrm{O}$}

'Kongen huska ikke om han hadde lest brevet.'

4. Sie tieđät [ette mie olen tälä].

'Du veit at jeg er her'.

5. Sie [et tieny] [(ette) kuka sie olit].

'Du visste ikke hvem du var.'

6. Hukka ymmärsi [lähteet pakhoon].

'Ulven forsto å dra på flukt.'

7. Hukka ymmärsi [ette nyt mennee huonosti].

'Ulven skjønte at det sto dårlig til nå.'

8. Hukka [ei ymmärtänny] [(ette) mitä nyt tapattuu].

'Ulven skjønte ikke hva som skjedde nå.' 
Også et nomen kan fungere som objekt, men da svarer det som regel til ei leddsetning. Jamfør setningene $(9,10)$ med setningene $(11,12)$.

9. Met

muistama

kaiken.

Pron[1.pl.]

$\mathrm{V}[$ muistaat, 1.pl.]

S

$\mathrm{V}$

Pron[sg. gen.]

'Vi husker alt'.

10. Mie muistan Pekan.

'Jeg husker Peder.'

11. Met muistama, mitä olema lukenheet ja nähnheet.

'Vi husker hva vi har lest og sett.'

12. Mie muistan, ette olen kohđatellut Pekan.

'Jeg husker at jeg har møtt Peder.'

Det vanlige mønsteret for KOGNISJON er:

KOGNISJON:

$\mathrm{S}[\mathrm{NP}[$ nom. $]]+\mathrm{V}[$ kognisjonsverb, subjektskongruens $]+\mathrm{O}[\mathrm{VP} /$ ette-setning/(ette

+) spørresetning]

\subsubsection{MEINING}

Setninger av typen MEINING forteller at noen antar, syns, trur eller håper at ei sak er slik eller slik. Blant de vanligste MEININGsverba finner vi luula ('anta; tru'), uskoot uskoa( $t$ ) ('tru'), pittää( $(t$ ) ('synes') og toivoot toivoa( $t$ ) ('håpe'). Som objekt fungerer som regel ei ette-setning (1-5).

1. Het luulthiin [ette kainun kieltä ei ole olemassakhaan].

Pron[3.pl.] V[luula, 3.pl.] SETN[ette-setning]

$\mathrm{S}$ $\mathrm{V}$

$\mathrm{O}$

'De trudde (at) kvensk ikke fantes en gang.'

2. Mie luulen [ette Matti oon hullu].

'Jeg trur (at) Mats er gal.'

3. Alattiolaiset piđethiin [ette amtmani oli oikhein paha].

'Altaværingene syntes (at) amtmannen var ordentlig slem.'

4. Pekka uskoi [ette Maija rakastaa häntä].

'Peder trudde (at) Maja elska han.' 
5. Met toivoma [ette kissa tullee takaisin].

'Vi håper (at) katten kommer tilbake.'

Verba uskoot uskoa( $t$ ) ('tru') ja toivoot toivoa( $t$ ) ('håpe') kan også ta en NP som objekt. Verbet toivoot tar objekt i partitiv (6), verbet uskoot tar også objekt i partitiv (7), men det kan også ta et adverbial som utfylling (8).

6. Met toivoma rauhaa.

Pron[1.pl., nom.]

$\mathrm{V}[$ toivoot, 1.pl. $]$

$\mathrm{N}$ [sg. part.]

S

$\mathrm{V}$

$\mathrm{O}$

'Vi håper på fred.'

7. Mie uskon sinnuu.

'Jeg trur deg.'

8. Pekka uskoi [Jumalan pääle] Jumalhaan.

'Peder trudde på Gud.'

NP-frasen og PP-frasen i disse setningene svarer på en måte til ei ette-setning. Vi kan jamføre setningene i (6-8) med vanlige MEININGSsetninger i (9-11):

9. Met toivoma [ette tulis rauha].

'Vi håper at det blir fred.'

10. Mie uskon [ette sie puhut totta].

'Jeg trur at du snakker sant.'

11. Pekka uskoi [ette Jumala oli olemassa].

'Peder trudde at Gud fantes.'

Det typiske setningsmønsteret for MEINING er slikt:

MEINING:

$\mathrm{S}[\mathrm{NP}[$ nom. $]]+\mathrm{V}[$ meiningsverb, subjektskongruens $]+\mathrm{O}$ [ette-setning $]$

I tilfeller hvor verba luula, uskoot $\sim$ uskoa $(t)$ eller toivoot $\sim$ toivoa $(t)$ tar som objekt ei ette-setning med predikativ, så kan vi erstatte ette-setninga med et setningsmønster hvor predikativet består av en NP eller AP i translativ (1217), eller essiv, når verbet er pittäät (18-20). Objektet er alltid i partitiv når verbet er luula eller pittäät (12-14, 18-20), mens det sammen med verba uskoot $\sim$ uskoa $(t)$ og toivoot toivoa $(t)$ også kan ha objektskasus (15-17). Vi har her altså med treverdige verbal å gjøre: 
12. Mie

$$
\text { Pron[1.sg.] }
$$
$S$ 'Jeg trudde (at) du var klok'. sinnuu

Pron[sg. part.]

$\mathrm{O}$ viishaaksi.

A[sg. transl.]

PRED

13. Perunka luuli meitä kummitukseksi.

'Beronka trudde (at) vi var spøkelser.'

14. Meitä luulthiin tyhmäksi.

'Vi blei sett på som dumme.'

15. Hukka

uskoi

$\mathrm{N}$ [sg. nom.]

$\mathrm{S}$

'Ulven trudde at reven var dum.'

16. Mie [en usko] sinnuu viishaaksi.

'Jeg trur ikke (at) du er klok.'

17. Kettu toivoi hukat kuolheeksi.

'Reven håpa (at) ulvene var døde.'

18. Matti

$$
\text { pittää }
$$

$\mathrm{N}$ [sg. nom.]

V[pittäät, 3. sg.]

$S$ $\mathrm{V}$

minnuu

Pron[sg. part.]

$\mathrm{O}$

ketun

$\mathrm{N}$ [sg. gen.]

$\mathrm{O}$ tyhmäksi.

A[sg. transl.]

PRED

'Mats syns (at) jeg er gal.'

19. Het piđethään meitä hulluna.

'De synes (at) vi er gale.'

20. Joonas piti valasta kalana.

'Jonas trudde (at) kvalen var en fisk.'

Men også i disse MEININGSsetninger er det likevel vanligere å bruke et setningsmønster med ette-setning (21-23):

21. Perunka luuli [ette met olima kummitukset].

'Beronka trudde (at) vi var spøkelser.'

22. Mie [en usko] [ette sie olet viisas].

'Jeg trur ikke (at) du er klok.' 
23. Het piđethiin [ette met olema hullut].

'De syntes (at) vi var gale'.

\subsubsection{SANSEOBSERVASJON}

I setningstypen SANSEOBSERVASJON uttrykker verbalet en sanseobservasjon. Verbet kan være transitivt eller intransitivt. Eksempler på TRANSITIVE SANSEVERB er kuula ('høre'), nähđä nähhä ('se'), haistaa( $t$ ) ('lukte'), maistaa( $t$ ) ('smake') ja tuntteet $\sim$ tuntea $(t) \sim$ tuntia ('kjenne, føle'). Verbalet har to utfyllinger, subjekt og objekt. Objektet kan være et nomen $(6,7,11)$ og tar da kasus etter de vanlige objektsreglene. Men vanligere er det at objektet består av ei leddsetning $(1-5,8-10)$ i form av ei ette-setning $(1,8,9)$, ei $k o$-setning $(2,10)$ eller ei spørresetning som kan være innleid av subjunksjonen ette (3-5).

1. [Kylän ihmiset] nähthiin [ette Knuutti tuli Aaronniemestä]. $\mathrm{N}[\mathrm{pl}$. nom.] $\quad \mathrm{V}[$ nähđä, 3.pl.] SETN[ette-setning]

$\mathrm{S} \quad \mathrm{O}$

'Bygdefolket så at Knut kom fra Aronneset'.

2. [Kylän ihmiset] nähthiin [koKnuuttituli Aaronniemestä]. $\mathrm{N}[$ pl. nom. $\quad \mathrm{V}[$ nähđä, 3. pl.] SETN $[k o$-setning]

$\mathrm{S} \quad \mathrm{O}$

'Bygdefolket så Knut da han kom fra Aronneset.'

3. [Kylän ihmiset] [ei nähnheet] [(ette) tuliko Knuutti Aaroninniemestä].

N[pl.nom. $\quad$ V[nähđä, nekt. 3.pl.] SETN[(ette+) $\mathrm{kO}$-spørresetning].

S $\mathrm{V} \quad \mathrm{O}$

'Bygdefolket så ikke om Knut kom fra Aronneset.'

4. Met näjimä [(ette) mitä sielä tapattui].

'Vi så hva som skjedde der.'

5. Mie kuulin [mitä sie sanoit].

'Jeg hørte hva du sa'.

6. Mie näjin aikamasiinin.

'Jeg så en tidsmaskin / tidsmaskinen.' 
7. Mie [en nähny] aikamasiinii.

'Jeg så ikke noen tidsmaskin / tidsmaskinen.'

8. Het tunnethiin [ette masiini lensi avaruuđen läpi].

'De kjente at maskinen fløy gjennom verdensrommet.'

9. Ragnhild kuuli [ette vielä oli sijjaa aikamasiinissa].

'Ragnhild fikk høre at det fortsatt var plass i tidsmaskinen.'

10. Pojat kuulthiin [ko tyttäret tulthiin].

'Guttene hørte jentene da de kom.'

11. Met kuulima kitarinpellaamista.

'Vi hørte gitarspell.'

Også her kan vi erstatte NP-objektet med ei ette-setning (12-14):

12. Mie näjin [ette sielä oli aikamasiini].

'Jeg så at det var en tidsmaskin der'.

13. Mie [en nähny] [ette sielä oli aikamasiini].

'Jeg så ikke at det var en tidsmaskin der.'

14. Met kuulima [ette joku pelas kitarilla].

'Vi hørte at noen spelte gitar.'

SANSEOBSERVASJONssesetninger følger dette mønsteret:

SANSEOBSERVASJON:

$\mathrm{S}[\mathrm{NP}[$ nom. $]]+\mathrm{V}[$ sanseverb, subjektskongruens $]+\mathrm{O}[$ ette- eller $k o$-setning/(ette +) spørresetning/ NP[objektskasus]]

Som intransitive sanseverb brukes først og fremst näyttää(t) ('se ut') og tunttuut tuntua( $t$ ) ('kjennes, føles'), og subjektet er da ei ette-setning $(15,16)$. Vi kan også legge til det tomme subjektet se (14) og ankerordet siltä, som står i ablativ $(17,18)$.

15. Näyttää [ette huomena tullee sađet].

'Det ser ut til at det blir regn i morgen.'

16. Minusta tunttuu [ette nyt alkkaa se onnelinen elämä].

'Jeg har inntrykk av at det lykkelige livet begynner nå.'

17. Se näyttää [siltä [ette huomena tullee sađet]].

'Det ser ut til at det blir regn i morgen.' 
18. Minusta tunttuu [siltä [ette nyt alkkaa se onnelinen elämä]].

'Jeg har inntrykk av at det lykkelige livet begynner nå.'

I ikke-generiske setninger er den som kjenner eller har inntrykk av noe, uttrykt som adverbial i elativ (18). Se også avsnitt 11.2.2.1 om setninger med intransitivt sanseverb og ette-setninger som subjekt. Men det fins også indirekte setninger av typen SANSEOBSERVASJON der utfyllinga består av et predikativ i ablativ (19):

19. Minusta tunttuu pahalta.

'Jeg syns det er ille.'

\subsubsection{INDIREKTE TALE}

INDIREKTE TALE kaller vi setninger som refererer til det noen sier eller tenker. Slike setninger kan som regel formes om til direkte tale eller sitat. Kjernen i INDIREKTE TALE er et TALEVERB som har to utfyllinger, subjekt og objekt. Subjektet står alltid for den aktive utøveren.

Eksempler på taleverb er sannoot sanoa( $t$ ) ('si'), muistela ('fortelle'), ilmo(i)ttaa(t) ('uttrykke; opplyse'), kirjo(i)ttaa( $t$ ) ('skrive'), ajatella ('tenke'), opettaa $(t)$ ('undervise'), valetella ('lyge'), luvata ('love'), kyssyyt kysyä( $t$ ) ('spørre'), lukkeet lukea( $t) \sim$ lukia ('lese') og tutkiit tutkia( $t$ ) ('studere, (ut) forske, undersøke'). Objektet er oftest ei leddsetning i form av ei ette-setning $(1,3,4)$ eller ei spørresetning $(2,5,6)$. Verbet luvata kan også ta en infinitivsfrase som objekt $(7)$.

$\begin{array}{lll}\text { 1. Perunka } & \text { sanoi } & \text { [ette hän kirjoittaa grammatikin]. } \\ \mathrm{N} \text { [sg. nom.] } & \mathrm{V}[\text { sannoot, 3. sg. }] & \text { SETN[ette-setning] } \\ \mathrm{S} & \mathrm{V} & \mathrm{O}\end{array}$

'Beronka sa at han skulle skrive en grammatikk.'

2. Äiji [oon muistelu] [(ette) kunka hän sai emänän].

$\mathrm{N}$ [sg. nom. $\quad \mathrm{V}$ [muistela, 3. sg. $\quad$ SETN $[($ ette +$)$ spørresetning]

$\mathrm{S} \quad \mathrm{V}$

$\mathrm{O}$

'Bestefar har fortalt hvordan han fikk seg kone.'

3. [Talmulahđen pappi] kirjoitti [ette amtmani kiussaa kainulaissii].

'Presten i Talvik skreiv at amtmannen plaga kvenene.' 
4. Het valetelthiin [ette heilä ei ollu sijjaa].

'De løy om at de ikke hadde plass.'

5. Sammeli kysyi [(ette) keitä tet oletta].

'Samuel spurte om hvem dere var'.

6. Het kysythiin [(ette) mitä met nyt häyđymä tehđä].

'De spurte om hva de måtte gjøre nå.'

7. Iisko lupas [anttaat mulle rahhaa].

$\mathrm{N}[$ sg. nom. $\quad \mathrm{V}[$ luvata, 3. sg. $] \quad \mathrm{VP}[$ 1. inf. + ADV + O $]$

$\begin{array}{lll}\mathrm{S} & \mathrm{V} & \mathrm{O}\end{array}$

'Isak lovte å gi meg penger'.

Det typiske setningsmønsteret for INDIREKTE TALE er slikt:

INDIREKTE TALE:

$\mathrm{S}[\mathrm{NP}[$ nom. $]]+\mathrm{V}[$ taleverb, subjektskongruens $]+\mathrm{O}[$ ette-setning/(ette +$)$ spørresetning]

I INDIREKTE TALE legger man gjerne til hvem som er mottakeren for talen, lovnaden, spørsmålet osv. Eksempler ser vi i $(8,9)$ :

8. Het valetelthiin meile, [ette heilä ei ollu sijjaa].

Pron[3.pl., nom.] V[valetella, 3.pl.] Pron[all.] SETN[ette-setning]

$\mathrm{S} \quad \mathrm{V} \quad$ ADV O

'De løy for oss om at de ikke hadde plass'.

9. Sammeli kysyi meiltä, [(ette) keitä tet oletta].

'Samuel spurte oss om hvem vi var.'

Når INDIREKTE TALE blir brukt etter mønster av STYRINGssetninger (se avsnitt 4.3.6), så kan vi i stedet for ette-setninga ha en infinitivsfrase som forbindes med oversetninga med hjelp av subjunksjonen ette (10) (se også avsnitt 11.2.2.2):

10. Iisakki sanoi [ette lähtiä heti kotia].

'Isak sa at han snart skulle dra heim.'

Også verbet seissoot seisoa( $t$ ) ('stå') kan brukes i INDIREKTE TALE, men slike setninger skiller seg fra dem vi har diskutert så langt, ved at leddsetninga her fungerer som subjekt (11): 
11. Aviisissa

seisoi,

[ette koko kylä oon myytävännä].

$\mathrm{N}[$ sg. iness.

$\mathrm{V}[$ seissoot, 3. sg. $]$

SETN[ette-setning]

ADV

$\mathrm{V}$

S

'I avisa sto det at heile bygda var til salgs.'

Slike setninger minner om EKSISTENSsetninger, og verbet står alltid i tredje person entall.

\subsubsection{NAVNGIVING}

NAVNGIVING er en treverdig indirekte setningstype som er spesiell på den måten at den ikke tar utfylling i form av ei leddsetning eller en verbfrase, men en nomen- eller adjektivfrase. Vi bruker denne setningstypen til å uttrykke hva noen eller noe kalles for. Eksempler på NAVNGIVINGSVERB er käskeet käskeät käskiä ('kalle'), kuttuut kuttua(t) ('kalle'), sannoot sanoa(t) ('si'), nimittää( $t$ ) ('navngi, kalle') og haukkuut haukkua(t) ('kjefte'). Som utfyllinger tar NAVNGIVINGssetninger i tillegg til subjekt et nomenobjekt og et predikativ i form at en $\operatorname{NP}(1,3)$ eller en $\operatorname{AP}(2)$ som står i translativ.
1. Solgunn käskee
[kainun kieltä]
[syđämen kieleksi].
$\mathrm{N}[\mathrm{sg}$. nom $]$
$\mathrm{V}[$ käskeet, $3 . \mathrm{sg}$.
$\mathrm{N}$ [sg. part.
$\mathrm{N}$ [sg. transl.]
S $\mathrm{V}$
$\mathrm{O}$
PRED

'Solgunn kaller kvensk for hjertespråket.'

2. Hanna haukkui minnuu hulluksi.

'Hanna kjefta på meg og kalte meg for gal.'

3. Ruijalaiset sanothiin meitä kvääniksi.

'Nordmennene kalte oss for kvener'.

Setningsmønsteret for NAVNGIVING er slikt:

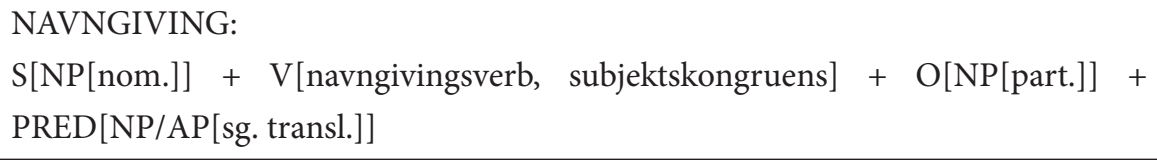

I bekreftende setninger kan objektet i entall også stå i genitiv (4), og i flertall kan det stå i nominativ (5):

4. Solgunn käskee [kainun kielen] [syđämen kieleksi].

'Solgunn kaller kvensk for (sitt) hjertespråk.' 
5. Ruijalaiset haukuthiin pojat kväänikläpiksi.

Nordmennene kjefta på guttene og kalte dem for kvenunger.'

\subsubsection{STYRING}

Kjernen i STYRINGssetninger er verb som uttrykker BEFALING, TILLATELSE, FORBUD eller liknende. Vi kaller disse for STYRINGSVERB. Slike setninger forteller at noen befaler, tillater eller forbyr noen å gjøre noe. Vanlige verb i STYRINGssetninger er käskeet käskeät käskiä ('befale; be'), ant(t)aa(t) ('tillate, gi lov'), neuvoot neuvoa( $t$ ) ('gi råd, veilede') og kielt $(t) \ddot{a} a ̈(t)$ ('forby, nekte'). Verb som uttrykker ønske eller tillatelse til at noen gjør noe, tar objekt i forma en verbfrase hvor subjektet i entall er i genitiv $(1,4,6)$ og i flertall i nominativ $(3,5,7)$; personlige pronomen i flertall står i såkalt akkusativ (2).
1. Mie
käskin
[Liisan
[lukkeet läksyt]].
Pron[1.sg.]
$\mathrm{V}[$ käskeet, 1.sg. $]$
$\mathrm{VP}[\mathrm{N}$ [sg. gen.]
$\mathrm{VP}[$ 1. inf. + N]]
$\mathrm{S}$
$\mathrm{V}$
$\mathrm{O}[\mathrm{S}+\mathrm{V}+\mathrm{O}]$

'Jeg ba Lisa om å gjøre leksene'.
2. Perunka käski [meiđät [tulla sisäle]].
$\mathrm{N}$ [sg. nom.] V[käskeet, 3. sg. $\quad \mathrm{VP}[\operatorname{Pron}[$ 1.pl., akk. $\quad \mathrm{VP}[$ 1. inf. + Adv]] $\mathrm{S} \quad \mathrm{V} \quad \mathrm{O}[\mathrm{S}+\mathrm{V}+\mathrm{ADV}]$

'Beronka ba oss om å komme inn.'

$\begin{array}{llll}\text { 3. } \text { Muori } & \text { käski } & \text { [pojat } & \text { [syöđä puuron]] } \\ \mathrm{N} \text { [sg. nom.] } & \mathrm{V}[\text { käskeet, 3. sg.] } & \mathrm{VP}[\mathrm{N}[\text { pl. nom.] } & \mathrm{VP}[\text { 1. inf. + N]] } \\ \mathrm{S} & \mathrm{V} & \mathrm{O}[\mathrm{S}+\mathrm{V}+\mathrm{O}] & \end{array}$

'Mora ba sønnene om å spise grøten.'

4. Ämmi antoi [pojan [summastaat kissaa]].

'Bestemora ga gutten lov til å kysse katten.'

5. Äiji antoi [pojat [lähteet pyythöön]].

'Bestefaren ga guttene lov til å dra på fiske.'

6. Pappi neuvoi [Nillan [lähteet reishuun]].

'Presten rådde Nils til å dra på ei reise.'

7. Opettaaja neuvoi [koululapset [lukkeet läksyt]].

'Læreren anbefalte elevene å gjøre leksene.' 
Setningstypen STYRING følger dette mønsteret:

STYRING:

$\mathrm{S}[\mathrm{NP}[$ nom. $]]+\mathrm{V}[$ styringsverb, subjektskongruens $]+\mathrm{O}[\mathrm{VP}[\mathrm{S}[\mathrm{NP}[$ sg. gen./pl. nom./akk.]] + VP[1. inf. (+ UTFYLLING)]]

Verbet pyyt(t)ää( $t$ ('fiske; fange; be om') opptrer sjelden i STYRINGSkonstruksjoner. Men når det gjør det, så tar det en 3. infinitivsfrase i illativ som objekt (8):

8. Isä pyysi [minun lähtemhään pyythöön].

'Far ba meg om å dra på fiske.'

Når vi bruker verbet kielt $(t) \ddot{a} a ̈(t)$ ('forby, nekte') som verbal, så står verbet i objektsverbfrasen i 3. infinitiv (9-11), og vi analyserer det som adverbial. Subjektet i objektsverbfrasen har objektskasus, det betyr at når oversetninga er nektende, så står det i partitiv (11).

9. Prosti kielsi

[Perungan [saarnaamasta kainuksi]]. $\mathrm{N}$ [sg. nom.] V[kielttäät, 3. sg.] $\mathrm{VP}[\mathrm{N}$ [sg. gen.] VP[3. inf. elat. + N]

$\mathrm{S} \quad \mathrm{V} \quad \mathrm{ADV}[\mathrm{S}+\mathrm{V}+\mathrm{ADV}]$

'Prosten nekta Beronka å preke på kvensk.'

10. Faari

kielsi

pojat

[lähtemästä

pyythöön].

$\mathrm{N}$ [sg. nom.] V[kielttäät, 3. sg. $\quad \mathrm{VP}[\mathrm{N}[$ pl. nom.] $\quad \mathrm{VP}[$ 3. inf. elat. + N]] $\mathrm{S}$

'Faren forbydde sønnene å dra på fiske.'

11. Papit

ei kieltänheet

[faarii

[juomasta viinaa]].

$\mathrm{N}$ [pl. nom.] V[kielttäät, nekt. 3.pl.] $\mathrm{VP}[\mathrm{N}$ [sg. part.] $\mathrm{VP}[1$. inf. elat. + N]

$\mathrm{S}$ $\mathrm{V}$

$\mathrm{ADV}[\mathrm{S}+\mathrm{V}+\mathrm{O}]$

'Prestene forbydde ikke faren å drikke brennevin.'

Mønsteret for STYRING med verbet kielttäät er slikt:

STYRING - med verbet kielttäät:

$\mathrm{S}[\mathrm{NP}[$ nom. $]]+\mathrm{V}[$ kielttäät, subjektskongruens $]+\mathrm{ADV}[\mathrm{VP}[\mathrm{S}[\mathrm{NP}[$ objektskasus$]]]$

$+\mathrm{V}$ [3. inf. elat. (+ UTFYLLING)]] 
Når verbfrasen i ei STYRINGssetning kan tenkes som et sitat av ei oppfordring, så er det mulig å legge til subjunksjonen ette framfor infinitiven $(12,13)$. Det er særlig utbredt i Varanger-varieteten, jf. disse eksemplene:

12. Mie käskin [Liisan ette lukia läksyt].

'Jeg ba Lisa om å gjøre leksene.'

13. Pappi neuvoi [Nillan ette lähtiä reishuun].

'Presten anbefalte Nils å dra på ei reise.'

I Varanger-varieteten brukes samme konstruksjonen også med verbet kieltää ('forby, nekte'). Verbet i objektsverbfrasen står da i 1. infinitiv, men vi må da legge til nektingsverbet ei (14):

14. Prosti kielsi [Perunkaa [ette ei saarnata kainuksi]]. $\mathrm{N}[$ sg. nom.] $\quad \mathrm{V}[$ kieltää, 3. sg. $] \quad \mathrm{VP}[\mathrm{N}[$ sg. part. $] \quad[\mathrm{VP}[$ ette + ei +1 . inf. $+\mathrm{N}]]]$ $\begin{array}{lll}\mathrm{S} & \mathrm{V} & \mathrm{O}[\mathrm{S}+\text { ette }+\mathrm{V}+\mathrm{ADV}]\end{array}$

'Prosten nekta Beronka å preke på kvensk.'

Objektsverbfrasen i setningene ovafor har et subjekt. Vanligere er likevel at slike VP-subjekt mangler i STYRINGssetninger (14-16):

15. Perunka käski [(ette) tulla sisäle].

'Beronka ba meg/deg/han/hun/oss/dere/dem om å komme inn.'

16. Pappi neuvoi [(ette) lähtiä sisäle].

'Presten anbefalte meg/deg/han/hun/oss/dere/dem å komme inn.'

17. Prosti kielsi [ette ei saarnata kainuksi].

'Prosten forbydde at det skulle prekes på kvensk.'

Samme setningsmønster kan vi også bruke med taleverb dersom objektsverbfrasen kan tolkes som ei oppfordring $(17,18)$ :

18. Mie sanoin Liisale [ette lähtiä Vesisaarheen minun kansa].

'Jeg sa til Lisa at hun skulle dra til Vadsø sammen med meg.'

19. Faari huusi [ette tulla aphuun].

'Faren ropte at jeg/du/han/hun/vi/dere/dem skulle komme til hjelp'.

Se også avsnitt 11.2.2.2 om slike ette-fraser. 


\subsection{Modifiserte setninger}

Som MODIFISERTE SETNINGER definerer vi her setninger som inneholder et verb eller verbsamband som ikke bidrar med ny informasjon, men som modifiserer saksforholdet som er framstilt i setninga $(1,2)$, eller bestemmer nærmere tida for når saksforholdet gjelder $(3,4)$. Eksempler på modifiserte setninger er:

Modifisert setning:

1. Mie häyđyn mennä hyysikkhään. 'Jeg må gå på do'.

2. Sinula oon lupa lähteet feeriälle. 'Du har lov til å dra på ferie.'

3. Pekka oon juomassa kaffii. 'Peder holder på å drikke kaffe.'

4. Pekka kerkes juomasta kaffii.
Tilsvarende umodifisert setning:

Mie menen hyysikkhään.

'Jeg går på do.'

Sie lähđet feeriälle.

'Du drar på ferie.'

Pekka juo kaffii.

'Peder drikker kaffe.'

Pekka joi kaffii.

Vi deler modifiserte setninger inn i tre hovedtyper:

- Verbalet i den modifiserte setninga er et modalverb som modifiserer handlinga i setninga, som for eksempel i (1) ovafor, hvor verbet häyttyyt häytyä ( $t$ ) ('måtte') uttrykker at handlinga er nødvendig.

- Setninger hvor modus blir uttrykt med hjelp av verbet olla og et nomentillegg. Et eksempel på denne typen er olla lupa-konstruksjonen i (2).

- Aspektsetninger hvor tidspunktet eller tidsperioden blir avgrensa med hjelp av et aspektverb eller en verbkonstruksjon. I eksemplet i (4) er det aspektverbet keritä, og i (3) er det olla tekemässä-konstruksjonen som er brukt. Heller ikke disse aspektuelle tillegga tilfører noen annen informasjon enn avgrensinga i tid.

Vi tar for oss de tre typene etter tur og orden.

\subsubsection{Modalsetninger}

Verbalet i modalsetninger består av et MODALVERB. Et modalverb forteller om saksforholdet i setninga etter talerens syn eller generelt er sikkert eller usikkert, nødvendig eller mulig, lovlig eller ulovlig, sannsynlig eller usannsynlig osv. Eksempler på modalverb er häyttyyt häytyä (t), häättyyt häätyä( $(t)$ ('måtte'), pittää(t) ('skulle, 
må), jouttuut joutua( $t$ ) ('måtte, bli tvunget til'), kannattaa( $t$ ) ('ønne seg'), saada $\sim$ saaha ('få), aikkoot aikoa( $t$ ) ('akte, ha til hensikt'), meinata ('tenke seg'), haluta ('ville, ha lyst til'), saattaa ( $t$ ) ('kunne'), sattuut sattua( $t$ ) ('falle seg, skje tilfeldigvis) og tait (t)aa(t) ('kunne; tørre'). Som modale verb brukes auttaa( $t$ ('nytte, hjelpe') og tarvita $\sim$ tarttee $(t)$ ('behøve, trenge') så å si bare i nektende setninger.

I tillegg til modalverbet er det alltid et anna verb i setninga som forteller om det faktiske saksforholdet som blir realisert, eller som forblir urealisert. Dette verbet danner alltid en infinitivsfrase i 1. eller 3. infinitiv, og det fungerer som utfylling til modalverbet.

- Oftest står infinitivsfrasen i 1. infinitiv. De følgende modalverba tar alltid utfylling i 1. infinitiv: häyttyyt häytyä( $t$ ) ('måtte'), häättyyt häätyä $(t)$ ('måtte'), pittää( $t$ ) ('skulle'), tarvita tarttee( $t$ ) ('behøve, trenge'), kannattaa $(t)$ ('lønne seg'), auttaa( $t$ ) ('hjelpe'), saađa saaha ('fă), aikkoot aikoa(t) (akte, ha til hensikt'), meinata ('tenke seg'), haluta ('ville, ha lyst til'), saattaa $(t)$ ('kunne'), sattuut sattua( $t$ ) ('falle seg, skje tilfeldigvis'), jout(t)aa(t) ('rekke, ha tid til') og tait $(t) a a(t)$ ('kunne; være vel / kanskje'). I disse tilfella fungerer infinitivsfrasen som objekt i setninga. I (1) ser vi et eksempel på hvordan funksjonsanalysen av slike setninger ser ut:
1. Sie
häyđyt
[lähteet Vesisaarheen].
Pron[2. sg, nom.]
$\mathrm{V}[$ häyttyyt, 2. sg.]
$\mathrm{VP}[1$. inf. + N[sg. ill.]]
$S$
$\mathrm{V}$
$\mathrm{O}[\mathrm{V}+\mathrm{ADV}]$

'Du må dra til Vadsø.'

Jamfør den tilsvarende umodifiserte setninga: Sie lähđet Vesisaarheen. Den samme strukturen finner vi i de følgende setningene (2-9):

Modalsetning:

2. Tet [että tarvitte] [kirjoittaat paljon]

'Dere trenger ikke å skrive mye.'

3. Aikamatkalaiset piđethiin [kohđata Perungan].

'Tidsmaskinpassasjerene skulle treffe Beronka.'

4. Met [emmä saa] [muuttaat tulleevaisuutta].

'Vi må ikke forandre framtida'
Jamfør direkte setning:

Tet [että kirjoita] paljon.

'Dere skriver ikke mye.'

Aikamatkalaiset kohđathiin

Perungan.

'Tidsmaskinpassasjerene traff

Beronka.'

Met [emmä muuta]

tulleevaisuutta.

'Vi forandrer ikke framtida.' 
5. Mie halluun [oppiit kainuu]. 'Jeg ønsker å lære meg kvensk.'

6. Aika saattaa muuttuut. 'Tida kan forandre seg.'

7. Mie aijon [siirttyyt Suomheen]. 'Jeg har tenkt å flytte til Finland.'

8. Tet taiđatta [olla oppinheet [koko grammatikin]].

'Dere har vel lært heile grammatikken.'

9. Hukka sattui [tulla vasthaan].

'En ulv slumpa til å komme imot oss.' 'En ulv kom imot oss.'
Mie opin kainuu.

'Jeg lærer meg kvensk.'

Aika muuttuu.

'Tida forandrer seg.'

Mie siiryn Suomheen.

'Jeg flytter til Finland.'

Tet [oletta oppinheet] [koko grammatikin].

'Dere har lært heile grammatikken.'

Hukka tuli vasthaan.

Modalverba jouttuut joutua(t) ('måtte; bli til at'), päästä ('slippe'), pakata ('bli, skje lett/ofte') og keritä ('rekke') krever at utfyllinga står i illativ av 3. infinitiv (10-13). Eksemplet i (10) illustrerer funksjonsanalysen av slike setninger:

10. Liisa jouttuu [kirjoittamhaan muisteluksen]. $\mathrm{NP}$ [sg. nom.] $\mathrm{V}[$ jouttuut, 3. sg. $]$ $\mathrm{VP}[3$. inf. ill. + N[sg. gen.]] $S$ $\mathrm{V}$ $\mathrm{ADV}[\mathrm{V}+\mathrm{O}]$

'Lisa er nødt til å skrive ei fortelling.'

De følgende setningene har samme strukturen:

Modalsetning:

11. Mie pääsin [lähtemhään kothiin]. 'Jeg fikk dratt heim.

12. Perunka kerkis [lukemhaan Bibliaa]. 'Beronka rakk å lese i Bibelen.'
Jamfør direkte setning:

Mie lähđin kothiin.

'Jeg dro heim.'

Perunka luki Bibliaa.

'Beronka leste i Bibelen.'

13. Maito pakkaa [happanemhaan lämpimässä]. Maito happanee lämpimässä. 'Mjølk blir lett sur i varmen.'

'Mjølk blir sur i varmen.'

I slike setninger analyserer vi infinitivsfrasen som adverbial ettersom den står i en kasus som er vanlig for adverbiale nominale ledd.

Modalsetninger følger dette mønsteret:

Modalsetning:

$\mathrm{S}[\mathrm{NP}[$ nom. $]]+\mathrm{V}[$ modalverb, subjektskongruens $]+\mathrm{O} / \mathrm{ADV}[\mathrm{VP}[1$. infinitiv/3. infinitiv illativ (+ UTFYLLING)]] 
Når vi ser på modalsetninger hvor utfyllinga står i 3. infinitiv, så kan vi legge merke til at den står i tilstedskasus på samme måte som NP-adverbialet ville ha gjort dersom modalverbet hadde blitt brukt som hovedverb i ei direkte setning. Dette er illustrert i setningene i $(14,15)$ :
Modalsetning:
Jamfør direkte setning:
14. Mie [en pääse] lähtemhään.
Mie [en pääse] Vesisaarheen.
'Jeg kan ikke dra.'
'Jeg kan ikke dra til Vadsø'.
15. Äiji joutui lähtemhään.
Äiji joutui fankilhaan.
'Bestefar blei nødt til å dra.'
'Bestfar havna i fengsel.'

Dersom hovedverbet i ei umodifisert setning tar et NP-objekt som utfylling, så tar det som modalverb i ei modifisert setning en 1. infinitivsfrase som utfylling. Eksempler på det ser vi i $(16,17)$ :

Modalsetning:

16. Sie saat [syöđä marjoi].

'Du får spise bær.'

17. Het piđethään lähteet.

'De må dra'.
Jamfør direkte setning:

Sie saat marjoi.

'Du får bær.'

Het piđethään elläimiitä.

'De holder seg med dyr.'

I likhet med andre setningstyper så står objektet i infinitivsfrasen i nektende modalsetninger alltid i partitiv. Også de andre utfyllingene i infinitivsfrasen har samme form som de ville ha hatt i ei tilsvarende setning uten modalverb.

Dei to verba kannattaa(t) ('ønne seg') og auttaa(t) ('nytte, hjelpe') skiller seg fra modalverba vi har diskutert så langt, ved at de ikke tar subjekt, men brukes i samme type adessivkonstruksjon som EIERSKAPssetninger $(18,19)$ :

$\begin{array}{lll}\text { 18. Meilä } & \text { kannattaa } & \text { [studeerata kainuu]. } \\ \text { Pron[adess., 1. pl.] } & \mathrm{V} \text { [kannattaat, 3. sg.] } & \mathrm{VP} \text { [1. inf. + N[sg. part.]] } \\ \text { ADV } & \mathrm{V} & \mathrm{S}[\mathrm{V}+\mathrm{O}]\end{array}$

'Det lønner seg for oss å lære oss kvensk.'

Jamfør: Met studeeraama kainuu. ('Vi studerer kvensk.')
19. Pojila
ei auttanu
[vaitela assiista].
$\mathrm{NP}$ [pl. adess.]
V[auttaat, nekt. 3. sg.]
$\mathrm{VP}[$ 1. inf. + N[sg. elat. $]]$
ADV
$\mathrm{V}$
$\mathrm{S}[\mathrm{V}+\mathrm{ADV}]$

'Det hjalp ikke for guttene å klage over saka.' 
Jamfør: Pojat vaitelthiin assiista. ('Guttene klaga over saka.')

Mer vanlig er at slike setninger er generiske $(20,21)$, eller at de inneholder det tomme subjektet se (22):

20. [Kainun kieltä] kannattaa oppiit.

'Det lønner seg å lære seg kvensk.'

21. Assiista [ei auttanu] vaitela.

'Det lønna seg ikke å klage over saka'.

22. Se [ei auttanu] [vaitela assiista].

'Det lønna seg ikke å klage over saka.'

Modalsetninger er også ellers oftest generiske.

\subsubsection{OON PAKKO-setninger}

Modale verbal kan stundom også være satt sammen av verbet olla ('være') og et substantiv, og de danner da til sammen et slags verbsamband. De to vanligste modale verbsambanda er olla lupa ('ha lov') og olla pakko ('være nødt'). De opptrer sammen med en adessivkonstruksjon på samme måte som $\mathrm{i}$ EIERSKAPssetninger (1-3):

1. Minula [oon lupa] [oppiit [kainun kieltä]]. Pron[1. sg., adess.] V[olla, 3.sg. + N[lupa[sg. nom.]]] VP[1. inf. + N[sg. part.]] ADV $\quad \mathrm{V} \quad \mathrm{S}[\mathrm{V}+\mathrm{O}]$

'Jeg har lov til å lære meg kvensk.'

Jamfør: Mie opin [kainun kieltä] ('Jeg lærer meg kvensk').

Flere eksempler:

Modalsetning:

2. Kainulaisila [oli pakko] [oppiit [ruijan kieltä]].

'Kvenene var nødt til å lære seg norsk.'

3. Kaikila [oli halu] [lähteet tunturhiin]. 'Alle hadde lyst til å dra til fjells.'
Jamfør direkte setning:

Kainulaset opithiin [ruijan kieltä].

'Kvenene lærte seg norsk'.

Kaikki lähđethiin tunturhiin.

'Alle dro til fjells.'

Kvensk har et tilsvarende modalt verbsamband hvor den andre delen ikke er et substantiv men et adjektiv (4): 
4. Minula [oon paha] [lähteet

tunturhiin].

Pron[1. sg., adess.] V[olla, 3. sg. + A[paha[sg. nom. $]]$ VP[1. inf. + N[sg.

ill.]]

ADV $\quad \mathrm{V} \quad \mathrm{S}[\mathrm{V}+\mathrm{ADV}]$

'Det er vanskelig for meg å dra til fjells.'

Jamfør: Mie lähđen tunturhiin. ('Jeg drar til fjells.')

NP- eller AP-utfyllinga til verbalet står alltid i nominativ entall.

Særlig i Varanger-varieteten har denne setningstypen en variant hvor 1. infinitivsfraser er innleid med subjunksjonen ette (5):

5. Simmala [oon halu] [ette lähtiä tunturhiin].

'Simma har et ønske om å dra til fjells.'

Det vanlige mønsteret for OON PAKKO-setninger er slikt:

OON PAKKO-setning:

ADV[NP[adess.] $]+\mathrm{V}[$ olla[3. sg. $]+\mathrm{NP} / \mathrm{AP}[$ sg. nom. $]]+\mathrm{S}[($ ette +$) \mathrm{VP}[1$. inf. (+ UTFYLLING)]]

En annen type OON PAKKO-setninger er generiske setninger hvor det først $\mathrm{i}$ setninga står det tomme subjektet se, og sist i setninga en 1. infinitivsfrase (6), ei ette-setning (7) eller ei ko-setning (8):

6. Se [oon soma] hihđata.

'Det er artig å gå på ski.'

7. Se [oli kummalinen] [ette hän lähti].

'Det var rart at han dro.'

8. Se [oli surulinen] [ko Maija kuoli].

'Det var trist at Maja døde.'

Også her kan 1. infinitivsfrasen være innleid med subjunksjonen ette $(9,10)$ :

9. Se [oon paha] [ette olla köyhä].

'Det er ille å være fattig.'

10. Se [oon soma] [ette hihđata].

'Det er artig å gå på ski.'

Denne setningstypen er egentlig ikke modal i og med at den gjengir et saksforhold direkte. Det er her heller snakk om en type predikasjonssetning hvor 
subjektsrolla er fylt av en infinitivsfrase eller ei ette- eller ko-setning. Det er mer naturlig å tolke ordet se i oversetninga som ankerord som representerer leddsetninga (se avsnitt 2.4.4).

Se også avsnitt 11.2.2.1 om setninger hvor subjektet er ei ette-setning eller -frase eller ei ko-setning.

\subsubsection{Aspektsetninger}

Det som kjennetegner den siste hovedtypen av modifiserte setninger, aspektsetninger, er at verbalet bestemmer nærmere tidspunktet for verbalhandlinga eller -hendelsen. Med hjelp av spesielle typer verb kan vi markere at ei handling eller en hendelse begynner, pågår eller blir avslutta. Slike verb kaller vi for ASPEKTVERB. De blir etterfulgt av en 3. infinitivsfrase. Blant aspektverba finner vi for eksempel alk(k)aa(t) ('begynne'), som tar 3. infinitiv i illativ (1), olla ('være'), som tar 3. infinitiv i inessiv (2), og keritä ('bli ferdig') og heittää(t) ('slutte'), som tar 3. infinitiv i elativ $(3,4)$ :

1. Met aloima [kuuntelemhaan [Perungan muistelusta]].

Pron[1.pl.] V[alkkaat, 1. pl.] VP[3. inf. ill. + N[sg. part.]]

$$
\text { S } \quad \mathrm{V} \quad \mathrm{ADV}[\mathrm{V}+\mathrm{O}]
$$

'Vi begynte å høre på Beronkas fortelling.' Jamfør: Met kuuntelimma [Perungan muistelusta]. ('Vi hørte på Beronkas fortelling.')

$\begin{array}{lll}\text { 2. Tyttäret } & \text { oon } & \text { [hihtaamassa vaarassa]. } \\ \text { N[pl. nom.] } & \mathrm{V} \text { [olla, 3. pl.] } & \mathrm{VP}[\text { 3. inf. iness. + N[sg. iness.] } \\ \mathrm{S} & \mathrm{V} & \mathrm{ADV}[\mathrm{V}+\mathrm{ADV}]\end{array}$

'Jentene holder på å gå på ski i fjellet.' Jamfør: Tyttäret hihđathaan vaarassa. ('Jentene går på ski i fjellet.')

3. Tet [että ole heittänheet] [laulamasta [vanhoita laului]].

Pron[2. pl.] V[heittäät, nekt. 2. pl.] VP[3. inf. elat. + N[pl. part.]]

S $\quad \mathrm{V} \quad \mathrm{ADV}[\mathrm{V}+\mathrm{O}]$

'Dere har ikke slutta med å synge gamle sanger.'

Jamfør: Tet [että ole laulanheet] [vanhoita laului]. ('Dere har ikke sunget gamle sanger.')
4. Perunka
kerkis
[lukemasta Bibliaa].
NP[sg. nom.]
V[keritä, 3. sg. $]$
VP[3. inf. elat. + N[sg. part.]]
$S$ 
'Beronka var ferdig med å lese i Bibelen.'

Jamfør: Perunka luki Bibliaa. ('Beronka leste i Bibelen.')

Aspektsetninger følger dette mønsteret:

Aspektsetning:

$\mathrm{S}[\mathrm{NP}[$ nom. $]]+\mathrm{V}$ [aspektverb, subjektskongruens] + ADV[VP[3.inf. iness./elat./ill. (+ UTFYLLING)]]

Også de to verbkonstruksjonene tulla tehtyksi ('få gjort') og saađa saaha tehtyksi ('få gjort') har aspektuell funksjon. I begge konstruksjonene står verbfrasen i passiv entall translativ av perfektum partisipp. På subjektsplass i tulla tehtyksi-konstruksjonen står et adverbial i adessiv som forteller hvem det er som utfører handlinga $(5,6)$. Også generisk bruk av tulla tehtyksi-konstruksjonen er vanlig $(7,8)$. I saada saaha tehtyksi-konstruksjonen er det et vanlig nominativssubjekt, og det gjelder subjektskongruens i setninga $(9,10)$ :

Aspektsetning:

Jamfør direkte setning:

5. Mulla [ei ole tullu] [käytyksi Helsingissä]. Mie [en ole käyny] Helsingissä. 'Jeg har ikke fått dratt til Helsingfors.' 'Jeg har ikke vært i Helsingfors.'

6. Liisala tuli [työt tehtyksi]. Liisa teki työt.

'Lisa fikk gjort arbeidet.' 'Lisa gjorde arbeidet.'

7. Paljon tullee [praatatuksi ruijaa]. Paljon praatathaan ruijaa.

'Det blir lett til at man snakker mye norsk.' 'Man snakker mye norsk.'

8. [Ei tullu] koskhaan [kysytyksi sitä assiita]. [Sitä assiita] [ei koskhaan 'Jeg/Vi fikk aldri spurt om den saka.' kysytty]. 'Jeg/Vi spurte aldri om den saka'.

9. Mie sain [kalat paistetuksi]. Mie paistoin kalat.

'Jeg fikk stekt fiskene.' 'Jeg stekte fiskene.'

10. Liisa sai [vantthuut kuđotuksi]. Liisa kutos vantthuut.

'Lisa fikk strikka vottene.' 'Lisa strikka vottene.'

Konstruksjonen tulla tehtyksi har sitt motstykke i konstruksjonen jä̈̈đä jäähä tekemättä ('forbli ugjort'), hvor 3. infinitivsfrasen står i abessiv $(11,12)$ :

11. Ruoka jäi syömättä.

'Maten forblei uspist.'

12. Minulta jäi [se assii] havaittematta.

'Den saka gikk meg hus forbi'. 


\subsection{Verbalutfyllingene og forma på dem}

Som vi har sett i dette kapitlet, så tar verbalet utfyllinger, det vil si element som er obligatoriske for at setninga skal bli grammatisk og semantisk korrekt. Vi kan si at verbalet krever visse typer utfyllinger.

De vanligste utfyllingene i tillegg til subjekt er predikativ, objekt og adverbial. Hvor mange og hvilke utfyllinger det er i ei setning, er avhengig av hvilket verb verbalet består av. I mange av setningstypene vi har diskutert ovafor, er det to utfyllinger. Men det fins også setninger med bare éi utfylling, som for eksempel Aurinko paistaa ('Sola skinner'), og setninger som krever tre utfyllinger, som for eksempel Nilla antoi preivin kuninkhaale ('Nils gav brevet til kongen'). Så fins det verb som ikke krever noen utfylling i det heile tatt, som for eksempel Sattaa ('Det regner').

Utfyllinga kan være en substantivfrase (NP), en adjektivfrase (AP), en adverbfrase (AdvP), en adposisjonsfrase ( $\mathrm{PP}$ ) eller en kvantorfrase (KvaP). Særlig indirekte setninger kan ha utfyllinger i form av en verbfrase (VP) eller ei leddsetning (SETN), som som regel er ei ette-setning eller ei spørresetning, stundom også ei ko-setning. Den andre utfyllinga i modifiserte setninger er alltid en verbfrase.

Vi skal her kort se på utfyllingene vi finner i de ulike setningstypene, og da særlig på hvilken form de nominale utfyllingene har.

\subsubsection{Kongruens mellom subjekt og verbal, og subjektskasus}

I setningsanalysene i dette kapitlet har vi sett at subjektet og verbalet oftest kongruerer med hverandre, det vil si at de står i samme tall og person. Manglende subjektskongruens har vi bare i setninger hvor subjektet står i partitiv. Det er tilfellet i EKSISTENSsetninger, for eksempel Kentälä oli miehii ja vaimoi ('På gårdsplassen var det menn og kvinner'), i EKSISTENSENDRINGssetninger, for eksempel Taivhaale syttyi tähtii ('Stjerner tentes / dukka opp på himmelen'), i EIERSKAPssetninger, for eksempel Minula oon rahhaa ('Jeg har penger'), i INTRANSITIVE EIERSKAPSENDRINGssetninger, for eksempel Faarile tullee vierhaita ('Far får gjester på besøk'), i kvantorsetninger, for eksempel Meitä oli viisi ('Vi var fem stykker') og i EKSISTENSPREDIKASJONssetninger, for eksempel Kukkii oon 
monen färissii ('Blomster fins det i mange farger'). I alle andre setningstyper står subjektet i nominativ.

Når det ikke er kongruens mellom subjekt og verbal, står det finitte verbet alltid i tredje person entall.

Også en infinitivsfrase (VP) kan fungere som subjekt i ei setning, for eksempel frasen lähteet tunturhiin ('dra til fjells') i setninga Simmasta oon soma lähteet tunturhiin ('Simon syns det er artig å dra til fjells'). En annen type subjekt er leddsetninger, for eksempel i setninga Pekasta oli paha, ette Liisa rakasti Mattii ('Peder syntes det var vondt at Lisa elska Mats'). Når subjektet er en verbfrase eller ei leddsetning, står verbalet alltid i tredje person entall.

\subsubsection{Forma på predikativet}

Korrelatet til predikativet i direkte setninger er som regel subjektet, men i TRANSITIVE ENDRINGssetninger er det objektet som er korrelatet, og i RESULTATsetninger er det adverbialet i elativ.

I EGENSKAPssetninger, t.d. Kaffi oli makkee ('Kaffen var søt'), og i RESULTATsetninger, t.d. Heikasta kasus kaunis mies ('Henry vokste seg til en kjekk mann'), står predikativet vanligvis i nominativ. I TILHØRIGHETssetninger er predikativet i partitiv, for eksempel Nilla oli torniolaista sukkuu) ('Nils var av tornedalsslekt'), på samme måte som i EKSISTENSPREDIKASJONssetninger, for eksempel Meitä oon monenlaissii) ('Vi er mange slags mennesker'). Når setningstypen er EIERSKAPSPREDIKASJON, står predikativet i genitiv, for eksempel Tämä pytinki oon amtmanin ('Dette er amtmannens bygning'). I ENDRINGssetninger står predikativet i translativ, for eksempel Amtmani tuli hulluksi ('Amtmannen blei gal') og Matti maalas huonheen valkkeeksi) ('Mats malte huset kvitt'). Når predikativet forekommer i setningstypen PREDIKATIV SANS, så står det i ablativ, for eksempel Kukka haissee hyvältä ('Blomsten lukter godt').

Går vi over til de indirekte setningene, så står predikativet i NAVNGIVINGssetninger i translativ, for eksempel Het käskethiin meitä kvääniksi ('De kalte oss for kvener'). Det fins to typer MEININGssetninger som har predikativ, typen Faari luuli Pekkaa hulluksi ('Far trudde (at) Peder var gal'), hvor predikativet står i translativ, og typen Faari piti Pekkaa hulluna ('Far så på Peder som gal'), hvor det står i essiv. I de andre indirekte setningstypene forekommer ikke predikativ. 
Predikativet kongruerer i tall med korrelatet i predikasjonssetningstypene EGENSKAP, EKSISTENS og RESULTAT. I de øvrige setningstypene kongruerer det ikke med korrelatet.

\subsubsection{Forma på objektet}

Direkte følelsessetninger og handlingssetninger tar begge objekt, det vil si at de har et transitivt verb som verbal. Objektet i følelsessetninger står som regel gjennomgående i partitiv, for eksempel Mie rakastan sinnuu ('Jeg elsker deg'), Minnuu itkettää) ('Jeg blir på gråten'). Et unntak er likevel verbet tykätä ('like'), som tar objekt i elativ, for eksempel Mie tykkään sinusta ('Jeg liker deg'). Forma på objektet $\mathrm{i}$ handlingssetninger varierer. Det kan stå i entall genitiv, for eksempel Pappi kirjoitti preivin ('Presten skreiv et brev'), i flertall nominativ, for eksempel Nilla antoi preivit kuninkhaale ('Nils ga breva til kongen'), eller i flertall partitiv, for eksempel Nilla ei kirjoittannu preivii (Nils skreiv ikke noen brev / breva'), Mie söin äpylii, mutten jaksanu kaikkee) ('Jeg spiste på et eple, men orka ikke heile'). Vi kaller denne varierende kasusforma på objektet for овJектSKASUs. Valget av objektskasus følger noen enkle regler:

- I entall kan objektet stå i genitiv, men ikke i flertall. I flertall kan objektet stå i nominativ, men ikke i entall.

- Når objektet kan stå i genitiv eller nominativ, kan det også stå i partitiv. Men når verbet krever et objekt i partitiv, så kan det aldri stå i genitiv eller nominativ.

- Objektet i ei nektende setning står alltid i partitiv, bortsett fra når verbet er tykäta, som alltid tar objekt i elativ.

- Objektet står også i partitiv når verbalhandlinga i setninga ikke er avslutta eller pågår, eller når objektet er en del av en delelig eller målbar mengde (det vil si at objektet er et flertallsord eller et stofford).

Indirekte setninger tar alltid objekt som utfylling. Oftest er objektet her en verbfrase (VP), for eksempel Pekka muisti lukkeet preivin ('Peder huska å lese brevet'), eller ei leddsetning (SETN), for eksempel Muori sanoi, ette hän tullee huomena ('Mor sa at hun skulle komme i morgen'). Men dersom objektet er en nomenfrase, så følger det de samme reglene for objektskasus som er framstilt ovafor.

I de tilfeller der en verbfrase i indirekte eller modifiserte setninger har et objekt, så har det samme form som det ville ha hatt i ei tilsvarende direkte eller umodifisert setning. 


\subsubsection{Forma på adverbialet}

Som adverbial analyserer vi i denne grammatikken bare slike nomenfraser som står i lokalkasus, eller adverb- eller adposisjonsfraser som har en tilsvarende funksjon. Den typiske funksjonen til adverbial er da også lokativ eller possessiv. I den possessive setningstypen EIERSKAP står adverbialet alltid i adessiv, for eksempel Kainulaisila oli sauna ('Kvenene hadde badstue'), men det står i ablativ eller allativ i både intransitive og transitive EIERSKAPSENDRINGssetninger, for eksempel Multa kuoli poika ('Jeg mista en sønn'), Liisale syntyi tytär ('Lisa fikk ei datter'), Mie sain skenkin ämmiltä ('Jeg fikk en gave av bestemor'), Ämmi lähätti skenkin minule ('Bestemor sendte en gave til meg'). Med andre ord bruker vi ytre lokalkasus ( $l$-kasus) når det er snakk om at noen eier eller rår over noe, eller at det skjer et skifte i eierskap til eller kontroll over noe.

I STEDssetninger, for eksempel Amtmani asui Jovensuussa ('Amtmannen bodde i Elvebakken), og i EKSISTENSsetninger, for eksempel Ariniemessä assuu amtmani ('Det bor en amtmann på Amtmannsnes'), står adverbialet nesten alltid i påstedskasus, det vil si inessiv eller adessiv. I BEVEGELSEssetninger, for eksempel Nilla lähti Kööpenhaminhaan ('Nils dro til København'), Matti tuli Ruottista ('Mats kom fra Sverige'), Ämmi kävi kaupungissa ('Bestemor dro en tur til byen'), i EKISTENSENDRINGssetninger, for eksempel Kothaan iti ihmissii ('Det dukka opp folk ved gammen'), Puista tippui vettä ('Det dryppa vatn fra trærne'), og i FLYTTINGssetninger, for eksempel Liisa vei Tromsshaan voita ('Lisa tok med seg smør til Tromsø'), Matti toi kaupungista tavaraa ('Mats hadde med seg varer fra byen'), er adverbialet vanligvis en nomenfrase i tilsteds- eller frastedskasus, eller en tilsvarende adposisjons- eller adverbfrase.

Når vi skal velge mellom indre og ytre lokalkasus, så er regelen den at stedsnavn i allmennhet bøyes i indre lokalkasus (1). Men de kan også stå i ytre lokalkasus (2). Ellers bruker vi indre lokalkasus når noe(n) er på innsida av noe (1), beveger seg eller blir flytta inn i eller til innsida av noe (3), eller ut av noe (4):

1. Mie asun Tromssassa, mutta Hansi assuu Valasnuorassa.

'Jeg bor i Tromsø, men Hans bor i Kvalsund.'

2. Jensi muutti Annijoele.

'Jens flytta til Vestre Jakobselv' 
3. Pekka tuli taivhaasseen.

'Peder kom til himmelen.'

4. Varas vei talosta mööpelit.

'Tjuven tok med seg møbla fra huset.'

Ytre lokalkasus bruker vi når noe(n) er på utsida eller overflata av noe (5), beveger seg eller blir flytta til utsida eller overflata av noe (6) eller fra utsida eller overflata av noe ( 7$)$ :

5. Flyyi lenttää taivhaala, mutta laiva seilaa merelä.

'Flyet flyr på himmelen, men båten seiler på havet.'

6. Kissa kaatoi maiđon laattiile.

'Katten velta mjølka på golvet'.

7. Kissä hyppäs tuolilta.

'Katten hoppa fra stolen.'

Når noe er på overflata av noe som det er en del av og ikke (på noen lett måte) kan fjernes fra, så bruker vi likevel indre lokalkasus (8):

8. Matin poskessa oon haava.

'Mats har et sår på kinnet.'

Adverbialet i setningstypene STED, EKSISTENS, BEVEGELSE og FLYTTING kan også være en adposisjons- eller en adverbfrase. En del av disse uttrykker også ei bestemt retning, og da bruker de samme kasus som tilsvarende nomenfraser. Jamfør for eksempel Mikkel meni talon taka ('Mikkel gikk bak huset'; retninga er den samme som med tilstedskasus) med Mikkel meni talhoon ('Mikkel gikk inn i huset'; med illativ, altså en tilstedskasus).

I tilstandssetninger av typen STATUS består adverbialutfyllinga alltid av et adverb som uttrykker hva slags tilstand subjektet er eller blir i, for eksempel Talo oon kaltossa ('Huset står på skrå), Liisa tuli päihin ('Lisa blei full').

Som adverbial har vi også analysert det elementet i RESULTATsetninger som står på subjektsplass, men er i elativ, for eksempel Mikosta tuli varas ('Det blei tjuv av Mikkel'). Ut ifra plasseringa kan dette leddet også analyseres som subjekt, men vi har avgrensa mulige subjektskasus til nominativ og partitiv. 
I aspektsetninger står verbet i verbfrasen i 3. infinitiv inessiv, elativ eller illativ, og vi analyserer derfor heile verbfrasen som adverbial. I modifiserte setninger finner vi adverbial $i$ adessiv som likner på eierleddet i EIERSKAPssetninger, som for eksempel i modalsetningene Minula oon pakko mennä hyysikkhään ('Jeg må gå på do') og Sinula kannattaa lukkeet kainun kieltä ('Det lønner seg for deg å lære deg kvensk'), og i aspektsetninga Minula tuli työt tehtyksi ('Jeg fikk gjort arbeidet). 



\section{5}

\section{Nomenbøying}

Vi deler NOMEN inn i fire grupper: SUBSTANTIV, ADJEKTIV, PRONOMEN og TALLORD. Substantiv og adjektiv danner eigne fraser og kan da stå sammen med en modifikator. Substantivfraser kan for eksempel ha et adjektiv (1) eller et substantiv i genitiv (2) som premodifikator, eller et substantiv i lokalkasus $(3,4)$, en infinitivsfrase (5) eller ei leddsetning $(6,7)$ som postmodifikator. Eksempler er:

1. [Nuoret tyttäret] tykäthään [pitkistä hyksistä].

'Unge jenter liker langt hår.'

2. [Matin muori] studeeraa [Tromssan univeristeetissa].

'Mora til Mats studerer på Universitetet i Tromsø'

3. [Preivi kuninkhaale] oli kirjoitettu tanskaksi.

'Brevet til kongen var skrevet på dansk.'

4. [Matka Tromssasta Rovaniemele] oon liian pitkä.

Reisa fra Tromsø til Rovaniemi er for lang.'

5. Minula ei ole [voimaa (ette) lähteet reishuun].

Jeg har ikke krefter til å dra på denne reisa.'

6. [Preivi, minkä pappi kirjoitti kuninkhaale], oli Nillala plakkarissa.

'Brevet som presten skreiv til kongen, hadde Nils i lomma si.'

7. Iisakille tuli [tieto, ette hän päässee myötä kursile].

'Isak fikk vite at han fikk plass på kurset.'

I adjektivfraser kan for eksempel gradsadverb (8) stå som premodifikatorer, mens etterstilte modifikatorer for eksempel kan være substantiv i lokalkasus (9), adposisjonsfraser (10), infinitivsfraser (11) eler ei leddsetning (12).

8. Hanna oon [hirmusen viisas].

'Hanna er veldig klok.'

9. Mie olen [sikkari siitä assiista].

'Jeg er sikker på den saka.' 
10. Kreeta oli [vihainen sen riiđan päältä].

'Greta var sint på grunn av den krangelen.'

11. Met olema [sepät hihtaamhaan].

'Vi er flinke til å gå på ski.'

12. Se oon [parasta, mitä sie olet koskhaan sanonu].

'Det er det beste du noensinne har sagt.'

Også pronomen kan stundom stå sammen med en modifikator $(13,14)$.

13. [Kaikki, jokka tunnethaan hänen], rakastethaan häntä.

'Alle som kjenner han/henne, elsker han/henne.'

14. [Jokhainen meistä] rakastaa Pekkaa.

'Enhver av oss elsker Peder.'

Pronomen står likevel alltid i stedet for substantiv, og vi skal her ikke diskutere pronomenfraser atskilt. Av tallorda bruker vi grunntall i kvantorfraser, og de skal vi se nærmere på i avsnitt 8.1.

I motsetning til norsk blir i kvensk nesten alle nomen bøyd på samme måte. Pronomen og tallord skiller seg litt ut, men substantiv og adjektiv bøyes nøyaktig likt.

Som nevnt utgjør verbalet kjernen i setninga, og det styrer hva slags andre fraser som fins i setninga. Forma på nomena, og da spesielt substantiva, retter seg oftest etter verbalet i setninga. Fraseinternt er det likevel slik at forma på nomenet retter seg etter frasekjernen. For eksempel har et adjektiv som står som premodifikator til et substantiv og bestemmer det nærmere, samme kasus og tall som substantivet som følger etter, og i en adposisjonsfrase er forma på nomenet styrt av adposisjonen.

I dette kapitlet går vi igjennom kasus- og tallbøying av substantiv og adjektiv. Tallord og pronomen er omtalt seinere, i hvert sitt kapittel.

\subsection{Nominale stammetyper og bøyingsklasser}

Nomen har både vokal- og konsonantstammer. Alle nomen har en vokalstamme, men bare en del av nomena har en konsonantstamme. Nomen som bare har vokalstamme, kaller vi her for ENSTAMMA NOMEN, og de som har både vokal- og konsonantstamme, kaller vi for TOSTAMMA NOMEN.

Viss et nomen har konsonantstamme, så brukes den i entall partitiv, og hos noen nomen også i flertall genitiv. I de andre kasusene bruker vi alltid vokalstamme. (Avsnitt 2.3.3 gir ei generell innføring i vokal- og konsonantstammer.) 
Det fins enstava, tostava og flerstava nomen, og vokalstammen kan ende på enkelt vokal eller to vokaler. I denne grammatikken deler vi nomena inn i grupper basert på hva slags stamme de har, og hvordan bøyingssuffiksa festes til disse stammene.

Tabell 5.1 viser hvilke nominale stammetyper som fins i kvensk, og hvordan disse bøyes. Entall essiv representerer her vokalstammen, flertall essiv flertallsstammen, og entall partitiv konsonantstammen, dersom nomenet har en slik. Kasussuffiksa festes til disse stammene. Noen av stammene gjennomgår også stadieveksling; det er forklart nærmere for hver bøyingstype. Det kan likevel være verdt å nevne allerede nå at stammen vi bruker i entall essiv, er en slags grunnstamme på et grunnstadium, og at de andre stadiene kan regnes som varianter av dette grunnstadiet.

Vi kaller her nominale bøyingstyper kort for nomentyper. Tabell 5.1 gir en oversikt over nomentypene i kvensk.

Tabell 5.1 Nomentyper

\begin{tabular}{|c|c|c|c|c|}
\hline Nomentype & $\begin{array}{l}\text { Entall } \\
\text { nominativ }\end{array}$ & $\begin{array}{l}\text { Vokalstamme: } \\
\text { entall essiv }\end{array}$ & $\begin{array}{l}\text { Flertallsstamme: } \\
\text { flertall essiv }\end{array}$ & $\begin{array}{l}\text { Konsonantstamme: } \\
\text { entall partitiv }\end{array}$ \\
\hline $\begin{array}{l}\text { 1.1 Enstamma nomen } \\
\text { med } \\
\text { tostavavokalstamme } \\
\text { på kort vokal }\end{array}$ & $\begin{array}{l}\text { aika } \\
\text { mettä } \\
\text { joki } \\
\text { pappi } \\
\text { juoppo }\end{array}$ & $\begin{array}{l}\text { aika/na } \\
\text { mettä/ä } \\
\text { joke/na } \\
\text { pappi/na } \\
\text { juoppo/na }\end{array}$ & $\begin{array}{l}\text { aiko/i/na } \\
\text { mett/i/nä } \\
\text { jok/i/na } \\
\text { pappi/i/na } \\
\text { papp/i/na } \\
\text { juoppo/i/na }\end{array}$ & \\
\hline $\begin{array}{l}\text { 1.2 Tostamma nomen } \\
\text { med vokalstamme på } \\
\text { kort vokal }\end{array}$ & $\begin{array}{l}\text { pieni } \\
\text { käsi } \\
\text { lapsi }\end{array}$ & $\begin{array}{l}\text { piene/nä } \\
\text { käte/nä } \\
\text { lapse/na }\end{array}$ & $\begin{array}{l}\text { pien/i/nä } \\
\text { käs/i/nä } \\
\text { laps/i/na }\end{array}$ & $\begin{array}{l}\text { pien/tä } \\
\text { kät/tä } \\
\text { las/ta }\end{array}$ \\
\hline $\begin{array}{l}2.1 \text { Enstamma nomen } \\
\text { med flerstava } \\
\text { vokalstamme på kort } \\
\text { vokal }\end{array}$ & $\begin{array}{l}\text { sivakka } \\
\text { kajava } \\
\text { tunturi } \\
\text { paijukko } \\
\text { valkea valkia }\end{array}$ & $\begin{array}{l}\text { sivakka/nna } \\
\text { kajava/nna } \\
\text { tunturi/nna } \\
\text { paijukko/nna } \\
\text { valkea/nna } \\
\text { valkia/nna }\end{array}$ & $\begin{array}{l}\text { sivako/i/na } \\
\text { kajav/i/nna } \\
\text { tunturi/i/na } \\
\text { tuntur/i/nna } \\
\text { paijuko/i/na } \\
\text { valke/i/na }\end{array}$ & \\
\hline $\begin{array}{l}2.2 \text { Tostamma } \\
\text { nomen med flerstava } \\
\text { vokalstamme på kort } \\
\text { vokal }\end{array}$ & $\begin{array}{l}\text { ty(t)är } \\
\text { taival } \\
\text { paimen } \\
\text { elläin } \\
\text { onneton } \\
\text { rakkhaus } \\
\text { veres } \\
\text { ihminen }\end{array}$ & $\begin{array}{l}\text { tyttäre/nnä } \\
\text { taipale/nna } \\
\text { paimene/nna } \\
\text { elläime/nnä } \\
\text { onnettoma/na } \\
\text { rakkhaute/na } \\
\text { verekse/nnä } \\
\text { ihmise/nnä }\end{array}$ & $\begin{array}{l}\text { tyttär/i/nnä } \\
\text { taipal/i/nna } \\
\text { paimen/i/nna } \\
\text { elläim/i/nnä } \\
\text { onnettom/i/na } \\
\text { rakkhauks/i/na } \\
\text { vereks/i/nnä } \\
\text { ihmis/i/nnä }\end{array}$ & $\begin{array}{l}\text { ty(t)är/tä } \\
\text { taival/ta } \\
\text { paimen/ta } \\
\text { elläin/tä } \\
\text { onneton/ta } \\
\text { rakkhaut/ta } \\
\text { veres/tä } \\
\text { ihmis/tä }\end{array}$ \\
\hline
\end{tabular}

(Fortsatt) 
Tabell 5.1 (Fortsatt)

\begin{tabular}{|c|c|c|c|c|}
\hline Nomentype & $\begin{array}{l}\text { Entall } \\
\text { nominativ }\end{array}$ & $\begin{array}{l}\text { Vokalstamme: } \\
\text { entall essiv }\end{array}$ & $\begin{array}{l}\text { Flertallsstamme: } \\
\text { flertall essiv }\end{array}$ & $\begin{array}{l}\text { Konsonantstamme: } \\
\text { entall partitiv }\end{array}$ \\
\hline $\begin{array}{l}3.1 \text { Enstamma nomen } \\
\text { med vokalstamme } \\
\text { på lang vokal eller } \\
\text { diftong }\end{array}$ & $\begin{array}{l}\text { maa } \\
\text { yö } \\
\text { tuorestai } \\
\text { valkkee } \\
\text { laattii }\end{array}$ & $\begin{array}{l}\text { maa/na } \\
\text { yö/nä } \\
\text { tuorestai/na } \\
\text { valkkee/na } \\
\text { laattii/na }\end{array}$ & $\begin{array}{l}\mathrm{ma} / \mathrm{i} / \mathrm{na} \\
\text { ö/i/nä } \\
\text { tuoresta/i/na } \\
\text { valkke/i/na } \\
\text { laatti/i/na }\end{array}$ & \\
\hline $\begin{array}{l}3.2 \text { Tostamma } \\
\text { nomen med } \\
\text { vokalstamme på } \\
\text { lang vokal }\end{array}$ & $\begin{array}{l}\text { rakas } \\
\text { kirves } \\
\text { kaunis } \\
\text { hylje(t) } \\
\text { perkele(t) } \\
\text { kuolu(t) }\end{array}$ & $\begin{array}{l}\text { rakkhaa/na } \\
\text { kirvhee/nä } \\
\text { kaunhii/na } \\
\text { hylkhee/nä } \\
\text { perkelhee/nä } \\
\text { kuolhee/na }\end{array}$ & $\begin{array}{l}\text { rakkha/i/na } \\
\text { kirvhe/i/nä } \\
\text { kaunhi/i/na } \\
\text { hylkhe/i/nä } \\
\text { perkelhe/i/nä } \\
\text { kuolhe/i/na }\end{array}$ & $\begin{array}{l}\text { rakas/ta } \\
\text { kirves/tä } \\
\text { kaunis/ta } \\
\text { hyljet/tä } \\
\text { perkelet/tä } \\
\text { kuolut/ta }\end{array}$ \\
\hline
\end{tabular}

Det er noen nomen som ikke passer inn i noen av gruppene i tabell 5.1. På spesiell måte bøyes for eksempel substantivet kevä( $t$ ) ('vår'): (sg. nom. : sg. adess) kevä $(t)(\sim$ kevväin) : kevväi/lä kevvää/lä kevhää/lä kevväime/llä kevvää/mellä. I slike tilfeller må man slå opp bøyingsmønsteret i ordboka. Det fins flere nomen med uregelmessig bøying, og de skal omtales nedafor sammen med nomentypene de likner mest på.

\subsubsection{Nomen med tostava vokalstamme på kort vokal (type 1)}

Type 1 består av nomen med tostava vokalstamme som slutter på enkelt vokal, som for eksempel (sg. nom. : sg. gen.) poika ('gutt; sønn') : poja/n, kroppi ('kropp') : kropi/n, tollo ('dum') : tollo/n, lapsi ('barn') : lapse/n. Slike ord har altså i nominativ alltid en konsonant foran sluttvokalen.

\subsubsection{Enstamma nomen med tostava vokalstamme på kort vokal (type 1.1)}

I type 1.1 finner vi ENSTAMMA NOMEN med TOSTAVA VOKALSTAMME på KORT vOKAL. Den korte stammevokalen kan være hvilken som helst vokal, det vil si $e, i, A, O$ eller $U$, for eksempel (sg. nom. : sg. gen.) aika ('tid') : ai(j)a/n, joki ('elv') : jo(v)e/n, järvi ('innsjø, vatn') : järve/n, nimi ('navn') : nime/n, juoppo 
('dranker') : juopo/n, hullu ('tulling; gal') : hullu/n, pappi ('prest; papp') : papi/n, tooli ('stol') : tooli/n. Stammevokalen er identisk med sluttvokalen i entall nominativ bortsett fra e-stammene, som slutter på $i$ i entall nominativ. Tostava e-stammer finner vi i gamle ord, og denne nomentypen er ikke produktiv lenger. Vi har her altså med en LUKKA KLASSE å gjøre. Derimot slutter mange nye lånord seg til i-stammene. Oftest er i-en her lagt til utgangsordet for å tilpasse det ordstrukturen i kvensk. Eksempler på slike ord er knappi ('knapp'), kortti ('kort'), pari ('par'), uuni ('ovn'), vaali ('valg') ja piili ('bil'). Det kommer stadig nye lånord av denne typen inn i språket, og i-stammer er derfor en ÅPEN KLASSE.

Tostava stammer gjennomgår stadieveksling, som kan være av tre typer. Stadievekslinga kommer til uttrykk når orda bøyes i entall nominativ, entall genitiv og entall partitiv:

- I : o : II I, for eksempel aika ('aika') : ai(j)a/n:aik(k)a/a, joki ('elv') : jo(v) en : jokkele joke/a joki/a, lato ('låve') : la(đ)o/n: latto/o lato/a, sota ('krig') : so(d)a/n: sotta/a eller

- II : I : II, for eksempel pappi ('prest') : papi/n : pappi/i pappi/a, katto ('tak') : kato/n: katto/o katto/a, kukka ('blomst') : kuka/n: kukka/a eller

- I : I : II I, for eksempel loma ('rom') : loma/n : lomma/a, talo ('gård; hus') : talo/n : tallo/o $\sim$ talo/a.

\subsubsection{Tostamma nomen med vokalstamme på kort vokal (type 1.2)}

Nomen av type 1.2 har også en tostava vokalstamme på kort vokal, men de har i tillegg en konsonanstamme. Stammevokalen er alltid $e$, og sluttvokalen i entall nominativ er alltid $i$. Denne gruppa er ikke særlig stor og utgjør en lukka klasse. Nomen av denne typen utgjør en liten, lukka klasse. Konsonantstammen er i bruk i entall partitiv og stundom også i flertall genitiv, ellers bruker vi vokalstammen. Eksempler på nomen av type 1.2 er (sg. nom. : sg. gen. : sg. part.) pieni ('liten') : piene/n : pien/tä, lumi ('snø') : lume/n:lun/ta, käsi ('hand') : kä(đ)e/n : kät/tä, viisi ('fem') : vii(đ)e/n : viit/tä, hirsi ('tømmer') : hirre/n : hirt/tä, kaksi ('to') : kah(đ)e/n : kah/ta, lapsi ('barn') : lapse/n: las/ta.

I tostamma nomen er ikke stadievekslinga synlig på samme måte som $\mathrm{i}$ enstamma nomen ettersom det er konsonantstammen som er i bruk i entall partitiv. Tostamma nomen med vokalstamme på -te veksler mellom $t$ og $s$, det 
vil si at de har $s$ foran $i$ i entall nominativ og flertalls $i$, men ellers $t$ (se mer om dette i avsnitt 3.1.5). Vi finner likevel stadieveksling av typen I : o i stammen, for eksempel (sg. nom. : sg. gen. : sg. part. : sg. ess.) käsi ('hand') : kä(đ)e/n : kät/tä : käte/nä, hirsi ('†ømmer') : hirre/n : hirt/tä : hirte/nä, kaksi ('to') : kah(d) en : kah/ta: kahte/na. I tillegg finner vi vekslinga I : II i flertall partitiv i varietetene i Porsanger og Nordreisa. Eksempler (sg. nom. : pl. part. : pl. iness.) lohi ('laks') : lohh/i/i : loh/i/ssa, käsi ('hand') : käss/i/i : käs/i/ssä, viisi ('fem') : viiss/i/i : viis/i/ssä, hirsi ('tømmer') : hirss/i/i : hirs/i/ssä.

\subsubsection{Nomen med flerstava vokalstamme på kort vokal (type 2)}

Vokalstammen i nomen av type 2 har flere enn to stavelser, og den slutter på kort vokal. I prinsippet kan vokalstammen bestå av så mange stavelser som helst, men i praksis er det som regel bare tre eller fire. Sammensetninger som for eksempel kesäpäivä ('sommerdag'), som er satt sammen av substantiva kesä ('sommer') og päivä ('dag'), og hvor stammen til sammen består av fire stavelser, regner vi likevel ikke som flerstava stamme. I sammensetninger er det bare siste leddet som blir bøyd, det vil si at kesäpäivä bøyes som et nomen med tostava vokalstamme.

Også blant type 2-nomen finner vi både slike som bare har én vokalstamme (type 2.1), og slike som i tillegg har en konsonantstamme (type 2.2). Til forskjell fra nomen med tostava vokalstamme er konsonantstammen i nomen med flerstava vokalstamme nesten alltid identisk med forma i entall nominativ. Tostamma nomen med tostava vokalstamme slutter derimot på $-i$ i entall nominativ.

\subsubsection{Enstamma nomen med flerstava vokalstamme på kort vokal (type 2.1)}

Stammevokalen i ENSTAMMA NOMEN med FLERSTAVA VOKALSTAMME på KORT vokAl kan være $i, A, O$ eller $U$, men aldri $e$. Stammevokalen i nomen av type 2.1 er den samme som endinga i entall nominativ, med unntak av komparativ (se avsnitt 5.5.1).

Nomen i den denne gruppa er ofte lånord på $-i$, men også ordformer med suffiks som for eksempel presens partisipp, handlerord (nomina 
agentis) og andre suffiksavleiinger. Eksempler på lånord er aviisi ('avis'), masiini ('maskin'), meininki ('meining'), tuomari ('dommer'), täppeni ('teppe'), tunturi ('fjellstrekning, vidde'). Eksempler på kollektivavleiinger er (kivi 'stein' $\rightarrow$ ) kivikkö ('steinrøys'), (mätäs 'stor tue' $\rightarrow$ ) mätikkö ('område med store tuer'), (paiju 'selje, vier' $\rightarrow$ ) paijukko ('vierkratt'), (pensas 'busk' $\rightarrow$ ) pensikkö ('kratt'), (pounu 'tue' $\rightarrow$ ) pounikko ('område med tuer'). Eksempler på presens partisipp er (soppi/it 'passe' :) sop(pi)iva ('passende'), (juosta 'springe' :) juokse(e)va ('springende'). Eksempler på handlerord er $($ kulkkeet $\sim$ kulkea $(t) \sim$ kulkia 'vandre' $\rightarrow)$ kulk(ki)ija ('vandrer'), (opettaa $(t)$ 'lære, undervise' $\rightarrow$ ) : opetta (a)ja ('lærer'). Stadievekslinga i slike ord er vanligvis av typen II : I: II, som for eksempel (sg. nom. : sg. gen. : sg. part.) paijukko ('vierkratt') : paijuko/n:paijukko/o paijukko/a. Ord på -nkV har i Porsanger- og Nordreisa-varietetene stadieveksling av typen I : o : II, som for eksempel meininki ('meining') : meiningi/n : meininkki/i, aurinko ('sol') : auringon : aurinkkoo. De andre varietetene har ikke stadieveksling i slike ord, og formene er altså meininki : meininki/n : meininki/ä, aurinko : aurin-ko/n : aurinko/a

\subsubsection{Tostamma nomen med flerstava vokalstamme på kort vokal (type 2.2)}

Nomen av type 2.2, det vil si NOMEN med FLERSTAVA VOKALSTAMME på KORT VOKAL, har flere undergrupper, som vi her kaller for $t y(t) \ddot{a r}$-nomen, taivalnomen, paimen-nomen, elläin-nomen, privative eller onneton-nomen, egenskapsnomen eller rakkhaus-nomen, veres-nomen og inen-nomen eller ihminen-nomen. Disse er nesten utelukka e-stammer, med unntak av privative adjektiv, som har vokalstamme på - $A$. Til type 2.2 hører også superlativ og ordenstall, som blir omtalt i avsnitt 5.5.2 og 8.2.

- ty(t)är-, taival-, paimen- og elläin-nomen slutter på $r, l$ eller $n$ i nominativ entall. Kjernekonsonanten kan gjennomgå stadieveksling av type I : II eller o : I, eller være uberørt av stadieveksling. Eksempler på nomen med stadieveksling er (sg. nom. : sg. gen. : sg. part.) ty(t)är ('jente; datter’) : tyttäre/n : tytärtä, taival ('vandring; eid') : taipale/n : taival/ta, $y(đ)$ in ('kjerne; marg') : ytime/n:y(đ)in/tä Nomen på $r$ og $l$ er sjeldne. Dessuten kan nomen på $l$ også bøyes etter mønster av nomen på let, det vil si tostamma nomen med vokalstamme på lang vokal (se type 3.2 nedafor). 
Nomen på - $n$ i nominativ entall er det to typer av. I nomen av den første typen er $n$-en bevart i vokalstammen, for eksempel (sg. nom. : sg. gen. : sg. part.) paimen ('gjeter') : paimene/n : paimen/ta, tyven ('(vind)stille') : tyvene/n : tyven/tä, siemen ('frø') : siemene/ $n$ : siemen/tä, ahven ('uer; abbor') : ahvene/ $n:$ ahven/ta, jäsen ('ledd; medlem') : jäsene/ $n$ : jäsen/tä. I nomen av den andre typen veksler $n$ med me i vokalstammen, for eksempel (sg. nom. : sg. gen. : sg. part.) elläin ('dyr') : elläime/n : elläin/tä, avvain ('nøkkel') : avvaime/n : avvain/ta, höyhen ('fjer,

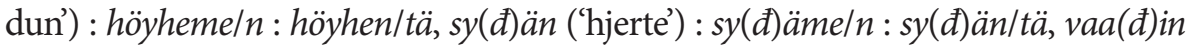
('simle') : vaatime/ $n:$ vaa(đ)in/ta, sierain ('nesebor') : sieraime/ $n:$ sierain/ta, morssiin $\sim$ morsian ('brud') : morssiime/ $n \sim$ morsiame/ $n:$ morssiin/ta $\sim$ morsian/ta. Det er ord som paimen som er mest vanlig av disse to typene. Men dersom nominativ entall slutter på -in, så veksler den med -ime i vokalstammen.

- Egenskapsnomen eller rakkhaus-nomen kaller vi her substantiv som er avleid av adjektiv, og som står for den egenskapen som adjektivet beskriver. Disse nomena gjennomgår stadieveksling mellom $u s: u(đ) e:$ ute i entallsstammen, og flertallsstammen ender på -ksi. Eksempler er (sg. nom. : sg. gen. : sg. ess. : sg. part. : pl. iness.) (rikas 'rik' $\rightarrow$ ) rikkhaus ('rikdom') : rikkhau( $(d) e / n$ : rikkhaute/nna : rikkhaut/ta : rikkhauks/i/ssa, (korkkee $\sim$ korkea korkia 'høg' $\rightarrow) \operatorname{kork}(k)$ eus ('høgde') : kork(k)eu(đ)e/n : kork(k)eut/ta : kork(k)eute/nna : kork $(k)$ euks/i/ssa, (tosi 'sann' $\rightarrow$ ) tottuus ('sannhet') : tottuu(d)e/n : tottuute/nna : tottuut/ta : tottuuks/i/ssa. Denne ordlagingstypen er produktiv, og egenskapsnomen kan lages av alle adjektiv.

- Privative adjektiv eller onneton-adjektiv er avleiinger på -tOn : ttomA, og de forteller at det avleiingsbasen står for, mangler. Avleiingsbasen er enten et substantiv eller et verb. Når avleiingsbasen er et verb, så føyer vi det privative suffikset $t O n$ : ttOmA til 3. infinitivsstammen (se avsnitt 6.8.1.3 om 3. infinitiv). Eksempler er (sg. nom. : sg. gen. : sg. part.) (onni 'lykke' $\rightarrow$ ) onneton ('ulykkelig') : onnettoma/n: onneton/ta, (vika 'feil' $\rightarrow$ ) vi(j)aton ('uskyldig') : vi(j)attoma/n: vi(j)aton/ta, (tiet $(t)$ $\ddot{a} / \ddot{a}(t)$ 'vite' $\rightarrow$ ) tietämätön ('uvitende') : tíetämättömä/n : tietämätön/tä, (usko/ot usko/a $(t)$ 'tru' $\rightarrow$ ) uskomaton ('utrulig') : uskomattoma/n : uskomaton/ta. Som vi ser, stadieveksler privativsuffikset alltid etter I : II-mønsteret.

De to siste undergruppene av nomentype 3.2, veres-nomen og (i)nen-nomen, skiller seg fra de andre undergruppene ved at de bruker konsonantstammen også i flertall genitiv, ikke bare i entall partitiv. 
- I veres-nomen veksler konsonantstammen på -s med vokalstammen på -kse. Eksempler er (sg. nom. : sg. part. : pl. gen. : pl. nom. : pl. iness.) veres ('fersk') : veres/tä: veres/ten $\sim$ vereks/i/tten $:$ verekse/t $:$ vereks/i/ssä, ilves ('gaupe') : ilves/tä : ilves/ten ilveks/i/tten : ilvekse/t : ilveks/i/ssä, kinos ('snøfonn') : kinos/ta : kinos/ten $\sim$ kinoks/i/tten : kinokse/t : kinoks/i/ssa, $($ kiittää $(t)$ 'takke' $\rightarrow$ ) kiitos ('takk') : kiitos/ta: kiitos/ten $\sim$ kiitoks/i/tten: kiitokse/t : kiitoks/i/ssa. Nye lånord som i kjeldespråket slutter på -s, bøyes alltid som veres-nomen. Eksempler er juhanes ('sankthans') : juhanes/ta : juhanes/ten juhaneks/i/tten : juhanekse/t : juhaneks/i/ssa, fiikus ('fikus') : fiikus/ta: fiikus/ten $\sim$ fikuks/i/tten : fikukse/t : fikuks/i/ssa.

- Etter mønster av veres-nomen bøyes også verbavleiinger på - Us, for eksempel $(k o(v) o / t a$ 'plukke, samle' $\rightarrow$ ) kokkous ('møte') : kokkous/ta : kokkous/ten kokkouks/i/tten : kokkoukselt: kokkouks/i/ssa, (rakent $(t) a / a(t)$ 'bygge' $\rightarrow$ ) rakenus ('bygning') : rakenus/ta : rakenus/ten $\sim$ rakenuks/i/tten : rakenukse/t : rakenuks/i/ssa, (räknä/tä 'regne' $\rightarrow$ ) räknäys ('regning') : räknäys/tä : räknäys/ten räknäyks/i/tten : räknäykse/t : räknäyks/i/ssä. Disse må ikke blandes med rakkhaus-nomena ovafor, som er avleid av adjektiv og stundom av substantiv.

- (i)nen-nomen er svært vanlige og inkluderer både substantiv og adjektiv. Eksempler er (sg. nom. : sg. part. : pl. gen. : pl. nom. : pl. iness.) ihminen ('menneske') : ihmis/tä : ihmis/ten : ihmise/t : ihmis/i/ssä, vihrinen ('grønn') : vihris/tä : vihris/ten : vihrise/t : vihris/i/ssä, puna(i)nen ('rød') : puna(i)s/ta : puna(i)s/ten : puna(i)se/t : puna(i)s/i/ssa, surulinen ('trist, sørgelig') : surulis/ta : surulis/ten : surulise/t : surulis/i/ssa. Til samme gruppe hører nomen på lAinen, som er avleid av stedsnavn, og som forteller hvor noen eller noe er ifra. Eksempler er (Tromssa 'Tromsø' $\rightarrow$ ) tromssalainen ('tromsøværing, Tromsø-'), (Alattio 'Alta' $\rightarrow$ ) alattiolainen ('altaværing, Alta-'), (Franska 'Frankrike' $\rightarrow$ ) franskalainen ('franskmann; fransk'), (Mogadishu $\rightarrow$ ) mogadishulainen ('person fra Mogadishu, Mogadishu-').

Nomen på $(i)$ nen er avleid av substantiv. Adjektiv på (i)nen forteller at noen eller noe har det avleiingsbasen uttrykker. Substantiv på (i)nen kan også være såkalte DIMINUTIV, det vil si at de betegner en mindre utgave eller variant av det avleiingsbasen står for, som for eksempel $($ kylä 'bygd' $\rightarrow$ ) kylä(i)nen ('lita bygd'), (poika 'gutt' $\rightarrow$ ) poika(i)nen ('guttunge'). 


\subsubsection{Nomen med vokalstamme på lang vokal (type 3)}

Vokalstammen i nomen av type 3 ender på lang vokal eller diftong. Også disse nomena deler vi inn i to hovedgrupper basert på om de bare har vokalstamme (type 3.1), eller også en konsonantstamme (type 3.2).

\subsubsection{Enstamma nomen med vokalstamme på lang vokal (type3.1)}

Alle enstava nomen hører til nomentype 3.1, dsv. ENSTAMMA NOMEN med VOKALSTAMME på LANG VOKAL, og det gjelder i alle de kvenske skriftspråksvarietetene. Disse orda er bygd opp etter mønsteret $(K) V V$ eller $(K) V_{1} V_{2}$, for eksempel maa ('jord, land'), yö ('natt'), tie ('veg'), täi ('lus'). Til samme nomentype regner vi også flerstava namn på ukedager og høytider som slutter på $A i$, for eksempel lauvantai ('ørdag'), maanantai ('mandag'), helluntai ('pinse').

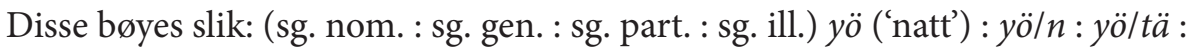
yö/hön, tee ('te') : tee/n : tee/tä: tee/hen, täi ('lus') : täi/n: täi/tä : täi/hin, lauvantai ('lørdag') : lauvantai/n: lauvantai/ta : lauvantai/hin.

I varietetene i Porsanger og Nordreisa er de to siste stavelsene i nomen blitt forenkla til én stavelse med lang vokal dersom den siste stavelsen opprinnelig bare besto av én enkelt vokal $(V)$, for eksempel (kauhea $>$ ) kauhee 'forferdelig' (se avsnitt 3.2.1). Disse orda hører derfor til nomentype 3.1. Slik utjamning har ikke skjedd i de andre varietetene, for eksempel kauhea kauhia ('forferdelig'), og der hører disse orda derfor til nomentype 2.1 (jf. sop(pi)iva ('passende')). Men i Porsanger- og Nordreisa-varietetene bøyes de som enstava Ai-nomen, med unntak av illativformene. Eksempler fra Porsanger og Nordreisa er (sg. nom. : sg. gen. : sg. part. : sg. ill.) kauhee ('fryktelig') : kauhee/n : kauhee/ta : kauhee/sseen, korkkee ('høg') : korkkee/n : korkkee/ta : korkkee/sseen, valkkee ('lys, kvit; bål, ild') : valkkee/n : valkkee/ta : valkkee/sseen, kurkkii ('foss') : kurkkii/n : kurkkii/ta : kurkkii/sseen, laattii ('golv') : laattii/n : laattii/ta : laattii/sseen, porstuu ('bårstue') : porstuu/n : porstuu/ta : porstuu/sseen. Utover de som er oppstått gjennom vokalutjamning, er det ytterst få to- eller fleirstava ord med stamme på lang vokal. Legg merke til at vi i enstava nomen på - Vi bruker illativsuffikset hVn, ellers er suffikset -sseen.

Adjektivet vapaa ('fri, ledig') er spesielt ved at stammen i nominativ står på I-stadiet sjøl om det følger en lang vokal etter, og ved at bøyingsstammen 
inneholder en $h$, for eksempel: (sg. nom. : sg. gen. : sg. part. : sg. ill.) vapaa : vaphaa/n : vaphaa/ta : vaphaa/sseen.

Adjektivet vanhaa ('gammal') har blanda bøying. I entall bøyes det som type 3.1, det vil si (sg. nom. : sg. gen. : sg. part.) vanhaa: vanhaa/n: vanhaa/ta. I flertall bøyes det til dels på samme måte som enstamma nomen med tostava vokalstamme på kort vokal (type 1.1), det vil si (pl. iness. : pl. adess.) vanho/i/ssa : vanho/i/la osv. Flertall partitiv er vanho/i/ta, og illativ er vanho/i/ssiin.

\subsubsection{Tostamma nomen med vokalstamme på lang vokal (type 3.2)}

Nomen av type 3.2 har en vokalstamme som slutter på lang vokal, og i tillegg en konsonantstamme som er identisk med nominativsforma. Dersom stammen gjennomgår stadieveksling (sg. nom. : sg. gen. : sg. part.), så er den av typen I : II : I eller o : I : o. Nomentype 3.2 har følgende undergrupper:

- rakas-, kirves- og kaunis-nomen. Her finner vi både substantiv og adjektiv. Konsonantstammen i disse orda er identisk med entall nominativ, og den slutter på -As, -es eller -is. Eksempler er (sg. nom. : sg. gen. : sg. part. : pl. part.) rakas ('kjær') : rakkhaa/n : rakas/ta : rakkha/i/ta rakkha/j/a, rikas ('rik') : rikkhaa/n: rikas/ta : rikkha/i/ta rikkha/j/a, opas ('kjent; guide') : opphaaln : opas/ta : opphalilta oppha/j/a, varas ('tjuv') : varkhaa/n : varas/ta : varkha/i/ta varkha/j/a, lammas ('sau') : lamphaa/n: lammas/ta : lampha/i/ta lampha/j/a, kirves ('øks') : kirvhee/n, kirves/tä : kirvhe/i/tä kirvhe/j/ä, kaunis ('pen') : kaunhii/n : kaunis/ta : kaunhi/i/ta kaunhi/j/a, ru(v)is ('rug') : rukhii/n : $r u(v) i s / t a:$ rukhi/i/ta rukhi/j/a, tyyris ('dyr' adj.) : tyyrhii/n : tyyris/tä : tyyrhi/i/tä tyyrhi/j/ä. Dette er ei lukka gruppe, det vil si at nye tostava ord ikke bøyes etter dette mønsteret. Et unntak er adjektiv som er avleid med suffikset -kAs, som også brukes til å lage nye ord. Eksempler er (sg. nom. : sg. gen. : sg. part. : pl. part.) (voima 'kraft, styrke' $\rightarrow$ ) voimakas ('kraftig, sterk') : voimakkhaa/n : voimakas/ta : voimakkha/i/ta voimakkhalj/a, (praatti/it " snakke, prate' $\rightarrow$ ) praatikas ('pratsom') : praatikkhaa/n : praatikas/ta : praatikkhali/ta $\sim$ praatikkha/j/a.

- hylje(t)- og perkele(t)-nomen. Også denne typen omfatter både substantiv og adjektiv. Med unntak av Varanger-varieteten er konsonantstammen til disse nomena identisk med entall nominativ, og begge slutter på - $t$. I Varanger mangler $t$-en i nominativ entall. Eksempler er (sg. nom. : sg. gen. : sg. part. : pl. part.) 
hylje(t) ('sel') : hylkhee/n : hyljet/tä : hylkhe/i/tä hylkhe/j/ä, vaate(t) ('klesplagg, tøy'): vaatthee/ $n$ :vaatet/ta: vaatthe/i/ta $\sim$ vaatthe/ $j / a$, huone( $t$ ) ('hus'): huonhee/ $n$ $:$ huonet/ta : huonhe/i/ta huonhe/j/a, terve( $t$ ) ('frisk') : tervhee/n : tervet/tä: tervhe/i/tä $\sim$ tervhelj/ä,perkele( $t$ ) ('djevel') : perkelhee/ $n:$ perkelet/tä : perkelhelil tä perkelhe/j/ä, siikate(t) ('dønning; brottsjø') : siikatthee/n : siikatet/ta : siikatthe/i/ta siikatthelj/a, askele( $t$ ) ('trinn') : askelhee/ $n:$ askelet/ta : askelhe/i/ta $\sim$ askelhelj/a, kantele(t) ('kantele') : kantelhee/n: kantele/tta : kantelheli/ta kantelhe/j/a. En del av nomena på let har blanda bøying: Nominativ og partitiv kan bøyes etter taival-typen, men den vokalstammebaserte bøyinga følger likevel mønsteret til perkelet-nomena. Eksempler er (sg. nom. : sg. gen. : sg. part.) kyynel kyynele( $t$ ) ('tåre') : kyynelhee/n: kyynel/tä kyynelet/tä, askel askele( $t$ ) ('trinn') : askelhee/n : askel/ta $\sim$ askelet/ta, kannel $\sim$ kantele( $t$ ) ('kantele') : kantelhee/ $n:$ kannel/ta $\sim$ kantelet/ta.

- Til nomentype 3.2 regner vi også aktive perfektum partisipp-former. Disse slutter på $-U(t)$ i entall nominativ, med valgfri $-t$ i alle varietetene. Derimot slutter konsonantstammen alltid på -Ut. Eksempler er (sg. nom. : sg. gen. : sg. part. : pl. part.) (kuol/a 'dø' :) kuolu(t) : kuolhee/n : kuollut/ta : kuolhe/i/ta, (vaippu/ut vaipu/at 'bli trøtt' :) vaipunu(t) : vaipunhee/n : vaipunut/ta : vaipunhe/i/ta. (Se avsnitt 6.4.2.3 om perfektum partisipp-former.)

Legg merke til at det alltid følger en $h$ etter stammekonsonanten i vokalstammen til tostamma nomen med vokalstamme på lang vokal. Denne $h$-en må ikke forveksles med $h$-en i illativ.

\subsection{Tall: entall og flertall}

Nomen bøyes i tall (numerus), de kan stå i entall eller flertall. Entall eller singularis (sg.) er den umarkerte kategorien og har ikke noe eige merke eller suffiks. Vi bruker entall når vi viser til éi enhet av en ting eller skapning, eller til et udelelig stoff eller fenomen. Eksempler er (1-3):

1. Poika lähti Naavuonhoon.

'Gutten dro til Kvænangen.'

2. Ilma oon kaunis.

'Det er fint vær.' 
3. Mie juon vettä.

'Jeg drikker vatn'.

Både poika ('gutt') og Naavuono ('Kvænangen') i setning (1) viser til ei enhet. Ordet ilma ('vær') i setning (2) viser til et fenomen som ikke kan deles opp i deler, og som ikke kan telles. Det samme er tilfellet for stoffordet vesi ('vatn') i setning (3), det kan ikke deles, men derimot måles.

Flertall eller pluralis (pl.) bruker vi når vi viser til flere enheter, for eksem$\operatorname{pel}(4,5)$ :

4. Poja/t lähđethiin Naavuonhoon.

'Guttene dro til Kvænangen.'

5. Poj/i/la ei ole tillaa lähteet Naavuonhoon.

'Guttene hadde ikke anledning til å dra til Kvænangen.'

I setning (4) står pojat i flertall nominativ, og i setning (5) står pojila i flertall adessiv.

Flertallssuffikset i nominativ er $-t$, og i de andre kasusene $-i(\sim-i i)$. Begge føyes alltid til vokalstammen. Varianten - $i$ i brukes kun i varietetene i Porsanger og Nordreisa og bare i genitiv og partitiv av visse nomen. Flertallssuffikset $i$ ( ii) kommer etter stammen og rett før kasussuffikset. For eksempel yö ('natt') + $i+t A>\ddot{o} / i /$ tä, juoppo ('dranker') $+i+n>j u o p p o / i / n \sim j u o p p o+i+$ tten $>$ juopo/i/tten. (Se avsnitt 3.1.4 om vokalendringer foran suffikset -i.) Den delen av ordet som består av vokalstammen og flertallssuffikset, kaller vi for FLERTALLSSTAMME.

Som i entall bruker vi også i flertall både vokal- og konsonantstamme. Men mens vi i entall bruker konsonantstamme i alle partitivformer av tostamma nomen, så er den i flertall bare i bruk i veres- og ihminen-nomen (type 2.2), og i genitivsformer av visse nomen av type 1.2.

Det spesielle med tre- eller flerstava nomen er at dersom stammekonsonanten i entall nominativ er lang plosiv $(k k, t t, p p)$, så står flertallsstammen på I-stadiet. For eksempel (sg. nom. : sg. gen. : pl. iness. : pl. part. : pl. ess.) paijukko ('vierkratt') : paijuko/n : paijuko/i/ssa : paijuko/i/ta : paijuko/i/na, harakka ('skjur') : haraka/n: harako/i/ssa: harako/i/ta : harako/i/na. Det gjelder sjølsagt ikke i ord hvor stammekonsonanten ikke er berørt av stadieveksling, som for eksempel i karitta ('lam') : karitta/n: karitto/i/ssa : karitto/i/ta : karitto/i/na. 


\subsection{Kasus}

Kvensk har 13 produktive kasus som alle har sine eigne kasussuffiks. Kasus i kvensk har til dels samme type funksjon som preposisjoner i norsk $(1,2)$. Men med hjelp av kasus uttrykker vi også grammatisk funksjon, for eksempel at objektet i handlingssetninger står i genitiv og subjektet i nominativ (3).

1. Pekka lähtee Tromsshaan. 'Peder drar til Tromsø.'

2. Kreeta assuu Alattiossa.

'Greta bor i Alta.'

3. Faari osti venheen.

'Far kjøpte (en) båt.'

Kasussystemet $\mathrm{i}$ kvensk er enkelt på den måten at man bruker de samme kasussuffiksa i entall og flertall, med genitiv som et viktig unntak. Kvensk har følgende kasus:

- Grammatiske Kasus er nominativ, genitiv og partitiv. De markerer først og fremst hvilken funksjon ordet har i setninga, det vil si om det er subjekt eller objekt. De brukes også som predikatskasus.

- Predikerende Kasus er essiv og translativ. De brukes først og fremst i predikasjonssetninger.

- Lokalkasus er inessiv, elativ, illativ, adessiv, ablativ og allativ. De brukes først og fremst i lokative og possessive setninger. De tre siste lokalkasusene adessiv, ablativ og allativ - kan vi også kalle for EIERSKAPSKASUs ettersom de er mest brukt i setningstypene EIERSKAP og EIERSKAPSENDRING. Etter suffiksa kan vi også dele lokalkasusene inn i s-kasus (de som har $s$ i suffikset), som er inessiv, elativ og illativ (den siste har ikke s i alle nomentypene), og l-kasus (de som har $l$ i suffikset), som er adessiv, ablativ og allativ. Disse to gruppene har også litt ulike funksjoner som lokalkasus.

- Følgekasus er abessiv og komitativ. Med komitativ markerer vi ledd som uttrykker at noe(n) er med, mens abessiv markerer at noe(n) ikke er med eller mangler. Komitativ er heller sjelden brukt i kvensk. Som følgekasus kan vi også regne instruktiv, som ikke kan anses som produktiv, men som brukes i visse konstruksjoner. 
Flertallspronomena met ('vi'), tet ('dere') og het ('de') har i tillegg også de såkalte totalobjektsformene meiđät meät ('oss'), teiđät teät ('dere'), heiđät heät ('dem'), som også går under navnet AKKUSATIVFORMER.

\subsubsection{Nominativ}

Nominativ er en grammatisk kasus, og subjektet i setninga står som oftest i nominativ. Men nominativsformer har også andre funksjoner i setninga.

\subsubsection{Entall nominativ}

ENTALL NOMINATIV er den forma som er oppført i ordbøker og ordlister. Entall nominativ har ikke noe eige suffiks. Men vi må huske at nominativsforma ikke alltid er identisk med ordstammen, og det er stammen som danner utgangspunkt for bøyinga, ikke nominativsforma.

Entall nominativ fungerer som subjektskasus i vanlige setninger (1), eller som predikativskasus (2). Utover det har ikke entall nominativ noen syntaktisk funksjon.

1. Knuutti tuli Kööpenhaminhaan.

'Knut kom til København.'

2. Sie olet [soma ihminen].

'Du er et trivelig menneske.'

\subsubsection{Flertall nominativ}

I tillegg til subjektskasus $(1,2)$ og predikativskasus (2) fungerer flertall nominativ også som objektskasus $(3,4,5)$.

1. Pojat opithaan $\sim$ oppi(i)va(t) kainun kieltä.

'Guttene lærer seg kvensk.'

2. [Vanhaat kainulaiset] olthiin [sepät ihmiset].

'De gamle kvenene var dyktige folk.'

3. Met pesimä laattiit laattiat.

'Vi vaska golvet.'

4. Muori osti kengät Matile.

Mor kjøpte sko til Mats.

5. Faari vei roskat tunkihoon.

'Far tok søpla ut på søppeldungen.' 
Suffikset i flertall nominativ er alltid $t$. Denne flertalls- $t$-en føyes alltid til vokalstammen i ordet. Viss ordet gjennomgår stadieveksling (nomentype 1 og 2 , det vil si de med vokalstamme på kort vokal), føyes $t$-en alltid til stammen på svakt stadium. Eksempler på vekslinga I : o er (sg. nom. : pl. nom.) aika ('tid') : ai(j)a/t, lupa ('lov') : luva/t, ranta ('strand') : ranna/t, käsi ('hand') : $k a ̈(đ) e / t$. Eksempler på vekslinga II : I er (sg. nom. : pl. nom.) niitty ('slått; eng') : niity/t, vittikko ('krattskog') : vittiko/t, pappi ('prest') : papi/t, lamppu ('lampe') : lampu/t. Andre stammekonsonanter enn $k, t$ og $p$ er de samme i flertall nominativ som i entall nominativ. Det gjelder også en del stammer med lang $t$, for eksempel mettä ('skog') : mettä/t, karitta ('lam') : karitta/t.

Også i nomen med vokalstamme på lang vokal (type 3) føyes flertalls- $t$-en til vokalstammen, som er uendra under heile bøyinga. Derimot er det stadieforskjell mellom vokalstammen og konsonantstammen i nomen av type 3.2. Her har vokalstammen sterkt stadium, mens konsonantstammen, som oftest er identisk med entall nominativ, har svakt stadium. Eksempler på vekslinga I : II er (sg. nom.:pl. nom.) rakas ('kjær'): rakkhaa/t, voimakas ('kraftig, sterk'): voimakkhaa/t. Eksempler på vekslinga o : I er (sg. nom. : pl. nom.) lammas ('sau') : lamphaa/t, $r u(v)$ is ('rug') : rukhii/t, hylje(t) ('sel') : hylkhee/t. Uten stadieveksling er for eksempel (sg. nom. : pl. nom.) tyyris ('dyr' adj.) : tyyrhii/t, terve(t) ('frisk') : tervhee/t.

\subsubsection{Genitiv}

Genitiv skiller seg fra de andre kasusene ved at det er forskjeller mellom entall og flertall både i bøying og funksjon.

\subsubsection{Entall genitiv}

Med ENTALL GENitiv markerer vi ledd som fungerer som predikativ eller objekt, og kasusen forekommer først og fremst i setningstypen EIERSKAPSPREDIKASJON (1) og i handlingssetninger (2-5). Men kasusen er også brukt i genitivsmodifikatorer i substantivfraser (6), i verbfrasesubjekt $(7,8)$, i objektsadverbial som forteller om hvor lenge noe varer (9), eller hvor langt noe er (10), og i utfyllinger til adposisjonsfraser $(11,12)$. Eksempler er:

1. Tämä piili oon Annan.

'Denne bilen er Annas.'

2. Faari rakensi piilin.

'Far bygde en bil.' 
3. Anna osti piilin Pekalta/kaupasta.

'Anna kjøpte bilen av Peder / i bilbutikken.'

4. Anna myi piilin Kaisale.

'Anna solgte bilen til Kaisa.'

5. Mikkel ajoi piilin merheen.

Mikkel kjørte bilen ut i sjøen.'

6. [Annan piili] makkaa meressä.

'Annas bil ligger i sjøen.'

7. Mikkel otti piilin [Annan tietämättä].

'Mikkel tok bilen uten at Anna visste om det.'

8. Anna käski [Mikon anttaat hänele piilin].

'Anna ba Mikkel om å gi henne bilen.'

9. Mikkel ajoi Annan piililä [yh(d)en illan].

'Mikkel kjørte med Annas bil en kveld.'

10. Se oli ajanu sillä miilan.

'Han/hun hadde kjørt ei mil med den.'

11. Eirala oon grammatikki [työn alla]

'Eira har en grammatikk under arbeid.'

12. Tyttäret kiikuthiin [vaaran pääle].

'Jentene klatra opp på fjellet.'

Suffikset i entall genitiv er alltid $-n$, som allid festes til samme stamme som flertallssuffikset - $t$ (se avsnitt 5.3.1.2). Eksempler er (sg. nom. : pl. nom. : sg. gen.) (nomentype 1.1) aika ('tid') : ai(j)a/t:ai(j)a/n, poika ('gutt; sønn') : pojalt: pojaln, (nomentype 1.2) lapsi ('barn') : lapselt: lapse/n, (nomentype 2.1) mustikka ('blåbær') : mustika/t : mustika/n, (nomentype 2.2) ty(t)är ('jente; datter') : tyttäre/t : tyttäre/n, (nomentype 3.1) vapaa (fri, ledig') : vaphaa/t : vaphaa/n, (nomentype 3.2) lammas ('sau') : lamphaalt : lamphaa/n.

\subsubsection{Flertall genitiv}

Flertall genitiv bruker vi i setningstypen EIERSKAPSPREDIKASJON (1) og i genitivsmodifikatorer i substantivfraser (2), og det er også vanlig som subjektskasus i visse verbfraser (3). 
1. Nämät vaattheet oon poikkiin pojitten.

'Disse klærne er guttenes.'

2. [Poikkiin pojitten vaatheet] oon lokaiset.

'Klærne til guttene er skitne.'

3. [Tyttäri(i)tten nähten] pojat haluthaan olla puhthaat.

'Guttene ønsker å være reine i jentenes påsyn.'

De kvenske varietetene varierer i måten de uttrykker flertall genitiv på. I Porsanger og Nordreisa brukes suffikset $-n$ i tostava vokalstammer, ellers -ten eller -tten. I disse to varietetene fins det også en regel som ikke fins i de andre varietetene. Regelen sier at dersom flertallsstammen ender på $K i$, så blir denne $i$-en forlenga, og vi skriver da lang $i$. Det vil også si at det i nomentype 1 og 2 alltid er lang vokalisme foran suffikset i flertall genitiv i Porsanger og Nordreisa, enten i form av en $\mathrm{V} i$-diftong eller lang ii. Det samme gjelder i flertall partitiv.

I de andre varietetene bruker man enten -ten eller -tten i flertall genitiv, i Varanger også -en. Suffikset -ten føyes til konsonantstammen, og det brukes bare sammen med veres- og ihminen-nomen (jf. nomentype 3.2) og til dels også med nomentype 1.2. Vi skal her se nærmere på de ulike nomentypene.

- I nomentype 1.1 (enstamma nomen med tostava vokalstamme på kort vokal) er det variasjon mellom varietetene. I Porsanger og Nordreisa bruker man - $n$ dersom flertallsstammen slutter på KVi. Dersom flertallsstammen slutter på $K i$, så føyer man til -in. Kjernekonsonanten foran suffikset er på det sterkeste stadiet. I de andre varietetene bruker vi suffikset -tten i nomentype 1.1, og det er festa til flertallsstammen på det svakest mulige stadiet, det vil si samme stadiet som i entall genitiv. Eksempler er (sg. nom. : sg. gen. : pl. gen.) poika ('gutt; sønn') : pojan : poikk/ii/n poj/i/tten, saita ('sei') : sai(d)an : saitto/i/n saio/i/tten, lato ('låve') : la(đ)on : latto/i/n lao/i/tten, joki ('elv') : jo(v)e/n : jokk/ii/n jo/i/tten, lehti ('blad') : leh(d)e/n : leht/ii/n leh/i/tten, tooli ('stol') : tooli/n : tooli/i/n $\sim$ tool/i/tten.

- I nomentype 1.2 (tostamma nomen med tostava vokalstamme på kort vokal) føyes flertallsgenitivssuffikset til vokalstammen, og det skjer på samme måte som i nomentype 1.1. Men hos noen av nomena kan vi bruke konsonantstammen i stedet. Eksempler er (sg. nom. : sg. gen. : pl. gen.) pieni ('liten’) : 
piene/n : pien/ii/n pien/i/tten pien/ten, lapsi ('barn') : lapse/ $n:$ laps/ii/n laps/i/tten $\sim$ las/ten, mies ('mann') : miehe/ $n:$ mieh/ii/ $n \sim$ mieh/i/tten $\sim$ mies/ ten. Det er det enkelte ordet som bestemmer om vi skal velge vokal- eller konsonantstamme. Det fins mange tostamma nomen som aldri danner flertall genitiv med hjelp av konsonantstammen, for eksempel (sg. nom. : sg. gen. : sg. part. : pl. gen.) vuosi ('år’) : vuo(đ)en : vuot/ta : vuoss/ii/n vuos/i/tten, lohi ('laks') : lohe/n : loh/ta: lohh/ii/n loh/i/tten, käsi ('hand') : kä(d)e/n: kät/tä : käss/ii/n käs/i/tten, hirsi ('tømmer') : hirre/n : hirt/tä: hirss/ii/n hirs/i/tten, uusi ('ny') : uu(đ)e/n : uut/ta : uuss/ii/n uus/i/tten, täysi ('full; voksen') : täy(d)e/n : täyt/tä : täyss/ii/n : täys/i/tten. Det er slik at alle tostava e-stammer kan danne flertall genitiv med vokalstammen, men bare en del av dem kan gjøre det samme med konsonantstammen.

- Nomentypene 2.1 og 2.2 (nomen med flerstava vokalstamme på kort vokal) danner flertall genitiv med suffikset -tten, som festes til flertallsstammen på svakest mulig stadium. I Porsanger og Nordreisa får vi også forlenging av flertalls-i-en dersom den står etter konsonant. Eksempler er (sg. nom. : sg. gen. : pl. gen.) (nomentype 2.1) mustikka ('blåbær') : mustika/n : mustiko/i/tten, opetta(a)ja ('lærer') : opetta(a)ja/n : opettaaj/ii/tten opettaj/i/tten, valkea valkia ('bål, ild; kvit') : valkea/n valkia/n : valke/i/tten, paijukko ('vierkratt') : paijuko/n : paijuko/i/tten, tunturi ('fjellstrekning, vidde') : tunturi/n : tunturi/i/tten tuntur/i/tten, (nomentype 2.2) ty(t)är ('jente; datter’) : tyttäre/n : tyttär/ii/tten tyttär/i/tten, sy(d)än ('hjerte') : sy(đ)äme/n: syđäm/ii/tten syäm/i/tten.

I veres- og ihminen-nomen festes suffikset likevel oftest til konsonantstammen, og vi bruker da suffikset -ten. Men med unntak av varietetene i Porsanger og Nordreisa kan disse orda også danne flertall genitiv ved at suffikset -tten føyes til vokalstammen. Eksempler er (sg. nom. : sg. gen. : pl. gen.) ihminen ('menneske') : ihmise/n : ihmis/ten, kainulainen ('kven; kvensk') : kainulaise/ $n$ : kainulais/ten, sininen ('blå) : sinise/n : sinis/ten, veres ('fersk') : verekse/ $n$ : veres/ten $\sim$ vereks/i/tten, jänes ('hare') : jänekse/n : jänes/ten jäneks/i/tten, kokkous ('møte') : kokkoukse/n : kokkous/ten kokkouks/i/tten.

- Nomentypene 3.1 og 3.2 (nomen med vokalstamme på lang vokal) danner som regel flertall genitiv ved å feste suffikset -tten til flertallsstammen. I Varanger bruker nomentype 3.2 også suffikset -en, og flertalls-i-en er da erstatta med $j$. Eksempler er (sg. nom. : sg. gen. : pl. gen.) (nomentype 3.1) yö ('natt') : yö/n : ö/i/tten, maa : maa/n : ma/i/tten, vapaa : vaphaa/n : 
vapha/i/tten, valkkee ('bål, ild; kvit') : valkkee/n: valkke/i/tten, (nomen type 3.2) rakas ('kjær') : rakkhaa/n : rakkha/i/tten $\sim$ rakkha/j/en, hylje(t) ('sel') : hylkhee/n : hylkheli/tten hylkhelj/en, turve(t) ('torv') : turphee/n: turphe/i/tten turphe/j/en, perkele $(t)$ ('djevel') : perkelhee/ $n:$ perkelhe/i/tten $\sim$ perkelhe/j/en, vaipunu(t) ('trøtt') : vaipunhee/n : vaipunhe/i/tten vaipunhe/j/en. I Porsanger-varieteten kan nomen med enstava vokalstamme også danne flertall genitiv på -nen, for eksempel (sg. nom. : pl. gen.) yö ('natt') : ö/i/nen, maa ('jord, land) : ma/i/nen.

Tabell 5.2 oppsummerer hvordan entall og flertall genitiv dannes i kvensk.

Tabell 5.2 Entall og flertall genitiv

\begin{tabular}{|c|c|c|c|}
\hline Nomentype & Entall nominativ & Entall genitiv & Flertall genitiv \\
\hline \multirow{5}{*}{$\begin{array}{l}1.1 \text { Enstamma } \\
\text { nomen med tostava } \\
\text { vokalstamme på } \\
\text { kort vokal }\end{array}$} & aika & ai(j)a/n & aikko/i/n aio/i/tten \\
\hline & mettä & mettä/n & mett/ii/n mett/i/tten \\
\hline & joki & jo(v)e/n & jokk/ii/n jo/i/tten \\
\hline & pappi & papi/n & pappi/i/n pap/i/tten \\
\hline & juoppo & juopo/n & juoppo/i/n juopo/i/tten \\
\hline \multirow{5}{*}{$\begin{array}{l}1.2 \text { Tostamma } \\
\text { nomen med tostava } \\
\text { vokalstamme på } \\
\text { kort vokal }\end{array}$} & pieni & piene/n & $\begin{array}{l}\text { pien/ii/n pien/i/tten pien/ } \\
\text { ten }\end{array}$ \\
\hline & lapsi & lapse/n & laps/ii/n laps/i/tten las/ten \\
\hline & mies & miehe/n & $\begin{array}{l}\text { mieh/ii/n } \sim \text { mieh/i/tten } \sim \text { mies/ } \\
\text { ten }\end{array}$ \\
\hline & käsi & kä(đ)e/n & käss/ii/n käs/i/tten \\
\hline & hirsi & hirre/n & hirss/ii/n hirs/i/tten \\
\hline \multirow{7}{*}{$\begin{array}{l}2.1 \text { Enstamma } \\
\text { nomen med } \\
\text { flerstava } \\
\text { vokalstamme på } \\
\text { kort vokal }\end{array}$} & sivakka & sivaka/n & sivako/i/tten \\
\hline & kajava & kajava/n & kajav/i(i)/tten \\
\hline & tunturi & tunturi/n & tuntur(i)/i/tten \\
\hline & meininki & $\begin{array}{l}\text { meiningi/n } \\
\text { meininki/n }\end{array}$ & $\begin{array}{l}\text { meiningi/i/tten meinink/i/ } \\
\text { tten }\end{array}$ \\
\hline & paijukko & paijuko/n & paijuko/i/tten \\
\hline & valkea valkia & valkea/n valkia/n & valke/i/tten \\
\hline & kurkkio & kurkkio/n & kurkkio/i/tten \\
\hline
\end{tabular}

(Fortsatt) 
Tabell 5.2 (Fortsatt)

\begin{tabular}{|c|c|c|c|}
\hline Nomentype & Entall nominativ & Entall genitiv & Flertall genitiv \\
\hline \multirow{10}{*}{$\begin{array}{l}2.2 \text { Tostamma } \\
\text { nomen med } \\
\text { flerstava } \\
\text { vokalstamme på } \\
\text { kort vokal }\end{array}$} & ty(t)är & tyttäre/n & tyttär/i(i)/tten \\
\hline & sisar & sisare/n & sisar/i(i)/tten \\
\hline & elläin & elläime/n & elläim/i(i)/tten \\
\hline & tyven & tyvene/n & tyven/i(i)/tten \\
\hline & tottuus & tottuu(đ)e/n & tottuuks/i(i)/tten \\
\hline & veres & verekse/n & veres/ten vereks/i/tten \\
\hline & kokkous & kokkoukse/n & kokkous/ten kokkouks/i/tten \\
\hline & ihminen & ihmise/n & ihmis/ten \\
\hline & vihrinen & vihrise/n & vihris/ten \\
\hline & kainulainen & kainulaise/n & kainulais/ten \\
\hline \multirow{5}{*}{$\begin{array}{l}3.1 \text { Enstamma } \\
\text { nomen med } \\
\text { vokalstamme på } \\
\text { lang vokal }\end{array}$} & maa & $\mathrm{maa} / \mathrm{n}$ & $\mathrm{ma} / \mathrm{i} /$ tten $~ \mathrm{ma} / \mathrm{i} / \mathrm{nen}$ \\
\hline & yö & yö/n & ö/i/tten ö/i/nen \\
\hline & tuorestai & tuorestai/n & tuoresta/i/tten \\
\hline & valkkee & valkkee/n & valkke/i/tten \\
\hline & kurkkii & kurkkii/n & kurkki/i/tten \\
\hline \multirow{8}{*}{$\begin{array}{l}3.2 \text { Tostamma } \\
\text { nomen med } \\
\text { vokalstamme på } \\
\text { lang vokal }\end{array}$} & rakas & rakkhaa/n & rakkha/i/tten rakkha/j/en \\
\hline & ru(v)is & rukhii/n & rukhi/i/tten rukhi/j/en \\
\hline & tyyris & tyyrhii/n & tyyrhi/i/tten tyyrhi/j/en \\
\hline & hylje(t) & hylkhee/n & hylkhe/i/tten hylkhe/j/en \\
\hline & terve(t) & tervhee/n & tervhe/i/tten $\sim$ tervhe/j/en \\
\hline & perkele(t) & perkelhee/n & perkelhe/i/tten perkelhe/j/en \\
\hline & askele(t) & askelhee/n & askelhe/i/tten askelhe/j/en \\
\hline & lukenu(t) & lukenhee/n & lukenhe/i/tten lukenhe/j/en \\
\hline
\end{tabular}

\subsubsection{Partitiv}

PARTITIV har nesten samme funksjon i entall og flertall. Det markerer enten subjektet i setningstypene EKSISTENS (1) og EIERSKAP (2), eller objekt i handlingssetninger (3-5), MEINING (6) og spesielt følelsessetninger $(7,8)$. Partitiv er også brukt i objektsadverbial i nektende setninger (9) og i utfyllinger til adposisjonsfraser (10). Eksempler er: 
1. Siljola seisoi kainulaissii kainulaisia.

'Det sto (noen) kvener på gårdsplassen.'

2. Kainulaisila oli karjaa.

'Kvenene hadde buskap.'

3. Amtmani hakkas puita.

'Amtmannen hogde trær.'

4. Pappi ei antanu preivii preiviä amtmanille.

'Presten ga ikke noe brev til amtmannen.'

5. Pappi ei vieny Knuuttii Knuuttia fankilhaan.

'Presten sendte ikke Knut i fengsel.'

6. Sammeli piti Pyssyjokkee $\sim$ Pyssyjokea Pyssyjokia kaunhiina.

'Samuel syntes Børselv var vakkert'.

7. Amtmani vihas kainulaissii kainulaisia.

'Amtmannen hata kvenene.'

8. Pikku-Liis(s)aa hävetti pierä äänheen.

'Vesle Lisa skjemtes over å fjerte høgt.'

9. Mie en ollu sielä tiimaakhaan.

'Jeg var ikke der i en time engang.'

10. [Ennen sottaa] Pyssyjoki oli iso kylä.

'Før krigen var Børselv ei stor bygd.'

\subsubsection{Entall partitiv}

Entall partitiv blir i Porsanger og i Nordreisa markert gjennom vokalforlenging eller med suffikset $-t a$, i de andre varietetene med suffiksa $-A$ og $-t A$.

- Vokalforlenging og suffikset $-A$ brukes i enstamma nomen med vokalstamme på kortvokal (nomentype 1.1 og 2.1). Type 2.1-nomen med vokalstamme på $e A, i A, i O$ og $U A$ kan også danne entall partitiv på - $t A$, det vil si at vi skriver for eksempel valkea ('bål, ild; kvit') : valkealta, kurkkio ('foss') : kurkkio/ta, porstua ('bårstue') : porstua/ta, med mindre man skriver på Porsangereller Varanger-varieteten.

Både vokalforlenging og suffikset $-A$ brukes alltid med stamme på det høgeste stadiet. I Porsanger og Nordreisa betyr det som regel stadium II, ettersom 
vokalforlenging nettopp er grunnen til dette stadiet. I de andre varietetene utløser $A$-suffikset stadium II bare i $A$-stammer, og bare dersom den foregående stavelsen er kort og trykksterk. (Se avsnitt 3.1.1 om stadieveksling.) Vi bør også huske at stamme-e og suffikset $A$ blir til $i A$ i Varanger-varieteten. Eksempler er (sg. nom. : sg. gen. : sg. part.) (nomentype 1.1) aika ('tid') : ai(j)a/n:aikka/a aika/a, lupa ('lov') : luva/n: luppa/a, joki ('elv') : jo(v)e/n:jokkele joke/a joki/a, juoppo ('dranker') : juopo/n : juoppo/o juoppo/a, mooli ('mål') : mooli/n: mooli/i mooli/a, hauska ('hyggelig') : hauska/n : hauska/a, (nomentype 2.1) meininki ('meining') : meiningi/n meininki/n: meininkki/i meininki/ä, matala ('grunne; låg') : matala/n : matala/a, valkea valkia ('bål, ild; kvit') : valkea/ $n \sim$ valkia/ $n$ : valkea/(t)a valkia/a, laattia ('golv') : laattia/ $(t) a \sim$ laattiala.

- I de andre nomentypene, det vil si i tostamma nomen med vokalstamme på kort vokal (type 1.2 og 2.2) og nomen med vokalstamme på lang vokal (type 3 ), bruker vi i entall alltid partitivsuffikset - $t A$. På dette punktet fins det heller ikke forskjeller mellom de ulike skriftspråksvarietetene. Suffikset blir lagt til konsonantstammen, så fremt ordet har en slik. Eksempler er (sg. nom. : sg. gen. : sg. part.) (nomentype 1.2) pieni ('liten') : piene/n : pien/tä, lapsi ('barn') : lapse/n : las/ta, (nomentype 2.2) ty(t)är ('jente; datter’) : tyttäre/n : ty(t)är/tä, lämmin ('varm') : lämpimä/n : lämmin/tä, tottuus ('sannhet') : tottuu(d)e/n : tottuut/ta, veres ('fersk') : verekse/ $n$ : veres/tä, ihminen ('menneske') : ihmise/ $n$ : ihmis/tä, kainulainen ('kven; kvensk') : kainulaise/n: kainulais/ta, (nomentype 3.1) tie ('veg') : tie/n : tie/tä, valkkee ('bål, ild; kvit') : valkkee/n : valkkee/ta, vapaa ('fri, ledig') : vaphaan/n : vaphaa/ta, (nomentype 3.2) rakas ('kjær') : rakkhaa/n : rakas/ta, hylje(t) ('sel') : hylkhee/n: hyljet/tä, kuolu(t) ('død, dødd') : kuolhee/n: kuolut/ta.

\subsubsection{Flertall partitiv}

Flertall partitiv dannes i Porsanger og Nordreisa med hjelp av vokalforlenging eller suffikset - $t A$, eller uten tillegg, dsv. at forma er identisk med flertallsstammen. Vi tar her for oss de ulike nomentypene i tur og orden.

- I nomen med tostava vokalstamme på kort vokal (typene 1.1 og 1.2) blir flertall partitiv i Porsanger og Nordreisa laga med hjelp av vokalforlenging eller uten noe tillegg eller endring i flertallsstammen. Vokalforlenging får vi når flertallsstammen slutter på Ki, ellers mangler den. I de andre varietetene 
brukes - $A$ som suffiks i flertall partitiv. Dersom ordet da ville ha slutta på tre vokaler etter hverandre, så blir flertalls-i-en erstatta med $j$. Eksempler er (sg. nom. : sg. gen. : pl. part.) poika ('gutt; sønn') : poja/n :poikk/i/i poik/i/a, saita

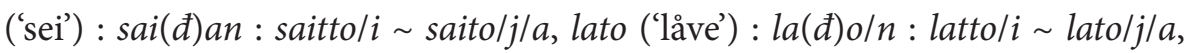
tooli ('stol') : tooli/n : tooli/i tool/i/a, pieni ('liten') : piene/n : pien/i/i $\sim$ pien/ i/ä, lapsi ('barn') : lapse/n : laps/i/i laps/i/a. Når det gjelder varietetene $\mathrm{i}$ Porsanger og Nordreisa, så ser vi at på samme måte som i flertall genitiv så har kjernekonsonanten sterkest mulig stadium i flertall partitiv, for eksempel poikkii, saittoi, lattoi osv.

- Nomen med flerstava vokalstamme på kort vokal (typene 2.1 og 2.2) danner flertall partitiv med suffiksa $-A$ og $-t A$. Suffikset er alltid $-t A$, med mindre flertallsstammen slutter på Ki. I det sistnevnte tilfellet blir $i$-en forlenga $\mathrm{i}$ Porsanger, på samme måte som i flertall genitiv, mens de andre varietetene bruker suffikset $-A$. Når stammen er utsatt for stadieveksling, så står kjernekonsonanten på stadium I foran diftong Vi. Eksempler er (sg. nom. : sg. gen. : pl. part.) (nomentype 2.1) mustikka ('blåbær') : mustika/n : mustiko/i/ta, opetta(a)ja ('lærer') : opetta(a)ja/n : opettaaj/ii/ta opettaj/i/a, valkea valkia ('bål, ild; kvit') : valkea/n valkia/n: valke/i/ta, paijukko ('vierkratt') : paijuko/n: paijuko/i/ta, tunturi ('fjellstrekning, vidde') : tunturi/n: tunturi/i/ta tuntur/i/ta, (nomentype 2.2) ty(t)är ('jente; datter') : tyttäre/n : tyttär/ii/tä tyttär/i/tä, sy(đ)än ('hjerte') : sy(đ)äme/n: syđäm/ii/tä syäm/i/ä, ihminen ('menneske') $:$ ihmise/n : ihmiss/ii/tä ihmis/i/ä, veres ('fersk') : verekse/n : vereks/ii/tä vereks/i/ä, ilves ('gaupe') : ilvekse/ $n:$ ilveks/ii/tä $\sim$ ilveks/i/ä. Formene på iitA kan i Porsanger og Nordreisa også mangle $t A$, og de har da samme ending som i nomentype 1 . Det er spesielt vanlig i veres- og ihminen-nomen, i nomen som slutter på $j A$ (handlerord) og på $v A$ (presens partisipp og adjektiv på $v A$ ), og i ordenstall. Vi får da former som (sg. nom. : pl. part.) veres ('fersk') : vereks/i/i, kokkous ('møte') : kokkouks/i/i, ihminen ('menneske') : ihmiss/i/i, puhhuuja ('taler; predikant') : puhhuuj/i/i,puhhuuva ('talende') : puhhuuv/i/i, väkkeevä ('sterk') : väkkeev/i/i, kolmas ('tredje') : kolmanss/i/i kolmass/i/i.

- Nomen med vokalstamme på lang vokal (typene 3.1 og 3.2) bruker vanligvis suffikset $-t A$ i flertall partitiv. Nomentype 3.2 kan i Varanger ha suffikset - $A$ samtidig som flertalls-i-en blir til $j$ (jf. varianten -en i flertall genitiv). Eksempler er (sg. nom. : sg. gen. : pl. part.) (nomentype 3.1) maa ('jord, land') : maa/n : ma/i/ta, yö ('natt') $: y \ddot{o} / n: \ddot{o} / i /$ tä, tuorestai ('torsdag') : tuorestai/ $n:$ tuoresta/i/ta, vapaa ('fri, ledig') : vaphaa/n : vapha/i/ta, valkkee 
('bål, ild; kvit') : valkkee/n : valkke/i/ta, (nomentype 3.2) rakas ('kjær') : rakkhaa/n: rakkha/i/ta rakkha/j/a, turve(t) ('torv') : turphee/n: turphe/i/ta $\sim$ turphe/j/a.

Jamfører vi flertall genitiv og partitiv, så ser vi at det gjelder en obligatorisk tovokalsregel i disse bøyingsformene i varietetene i Porsanger og Nordreisa. Det betyr at dersom stammevokalen faller bort foran flertalls-i, så blir flertalls-i-en forlenga, og vi skriver $i$. Med andre ord slutter flertallsstammen enten på Vi eller ii. Eksempler er (sg. nom. : pl. gen. : pl. part.) (nomentype 1.1) juорро ('dranker') : juoppo/i/n : juoppo/i, joki ('elv') : jokk/ii/n : jokk/i/i, (nomentype 1.2) vuosi ('år') : vuoss/ii/n : vuoss/i/i, (nomentype 2.1) mustikka ('blåbær') : mustiko/i/tten : mustiko/i/ta, tunturi ('fjellstrekning, vidde') : tunturi/i/tten: tunturi/i/ta, (nomentype 2.2) tyven ('(vind)stille') : tyven/ii/tten : tyven/ii/tä, rakkhaus : rakkhauks/ii/tten : rakkhauks/ii/ta, (nomentype 3.1) assii ('sak') : assi/i/tten: assi/i/ta, (nomentype 3.2) rakas ('kjær') : rakkha/i/tten : rakkha/i/ta. Det er kun i flertall genitiv og partitiv denne obligatoriske tovokalsregelen gjelder i Porsanger og Nordreisa.

I tabell 5.3 er bøyingsmønstra for entall og flertall partitiv oppsummert.

Tabell 5.3 Entall og flertall partitiv

\begin{tabular}{|c|c|c|c|}
\hline Nomentype & Entall nominativ & Entall partitiv & Flertall partitiv \\
\hline \multirow{5}{*}{$\begin{array}{l}1.1 \text { Enstamma } \\
\text { nomen med } \\
\text { tostava } \\
\text { vokalstamme på } \\
\text { kort vokal }\end{array}$} & aika & $\operatorname{aik}(k) a / a$ & aikko/i aiko/j/a \\
\hline & mettä & mettä/ä & mett/i/i mett/i/ä \\
\hline & joki & jokke/e joke/a joki/a & jokk/i/i jok/i/a \\
\hline & pappi & pappi/i pappi/a & pappi/i papp/i/a \\
\hline & juoppo & juoppo/o juoppo/a & juoppo/i juoppo/j/a \\
\hline \multirow{5}{*}{$\begin{array}{l}1.2 \text { Tostamma } \\
\text { nomen med } \\
\text { tostava } \\
\text { vokalstamme på } \\
\text { kort vokal }\end{array}$} & pieni & pien/tä & pien/i/i pien/i/ä \\
\hline & käsi & kät/tä & käss/i/i käs/i/ä \\
\hline & hirsi & hirt/tä & hirss/i/i hirs/i/ä \\
\hline & lapsi & las/ta & laps/i/i laps/i/a \\
\hline & mies & mies/tä & mieh/i/i mieh/i/ä \\
\hline
\end{tabular}

(Fortsatt) 
Tabell $\mathbf{5 . 3}$ (Fortsatt)

\begin{tabular}{|c|c|c|c|}
\hline Nomentype & Entall nominativ & Entall partitiv & Flertall partitiv \\
\hline \multirow{6}{*}{$\begin{array}{l}2.1 \text { Enstamma } \\
\text { nomen med } \\
\text { flerstava } \\
\text { vokalstamme på } \\
\text { kort vokal }\end{array}$} & meininki & meininkki/i meininki/ä & meininkki/i/tä meinink/i/ä \\
\hline & tunturi & tunturi/i tunturi/a & tunturi/i/ta tuntur/i/a \\
\hline & paijukko & paijukko/o paijukko/a & paijuko/i/ta \\
\hline & sivakka & sivakka/a & sivako/i/ta \\
\hline & valkea valkia & valkea/(t)a valkia/a & valke/i/ta \\
\hline & kurkkio & kurkkio/ta kurkkioa & kurkkio/i/ta \\
\hline \multirow{10}{*}{$\begin{array}{l}2.2 \text { Tostamma } \\
\text { nomen med } \\
\text { flerstava } \\
\text { vokalstamme på } \\
\text { kort vokal }\end{array}$} & ty(t)är & tytär/tä & tyttär/ii/tä tyttär/i/ä \\
\hline & sisar & sisar/ta & sisar/ii/ta sisar/i/a \\
\hline & elläin & elläin/tä & elläim/ii/tä elläim/i/ä \\
\hline & tyven & tyven/tä & tyven/ii/tä tyven/i/ä \\
\hline & rakkhaus & rakkhaut/ta & $\begin{array}{l}\text { rakkhauks/ii/ta } \\
\text { rakkhauks/i/a }\end{array}$ \\
\hline & veres & veres/tä & vereks/ii(tä) vereks/i/ä \\
\hline & kokkous & kokkous/ta & $\begin{array}{l}\text { kokkouks/ii(ta) } \\
\text { kokkouks/i/a }\end{array}$ \\
\hline & vihrinen & vihris/tä & vihriss/ii(tä) vihris/i/ä \\
\hline & ihminen & ihmis/tä & ihmiss/ii(tä) ihmis/i/ä \\
\hline & kainulainen & kainulais/ta & $\begin{array}{l}\text { kainulaiss/ii(ta) } \\
\text { kainulais/i/a }\end{array}$ \\
\hline \multirow{5}{*}{$\begin{array}{l}3.1 \text { Enstamma } \\
\text { nomen med } \\
\text { vokalstamme på } \\
\text { lang vokal }\end{array}$} & maa & $\mathrm{maa} / \mathrm{ta}$ & $\mathrm{ma} / \mathrm{i} / \mathrm{ta}$ \\
\hline & yö & yö/tä & ö/i/tä \\
\hline & tuorestai & tuorestai/ta & tuoresta/i/ta \\
\hline & valkkee & valkkee/ta & valkke/i/ta \\
\hline & kurkkii & kurkkii/ta & kurkki/i/ta \\
\hline \multirow{7}{*}{$\begin{array}{l}3.2 \text { Tostamma } \\
\text { nomen med } \\
\text { vokalstamme på } \\
\text { lang vokal }\end{array}$} & rakas & rakas/ta & rakkha/i/ta rakkha/j/a \\
\hline & ru(v)is & $\mathrm{ru}(\mathrm{v}) \mathrm{is} / \mathrm{ta}$ & rukhi/i/ta rukh/i/ja \\
\hline & tyyris & tyyris/tä & tyyrhi/i/tä tyyrhi/j/ä \\
\hline & hylje(t) & hyljet/tä & hylkhe/i/tä hylkhe/j/ä \\
\hline & terve(t) & tervet/tä & tervhe/i/tä tervhe/j/ä \\
\hline & askele(t) & askelet/ta & askelhe/i/ta askelhe/j/a \\
\hline & lukenu(t) & lukenut/ta & lukenhe/i/ta lukenhe/j/a \\
\hline
\end{tabular}




\subsubsection{Predikerende kasus: essiv og translativ}

Kasusene ESSIV og TRANSLATIV kalles for predikerende sia de begge brukes i predikasjonssetninger (se avsnitt 4.2.3). Men begge har også andre funksjoner; de er for eksempel vanlige i tidsuttrykk.

\subsubsection{Essiv}

Essiv er ikke like mye brukt som kasusene nominativ, genitiv og partitiv, men den brukes for eksempel i rammeadverbial (1) og i predikativ funksjon i setningstypen MEINING (2). Med essiv markerer vi også visse ledd som uttrykker tidspunkt $(3,4)$.

1. Lapsena Knuutti asui Torniossa.

'Som barn bodde Knut i Torneå.'

2. Sammeli piti Pyssyjokkee kaunhiina.

'Samuel syntes Børselv var vakkert.'

3. Tuorestaina syömä hernetvellii $\sim$ herne(t)velliä, lau(v)antaina riisipuuroo $\sim$ riisipuuroa.

'På torsdag(er) spiser vi ertesuppe, på lørdag(er) risgraut'.

4. Juhaneksena poltama valk(k)eita.

'På sankthans brenner vi bål.'

Essiv lages med hjelp av suffikset $-(n) n A$. Valget mellom kort og lang $n$ i suffikset er styrt av lengderegelen for konsonantene $m, n, l$ og $r$ (se avsnitt 3.1.2).

I entall essiv føyes suffikset alltid til vokalstammen. I nomen med vokalstamme på kortvokal står denne i essiv på samme stadiet som den har i nominativ entall. I flertall festes essivsuffikset direkte til flertallsstammen, som har samme stadium som i entall essiv.

Her må vi huske at i nomen av type 2.1 der geminerte plosiver stadieveksler, så står flertallsstammen alltid på stadium I. Eksempler er (sg. nom. : sg. gen. : sg. ess. : pl. ess.) aika ('tid') : ai(j)a/n : aika/na : aiko/i/na, lupa ('lov') : luva/n : lupa/na: lup/i/na, joki ('elv') : jo(v)e/n: joke/na : jok/i/na, juoppo ('dranker') : juopo/n:juoppo/na:juoppo/i/na, pöllö ('tulling') : pöllö/n:pöllö/nä:pöllö/i/nä, mustikka ('blåbær') : mustika/n : mustikka/nna: mustiko/i/na. I andre nomentyper er ikke vokalstammen utsatt for stadieveksling. Eksempler er (sg. nom. : sg. gen. : sg. ess. : sg. part.) lapsi ('barn') : lapse/n : lapse/na : laps/i/na, sisar 


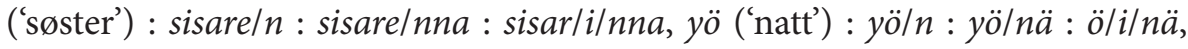
tiistai ('tirsdag') : tiistai/n : tiistai/na : tiista/i/na, vapaa ('fri, ledig') : vaphaa/n: vaphaa/na : vaphali/na, lämmin ('varm') : lämpimä/n : lämpimä/nnä : lämpim/i/nnä, kantele( $t$ ) ('kantele') : kantelhee/ $n$ : kantelhee/na : kantelhe/i/na.

Essivstammen blir regna som en slags grunnstamme: Den viser det opprinnelige stadiet i ordstammen som de andre stadiene kan sies å være variasjoner av.

\subsubsection{Translativ}

TRAnslativ likner mye på essiv. Der essiv markerer ledd som forteller om tilstanden på noe eller noen, så bruker vi translativ på ledd som forteller om tilstandsendring. Begge er såkalte predikerende kasus. Translativ er i bruk i setningstypene ENDRING (1), MEINING (2), NAVNGIVING (3) og i aspektuelle tulla tehtyksi-konstruksjoner (4). I tillegg brukes translativ også i frie tidsadverbial (5).

1. Met tulima iloiseksi.

'Vi blei glade.'

2. Sammeli luuli hänen vaimoo vaimoa iloiseksi.

'Samuel trudde at kona hans var glad.'

3. Joonas käski valasta kalaksi.

'Jonas kalte kvalen for fisk.'

4. Läksyt tuli tehtyksi.

'Man / Folk blei ferdig med leksene.'

5. Met tulema kothiin jouluiksi.

'Vi kommer heim til jul.'

Suffikset i translativ er alltid - $k s i$, og i entall festes det til samme stamme som genitivssuffikset. I flertall legger vi - ksi direkte til flertallsstammen, som står på samme stadiet som i entall translativ. Eksempler er (sg. nom. : sg. gen. : sg. transl. : pl. transl.) pappi ('prest') : papi/n : papi/ksi : papi/i/ksi pap/i/ksi, lapsi ('barn') : lapse/n : lapse/ksi : laps/i/ksi, sivakka ('ski') : sivaka/n : sivaka/ksi : sivako/i/ksi, ty(t)är ('jente; datter’) : tyttäre/n : tyttäre/ksi : tyttär/i/ksi, rakas ('kjær') : rakkhaa/n : rakkhaa/ksi : rakkha/i/ksi.

Tabell 5.4 gir en oversikt over bøyingsformene i entall og flertall essiv og translativ. 
Tabell 5.4 Entall og flertall essiv og translativ

\begin{tabular}{|c|c|c|c|c|c|}
\hline Nomentype & $\begin{array}{l}\text { Entall } \\
\text { nominativ }\end{array}$ & Entall essiv & Flertall essiv & $\begin{array}{l}\text { Entall } \\
\text { translativ }\end{array}$ & $\begin{array}{l}\text { Flertall } \\
\text { translativ }\end{array}$ \\
\hline \multirow{5}{*}{$\begin{array}{l}\text { 1.1 Enstamma } \\
\text { nomen med } \\
\text { tostava } \\
\text { vokalstamme på } \\
\text { kort vokal }\end{array}$} & aika & aika/na & aiko/i/na & ai(j)a/ksi & ai(j)o/i/ksi \\
\hline & mettä & mettä/nä & mett/i/nä & mettä/ksi & mett/i/ksi \\
\hline & joki & joke/na & jok/i/na & jo(v)e/ksi & $\mathrm{jo}(\mathrm{v}) / \mathrm{i} / \mathrm{ksi}$ \\
\hline & pappi & pappi/na & $\begin{array}{l}\text { pappi/i/na } \\
\text { papp/i/na }\end{array}$ & papi/ksi & $\begin{array}{l}\text { papi/i/ksi } \\
\text { pap/i/ksi }\end{array}$ \\
\hline & juoppo & juoppo/na & juoppo/i/na & juopo/ksi & juopo/i/ksi \\
\hline \multirow{4}{*}{$\begin{array}{l}1.2 \text { Tostamma } \\
\text { nomen med } \\
\text { tostava } \\
\text { vokalstamme på } \\
\text { kort vokal }\end{array}$} & pieni & piene/nä & pien/i/nä & piene/ksi & pien/i/ksi \\
\hline & käsi & käte/nä & käs/i/nä & kä(đ)e/ksi & käs/i/ksi \\
\hline & lapsi & lapse/na & laps/i/na & lapse/ksi & laps/i/ksi \\
\hline & mies & miehe/nä & mieh/i/nä & miehe/ksi & mieh/i/ksi \\
\hline \multirow{4}{*}{$\begin{array}{l}2.1 \text { Enstamma } \\
\text { nomen med } \\
\text { flerstava } \\
\text { vokalstamme på } \\
\text { kort vokal }\end{array}$} & meininki & meninki/nnä & $\begin{array}{l}\text { meninki/i/nä } \\
\text { meinink/i/nnä }\end{array}$ & $\begin{array}{l}\text { meiningi/ksi } \\
\text { meininki/ksi }\end{array}$ & $\begin{array}{l}\text { meningi/i/ksi } \\
\text { meinink/i/ksi }\end{array}$ \\
\hline & paijukko & paijukko/nna & paijuko/i/na & paijuko/ksi & paijuko/i/ksi \\
\hline & sivakka & sivakka/nna & sivako/i/na & sivaka/ksi & sivako/i/ksi \\
\hline & $\begin{array}{l}\text { valkea } \\
\text { valkia }\end{array}$ & $\begin{array}{l}\text { valkea/nna } \\
\text { valkia/nna }\end{array}$ & valke/i/na & $\begin{array}{l}\text { valkea/ksi } \\
\text { valkia/ksi }\end{array}$ & valke/i/ksi \\
\hline \multirow{6}{*}{$\begin{array}{l}2.2 \text { Tostamma } \\
\text { nomen med } \\
\text { flerstava } \\
\text { vokalstamme på } \\
\text { kort vokal }\end{array}$} & ty(t)är & tyttäre/nnä & tyttär/i/nnä & tyttäre/ksi & tyttär/i/ksi \\
\hline & elläin & elläime/nnä & elläim/i/nnä & elläime/ksi & elläim/i/ksi \\
\hline & tottuus & tottuute/nna & tottuuks/i/nna & tottuu(đ)e/ksi & tottuuks/i/ksi \\
\hline & veres & verekse/nnä & vereks/i/nnä & verekse/ksi & vereks/i/ksi \\
\hline & kokkous & $\begin{array}{l}\text { kokkoukse/ } \\
\text { na }\end{array}$ & kokkouks/i/na & kokkoukse/ksi & kokkouks/i/ksi \\
\hline & ihminen & inmise/nnä & inmis/i/nnä & inmise/ksi & inmis/i/ksi \\
\hline \multirow{3}{*}{$\begin{array}{l}\text { 3.1 Enstamma } \\
\text { nomen med } \\
\text { vokalstamme på } \\
\text { lang vokal }\end{array}$} & yö & yö/nä & ö/i/nä & yö/ksi & ö/i/ksi \\
\hline & tuorestai & tuorestai/na & tuoresta/i/na & tuorestai/ksi & tuoresta/i/ksi \\
\hline & kurkkii & kurkkii/na & kurkki/i/na & kurkkii/ksi & kurkki/i/ksi \\
\hline \multirow{5}{*}{$\begin{array}{l}3.2 \text { Tostamma } \\
\text { nomen med } \\
\text { vokalstamme på } \\
\text { lang vokal }\end{array}$} & rakas & rakkhaa/na & rakkha/i/na & rakkhaa/ksi & rakkha/i/ksi \\
\hline & ru(v)is & rukhii/na & rukhi/i/na & rukhii/ksi & rukhi/i/ksi \\
\hline & hylje(t) & hylkhee/nä & hylkhe/i/nä & hylkhee/ksi & hylkhe/i/ksi \\
\hline & perkele(t) & perkelhee/nä & perkelhe/i/nä & perkelhee/ksi & perkelhe/i/ksi \\
\hline & lukenu(t) & lukenhee/na & lukenhe/i/na & lukenhee/ksi & lukenhe/i/ksi \\
\hline
\end{tabular}




\subsubsection{Indre lokalkasus: inessiv, elativ, illativ}

De INDRE LOKALKASUSENE er INESSIV, ELATIV og ILLATIV. Inessiv bruker vi særlig i setningstypene STED (1) og EKSISTENS (2), mens elativ (3) og illativ (5) er vanlig i setningstypene BEVEGELSE og FLYTTING. I setningstypen RESULTAT markerer elativ korrelatet (4).

1. Met kävelemmä koijukossa.

'Vi går tur i bjørkeskog(en)'.

2. Koijukossa oon paljon mustikoita.

'Det er mye blæbær i bjørkeskogen.'

3. Läh(đ)emä koijukosta.

'Vi forlater bjørkeskogen.'

4. Mustikoista tullee hyvä safti.

'Det blir god saft av blåbær.'

5. Kotona menemä heti köökhiin.

'Heime går vi rett på kjøkkenet.'

Som vi har vært inne på før, så bruker vi vanligvis indre lokalkasus ved stedsnavn (6).

6. Sammeli siirtyi Kaarasjo(v)esta Pyssyjokheen.

'Samuel flytta fra Karasjok til Børselv'

Ettersom nesten alle bøyingsformene i indre lokalkasus inneholder konsonanten $s$, så kaller vi dem også for s-KAsus.

\subsubsection{Inessiv og elativ}

Både INESSIV og ELATIV bruker identiske suffiks i entall og flertall. Inessivsuffikset er -ssA, og elativsuffikset er -stA. Suffiksa festes både i entall og flertall på samme måte som translativsuffikset. Eksempler er (sg. nom. : sg. transl. : sg. iness. : pl. elat.) pappi ('prest') : papi/ksi : papi/ssa : papi/i/sta pap/i/sta, lapsi ('barn') : lapse/ksi : lapse/ssa : laps/i/sta, sivakka ('ski') : sivaka/ksi : sivaka/ssa : sivako/i/sta, ty(t)är ('jente; datter’) : tyttäre/ksi : tyttäre/ssä : tyttär/i/stä, rakas ('kjær') : rakkhaa/ksi : rakkhaa/ssa : rakkha/i/sta.

\subsubsection{Illativ}

ENTALL ILLATIV dannes med hjelp av tre suffiks: $-h V n,-h V V n$ og sseen. I flertall er flertalls-i-en flytta over på kasussuffikset, og illativ ender på hin, $h V i n$ og 
ssiin. Hovedregelen er at når suffikset i entall er - $h V n$, så bruker vi - hin i flertall, når suffikset i entall er $-h V V n$, så bruker vi - $h$ Vin i flertall, og når suffikset i entall er -sseen, så bruker vi -ssiin i flertall. Suffiksvokalen, som her er symbolisert med V, kan også være $i$. La oss se nærmere på hvordan disse suffiksa føyes til stammen i de ulike nomentypene:

- Illativ av nomen med enstava vokalstamme på lang vokal og to- eller flerstava nomen på diftong $V i$ (begge av type 3.1) danner vi ved å legge suffikset - $h V n$ til stammen. Suffiksvokalen $V$ er den samme som siste vokalen i stammen. På samme måte legger vi -hin til flertallsstammen. Vi får da illativsformer som (sg. nom. : sg. ill. : pl. ill.) puu ('tre') : puu/hun : pu/i/hin, tie ('veg') : tie/hen : te/i/hin, yö ('natt') : yö/hön : ö/i/hin, tuorestai ('torsdag') : tuorestai/hin : tuoresta/i/hin.

- Resten av type 3-nomen bruker illativsuffikset -sseen. Her slutter vokalstammen alltid på lang vokal. I flertall bruker vi suffikset -ssiin, som festes til flertallsstammen. Eksempler er (sg. nom. : sg. ill. : pl. ill.) korkkee ('høg') : korkkee/sseen : korkke/i/ssiin, lammas ('sau') : lamphaa/sseen : lampha/i/ssiin, terve( $t$ ) ('frisk') : tervhee/sseen : tervhe/i/ssiin, kuolu( $t$ ) ('død; dødd') : kuolhee/sseen: kuolhe/i/ssiin. Det noe særegne med ssiin-suffikset er at det også er brukt i flertall illativ av eA- og $i A$-nomen (type 2.1) i de skriftspråksvarietetene der disse fins. Som for eksempel i (sg. nom. : pl. ill.) valkea valkia ('bål, ild; kvit') : valke/i/ssiin, korkea korkia ('høg') : korke/i/ssiin. I entall illativ slutter disse nomena likevel på - $h V V n$ (se nedafor), for eksempel valke/haan valki/haan, korke/haan $\sim$ korki/haan.

- De andre nomentypene danner illativ ved at man tar samme stamme som i essiv (se avsnitt 5.3.4.1), men tar bort stammevokalen og legger i stedet til suffikset - $h V V n$. Suffiksvokalene VV er identiske med stammevokalen som er blitt tatt bort. I flertall vil det si at vi flytter de to siste vokalene i flertallsstemmen over på suffikset. Eksempler på illativsformer i entall og flertall er (sg. nom. : sg. ess. : sg. ill. : pl. ill.) (nomentype 1) aika ('tid') : aika/na : aik/haan : aik/hoin, joki ('elv') : joke/na : jok/heen : jok/hiin, juoppo ('dranker') : juoppo/na : juopp/hoon : juopp/hoin, (nomentype 2) mansikka ('markjordbær') : mansikka/nna: mansikk/haan : mansikk/hoin, tunturi ('fjellstrekning, vidde') : tunturi/nna : tuntur/hiin : tuntur/hiin, kurkkio ('foss') : kurkkio/nna : kurkki/hoon : kurkki/hoin, ty(t)är ('jente; datter') : tyttäre/nnä : tyttär/heen : tyttär/hiin, jänes ('hare') : jänekse/nnä : jäneks/heen : jäneks/hiin, ihminen ('menneske') : ihmise/nnä : ihmis/heen : ihmis/hiin. (Se også avsnitt 3.1.3 om $h$-flytting.)

Tabell 5.5 oppsummerer bøyingsformene for de indre lokalkasusene i kvensk. 
Tabell 5.5 Indre lokalkasus

\begin{tabular}{|c|c|c|c|c|c|}
\hline Nomentype & Entall nominativ & Entall elativ & Flertall elativ & Entall illativ & Flertall illativ \\
\hline \multirow{5}{*}{$\begin{array}{l}\text { 1.1 Enstamma } \\
\text { nomen med } \\
\text { tostava } \\
\text { vokalstamme } \\
\text { på kort vokal }\end{array}$} & aika & ai(j)a/sta & ai(j)o/i/sta & aik/haan & aik/hoin \\
\hline & mettä & mettä/stä & mett/i/stä & mett/hään & mett/hiin \\
\hline & joki & jo(v)e/sta & $\mathrm{jo}(\mathrm{v}) / \mathrm{i} / \mathrm{sta}$ & jok/heen & jok/hiin \\
\hline & pappi & papi/sta & pap(i)/i/sta & papp/hiin & papp/hiin \\
\hline & joukko & juopo/sta & juopo/i/sta & juopp/hoon & juopp/hoin \\
\hline \multirow{5}{*}{$\begin{array}{l}1.2 \text { Tostamma } \\
\text { nomen med } \\
\text { tostava } \\
\text { vokalstamme } \\
\text { på kort vokal }\end{array}$} & pieni & piene/stä & pien/i/stä & pien/heen & pien/hiin \\
\hline & käsi & kä(đ)e/stä & käs/i/stä & kät/heen & käs/hiin \\
\hline & hirsi & hirre/stä & hirs/i/stä & hirt/heen & hirs/hiin \\
\hline & lapsi & lapse/sta & laps/i/sta & laps/heen & laps/hiin \\
\hline & mies & miehe/stä & mieh/i/stä & mieh/heen & mieh/hiin \\
\hline \multirow{5}{*}{$\begin{array}{l}2.1 \text { Enstamma } \\
\text { nomen med } \\
\text { flerstava } \\
\text { vokalstamme } \\
\text { på kort vokal }\end{array}$} & tunturi & tunturi/sta & tuntur(i)/i/sta & tuntur/hiin & tuntur/hiin \\
\hline & paijukko & paijuko/sta & paijuko/i/sta & $\begin{array}{l}\text { paijukk/ } \\
\text { hoon }\end{array}$ & paijukk/hoin \\
\hline & sivakka & sivaka/sta & sivako/i/sta & sivakk/haan & sivakk/hoin \\
\hline & valkea valkia & $\begin{array}{l}\text { valkea/sta } \\
\text { valkia/sta }\end{array}$ & valke/i/sta & $\begin{array}{l}\text { valke/haan } \\
\text { valki/haan }\end{array}$ & valke/i/ssiin \\
\hline & kurkkio & kurkkio/sta & kurkkio/i/sta & kurkki/hoon & kurkki/hoin \\
\hline \multirow{8}{*}{$\begin{array}{l}2.2 \\
\text { Tostamma } \\
\text { nomen med } \\
\text { flerstava } \\
\text { vokalstamme } \\
\text { på kort vokal }\end{array}$} & ty(t)är & tyttäre/stä & tyttär/i/stä & tyttär/heen & tyttär/hiin \\
\hline & sisar & sisare/sta & sisar/i/sta & sisar/heen & sisar/hiin \\
\hline & elläin & elläime/stä & elläim/i/stä & elläim/heen & elläim/hiin \\
\hline & tottuus & $\begin{array}{l}\text { tottuu(đ)e/ } \\
\text { sta }\end{array}$ & tottuuks/i/sta & $\begin{array}{l}\text { tottuut/ } \\
\text { heen }\end{array}$ & tottuuks/hiin \\
\hline & veres & verekse/stä & vereks/i/stä & vereks/heen & vereks/hiin \\
\hline & kokkous & $\begin{array}{l}\text { kokkoukse/ } \\
\text { sta }\end{array}$ & $\begin{array}{l}\text { kokkouks/i/ } \\
\text { sta }\end{array}$ & $\begin{array}{l}\text { kokkouks/ } \\
\text { heen }\end{array}$ & kokkouks/hiin \\
\hline & inminen & inmise/stä & inmis/i/stä & ihmis/heen & inmis/hiin \\
\hline & sininen & sinise/stä & sinis/i/stä & sinis/heen & sinis/hiin \\
\hline \multirow{5}{*}{$\begin{array}{l}\text { 3.1 Enstamma } \\
\text { nomen med } \\
\text { vokalstamme } \\
\text { på lang vokal }\end{array}$} & maa & maa/sta & $\mathrm{ma} / \mathrm{i} / \mathrm{sta}$ & maa/han & $\mathrm{ma} / \mathrm{i} / \mathrm{hin}$ \\
\hline & yö & yö/stä & ö/i/stä & yö/hön & ö/i/hin \\
\hline & tuorestai & tuorestai/sta & tuoresta/i/sta & $\begin{array}{l}\text { tuorestai/ } \\
\text { hin }\end{array}$ & tuoresta/i/hin \\
\hline & valkkee & valkkee/sta & valkke/i/sta & $\begin{array}{l}\text { valkkee/ } \\
\text { sseen }\end{array}$ & valkke/i/ssiin \\
\hline & kurkkii & kurkkii/sta & kurkki/i/sta & $\begin{array}{l}\text { kurkkii/ } \\
\text { sseen }\end{array}$ & kurkki/i/ssiin \\
\hline
\end{tabular}




\begin{tabular}{|c|c|c|c|c|c|}
\hline Nomentype & Entall nominativ & Entall elativ & Flertall elativ & Entall illativ & Flertall illativ \\
\hline \multirow{5}{*}{$\begin{array}{l}3.2 \\
\text { Tostamma } \\
\text { nomen med } \\
\text { vokalstamme } \\
\text { på lang vokal }\end{array}$} & rakas & rakkhaa/sta & rakkha/i/sta & $\begin{array}{l}\text { rakkhaa/ } \\
\text { sseen }\end{array}$ & rakkha/i/ssiin \\
\hline & ru(v)is & rukhii/sta & rukhi/i/sta & rukhii/sseen & rukhi/i/ssiin \\
\hline & hylje(t) & hylkhee/stä & hylkhe/i/stä & $\begin{array}{l}\text { hylkhee/ } \\
\text { sseen }\end{array}$ & hylkhe/i/ssiin \\
\hline & perkele(t) & $\begin{array}{l}\text { perkelhee/ } \\
\text { stä }\end{array}$ & perkelhe/i/stä & $\begin{array}{l}\text { perkelhee/ } \\
\text { sseen }\end{array}$ & $\begin{array}{l}\text { perkelhe/i/ } \\
\text { ssiin }\end{array}$ \\
\hline & lukenu(t) & lukenhee/sta & lukenhe/i/sta & $\begin{array}{l}\text { lukenhee/ } \\
\text { sseen }\end{array}$ & lukenhe/i/ssiin \\
\hline
\end{tabular}

\subsubsection{Ytre lokalkasus: adessiv, ablativ, allativ}

AdEssiv, ABLATIV og ALLATIV kaller vi for YTRE LOKALKASUs i og med at når de opptrer i setningstypene STED (1), EKSISTENS (2) og BEVEGELSE (3, 4, 12), så markerer de som regel ledd som fokuserer på utsida eller overflata av et sted, ikke på innsida eller det indre. (Valget mellom indre og ytre lokalkasus er nærmere utgreid i avsnitt 4.5.4.)

Ytre lokalkasus markerer også eierleddet i setningstypene EIERSKAP (5) og EIERSKAPSENDRING (6). Bruken av adessiv i slike konstruksjoner likner på hvordan kasusen markerer subjektsplassen i modale oon pakko-setninger (7) og i tulla tehtyksi-konstruksjoner (8).

Ablativ brukes også i predikativledd i setningstypen PREDIKATIV SANS (9) og SANSETILSTAND (10).

Som frie adverbial kan adessivkonstruksjoner uttrykke redskapen (11) som ei handling utføres med. Til slutt er adessivkonstruksjoner også brukt i tidsuttrykk $(12,13)$.

1. Met istuma tuolila.

'Vi sitter på en stol / stolen.'

2. Kentälä seisoi paljon ihmistä.

'Det sto mye folk på sletta.'

3. Met tulima ulos kentäle.

'Vi kom ut på sletta.'

4. Het kävelthiin kentältä jo(v)ele.

'De gikk fra sletta og ned til elva' 
5. Liisala oon fini piili. 'Lisa har (en) fin bil.'

6. Liisa osti piilin Maijalta, mutta antoi sen sitte faarile.

'Lisa kjøpte en bil av Maija, men ga den siden til far.'

7. Lapsila oon lupa tierata.

'Barn har lov til å leke.'

8. Minula ei tullu läh(đ)etyksi hihtaamhaan.

'Jeg fikk meg ikke til å gå på ski.'

9. Paska hais(s)ee pahalta.

'Skit lukter vondt.'

10. Hyysikässä hais(s)ee paskalta.

'Det lukter skit på doen.'

11. Ämmi tuli kothiin sykkelillä.

'Bestemor kom heim på sykkel.'

12. Tule meile illala.

'Kom til oss i kveld / om kvelden.'

13. Kesälä täällä oon paljon sääskii sääskiä.

'Det er mye mygg her om sommeren.'

Alle ytre kasusformer inneholder konsonanten $l$ og kalles derfor også for l-kasus. Adessivsuffikset er -(l)lA, ablativsuffikset er -ltA, og allativsuffikset er -(l)le(t). (Variasjonen i de ulike varietetene mellom allativformer med og uten final $t$ er redegjort i avsnitt 3.2.2.) Suffiksa føyes til de samme stammene i entall og flertall som translativsuffikset og lokalkasussuffiksa i inessiv og elativ. Eksempler er (sg. nom. : sg. adess. : pl. all.) silta ('bru') : silla/la : sillo/i/le(t), hullu ('tulling') : hullu/la : hullu/i/le(t), lehti ('blad') : leh(đ)e/lä : leh(đ)/i/le(t), tooli ('stol') : tooli/la : tool( $i) / i / l e(t)$, mies ('mann') : miehe/lä : mieh/i/le $(t)$, rakastettu ('kjæreste') : rakastetu/la : rakastetu/i/le(t), sisar (søster') : sisare/lla : sisar/i/lle(t), veres ('fersk') : verekse/llä : vereks/i/lle(t), ruottalainen ('svenske; svensk') : ruottalaise/la : ruottalais/i/le(t), maa ('jord, land') : maa/la : $m a / i / l e(t)$, vapaa ('fri, ledig') : vaphaa/la : vapha/i/le(t), rakas ('kjær') : rakkhaa/la : rakkha/i/le(t), vene(t) 'båt') : venhee/lä : venhe/i/le(t).

I tabell 5.6 har vi sammenstilt de ulike bruksområda til lokalkasus der de markerer utfyllinga i setninga. 
Tabell 5.6 Bruk av lokalkasus

\begin{tabular}{|c|c|c|c|c|c|c|}
\hline Setningstype & Inessiv & Elativ & Illativ & Adessiv & Ablativ & Allativ \\
\hline STED & $x$ & & & $x$ & & \\
\hline BEVEGELSE & & $x$ & $x$ & & $x$ & $\mathrm{x}$ \\
\hline EKSISTENS & $x$ & & & $x$ & & \\
\hline FLYTTING & & $x$ & $x$ & & $x$ & $x$ \\
\hline EIERSKAP & & & & $x$ & & \\
\hline EIERSKAPSENDRING & & & & & $x$ & $x$ \\
\hline RESULTAT & & $x$ & & & & \\
\hline PREDIKATIV SANS & & & & & $x$ & \\
\hline SANSETILSTAND & & & & & $x$ & \\
\hline OON PAKKO-setning & & & & $x$ & & \\
\hline tulla tehtyksi-konstruksjon & & & & $x$ & & \\
\hline
\end{tabular}

\subsubsection{Følgekasus: Abessiv og komitativ}

Vi kaller her ABESSIV og комitATIV for FøLGEKASUs fordi de markerer ledd som forteller at noe eller noen er med eller ikke med i handlinga eller tilstanden som verbet uttrykker. Det fins faktisk også en tredje følgekasus i kvensk, såkalt INSTRUKTIV, som dannes med hjelp av suffikset -in, og som ikke har særskilte former for entall og flertall. Instruktiv er i liten grad produktiv, og instruktivformer kan ses på som adverb heller enn nomenformer. Grunnen til at vi likevel omtaler dem sammen med nomen, er at de kan knytte til seg kongruerende modifikatorer. Eksempler er (1-3):

1. Jänttevin jaloin hän teki matkaa ithään päin.

'Med seige skritt vandra han austover.'

2. Jos onni taas oli huonomanlaista, silloin täytyis mennä tyyhin käsin Kuosuvaaran taka eli sitte tyskälaisen myötä.

'Viss vi igjen skulle ha uflaks, så var det enten å dra tomhendt bak Kuosuvaara-fjellet eller å bli med tyskeren.'

3. Kahđen het kävelthiin hithaasti ja raskhain askelin päin kottii - kumpiki päin elämää.

'Sammen gikk de to sakte og med tunge steg heimover - og begge gikk mot livet.' 
(Eksempla ovafor er henta fra Alf Nilsen-Børsskogs roman Kuosuvaaran takana.)

Instruktivformer er sjeldne, og vi skal ikke diskutere dem nærmere her.

\subsubsection{Abessiv}

Med ABESSIV markerer vi ledd som uttrykker at noe eller noen mangler. Slike konstruksjoner kan brukes med (1) eller uten (2) preposisjonen ilman ('uten'). Abessiv er ei ganske vanlig bøyingsform, men vi kan også uttrykke det samme saksforholdet med hjelp av en adposisjonsfrase der preposisjonen ilman ('uten') tar ei utfylling i partitiv (3). Jamfør setningene 1-3, som alle betyr det samme.

1. [Ilman rahatta ja ruvatta] ihminen nälkkyy.

'Uten penger og mat sulter mennesket.'

2. Rahatta ja ruvatta ihminen nälkkyy.

3. [Ilman rahhaa ja ruokkaa] ihminen nälkkyy.

Suffikset i allativ er alltid -ttA, og det festes både i entall og flertall til samme stamme som er brukt i translativ. Eksempler er (sg. nom. : sg. transl. : sg. abess. : pl. abess.) silta ('bru') : silla/ksi : silla/tta : sillo/i/tta, mies ('mann') : miehe/ksi : miehe/ttä : mieh/i/ttä, sivakka ('ski') : sivaka/ksi : sivaka/tta : sivako/i/tta, ty(t)är ('jente; datter') : tyttäre/ksi : tyttäre/ttä : tyttär/i/ttä, työ ('arbeid') : työ/ksi : työ/ttä : tö/i/ttä, vaate(t) ('klesplagg') : vaatthee/ksi : vaatthee/tta : vaatthe/i/tta.

\subsubsection{Komitativ}

Komitativ er brukt som kasus i ledd som forteller at noe eller noen er med i den tilstanden eller handlinga som verbet uttrykker. Kasusen er spesiell på det viset at den ikke skiller mellom entalls- og flertallsformer, men at ei flertallsliknende form fungerer både i entall (1) og i flertall $(2,3)$. For eksempel:

1. Liisa tuli kylästelemhään miehinensä.

'Lisa kom på besøk sammen med mannen sin.'

2. Kentälä seisoi hevo(i)nen neuvoinensa.

'På gårdsplassen stod en hest med kjøreutstyr'.

3. Mie kiskoin kukkaset ylös juurinensa.

'Jeg røska opp blomstene med rota.'

Komitativ opptrer alltid sammen med possessivsuffikset, og bare i tredje person. (Possessivsuffiks er framstilt i avsnitt 5.4.) 
Komitativ er mindre brukt enn abessiv, og kasusen kan derfor ikke sies å være produktiv. Komitativformer kan alltid erstattes med adposisjonsfraser som består av kjernen kans ('med, sammen med') og utfylling i genitiv (4). I teorien kan vi likevel lage komitativformer av hvilket som helst nomen.

4. Mie kiskoin kukkaset ylös [juuriin juuritten kans].

\subsection{Possessivsuffiks}

Possessivsuffiks er suffiks som kan festes til substantiv, og som forteller hvem som eier noe, eller hvem noe hører til, eller at noe er knytta til subjektet og i mindre grad også objektet i setninga. Possessivsuffiks blir lagt etter de andre bøyingssuffiksa; enklitika derimot legges til heilt til slutt. Merk at genitivs- $n$ og flertalls- $t$ alltid faller bort foran possessivsuffiks.

Possessivsuffiks har de samme personformene som finitte verb eller personlige pronomen, det vil si første, andre og tredje person i entall og flertall. Formene i tredje person er identiske i entall og flertall. Tabell 5.7 viser possessivsuffiksa i kvensk.

Tabell 5.7 Possessivsuffiks

\begin{tabular}{|l|l|l|}
\hline Person & Entall & Flertall \\
\hline Første person & $-(n) n i$ & $-(m) m A$ \\
\hline Andre person & $-s t i$ & $-(n) n A$ \\
\hline Tredje person & $-n s A$ & $-n s A$ \\
\hline
\end{tabular}

Konsonantene $n$ og $m$ i possessivsuffiksa - $(n) n i,-(m) m A$ og - $(n) n A$ følger den vanlige lengderegelen for stemte konsonanter (se avsnitt 3.1.2). Jamfør eksemplene (1-4):

1. Tämä oon [minun kotini] / [meiđän $\sim$ meän kotima].

'Dette er heimen min/heimen vår.'

2. Se oon [sinun kirjasti] / [teiđän teän kirjana].

'Det er boka di / boka deres.'

3. Tuo oon [hänen talonsa] / [heiđän heän talonsa].

'Det der er huset hans/hennes / huset deres.'

4. Hän pesi jalkansa. Het pesthiin jalkansa.

'Han vasker foten sin / føttene sine. De vasker foten sin / føttene sine.' 
Possessivsuffiks er lite brukt i kvensk. Det vanlige er at substantiv opptrer uten possessivsuffiks. Jamfør eksemplene (5-7), som svarer til setningene i (1) - (3):

5. Tämä oon [minun koti] / [meiđän meän koti].

6. Se oon [sinun kirja] / [teiđän teän kirja].

7. Tuo oon [hänen talo] / [heiđän heän talo].

Når personen i subjektet og i possessivleddet ikke er identiske (5-7), er possessivleddet uttrykt med genitivsforma av personlig pronomen (se avsnitt 7.1). Disse svarer til possessiv i norsk. I første og andre person er dette også mulig når personen i subjektet og $\mathrm{i}$ possessivleddet er identiske $(8,9)$ :

8. $\mathrm{Mie}_{\mathrm{i}}{ }^{1}$ en asu ennää minun ${ }_{\mathrm{i}}$ kotipaikassa.

'Jeg bor ikke lenger på heimplassen min.'

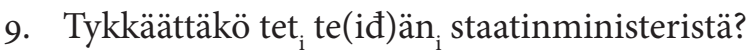

'Liker dere statsministeren deres?'

Derimot bruker man ikke genitivsform av personlig pronomen i tredje person når possessivleddet og subjektet viser til samme person. I stedet bruker man da adjektivet oma 'eigen', som kongruerer med frasekjernen etter de samme reglene som gjelder for adjektivmodifikatorer ellers (10-12):

10. Hän ${ }_{\mathrm{i}}$ pesi [omat ${ }_{\mathrm{i}}$ jalat].

'Han vaska føttene sine.'

11. Het ${ }_{\mathrm{i}}$ pesthiin [omat jalat]. $_{\mathrm{i}}$.

'De vaska føttene sine.'

12. Ihmisellä ${ }_{\mathrm{i}}$ ei ole helppo havata [omia $a_{\mathrm{i}}$ vikoja].

'Mennesket har ikke lett for å oppdage eigne feil.'

I stedet for oma bruker man særlig i Porsanger genitivsforma av refleksivt pronomen i samme person. Jamfør setningene (13-15), som betyr det samme som setningene (10-12). (Refleksive pronomen er omtalt i avsnitt 7.5.1.)

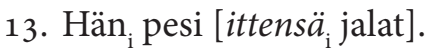

14. Het ${ }_{\mathrm{i}}$ pesthiin [ittens $\ddot{a}_{\mathrm{i}}$ jalat].

15. Ihmisellä ${ }_{i}$ ei ole helppo havaita [ittens $\ddot{a}_{\mathrm{i}}$ vikkoi].

1 Symbolet ${ }_{i}$ etter et ord eller en frase betyr at den har samme referent som et anna ord eller en annen frase med samme symbolet. 
Dette systemet likner altså på bruken av de refleksive possessivformene (sin, si, sitt, sine) i norsk.

I kvensk forekommer possessivsuffiks vanligvis bare sammen med substantiv i komitativ (se avsnitt 5.3.7.2), sammen med refleksive pronomen (16-18) og resiproke pronomen (19-21) (se avsnitt 7.5). Eksempler er:

16. $\mathrm{Mie}_{\mathrm{i}}$ en anna sitä ittelenni $i_{\mathrm{i}}$ antheeksi.

'Jeg kan ikke tilgi meg (sjøl for) dette.'

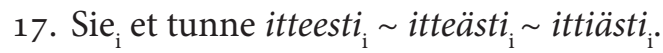

'Du kjenner ikke deg sjøl.'

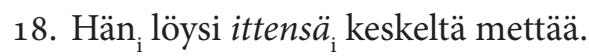

'Han fant seg sjøl midt i skogen.'

19. Met ${ }_{\mathrm{i}}$ rakastamma [toinen toistama ${ }_{\mathrm{i}}$.

'Vi elsker hverandre.'

20. Antakkaa ${ }_{\mathrm{i}}$ antheeksi [toinen toiselenna $a_{\mathrm{i}}$ !

'Tilgi hverandre!'

21. Vihathaanko het ${ }_{\mathrm{i}}\left[\right.$ toinen toistansa $\mathrm{i}_{\mathrm{i}}$ ?

'Hater de hverandre?'

Som stivna former finner vi possessivsuffiksa også i adverb. De har da blitt en del av adverbet og oppfattes ikke lenger som egentlige possessivsuffiks. Adverb av denne typen er for eksempel aikoinansa ('i si tid'), erilänsä ('atskilt'), justhiinsa ('nøyaktig, aldeles'), keskenänsä ('seg imellom'), kokonhansa ('heilt'), umpinansa ('lukka, tildekt').

\subsection{Gradbøying}

Det er vanlig å behandle gradbøying som en del av adjektivbøyinga. Men ser vi på suffiksrekkefølgen, så blir det fort klart at gradbøyingssuffiks har samme plassering som avleiingssuffiks. Eller med andre ord er det mulig å legge til et avleiingssuffiks etter gradbøyingssuffikset, for eksempel: huono ('dårlig') $\rightarrow$ (komparativ) huono/mpi ('dårligere') $\rightarrow$ (egenskapssubstantiv) huono/m/uus ('det å være dårligere').

Det gjelder generelt i kvensk at avleiingssuffiks ikke kan følge etter bøyingssuffiks. Det er også slik at gradbøyde adjektiv bøyes og ellers oppfører seg på samme måte som andre adjektiv. 
Men ettersom gradbøying er et fullstendig produktivt morfologisk mønster ved alle adjektiv og en del substantiv, så behandler vi den her som del av nomenbøyinga. Vi skiller mellom tre grader: positiv, komparativ og superlativ. Positiv er den umarkerte graden og har ikke noe suffiks (for eksempel iso 'stor'). Komparativ uttrykker større grad (for eksempel isompi 'større'), og superlativ størst grad (for eksempel issoin 'størst') av det adjektivet (og i visse tilfeller substantivet) står for.

\subsubsection{Komparativ}

Komparativ dannes ved at en til vokalstammen legger suffikset - mpi i nominativ og $-m p(p) A:-m(m) A$ i de andre kasusene. Stammen er på samme stadiet som i genitiv i nomentype 1 og 2.1, det vil si på det svakeste stadiet. De andre nomentypene har bare én vokalstamme, og suffikset festes da til denne. Når vokalstammen er tostava og slutter på $-A$, så endres denne stammevokalen til $e$. Slutter vokalstammen på $i$, så kan vi velge om vi vil bevare $i$-en, eller om vi vil erstatte den med $e$ foran komparativsuffikset. Når sluttvokalen $A$ i komparativsuffikset møter flertalls-i-en, så er resultatet alltid $i$. Vi får da følgende former i de ulike nomentypene (sg. nom. : sg. gen. : sg. part. : pl. part.):

Nomentype 1.1:

paha ('ondskapsfull, ond') $\rightarrow$ pahe/mpi : pahe/ma/n : pahe/mp(p)a/a : pahe/mpp/ii(ta) pahe/mp/i/a,

märkä ('våt') $\rightarrow$ mär $(j) e / m p i: m \ddot{r}(j) e / m \ddot{a} / n: m a ̈ r(j) e / m p(p) \ddot{a} / \ddot{a}:$ märe/mpp/ii(tä) mär(j)emp/i/ä,

villi ('vill') $\rightarrow$ villi/mpi $\sim$ ville/mpi : villi/mä/n ville/mä/n : villi/mp(p) $\ddot{a} / \ddot{a} \sim$

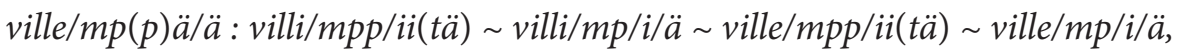
outo ('uvanlig; rar') $\rightarrow$ ou $(đ) o / m p i: o u(đ) o / m a / n: o u(đ) o / m p(p) a / a$ : oudo/mpp/ii(ta) ou'o/mp/i/a

Nomentype 1.2:

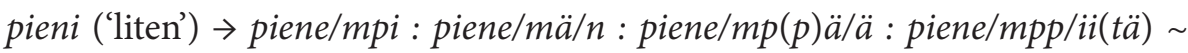
piene/mp/i/ä,

uusi ('ny') $\rightarrow$ uu(đ)e/mpi : uu(đ)e/ma/n : uu(đ)e/mp(p)a/a : uude/mpp/ii(ta) uиe/mp/i/a

Nomentype 2.1:

harmaja ('grå) $\rightarrow$ harmaja/mpi : harmaja/mma/n : harmaja/mp(p)a/a : harmaja/mpp/ii(ta) harmaja/mp/i/a, 
valkea ('lys') valkia $\rightarrow$ valkea/mpi $\sim$ valkia/mpi : valkea/mma/n valkia/mma/n:valkea/mpa/a valkia/mpa/a : valkea/mp/i/a valkia/mp/i/a, suipero ('spiss') $\rightarrow$ suipero/mpi : suipero/mma/n : suipero/mp(p)a/a : suipero/mpp/ii(ta) suipero/mp/i/a

\section{Nomentype 2.2:}

onneton ('ulykkelig') $\rightarrow$ onnettoma/mpi : onnettoma/ma/n : onnettoma/mp $(p) a / a$ : onnettoma/mpp/ii(ta) onnettoma/mp/i/a,

veres ('fersk') $\rightarrow$ verekse/mpi : verekse/mmä/n : verekse/mp(p)ä/ä : verekse/mpp/ii(tä) verekse/mp/i/ä,

sininen ('blå) $\rightarrow$ sinise/mpi : sinise/mmä/n : sinise/mp $(p) \ddot{a} / \ddot{a}:$ sinise/mpp/ii(tä) sinise $/ m p / i / \ddot{a}$

Nomentype 3.1:

valkkee ('lys') $\rightarrow$ valkkee/mpi : valkkee/ma/n : valkkee/mppa/a : valkkee/mpp/ii(ta), vapaa ('fri, ledig') $\rightarrow$ vaphaa/mpi : vaphaa/ma/n : vaphaa/mp(p)a/a : vaphaa/mpp/ii(ta) vaphaa/mp/i/a

Nomentype 3.2:

rakas ('kjær') $\rightarrow$ rakkhaa/mpi : rakkhaa/ma/n : rakkhaa/mp(p)a/a : rakkhaa/mpp/ii(ta) rakkhaa/mp/i/a,

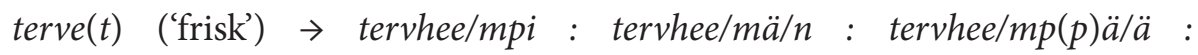
tervhee/mpp/ii(tä) tervhee/mp/i/ä,

rakastunu $(t)$ ('elska') $\rightarrow$ rakastunhee/mpi : rakastunhee/ma/n : rakastunhee/mp $(p) a / a:$ rakastunhee/mpp/ii $($ ta $) \sim$ rakastunhee/mp/i/a.

Adjektivet vasen ('venstre') bøyes på samme måte som ord i komparativ form: (sg. nom. : sg. gen. : sg. part. : pl. part.) vasen : vasema/n : vasemp(p)a/a : vasempp/ii (ta) $\sim$ vasemp/i/a.

\subsubsection{Superlativ}

Superlativ danner vi med suffikset -(i)in i nominativ, og -(i)im(m)A:(i) $\operatorname{imp}(p) A$ i de andre kasusene. I vokalstammer faller stammevokalene $e$ og $A$ bort foran superlativs-i-en, og suffikset blir da -iin : -iim $(m) A$ : -iimp $(p) A$. I de andre vokalstammene står $i, O$ og $U$ ved lag, og $V V$ blir forkorta til $V$. Superlativsuffikset blir da $-i n:-i m(m) A:-i m p(p) A$. 
I nomentype 1 og 2 fester vi superlativsuffikset som regel til vokalstammen på sterkest mulig stadium. Men med unntak av Porsanger-varieteten er det slik at dersom stammekonsonanten i positiv grad er en av plosivene $k, t$ eller $p$, så er stammen i superlativ ett stadium svakere enn i positiv grad.

I entall partitiv legger vi superlativssuffikset til en konsonantstamme som er identisk med superlativforma i entall nominativ. Ellers bøyes superlativsformene på samme måte som komparativ. Eksempler fra de ulike nomentypene er (sg. nom. : sg. gen. : sg. part. : pl. part.):

Nomentype 1.1:

paha ('ondskapsfull, ond') $\rightarrow$ pahh/iin : pahh/iima/n : pahh/iin/ta : pahh/iimpp/ii(ta) pahh/iimp/i/a,

märkä ('våt') $\rightarrow$ märkk/iin märj/iin : märk $(k) /$ iimä/n $\sim$ märj/iimä/n : märkk/iin/tä märj/iin/tä : märkk/iimpp/ii(tä) märj/iimp/i/ä,

villi ('vill') $\rightarrow$ villi/in : villi/imä/n : villi/in/tä : villi/impp/ii(tä) villi/imp/i/ä, outo ('uvanlig, rar') $\rightarrow$ outto/in ou'o/in : outto/ima/n ou'o/ima/n:outto/in/ta $\sim$ ou'o/in/ta : outto/impp/ii(ta) ou'o/imp/i/a

Nomentype 1.2:

pieni ('liten') $\rightarrow$ pien/iin : pien/iimä/n : pien/iin/tä : pien/iimpp/ii(tä) pien/iimp/i/ä,

uusi ('ny') $\rightarrow$ uus(s)/iin : uus(s)/iima/n : uus(s)/iin/ta : uuss/iimpp/ii/ta uus/iimp/i/a

Nomentype 2.1:

harmaja ('grå') $\rightarrow$ harmaj/iin : harmaj/iima/n : harmaj/iin/ta : harmaj/iimpp/ii(ta) $\sim$ harmaj/ii/mp/i/a, valkea ('kvit') valkia $\rightarrow$ valke/in : valke/ima/n : valke/in/ta : valke/imp/i/a, suipero ('spiss') $\rightarrow$ suipero/in : suipero/ima/n : suipero/in/ta : suipero/impp/ii(ta) $\sim$ suipero/imp/i/a

Nomentype 2.2:

onneton ('ulykkelig') $\rightarrow$ onnettomm/iin : onnettomm/iima/n : onnettomm/iin/ta : onnettomm/iimpp/ii/ta onnettomm/iimp/i/a,

veres ('fersk') $\rightarrow$ vereks/iin : vereks/iimä/n : vereks/iin/tä : vereks/iimpp/ii(tä) vereks/iimp/i/ä,

sininen ('blå') $\rightarrow \operatorname{sinis(s)/iin~:~sinis(s)/iimä/n~:~sinis(s)/iin/tä~:~siniss/iimpp/ii(tä)~~~}$ sinis/iimp/i/ä 
Nomentype 3.1:

valkkee ('lys') $\rightarrow$ valkke/in : valkke/ima/n : valkke/in/ta : valkke/impp/ii(ta)

\section{Nomentype 3.2:}

rakas ('kjær') $\rightarrow$ rakkha/in : rakkha/ima/n : rakkha/in/ta : rakkha/impp/ii(ta) rakkha/imp/i/a,

terve $(t)$ ('frisk') $\rightarrow$ tervhe/in : tervhe/imä/n : tervhe/in/tä : tervhe/impp/ii(tä) tervhe/imp/i/ä, rakastunu( $t$ ) ('elska') $\rightarrow$ rakastunhe/in : rakastunhe/ima/n : rakastunhe/in/ta : rakastunhe/impp/ii $($ ta $) \sim$ rakastunhe/imp/i/a

I Varanger er det også mulig å danne superlativsformer med gjennomført kort $i$ i suffikset, det vil si -in : $-i m(m) A:-i m p A$, og med stamme på ett stadium lågere enn i positiv grad. Vi får da superlativsformer av typen paha ('ondskapsfull, ond') $\rightarrow$ pah/i/n : pah/ima/n : pah/in/ta : pah/imp/i/a. Men dette er ikke noe vanlig mønster for superlativ.

Tabell 5.8 lister opp de viktigste bøyingsformene i komparativ og superlativ for tre ulike nomentyper.

Tabell 5.8 Gradbøying

\begin{tabular}{|c|c|c|c|}
\hline Positiv & Form & Komparativ & Superlativ \\
\hline \multirow[t]{10}{*}{ paha } & Sg. nom. & pahe/mpi & pahh/iin \\
\hline & Sg. gen. & pahe/ma/n & pahh/iima/n \\
\hline & Sg. part. & pahe/mp(p)a/a & pahh/iin/ta \\
\hline & Sg. ess. & pahe/mpa/nna & pahh/iimpa/nna \\
\hline & Sg. ill. & pahe/mp/haan & pahh/iimp/haan \\
\hline & PI. nom. & pahe/ma/t & pahh/iima/t \\
\hline & Pl. gen. & pahe/m/i(i)/tten & pahh/iim/i(i)/tten \\
\hline & PI. part. & pahe/mpp/ii(ta) pahe/mp/i/a & pahh/iimpp/ii(ta) pahh/iimp/i/a \\
\hline & Pl. ess. & pahe/mp/i/nna & pahh/iimp/i/nna \\
\hline & PI. ill. & pahe/mp/hiin & pahh/iimp/hiin \\
\hline \multirow[t]{5}{*}{ harmaja } & Sg. nom. & harmaja/mpi & harmaj/iin \\
\hline & Sg. gen. & harmaja/mma/n & harmaj/iimma/n \\
\hline & Sg. part. & harmaja/mp(p)a/a & harmaj/iin/ta \\
\hline & Sg. ess. & harmaja/mpa/na & harmaj/iimpa/na \\
\hline & Sg. ill. & harmaja/mp/haan & harmaj/iimp/haan \\
\hline
\end{tabular}

(Fortsatt) 
Tabell $\mathbf{5 . 8}$ (Fortsatt)

\begin{tabular}{|c|c|c|c|}
\hline \multirow[t]{6}{*}{ Positiv } & Form & Komparativ & Superlativ \\
\hline & PI. nom. & harmaja/mma/t & harmaj/iima/t \\
\hline & Pl. gen. & harmaja/mm/i(i)/tten & harmaj/iim/i(i)/tten \\
\hline & PI. part. & $\begin{array}{l}\text { harmaja/mpp/ii(ta) harmaja/ } \\
\text { mp/i/a }\end{array}$ & $\begin{array}{l}\text { harmaj/iimpp/ii(ta) harmaj/ } \\
\text { iimp/i/a }\end{array}$ \\
\hline & Pl. ess. & harmaja/mp/i/na & harmaj/iimp/i/na \\
\hline & PI. ill. & harmaja/mp/hiin & harmaj/iimp/hiin \\
\hline \multirow[t]{10}{*}{ rakas } & Sg. nom. & rakkhaa/mpi & rakkha/in \\
\hline & Sg. gen. & rakkhaa/ma/n & rakkha/ima/n \\
\hline & Sg. part. & rakkhaa/mp(p)a/a & rakkha/in/ta \\
\hline & Sg. ess. & rakkhaa/mpa/nna & rakkha/impa/nna \\
\hline & Sg. ill. & rakkhaa/mp/haan & rakkha/imp/haan \\
\hline & PI. nom. & rakkhaa/ma/t & rakkha/ima/t \\
\hline & Pl. gen. & rakkhaa/m/i(i)/tten & rakkha/im/i(i)/tten \\
\hline & PI. part. & $\begin{array}{l}\text { rakkhaa/mpp/ii(ta) rakkhaa/ } \\
\mathrm{mp} / \mathrm{i} / \mathrm{a}\end{array}$ & $\begin{array}{l}\text { rakkha/impp/ii(ta) rakkha/imp/ } \\
\text { i/a }\end{array}$ \\
\hline & Pl. ess. & rakkhaa/mp/i/nna & rakkha/imp/i/nna \\
\hline & PI. ill. & rakkhaa/mp/hiin & rakkha/imp/hiin \\
\hline
\end{tabular}

Noen få adjektiv har uregelmessig gradbøying eller såkalt suppletiv gradbøying, det vil si at stammen i positiv er forskjellig fra stammen i komparativ og/ eller superlativ:

hyvä ('bra, god') $\rightarrow$ parempi - parhain paras

huono ('dårlig') $\rightarrow$ huonompi värrempi - huonoin

pitkä ('lang') $\rightarrow$ pitempi piđempi - pissiin

lyhy(t) ('kort') $\rightarrow$ lyhempi - lyhhiin

ohu $(t)$ ('tynn') $\rightarrow$ ohempi - ohhuin

vanhaa ('gammal') $\rightarrow$ vanhempi - vanhiin

Av og til dannes superlativ med suffikset -(i)mUs. Vanligst er slike former ved adjektiva (vanhaa 'gammal' $\rightarrow$ ) vanhimus, (paha 'ondskapsfull, ond' $\rightarrow$ ) pahimus og (iso 'stor' $\rightarrow$ ) isomus, men de kan også dannes av andre adjektiv. 
Suffikset - $m U s$ bøyes etter samme mønster som veres-nomen (type 2.2), det vil si (sg. nom. : sg. gen. : sg. part. : pl. nom.) pahimus ('dårligst') : pahimukse/n : pahimus/ta : pahimukse/t, pimmeemys ('mørkest') : pimmeemyksen/n : pimmeemys/tä: pimmeemykse/t.

\subsubsection{Bruk av komparativ og superlativ}

Komparativ- og superlativformer brukes på samme måte som positivformer av adjektiv. Når de står som modifikatorer, kongruerer de med hovedleddet. Jamfør eksemplene (1-4):

1. Taivas oli kirkkhaampi ko koskhaan ennen. 'Himmelen var klarere enn noen gang før.'

2. Muorin pannukakot oon parhaat. 'Mors pannekaker er de beste.'

3. Liisa ja Maija oon [viishaimat tyttäret] koko koulussa. 'Lisa og Maja er de klokeste jentene på heile skolen.'

4. Ojena, ole siivo, minule tuon [piđemän pitemän kepin]. 'Vær så snill og rekk meg den lengre/lengste stokken.'

I jamføring mellom to bruker vi komparativ i kvensk, ikke superlativ, som i norsk. For eksempel (5-7):

5. Kumpi oon kaunhiimpi, Liisa vain Maija? 'Hvem er vakrest, Lisa eller Maja?'

6. Näistä kah(đ)esta tyttärestä Anna-Riitta oon vaaleempi vaaleampi vaaliampi.

'Det er Anna-Riitta som er lysest av disse to jentene.'

7. Faari ja muori paistethiin pannukakkoi. Niistä muorin paistamat oon makkeemat.

'Far og mor har laga pannekaker. Mor sine er best.'

Legg også merke til at vi i komparativkonstruksjoner bruker den samme subjunksjonen, $k o$ ('som, enn'), som i konstruksjoner der vi jamfører to enheter av lik grad. For eksempel $(8,9)$ : 
Jamføring av ulik grad

8. Liisa oon viishaampi ko Maija. 'Lisa er klokere enn Maja.'

9. Nämät kakot tässä oon makkeemat $\sim$ makeammat $\sim$ makiammat ko nuot tuossa.

'De her kakene er bedre enn de der'.
Jamføring av lik grad Liisa oon yhtä viisas ko Maija. 'Lisa er like klok som Maja'.

Nämät kakot tässä oon $y h t a ̈$ makkeet $\sim$ makeat $\sim$ makiat ko nuot tuossa.

'De her kakene er like gode som de der.'

Som forsterkende element i superlativkonstruksjoner kan vi bruke genitivsforma av ordet kaikki ('alle'), jf. eksemplene $(10,11)$ :

10. Liisa oon kaikkiin viishain ja kaunhiin. 'Lisa er den aller klokeste og vakreste.'

11. Matti tietenki halus ostaat [kaikkiin kalliiman piilin]. 'Mats ønska sjølsagt å få kjøpt den aller dyreste bilen.' 


\section{6}

\section{Verbbøying}

\subsection{Verbbøyingskategorier}

Enhver fullstendig setning inneholder et verbal, og vi sier derfor at verbalet utgjør kjernen i setninga. Verbalet i setninga kan ta ei eller flere utfyllinger, og det bestemmer også hvilken form utfyllinga har.

Verbet har mange bøyingskategorier. Et overordna skille går mellom FINITTE og INFINITTE verbformer, som hver har sine bøyingskategorier.

- Finitte verbformer er verbformer som aleine kan fungere som verbal i ei setning. De er alltid bøyd i PERSON og TID, som for eksempel i første person flertall presens $(1,2)$ eller første person entall presens (3). Når verbformene er knytta til et subjekt, eller når det er mulig å legge til et subjekt, så kaller vi dem for AKTIVE VERBFORMER, og de danner da kjernen i AKTIVE SETNINGER. Når de ikke er knytta til noe subjekt og det heller ikke er mulig å legge til et subjekt, så har vi med PASSIVE VERBFORMER å gjøre, og setningene kaller vi tilsvarende for PASSIVE SETNINGER $(4,5)$. Eksempler er:

1. Met lähđemä Alattihoon.

'Vi drar til Alta'

2. Met syömä ruokkaa.

'Vi spiser mat.'

3. Mie lähđen huomena Alattihoon.

'Jeg drar til Alta i morgen.'

4. Alattion korkkeekoulussa opetethiin varhemin suomen kieltä.

'På Høgskolen i Alta blei det tidligere undervist i finsk'.

5. Sitte sitä heitethiin opettamasta.

'Så slutta man å undervise i det.' 
Som i norsk er det to TIDSFORMER (TEMPUS) i kvensk: PRESENS Og PRETERITUM. I tillegg kan vi lage to SAMMENSATTE TIDSFORMER: PRESENS PERFEKTUM og PRETERITUM PERFEKTUM. Disse tidsformene brukes i stor grad som på norsk. I likhet med norsk har heller ikke kvensk eigne former for framtid (futurum). I stedet bruker man presensformer, jamfør setningene ovafor, som står i presens $(1-3)$ og preteritum $(4,5)$.

Kvenske verb bøyes også i Modus, det vil si at de enten står i INDIKATIV, KONDISJONALIS eller IMPERATIV. Vi bruker indikativ (6) når verbet skildrer et nøytralt saksforhold, kondisjonalis (7) når det er knytta visse forbehold eller betingelser til utsagnet, og imperativ (8) i setninger som befaler eller oppfordrer noen til å gjøre noe.

6. Met istuma tässä lomassa.

'Vi sitter på dette rommet.'

7. Met istuisimma tässä lomassa, jos halluisimma.

'Vi skulle sitte på dette rommet viss vi ville det.'

8. Istukkaa tässä lomassa!

'Sitt [til flere] på dette rommet.'

- InfinitTe VerbFormer kan ikke opptre i vanlige setninger uten finitte verbformer. For eksempel:

9. Mie hää (đ)yn lähtee $(t) \sim$ lähteä $(t) \sim$ lähtiä kothiin.

'Jeg må dra heim.'

10. Mie olen lähteny $(t)$ kothiin.

'Jeg er dratt heim.

11. Nilla kuului käynheen Kööpenhaminassa.

'Nils skal ha dratt til København.'

Infinitte verbformer er infinitiv som for eksempel lähteet $~$ lähteä $(t) \sim$ lähtiä ('dra av gårde') i setning (9) og partisipp som for eksempel lähteny(t) (av lähteet lähteä $(t) \sim$ lähtiä ('dra av gårde') i setning (10) og käynheen (av käyđä 'dra en tur') i setning (11). Det fins flere typer infinitiv og partisipp, og vi skal se nærmere på dem i avsnitt 6.8. Vi minner allerede nå om at den såkalte 1. infinitiven er den verbforma som er oppført som oppslagsform i ordbøker og ordlister. 


\subsection{Verbbøyingstyper}

I likhet med nomena kan vi også dele verba inn i grupper basert på hva slags stammer de har, og hvordan bøyingssuffiksa festes til disse stammene. Med STAMME meiner vi her den delen av ordet som bøyingssuffiks legges til (se avsnitt 2.3.3). Eller for å si det på en annen måte: Vi finner stammen ved å ta bort alle bøyingssuffiksa, men ikke avleiingssuffiksa. Vi skiller her mellom fire hovedbøyingstyper med utgangspunkt i hva slags stamme verba har:

- Verbstammen består av bare én stavelse: bøyingstype 1, ENSTAVA VERB.

- Verbstammen har bare vokalstamme, men den har flere enn én stavelse: bøyingstype 2, ENSTAMMA VERB.

- Verbet har i tillegg til vokalstammen også konsonantstamme: bøyingstype 3, VERB med KONSONANTSTAMME.

- Verb som ikke har konsonantstamme, men som har to vokalstammer, det vil si kort og lang vokalstamme: bøyingstype 4, VERB med to VOKALSTAMMER.

Type 3 og 4 deler vi videre inn i undergrupper etter hvilke avleiingssuffiks de har. Her er det viktig å være klar over at lydendringer i stammen som skyldes stadieveksling, ikke har noen innvirkning på hvilken bøyingstype et verb hører til. Nedafor skal vi ta for oss de ulike verbbøyingstypene, som vi her for enkelthets skyld kaller for VERBTYPER. Ei sammenfattende oversikt over de ulike verbtypene med undertyper er satt opp i tabell 6.1 heilt til slutt i denne gjennomgangen.

\subsubsection{Verbtype 1: enstava verb}

EnstaVA VERB (verbtype 1) er verb med bare én stamme (vokalstamme), som består av bare én stavelse, og som danner 1. infinitiv med suffikset - ¿A eller - $h A \sim-A$. Eksempler på slike verb er (1. inf. : 1. sg. pres.) saa/ đa saa/ha ('fă) : saa/n, juo/đa juu/a ('drikke') : juo/n, syö/đä syy/ä ('spise') : syö/n.

Forma på suffikset i 1 . infinitiv varierer mellom de ulike varietetene: I Porsanger brukes alltid - $₫ A$, mens de andre varietetene kan ha $-h A$ eller $-A$.

Til denne gruppa regner vi her også verbet käy/ đä käy/ä ('dra en tur'), som rett nok har blanda bøying: I bekreftende form aktiv preteritum og kondisjonalis bruker vi tostavelsesstammen käve-, og verbet bøyes da etter mønster av verbtype 2. Verbet bøyes altså slik: käy/ä̈ käy/ä: käy/n:käv/i/n:käy/ny(t). I de ulike varietetene finner vi også denne bøyinga: käy/dä käy/ä : käve/n :käv/i/n: käy/ny. 


\subsubsection{Verbtype 2: enstamma verb}

Enstamma verb (verbtype 2) er to- eller flerstava verb som bare har vokalstamme. Stammevokalen er en enkelt vokal. Stammen kan gjennomgå stadieveksling, og stammekonsonanten eller konsonantkombinasjonen kan derfor skifte under bøyinga.

Til gruppa av enstamma verb hører alle verb som i 1 . infinitiv slutter på $V_{1} / V_{2}(t)$, det vil si to vokaler og valgfri $t$ (se avsnitt 3.2.2 om ordfinal $t$ ). I Porsanger og Nordreisa er suffiksvokalen i 1. infinitiv $\left(V_{2}\right)$ utjamna med stammevokalen $\left(V_{1}\right)$, det vil si at vi får én lang vokal $(V V t)$. De andre varietetene bruker $-A$ som suffiksvokal. Stammevokalen $\left(V_{1}\right)$ kan være $e, i, A(=a$ eller $\ddot{a}), U(=u$ eller $y$ ) eller $o$. Av verba som opprinnelig hører til denne gruppa (verbtype 2a; se nedafor), er det bare tostava stammer som kan slutte på -e. Eksempler er: (1. inf. : 1. sg. pres.) häytty/yt häyty/ä(t) ('måtte') : $h \ddot{a} y(d) y / n$, lähtelet lähte/ä $(t) \sim$ lähti/ä ('dra av gårde') : läh(d)eln, lukkelet $\sim \operatorname{luke/a}(t) \sim \operatorname{luki} / a$ ('lese') : lu(j)e/n, tiet(t)älä(t) ('vite') : tie(đ)äln tiiä/n, varasta/a( $t$ ) ('stjele') : varasta/n, loukkaanttu/ut loukkaantu/a(t) ('bli såra, bli skada') : loukkaanu/n.

Spesielt i varietetene i Nord-Troms er det en tendens til at verb av type 3.2, 3.3 4.1, 4.2 og 4.3 (se nedafor) går over til å bli bøyd etter mønster av verbtype 2. Vi grupperer dem her $i$ undergruppe $2 b$ (til forskjell fra de opprinnelige verba av type 2, som vi kaller for verbtype 2a). Velger man å skrive på en skriftspråksvariant basert på varietetene i Nord-Troms, så kan man altså bruke verbbøyingsformer etter type $2 \mathrm{~b}$. Vi kaller slike verb her for OVERGANGSVERB, og stammene deres tilsvarende for OVERGANGSSTAMMER. Disse stammene består alle av flere - det vil si flere enn to - stavelser, og de slutter på $e$. Dette er en ny verbtype: Etter den opprinnelige inndelinga er alle e-stammeverb bare tostava (se ovafor). Legg også merke til at to undergrupper av denne nye verbtypen, nemlig verb av typen valittela( $(t)$ ('velge') og verb av typen piikaroittela( $t$ ) ('spikre'), unngår stadieveksling, på samme måte som verb med to vokalstammer (se type 4 nedafor). Vi får da følgende bøyingsformer av overgangsverb (1. inf. : 1. sg. pres. : perf. pts.): muistele/a(t) ('fortelle') : muistele/n : muistele/nnu, ajattele/a(t) ('tenke') : ajattele/ $n:$ ajattele/nu(t), aukaste/a(t) ('åpne') : aukase/ $n$ : aukase/nnu( $(t)$, halkasela(t) ('kløyve') : halkase/n : halkase/nnu( $(t)$, tärise/ä( $(t)$ ('dirre') : tärise/n : tärise/nny $(t)$, valittela( $t$ ) ('velge') : valitte/n : valitte/nnu( $t$ ), havattela $(t)$ ('merke') : havatte/n : havatte/nnu( $t$ ), piikaroitte/a(t) ('spikre') : piikaroitte/n : piikaroitte/nu(t), haravoittela(t) ('rake') : haravoitte/n : 
haravoitte/nu(t), likene/ä( $($ ) ('nærme seg') : likene/n : likene/nny $(t)$, vanhenel $a(t)$ ('bli eldre') : vanhene/ $n$ : vanhene/nnu( $t$ ).

Dersom en ikke ønsker å bøye disse verba etter dette nye systemet, så kan en bare se bort fra verbtype $2 b$.

\subsubsection{Verbtype 3: verb med konsonantstamme}

VERB med KONSONANTSTAMME (verbtype 3) har både vokalstamme og konsonantstamme. Konsonantstammen er brukt i 1 . infinitiv, og den slutter alltid på $l, n$, $r$ eller $s$. Vokalstammen slutter alltid på $e$. Verbtype 3 har disse tre undergruppene:

- Til verbtype 3.1 hører mange tostava verb med vokalstamme på $e$. Konsonantstammen slutter på enkelt $l, n, r$ eller $s$. I tillegg regner vi hit de to

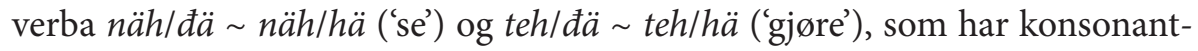
stamme på $h$. Når konsonantstammen slutter på s, så kan vokalstammen i tilsvarende posisjon ha konsonantsambandet ks. For eksempel: (1. inf. : 3. sg. pres. : 1. sg. pres.) tul/la ('komme') : tulle/e : tule/n, men/nä ('gå') : menne/e : mene/n, juos/ta ('springe') : juoksele : juokse/n, näh/đä näh/hä ('se') : näkke/e : nä(j)e/n, ol/la ('være') : oon (sic!) : ole/n.

- Vokalstammen i verb av verbtype 3.2 slutter på ele ile, og konsonantstammen slutter tilsvarende på el $\sim i l$, som for eksempel i (1. inf. : 3. sg. pres. : 1. sg. pres.) muistel/a ('fortelle') : muistele/e : muistele/n, kävel/ä ('spasere, gå) : kävelele : kävele/n, ajatel/la ('tenke') : ajattelle/e : ajattele/n, rukkoil/a ('bønnfalle, be') : rukkoile/e : rukkoile/n.

- Verb av verbtype 3.3 har vokalstamme som slutter på $A(i)$ se eller ise, og konsonantstamme som slutter på $A(i) s$ eller is, som for eksempel i (1. inf. : 3 . sg. pres. : 1. sg. pres.) auka(i)s/ta ('åpne') : auka(i)s(s)e/e : auka(i)se/n, täris/tä ('dirre') : täris(s)e/e : tärise/n.

Dersom vi bruker en skriftspråksvariant med såkalte overgangsverb, så bøyer vi verba som her er oppført under verbtype $3.2 \mathrm{og} 3.3$, etter mønster av enstamma verb (se verbtype $2 \mathrm{~b}$ ovafor).

\subsubsection{Verbtype 4: verb med to vokalstammer}

Verbtype 4 består av verb med to forskjellige vokalstammer, kort og lang vokalstamme. 1. infinitiv av slike verb slutter nesten alltid på $V / t A$, men det fins også 
en del verb som slutter på Oi/tA. Vi kan dele denne verbtypen inn i fire undergrupper:

- I verbtype 4.1, såkalte itte-verb, slutter den korte vokalstammen på enten $K i$ eller $K A(i)$, mens den lange vokalstammen slutter på Kitte eller KA(i)tte (K står her for hvilken som helst konsonant). For eksempel (1. inf. : 1. sg. pres. : perf. pts.) vali/ta ('velge') : valitte/ $n$ : vali/nu( $t)$, tarvi/ta ('trenge') : tarvitte/ $n$ : tarvi/nu(t), hava(i)/ta ('merke') : hava(i)tte/n: hava(i)/nu(t). Vi ser her at den lange vokalstammen er unntatt fra gradveksling.

- I verb av verbtype 4.2, såkalte Oitte-verb, slutter den korte vokalstammen på diftongen $O i$, og den lange vokalstammen slutter på Oitte. Disse verba danner 1 . infinitiv med suffikset $t A$. På samme måte som verbtype 4.1 mangler også denne gruppa gradveksling i den lange vokalstammen. Eksempler er (1. inf. : 1. sg. pres. : perf. pts.) piikaroi/ta ('spikre') : piikaroitte/n : piikaroi/nu, haravoi/ta ('rake') : haravoitte/n: haravoi/nu( $t$ ). I de ulike varietetene fins det også 1. infinitivsformer på - $đ A \sim-A$, altså piikaroi/(đ)a, haravoi/(đ)a.

- I verbtype 4.3 finner vi trestava ne-verb der den korte vokalstammen vanligvis slutter på $e$, til dels også på andre vokaler. Den lange vokalstammen slutter på ne. For eksempel (1. inf. : 1. sg. pres. : perf. pts.) li(j)e/tä ('nærme seg') : likene/n: li(j)e/ny(t), para/ta ('bli bra') : parane/n:para/nu(t).

- Verba i verbtype 4.4 kaller vi for Kontrakte Verb. De har allid suffikset - $t A$ i 1 . infinitiv, og stammen veksler mellom $V_{1}$ (kort vokalstamme) og $V_{1} V_{1} \sim$ $V_{1} A$ (lang vokalstamme). Eksempler er (1. inf. : 3. sg. pres. : 1. sg. pres. : perf. pts.): halu/ta ('ha lyst til') : halluu halua/a : halluu/n halua/n: halu/nu(t),

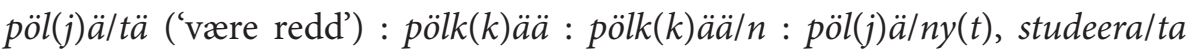
('studere') : studeeraa : studeeraa/n : studeera/nnu(t).

Av disse verba er det i ne-verba og i de kontrakte verba at kjernekonsonanten gjennomgår stadieveksling: Den korte vokalstammen er på lågere stadium, mens den lange vokalstammen er på høgere stadium. Alle nye lånord fra norsk eller andre internasjonale språk havner i gruppa med kontrakte verb.

Dersom vi bruker varianten med overgangsverb, så bøyer vi verba som ovafor er oppført under verbtype 4.1, 4.2 og 4.3, etter mønster av enstamma verb (se verbtype 2 b ovafor).

Tabell 6.1 gir ei samla framstilling av de ulike verbtypene i kvensk. 
Tabell 6.1 Verbtyper

\begin{tabular}{|c|c|}
\hline Verbtype & Eksempler (1. inf. : 1. sg. pres. : perf. pts.) \\
\hline 1 Enstava verb & $\begin{array}{l}\text { saa/đa saa/ha : saa/n : saa/nu(t) } \\
\text { syö/đä syy/ä : syö/n : syö/ny(t) } \\
\text { vie/đä vii/ä : vie/n : vie/ny(t) }\end{array}$ \\
\hline \multicolumn{2}{|l|}{2 Enstamma verb som er to- eller flerstava } \\
\hline 2a Opprinnelige enstamma verb & $\begin{array}{l}\text { ant(t)a/a(t) : anna/n : anta/nu(t) } \\
\text { lukke/et luke/a(t) luki/a : lu(j)e/n : luke/ } \\
\text { nu(t) } \\
\text { varasta/a(t) : varasta/n : varasta/nnu(t) }\end{array}$ \\
\hline $\begin{array}{l}\text { 2b Overgangsverb (= verb som har gått over fra } \\
\text { tostamma verb til enstamma verb) }\end{array}$ & $\begin{array}{l}\text { muistele/a(t) : muistele/n : muistele/nnu(t) } \\
\text { aukase/a(t) : aukase/n : aukase/nnu(t) } \\
\text { tärise/ä(t) : tärise/n : tärise/nny(t) } \\
\text { valitte/a(t) : valitte/n : valitte/nnu(t) } \\
\text { piikaroitte/a(t) : piikaroitte/n : piikaroitte/ } \\
\text { nu(t) } \\
\text { likene/ät : likene/n : likene/nny(t) }\end{array}$ \\
\hline \multicolumn{2}{|l|}{3 Verb med konsonantstamme } \\
\hline 3.1 Tostava verb & $\begin{array}{l}\text { tul/la : tule/n : tul/lu(t) } \\
\text { men/nä : mene/n : men/ny(t) } \\
\text { pes/tä : pese/n : pes/sy(t) } \\
\text { sur/ra : sure/n : sur/ru(t) } \\
\text { näh/đä näh/hä : nä(j)e/n : näh/ny(t) } \\
\text { teh/đä teh/hä : tehe/n : teh/ny(t) }\end{array}$ \\
\hline 3.2 Flerstava le-verb & $\begin{array}{l}\text { muistel/a : muistele/n : muistel/u(t) } \\
\text { kylästel/lä : kylästele/n : kylästel/ly(t) }\end{array}$ \\
\hline 3.3 Flerstava $A(I)$ se-verb og ise-verb & $\begin{array}{l}\text { auka(i)s/ta : auka(i)se/n : auka(i)s/su(t) } \\
\text { täris/tä : tärise/n : täris/sy(t) }\end{array}$ \\
\hline \multicolumn{2}{|l|}{4 Verb med to vokalstammer } \\
\hline 4.1 Itte-verb & $\begin{array}{l}\text { vali/ta : valitte/n : vali/nu(t) } \\
\text { havai/ta : havaitte/n : havai/nu(t) }\end{array}$ \\
\hline 4.2 Oitte-verb & piikaroi/ta : piikaroitte/n : piikaroi/nu(t) \\
\hline 4.3 ne-verb & li(j)e/tä : likene/n : li(j)e/ny(t) \\
\hline 4.4 Kontrakte verb & $\begin{array}{l}\text { hih(đ)a/ta : hihtaa/n : hih(đ)a/nu(t) } \\
\text { kasu/ta : kassuu/n kasua/n : kasu/nu(t) }\end{array}$ \\
\hline
\end{tabular}

\subsubsection{Tostamma verb og passivstamme}

Både verbtype 3 og 4 kan vi kalle for TOSTAMMA VERB ettersom de har to ulike stammer. Den ene stammen er kort og den andre lang.

I type 3 er det konsonantstammen som er den korte verbstammen. I type 4 er den korte stammen den vokalstammen som har en stavelse mindre enn den 
lange vokalstammen (verbtyper 4.1, 4.2, 4.3), eller den som slutter på kortere vokal enn den lange vokalstammen (verbtype 4.4 i Porsanger- og Nordreisavarietetene; verb med $A$ i kort stamme også i andre varieteter).

Den korte stammen er i bruk i følgende bøyingsformer:

- 1. infinitiv

- aktiv form av perfektum partisipp

- imperativ andre person flertall og imperativ tredje person entall og flertall

- alle passivformer, og også tredje persons flertallsformer som er identiske med passivformer

I de øvrige bøyingsformene bruker vi alltid den lange verbstammen. Men dersom vi velger varianten med overgangsverb (verbtype $2 b$ ), så er den korte stammen bare i bruk i verbtype 3 og i kontrakte verb (verbtype 4.4).

I passiv og i de formene for tredje person flertall som er identiske med tilsvarende passivformer, bruker vi den samme stammen i alle bøyingsformene. Vi kaller denne stammen for PAssivstamme. I tostamma verb bruker vi alltid den korte stammen som passivstamme. I verbtype 2 er passivstammen på lågeste stadium, og dersom vokalstammen slutter på $A$, så blir denne erstatta med $e$ i passivstammen. Eksempler er (1. inf. : pass. pres.):

Verbtype 1:

syö/đä syy/ä ('spise') : syö/(đ)hään,

Verbtype 2a:

ant $(t) a / a(t)$ ('gi') : anne/thaan, jakka/a(t) ('dele') : ja(j)e/thaan,

Verbtype $2 \mathrm{~b}$ :

muistele/at ('fortelle') : muistele/thaan, piikaroitte/at ('spikre') : piikaroitte/thaan, Verbtype 3:

tul/la ('komme') : tul/haan, pes/tä ('vaske') : pes/thään, muistel/a(t) ('fortelle') : muistel/haan, auka(i)s/ta ('åpne’) : auka(i)s/thaan,

Verbtype 4:

vali/ta ('velge') : vali/thaan, piikaroi/ta ('spikre') : piikaroi/thaan, para/ta ('bli bra') : para/thaan, kasu/ta ('vokse') : kasu/thaan. 


\subsection{Personbøying}

De finitte verbformene i kvensk har PERSONBøyIng. Vi skiller mellom seks personer, tre i entall (singularis) og tre i flertall (pluralis). Med PERsonsufFiKsA markerer vi hvem som er subjekt for verbalhandlinga, om det er taleren eller talerne sjøl (= første person), den eller de som blir talt til eller med (= andre person), eller noen eller noe som ikke er med i samtalen (= tredje person). Til sammen blir det disse personene: FøRSTE PERSON ENTALL (1. sg.), ANDRE PERSON ENTALL (2. sg.), TREDJE PERSON ENTALL (3. sg.) Og FøRSTE PERSON FLERTALL (1. pl.), ANDRE PERSON FleRtall (2. pl.), TREDJE PERSON FLERTAll (3. pl.).

I kvensk bruker vi stort sett de samme personsuffiksa i alle tids- og modusformene med unntak av imperativ, som opererer med andre personsuffiks enn indikativ og kondisjonalis. Imperativsformene skal vi komme tilbake til i avsnitt 6.6.

\subsubsection{Første og andre person entall og flertall}

Personsuffiksa i første og andre person entall og flertall er de samme i alle bøyingsformene av indikativ og kondisjonalis, og det er heller ikke noen variasjon mellom de ulike varietetene når det gjelder disse suffiksa. Her er noen eksempler på hvordan disse suffiksa er brukt i de ulike verbtypene:

Første person entall: $-n$. For eksempel (1. inf. : 1. sg. ind. pres. : 1. sg. ind. pret.) (verbtype 1) saa/da saa/ha ('få) $: s a a / n: s a / i / n, j u o /$ đa juula ('drikke') : juo/n : jo/i/n, (verbtype 2) ant(t)aa(t) ('gi') : anna/n : anno/i/n, lukkelet lukela $(t) \sim \operatorname{luki} / a$ ('lese') : lu(j)e/n:lu(j)/i/n,varasta/a(t) ('stjele') : varasta/n: varast $/ i / n$, (verbtype 3) ol/la ('være') : ole/n :ol/i/n, men/nä ('gå') : mene/n : men/i/n, ajatel/la ('tenke') : ajattele/n : ajattel/i/n, (verbtype 4) piikaroi/ta ('spikre') : piikaroitte/n:piikaroitt/i/n, hih(đ)/ta ('gå på ski') : hihtaa/n: hihta/si/n.

Andre person entall: - $t$. For eksempel (1. inf. : 2. sg. ind. pres. : 2. sg. ind. pret.) (verbtype 1) saa/ đa saa/ha ('få) : saa/t: sa/i/t, juo/da juu/a ('drikke') : juo/t $:$ jo/ilt, (verbtype 2) ant $(t) a a(t)($ 'gi') : annalt : annolilt, lukkelet $\sim$ lukela $(t) \sim$ luki/a ('lese') : lu(j)e/t : lu(j)/i/t, varasta/a(t) ('stjele') : varasta/t : varast $/ i / t$, (verbtype 3) ol/la ('være') : ole/t : ol/i/t, men/nä ('gå') : mene/t : $m e n / i / t$, ajatel/la ('tenke') : ajattele/t : ajattel/i/t, (verbtype 4) piikaroi/ta ('spikre') : piikaroitte/t: piikaroitt/i/t, hih(đ)/ta ('gå på ski') : hihtaa/t: hihta/si/t.

Første person flertall: - $(m) m A$. For eksempel (1. inf. : 1. pl. ind. pres. : 1. pl. ind. pret.) (verbtype 1) saa/đa saa/ha ('få) : saa/ma : sa/i/ma, juo/da juu/a 
('drikke') : juo/ma : jo/i/ma, (verbtype 2) ant(t)aa(t) ('gi') : anna/ma : anno/i/ma, lukke/et luke/a(t) luki/a ('lese') $: \operatorname{lu}(j) e / m a: l u(j) / i / m a, v a r a s t a / a(t)$ ('stjele') : varasta/mma : varast/i/mma, (verbtype 3) ol/la ('være') : ole/ma : ol/i/ma, men/nä ('gå') : mene/mä : men/i/mä, ajatel/la ('tenke') : ajattele/ma : ajattel/i/ma, (verbtype 4) piikaroi/ta ('spikre') : piikaroitte/ma: piikaroitt/i/ma, hih(đ)/ta ('gå på ski') : hihtaa/ma: hihta/si/mma. Valget mellom kort og lang $m$ i suffikset er styrt av lengderegelen for stemte konsonanter (se avsnitt 3.1.2).

Andre person flertall: -ttA. For eksempel (1. inf. : 2. pl. ind. pres. : 2. pl. ind. pret.) (verbtype 1) saa/da saa/ha ('få) : saa/tta : sa/iltta, juo/da juu/a ('drikke') : juo/tta : jo/i/tta, (verbtype 2) ant $(t) a a(t)$ ('gi') : anna/tta : anno/i/tta, lukkelet luke/a(t) luki/a ('lese') : lu(j)e/tta : lu(j)/i/tta, varasta/a(t) ('stjele') : varasta/tta: varast/i/tta, (verbtype 3) ol/la ('være') : ole/tta : ol/i/tta, men/nä ('gå) : mene/ttä : men/i/ttä, ajatel/la ('tenke') : ajattele/tta : ajattel/i/tta, (verbtype 4) piikaroi/ta ('spikre') : piikaroitte/tta: piikaroitt/i/tta, hih(đ)/ta ('gå på ski') : hihtaa/tta: hihta/si/tta.

I tabell 6.2 får vi en oversikt over personsuffiksa i første og andre person entall og flertall.

Tabell 6.2 Personsuffiks i første og andre person entall og flertall

\begin{tabular}{|c|c|c|c|c|}
\hline 1. infinitiv & 1. sg.: $-n$ & 2. sg.: $-t$ & 1. pl.: $-(m) m A$ & 2. pl.: -ttA \\
\hline saa/đa saa/ha & saa/n & $\mathrm{saa} / \mathrm{t}$ & saa/ma & $\mathrm{saa} / \mathrm{tta}$ \\
\hline $\operatorname{an}(\mathrm{t}) \mathrm{ta} / \mathrm{a}(\mathrm{t})$ & anna/n & anna/t & anna/ma & anna/tta \\
\hline $\begin{array}{l}\text { lukke/et luke/a(t) } \\
\sim \text { luki/a }\end{array}$ & $\operatorname{lu}(j) e / n$ & $\operatorname{lu}(j) e / t$ & $\mathrm{lu}(\mathrm{j}) \mathrm{e} / \mathrm{ma}$ & $\mathrm{lu}(\mathrm{j}) \mathrm{e} / \mathrm{tta}$ \\
\hline varasta/a(t) & varasta/n & varasta/t & varasta/mma & varasta/tta \\
\hline ol/la & ole/n & $\mathrm{ole} / \mathrm{t}$ & ole/ma & ole/tta \\
\hline men/nä & mene/n & mene/t & mene/mä & mene/ttä \\
\hline muistel/a & muistele/n & muistele/t & muistele/mma & muistele/tta \\
\hline auka(i)s/ta & auka(i)se/n & auka(i)se/t & auka(i)se/mma & auka(i)se/tta \\
\hline kyyti/tä & kyytitte/n & kyytitte/t & kyytitte/mmä & kyytitte/ttä \\
\hline piikaroi/ta & piikaroitte/n & piikaroitte/t & piikaroitte/ma & piikaroitte/tta \\
\hline li(j)e/tä & likene/n & likene/t & likene/mmä & likene/ttä \\
\hline $\mathrm{maa} / \mathrm{ta}$ & makkaa/n & makkaa/t & makkaa/ma & makkaa/tta \\
\hline keri/tä & $\begin{array}{l}\text { kerkkii/n } \\
\text { kerkiä/n }\end{array}$ & $\begin{array}{l}\text { kerkkii/t } \\
\text { kerkiä/t }\end{array}$ & $\begin{array}{l}\text { kerkkii/mä } \\
\text { kerkiä/mmä }\end{array}$ & $\begin{array}{l}\text { kerkkii/ttä } \\
\text { kerkiä/ttä }\end{array}$ \\
\hline
\end{tabular}




\subsubsection{Tredje person entall}

Det fins flere suffiks som markerer tredje person entall. I indikativ preteritum og i kondisjonalis presens er tredje person entall alltid uten suffiks. Derimot varierer bøyingsforma i indikativ presens. Vi skal se nærmere på hvordan tredje person entall ter seg her i de ulike verbtypene.

- I verbtype 1 er suffikset i tredje person entall indikativ presens alltid -pi. For eksempel (1. inf. : 3. sg. ind. pres. : 3. sg. ind. pret.) saa/ da saa/ha ('fä) : saa/pi : sa/i, juo/da juu/a ('drikke') : juo/pi : jo/i.

- I verbtype 2, 3, 4.1, 4.2 og 4.3 bruker vi - $V$ som suffiks i tredje person entall indikativ presens, det vil si at stammevokalen blir forlenga. For eksempel (1. inf. : 3. sg. ind. pres. : 3. sg. ind. pret.) (verbtype 2) an (t)ta/a(t) ('gi'):an(t)ta/a $:$ anto/i, lukkelet $\sim$ lukelat luki/a ('lese') :lukke/e : luk/i, varastala(t) ('stjele') : varastala : varast $i$, (verbtype 3) men/nä ('gå) : mennele : men/i, ajatellla ('tenke') : ajattelle/e : ajattelli, auka(i)s/ta ('åpne') : auka(i)s(s)e/e : auka(i)s/i, (verbtype 4.1) kyyti/tä ('følge etter') : kyytittele : kyytitt/i, (verbtype 4.2) piikaroilta ('spikre') : piikaroittele : piikaroitt/i, (verbtype 4.3) li(j)e/tä ('nærme seg') : likene/e : liken/i.

- I varietetene i Porsanger og Nordreisa, der vi har vokalutjamning $\left(V_{1} A>\right.$ $V_{1} V_{1}$ ), er kontrakte verb (type 4.4) uten suffiks i tredje person entall. Denne forma er her identisk med den lange vokalstammen. I de andre varietetene blir tredje person entall markert gjennom vokalforlenging i de tilfella der den lange vokalstammen slutter på to ulike vokaler. Eksempler er (1. inf. : 1. sg. ind. pres. : 3. sg. ind. pres. : 3. sg. ind. pret.) hih(đ)a/ta ('gå på ski') : hihtaa/n: hihtaa : hihta/s, maa/ta ('ligge') : makkaa/n: makkaa : maka/s, halu/ta ('ha lyst til') : halluu/n halua/n: halluu halua/a : halu/s, keri/tä ('rekke, nå) : kerkkii/n kerkiä/n : kerkkii kerkiä/ä: kerki/s.

Verbet olla ('være') bøyes etter mønster av type 3, men legg merke til at det har den noe spesielle forma oon i tredje person entall og flertall av indikativ presens.

Tabell 6.3 gir en oversikt over bøyingssuffiksa i tredje person entall.

\subsubsection{Tredje person flertall og passiv}

Personbøyinga i tredje person flertall og i passiv varierer litt, både mellom de ulike verbtypene, bøyingskategoriene og varietetene. 
Tabell 6.3 Personsuffiks i tredje person entall

\begin{tabular}{|c|c|c|}
\hline 1. infinitiv & $\begin{array}{l}\text { Tredje person entall indikativ } \\
\text { presens: }-p i,-V,-\varnothing\end{array}$ & $\begin{array}{l}\text { Tredje person entall } \\
\text { indikativ preteritum: } \\
\text { ingen personsuffiks }\end{array}$ \\
\hline \multicolumn{3}{|l|}{ Verbtype 1: } \\
\hline saa/đa saa/ha & saa/pi & $\mathrm{sa} / \mathrm{i}$ \\
\hline juo/da juu/a & juo/pi & jo/i \\
\hline \multicolumn{3}{|l|}{ Verbtype 2: } \\
\hline $\operatorname{an}(\mathrm{t}) \operatorname{ta} / \mathrm{a}(\mathrm{t})$ & an $(\mathrm{t}) \mathrm{ta} / \mathrm{a}$ & anto/i \\
\hline lukke/et $\sim$ luke/a(t) luki/a & lukke/e & luk/i \\
\hline varasta/a(t) & varasta/a & varast/i \\
\hline \multicolumn{3}{|l|}{ Verbtype 3: } \\
\hline ol/la & oon (sic!) & $\mathrm{ol} / \mathrm{i}$ \\
\hline men/nä & menne/e & men/i \\
\hline muistel/a & muistele/e & muistel/i \\
\hline auka(i)s/ta & auka(i)s(s)e/e & auka(i)s/i \\
\hline \multicolumn{3}{|l|}{ Verbtype 4: } \\
\hline kyyti/tä & kyytitte/e & kyytitt/i \\
\hline piikaroi/ta & piikaroitte/e & piikaroitt/i \\
\hline li(j)e/tä & likene/e & liken/i \\
\hline maa/ta & makkaa & maka/s \\
\hline keri/tä & kerkkii kerkiä/ä & kerki/s \\
\hline
\end{tabular}

Særlig i Porsanger, og til dels i Nordreisa, er det vanlig at formene i tredje person flertall både i presens og preteritum er identiske med passivformene. I presens gjelder dette særlig verb med konsonantstamme. I de andre varietetene er det vanlig å bruke suffikset $-v A(t)$ i alle verbtypene i tredje person flertall presens. Vi kaller denne forma også for EGENTLIG TREDJE PERSON FLERTALL. Sluttkonsonanten $t$ er valgfri. Bøyingsforma på $-v A(t)$ er identisk med forma i presens partisipp (se avsnitt 6.4.1.1 om bekreftende presens, og avsnitt 6.8.2 om presens partisipp).

Personsuffikset i presens passiv, som i Porsanger også er brukt i tredje person flertall, varierer etter hvilken verbtype det er festa til: 
- I verbtype 1 bruker Porsanger alltid passivsuffikset - thAAn i presens, mens de andre varietetene bruker - $h A A n$. For eksempel (1. inf. : pass. pres.) saa/da saa/ha ('fă') : saa/đhaan : saa/haan, vie/ đä vii/ä ('bringe, ta med') : vie/ đhään : vie/hään, syö/đä syy/ä ('spise') : syö/dhään syö/hään, käy/đä käy/ä ('dra en tur') : käy/dhään käy/hään.

- I verbtype 2 bruker alle varietetene passivsuffikset -thAAn i presens. For eksempel (1. inf. : pass. pres.) ant(t)a/a(t) ('gi') : anne/thaan, lukkelet lukea $(t) \sim$ lukia ('lese') : lu(j)elthaan, siirt(t)yyt siirtyä(t) ('flytte') : siiry/thään.

- I verb av type 3 fester vi passivsuffikset til konsonantstammen. Når stammen slutter på s, bruker vi passivsuffikset -thAAn, ellers suffikset - $h A A n$. Slik er det i alle varietetene. For eksempel (1. inf. : pass. pres.) kuul/a ('høre') : kuul/haan, tul/la ('komme') : tul/haan, men/nä ('gå) : men/hään, pes/tä ('vaske') : pes/thään, muistel/a ('fortelle') : muistel/haan, auka(i)s/ta ('åpne') : auka(i)s/thaan. Verbet olla ('være') har forma ol/haan i passiv presens. (I aktiv tredje person flertall har olla alltid forma oon.)

- Verbtype 4 danner passiv presens med suffikset -thAAn i alle varietetene. For eksempel (1. inf. : pass. pres.) halli/ta ('styre') : halli/thaan, piikaroi/ta ('spikre') : piikaroi/thaan, pa(j)e/ta ('rømme') : pa(j)e/thaan.

Overgangsverb (type $2 b$ ) danner passiv presens på samme måte som andre type 2-verb, det vil si med hjelp av suffikset -thaan.

I preteritum er det vanlig å bruke bøyingsformer i tredje person flertall som er identiske med passivformer, ikke bare i Porsanger og Nordreisa, men i alle varietetene. Passivsuffikset er i utgangspunktet satt sammen av to ulike suffiks, passivsuffikset $-(t) t A$ og det egentlige personsuffikset - $h V n$. Preteritumssuffikset og modussuffiksa som er plassert mellom disse to suffiksa, har smelta i hop med dem. Resultatet er at vi i preteritum bruker suffikset -thiin i alle verbtyper (se avsnitt 6.4.2), og i passiv imperativ bruker vi suffikset - $(t)$ tAkhoon (se avsnitt 6.6.5). I kondisjonalis har det egentlige personsuffikset falt bort, og resultatet er suffikset - $(t) t$ Ais (se avsnitt 6.5.1.1).

Men i preteritum tredje person flertall er det også mulig å bruke det eldre personsuffikset - $t$. I så fall får vi identiske former i tredje person flertall og andre person entall.

Tabell 6.4 oppsummerer bøyingsformene i tredje person flertall og i passiv. 
Tabell 6.4 Personsuffiks i tredje person flertall og i passiv

\begin{tabular}{|c|c|c|c|c|}
\hline \multirow{2}{*}{ 1. infinitiv } & \multicolumn{2}{|c|}{ Indikativ presens: 3. pl. og passiv } & \multicolumn{2}{|c|}{ Indikativ preteritum: 3. pl. og passiv } \\
\hline & $\begin{array}{l}\text { 3. pl. i Porsanger, } \\
\text { passiv i alle } \\
\text { varietetene: } \\
\text {-đhAAn, -haan, -thaan }\end{array}$ & 3. pl.: $-v A(t)$ & $\begin{array}{l}\text { 3. pl. og passiv i alle } \\
\text { varietetene: } \\
\text {-thiin }\end{array}$ & $\begin{array}{l}\text { 3. pl., } \\
\text { sjelden } \\
\text { variant: } \\
-t\end{array}$ \\
\hline \multicolumn{5}{|l|}{ Verbtype 1: } \\
\hline $\begin{array}{l}\text { saa/đa saa/ } \\
\text { ha }\end{array}$ & saa/(đ)haan & saa/va(t) & saa/thiin & $\mathrm{sa} / \mathrm{i} / \mathrm{t}$ \\
\hline juo/đa juu/a & juo/đhaan juu/haan & juo/va(t) & juo/thiin & $\mathrm{jo} / \mathrm{i} / \mathrm{t}$ \\
\hline \multicolumn{5}{|l|}{ Verbtype 2: } \\
\hline anct)ta/a(t) & anne/thaan & ant(ta)a/va(t) & anne/thiin & anno/i/t \\
\hline $\begin{array}{l}\text { lukke/et luke/ } \\
\mathrm{a}(\mathrm{t}) \sim \text { luki/a }\end{array}$ & lu(j)e/thaan & luk(ke)e/va(t) & lu(j)e/thiin & $\mathrm{lu} / \mathrm{i} / \mathrm{t}$ \\
\hline varasta/a(t) & varaste/thaan & varast(a)a/va(t) & varaste/thiin & varast/i/t \\
\hline \multicolumn{5}{|l|}{ Verbtype 3: } \\
\hline ol/la & ol/haan (pass.) & oon & ol/thiin & $\mathrm{ol} / \mathrm{i} / \mathrm{t}$ \\
\hline men/nä & men/hään & mene/vä(t) & men/thiin & men/i/t \\
\hline muistel/a & muistel/haan & muistele/va(t) & muistel/thiin & muistel/i/t \\
\hline auka(i)s/ta & auka(i)s/thaan & aukase/va(t) & auka(i)s/thiin & aukas/i/t \\
\hline \multicolumn{5}{|l|}{ Verbtype 4: } \\
\hline kyyti/tä & kyyti/thään & kyytitte(e)/vä(t) & kyyti/thiin & kyytitt/i/t \\
\hline piikaroi/ta & piikaroi/thaan & $\begin{array}{l}\text { piikaroitte(e)/ } \\
\text { va(t) }\end{array}$ & piikaroi/thiin & piikaroitt/i/t \\
\hline li(j)e/tä & li(j)e/thään & likene(e)/vä(t) & li(j)e/thiin & liken/i/t \\
\hline maa/ta & maa/thaan & makkaa/va(t) & maa/thiin & maka/si/t \\
\hline keri/tä & keri/thään & $\begin{array}{l}\text { kerkkii/vät } \\
\text { kerkiä/vä(t) }\end{array}$ & keri/thiin & kerki/si/t \\
\hline
\end{tabular}

Presensformene med lang vokal foran $-v A(t)$ i verbtypene 2 og 4 hører til Porsanger-varieteten.

\subsection{Indikativ}

Modusforma InDikativ har ikke noe eige bøyingssuffiks, og den markeres heller ikke på noen annen måte. Vi kan si at indikativ er den UMARKERTE FORMA av kategorien modus. Denne nøytrale modusforma bidrar 
ikke ytterligere til verbbetydninga. Eksempler på indikativsformer er lista opp i (1-4):

1. Mie kirjo(i)tan kirjaa.

'Jeg skriver på ei bok.'

2. Pekka oon pyytämässä lohta.

'Peder holder på å fiske laks.'

3. Missä sie olit eilen?

'Hvor var du i går?'

4. Kainun kieltä ei saanu puhhuut puhua(t) koulussa.

'Man fikk ikke prate kvensk på skolen.'

\subsubsection{Indikativ presens}

Tidsforma PRESENs bruker vi når verbalhandlinga handler om nåtida eller om framtida, som i eksempla (1-2):

1. Mie istun ja opettelen kainun kieltä.

'Jeg sitter og lærer meg kvensk.'

2. Ensi vuona mie jo puhunki kainun kieltä.

'Til neste år kommer jeg allerede til å snakke kvensk.'

\subsubsection{Bekreftende presens}

I likhet med indikativ har ikke presens noe eige suffiks, men derimot bruker vi personsuffiks (se avsnitt 6.3 ovafor). Alle verbtypene bortsett fra enstava verb (type 1) og itte- og Oitte-verb (type $4.1 \mathrm{og}$ 4.2) gjennomgår ei eller anna form for stadieveksling. Bøyingsformene er oppsummert i tabell 6.5 i slutten av dette avsnittet. Vi skal se nærmere på hvordan stadieveksling arter seg i de ulike verbtypene.

- I enstamma verb med to- eller flerstava vokalstamme (verbtype 2) gjelder følgende regel: Dersom stammen stadieveksler etter mønster II : I : o, så er bøyingsforma i tredje person entall indikativ presens alltid på det sterkeste stadiet, det vil si stadium II. Bøyingsforma i egentlig tredje person flertall, $-v A(t)$, er alltid på stadium I, bortsett fra Porsanger-varieteten, der den er på stadium II. I de andre personene står verbet på stadium o dersom mønsteret er (II :) I : o, og på stadium I dersom mønsteret er II : I.

Eksempler på (II :) I : o-stadieveksling: 
(1. inf. : 3. sg. : 1. sg. : pass./3.pl. : 3. pl.) kulkkelet kulke/a(t) kulki/a ('vandre, gå) : kulk(k)e/e : kulje/n: kulje/thaan: kulk(ke)e/va(t), lukkelet lukela(t) luki/a ('lese') : lukkele: $\operatorname{lu}(j) e / n: \operatorname{lu}(j) e /$ thaan: luk(ke)elva(t), tunttelet $\sim$ tuntela $(t) \sim$ tunti/a ('kjenne, føle') : tunt(t)e/e : tunne/n : tunne/thaan : tunt(te)e/va(t), häytty/yt

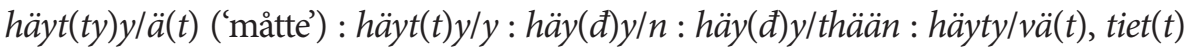
$\ddot{a} / \ddot{a}(t)$ ('vite') : tiet $(t) \ddot{a} / \ddot{a}:$ tieđä/ $n \sim$ tiï̈ $(n)$ : tiede/thään tiielthään : tiet(tä) $\ddot{a} / v \ddot{a}(t)$. Eksempler på II : I-stadieveksling:

(1. inf. : 3. sg. : 1. sg. : pass./3. pl. : 3. pl.) suuttu/ut suuttu/a(t) ('bli sint') :

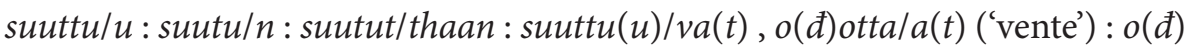
otta/a:o(đ)ota/n:o(đ)ote/thaan :ootta $(a) / v a(t), k y s s y / y t \sim k y s y / \ddot{a}(t)$ ('spørre') $: k y s s y / y: k y s y / n: k y s y /$ thään : kys(sy)y/vä(t), sanno/ot sano/a(t) ('si') : sanno/o : sanon : sano/thaan: $\operatorname{san}(n o) o / v a(t)$.

Som vi har understreka tidligere, så forekommer stadium o bare i ord med kjernekonsonant $k, t$ eller $p$. Endringa i stammevokalen fra $A$ til $e$ er forklart i avsnitt 6.2.5.

- I verb med konsonantstamme (type 3) er bøyingsforma i tredje person entall indikativ presens på stadium II, på samme måte som i verbtype 2 . Personsuffikset i passiv og i den identiske forma i tredje person flertall legges til konsonantstammen, det vil si den samme stammen som vi fester suffikset $i$ 1. infinitiv til. Personsuffiksa i egentlig tredje person flertall, i første og andre person entall, og i første og andre person flertall festes til vokalstammen på stadium I. Unntaket er Porsanger, der personsuffikset - $v$ At føyes til ordforma som er lik tredje person entall. Stadium o fins ikke i verb av type 3 anna enn i de to verba näh/đä näh/hä ('se') og teh/đä teh/hä ('gjøre'). Eksempler:

(1. inf. : 3. sg. : 1. sg. : pass./3.pl.: 3.pl.) pes/tä ('vaske') : pesse/e :pese/n:pes/ thään : pese/vä(t), pur/ra ('bite') : purre/e : pure/n : pur/haan : pure/va(t), tul/la ('komme') : tulle/e : tule/n : tul/haan : tule/va(t), men/nä ('gå') : mennele : mene/ $n:$ men/hään : mene/vä( $t)$, ajatel/la ('tenke') : ajattelle/e : ajattele/ $n:$ ajatel/haan : ajattele/va(t), auka(i)s/ta ('åpne') : auka(i)s(s)ele : auka(i)se/n : auka(i)s/thaan : aukase/va(t).

Dei to verba näh/đä näh/hä ('se') og teh/đä teh/hä ('gjøre') har en spesiell stamme på o-stadium, og det er den vi bruker i første og andre person entall og første og andre person flertall. Personbøyinga i presens blir da slik: (1. inf. : 3. sg. : 1. sg. : pass./3. pl. : 3. pl.) teh/đä $\sim$ teh/hä: tekke/e : tehe/n : teh/(đ)hään: teke/vä(t), näh/đä näh/hä: näkkele : nä(j)e/n: näh/(đ)hään: näke/vä $(t)$. 
Dersom vi i stedet for verbtype 3.2 og 3.3 bruker overgangsverb, så bøyes de slik: (1. inf. : 3. sg. : 1. sg. : pass./3. pl. : 3. pl.) ajattele/a(t) ('tenke') : ajattelle/e : ajattele/ $n$ : ajattele/thaan : ajattele/va(t), aukase/a(t) ('åpne') : aukase/n : aukas(s)ele : aukase/thaan: aukase/va(t).

- Verb med to vokalstammer (type 4) danner 1. infinitiv så vel som de to identiske formene passiv og tredje person flertall med hjelp av den korte vokalstammen. I de andre personene brukes den lange vokalstammen.

Av undergruppene er itte-verb (type 4.1) og Oitte-verb (type 4.2) unntatt fra stadieveksling. Her står lang $t t$ ved lag i alle personbøyingsformene som bruker den lange vokalstammen. Eksempler (1. inf. : 3. sg. : 1. sg. : pass./3. pl. : 3. pl.) kyyti/tä ('skysse') : kyytittele : kyytitte/n: kyyti/thään: kyytitte(e)/vä(t), piikaroi/ta ('spikre') : piikaroittele : piikaroitte/ $n$ : piikaroi/thaan: piikaroitte(e)/va(t).

I den tredje undergruppa, de såkalte ne-verba (type 4.3), gjennomgår kjernekonsonantene i stammen gradveksling på denne måten: (1. inf. : 3. sg. : 1. sg. : pass./3. pl. : 3. pl.) li(j)e/tä ('nærme seg') : likenele : likene/n : li(j)e/thään : likene $(e) / v \ddot{a}(t)$. I slike verb står den korte vokalstammen på o-stadiet, og den lange vokalstammen på I-stadiet, men stadievekslinga omfatter bare verb med plosiv $k, t$ eller $p$ mellom første og andre stavelse.

Dersom man i stedet for bøyingsmønstra for verbtypene 4.1, 4.2 eller 4.3 bøyer disse verba som overgangsverb, så ser bøyingsformene slik ut: (1. inf. : 3 . sg. : 1. sg. : pass./3. pl. : 3. pl.) kyytitte/ä(t) ('skysse') : kyytittele : kyytitte/n : kyytitte/thään : kyytitte $(e) / v a ̈(t)$, piikaroittela(t) ('spikre') : piikaroittele : piikaroitte/ $n$ : piikaroitte/thaan: piikaroitte $(e) / v a(t)$, likene/ä( $t$ ) ('nærme seg') : likene/e : likene/ $n$ : likene/thään : likene $(e) / v a ̈(t)$.

Også i den fjerde undergruppa, de såkalte kontrakte verba (type 4.4), er kjernekonsonanten utsatt for stadieveksling. I disse verba er 1 . infinitiv og passivstammen alltid på et lågere stadium enn de andre bøyingsformene. De oppfører seg som neverb når det gjelder stadieveksling. I Porsanger og Nordreisa er stammevokalen utjamna, og stammen står derfor på II-stadiet. I de andre varietetene stadieveksler stammen avhengig av om stammekonsonanten er etterfulgt av lang vokalisme eller av to vokaler som står i hver sin stavelse, som illustrert i disse eksempla:

(1. inf. : 3. sg. : 1. sg. : pass./3. pl. : 3. pl.) pöl(j)ä/tä ('være redd') : pölk(k)ää :

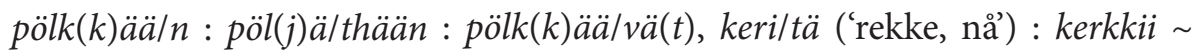
kerkiä/ä: kerkkii/n kerkiä/n : keri/thään: kerkkii/vät kerkiä/vä(t), maa/ta ('ligge') : makkaa : makkaa/n : maa/thaan : makkaa/va(t), halu/ta: halluu halua/a : halluu/ $n \sim$ halua/ $n$ : halu/thaan : halua/va( $t)$. 
Legg merke til at ikke alle verb av type 4.4 gjennomgår gradveksling, for eksempel maala/ta ('male') : maala/thaan : maalaa : maalaa/ $n$. Her er $l$-en alltid kort etter lang vokal.

Gradvekslingsreglene for personbøying i indikativ presens kan oppsummeres slik:

- Enstava verb (type 1): Inga gradveksling, personsuffiksa -er - $n,-t,-p i,-m A$, $-t t A,-v A(t)$ og $-\not h A A n \sim-h A A n$, som festes direkte til stammen.

- Enstamma verb (type 2): Stammen gjennomgår gradveksling etter mønsteret (II :) I : o eller II : I. Dersom stammen har gradveksling, festes personsuffiksa - $n$, - $t$, $-(m) m A,-t t A,-v A(t)$ og $-t h A A n$ til stammen på I- eller o-stadiet, suffikset i tredje person entall, $-V$, festes til samme stamme som suffikset i 1 . infinitiv. I Porsangervarieteten festes $-v A t$ til den forma som ordet har i tredje person entall.

- Verb med konsonantstamme (type 3): Stammen gjennomgår stadieveksling etter mønsteret II : I. Personsuffiksa festes til vokalstammen med unntak av de to identiske formene passiv og tredje person flertall. Dersom stammen har stadieveksling, så festes personsuffiksa $-n,-t,-(m) m A,-t t A$ og $-v A(t)$ til stammen på I-stadiet, suffikset $i$ tredje person entall, $-V$, festes til stammen på II-stadiet. I de to identiske bøyingsformene passiv og tredje person flertall bruker vi konsonantstammen.

- Verb med to vokalstammer (type 4): Personsuffiksa $-n,-t,(-V)-,(m) m A$, - $t t A$ og $-v A(t)$ festes til den lange vokalstammen, personsuffikset - thAAn festes til den korte vokalstammen. Kjernekonsonanten gjennomgår stadieveksling bortsett fra i itte-verb (type 4.1) og Oitte-verb (type 4.2). I typene 4.3 og $4.4 \mathrm{er}$ den korte vokalstammen på et lågere stadium enn den lange vokalstammen. Den lange vokalstammen i ne-verb (4.3) er alltid på stadium I, og i kontrakte verb (type 4.4) er den på stadium II - i den grad det er mulig etter stadievekslingsreglene.

Husk også at vi alternativt kan bruke vokalstammen i alle personbøyingsformene av verb med flerstava stamme i verbtype 3 , og den lange vokalstammen i alle personbøyingsformene i verbtype 4 - med unntak av kontrakte verb. Det vil si at vi da behandler disse verba som overgangsverb (verbtype $2 b$ ).

Tabellen viser bare formene i tredje person entall, første og tredje person flertall og passiv. Passivforma fungerer også som bøyingsform i tredje person flertall. Første og andre person entall og andre person flertall lager vi ved å feste personsuffiksa - $n$ (1. sg.), - $t$ (2. sg.) og - $t t A$ (2. pl.) til samme stamme som er brukt i første person flertall, eller med andre ord ved å erstatte suffikset $-m(m) A$ med de nevnte suffiksa. 
Tabell 6.5 Personbøying av bekreftende indikativ presens

\begin{tabular}{|c|c|c|c|c|c|}
\hline Verbtype & 1. infinitiv & 3. sg. hän/se & 1. pl. met & 3. pl. het/net & $\begin{array}{l}\text { 3. pl. / passiv } \\
\text { het/net / - }\end{array}$ \\
\hline \multirow[t]{3}{*}{1 Enstava verb } & $\begin{array}{l}\text { saa/đa } \\
\text { saa/ha }\end{array}$ & saa/pi & $\mathrm{saa} / \mathrm{ma}$ & $\mathrm{saa} / \mathrm{va}(\mathrm{t})$ & saa/(đ)haan \\
\hline & $\begin{array}{l}\text { vie/đä } \\
\text { vii/ä }\end{array}$ & vie/pi & vie/mä & vie/vä(t) & vie/(đ)hään \\
\hline & ui/(đ)a & ui/pi & ui/ma & ui/va(t) & ui/(đ)haan \\
\hline \multicolumn{6}{|l|}{2 Enstamma verb } \\
\hline \multicolumn{6}{|l|}{ 2a Opprinnelige } \\
\hline e-stammer & $\begin{array}{l}\text { kulkke/et } \\
\text { kulke/a(t) } \\
\text { kulki/a }\end{array}$ & kul(k)ke/e & kulje/ma & $\begin{array}{l}\text { kulkkee/vat } \\
\text { kulke/va(t) }\end{array}$ & kulje/thaan \\
\hline$i$-stammer & $\begin{array}{l}\text { soppi/it } \\
\text { sopi/a(t) }\end{array}$ & soppi/i & sovi/ma & $\begin{array}{l}\text { soppii/vat } \\
\text { sopi/va(t) }\end{array}$ & sovi/thaan \\
\hline \multirow[t]{2}{*}{ O-, U-stammer } & $\begin{array}{l}\text { aikko/ot } \\
\text { aiko/a(t) }\end{array}$ & ai(k)ko/o & $\mathrm{ai}(\mathrm{j}) \mathrm{o} / \mathrm{ma}$ & $\begin{array}{l}\text { aikkoo/vat } \\
\text { aiko/va(t) }\end{array}$ & ai(j)o/thaan \\
\hline & $\begin{array}{l}\text { näkky/yt } \\
\text { näky/ä(t) }\end{array}$ & näkky/y & nä(v)y/mä & $\begin{array}{l}\text { näkkyy/vät } \\
\text { näky/vä(t) }\end{array}$ & nä(v)y/thään \\
\hline \multirow[t]{3}{*}{ A-stammer } & luotta/a(t) & luotta/a & luota/ma & $\begin{array}{l}\text { luottaa/vat } \\
\text { luotta/va(t) }\end{array}$ & luote/thaan \\
\hline & $\begin{array}{l}\text { len(t)tä/ } \\
\text { ä(t) }\end{array}$ & len(t)tä/ä & lennä/mä & $\begin{array}{l}\text { lenttää/vät } \\
\text { lentä/vä(t) }\end{array}$ & lenne/thään \\
\hline & $\begin{array}{l}\text { varasta/ } \\
\mathrm{a}(\mathrm{t})\end{array}$ & varasta/a & varasta/mma & $\begin{array}{l}\text { varastaa/vat } \\
\text { varasta/va(t) }\end{array}$ & varaste/thaan \\
\hline \multirow[t]{2}{*}{$2 \mathrm{~b}$ Overgangsverb } & $\begin{array}{l}\text { muistele/ } \\
\mathrm{a}(\mathrm{t})\end{array}$ & muistele/e & $\begin{array}{l}\text { muistele/ } \\
\text { mma }\end{array}$ & muistele/va(t) & $\begin{array}{l}\text { muistele/ } \\
\text { thaan }\end{array}$ \\
\hline & kyyti/tä & kyytitte/e & kyytitte/mmä & kyytitte/vä(t) & kyytitte/thään \\
\hline \multicolumn{6}{|l|}{$\begin{array}{l}3 \text { Verb med } \\
\text { konsonantstamme }\end{array}$} \\
\hline \multirow[t]{3}{*}{ 3.1 Tostava } & tul/la & tulle/e & tule/ma & tule/va(t) & tul/haan \\
\hline & juos/ta & juokse/e & juokse/ma & juokse/va(t) & juos/thaan \\
\hline & $\begin{array}{l}\text { näh/đä } \\
\text { näh/hä }\end{array}$ & näkke/e & nä(j)e/mä & näke/vä(t) & näh/(đ)hään \\
\hline \multirow{2}{*}{$\begin{array}{l}3.2 \text { Flerstava ele- } \\
\text { verb }\end{array}$} & ajatel/la & ajattelle/e & ajattele/ma & ajattele/va(t) & ajatel/haan \\
\hline & kävel/ä & kävele/e & kävele/mmä & kävele/vä(t) & kävel/hään \\
\hline \multirow{2}{*}{$\begin{array}{l}.3 \text { Flerstava } A(I) \\
\text { se-verb } \\
\text { ise-verbit }\end{array}$} & auka(i)s/ta & auka(is)se/e & $\begin{array}{l}\text { auka(i)se/ } \\
\text { mma }\end{array}$ & aukase/va(t) & $\begin{array}{l}\text { auka(i)s/ } \\
\text { thaan }\end{array}$ \\
\hline & täris/tä & täri(s)se/e & tärise/mmä & tärise/vä(t) & täris/thään \\
\hline \multicolumn{6}{|l|}{$\begin{array}{l}4 \text { Verb med to } \\
\text { vokalstammer }\end{array}$} \\
\hline 4.1 itte-verb & kyytitä & kyytitte/e & kyytitte/mmä & $\begin{array}{l}\text { kyytittee/vät } \\
\text { kyytitte/vä(t) }\end{array}$ & kyyti/thään \\
\hline
\end{tabular}


Tabell 6.5 (Fortsatt)

\begin{tabular}{|c|c|c|c|c|c|}
\hline Verbtype & 1. infinitiv & 3. sg. hän/se & 1. pl. met & 3. pl. het/net & $\begin{array}{l}\text { 3. pl. / passiv } \\
\text { het/net / - }\end{array}$ \\
\hline 4.2 Oitte-verb & piikaroi/ta & piikaroitte/e & $\begin{array}{l}\text { piikaroitte/ } \\
\text { ma }\end{array}$ & $\begin{array}{l}\text { piikaroittee/vat } \\
\sim \text { piikaroitte/ } \\
\text { va(t) }\end{array}$ & $\begin{array}{l}\text { piikaroi/ } \\
\text { thaan }\end{array}$ \\
\hline 4.3 ne-verb & li(j)e/tä & likene/e & likene/mmä & $\begin{array}{l}\text { likenee/vät } \\
\text { likene/vä(t) }\end{array}$ & li(j)e/thään \\
\hline \multirow{3}{*}{$\begin{array}{l}4.4 \text { Kontrakte } \\
\text { verb }\end{array}$} & jatka/ta & jatkaa & jatkaa/ma & jatkaa/va(t) & jatka/thaan \\
\hline & pöl(j)ä/tä & pölk(k)ää & $\begin{array}{l}\text { pölk(k)ää/ } \\
\text { mä }\end{array}$ & pölkää/vä(t) & pöl(j)ä/thään \\
\hline & $\mathrm{ka}(đ) \mathrm{o} / \mathrm{ta}$ & $\begin{array}{l}\text { kattoo } \\
\text { katoa/a }\end{array}$ & $\begin{array}{l}\text { kattoo/ma } \\
\text { katoa/mma }\end{array}$ & $\begin{array}{l}\text { kattoo/va(t) } \\
\text { katoa/va(t) }\end{array}$ & $\mathrm{ka}(đ) \mathrm{o} /$ thaan \\
\hline
\end{tabular}

\subsubsection{Nektende presens}

Kvensk skiller seg fra språk som norsk ved at det har et nektingsord som bøyes, nemlig ordet ei. Det kalles for NeKTingsverb. Til forskjell fra andre verb så bøyes ikke nektingsverbet $\mathrm{i}$ tid eller modus, men derimot har det personbøying: mie en (1. sg.), sie et (2. sg.), hän/se ei (3. sg.), met emmä (1. pl.), tet että (2. pl.), het/net ei (3. pl.). I passiv bruker vi også forma ei. I presens står nektingsverbet sammen med den såkalte NEKTENDE FORMA av HOVEDVERBET, som er den samme i alle personer, for eksempel mie en lähđe ('jeg drar ikke'), der forma lähđe er den nektende forma av verbet lähteet ('dra').

Slike tilfeller der to eller flere verbformer til sammen danner verbalet i setninga, kaller vi for SAMMENSATTE VERBALFORMER.

- Den aktive nektingsforma av type 1-verb er identisk med verbstammen. I type 2- og type 3-verb er den aktive nektingsforma identisk med vokalstammen på svakt stadium, og i type 4-verb er den identisk med den lange vokalstammen.

En enkel måte å finne fram til nektingsforma på er å ta bort personsuffikset - $n \mathrm{i}$ første person entall av bekreftende indikativ presens. For eksempel (1. inf. : 1 . sg. : akt. nektingsform) saa/đa saa/ha ('fä) : saa/n : saa, lähteet lähte/ä(t) lähti/ä ('dra av gårde') : läh(đ)e/n : läh(đ)e, tul/la ('komme') : tule/n : tule, kylästel/lä ('besøke') : kylästele/n : kylästele, tarvi/ta ('trenge') : tarvitte/n : 
tarvitte, piikaroi/ta ('spikre') : piikaroitte/ $n$ : piikaroitte, li(j)e/tä ('nærme seg') :

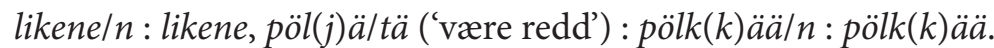

Her er noen eksempelsetninger med aktive nektingsverb:

Entall

Mie en läh $(d)$ e myötä.

Jeg blir ikke med.'

Sie et nä $(j)$ e mettää.

'Du ser ikke skog(en).'

Hän/Se ei pölk(k)ää mithään.

'Han/Hun/Den/Det er ikke redd for noe.'
Flertall

Met emmä läh(đ)e myötä.

'Vi blir ikke med.'

Tet että nä(j)e mettää.

'Dere ser ikke skog(en).'

Het/Net ei pölk(k)ää mithään.

'De er ikke redd for noe.'

Som vi ser, bruker vi i tredje person flertall den samme nektende forma som i de andre aktive personene. Med andre ord er nektende form av tredje person flertall ikke identisk med tilsvarende form i passiv.

- Den Passive neKtingsforma er i verb av type 1, 3 og 4 identisk med forma i 1. infinitiv. I type 2-verb danner vi den passive nektingsforma ved å legge endinga $t A$ til passivstammen. For eksempel (1. inf. : pass. pres. : pass. nektingsform) (verbtype 1) juo/đa juu/a ('drikke') : juo/(đ)haan : juo/đa juu/a, (verbtype 2) lähtelet lähte/ä(t) lähti/ä ('dra av gårde') : läh(đ)e/thään : läh(đ)e/tä, jakka/a(t) ('dele') : ja(j)e/thaan : ja(j)e/ta, (verbtype 3) pes/tä ('vaske') : pes/thään : pes/tä, teh/đä teh/hä ('gjøre') : teh/(đ)hään : teh/đä teh/hä, (verbtype 4) tarvi/ta ('trenge') : tarvi/thaan : tarvi/ta, piikaroi/ta ('spikre') : piikaroi/thaan : piikaroi/ta, pöl(j)ä/tä ('være redd') : pöl(j)ä/thään : pöl(j) ältä.

Her er noen eksempelsetninger med passive nektingsverb:

Bekreftende passiv

Ruijassa juo/ thaan juu/haan vettä.

'I Norge drikkes det vatn.'

Sieltä läh(đ)e/thään Sotšhiin.

'Derifra reiser man til Sotsji.'

Sielä kirjo(i)te/ thaan preivii preiviä.

'Der skrives det på et brev'
Nektende passiv

Franskassa ei juo/đa juu/a vettä.

I Frankrike drikkes det ikke vatn.'

Sieltä ei läh(d)e/tä Sotšhiin.

'Derifra reiser man ikke til Sotsji.'

Sielä ei kirjo(i)te/ta preivii preiviä.

'Der skrives det ikke på noe brev' 
Täälä teh/đ̆ään teh/hään paljon työtä.

'Her arbeides det mye.'

Sitte lau(đ)an piikaroithaan seinhään.

'Så spikres bordet til veggen.'

Alattiossa pöl(j)ä/thä̈̈n kaikkee kaikkea kaikkia.

'I Alta er man redd for alt.'
Täälä ei teh/đä teh/hä mithään.

'Her arbeides ikke mye.'

\subsubsection{Indikativ preteritum}

Tidsforma preteritum bruker vi for å fortelle om noe som skjedde i fortida og/ eller før utsagnsøyeblikket. Jamfør følgende eksempler (1-3):

1. Mie kävin menheenä vuona Tromssassa.

'Jeg dro en tur til Tromsø i fjor.'

2. Pekka pyysi äitiltä rahhaa.

'Peder ba mor om penger.'

3. Pekka ei saanu äitiltä rahhaa.

'Peder fikk ikke penger av mor.'

På samme måte som i presens er det i preteritum forskjell mellom hvordan vi uttrykker bekreftende og nektende former. Vi skal først se på bekreftende preteritum og så på nektende preteritum.

\subsubsection{Bekreftende preteritum}

For å danne aktiv form av BEKREFTENDE PRETERITUM bruker vi som regel suffikset $-i$, men i kontrakte verb (type 4.4) bruker vi -s i tredje person entall, og -si i de andre personene. Til grunn for bøyingsforma i aktiv preteritum ligger presensstammen. Men når vi legger til preteritums-i-en, så kan sluttvokalen i stammen endre seg eller falle bort. Ei anna lydendring som skjer i stammen når vi danner preteritum, er at enkelt $t$ blir til $s$. Disse lydendringene er forklart i avsnitt 3.1.4 og 3.1.5. Tabell 6.6 viser hvordan vi danner bekreftende preteritum i kvensk. 
Tabell 6.6 Personbøying av bekreftende indikativ preteritum

\begin{tabular}{|c|c|c|c|c|c|}
\hline Verbtype & 1. infinitiv & 2. sg. (3. pl.) & 3. sg. & 1. pl. & 3. pl./pass. \\
\hline \multirow[t]{3}{*}{1 Enstava verb } & saa/đa saa/ha & $\mathrm{sa} / \mathrm{i} / \mathrm{t}$ & $\mathrm{sa} / \mathrm{i}$ & $\mathrm{sa} / \mathrm{i} / \mathrm{ma}$ & saa/thiin \\
\hline & vie/đä vii/ä & $\mathrm{ve} / \mathrm{i} / \mathrm{t}$ & ve/i & ve/i/mä & vie/thiin \\
\hline & ui/đa ui/a & $\mathrm{u} / \mathrm{i} / \mathrm{t}$ & $u / i$ & $\mathrm{u} / \mathrm{i} / \mathrm{ma}$ & ui/thiin \\
\hline \multicolumn{6}{|l|}{$\begin{array}{l}2 \text { Enstamma verb } \\
\text { 2a Opprinnelige }\end{array}$} \\
\hline e-stammer & $\begin{array}{l}\text { kulkke/et kulke/ } \\
\mathrm{a}(\mathrm{t}) \sim \text { kulki/a }\end{array}$ & $\mathrm{kulj} / \mathrm{i} / \mathrm{t}$ & kulk/i & kulj/i/ma & kulje/thiin \\
\hline$i$-stammer & soppi/it sopi/a(t) & sov/i/t & sop/i & sov/i/ma & sovi/thiin \\
\hline \multirow[t]{2}{*}{ O-, U-stammer } & $\begin{array}{l}\text { katto/ot katto/ } \\
\text { a(t) }\end{array}$ & katto/i/t & katto/i & katto/i/ma & katto/thiin \\
\hline & $\begin{array}{l}\text { näkky/yt näky/ } \\
\text { ä(t) }\end{array}$ & nä(v)y/i/t & näky/i & nä(v)y/i/mä & nä(v)y/thiin \\
\hline \multirow[t]{4}{*}{ A-stammer } & luotta/a(t) & luot/i/t & luott/i & luot/i/ma & luote/thiin \\
\hline & $\operatorname{ant}(t) a / a(t)$ & anno/i/t & anto/i & anno/i/ma & anne/thiin \\
\hline & lent(t)ä/ä(t) & lens/i/t & lens/i & lens/i/mä & lenne/thiin \\
\hline & varasta/a(t) & varast/i/t & varast/i & varast/i/mma & varaste/thiin \\
\hline \multirow[t]{2}{*}{ 2b Overgangsverb } & muistele/a(t) & muistel/i/t & muistel/i & $\begin{array}{l}\text { muistel/i/ } \\
\mathrm{mma}\end{array}$ & $\begin{array}{l}\text { muistele/ } \\
\text { thiin }\end{array}$ \\
\hline & kyytitte/ä(t) & kyytitt/i/t & kyytitt/i & kyytitt/i/mmä & kyytitte/thiin \\
\hline \multicolumn{6}{|l|}{$\begin{array}{l}3 \text { Verb med } \\
\text { konsonantstamme }\end{array}$} \\
\hline \multirow[t]{3}{*}{ 3.1 Tostava } & ol/la & $\mathrm{ol} / \mathrm{i} / \mathrm{t}$ & $\mathrm{ol} / \mathrm{i}$ & $\mathrm{ol} / \mathrm{i} / \mathrm{ma}$ & ol/thiin \\
\hline & juos/ta & juoks/i/t & juoks/i & juoks/i/ma & juos/thiin \\
\hline & näh/đä näh/hä & nä(j)/i/t & näk/i & nä(j)/i/mä & näh/thiin \\
\hline $\begin{array}{l}3.2 \text { Flerstava ele- } \\
\text { verb }\end{array}$ & ajatel/la & ajattel/i/t & ajattel/i & ajattel/i/ma & ajatel/thiin \\
\hline \multirow[t]{2}{*}{$\begin{array}{l}\text { 3.3 Flerstava } A(I) \\
\text { se- og ise-verb }\end{array}$} & auka(i)s/ta & auka(i)s/i/t & auka(i)s/i & $\begin{array}{l}\text { auka(i)s/i/ } \\
\text { mma }\end{array}$ & $\begin{array}{l}\text { auka(i)s/ } \\
\text { thiin }\end{array}$ \\
\hline & täris/tä & täris/i/t & täris/i & täris/i/mmä & täris/thiin \\
\hline \multicolumn{6}{|l|}{$\begin{array}{l}4 \text { Verb med to } \\
\text { vokalstammer }\end{array}$} \\
\hline \multirow[t]{2}{*}{4.1 itte-verb } & kyyti/tä & kyytitt/i/t & kyytitt/i & kyytitt/i/mmä & kyyti/thiin \\
\hline & tarvi/ta & tarvitt/i/t & tarvitt/i & tarvitt/i/mma & tarvi/thiin \\
\hline 4.2 Oitta-verb & piikaroi/ta & piikaroitt/i/t & piikaroitt/i & $\begin{array}{l}\text { piikaroitt/i/ } \\
\text { ma }\end{array}$ & piikaroi/thiin \\
\hline
\end{tabular}

(Fortsatt) 
Tabell 6.6 (Fortsatt)

\begin{tabular}{|c|c|c|c|c|c|}
\hline Verbtype & 1. infinitiv & 2. sg. (3. pl.) & 3. sg. & 1. pl. & 3. pl./pass. \\
\hline \multirow[t]{2}{*}{4.3 ne-verb } & li(j)e/tä & liken/i/t & liken/i & liken/i/mmä & li(j)e/thiin \\
\hline & vanhe/ta & vanhen/i/t & vanhen/i & $\begin{array}{l}\text { vanhen/i/ } \\
\text { mma }\end{array}$ & vanhe/thiin \\
\hline \multirow[t]{4}{*}{ 4.4 Kontrakte verb } & jatka/ta & jatka/si/t & jatka/s & jatka/si/mma & jatka/thiin \\
\hline & pöl(j)ä/tä & pölkä/si/t & pölkä/s & pölkä/si/mmä & pöl(j)ä/thiin \\
\hline & keri/tä & kerki/si/t & kerki/s & kerki/si/mmä & keri/thiin \\
\hline & $\mathrm{ka}(đ) \mathrm{o} / \mathrm{ta}$ & kato/si/t & kato/s & kato/si/mma & $\mathrm{ka}(đ) \mathrm{o} /$ thiin \\
\hline
\end{tabular}

I de to identiske formene passiv og tredje person flertall er preteritumssuffikset smelta i hop med passivsuffikset. Resultatet er suffikset -thiin, som festes til passivstammen.

Preteritum blir danna på samme måte i de ulike skriftspråksvarietetene, med tredje person flertall som eneste unntak: Bøyingsvarianten - $t$, som er identisk med forma i andre person entall, er det ikke naturlig å bruke i Porsanger-varieteten. Den er sjelden også i de andre varietetene. Derimot er passivforma i tredje person flertall gangbar i alle varietetene.

Preteritumsformer deltar også i stadieveksling. Oftest følger stadievekslinga i første og andre person entall, første og andre person flertall og i passiv de samme reglene i preteritum som i presens.

I tredje person entall av type 2- og 3-verb ter stadievekslinga seg litt annleis enn i presens: Verb som i presens stadieveksler etter mønsteret II : o eller I : o, følger i preteritum mønsteret I : o, som for eksempel verbet kulkkeet kulkea $(t) \sim$ kulkia 'vandre, gå': (3. sg. pres. : 1. sg. pres.) hän kulk(k)ele : mie kulje/n, men (3. sg. pret. : 1. sg. pret.) hän kulk/i : mie kulj/i/n.

I verb med vekslinga $t V: s i$ i stammen er preteritumsformene unntatt fra stadieveksling, og stammen slutter på $-s$ i alle personer. For eksempel (1. inf. : 1 . sg. pres. : 3. sg. pres. : 1. sg. pret. : 3. sg. pret.) tiet $(t) \ddot{a} / \ddot{a}(t)$ ('vite') : tie(đ) ä/n : tiet $(t) \ddot{a} / \ddot{a}:$ ties/i/n : ties/i, lent $(t) \ddot{a} / \ddot{a}(t)$ ('fly') : lennä/n:lent $(t) \ddot{a} / a ̈: l e n s / i / n: l e n s / i$.

Kontrakte verb har sine eigne regler for stadieveksling i preteritum: Kjernekonsonantene med stadieveksling II : I : o er bestandig på I-stadiet $\mathrm{i}$ preteritum, og de med II : I opptrer i preteritum også bare stadium I. Dersom kjernekonsonanten i presensbøyinga veksler mellom stadium II og o eller mellom stadium I og o, så følger stadievekslinga mønsteret I : o også i preteritum. 
For eksempel (1. inf. : 1. sg. pres. : 1. sg. pret. : 3. sg. pret.) pöl(j) $\ddot{a} /$ tä ('være

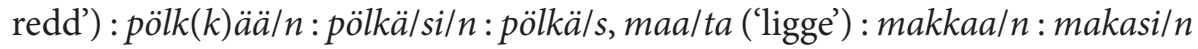
: maka/s, osata ('treffe') : ossaa/n:osa/si/n:osa/s.

Også her minner vi om at type 3-verb med flerstava stamme kan bøyes med hjelp av vokalstammen i alle personer, og at type 4-verb - med unntak av kontrakte verb - kan bøyes med hjelp av den lengre vokalstammen, det vil si at vi behandler disse verba som overgangsverb (type $2 b$ ).

Første person entall lager vi ved å bytte ut suffikset $-t \mathrm{i}$ andre person entall med suffikset $-n$. For å lage andre person flertall bytter vi ut suffikset $-m(m) A$ i første person flertall med suffikset $-t t A$. Den sjeldnere bøyingsforma på - $t \mathrm{i}$ tredje person flertall er identisk med forma i andre person entall.

\subsubsection{Nektende preteritum}

NEKTENDE PRETERITUM dannes som sammensatt verbalform, på samme måte som nektende presens, men i stedet for den nektende forma bruker vi perfektum partisipp. Perfektum partisipp bøyes, og i entall av nektende preteritum bruker vi nominativ entall, og i flertall nominativ flertall.

Her er noen eksempelsetninger med verb i bekreftende og nektende form av aktiv indikativ preteritum, både i entall og flertall:

Bekreftende entall/flertall

Mie $s a / i / n$ preivin.

'Jeg fikk brev(et).'

Sie läh(d)/i/t Alattiohoon.

'Du dro til Alta.'

Nilla $t u l / i$ kothiin.

'Nils kom heim.'

Mie tarvitt/i/ $n$ piilin.

'Jeg trengte bil(en).'

Sie vanhen/i/t hopusti.

'Du blei fort eldre.'

Hän/Se pölkä/s kummitusta.

'Han/Hun/Den/Det var redd for

spøkelset.'

Met sa/i/ma preivin.

'Vi fikk et brev / brevet.'
Nektende entall/flertall

Mie en saa/nu(t) preivii.

'Jeg fikk ikke (noe) brev / brevet.'

Sie et lähte/ny(t) Alattihoon.

'Du dro ikke til Alta.'

Nilla ei $t u l / l u(t)$ kothiin.

'Nils kom ikke heim.'

Mie en tarvi/nu( $t)$ pilii piiliä.

'Jeg trengte ikke (noen) bil / bilen.'

Sie et vanhe/nu(t) hopusti.

'Du blei ikke fort eldre.'

Hän/Se ei pöl(j)ä/ny(t) mithään.

'Han/Hun/Den/Det var ikke redd for noe.'

Met emmä saan/heet preivii preiviä.

'Vi fikk ikke (noe) brev / brevet.' 
Tet läh(đ)/i/ttä Alattihoon.

'Dere dro til Alta.'

Pojat tul/thiin tul/i/t kothiin.

'Guttene kom heim.'

Met tarvitt/i/mma piilin.

'Vi trengte bil(en).'

Tet vanhen/i/tta hopusti.

'Dere blei fort eldre.'
Tet että lähte/nheet Alattihoon.

'Dere dro ikke til Alta.'

Pojat ei tul/heet kothiin.

'Guttene kom ikke heim.'

Met emmä tarvi/nheet piilii piiliä.

'Vi trengte ikke (noen) bil/bilen.'

Tet että vanhe/nheet hopusti.

'Dere blei ikke fort eldre.'

Het pöljä/thiin pölkä/si/t kummitusta. Het ei pöljä/nheet kummitusta.

'De var redd for spøkelset.'

'De var ikke redd for spøkelset.'

Nektende form av passiv indikativ preteritum dannes på tilsvarende måte med nektingsverbet $e i$ og passiv form av perfektum partisipp av hovedverbet. For eksempel:

Bekreftende passiv

Laattarissa uithiin.

'Man/Folk bada på Laattari'.

Sieltä läh(đ)e/thiin Alattihoon.

'Derifra dro man/folk til Alta.'

Aamula tul/thiin kothiin.

'Om morgenen kom man/folk heim.

Tarvi/thiin piilii piiliä.

'Man/Folk trengte bil(en).'

Ennen vanhe/thiin hopusti.

'Før i tida blei man/folk fort gamle.'

Sielä pöl(j)ä/thiin kummitusta.

'Der var man/folk redd for spøkelset.'
Nektende passiv

Possukopassa ei uitu.

'I Bossekop bada man/folk ikke'

Sieltä ei läh(đ)e/tty Alattihoon.

'Derifra dro man/de/folk ikke til Alta.'

Kothiin ei tul/tu aamula.

'Man/Folk kom ikke heim om morgenen.'

Piilii piiliä ei tarvi/ttu.

'Bil(en) trengte man/folk ikke.'

Ennen ei vanhe/ttu hopusti.

'Før i tida blei man/folk ikke fort gamle.'

Sielä ei pöl(j)ä/tty mithään.

'Der var man/folk ikke redd for noe.'

Nedafor greier vi ut om hvordan vi danner perfektum partisipp.

\subsubsection{Perfektum partisipp}

Perfektum partisipp deltar i flere sammensatte verbalformer, ikke bare i nektende preteritum. I tabell 6.7 ser vi en oversikt over perfektum partisipp-former. Vi skal her se nærmere på hvordan vi lager disse formene. 
Tabell 6.7 Nominativsformer av perfektum partisipp

\begin{tabular}{|c|c|c|c|c|}
\hline Verbtype & 1. infinitiv & $\begin{array}{l}\text { Akt. perf. pts., } \\
\text { sg. nom. }\end{array}$ & $\begin{array}{l}\text { Akt. perf. pts., } \\
\text { pl. nom. }\end{array}$ & $\begin{array}{l}\text { Pass. perf. pts., } \\
\text { sg. nom. }\end{array}$ \\
\hline \multirow[t]{2}{*}{1 Enstava verb } & saa/đa saa/ha & saa/nu(t) & saa/nhee/t & saa/tu \\
\hline & vie/đä vii/ä & $\mathrm{vie} / \mathrm{ny}(\mathrm{t})$ & vie/nhee/t & vie/ty \\
\hline \multicolumn{5}{|l|}{2 Enstamma verb } \\
\hline \multirow[t]{5}{*}{ 2a Opprinnelige } & $\begin{array}{l}\text { kulkke/et kulke/ } \\
\text { a(t) kulki/a }\end{array}$ & kulke/nu(t) & kulke/nhee/t & kulje/ttu \\
\hline & $\begin{array}{l}\text { lukke/et luke/ } \\
\mathrm{a}(\mathrm{t}) \sim \text { luki/a }\end{array}$ & luke/nu(t) & luke/nhee/t & lu(j)e/ttu \\
\hline & soppi/it sopi/a(t) & sopi/nu(t) & sopi/nhee/t & sovi/ttu \\
\hline & lent(t)ä/ä(t) & lentä/ny(t) & lentä/nhee/t & lenne/tty \\
\hline & varasta/a(t) & varasta/nnu(t) & varasta/nhee/t & varaste/ttu \\
\hline \multirow[t]{5}{*}{ 2b Overgangsverb } & muistele/a(t) & $\begin{array}{l}\text { muistele/ } \\
\text { nnu(t) }\end{array}$ & muistele/nhee/t & muistele/ttu \\
\hline & aukase/a(t) & aukase/nnu(t) & aukase/nhee/t & aikase/ttu \\
\hline & kyytitte/ä(t) & kyytitte/nny(t) & kyytitte/nhee/t & kyytitte/tty \\
\hline & piikaroitte/a(t) & $\begin{array}{l}\text { piikaroitte/ } \\
\text { nu(t) }\end{array}$ & $\begin{array}{l}\text { piikaroitte/ } \\
\text { nhee/t }\end{array}$ & piikaroitte/ttu \\
\hline & likene/ä(t) & likene/nny(t) & likene/nhee/t & likene/tty \\
\hline \multicolumn{5}{|l|}{$\begin{array}{l}3 \text { Verb med } \\
\text { konsonantstamme }\end{array}$} \\
\hline \multirow[t]{3}{*}{ 3.1 Tostava } & ol/la & ol/lu(t) & ol/hee/t & $\mathrm{ol} / \mathrm{tu}$ \\
\hline & juos/ta & juos/su(t) & juos/hee/t & juos/tu \\
\hline & näh/đä näh/hä & näh/ny(t) & näh/nhee/t & näh/ty \\
\hline \multirow{2}{*}{$\begin{array}{l}3.2 \text { Flerstava } \\
\text { ele-verb }\end{array}$} & kävel/ä & kävel/y(t) & kävel/hee/t & kävel/ty \\
\hline & ajatel/la & ajatel/lu(t) & ajatel/heet & ajatel/tu \\
\hline \multirow{2}{*}{$\begin{array}{l}3.3 \text { Flerstava } A(I) \\
\text { se- og ise-verb }\end{array}$} & auka(i)s/ta & auka(i)s/su(t) & auka(i)s/heet & auka(i)s/tu \\
\hline & täris/tä & täris/sy(t) & täris/heet & täris/ty \\
\hline \multicolumn{5}{|l|}{$\begin{array}{l}4 \text { Verb med to } \\
\text { vokalstammer }\end{array}$} \\
\hline 4.1 itte-verb & kyyti/tä & kyyti/ny(t) & kyyti/nhee/t & kyyti/tty \\
\hline 4.2 Oitte-verb & piikaroi/ta & piikaroi/nu(t) & piikaroi/nhee/t & piikaroi/ttu \\
\hline \multirow[t]{2}{*}{4.3 ne-verb } & li(j)e/tä & li(j)e/ny(t) & li(j)e/nhee/t & li(j)e/tty \\
\hline & vanhe/ta & vanhe/nu(t) & vanhe/nhee/t & vanhe/ttu \\
\hline \multirow[t]{4}{*}{4.4 Kontrakte verb } & jatka/ta & jatka/nu(t) & jatka/nhee/t & jatka/ttu \\
\hline & pöl(j)ä/tä & pöl(j)ä/ny(t) & pöl(j)ä/nhee/t & pöl(j)ä/tty \\
\hline & keri/tä & keri/ny(t) & keri/nhee/t & keri/tty \\
\hline & $\mathrm{ka}(đ) \mathrm{o} / \mathrm{ta}$ & $\mathrm{ka}(\mathrm{d}) \mathrm{o} / \mathrm{nu}(\mathrm{t})$ & ka(đ)o/nhee/t & $\mathrm{ka}(đ) \mathrm{o} / \mathrm{ttu}$ \\
\hline
\end{tabular}


- I AKTIV form av PERFEKTUM PARTISIPP bruker vi suffikset - $(n) n U(t)$, som markerer nominativ entall. Forma uten $t$ på slutten er mest utbreid, og det hender derfor at vi bruker den $t$-lause forma også i eksempla våre på sammensatte verbalformer. Lengda på $n$ i suffikset følger lengderegelen for stemte konsonanter (se avsnitt 3.1.2). Vokalstammeforma av suffikset er alltid - $(n)$ hee-. Vi bøyer perfektum partisipp etter mønster av nomentype 3.2, og nominativ flertall ender dermed på - $(n)$ hee/t. Disse entalls- og flertallsformene bruker vi når vi danner aktive sammensatte verbalformer.

Suffiksa i aktiv form av perfektum partisipp festes til verbstammen på følgende måte:

I enstava verb (type 1 ) fester vi suffikset $-n U(t)$ : nhee til stammen. For eksempel (1. inf. : perf. pts. sg. nom. : perf. pts. pl. nom.) saa/da saaha ('få) $: s a a / n u(t):$ saa/nhee/t, vie/dä $\sim$ vii/ä ('bringe, ta med') : vie/ny(t) : vie/nhee/t.

I enstamma verb (type 2) fester vi suffikset $-n U(t)$ : -nhee til stammen på samme stadiet som vi bruker i tredje person entall bekreftende form av indikativ preteritum. For eksempel (1. inf. : 3. sg. pret. : perf. pts. sg. nom. : perf. pts. pl. nom.) kulkke/et $\sim$ kulke/a(t) kulki/a ('vandre, gå') : kulk/i: kulke/nu(t) : kulke/nhee/t, sanno/ot sano/a(t) ('si') : sano/i : sano/nu(t) : sanon/nhee/t, jakka/a(t) ('dele') : jako/i: jaka/nu(t) : jaka/nhee/t, suuttu/ut suuttu/a(t) ('bli sint') : suuttu/i:suuttu/nu(t) : suuttu/nhee/t, kirjo(i)tta/a(t) ('skrive') : kirjo(i) tt/i: $\operatorname{kirjo}(i) t t a / n n u(t): k i r j o(i) t t a / n h e e / t$.

I verb med konsonantstamme (type 3) legger vi perfektum partisippsuffikset alltid til konsonantstammen. Dersom stammen slutter på en av konsonantene $l, r$ eller $s$, så blir $n$ i suffikset assimilert av denne konsonanten. Suffiksformene i nominativ entall blir da $-n U(t),-l U(t),-r U(t)$ og $-s U(t)$. Vokalstammeforma av suffikset er alltid hee-. For eksempel: (1. inf. : perf. pts. sg. nom. : perf. pts. pl. nom.) men/nä ('gå') : men/ny(t) : men/hee/t, tul/la ('komme') : tul/lu(t) : tul/hee/t, kuul/a ('høre') : kuul/u(t) : kuul/hee/t, juos/ta ('springe') : juos/su(t) : juos/hee/t, kävel/ä ('spasere, gå') : kävel/y(t): kävel/hee/t, ajatel/la ('tenke') : ajatel/lu( $t)$ : ajatel/hee/t, auka(i)s/ta ('åpne') : auka(i)s/su(t) : auka(i)s/hee/t. Også her er lengda av konsonantene $n, l$ og $r$ bestemt av lengderegelen for stemte konsonanter (se avsnitt 3.1.2).

Til verbtype 3 hører også verba näh/đä näh/hä ('se') og teh/đä teh/hä ('gjøre'), som bøyes slik i aktiv form av perfektum partisipp: (akt. perf. pts. 
sg. nom. : akt. perf. pts. pl. nom.) näh/ny(t) : näh/nhee/t og teh/ny(t) : teh/nhee/t.

I verb med to vokalstammer (type 4) legger vi perfektum partisipp-suffikset direkte til den korte vokalstammen, som også brukes i 1. infinitiv. For eksempel (1. inf. : perf. pts. sg. nom. : perf. pts. pl. nom.) tarvi/ta ('trenge') : tarvi/nu(t) : tarvi/nhee/t, häiri/tä ('forstyrre') : häiri/ny(t) : häiri/nhee/t, piikaroi/ta ('spikre') : piikaroi/nu(t) : piikaroi/nhee/t, li(j)e/tä ('nærme seg') :

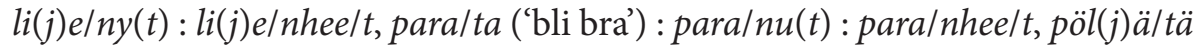
('være redd') : pöl(j)ä/ny(t) : pöl(j)ä/nhee/t, maa/ta ('ligge') : maa/nu(t) : maa/nhee/t.

Perfektum partisipp-formene til overgangsverb (type $2 b$ ) ser slik ut: (1. inf. : perf. pts. sg. nom. : perf. pts. pl. nom.) ajattele/a(t) ('tenke') : ajattele/nu( $t)$ : ajattele/nhee/t, aukase/a(t) ('åpne’) : aukase/nnu(t): aukase/nhee/t, häiritte/ä $(t)$ ('forstyrre') : häiritte/nny $(t)$ : häiritte/nhee/t, piikaroitte/a(t) ('spikre') : piikaroitte/nu( $t$ ) : piikaroitte/nhee/t, likene/ä( $t$ ) ('nærme seg') : likene/nny $(t)$ : likene/nhee/t.

- Den PAssive forma av PERfEKTUm PARTISIPP danner vi med et heilt anna suffiks, nemlig - $(t) t U$, som legges til passivstammen, akkurat som de andre passivsuffiksa. I enstava verb (type 1) og i verb med konsonantstamme (type 3) bruker vi suffiksforma $-t U$, i de andre verbtypene $-t t U$. For eksempel (1. inf. : pass. pres. : pass. perf. pts. sg. nom.) saa/đa saa/ha ('få) : saa/(đ)haan : saa/tu, kirjo(i)ttala(t) ('skrive') : kirjo(i)te/thaan : kirjo(i)telttu, lähtelet

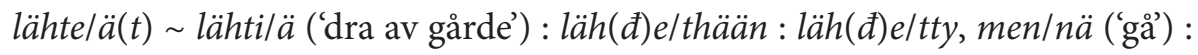
men/hään : men/ty, näh/đä näh/hä ('se') : näh(đ)hään : näh/ty, auka(i)s/ta ('åpne') : auka(i)s/thaan: auka(i)s/tu, tarvi/ta ('trenge') : tarvi/thaan: tarvi/ttu, piikaroi/ta ('spikre') : piikaroi/thaan : piikaroi/ttu, (li(j)e/tä ('nærme seg') :

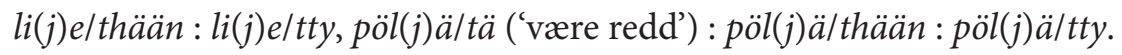

De passive perfektum partisipp-formene av overgangsverb ser slik ut: (1. inf : pass. perf. pts. sg. nom.) ajattele/a(t) ('tenke') : ajattele/ttu, aukase/a(t) ('åpne') : aukaselttu, häirittelä( $t$ ) ('forstyrre') : häiritteltty, piikaroittela(t) ('spikre') : piikaroitte/ttu, likene/ä(t) ('nærme seg') : likene/tty.

De passive perfektum partisipp-formene bruker vi når vi danner passive sammensatte verbalformer.

Som vi har nevnt før, så bøyes perfektum partisipp. Det har fullstendig kasus- og personbøying. 


\subsubsection{Indikativ presens perfektum og preteritum perfektum}

Tidsforma perfektum bruker vi når vi forteller at noe har skjedd eller blitt gjort før utsagnsøyeblikket. Men vi ser på handlinga eller hendelsen med utsagnsøyeblikket som utgangspunkt. Det viktigste er altså ikke når handlinga eller hendelsen skjedde, men at den skjedde før utsagnsøyeblikket, og at den på en eller annen måte er relevant for situasjonen i utsagnsøyeblikket. Vi skiller mellom to typer perfektum. I PRESENS PERFEKTUM faller utsagnsøyeblikket sammen med nåtida, det vil si at det forteller at noe har skjedd før nå, mens i PRETERITUM PERFEKTUM ligger utsagnsøyeblikket i fortida, det vil si at det forteller at noe hadde skjedd før et bestemt tidspunkt i fortida. I tradisjonelle grammatikker bruker man begrepet perfektum om det vi her kaller for presens perfektum, og begrepet pluskvamperfektum om det vi her kaller for preteritum perfektum.

Her er noen eksempler på presens perfektum og preteritum perfektum:

Presens perfektum

Mie olen ollu aikamatkala.

'Jeg har vært på tidsreise.'

Sie olet käyny Englanissa.

'Du har vært en tur i England.'

Se/Hän oon kirjo(i)ttannu preivin.

'Han/Hun har skrevet et brev /

brevet.'

Met olema olheet aikamatkala.

'Vi har vært på tidsreise.'

Tet oletta käynheet Englanissa.

'Dere har dratt en tur til England.'

Net/Het oon kirjo(i)ttanheet preivin.

'De har skrevet et brev / brevet.'

Preivin oon kirjo(i)tettu.

'Brevet / Et brev er (blitt) skrevet. /

Det har blitt skrevet et brev.'
Preteritum perfektum

Mie olin ollu aikamatkala.

'Jeg hadde vært på tidsreise.'

Sie olit käyny Englanissa.

'Du hadde dratt en tur til England.'

Se/Hän oli kirjo(i)ttannu preivin.

'Han/Hun hadde skrevet et brev /

brevet.'

Met olima olheet aikamatkala.

'Vi hadde vært på tidsreise.'

Tet olitta käynheet Englanissa.

'Dere hadde dratt en tur til England.'

Net/Het olthiin olit kirjo(i)ttanheet preivin.

'De hadde skrevet et brev / brevet.'

Preivin oli kirjo(i)tettu.

'Brevet / Et brev var (blitt) skrevet. /

Det var blitt skrevet et brev'. 


\subsubsection{Bekreftende presens perfektum og preteritum perfektum}

INDIKATIV PRESENS PERFEKTUM Og PRETERITUM PERFEKTUM er begge sammensatte verbalformer. De består av hjelpeverbet olla ('være'), som bøyes i tid og person, og som altså er det finitte verbet i setninga, og hovedverbet i form av perfektum partisipp i entall eller flertall nominativ. (Se avsnitt 6.4.2.3 om hvordan en danner perfektum partisipp.)

- I AKTIV form av presens perfektum står verbet olla ('være') i presens: olen, olet, oon, olema, oletta, oon. I preteritum perfektum står det i preteritum: olin, olit, oli, olima, olitta, olthiin olit. I entall står hovedverbet i den aktive forma av perfektum partisipp i nominativ entall. I flertall står det i den tilsvarende forma i nominativ flertall. For eksempel: (1. inf. : akt. 1. sg. ind. pres. perf. : 2. pl. akt. ind. pres. perf. : 3. sg. akt. ind. pret. perf. : 3. pl. akt. ind.

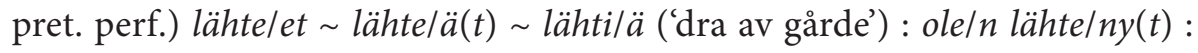
ole/tta lähte/nhee/t : ol/i lähte/ny $(t):$ ol/thiin ol/i/t lähte/nhee/t, tul/la ('komme') : ole/n tul/lu(t) : ole/tta tul/hee/t : ol/i tul/lu(t) : ol/thiin oli/t tull hee/t.

- I PASSIV form av presens perfektum og preteritum perfektum bruker vi hjelpeverbet olla ('være') i tredje person entall (oon, oli) og hovedverbet i den passive forma av perfektum partisipp, som dannes med suffikset $-(t) t U$. For eksempel: (1. inf. : pass. ind. pres. perf. : pass. ind. pret. perf.) lähtelet lähte/ä(t) lähti/ä ('dra av gårde') : oon läh(đ)e/tty : ol/i läh(d)e/tty, tul/la ('komme') : oon tul/tu : ol/i tul/tu.

\subsubsection{Nektende presens perfektum og preteritum perfektum}

Som de enkle tidsformene presens og preteritum så har også de sammensatte perfektumsformene eigne NEKTENDE former.

NEKTENDE PRESENS PERFEKTUM i aktiv dannes ved at en kombinerer det personbøyde nektingsverbet ei med nektingsforma av hjelpeverbet olla ('være') og hovedverbet i aktiv form av perfektum partisipp i entall eller flertall nominativ. Nektende presens perfektum i passiv dannes på samme måte bortsett fra at vi her bruker hovedverbet i passiv form av perfektum partisipp. NeKTENDE PRETERItum PERFEKTUm lager vi etter samme mønster, men i stedet for nektingsforma bruker vi her perfektum partisipp-form av hjelpeverbet olla ('være'). I entall og i passiv bruker vi forma ollu(t), og i flertall bruker vi forma olheet. 
For eksempel:

Nektende presens perfektum

Mie en ole ollu( $t$ ) Kiinassa.

'Jeg har ikke vært i Kina.'

Sie et ole käyny $(t)$ Englanissa.

'Du har ikke besøkt England.'

Se/Hän ei ole kirjo(i)ttannu(t) preivii $\sim$ preiviä.

'Han/Hun har ikke skrevet noe(n) brev.'

Met emmä ole olheet Kiinassa.

'Vi har ikke vært i Kina.'

Tet että ole käynheet Englanissa.

'Dere har ikke besøkt England.'

Net/Het ei ole kirjo(i)ttanheet preivii $\sim$ preiviä.

'De har ikke skrevet noe(n) brev'.

Preivii Preiviä ei ole kirjo(i)tettu.

'Det har ikke blitt skrevet noe(n) brev.'
Nektende preteritum perfektum

Mie en ollu $(t)$ ollu $(t)$ Kiinassa.

'Jeg hadde ikke vært i Kina.'

Sie et ollu( $(t)$ käyny $(t)$ Englanissa.

'Du hadde ikke besøkt England.'

Se/Hän ei ollu(t) kirjo(i)ttannu(t) preivii preiviä.

'Han/Hun hadde ikke skrevet noe(n) brev'

Met emmä olheet olheet Kiinassa.

'Vi hadde ikke vært i Kina.'

Tet että olheet käynheet Englanissa.

'Dere hadde ikke besøkt England.'

Net/Het ei olheet kirjo(i)ttanheet preivii preiviä.

'De hadde ikke skrevet noe(n) brev'.

Preivii Preiviä ei ollu(t) kirjo(i)tettu.

'Det hadde ikke blitt skrevet noe(n) brev'

\subsubsection{Perfektum partisipp i sammensatte verbalformer}

Av framstillinga ovafor ser vi at hovedverbet står i perfektum partisipp

- i nektende preteritum sammen med nektingsverbet,

- i bekreftende presens perfektum sammen med den personbøyde forma av hjelpeverbet olla ('være'),

- i nektende presens perfektum sammen med nektingsverbet og nektende form av hjelpeverbet olla ('være'),

- i bekreftende preteritum perfektum sammen med den personbøyde forma av hjelpeverbet olla ('være'), og

- i nektende preteritum perfektum sammen med nektingsverbet og hjelpeverbet olla ('være') i perfektum partisipp. 
I entall står perfektum partisipp i nominativ entall, og i flertall står det i nominativ flertall. I passiv kombinerer vi aktive perfektum partisipp-former av hjelpeverbet olla ('være') i entall og passive perfektum partisipp-former av hovedverbet i entall. I tabell 6.8 er det samla eksempler på alle bøyingsformer

Tabell 6.8 Sammensatte verbalformer med perfektum partisipp

\begin{tabular}{|c|c|c|}
\hline Sammensatt verbalform & $\begin{array}{l}\text { Aktiv 1. sg., 2. sg., } 3 . \\
\text { sg. }\end{array}$ & $\begin{array}{l}\text { Aktiv form av perfektum partisipp, entall } \\
\text { nominativ }\end{array}$ \\
\hline Nektende preteritum & en, et, ei & \multirow{5}{*}{$\begin{array}{l}\text { (1) saa/nu(t), vie/ny(t), ui/nu(t); (2a) kulke/nu(t), } \\
\text { luke/nu(t), sopi/nu(t), tohti/nu(t), aiko/nu(t), } \\
\text { katto/nu(t), näky/ny(t), luotta/nu(t), anta/nu(t), } \\
\text { lentä/ny(t), varasta/nnu(t), näytästä/nny(t); } \\
\text { (2b) kävele/nny(t), aukase/nnu(t), kyytitte/nny(t), } \\
\text { piikaroitte/nu(t), vanhene/nnu(t); (3) ol/lu(t), } \\
\text { juos/su(t), näh/ny(t), kävel/y(t), ajatel/lu(t), } \\
\text { auka(i)s/su(t); (4) kyyti/ny(t), tarvi/nu(t), } \\
\text { piikaroi/nu(t), li(j)e/ny(t), vanhe/nu(t), jatka/nu(t), } \\
\text { pöl(j)ä/ny(t), keri/ny(t), ka(đ)o/nu(t) }\end{array}$} \\
\hline $\begin{array}{l}\text { Bekreftende presens } \\
\text { perfektum }\end{array}$ & olen, olet, oon & \\
\hline $\begin{array}{l}\text { Nektende presens } \\
\text { perfektum }\end{array}$ & en ole, et ole, ei ole & \\
\hline $\begin{array}{l}\text { Bekreftende preteritum } \\
\text { perfektum }\end{array}$ & olin, olit, oli & \\
\hline $\begin{array}{l}\text { Nektende preteritum } \\
\text { perfektum }\end{array}$ & $\begin{array}{l}\text { en ollu(t), et ollu(t), } \\
\text { ei ollu(t) }\end{array}$ & \\
\hline Sammensatt verbalform & Aktiv 1. pl., 2. pl., 3. pl. & $\begin{array}{l}\text { Aktiv form av perfektum partisipp, flertall } \\
\text { nominativ }\end{array}$ \\
\hline Nektende preteritum & emmä, että, ei & \multirow{5}{*}{$\begin{array}{l}\text { (1) saa/nhee/t, vie/nhee/t, ui/nhee/t; } \\
\text { (2a) kulke/nhee/t, luke/nhee/t, sopi/nhee/t, } \\
\text { tohti/nhee/t, aiko/nhee/t, katto/nhee/t, } \\
\text { näky/nhee/t, luotta/nhee/t, anta/nhee/t, } \\
\text { lentä/nhee/t, varasta/nhee/t, näytästä/nhee/t; } \\
\text { (2b) kävele/nheet, aukase/nheet, } \\
\text { kyytitte/nheet, piikatoitte/nheet, } \\
\text { vanhene/nheet; (3) ol/hee/t, juos/hee/t, } \\
\text { näh/nhee/t, kävel/hee/t, ajatel/hee/t, } \\
\text { auka(i)s/hee/t; (4) kyyti/nhee/t, tarvi/nhee/t, } \\
\text { piikaroi/nhee/t, li(j)e/nhee/t, vanhe/nhee/t, } \\
\text { jatka/nhee/t, pöl(j)ä/nhee/t, keri/nhee/t, } \\
\text { ka(đ)o/nhee/t }\end{array}$} \\
\hline $\begin{array}{l}\text { Bekreftende presens } \\
\text { perfektum }\end{array}$ & olema, oletta, oon & \\
\hline $\begin{array}{l}\text { Nektende presens } \\
\text { perfektum }\end{array}$ & $\begin{array}{l}\text { emmä ole, että ole, } \\
\text { ei ole }\end{array}$ & \\
\hline $\begin{array}{l}\text { Bekreftende preteritum } \\
\text { perfektum }\end{array}$ & $\begin{array}{l}\text { olima, olitta, olthiin } \\
\text { olit }\end{array}$ & \\
\hline $\begin{array}{l}\text { Nektende preteritum } \\
\text { perfektum }\end{array}$ & $\begin{array}{l}\text { emmä olheet, että } \\
\text { olheet, ei olheet }\end{array}$ & \\
\hline Sammensatt verbalform & Passiv & $\begin{array}{l}\text { Passiv form av perfektum partisipp, entall } \\
\text { nominativ }\end{array}$ \\
\hline Nektende preteritum & ei & \multirow{5}{*}{$\begin{array}{l}\text { (1) saa/tu, vie/ty, ui/tu; (2a) kulje/ttu, } \\
\text { lu(j)e/ttu, sovi/ttu, toh(đ)i/ttu, ai(j)o/ttu, } \\
\text { katto/ttu, nä(v)y/tty, luote/ttu, anne/ttu, } \\
\text { lenne/tty, varaste/ttu, näytäste/tty; } \\
\text { (2b) kävele/tty, aukase/ttu, kyytitte/tty, } \\
\text { piikaroitte/ttu, vanhene/ttu; (3) ol/tu, juos/tu, } \\
\text { näh/ty, kävel/ty, ajatel/tu, auka(i)s/tu; } \\
\text { (4) kyyti/tty, tarvi/ttu, piikaroi/ttu, li(j)e/tty, } \\
\text { vanhe/ttu, jatka/ttu, pöl(j)ä/tty, keri/tty, } \\
\text { ka(đ)o/ttu }\end{array}$} \\
\hline $\begin{array}{l}\text { Bekreftende presens } \\
\text { perfektum }\end{array}$ & oon & \\
\hline $\begin{array}{l}\text { Nektende presens } \\
\text { perfektum }\end{array}$ & ei ole & \\
\hline $\begin{array}{l}\text { Bekreftende preteritum } \\
\text { perfektum }\end{array}$ & oli & \\
\hline $\begin{array}{l}\text { Nektende preteritum } \\
\text { perfektum }\end{array}$ & ei ollu & \\
\hline
\end{tabular}


i indikativ som dannes med hjelp av perfektum partisipp. Talla i parentes viser til de ulike verbtypene.

\subsection{Kondisjonalis}

Modusforma KONDISJONALIs er ganske vanlig både i muntlig og skriftlig kvensk. I kondisjonalis brukes samme person- og tallbøying som i indikativ, det vil si første, andre og tredje person entall og flertall og passiv form. Videre brukes kondisjonalis i to tidsformer, i presens og i presens perfektum. I motsetning til indikativ markeres kondisjonalis med et eige suffiks. I tredje person entall og i passiv bruker vi suffikset -is, ellers -isi. Suffikset er med i alle kondisjonalisformene. Setningene i (1-8) gir eksempler på bruken av kondisjonalis:

1. Mie lähtisin mielelä Tromsshaan.

'Jeg skulle gjerne dra til Tromsø'

2. Sie saisit jo lähteet $\sim$ lähteä(t) lähtiä kothiin.

'Det hadde vært best om du allerede dro heim.'

3. Ville opastuis Priitan kans, jos se olis mah(đ)olinen.

'Ville skulle bli kjent med Brita om det var mulig.'

4. Jos met halluisimma haluaisima, met saattaisimma matkustaa(t) vaikka kuuhun.

'Dersom vi ville, så kunne vi reise om så til månen.'

5. Tet pölk(k)äisittä hukkii hukkia, jos tet niitä kohtaisitta.

'Dere ville være redd for ulv om dere møtte noen.'

6. Liisa ja Pekka jatkattais/jatkaisit matkaa, jos heilä olis piili.

'Lisa og Peder skulle fortsette turen om de hadde bil.'

7. Kuuhunki läh(đ)ettäis, jos olis aikamasiini.

'Også til månen skulle man reise om det fantes en tidsmaskin.'

8. Jos met emmä olis lähtenheet pyythöön, se met emmä olis saanheet kallaa. 'Om vi ikke hadde dratt på fiske, ville vi ikke ha fått fisk.'

\subsubsection{Kondisjonalis presens}

Nedafor skal vi ta for oss hvordan vi danner bekreftende og nektende former av kondisjonalis presens. De viktigste formene er oppført i tabell 6.9, som følger heilt til slutt i utgreiinga. 


\subsubsection{Bekreftende kondisjonalis presens}

KondisjonAlis PRESENS dannes på følgende måte:

- AKTIV form av KONDISJONALIS PRESENs består av vokalstammen til verbet etterfulgt av kondisjonalissuffikset -is(i) og personsuffikset. Stammen er på samme stadiet som i tredje person av bekreftende indikativ preteritum (se avsnitt 6.4.2.1). I kontrakte verb (type 4.4) er stammen likevel på stadium II dersom det er mulig i det aktuelle verbet og i den aktuelle varieteten. I tredje person flertall kan vi bruke to varianter: Enten samme form som i passiv eller en variant med personsuffikset $-t$, det vil si samme form som i andre person entall.

Vokalvekslingene i stammen følger generelt de samme reglene som foran preteritums- $i$, med unntak av at stammevokalen $A$ står ved lag foran kondisjonalissuffikset -is(i). (Vokalvekslinger foran suffikset - $i$ er forklart i avsnitt 3.1.4.)

Eksempler på aktiv form av kondisjonalis presens: (1. inf. : 3. sg. ind. pret. : 3. sg. kond. pres. : 2. sg. kond. pres./3. pl. kond. pres.) (verbtype 1) saa/da saa/ha ('få) : sali : salis, sa/isi/t, vie/(đ) ä vii/ä ('bringe, ta med') : veli : ve/is : ve/isi/t, ui/(đ)a ('svømme') : u/i : u/is : u/isi/t, (verbtype 2) kulkke/et kulke/a(t) kulki/a ('vandre, gå') : kulk/i: kulk/is: kulk/isi/t, soppi/it sopi/a(t) ('passe') : sop/i : sop/is : sop/isi/t, neuvo/ot neuvo/a(t) ('gi råd') : neuvo/i : neuvo/is : neuvo/isi/t, ant $(t) a / a(t)$ ('gi') : anto/ $i$ : anta/is : anta/isi/t, lent $(t) \ddot{a} / \ddot{a}(t)$ ('fly') : lens/i : lentä/is : lentä/isi/t, (verbtype 3) ol/la ('være') :ol/i:ol/is :ol/isi/t, juos/ta ('springe') : juoks/i : juoks/is : juoks/isi/t, ajatel/la ('tenke') : ajattel/i : ajattel/is : ajattel/isi/t, auka(i)s/ta ('åpne') : auka(i)s/i:auka(i)s/isi/t, (verbtype 4) kyyti/tä ('skysse') : kyytitt/i : kyytitt/is : kyytitt/isi/t, piikaroi/ta ('spikre') : piikaroitt/i : piikaroitt/is : piikaroitt/isi/t, li(j)e/tä ('nærme seg') : liken/i : liken/is : liken/isi/t, pöl(j)ätä ('være redd') : pölkä/s : pölk(k)ä/is : pölk(k)ä/isi/t, ka(đ)o/ta ('forsvinne') : kato/s : katto/is katoa/is : katto/isi/t katoa/isi/t, keri/tä ('rekke') : kerki/s : kerkki/is kerkiä/is : kerkki/isi/t kerkiä/isi/t.

- PASSIV form av KONDISJONALIS PRESENS består av passivstammen etterfulgt av suffikset - $(t) t$ Ais. I enstava verb (type 1 ) og -i verb med konsonantstamme (type 3 ) bruker vi varianten - $t$ Ais, ellers varianten $t$ tAis.

Eksempler på passiv form av kondisjonalis presens: (1. inf. : 3. pl. kond. pres./pass. kond. pres.) (verbtype 1) saa/đa saa/ha ('fă') : saa/tais, vie/(đ) a vii/ä ('bringe, ta med') : vie/täis, ui/(đ)a : ui/tais ('svømme'), (verbtype 2a) 
kulkkelet $\sim$ kulkela( $(t) \sim$ kulkila ('vandre, gå) : kuljelttais, soppi/it sopi/a(t) ('passe') : sovi/ttais, katto/ot katto/a(t) ('se på) : katto/ttais, luottala(t) ('stole på) : luote/ttais, lent(t)ä/ät ('fly') : lenne/ttäis, (verbtype 3) ol/la ('være') : ol/tais, juos/ta ('springe') : juos/tais, ajatel/la ('tenke') : ajatel/tais, auka(i)s/ta ('åpne') : auka(i)s/tais, (verbtype 4) kyyti/tä ('skysse') : kyyti/ttäis, piikaroi/ta ('spikre') : piikaroi/ttais, li(j)eltä ('nærme seg') : li(j)elttäis, pöl(j)ä/tä ('være redd') : pöl(j)ä/ttäis, ka(đ)o/ta ('forsvinne') : ka(đ)o/ttais, keri/tä ('rekke') : keri/ttäis.

Det er vanlig å bruke den passive kondisjonalisforma også i tredje person flertall. Dersom man velger å bøye verb av type 3 og 4 som overgangsverb (type 2b), så dannes kondisjonalis som illustrert i disse verba: ajattele/ttais og aukase/ttais (type 3), og kyytitte/ttäis, piikaroittelttais, likene/ttäis (type 4).

\subsubsection{Nektende kondisjonalis presens}

Formene for NEKTENDE KONDISJONALIS PRESENS er enkelt å lage:

- AKTiv form av NEKTENDE KONDISJONALIS PRESENS danner vi ved å kombinere den personbøyde forma av nektingsverbet ei og hovedverbet i tredje person entall av aktiv kondisjonalis. I tredje person flertall kan vi også bruke den passive forma av kondisjonalis presens. Jamfør de nektende eksempla i (1-6) nedafor med de bekreftende eksempla (1-6) i innleiinga til avsnitt 6.5 ovafor:

1. Mie en lähtis mielelä Tromsshaan.

'Jeg skulle helst ikke dra til Tromsø.'

2. Sie et sais vielä lähteet lähteä $(t) \sim$ lähtiä kothiin.

'Det hadde vært best om du ikke dro heim enda.'

3. Ville ei opastuis Priitan kans, vaikka se olis mah(đ)olinen.

'Ville skulle ikke bli kjent med Brita sjøl om det var mulig.'

4. Jos met emmä halluis haluais, met emmä tarvittis lähteet lähteä(t) lähtiä kuuhun.

'Dersom vi ikke ville, så behøvde vi ikke å reise til månen.'

5. Tet että pölk(k)äis hukkii hukkia, vaikka niitä kohtaisitta.

'Dere ville ikke være redd for ulv sjøl om dere møtte noen.'

6. Liisa ja Pekka ei jatkais jatkattais matkaa, jos heilä ei olis piilii piliä.

'Lisa og Peder skulle ikke fortsette turen om de ikke hadde bil.' 
Tabell 6.9 Bekreftende og nektende kondisjonalis presens

\begin{tabular}{|c|c|c|c|c|c|}
\hline Verbtype & 1. infinitiv & $\begin{array}{l}\text { Bekreftende } \\
\text { 2. sg./3. pl. }\end{array}$ & $\begin{array}{l}\text { Bekreftende } 3 . \\
\text { sg. / nektende, } \\
\text { alle personer: } \\
\text { en, et, ei, } \\
\text { emmä, että, ei + }\end{array}$ & $\begin{array}{l}\text { Bekreftende } 1 . \\
\text { pl. }\end{array}$ & $\begin{array}{l}\text { Bekreftende } \\
\text { pass./3. pl. / } \\
\text { nektende } \\
\text { pass./3. pl.: } \\
\text { ei + }\end{array}$ \\
\hline \multirow[t]{3}{*}{1 Enstava verb } & $\begin{array}{l}\text { saa/đa saa/ } \\
\text { ha }\end{array}$ & $\mathrm{sa} / \mathrm{isi} / \mathrm{t}$ & $\mathrm{sa} /$ is & $\mathrm{sa} / \mathrm{isi} / \mathrm{ma}$ & saa/tais \\
\hline & vie/(đ)ä vii/ä & ve/isi/t & ve/is & ve/isi/mä & vie/täis \\
\hline & ui/(d)a & $\mathrm{u} / \mathrm{isi} / \mathrm{t}$ & $\mathrm{u} / \mathrm{is}$ & u/isi/ma & ui/tais \\
\hline \multirow[t]{8}{*}{2 Enstamma verb } & $\begin{array}{l}\text { kulkke/et } \\
\text { kulke/a(t) } \\
\text { kulki/a }\end{array}$ & kulk/isi/t & kulk/is & kulk/isi/mma & kulje/ttais \\
\hline & $\begin{array}{l}\text { soppi/it sopi/ } \\
\text { a(t) }\end{array}$ & sop/isi/t & sop/is & sop/isi/mma & sovi/ttais \\
\hline & $\begin{array}{l}\text { kattoot } \\
\text { katto/a(t) }\end{array}$ & katto/isi/t & katto/is & $\begin{array}{l}\text { katto/isi/ } \\
\mathrm{mma}\end{array}$ & katto/ttais \\
\hline & $\begin{array}{l}\text { näkky/yt } \\
\text { näky/ä(t) }\end{array}$ & näky/isi/t & näky/is & näky/isi/mmä & nä(v)y/ttäis \\
\hline & luotta/a(t) & luotta/isi/t & luotta/is & $\begin{array}{l}\text { luotta/isi/ } \\
\text { mma }\end{array}$ & luote/ttais \\
\hline & $\operatorname{ant}(t) a / a(t)$ & anta/isi/t & anta/is & anta/isi/mma & anne/ttais \\
\hline & lent(t)ä/ä(t) & lentä/isi/t & lentä/is & lentä/isi/mmä & lenne/ttäis \\
\hline & varasta/at & varasta/isi/t & varasta/is & varasta/isi/ma & varaste/ttais \\
\hline \multirow{6}{*}{$\begin{array}{l}3 \text { Verb med } \\
\text { konsonantstamme }\end{array}$} & ol/la & ol/isi/t & ol/is & ol/isi/mma & ol/tais \\
\hline & juos/ta & juoks/isi/t & juoks/is & juoks/isi/mma & juos/tais \\
\hline & $\begin{array}{l}\text { näh/đä näh/ } \\
\text { hä }\end{array}$ & näk/isi/t & näk/is & näk/isi/mmä & näh/täis \\
\hline & kävel/ä & kävel/isi/t & kävel/is & kävel/isi/mä & kävel/täis \\
\hline & ajatel/la & ajattel/isi/t & ajattel/is & $\begin{array}{l}\text { ajattel/isi/ } \\
\text { mma }\end{array}$ & ajatel/tais \\
\hline & auka(i)s/ta & auka(i)s/isi/t & auka(i)s/is & $\begin{array}{l}\text { auka(i)s/isi/ } \\
\text { ma }\end{array}$ & $\begin{array}{l}\text { auka(i)s/ } \\
\text { tais }\end{array}$ \\
\hline \multirow{7}{*}{$\begin{array}{l}4 \text { Verb med to } \\
\text { vokalstammer }\end{array}$} & kyyti/tä & kyytitt/isi/t & kyytitt/is & kyytitt/isi/mä & kyyti/ttäis \\
\hline & piikaroi/ta & $\begin{array}{l}\text { piikaroitt/ } \\
\text { isi/t }\end{array}$ & piikaroitt/is & $\begin{array}{l}\text { piikaroitt/isi/ } \\
\text { mma }\end{array}$ & $\begin{array}{l}\text { piikaroi/ } \\
\text { ttais }\end{array}$ \\
\hline & li(j)e/tä & liken/isi/t & liken/is & liken/isi/mä & li(j)e/ttäis \\
\hline & vanhe/ta & vanhen/isi/t & vanhen/is & vanhen/isi/ma & vanhe/ttais \\
\hline & jatka/ta & jatka/isi/t & jatka/is & jatka/isi/mma & jatka/ttais \\
\hline & pöl(j)ä/tä & $\begin{array}{l}\text { pölk(k)ä/ } \\
\text { isi/t }\end{array}$ & pölk(k)ä/is & $\begin{array}{l}\text { pölk(k)ä/isi/ } \\
\text { mmä }\end{array}$ & pöl(j)ä/ttäis \\
\hline & $\mathrm{ka}(đ) \mathrm{o} / \mathrm{ta}$ & $\begin{array}{l}\text { katto/isi/t } \\
\text { katoa/isi/t }\end{array}$ & $\begin{array}{l}\text { katto/is } \\
\text { katoa/is }\end{array}$ & $\begin{array}{l}\text { katto/isi/ } \\
\mathrm{mma} \sim \text { katoa/ } \\
\text { isi/ma }\end{array}$ & $\mathrm{ka}(\mathrm{d}) \mathrm{o} /$ ttais \\
\hline
\end{tabular}


- PAssiv form av NeKTENDE KONDisjonalis PRESEns danner vi ved å kombinere den personbøyde forma av nektingsverbet ei og hovedverbet i passiv form av bekreftende kondisjonalis $(7,8)$ :

7. Kuuhunkhaan ei läh(đ)ettäis, jos ei olis aikamasiinii aikamasiinia. 'Man skulle heller ikke dra til månen om det ikke fantes noen tidsmaskin'

8. Priitankhaan kans ei opastuttais, vaikka se olis mah(đ)olinen.

'Man skulle ikke bli kjent med Priita sjøl om det var mulig.'

\subsubsection{Kondisjonalis presens perfektum}

Nedafor skal vi gå igjennom bekreftende og nektende former av kondisjonalis presens. De viktigste formene er oppført i tabell 6.10, som følger etter gjennomgangen.

\subsubsection{Bekreftende kondisjonalis presens perfektum}

BEKREFTENDE KONDISJONALIS PRESENS PERFEKTUM danner vi ved å kombinere den personbøyde forma av hjelpeverbet olla ('være') i bekreftende kondisjonalis presens (olisin, olisit, olis, olisimma, olisitta, oltais) og hovedverbet i perfektum partisipp. (Perfektum partisipp er framstilt i avsnitt 6.4.2.3.) Det er altså den samme perfektum partisipp-forma som også er i bruk i nektende form av indikativ preteritum og i presens perfektum og preteritum perfektum. Eksempler på kondisjonalis perfektum (1-7):

1. Mie olisin lähteny $(t)$ mielelä Tromsshaan. 'Jeg skulle gjerne ha dratt til Tromsø.'

2. Sie olisit jo saanu(t) lähteet lähteä(t) lähtiä kothiin.

'Det ville ha vært bra om du allerede skulle ha dratt heim.

3. Ville olis opastunnu(t) Priitan kans, jos se olis ollu(t) mah(đ)olinen. 'Ville skulle ha blitt kjent med Brita om det hadde vært mulig'.

4. Jos met olisimma halunheet, met olisimma saattanheet lähteet $\sim$ lähteä(t) lähtiä vaikka kuuhun.

'Dersom vi hadde ønska det, så skulle vi ha fått reist om så til månen.'

5. Tet olisitta pöl(j)änheet hukkii hukkia, jos niitä olisitta koh(d)anheet. 'Dere skulle ha blitt redd for ulv om dere hadde møtt noen.' 
6. Liisa ja Pekka olisit/oltais jatkanheet matkaa, jos heilä olis ollu(t) piili.

'Lisa og Peder skulle ha fortsatt turen om de hadde hatt bil'.

7. Kuuhunki olis lähđetty, jos olis ollu(t) aikamasiini.

'Også til månen skulle man ha reist om det hadde funnes en tidsmaskin.'

Legg også merke til at tredje person flertall og passiv har samme form i bekreftende presens kondisjonalis. I kondisjonalis presens perfektum har hjelpeverbet to alternative former: oltais og olisit, men hovedverbet står i nominativ flertall av den aktive forma av perfektum partisipp (6). I passiv form av kondisjonalis presens perfektum har hjelpeverbet aktiv form (olis), men hovedverbet står i passiv form av perfektum partisipp (7).

\subsubsection{Nektende kondisjonalis presens perfektum}

Aktiv form av nektende kondisjonalis presens perfektum danner vi slik: Personbøyd form av nektingsverbet ei (en, et, ei, emmä, että, ei) + olis (i tredje person flertall også oltais) + samme form av perfektum partisipp av hovedverbet som i bekreftende kondisjonalis presens perfektum. Eksempler (1-6):

1. Mie en olis lähteny $(t)$ mielelä aikamatkale.

'Jeg skulle helst ikke ha dratt på tidsreise.'

2. Sie et olis vielä saanu $(t)$ lähteet $\sim$ lähteä $(\mathrm{t}) \sim$ lähtiä kothiin.

'Du burde ikke ha dratt heim enda.'

3. Kalle ei olis opastunnu(t) Priitan kans, jos se ei olis ollu(t) mah(d)olinen. 'Karl skulle ikke ha blitt kjent med Brita om det ikke hadde vært mulig.'

4. Jos met emmä olis halunheet, met emmä olis tarvinheet lähteet $\sim$ lähteä(t) lähtiä kuuhun.

'Dersom vi ikke hadde ønska det, så ville vi ikke ha behøvd å reise til månen'.

5. Tet että olis pöl(j)änheet hukkii hukkia, jos tet että olis niitä koh(d)atelheet.

'Dere skulle ikke ha blitt redd for ulv om dere ikke hadde møtt noen.'

6. Liisa ja Pekka ei olis oltais jatkanheet matkaa, jos heilä ei olis ollu(t) piilii $\sim$ piiliä.

'Lisa og Peder skulle ikke ha fortsatt turen om de ikke hadde hatt bil.' 
Passiv form av nektende kondisjonalis presens perfektum danner vi slik: nektingsforma $e i+$ hjelpeverbsforma olis + hovedverbet i passiv form av perfektum partisipp:

7. Kuuhunkhaan ei olis lähđetty, jos ei olis ollu(t) aikamasiinii aikamasiinia. 'Heller ikke til månen skulle man ha reist om det ikke hadde funnes noen tidsmaskin.'

Merk at i tredje person flertall av nektende kondisjonalis er det mulig å bruke den passive hjelpeverbsforma oltais, men i passiv form av nektende kondisjonalis har hjelpeverbet aktiv form (olis).

Tabell 6.10 Bekreftende og nektende kondisjonalis presens perfektum

\begin{tabular}{|c|c|c|}
\hline $\begin{array}{l}\text { Sammensatt } \\
\text { verbalform }\end{array}$ & $\begin{array}{l}\text { Aktiv 1. sg., } 2 . \\
\text { sg., 3. sg. }\end{array}$ & Aktiv form av perfektum partisipp, entall nominativ \\
\hline $\begin{array}{l}\text { Kondisjonalis presens } \\
\text { perfektum }\end{array}$ & olisin, olisit, olis & \multirow{2}{*}{$\begin{array}{l}\text { (1) saa/nu(t), vie/ny(t), ui/nu(t); (2a) kulke/nu(t), } \\
\text { luke/nu(t), sopi/nu(t), tohti/nu(t), aiko/nu(t), } \\
\text { katto/nu(t), näky/ny(t), luotta/nu(t), anta/nu(t), } \\
\text { lentä/ny(t), varasta/nnu(t), näytästä/nny(t); } \\
\text { (2b) kyytitte/nny(t), piikaroitte/nu(t), } \\
\text { vanhene/nnu(t); (3) ol/lu(t), juos/su(t), näh/ny(t), } \\
\text { kävel/y(t), ajatel/lu(t), auka(i)s/su(t); } \\
\text { (4) kyyti/ny(t), tarvi/nu(t), piikaroi/nu(t), } \\
\text { li(j)e/ny(t), vanhe/nu(t), jatka/nu(t), pöl(j)ä/ny(t), } \\
\text { keri/ny(t), ka(đ)o/nu(t) }\end{array}$} \\
\hline $\begin{array}{l}\text { Nektende kondisjonalis } \\
\text { presens perfektum }\end{array}$ & $\begin{array}{l}\text { en olis, et olis, ei } \\
\text { olis }\end{array}$ & \\
\hline $\begin{array}{l}\text { Sammensatt } \\
\text { verbalform }\end{array}$ & $\begin{array}{l}\text { Aktiv 1. pl., 2. pl., } \\
\text { 3. pl. }\end{array}$ & $\begin{array}{l}\text { Aktiv form av perfektum partisipp, flertall } \\
\text { nominativ }\end{array}$ \\
\hline $\begin{array}{l}\text { Kondisjonalis presens } \\
\text { perfektum }\end{array}$ & $\begin{array}{l}\text { olisimma, } \\
\text { olisitta, olisit } \\
\text { oltais }\end{array}$ & \multirow{2}{*}{$\begin{array}{l}\text { (1) saa/nhee/t, vie/nhee/t, ui/nhee/t; } \\
\text { (2a) kulke/nhee/t, luke/nhee/t, sopi/nhee/t, } \\
\text { tohti/nhee/t, aiko/nhee/t, katto/nhee/t, } \\
\text { näky/nhee/t, luotta/nhee/t, anta/nhee/t, } \\
\text { lentä/nhee/t, varasta/nhee/t, näytästä/nhee/t; } \\
\text { (2b) kyytitte/nheet, piikatoitte/nheet, } \\
\text { vanhene/nheet; (3) ol/hee/t, juos/hee/t, } \\
\text { näh/nhee/t, kävel/hee/t, ajatel/hee/t, } \\
\text { auka(i)s/hee/t; (4) kyyti/nhee/t, tarvi/nhee/t, } \\
\text { piikaroi/nhee/t, li(j)e/nhee/t, vanhe/nhee/t, } \\
\text { jatka/nhee/t, pöl(j)ä/nhee/t, keri/nhee/t, } \\
\text { ka(đ)o/nhee/t }\end{array}$} \\
\hline $\begin{array}{l}\text { Nektende kondisjonalis } \\
\text { presens perfektum }\end{array}$ & $\begin{array}{l}\text { emmä olis, että } \\
\text { olis, ei olis } \\
\text { oltais }\end{array}$ & \\
\hline $\begin{array}{l}\text { Sammensatt } \\
\text { verbalform }\end{array}$ & Passiv & $\begin{array}{l}\text { Passiv form av perfektum partisipp, entall } \\
\text { nominativ }\end{array}$ \\
\hline $\begin{array}{l}\text { Kondisjonalis presens } \\
\text { perfektum }\end{array}$ & olis & \multirow{2}{*}{$\begin{array}{l}\text { (1) saa/tu, vie/ty, ui/tu; (2a) kulje/ttu, lu(j)e/ttu, } \\
\text { sovi/ttu, toh(đ)i/ttu, ai(j)o/ttu, katto/ttu, nä(v)y/tty, } \\
\text { luote/ttu, anne/ttu, lenne/tty, varaste/ttu, } \\
\text { näytäste/tty; (3) ol/tu, juos/tu, näh/ty, kävel/ty, } \\
\text { ajatel/tu, auka(i)s/tu; (2b) kyytitte/tty, piikaroitte/ttu, } \\
\text { vanhene/ttu; (4) kyyti/tty, tarvi/ttu, piikaroi/ttu, } \\
\text { li(j)e/tty, vanhe/ttu, jatka/ttu, pöl(j)ä/tty, keri/tty, } \\
\text { ka(đ)o/ttu }\end{array}$} \\
\hline $\begin{array}{l}\text { Nektende kondisjonalis } \\
\text { presens perfektum }\end{array}$ & ei olis & \\
\hline
\end{tabular}




\subsection{Imperativ}

Med modusforma IMPERATIV markerer vi det finitte verbet i bydesetninger (se avsnitt 2.4.6.3). Til liks med de andre to modusformene, indikativ og kondisjonalis, så har også imperativ to tallformer og tre personer, første, andre og tredje person. I tillegg forekommer ei passiv form av imperativ, men den er bare i liten grad brukt.

Imperativ er vanligst i andre person entall og flertall. Som regel oppfordrer eller befaler man jo noen som er til stede. Men det er også mulig at taleren eller talerne retter ønsket eller befalinga mot si eiga gruppe, og da bruker vi første person flertall. Dersom oppfordringa er adressert til en eller flere personer som ikke er til stede, så står imperativsforma i tredje person entall eller flertall. Derimot fins det ikke eigne imperativsformer i første person entall.

I prinsippet kan vi også danne imperativ i presens perfektum, men slike former er nesten ikke i bruk og skal derfor ikke behandles her.

Nedafor skal vi se nærmere på hvordan vi danner imperativ i de ulike personene og - i den grad det er relevant - i de ulike verbgruppene. Til slutt følger en tabell hvor de viktigste bøyingsformene er sammenstilt (se tabell 6.11).

\subsubsection{Imperativ første person flertall}

I IMPERATIV FØRSTE PERSON FLERTALL bruker vi samme verbform som i første person flertall av indikativ presens. Men til forskjell fra indikativ, hvor subjektet som regel er uttrykt gjennom det personlige pronomenet met ('vi'), så er pronomenet utelatt i bydesetninger. Jamfør imperativssetningene i (5-8) med indikativssetningene i (1-4):

Indikativ presens, 1. pl.

1. Met läh(d)emä Raishiin. 'Vi drar til Nordreisa.'

2. Met emmä läh(d)e Raishiin. 'Vi drar ikke til Nordreisa.'

3. Met kirjo(i)tamma preivin faarile. 'Vi skriver et brev til far.'

4. Met emmä kirjo(i)ta preivii preiviä faarile.

'Vi skriver ikke (noe) brev til far.'
Imperativ, 1.pl.

5. Läh(d)emä Raishiin! 'La oss dra til Nordreisa!'

6. Emmä läh(đ)e Raishiin! 'Ikke la oss dra til Nordreisa!'

7. Kirjo(i)tamma preivin faarile! 'La oss skrive et brev til far!'

8. Emmä kirjo(i)ta preivii preiviä faarile! 'Ikke la oss skrive (noe) brev til far!' 


\subsubsection{Imperativ andre person entall}

IMPERATIV i ANDRE PERSON ENTALL og FLERTALL er gjengs både i tale og skrift. Bekreftende form av imperativ $i$ andre person entall er identisk med nektingsforma i presens (se avsnitt 6.4.1.2). Jamfør imperativsformene i (5-8) med de nektende presensformene i (1-4):

Nektende presens

1. Mie en läh(đ)e aikamatkale. 'Jeg drar ikke på tidsreise.'

2. Met emmä kirjo(i)ta preivii preiviä faarile. 'Vi skriver ikke (noe) brev til far.'

3. Het ei hihtaa pääs(s)iäisinä. 'De går ikke på ski i påska.'

4. Pekka ei kattoo katoa mihinkhään. 'Peder forsvinner ikke noen steder.'
Bekreftende imperativ, 2. sg.

5. Läh(đ)e aikamatkale!

'Dra på tidsreise!'

6. Kirjo(i)ta preivin faarile! 'Skriv (et) brev til far!'

7. Hihtaa pääs(s)iäisinä! 'Gå på ski i påska!'

8. Kattoo Katoa täältä! 'Forsvinn herifra!'

Nektende imperativ i andre person entall danner vi ved å kombinere imperativsforma av nektingsverbet $\mathrm{i}$ andre person entall, älä, med hovedverbet i samme form som i bekreftende imperativ. Jamfør de nektende imperativsformene i (9-11) med de bekreftende imperativsformene i $(12-14)$ :

Bekreftende imperativ, 2. sg.

9. Läh(đ)e aikamatkale! 'Dra på tidsreise!'

10. Kirjo(i)ta preivin faarile! 'Skriv (et) brev til far!'

11. Hihtaa pääs(s)iäisinä! 'Gå på ski i påska!'
Nektende imperativ, 2. sg.

12. Äläläh(đ)e aikamatkale! 'Ikke dra på tidsreise.'

13. Älä kirjo(i)ta preivii preiviä faarile! 'Ikke skriv (noe) brev til far.'

14. Älä hiihtaa pääs(s)iäisinä! 'Ikke gå på ski i påska'.

\subsubsection{Imperativ andre person flertall}

Suffikset i ANDRE PERSON FLERTALL av IMPERATIV er $-(k) k A A$. Varianten -kkAA brukes i verbtype 1, 2 og 3, men bare i skriftspråksvarieteter som har spesialstadieveksling (se avsnitt 3.1.1.2). Andre person flertall av imperativ dannes på følgende måte: 
- I verbtype 1 (enstava verb) fester vi imperativssuffikset direkte til verbstammen. For eksempel (1. inf. : 2. pl. imp.) saa/da saa/ha ('fä) : saa/(k)kaa, vie/ đä vii/ä ('bringe, ta med') : vie/(k)kää.

- I verbtype 2 (enstamma verb) fester vi imperativssuffikset til verbstammen på stadium II dersom den veksler etter mønster II : I. For eksempel (1. inf. : perf. pts. : 1. sg. ind. pres. : 2. pl. imp.) autta/a(t) ('hjelpe') : autta/nu(t) : auta/n : autta/(k)kaa, kirjo(i)tta/a(t) ('skrive') : kirjo(i)tta/nnu(t) : kirjo(i)ta/n : kirjo(i)tta/(k)kaa, lähättä/ä(t) ('sende') : lähättä/nny(t) : lähätä/n : lähättä/(k) kää. Dersom stammen veksler etter mønster (II :) I : o, så fester vi imperativssuffikset til I-stammen. For eksempel (1. inf. : perf. pts. : 1. sg. ind. pres. : 2. pl. imp.) ant $(t) a / a(t)$ ('gi') : anta/nu(t) : anna/n:anta/(k)kaa, jakka/a(t) ('dele') : jaka/nu(t): ja(j)an : jakal(k)kaa, kulkkelet kulkela(t) kulki/a ('vandre, gå') : kulke/nu(t) : kulje/n: kulke/(k)kaa, soppi/it sopi/a(t) ('passe') : sopi/nu(t) : sovi/n : sopi/(k)kaa. Dersom stammen ikke gjennomgår gradveksling, så fester vi imperativssuffikset til denne ene stammen. For eksempel (1. inf. : perf. pts. : 1. sg. ind. pres. : 2. pl. imp.) katto/ot katto/a(t) ('se på) : katto/nu(t):katto/n : katto/(k)kaa, painalat ('presse, trykke') : paina/nu(t):paina/n : paina/(k)kaa. - I verbtype 3 (verb med konsonantstamme) fester vi imperativssuffikset til konsonantstammen. Dersom stammekonsonanten er $h$ eller s, så er suffiksforma alltid $-k A A$, ellers bruker vi $-k A A$ eller $-k k A A$, avhengig av om varieteten har spesialstadieveksling eller ikke. For eksempel: (1. inf. : 1. sg. ind. pres. : 2. pl. imp.) men/nä ('gå) : mene/n : men/(k)kää, kävel/ä ('spasere, gå) : kävele/n : kävel/(k)kää,pur/ra ('bite') : pure/n:pur/(k)kaa, pes/tä ('vaske') : pese/n:pes/kää, näh/đä näh/hä ('se') : nä(j)e/n : näh/kää, teh/đä teh/hä ('gjøre') : tehe/n : teh/kää, auka(i)s/ta ('åpne’) : auka(i)se/n : auka(i)s/kaa.

- I verbtype 4 (verb med to vokalstammer) fester vi imperativssuffikset til den korte vokalstammen. Suffikset har forma $-k k A A$ i alle varietetene. For eksempel: (1. inf. : 1. sg. ind. pres. : 2. pl. imp.) kyyti/tä ('skysse') : kyytitte/n : kyyti/kkää, piikaroi/ta ('spikre') : piikaroitte/n : piikaroi/kkaa, li(j)e/tä ('nærme seg') : likene/n : li(j)e/kkää, hih(đ)a/ta ('gå på ski') : hihtaa/n: hih(d)a/kkaa.

Nektende form av imperativ i andre person flertall danner vi på samme måte som i entall. Det vil si at vi kombinerer imperativsforma av nektingsverbet $\mathrm{i}$ andre person flertall, äl $(k) k a ̈ a ̈$, med hovedverbet i samme form som i bekreftende imperativ. Jamfør de nektende imperativsformene i (5-8) med de bekreftende imperativsformene i (1-4): 
Bekreftende imperativ, 2. pl.

1. Viek(k)ää preivin posthiin! 'Ta med brevet til postkontoret!'

2. Auttak(k)aa aina muorii muoria! 'Hjelp alltid mor!'

3. Men(k)kää kothiin! 'Gå heim!'

4. Hih(đ)akkaa pääs(s)iäisinä! 'Gå på ski i påska!'
Nektende imperativ, 2. pl.

5. Äl(k)kää viek(k)ää preivii preiviä posthiin!

'Ikke ta med brevet til postkontoret!'

6. Äl(k)kää koskhaan autta(k)kaa muorii muoria!

'Aldri hjelp mor!'

7. Äl(k)kää men(k)kää kothiin! 'Ikke gå heim!'

8. Äl(k)kää hih(đ)akkaa pääs(s)iäisinä! 'Ikke gå på ski i påska!'

\subsubsection{Imperativ tredje person entall og flertall}

I tredje person av imperativ bruker vi suffiksa $-k h O O n$ (entall) og $-k h O O t$ (flertall). Disse suffiksa festes til verbstammen på samme måte som imperativssuffiksa i andre person flertall (se avsnitt 6.6.3). Det som skiller imperativ i tredje person fra imperativ i de andre personene, er at imperativsetninger i tredje person vanligvis også har med et synlig subjekt, det vil si den som befalinga eller oppfordringa er retta mot. Setningene i (1-5) er eksempler på imperativ i tredje person entall / tredje person flertall. Ofte fins det ingen fullgod norsk oversettelse av kvenske imperativsformer i tredje person. Et unntak er mer høgtidelig språkbruk, som i eksempel (10).

1. Viekhöön Pekka / Viekhööt pojat preivin posthiin!

'Peder/Guttene får ta brevet til postkontoret!'

2. Auttakhoon faari / Auttakhoot kläpit muorii muoria!

'Far/Ungene får hjelpe mor!'

3. Hih(đ)akhoon Liisa / Hih(đ)akhoot krannit tänne pääs(s)iäisinä!

'Lisa/Naboene får komme hit på ski i påska!'

4. Menkhöön äiji / Menkhööt tyttäret kothiin!

'Bestefar/Jentene får gå heim!'

5. Olkhoon Jumala armolinen! / Olkhoot herrat armoliset köyhile!

'Måtte Gud være nådig!' / 'Måtte herrefolket være nådig med de fattige!'

Nektende imperativ i tredje person dannes som regel ved å kombinere bekreftende form av hjelpeverbet olla ('være) i tredje person (olkhoon/olkhoot) 
med hovedverbet i 3 . infinitiv abessiv, det vil si med suffikset $m A / t t A$. (Se avsnitt 6.8.1.3 om 3. infinitiv.) Setningene i (6-10) er eksempler på nektende imperativ i tredje entall / tredje person flertall:

6. Olkhoon Pekka / Olkhoot pojat viemättä preivii preiviä posthiin!

'Peder/Guttene får la være å ta med brevet til postkontoret!'

7. Olkhoon faari / Olkhoot kläpit auttamatta muorii muoria!

'Far/Ungene får la være å hjelpe mor!'

8. Olkhoon Liisa / Olkhoot krannit hihtaamatta tänne pääs(s)iäisinä!

'Lisa/Naboene får la være å komme hit på ski i påska!'

9. Olkhoon äiji / Olkhoot tyttäret menemättä kothiin!

'Bestefar/Jentene får la være å gå heim!'

10. Olkhoon Jumala olematta armolinen. / Olkhoot herrat olematta armoliset köyhile!

'Måtte Gud ikke være nådig! / Måtte herrefolket ikke være nådig med de fattige!'

I stedet for imperativsformene i tredje person flertall kan vi bruke imperativsformer i tredje person entall. Vi får da bydesetninger som i (11-13):

11. Menkhöön tyttäret kothiin!

'Måtte jentene gå heim!'

12. Olkhoon herrat armoliset köyhile!

'Måtte herskapet være nådig med de fattige!'

13. Olkhoon kläpit auttamatta muorii muoria!

'Ungene får la være å hjelpe mor!'

\subsubsection{Passiv imperativ}

PAssiv IMPERATIV er ikke vanlig i kvensk, verken i talemålet eller i skriftspråket. Dersom man likevel ønsker å bruke slike former - for eksempel i lovtekster eller andre offisielle skriv - så kan setningene i (1-4) tjene som eksempler. Også her er det vanskelig å gi fullgode norske oversettelser.

1. Ostettakhoon ensistä mettän ja sitte vasta kaa(đ)ettakhoon sen!

'Først skal det kjøpes skog, og så skal den hogges ned!' 
2. Annettakhoon keisarille mitä keisarille kuuluu!

'Gi keiseren det som tilhører keiseren!'

3. Tuomittakhoon rikolisen vii(đ)eksi vuo(đ)eksi fankilhaan!

'Gjerningsmannen skal dømmes til fem års fengsel!'

4. Ajateltakhoon minusta mitä vain, mie en siitä perusta!

'Folk får synes om meg hva som helst, jeg bryr meg ikke om det!'

BEKREFTENDE PASSIV IMPERATIV dannes ved å feste det passive imperativssuffikset til passivstammen (se avsnitt 6.2.5). I enstava verb (type 1) og i verb med konsonantstamme (type 3) bruker vi suffiksforma -tAkhOOn, ellers ttAkhOOn. Vi får da følgende former i de ulike verbtypene:

-Verbtype 1: (1. inf. : pass. ind. pres. : pass. imp.) saa/da saa/ha ('få) : saal (đ)haan : saa/takhoon, vie/(đ)ä ('bringe, ta med') : vie/(đ)hään : vie/täkhöön, ui/(đ)a ('svømme') : ui/(đ)haan : ui/takhoon;

- Verbtype 2: (1. inf. : pass. ind. pres. : pass. imp.) kulkkelet $\sim$ kulke $(a(t) \sim$ kulki/a ('vandre, gå') : kulje/thaan: kulje/ttakhoon, lukkelet luke/a(t) luki/a ('lese') : lu(j)e/thaan: lu(j)e/ttakhoon, soppi/it sopia(t) ('passe') : sovi/thaan: sovi/ttakhoon, tohti/it tohti/a(t) ('tørre') : toh(d)i/thaan : toh(d)i/ttakhoon, aikko/ot $\sim$ aiko/a(t) ('akte, ha til hensikt') : ai(j)o/thaan : ai(j)o/ttakhoon, katto/ot katto/a(t) ('se på) : katto/thaan: katto/ttakhoon, näkky/yt näky/ä(t) ('synes') : nä( $v) y /$ thään : nä( $v) y /$ ttäkhöön, luotta/a(t) ('stole på) : luotelthaan : luote/ttakhoon, ant $(t) a / a(t)$ ('gi') : anne/thaan : anne/ttakhoon, varastalat ('stjele') : varaste/thaan : varaste/ttakhoon, lent $(t) \ddot{a} / \ddot{a}(t)$ ('fly') : lenne/thään : lenne/ttäkhöön, näytästä/ät ('vise') : näytäste/thään : näytäste/ttäkhöön;

- Verbtype 3: (1. inf. : pass. ind. pres. : pass. imp.) ol/la ('være') : ol/haan : ol/takhoon, juos/ta ('springe') : juos/thaan : juos/takhoon, näh/đä näh/hä ('se') : näh/(đ)hään : näh/täkhöön, kävel/ä ('spasere, gå) : kävel/hään : kävel/täkhöön, ajatel/la ('tenke') : ajatel/haan : ajatel/takhoon, auka(i)s/ta ('åpne') : auka(i)s/thaan : auka(i)s/takhoon, täris/tä ('dirre') : täris/thään : täris/täkhöön;

- Verbtype 4: (1. inf. : pass. ind. pres. : pass. imp.) kyyti/tä ('skysse') : kyyti/thään : kyyti/ttäkhöön, tarvi/ta ('trenge') : tarvi/thaan : tarvi/ttakhoon, li(j)e/tä ('nærme seg') : li(j)e/thään : li(j)e/ttäkhöön, vanhe/ta ('bli eldre') : vanhe/thaan: vanhe/ttakhoon, jatka/ta ('fortsette') : jatka/thaan : jatka/ttakhoon,

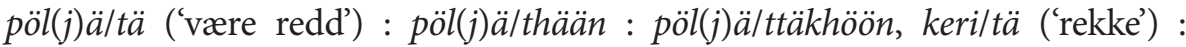
keri/thään : keri/ttäkhöön, ka(đ)o/ta ('forsvinne') : ka(đ)o/thaan : ka(đ)o/ttakhoon. 
I overgangsverb (type 2 b) får vi passive imperativsformer som (1. inf. : pass. imp.) ajattele/a(t) ('tenke') : ajattele/ttakhoon, aukasela(t) ('åpne') : aukase/ttakhoon, kyytittelä $(t)$ ('skysse') : kyytitte/ttäkhöön, piikaroittela(t) ('spikre') : piikaroittelttakhoon, likene/ä( $t$ ) ('nærme seg') : likene/ttäkhöön.

NEKTENDE PASSIV IMPERATIV er enda mer perifert. Den kan dannes ved å kombinere den passive imperativsforma av hjelpeverbet olla ('være'), oltakhoon, med hovedverbet i 3. infinitiv abessiv, altså som i aktiv form av nektende imperativ i tredje person. Jamfør eksemplet på nektende passiv imperativ i (5) med eksempla på aktiv form av nektende imperativ i tredje person i (6-10) i avsnitt 6.6.4).

5. Oltakhoon kaatamatta mettää ennen ko se oon ostettu.

'Skog skal ikke hogges før en har kjøpt den.'

Tabell 6.11 oppsummerer hvordan de ulike imperativsformene dannes. I tabellen har vi utelatt imperativ i tredje person flertall. Denne forma dannes ved å erstatte suffikset -khOOn med suffikset -khOOt. Tabellen mangler også imperativsformer i første person flertall. De er identiske med formene i første person flertall i indikativ presens.

Tabell 6.11 Imperativ

\begin{tabular}{|c|c|c|c|c|c|}
\hline Verbtype & 1. infinitiv & $\begin{array}{l}\text { 2. sg. } \\
\text { (älä) }\end{array}$ & $\begin{array}{l}\text { 3. sg. } \\
\text { hän/se }\end{array}$ & $\begin{array}{l}\text { 2. pl. } \\
\text { (äl(k)kää) }\end{array}$ & Passiv \\
\hline \multirow[t]{3}{*}{1 Enstava verb } & $\begin{array}{l}\text { saa/đa } \\
\text { saa/ha }\end{array}$ & saa & saa/khoon & saa/(k)kaa & saa/takhoon \\
\hline & $\begin{array}{l}\text { vie/(đ)ä } \\
\text { vii/ä }\end{array}$ & vie & vie/khöön & vie/(k)kää & vie/täkhöön \\
\hline & ui/(đ)a & ui & ui/khoon & ui/(k)kaa & ui/takhoon \\
\hline \multicolumn{6}{|l|}{2 Enstamma verb } \\
\hline \multirow[t]{7}{*}{ 2a Opprinnelige } & $\begin{array}{l}\text { kulkke/et } \\
\text { kulke/a(t) } \\
\text { kulki/a }\end{array}$ & kulje & kulke/khoon & kulke/(k)kaa & kulje/ttakhoon \\
\hline & $\begin{array}{l}\text { soppi/it } \\
\text { sopi/a(t) }\end{array}$ & sovi & sopi/khoon & sopi/(k)kaa & sovi/ttakhoon \\
\hline & $\begin{array}{l}\text { katto/ot } \\
\text { katto/at }\end{array}$ & katto & katto/khoon & katto/(k)kaa & katto/ttakhoon \\
\hline & $\begin{array}{l}\text { kyssy/yt } \\
\text { kysy/ä(t) }\end{array}$ & kysy & kysy/khöön & kysy/(k)kää & kysy/ttäkhöön \\
\hline & luotta/a(t) & luota & luotta/khoon & luotta/(k)kaa & luote/ttakhoon \\
\hline & $\operatorname{ant}(t) a / a(t)$ & anna & anta/khoon & anta/(k)kaa & anne/ttakhoon \\
\hline & varasta/a(t) & varasta & varasta/khoon & varasta/kkaa & varaste/ttakhoon \\
\hline
\end{tabular}


Tabell 6.11 (Fortsatt)

\begin{tabular}{|c|c|c|c|c|c|}
\hline Verbtype & 1. infinitiv & $\begin{array}{l}\text { 2. sg. } \\
\text { (älä) }\end{array}$ & $\begin{array}{l}\text { 3. sg. } \\
\text { hän/se }\end{array}$ & $\begin{array}{l}\text { 2. pl. } \\
\text { (äl(k)kää) }\end{array}$ & Passiv \\
\hline \multirow[t]{4}{*}{$2 \mathrm{~b}$ Overgangsverb } & muistele/a(t) & muistele & muistele/khoon & $\begin{array}{l}\text { muistele/ } \\
\text { kkaa }\end{array}$ & $\begin{array}{l}\text { muistele/ } \\
\text { ttakhoon }\end{array}$ \\
\hline & aukase/a(t) & aukase & aukase/khoon & aukase/kkaa & aukase/ttakhoon \\
\hline & kyytitte/ä(t) & kyytitte & kyytitte/khöön & kyytitte/kkää & $\begin{array}{l}\text { kyytitte/ } \\
\text { ttäkhöön }\end{array}$ \\
\hline & likene/ät & likene & likene/khöön & likene/kkää & likene/ttäkhöön \\
\hline \multirow{5}{*}{$\begin{array}{l}3 \text { Verb med } \\
\text { konsonantstamme }\end{array}$} & ol/la & ole & ol/khoon & ol/(k)kaa & ol/takhoon \\
\hline & juos/ta & juokse & juos/khoon & juos/kaa & juos/takhoon \\
\hline & $\begin{array}{l}\text { näh/đä } \\
\text { näh/hä }\end{array}$ & nä(j)e & näh/khöön & näh/kää & näh/täkhöön \\
\hline & ajatel/la & ajattele & ajatel/khoon & ajatel/(k)kaa & ajatel/takhoon \\
\hline & auka(i)s/ta & auka(i)se & auka(i)s/khoon & auka(i)s/kaa & auka(i)s/takhoon \\
\hline \multirow{7}{*}{$\begin{array}{l}4 \text { Verb med to } \\
\text { vokalstammer }\end{array}$} & kyyti/tä & kyytitte & kyyti/khöön & kyyti/kkää & kyyti/ttäkhöön \\
\hline & piikaroi/ta & piikaroitte & piikaroi/khoon & piikaroi/kkaa & piikaroi/ttakhoon \\
\hline & li(j)e/tä & likene & li(j)e/khöön & li(j)e/kkää & li(j)e/ttäkhöön \\
\hline & vanhe/ta & vanhene & vanhe/khoon & vanhe/kkaa & vanhe/ttakhoon \\
\hline & jatka/ta & jatkaa & jatka/khoon & jatka/kkaa & jatka/ttakhoon \\
\hline & pöl(j)ä/tä & pöl(k)kää & pöl(j)ä/khöön & pöl(j)ä/kkää & pöl(j)ä/ttäkhöön \\
\hline & $\mathrm{ka}(đ) \mathrm{o} / \mathrm{ta}$ & $\begin{array}{l}\text { kattoo } \\
\text { katoa }\end{array}$ & ka(đ)o/khoon & ka(đ)o/kkaa & ka(đ)o/ttakhoon \\
\hline
\end{tabular}

\subsection{Jamføring av tredje person flertall og passiv}

I gjennomgangen av de verbale bøyingskategoriene så langt har vi sett at tredje person flertall noen ganger har samme form som passiv, mens de andre ganger har hver si bøyingsform. I tabell 6.12 har vi oppsummert når bøyingsforma i tredje person flertall er identisk med passiv, og når de to skiller lag. Jamføringa er illustrert med eksempelverbet ant $(t) a / a$ ( $t$ ) ('gi', verbtype 2). I tabellen er former som inneholder passivsuffiks, kursivert. 
Tabell 6.12 Jamføring mellom tredje person flertall og passiv

\begin{tabular}{|c|c|c|}
\hline Bøyingskategori/-trekk & Tredje person flertall (het, net) & Passiv \\
\hline \multicolumn{3}{|l|}{ Enkle verbalformer: } \\
\hline $\begin{array}{l}\text { Indikativ presens } \\
\text { Indikativ preteritum } \\
\text { Kondisjonalis presens } \\
\text { Imperativ presens }\end{array}$ & $\begin{array}{l}\text { annethaan ant(ta)ava(t) } \\
\text { annethiin annoit } \\
\text { annettais antaisit } \\
\text { antakhoot antakhoon }\end{array}$ & $\begin{array}{l}\text { annethaan } \\
\text { annethiin } \\
\text { annettais } \\
\text { annettakhoon }\end{array}$ \\
\hline \multicolumn{3}{|l|}{ Sammensatte verbalformer: } \\
\hline $\begin{array}{l}\text { Indikativ presens perfektum } \\
\text { Indikativ preteritum perfektum } \\
\text { Kondisjonalis presens perfektum }\end{array}$ & $\begin{array}{l}\text { oon antanheet } \\
\text { olthiin olit antanheet } \\
\text { oltais olisit antanheet }\end{array}$ & $\begin{array}{l}\text { oon annettu } \\
\text { oli kirjoitettu } \\
\text { olis annettu }\end{array}$ \\
\hline \multicolumn{3}{|l|}{ Nektende former: } \\
\hline $\begin{array}{l}\text { Indikativ presens } \\
\text { Indikativ preteritum } \\
\text { Indikativ presens perfektum } \\
\text { Indikativ preteritum perfektum } \\
\text { Kondisjonalis presens } \\
\text { Kondisjonalis presens perfektum } \\
\text { Imperativ presens }\end{array}$ & $\begin{array}{l}\text { ei anna } \\
\text { ei antanheet } \\
\text { ei ole antanheet } \\
\text { ei olheet antanheet } \\
\text { ei annettais ei antais } \\
\text { ei oltais ei olis antanheet } \\
\text { olkhoot antamatta }\end{array}$ & $\begin{array}{l}\text { ei anneta } \\
\text { ei annettu } \\
\text { ei ole annettu } \\
\text { ei ollu annettu } \\
\text { ei annettais } \\
\text { ei olis annettu } \\
\text { oltakhoon antamatta }\end{array}$ \\
\hline
\end{tabular}

\subsection{Infinitte verbformer}

Infinitte verbformer kan ikke opptre aleine som verbal i ei setning, men derimot som del av ei sammensatt verbalform sammen med nektingsverbet og/ eller sammen med et hjelpeverb. Det er illustrert i setningene i (1-3):

1. Mie olen juonu $(t)$ paljon vettä.

'Jeg har drukket mye vatn.'

2. Pojat oon syönheet poronlihhaa.

'Guttene har spist reinkjøtt.'

3. Mulla ei ole tullu(t) käytyksi Helsingissä.

'Jeg fikk ikke reist til Helsingfors.'

Det fins to typer infinitte verbformer, infinitiv og partisipp, og de skiller seg på ett grunnleggende punkt med hensyn til syntaktisk funksjon: Infinitiver har 
som regel samme funksjoner som NP-er (4), mens partisipp har samme funksjoner som AP-er (5). Jamfør de infinitte verbformene i setningene i $(4,5)$ med NP-en og AP-en i setningene i $(6,7)$.

Infinitt verbform

4. Mie halluun syöđä syyä. 'Jeg har lyst til å spise.'

5. Kuolu(t) mies makas ruumiskirstussa.

'Den døde mannen lå i likkista'
NP/AP

6. Mie halluun ruok(k)aa. 'Jeg har lyst på mat'.

7. Vanhaa mies makas ruumiskirstussa.

'Den gamle mannen lå i likkista'.

1. infinitivsforma syöđä syyä i den første setninga (4) fungerer som objekt og kan erstattes med NP-en ruok(k)aa (6). I den andre setninga (5) har vi kuolu( $t$ ), som er nominativ entall av den aktive perfektum partisipp-forma av verbet kuola ('dø'), og som kan erstattes med AP-en vanhaa (7).

Infinitiv og partisipp skiller seg også på et anna punkt: Mens partisipp bøyes i kasus og tall, så er kasusbøying av infinitiv mindre vanlig, og de har inga tallbøying.

\subsubsection{Infinitiv}

Det fins tre typer infinitiv i kvensk, og de kalles for FøRSTE, ANDRE og TREDJE INFINITIV. Infinitiv danner sin eigen frasetype, som vi kaller for INFINITIVsFRASE. Her er tre eksempler på setninger med infinitivsfrase (1-3):

1. Oon paha [(ette) kuola nuorena].

'Det er ille å dø ung.'

2. Nukkuissa ihmisen oon hyvä olla.

'Mennesket har det godt når det sover.'

3. Miina lähti [hihtaamhaan tunturhiin].

'Miina dro til fjells for å gå på ski.'

\subsubsection{Første infinitiv}

FøRSTE INFINITIV fungerer vanligvis som subjekt eller objekt i setninga, og den danner da sin eigen VP i form av infinitivsfrase. I objektsfunksjon er infinitivsfraser vanlig i for eksempel indirekte setninger (1) og i modalsetninger 
(2) (se avsnitt 4.3 og 4.4.1). Som subjekt fungerer infinitivsfraser i modale setninger med verbsamband som verbal (3) (se avsnitt 4.4.2):

1. Hukka ajatteli [lähtele $(t) \sim$ lähteä $(t) \sim$ lähtiä jäneksenpyythöön].

'Ulven tenkte å dra på harejakt.'

2. Hukka häytyi [saađa saaha ruok(k)aa].

'Ulven må få mat.'

3. Tunturissa oon soma hih(d)ata.

'Det er fint å gå på ski på vidda'

I indirekte setninger kan vi legge til subjunksjonen ette ('at') (4). Men konstruksjoner med ette og 1. infinitiv kan også fungere som etterstilte modifikatorer til substantiv (5):

4. Mie sanoin pojile [ette lähtiä minun myötä kotia].

'Jeg sa til guttene at de skulle dra heim sammen med meg.'

5. Hänelä ei ole tarmoa [ette heittää polttamasta].

'Han/Hun har ikke ork til å slutte å røyke.'

Første infinitiv har bare éi form, og det er den som vi kjenner som oppslagsforma til verbet. Infinitivssuffikset festes til den korte verbstammen dersom verbet har slik. Suffikset i første infinitiv har til dels litt ulik form i de ulike varietetene. Vi skiller mellom disse suffiksvariantene:

- Verbtype 1: $-d A$ eller - $h A \sim-A$. I Porsanger-varieteten er suffikset alltid - $d A$, for eksempel saa/đa ('få), jää/đä ('bli igjen'), ui/đa ('svømme'), myy/đä ('selge'), tuo/da ('bringe, ha med'), vie/đä ('bringe, ta med'), syö/đä ('spise'), juo/đa ('drikke').

I de andre varietetene veksler suffikset mellom $-h A$ og $-A$ avhengig av hvilke vokaler vi finner i verbstammen. Slutter stammen på lang vokal, bruker vi suffikset $-h A$, som for eksempel i verba saa/ha ('få) og jää/hä ('bli igjen'). Slutter stammen på diftong, bruker vi suffikset $-A$, som for eksempel i (1. inf. : 1. sg. akt. ind. pres.) käy/ä ('dra en tur') : käy/n, ui/a ('svømme') : $u i / n$. Et unntak er verbet myy/ä ('selge') : myy/n. Derimot blir diftongene ou, öy og ie utjamna foran 1. infinitivssuffiks. Vi får da former som juu/a ('drikke') : juo/n, tuu/a ('bringe, ha med') : tuo/n, syy/ä ('spise') : syö/n, vii/ä ('bringe, ta med') : vie/n. 
- Verbtype 2: - Vt $\sim-A(t)$. I varietetene i Porsanger og Nordreisa, som begge har vokalutjamning, brukes suffikset - Vt. Her er $V$ for samme vokal som siste vokalen i stammen. Eksempler: (1. inf. : akt. perf. pts. sg. nom.) jakka/at ('dele') : jaka/nu(t), lähtelet ('dra av gårde') : lähte/ny(t), soppi/i(t) ('passe') : sopi/nu(t), siirtty/yt ('flytte') : siirty/ny(t). I Nordreisa er det vanlig å sløyfe final $t$ i 1 . infinitiv, altså for eksempel jakkaa.

I de andre varietetene slutter type 2-verb på - $A$ eller -At i 1. infinitiv. Former med final $t$ er ganske vanlige i de vestlige varietetene, mens suffikset i Varanger alltid er - $A$. I Varanger må vi også huske regelen om at $e A$ blir til $i A$. Vi får da former som jakka/a(t) ('dele’), lähte/ä( $t)$ lähti/ä ('dra av gårde’), sopila(t) ('passe’).

I overgangsverb (type 2 b) ser 1 . infinitiv ut som i disse eksempla: muistele/a $(t)$ ('fortelle'), ajattelela(t) ('tenke’), aukasela(t) ('åpne'), täriselä(t) ('dirre’), havaittela(t) ('merke'), piikaroittela(t) ('spikre'), likene/ä( $t$ ) ('nærme seg').

- Verbtype 3: Infinitivssuffiksa er stort sett de samme i alle varietetene med unntak av verba näh/đä näh/hä ('se') og teh/đä teh/hä ('gjøre'), som utenom Porsanger bruker suffikset $-h A$. I de andre verba av type 3 slutter 1 . infinitiv på - $t A$ dersom stammekonsonanten er $s$, ellers blir t-en i suffikset assimilert av stammekonsonanten, det vil si at den er identisk med stammekonsonanten. Eksempler: pes/tä ('vaske'), juos/ta ('springe'), auka(i)s/ta ('åpne'), tul/la ('komme'), men/nä ('gå), pur/ra ('bite'). Er stammekonsonanten $l$, så gjelder den vanlige lengderegelen for stemte konsonanter (se avsnitt 3.1.2). Jamfør for eksempel kuul/a ('høre') og muistel/a ('fortelle') med ajatel/la ('tenke').

- Verbtype 4: Suffikset er $t A$ i alle varietetene. Eksempler: tarvi/ta ('trenge'), vali/ta ('velge'), piikaroi/ta ('spikre'), li(j)e/tä ('nærme seg'), para/ta ('bli bra'), maa/ta ('ligge'), jatka/ta ('fortsette'), keri/tä ('rekke'), pöl(j)̈̈/tä ('være redd'), $k a(d) o / t a$ ('forsvinne').

\subsubsection{Andre infinitiv}

Som infinitiv regner vi også verbformer som juostessa, nukkuissa, uiten, käyten, juosten (jf. juosta 'springe', nukkuu(t) nukkua 'sove', ui(đ)a 'svømme', $k \ddot{a} y(đ) \ddot{a}$ 'dra en tur'). Vi kaller slike former for ANDRE INFINITIV. De ser ut som kasusformer, med suffikset $s s A$ i inessiv og $n$ i såkalt instruktiv, og de fungerer som frie adverbial i setninga, og de brukes oftest som adverb (1-3): 
1. Mie näjin, ette Pekka tuli tietä pitkin juosten.

'Jeg så at Peder kom springende langs vegen.'

2. Mie en näje minun miestä ennää ko nukkuissa.

'Jeg ser ikke lenger til mannen min anna enn når han sover.'

3. Mie hajen sen nyt heti muistaissa.

'Jeg henter den/det nå mens jeg husker det.'

Slike verbformer likner på infinitiv ved at de kan danne en frase som har sitt eige genitivssubjekt $(4,5)$ eller ei anna utfylling $(6,7)$ :

4. Ei semmoista saata puhhuut $\sim$ puhu/at [ihmisten kuulten].

'Slikt får man ikke snakke om i folks påhør'.

5. [Vanhemi(i)tten elläissä] mie en koskhaan käyny sielä.

'Jeg var aldri på besøk der mens foreldra var i live.'

6. [Leip(p)ää syötessä] Mikkel maiskutteli suuta.

'Mikkel smatta mens han spiste brød.'

7. [Vaarassa kulk(k)eissa] hän ampui jäniksen.

'Han/Hun skaut en hare mens han/hun gikk på fjellet.'

Andre infinitiv er likevel ikke noen produktiv verbform, det vil si at den ikke brukes ved alle verb. Brorparten av andre infinitivsformer bør klassifiseres som stivna adverb og oppføres som faste innførsler i leksikon. Fraser med andre infinitiv kan omskrives med heile setninger, og det er derfor strengt tatt ikke behov for dem. Jamfør setningene med 2. infinitiv i $(4,6)$ med tilsvarende omskrivning i $(8,9)$ :

8. Ei semmoista saata puhhuut [ko ihmiset kuulhaan].

'Slikt får man ikke snakke om når folk hører på.'

9. Mikkel maiskutteli suuta, [ko hän söi leippää].

'Mikka smatta mens han spiste brød.'

\subsubsection{Tredje infinitiv}

Tredje infinitiv er mye brukt både i tale og skrift. Den bøyes i fem kasus: inessiv, elativ, illativ, adessiv og abessiv. Av disse er inessiv, elativ, illativ og abessiv styrt av verb (1-5). Det kan være modalverb som jouttuut joutu/a(t) ('måtte, bli tvunget til'), päästä ('slippe'), pakata ('bli, skje lett') og keritä ('rekke, 
nå) $(1,2)$ eller aspektuelle verb som olla ('være), heittäät ('slutte') og keritä ('bli ferdig') (3, 4). I konstruksjonen jääđä jäähä tekemättä ('forbli ugjort') (5) krever verbet at 3. infinitiv står i abessiv. (Se avsnitt 4.4.1 og 4.4.3 om modalsetninger og aspektsetninger.)

1. Matti joutui [uimhaan ranthaan]. 'Mats blei nødt til å svømme i land.'

2. En mie kerkiä [plokkaamhaan marjoja]. 'Jeg rekker ikke å plukke bær.'

3. Liisa heitti [plokkaamasta marjoja]. 'Lisa slutta å plukke bær.'

4. Joko sie kerkisit [plokkaamasta marjoja]?

'Er du allerede blitt ferdig med å plukke bær?'

5. Ruoka jäi syömättä.

'Maten blei stående uspist.'

I indre lokalkasus brukes 3. infinitiv også i adverbiell funksjon i setningstypene STED og BEVEGELSE (6-8) (se avsnitt 4.2.1.1 og 4.2.1.2):

6. Pekka istuu [lukemassa kirjaa]. 'Peder sitter og leser i ei bok.'

7. Pekka tuli hihtaamasta.

'Peder kom tilbake etter å ha gått på ski'.

8. Pekka ui [kattomhaan kalloi].

'Peder svømte (i sjøen) for å se på fisk.'

3. infinitiv i adessiv $(9,10)$ forekommer bare som fritt adverbial; her er kasusen ikke styrt av et verb. Like ens fungerer også 3. infinitiv i abessiv (11) oftest som fritt adverbial. I begge tilfella uttrykker adverbialet måten noe blir gjort på.

9. Hylkheet tapethaan enimästi ampumalla.

'Sel dreper man for det meste ved å skyte dem.'

10. Alattionjoen pääsi ylös Sautshoon asti sauvomalla.

'Fra Altaelva kan en stake seg enda opp til Sautso.'

11. Pekka istui pöyđässä syömättä.

'Peder satt ved bordet uten å spise.' 
Infinitivsfrasen i abessiv kan ha sitt eige genitivssubjekt (12), som er forskjellig fra subjektet som står til verbalet:

12. Hän lähti hyysikkhään [toisten kuulematta].

'Han/Hun gikk på do uten at de andre hørte noe.'

3. infinitiv dannes på følgende måte:

- Infinitivssuffikset - $m A$ festes alltid til vokalstammen. Kasussuffiksa følger etter $m A$-suffikset. I illativ smelter infinitivssuffikset og kasussuffikset i hop til -mhAAn. - Dersom stammen gjennomgår stadieveksling etter mønster (II :) I : o, så velger vi stammen på I-stadiet, dersom mønsteret er II : I, så velger vi stammen på II-stadiet. Eksempler: (1. inf. : 1. sg. akt. ind. pres. : akt. perf. pts. sg. nom. : 3. inf. iness. : 4. inf. illat.) jakka/a(t) ('dele') : ja(j)a/n : jaka/nu(t) : jaka/ma/ssa : jaka/mhaan, kulkkelet kulkela(t) kulki/a ('vandre, gå) : kulje/n: kulke/nu(t): kulke/ma/ssa: kulke/mhaan, suuttu/ut suuttu/a(t) ('bli sint') : suutu/n:suuttu/nu(t): suuttu/ma/ssa: suuttu/mhaan.

- I verb av verbtype 4 bruker vi den lange vokalstammen. For eksempel (1. inf. : 1. sg. akt. ind. pres. : 3. inf. iness. : 3. inf. illat.) piikaroi/ta ('spikre') : piikaroitte/n : piikaroitte/ma/ssa : piikaroitte/mhaan, halli/ta ('styre') : hallitte/ $n$ : hallitte/mal ssa : hallitte/mhaan, li(j)e/tä ('nærme seg') : likene/n : likene/mä/ssä : likenel mhään, maa/ta ('ligge') : makkaa/n: makkaa/ma/ssa : makkaa/mhaan.

Tabell 6.13 gir en oversikt over hvordan vi danner 1. og 3. infinitiv i de ulike verbtypene.

Tabell 6.13 Første og tredje infinitiv

\begin{tabular}{|c|c|c|c|}
\hline Verbtype & 1. infinitiv & 3. infinitiv elativ & 3. infinitiv illativ \\
\hline \multirow[t]{3}{*}{1 Enstava verb } & saa/đa saa/ha & saa/ma/sta & saa/mhaan \\
\hline & vie/đä vii/ä & vie/mä/stä & vie/mhään \\
\hline & ui/(đ)a & ui/ma/sta & ui/mhaan \\
\hline \multicolumn{4}{|l|}{2 Enstamma verb } \\
\hline \multicolumn{4}{|l|}{ 2a Opprinnelige } \\
\hline \multirow[t]{2}{*}{ e-stammer } & $\begin{array}{l}\text { kulkke/e(t) kulke/a(t) } \\
\text { kulki/a }\end{array}$ & kulke/ma/sta & kulke/mhaan \\
\hline & $\begin{array}{l}\text { lukke/e(t) luke/a(t) } \\
\text { luki/a }\end{array}$ & luke/ma/sta & luke/mhaan \\
\hline
\end{tabular}

(Fortsatt) 
Tabell 6.13 (Fortsatt)

\begin{tabular}{|c|c|c|c|}
\hline Verbtype & 1. infinitiv & 3. infinitiv elativ & 3. infinitiv illativ \\
\hline \multirow[t]{2}{*}{$i$-stammer } & soppi/i(t) sopi/a(t) & sopi/ma/sta & sopi/mhaan \\
\hline & tohti/i(t) tohti/a(t) & tohti/ma/sta & tohti/mhaan \\
\hline \multirow[t]{2}{*}{ O-, U-stammer } & katto/o(t) katto/a(t) & katto/ma/sta & katto/mhaan \\
\hline & nukku/u(t) nukku/a(t) & nukku/ma/sta & nukku/mhaan \\
\hline \multirow[t]{4}{*}{ A-stammer } & $\operatorname{ant}(t) a / a(t)$ & anta/ma/sta & anta/mhaan \\
\hline & $\operatorname{lent}(t) a ̈ / a ̈(t)$ & lentä/mä/stä & lentä/mhään \\
\hline & varasta/a(t) & varasta/ma/sta & varasta/mhaan \\
\hline & näytästä/ä(t) & näytästä/mä/stä & näytästä/mhään \\
\hline \multirow[t]{6}{*}{$2 \mathrm{~b}$ Overgangsverb } & muistele/a(t) & muistele/ma/sta & muistele/mhaan \\
\hline & aukase/a(t) & aukase/ma/sta & aukase/mhaan \\
\hline & tärise/ä(t) & tärise/mä/stä & tärise/mhään \\
\hline & hallitte/a(t) & hallitte/ma/sta & hallitte/mhaan \\
\hline & piikaroitte/a(t) & piikaroitte/ma/sta & piikaroitte/mhaan \\
\hline & valkene/a(t) & valkene/ma/sta & valkene/mhaan \\
\hline \multicolumn{4}{|l|}{$\begin{array}{l}3 \text { Verb med } \\
\text { konsonantstamme }\end{array}$} \\
\hline \multirow{3}{*}{ 3.1 Tostava } & ol/la & ole/ma/sta & ole/mhaan \\
\hline & juos/ta & juokse/ma/sta & juokse/mhaan \\
\hline & näh/(đ)ä näh/hä & näke/mä/stä & näke/mhään \\
\hline \multirow[t]{2}{*}{ 3.2 Flerstava ele-verb } & kävel/ä & kävele/mä/stä & kävele/mhään \\
\hline & ajatel/la & ajattele/ma/sta & ajattele/mhaan \\
\hline \multirow{2}{*}{$\begin{array}{l}3.3 \text { Flerstava } A(i) \text { se- } \\
\text { verb }\end{array}$} & auka(i)s/ta & auka(i)se/ma/sta & auka(i)se/mhaan \\
\hline & täris/tä & tärise/mä/stä & tärise/mhään \\
\hline \multicolumn{4}{|l|}{$\begin{array}{l}4 \text { Verb med to } \\
\text { vokalstammer }\end{array}$} \\
\hline \multirow[t]{2}{*}{4.1 itte-verb } & kyyti/tä & kyytitte/mä/stä & kyytitte/mhään \\
\hline & halli/ta & hallitte/ma/sta & hallitte/mhaan \\
\hline 4.2 Oitte-verb & piikaroi/ta & piikaroitte/ma/sta & piikaroitte/mhaan \\
\hline \multirow[t]{2}{*}{4.3 ne-verb } & valje/ta & valkene/ma/sta & valkene/mhaan \\
\hline & vanhe/ta & vanhene/ma/sta & vanhene/mhaan \\
\hline \multirow[t]{4}{*}{ 4.4 Kontrakte verb } & jatka/ta & jatkaa/ma/sta & jatkaa/mhaan \\
\hline & pöl(j)ä/tä & pölk(k)ää/mä/stä & pölk(k)ää/mhään \\
\hline & keri/tä & $\begin{array}{l}\text { kerkkii/mä/stä } \\
\text { kerkiä/mä/stä }\end{array}$ & $\begin{array}{l}\text { kerkkii/mhään } \\
\text { kerkiä/mhään }\end{array}$ \\
\hline & $\mathrm{ka}(đ) \mathrm{o} / \mathrm{ta}$ & $\begin{array}{l}\text { kattoo/ma/sta } \\
\text { katoa/ma/sta }\end{array}$ & $\begin{array}{l}\text { kattoo/mhaan } \\
\text { katoa/mhaan }\end{array}$ \\
\hline
\end{tabular}




\subsubsection{Partisipp}

PARTISIPP er den andre infinitte verbforma i kvensk. Det fins to hovedtyper partisipp, PRESENS PARTISIPP og PERFEKTUM PARTISIPP, og begge har både aktiv og passiv form. I tillegg fins det såkalt AGENTPARTISIPP, som bare har aktiv form.

Vi skal her først ta for oss hva slags funksjoner presens og perfektum partisipp har, og hvordan de dannes og bøyes. Til slutt ser vi på bruken og dannelsen av agentpartisipp.

\subsubsection{Bruk av presens partisipp og perfektum partisipp}

Partisipp fyller ofte de samme setningsfunksjonene som adjektiv, og de fungerer da som adjektivmodifikatorer (1-3). De har både kasus- og tallbøying, eller med andre ord bøyes de som et hvilket som helst nomen. I tillegg opptrer perfektum partisipp i de sammensatte verbformene nektende preteritum $(4,5)$, presens perfektum (7) og preteritum perfektum $(6,8)$.

1. Astiita ei ole hyvä pestä [juokse(e) vassa ve(đ)essä].

'Det er ikke bra å vaske kopper og kar i rennende vatn.'

2. Rannasta löytyi [hukkunu(t) mies].

'Det blei funnet en drukna mann på stranda.'

3. Mettästä löyđethiin [tapetun karhuun].

'Det blei funnet en drept bjørn i skogen.'

4. Mie [en kirjoittannu(t)] preivii preiviä kuninkhaale.

'Jeg skreiv ikke (noe) brev til kongen.'

5. Met [emmä pöl(j)änheet] hukkaa.

'Vi var ikke redd for ulv(en).'

6. Hän [oli häviny $(t)]$ aaphaan.

'Han/Hun hadde drukna i havet.'

7. Met [olisimma lähättänheet] kuninkhaale preivin.

'Vi skulle ha sendt (et) brev til kongen.'

8. Karhuun [oli tapettu] jo kevväilä.

'Bjørnen var blitt drept allerede på våren.'

Videre er både presens partisipp og perfektum partisipp brukt i partisippfraser (9-15). Da erstatter de ei indirekte leddsetning (se avsnitt 4.3). Jamfør partisippfrasene i a-eksempla med de tilsvarende leddsetningene i b-eksempla i (9-15): 
9. a) Näkkyy [tul(le)evan kaunis päivä].

b) Näkkyy [ette tullee kaunis päivä].

'Det ser ut til å bli en fin dag.'

10. a) Pekka kuului [käynheen Kööpenhaminassa].

b) Kuului [ette Pekka oli käyny(t) Kööpenhaminassa].

'Det blei fortalt at Peder hadde vært i København.'

11. a) Mie kuulin [Knuutin tul(le)evan].

'Jeg hørte Knut komme.'

b) Mie kuulin [ette Knuutti tullee/tuli].

'Jeg hørte at Knut kom.'

12. a) Het muistelthiin [Knuutin jo ol(le)evan amtmanin tykönä].

b) Het muistelthiin [ette Knuutti oon/oli jo amtmanin tykönä].

'De fortalte at Knut allerede var hos amtmannen.'

13. a) Het luulthiin [Knuutin jo tulheen Alattihoon].

b) Het luulthiin [ette Knuutti oon/oli jo tullu(t) Alattihoon].

'De trudde (at) Knut allerede var kommet til Alta.'

14. a) Klemetti sanoi [ittensä käyvän tulleevalla viikola Kaarasjovessa].

b) Klemetti sanoi [ette hän käy tul(le)evalla viikola Kaarasjovessa].

'Klemet sa (at) han skulle dra en tur til Karasjok til uka.'

15. a) Pojat luulthiin [ittensä nähnheen hukan].

b) Pojat luulthiin [ette het olthiin nähnheet hukan].

'Guttene trudde (at) de hadde sett ulv(en).'

I disse partisippfrasene svarer presens partisipp til det finitte verbet i presens eller preteritum (jf. a-eksemplet med b-eksemplet i setning 9, 11, 12 og 14), og perfektum partisipp svarer til det finitte verbet i presens perfektum eller preteritum perfektum (jf. a-eksemplet med b-eksemplet i setning (10, 13 og 15). Vi skal ikke gå nærmere inn på slike partisippfraser ettersom de ikke er vanlige verken i tale eller skrift, og ettersom de alltid kan erstattes med ei finitt leddsetning.

En spesiell bruk av aktiv form av presens partisipp har vi som tidligere sett i tredje person flertall (se avsnitt 6.3.3). I Porsanger er denne bruken ikke like vanlig i alle verbtyper som i de andre varietetene, men den brukes også i Porsanger (16-18). I verb med konsonantstamme (type 3 ) bruker vi som regel likevel samme bøyingsform i tredje person flertall som i passiv (19): 
16. Lapset saavat nukkuut kauvan.

'Barna får sove lenge.'

17. Het jo ođottaavat meitä.

'De venter allerede på oss.'

18. Tyttäret kyytitteevät kaikki kothiin.

'Jentene skyssa alle heim.'

19. Tyttäret tulhaan huomena kothiin.

'Jentene kommer heim i morgen.'

\subsubsection{Danning av perfektum partisipp}

Vi har allerede tidligere gjort greie for hvordan vi danner aktiv og passiv form av perfektum partisipp da vi behandla nektende preteritum (se avsnitt 6.4.2.3).

Men vi har enda ikke forklart nærmere hvordan perfektum partisipp-former bøyes i kasus, både i entall og flertall. Den aktive perfektum partisipp-stammen gjennomgår en spesiell type lydveksling: Nominativ entall slutter på $U(t)$, konsonantstammen slutter på $U t$, men vokalstammen slutter på lang ee, som følger etter en $h$. For eksempel: (1. inf. : akt. perf. pts. sg. nom. : akt. perf. pts. sg. part. : akt. perf. pts. pl. nom. : akt. perf. pts. pl. part.) vaip $(p) u / u t \sim v a i p u / a(t)$ ('bli trøtt') : vaipu/nu(t) : vaipu/nut/ta : vaipu/nhee/t : vaipu/nhe/i/ta, ka(d)o/ta ('forsvinne') : $k a(d) o / n u(t): k a(d) o / n u t / t a: k a(d) o / n h e e / t: k a(d) o / n h e / i / t a$.

\subsubsection{Danning av presens partisipp}

De aktive og passive presens partisipp-formene dannes på følgende måte:

- AKtiv form av PRESENS PARTISIPp danner vi med hjelp av suffiksa $p A$ og $-v A$. Suffikset $-p A$ bruker vi sammen med enstava verb (type 1). For eksempel: (1. inf. : akt. pres. pts. sg. nom.) vie/ đä vii/ä ('bringe, ta med') : vie/pä, syö/ đä $\sim$ syy/ä ('spise') : syö/pä.

I de andre verbtypene varierer presens partisipp-formene mellom de ulike varietetene. Det er Porsanger som avviker fra de andre varietetene. I Porsanger dannes presens partisipp ved at suffikset $-v A$ festes til aktiv form av indikativ presens i tredje person entall, og det er den eneste bøyingsforma som bruker slik stamme. I de andre kvenske skriftspråksvarietetene festes suffikset - $v A$ til samme stamme som brukes i 3 . infinitiv (se avsnitt 6.8.1.3). Eksempler på begge variantene: (1. inf. : 1. sg. akt. ind. pres. : 3 . sg. akt. ind. pres. : akt. perf. 
pts. sg. nom. : akt. pres. pts. sg. nom.): (verbtype 2) jakka/a(t) ('dele') : ja(j)a/n : jakkala : jakalnu(t) : jakkaa/va jaka/va, kulkkelet $\sim$ kulkela $(t) \sim k u l k i / a$ ('vandre, gå) : kulje/n: kulk(k)ele : kulke/nu(t) : kulkkee/va kulke/va, (verbtype 3) tul/la ('komme') : tule/n: tulle/e: tul/lu(t): tullee/va tule/va, muistel/a ('fortelle') : muistele/ $n:$ muistele/e : muistel/u(t) : muistelee/va $\sim$ muistele/va, auka(i)s/ta ('åpne’) : auka(i)se/n : auka(i)s(s)e/e : auka(i)s/su(t) : aukaissee/va aukase/va, (verbtype 4) piikaroi/ta ('spikre') : piikaroitte/n : piikaroittele : piikaroi/nu(t) : piikaroittee/va piikaroitte/va, li(j)e/tä ('nærme seg') : likene/n : likenele : li(j)e/ny(t): likenee/vä likene/vä, maa/ta ('ligge') : makkaa/n: makkaa: maa/nu(t) : makkaa/va, ka(d)o/ta ('forsvinne') : kattoo/n katoa/n: kattoo $\sim$ katoa/a: ka(đ)o/nu(t): kattoo/va $\sim$ katoa/va.

- Suffikset i PASSIV form av PRESENS PARTISIPp, - $(t) t A v A$, festes til samme stamme som de andre passivsuffiksa (se avsnitt 6.2.5). Suffiksvarianten -tAvA brukes i enstava verb (type 1) og verb med konsonantstamme (type 2), ellers brukes varianten $t t A v A$. For eksempel: (1. inf. : pass. ind. pret. : pass. pres. pts. sg. nom.) (verbtype 1) saa/đa saa/ha ('fä) : saa/thiin: saa/tava, (verbtype 2) jakka/a(t) ('dele') : ja(j)elthiin : ja(j)elttava, (verbtype 3) tul/la ('komme') : tul/thiin: tul/tava, muistel/a ('fortelle') : muistel/thiin: muistel/tava, auka(i)s/ta ('åpne’) : auka(i)s/thiin: auka(i)s/tava, (verbtype 4) halli/ta ('styre') : halli/thiin : halli/ttava, piikaroi/ta ('spikre') : piikaroi/thiin : piikaroi/ttava, li(j)e/tä ('nærme seg') : li(j)e/thiin: li(j)e/ttävä, maa/ta ('ligge') : maa/thiin : maa/ttava.

I overgangsverb (verbtype $2 \mathrm{~b}$ ) får vi passive presens partitipp-former som for eksempel (1. inf. : pass. pres. pts. sg. nom.) muistele/a(t) ('fortelle') : muistele/ttava, aukase/a(t) ('åpne') : aukase/ttava, hallitte/a(t) ('styre') : hallitte/ttava, piikaroitte/a(t) ('spikre') : piikaroitte/ttava, likene/ä( $t$ ) ('nærme seg') : likene/ttävä.

I FLERTALLSFORMER av PRESENS PARTISIPP faller stammevokalen $A$ bort foran flertalls-i. For eksempel: (1. inf. : akt. pres. pts. sg. nom. : akt. pres. pts. pl. iness. :

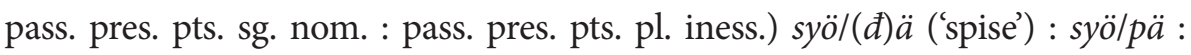
syö/v/i/ssä : syö/tävä : syö/täv/i/ssä, kirjo(i)tta/a(t) ('skrive') : kirjo(i)tta(a)/va : kirjo(i)tta(a)/v/i/ssa : kirjo(i)te/ttava : kirjo(i)te/ttav/i/ssa, juos/ta ('springe') : juokse(e)/va : juokse(e)/v/i/ssa : juos/tava : juos/tav/i/ssa, hävi/tä ('forsvinne') : hävvii/vä häviä/vä : hävvii/v/i/ssä häviä/v/i/ssä : hävi/ttävä : hävi/ttäv/i/ssä.

Tabell 6.14 viser aktive og passive presens- og perfektum partisipp-former i nominativ entall gruppert etter de ulike verbtypene. 
Tabell 6.14 Partisippformer

\begin{tabular}{|c|c|c|c|c|c|}
\hline Verbtype & 1. infinitiv & $\begin{array}{l}\text { Akt. pres. pts. } \\
\text { sg. nom. }\end{array}$ & $\begin{array}{l}\text { Akt. perf. } \\
\text { pts. sg. nom. }\end{array}$ & $\begin{array}{l}\text { Pass. pres. } \\
\text { pts. sg. nom. }\end{array}$ & $\begin{array}{l}\text { Pass. perf. } \\
\text { pts. sg. } \\
\text { nom. }\end{array}$ \\
\hline \multirow[t]{2}{*}{1 Enstava verb } & $\begin{array}{l}\text { saa/đa saa/ } \\
\text { ha }\end{array}$ & saa/pa & saa/nu(t) & saa/tava & saa/tu \\
\hline & vie/đä vii/ä & vie/pä & vie/ny(t) & vie/tävä & vie/ty \\
\hline \multicolumn{6}{|l|}{2 Enstamma verb } \\
\hline \multicolumn{6}{|l|}{ 2a Opprinnelige } \\
\hline \multirow[t]{2}{*}{ e-stammer } & $\begin{array}{l}\text { kulkke/et } \\
\text { kulke/a(t) } \\
\text { kulki/a }\end{array}$ & $\begin{array}{l}\text { kulkkee/va } \\
\text { kulke/va }\end{array}$ & kulke/nu(t) & kulje/ttava & kulje/ttu \\
\hline & $\begin{array}{l}\text { lukke/et } \\
\text { luke/a(t) } \\
\text { luki/a }\end{array}$ & $\begin{array}{l}\text { lukkee/va } \\
\text { luke/va }\end{array}$ & luke/nu(t) & lu(j)e/ttava & lu(j)e/ttu \\
\hline i-stammer & $\begin{array}{l}\text { soppi/it } \\
\text { sopi/a(t) }\end{array}$ & $\begin{array}{l}\text { soppii/va } \\
\text { sopi/va }\end{array}$ & sopi/nu(t) & sovi/ttava & sovi/ttu \\
\hline \multirow[t]{2}{*}{ O-, U-stammer } & $\begin{array}{l}\text { katto/ot } \\
\text { katto/a(t) }\end{array}$ & $\begin{array}{l}\text { kattoova } \\
\text { katto/va }\end{array}$ & katto/nu(t) & katto/ttava & katto/ttu \\
\hline & $\begin{array}{l}\text { näkky/yt } \\
\text { näky/ä(t) }\end{array}$ & $\begin{array}{l}\text { näkkyy/vä } \\
\text { näky/vä }\end{array}$ & näky/ny(t) & nä(v)y/ttävä & nä(v)y/tty \\
\hline \multirow[t]{3}{*}{ A-stammer } & luotta/a(t) & luotta(a)/va & luotta/nu(t) & luote/ttava & luote/ttu \\
\hline & lent(t)ä/ä(t) & $\begin{array}{l}\text { lenttää/vä } \\
\text { lentä/vä }\end{array}$ & lentä/ny(t) & lenne/ttävä & lenne/tty \\
\hline & varasta/a(t) & varasta(a)/va & varasta/nnu(t) & $\begin{array}{l}\text { varaste/ } \\
\text { ttava }\end{array}$ & varaste/ttu \\
\hline \multirow[t]{4}{*}{$\begin{array}{l}\mathrm{b} \\
\text { Overgangsverb }\end{array}$} & ajattele/a(t) & ajattele/va & $\begin{array}{l}\text { ajattele/ } \\
\text { nu(t) }\end{array}$ & $\begin{array}{l}\text { ajattele/ } \\
\text { ttava }\end{array}$ & $\begin{array}{l}\text { ajattele/ } \\
\text { ttu }\end{array}$ \\
\hline & aukase/a(t) & aukase/va & $\begin{array}{l}\text { aukase/ } \\
\text { nnu(t) }\end{array}$ & $\begin{array}{l}\text { aukase/ } \\
\text { ttava }\end{array}$ & $\begin{array}{l}\text { aukase/ } \\
\text { ttu }\end{array}$ \\
\hline & kyytitte/ä(t) & kyytitte/vä & $\begin{array}{l}\text { kyytitte/ } \\
\text { nny(t) }\end{array}$ & $\begin{array}{l}\text { kyytitte/ } \\
\text { ttävä }\end{array}$ & $\begin{array}{l}\text { kyytitte/ } \\
\text { tty }\end{array}$ \\
\hline & likene/ä(t) & likene/vä & likene/nny(t) & likene/ttävä & likene/tty \\
\hline \multicolumn{6}{|l|}{$\begin{array}{l}3 \text { Verb med } \\
\text { konsonantstamme }\end{array}$} \\
\hline \multirow[t]{3}{*}{ 3.1 Tostava } & ol/la & ollee/va ole/va & $\mathrm{ol} / \mathrm{lu}(\mathrm{t})$ & ol/tava & $\mathrm{ol} / \mathrm{tu}$ \\
\hline & juos/ta & $\begin{array}{l}\text { juoksee/va } \\
\text { juokse/va }\end{array}$ & juos/su(t) & juos/tava & juos/tu \\
\hline & $\begin{array}{l}\text { näh/đä } \\
\text { näh/hä }\end{array}$ & $\begin{array}{l}\text { näkkee/vä } \\
\text { näke/vä }\end{array}$ & näh/ny(t) & näh/tävä & näh/ty \\
\hline
\end{tabular}

(Fortsatt) 
Tabell 6.14 (Fortsatt)

\begin{tabular}{|c|c|c|c|c|c|}
\hline Verbtype & 1. infinitiv & $\begin{array}{l}\text { Akt. pres. pts. } \\
\text { sg. nom. }\end{array}$ & $\begin{array}{l}\text { Akt. perf. } \\
\text { pts. sg. nom. }\end{array}$ & $\begin{array}{l}\text { Pass. pres. } \\
\text { pts. sg. nom. }\end{array}$ & $\begin{array}{l}\text { Pass. perf. } \\
\text { pts. sg. } \\
\text { nom. }\end{array}$ \\
\hline \multirow[t]{2}{*}{$\begin{array}{l}\text { 3.2 Flerstava } \\
\text { ele-verb }\end{array}$} & kävel/ä & $\begin{array}{l}\text { kävelee/vä } \\
\text { kävele/vä }\end{array}$ & kävel/y(t) & kävel/tävä & kävel/ty \\
\hline & ajatel/la & $\begin{array}{l}\text { ajattellee/va } \\
\text { ajattele/va }\end{array}$ & ajatel/lu(t) & ajatel/tava & ajatel/tu \\
\hline \multirow[t]{2}{*}{$\begin{array}{l}3.3 \text { Flerstava } A(I) \\
\text { se- og ise-verb }\end{array}$} & auka(i)s/ta & $\begin{array}{l}\text { aukaissee/va } \\
\text { aukase/va }\end{array}$ & $\begin{array}{l}\text { auka(i)s/ } \\
\text { su(t) }\end{array}$ & $\begin{array}{l}\text { auka(i)s/ } \\
\text { tava }\end{array}$ & $\begin{array}{l}\text { auka(i)s/ } \\
\text { tu }\end{array}$ \\
\hline & täris/tä & $\begin{array}{l}\text { tärissee/vä } \\
\text { tärisevä }\end{array}$ & täris/sy(t) & täris/tävä & täris/ty \\
\hline \multicolumn{6}{|l|}{$\begin{array}{l}4 \text { Verb med to } \\
\text { vokalstammer }\end{array}$} \\
\hline 4.1 itte-verb & kyyti/tä & $\begin{array}{l}\text { kyytittee/vä } \\
\text { kyytitte/vä }\end{array}$ & kyyti/ny(t) & kyyti/ttävä & kyyti/tty \\
\hline 4.2 Oitte-verb & piikaroi/ta & $\begin{array}{l}\text { piikaroitte(e)/va } \\
\text { piikaroitte/va }\end{array}$ & piikaroi/nu(t) & $\begin{array}{l}\text { piikaroi/ } \\
\text { ttava }\end{array}$ & $\begin{array}{l}\text { piikaroi/ } \\
\text { ttu }\end{array}$ \\
\hline \multirow[t]{2}{*}{4.3 ne-verb } & li(j)e/tä & $\begin{array}{l}\text { likenee/vä } \\
\text { likene/vä }\end{array}$ & li(j)e/ny(t) & li(j)e/ttävä & li(j)e/tty \\
\hline & vanhe/ta & $\begin{array}{l}\text { vanhenee/va } \\
\text { vanheneva }\end{array}$ & vanhe/nu(t) & vanhe/ttava & vanhe/ttu \\
\hline \multirow{4}{*}{$\begin{array}{l}4.4 \text { Kontrakte } \\
\text { verb }\end{array}$} & jatka/ta & jatkaa/va & jatka/nu(t) & jatka/ttava & jatka/ttu \\
\hline & pöl(j)ä/tä & pölk(k)ää/vä & pöl(j)ä/ny(t) & pöl(j)ä/ttävä & $\begin{array}{l}\text { pöl(j)ä/ } \\
\text { tty }\end{array}$ \\
\hline & keri/tä & $\begin{array}{l}\text { kerkkii/vä } \\
\text { kerkiä/vä }\end{array}$ & keri/ny(t) & keri/ttävä & keri/tty \\
\hline & $\mathrm{ka}(đ) \mathrm{o} / \mathrm{ta}$ & $\begin{array}{l}\text { kattoo/va } \\
\text { katoa/va }\end{array}$ & $\mathrm{ka}(\mathrm{d}) \mathrm{o} / \mathrm{nu}(\mathrm{t})$ & ka(đ)o/ttava & $\begin{array}{l}\mathrm{ka}(\mathrm{d}) \mathrm{o} / \\
\mathrm{ttu}\end{array}$ \\
\hline
\end{tabular}

\subsubsection{Bruk og danning av agentpartisipp}

AgENTPARTISIPP er brukt i såkalte AGENTKOnSTRUKSJONER, og de opptrer som modifikatorer til substantiv, både i foranstilt (1-3) og etterstilt (4). Slike agentkonstruksjoner har et eige genitivssubjekt som står foran agentpartisippet. Sjølve agentpartisippet bøyes på samme måte som et adjektiv ville ha blitt bøyd i samme funksjon.

1. Tämä oon [äitin paistama leipä].

'Det er mor som har bakt dette brødet.'

2. [Kenen tappama karhuu] tämä oon?

'Hvem har drept denne bjørnen?' 
3. Mie nyljin [faarin tappaman karhuun].

'Jeg flådde bjørnen som far hadde drept.'

4. Kyllä tuo paita oon [minun neuloma].

'Visst er det jeg som har sydd den der skjorta'.

Agentkonstruksjoner er sjeldne i kvensk. Det er vanligere å bruke setninger som i stedet for genitivssubjekt og agentpartisipp har vanlig subjekt og verbal, som gjelder heile setninga (5-7):

5. Äiti paistoi tämän leivän. (Betyr det samme som (1) ovafor.)

6. Kuka tappoi tämän karhuun? (Betyr det samme som (2) ovafor.)

7. Kyllä mie olen neulonu tuon paiđan. (Betyr det samme som (4) ovafor.)

Noen ganger svarer en agentkonstruksjon til ei leddsetning (8):

8. Mie nyljin sen karhuun, minkä faari tappoi. (Betyr det samme som (3) ovafor.)

Når det er sagt, så er det lett å lage agentpartisipp. Det dannes og bøyes nemlig på samme måte som 3. infinitiv (se avsnitt 6.8.1.3). 



\section{7}

\section{Pronomen og andre pro-ord}

Pronomen er ord som vi bruker i stedet for andre nomen. Det er også det som ligger bak sjølve navnet: Ordet pronomen kommer fra latin pro nomen, som betyr 'for (et) nomen'. Pronomen refererer til et anna ord eller noe anna som på et eller anna vis framgår av konteksten et anna sted. Det pronomenet viser til, kaller vi for KORRELAT.

Pronomen står som regel i stedet for et substantiv og danner en NP i setninga, men de kan også ha adjektivisk funksjon. Jamfør setningene i (1-3):

1. Matti juksas pirruu.

'Mats lurte djevelen.'

2. Se juksas pirruu.

'Han lurte djevelen.'

3. Tämä mies juksas pirruu.

'Denne mannen lurte djevelen.'

Pronomenet se i setning (2) har substantivisk funksjon, mens pronomenet tämä i setning (3) har adjektivisk funksjon.

I tillegg til egentlige pronomen er det ei gruppe ord som vi kaller for PROORD, nærmere bestemt PROADJEKTIV, som alltid står i stedet for og har samme funksjon som adjektiv eller adjektivfraser (AP) (4), og PROADVERB, som står i stedet for og har samme funksjon som adverb eller adverbfraser (AdvP) (5).

4. Tuomoista miestä oon helppo rakastaat.

'En slik mann er det lett å elske.'

5. Miksi sie vihhaat minnuu?

'Hvorfor hater du meg?'

Ofte er det slik at samme rot har gitt opphav til pronomen, proadjektiv og proadverb. Det er tilfellet i flere såkalte DEMONSTRATIVE PRO-ORD, for eksempel: 


$\begin{array}{lll}\begin{array}{l}\text { Pronomen } \\ \text { tämä ('denne') }\end{array} & \begin{array}{l}\text { Proadjektiv } \\ \text { tämmöinen ('slik (som denne / den her } \\ \text { slags)') }\end{array} & \begin{array}{l}\text { Proadverb } \\ \text { täälä ('her') }\end{array} \\ \text { tuo ('den der') } & \begin{array}{l}\text { tuomoinen ('slik som den der / slik som } \\ \text { den der slags') }\end{array} & \text { tuola ('der borte') } \\ \text { se ('den') } & \begin{array}{l}\text { semmoinen ('slik som den / slik som den } \\ \text { slags') }\end{array}\end{array}$

Proadverb kan ha samme form som kasusbøyde pronomen, som illustrert i setningene (6-7):

6. Tuola tyttärellä oon kissa sylissä.

'Den der jenta har en katt på fanget.'

7. Kissa istuu tuola.

'Katten sitter der borte.'

I setning (6) er tuola et pronomen, mens det i setning (7) er et proadverb.

Proadverb kan deles inn i grupper etter betydninga deres. De kan uttrykke sted (8), tid (9), måte $(10)$ og årsak $(11,12)$. I tillegg fins det proadverb som uttrykker grad (13):

8. Tule tänne!

'Kom hit!'

9. Het pyyđethään kallaa tuoloin tällöin.

'De fiska i ny og ne.'

10. Kunka sie sen kalan laitat?

'Hvordan lager du den fisken?'

11. Miksi sie nuoin sanoit?

'Hvorfor sa du slikt?'

12. En mie sitä sillä sanonu, ette mie olisin halunu sinun suututtaat.

'Jeg sa det ikke fordi jeg skulle ha ønska å gjøre deg sint.'

13. Se oon siksi tyyris, ettei minula ole varraa sitä ostaat.

'Det er så dyrt at jeg ikke har råd til å kjøpe det.' 
Vi skal komme tilbake til proadverb når vi tar for oss adverb (se avsnitt 9.2.1).

Nedafor skal vi se nærmere på de ulike pronomentypene og hvordan de bøyes. Samtidig skal vi også undersøke om det fins andre pro-ord som er laga til de ulike pronomenrøttene.

\subsection{Personlige pronomen}

Personlige pronomen refererer til en person eller en annen skapning. Som andre nomen skiller også personlige pronomen mellom to tall, entall og flertall. I tillegg skiller de mellom tre ulike personer, første, andre og tredje person, på samme måte som finitte verb. Første person viser til den eller de som taler eller skriver (1). Andre person bruker vi om den eller dem som blir snakka eller skrevet til (2), og tredje person viser til en eller flere personer som ikke er med i samtalen eller den skriftlige kommunikasjonen (3):

1. Mie kirjoitan grammatikkii.

'Jeg skriver på en grammatikk'.

2. Tet lujetta grammatikkii.

'Dere leser i grammatikken.'

3. Het opithaan kainun kieltä.

'De lærer seg kvensk.'

Kvensk har følgende personlige pronomen: (første, andre, tredje person entall nominativ:) mie ('jeg'), sie ('du'), hän/se ('han/hun/det'), (første, andre, tredje person flertall nominativ:) met ('vi'), tet ('dere'), het/net ('de'). Som vi ser, er det to varianter i tredje person, hän og se i entall, og het og net i flertall. Begge variantene er fullt brukbare i alle sammenhenger, og det er stort sett opp til hver enkelt språkbruker å velge hvilken variant han eller hun vil bruke i skriftlig kvensk. Men det fins likevel en allmenn regel: Når vi viser til levende skapninger i tredje person (altså han eller hun eller den/det) i indirekte utsagn, det vil si når vi gjengir det noen har sagt eller tenkt, så bruker vi variantene hän ja het. Ellers kan vi bruke begge variantene om hverandre. Jamfør første med andre setning i eksempel $(4,5)$ :

4. Pekka sanoi, ette nyt hän kyllä lähtee. Ja niin se/hän sitte lähti.

'Peder sa at han skulle dra. Og så dro han da også.' 


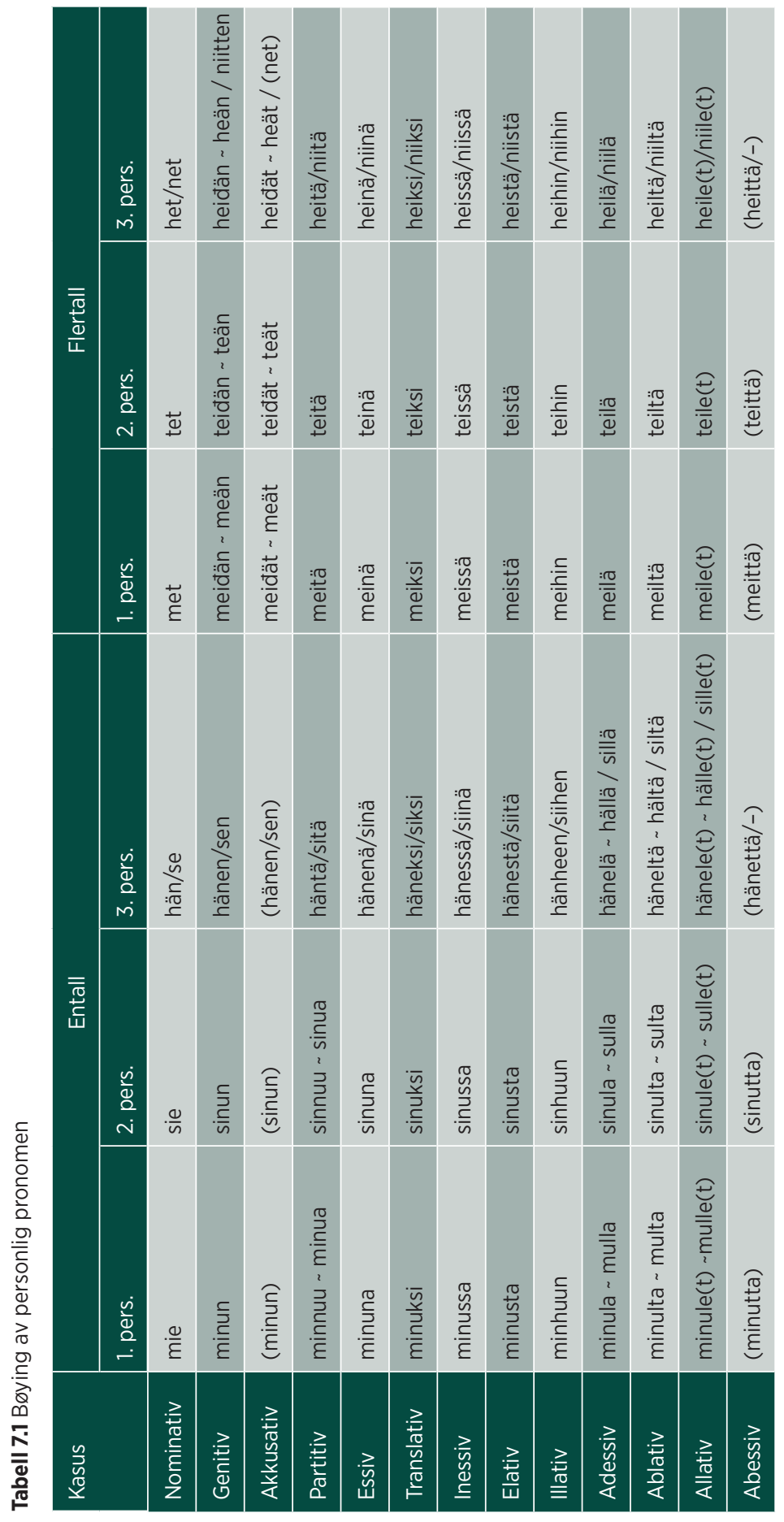


5. Hukka meinas, ette nyt hän saapi sen jäneksen.

'Ulven tenkte at nå fikk han tak i den haren.'

Personlige pronomen bøyes i kasus på nesten samme vis som andre nomen, det vil si at de har de samme bøyingssuffiksa, med ett større unntak, og det er at personlige pronomen har eigne akkusativsformer i flertall: me(id)ät ('oss'), te(iđ)ät ('dere'), he(iđ)ät ('dem'). Disse brukes kun når pronomenet fungerer som objekt i setninga, som for eksempel i (6):

6. Pekka kohđatteli meiđät tielä.

'Peder møtte oss på vegen'.

Personlige pronomen kan også danne abessivformer, men de er lite brukt. Tabell 7.1 viser hvordan vi bøyer personlige pronomen.

\subsection{Demonstrative pronomen og andre demonstrative pro-ord}

Demonstrative pronomen utpeker noe eller noen som fins i eller utafor konteksten for samtalen eller teksten. I likhet med personlige pronomen har de også tall- og kasusbøying. De mangler derimot abessivformer, og de har heller ikke personbøying. Det fins tre typer demonstrative pronomen:

- tämä ('denne/dette') og nämät ('disse') eller slike som refererer til noe eller noen som befinner seg nær taleren i heilt konkret forstand $(1,3)$, eller som refererer til et ledd i den nærmeste konteksten (2);

- tuo ('den/det der') og nuot ('de der') eller slike som refererer til noe eller noen som ligger litt lenger borte, men som likevel er innafor synsvidda til taleren $(1,3)$, i hvert fall i overført betydning;

- se ('den/det') og net ('de'), som brukes om noe eller noen som allerede er kjent fra før i tale- eller tekstsammenhengen $(1,2,3)$.

1. Täm $\ddot{a}_{\mathrm{i}}$ tässä oon meiđän huonet, mutta $t u o_{\mathrm{ii}}$ tuola rannassa oon minun sisaren. $S e_{\mathrm{ii}}$ oon uuđempi ko meiđän huonet. ${ }^{1}$

1 Når pro-ord og fraser i disse og seinere eksempler er etterfulgt av identiske symboler i senka posisjon, så betyr det at de har identiske referenter. 
'Det her er vårt hus, men det der borte på stranda er huset til søstera mi. Det er nyere enn vårt hus.'

2. Kainun kieli sai oman kielen statuksen vuona 2005. $]_{\mathrm{i}}$ [Tämä ${ }_{i}$ oon parantannu kielen tillaa. $]_{\text {ii }}$ Kaikki ei kuitenkhaan ole siitä ${ }_{i i}$ sammaa mieltä.

'Kvensk fikk status som eige språk i 2005. Det har forbedra situasjonen for språket. Men alle er ikke enig i det.'

3. Älä osta minule [näitä housui] $]_{\mathrm{i}}$ äläkä nuoitakhaan ii Mie en halluu niitäkhään .ii 'Ikke kjøp de her buksene til meg, ikke de der heller. Jeg ønsker ikke dem heller.'

Tabell 7.2 gir en oversikt over hvordan demonstrative pronomen bøyes i entall og flertall.

Vi ser at de demonstrative pronomena se og net er identiske med de personlige pronomena se og net.

I tabell 7.3 har vi ført opp proadjektiv og -adverb som er laga til røttene av demonstrative pronomen.

Tabell 7.2 Bøying av demonstrativt pronomen

\begin{tabular}{|c|c|c|c|c|c|c|}
\hline Kasus & \multicolumn{3}{|c|}{ Entall } & \multicolumn{3}{|c|}{ Flertall } \\
\hline Nominativ & tämä & tuo & se & nämät & nuot & net \\
\hline Genitiv & tämän & tuon & sen & $\begin{array}{l}\text { näitten } \\
\text { näinen }\end{array}$ & $\begin{array}{l}\text { nuoitten nuoinen } \\
\text { nuitten }\end{array}$ & niitten niinen \\
\hline Partitiv & tätä & tuota & sitä & näitä & nuoita nuita & niitä \\
\hline Essiv & tänä & tuona & sinä & näinä & nuoina nuina & niinä \\
\hline Translativ & täksi & tuoksi & siksi & näiksi & nuoiksi nuiksi & niiksi \\
\hline Inessiv & tässä & tuossa & siinä & näissä & nuoissa nuissa & niissä \\
\hline Elativ & tästä & tuosta & siitä siittä & näistä & nuoista nuista & niistä \\
\hline Illativ & tähän & tuohon & siihen & näihin & nuoihin nuihin & niihin \\
\hline Adessiv & tällä & tuola & sillä & näilä & nuoila nuila & niilä \\
\hline Ablativ & tältä & tuolta & siltä & näiltä & nuoilta nuilta & niiltä \\
\hline Allativ & tälle(t) & tuole(t) & sille(t) & näile(t) & nuoile(t) nuile(t) & niile(t) \\
\hline
\end{tabular}




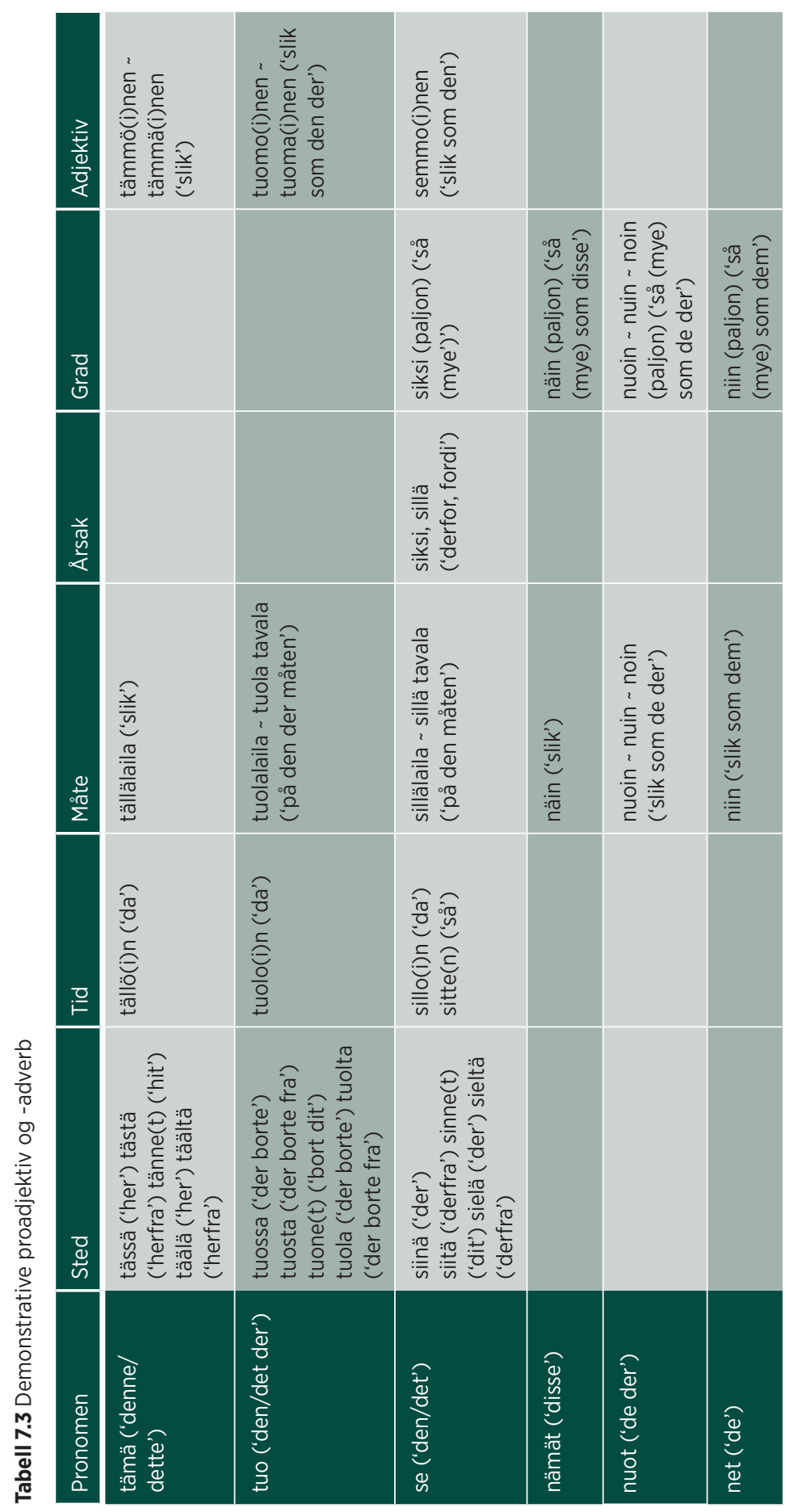




\subsection{Spørrepronomen og spørrende pro-ord}

Som vi har gjort rede for tidligere (se avsnitt 2.4.6.2), så dannes spørresetninger i kvensk med hjelp av enklitikonet $k O$ eller med spørreord. Hvilken spørremåte vi velger, er avhengig av hva slags svar vi forventer.

Som spørreord bruker vi oftest SPøRREPRONOMEN, men det fins også SPøRREADVERB og -ADJEKTIV. Ofte har spørrepronomen og spørreadverb identisk form, for eksempel:

1. Miksi sie minnuu luulet?

'Hva trur du jeg er?'

2. Miksi sie et tullukhaan, vaikka lupasit?

'Hvorfor kom du ikke, sjøl om du hadde lovt det?'

I eksempel (1) er spørrepronomenet mikä ('hva') brukt i translativ, og spørreordet i eksempel (2) er spørreadverbet miksi ('hvorfor').

Kvensk har to spørrepronomen, kuka ('hvem') og mikä ('hva'). Spørrepronomenet kuka refererer til mennesker, mens mikä refererer til andre skapninger og ting. Som andre nomen bøyes spørrepronomen i kasus. De har også tallbøying, men oftest har de samme form i flertall som i entall. Tabell 7.4 viser bøyingsformene til spørrepronomena kuka og mikä.

Tabell 7.4 Bøying av spørrepronmena kuka og mikä

\begin{tabular}{|c|c|c|c|c|}
\hline \multirow[t]{2}{*}{ Kasus } & \multicolumn{2}{|c|}{ kuka } & \multicolumn{2}{|c|}{ mikä } \\
\hline & Entall & Flertall & Entall & Flertall \\
\hline Nominativ & kuka & $\begin{array}{l}\text { kukka kutka } \\
\text { kekkä ketkä }\end{array}$ & mikä & mikkä mitkä \\
\hline Genitiv & kenen kenenkä & kenen kenenkä & minkä & minkä \\
\hline Partitiv & ketä & ketä keitä & mitä & mitä \\
\hline Essiv & kenenä & kenenä & minä & minä \\
\hline Translativ & keneksi & keneksi & miksi & miksi \\
\hline Inessiv & kenessä & kenessä & missä & missä \\
\hline Elativ & kenestä & kenestä & mistä & mistä \\
\hline Illativ & kenheen & kenheen & mihin mihinkä & mihin mihinkä \\
\hline Adessiv & kenelä kellä & kenelä kellä & millä & millä \\
\hline Ablativ & keneltä keltä & keneltä keltä & miltä & miltä \\
\hline Allativ & kenele $(t) \sim$ kelle $(t)$ & kenele $(t) \sim$ kelle $(t)$ & mille(t) & mille(t) \\
\hline
\end{tabular}


Vi ser at flertallsformene er identiske med entallsformene i nesten alle kasusene. Det er bare i nominativ at de to spørrepronomena har eigne flertallsformer: kukka kutka kekkä ketkä (flertall) versus kuka (entall), og mikkä mitkä (flertall) versus mikä (entall). Spørrepronomenet kuka har eigne flertallsformer også i partitiv: keitä (flertall) versus ketä (entall). Men entallsforma ketä kan også brukes i stedet for flertallsforma keitä.

Til hver spørrepronomenform fins det et tilsvarende nektende KVANTORPRONOMEN eller NEKTINGSPRONOMEN, som vi bruker når vi svarer nektende på et spørreordspørsmål (3-8).

3. Kuka assuu Alattiossa?

'Hvem bor i Alta?

4. Missä paikassa aikamasiini oon?

'Hvor er tidsmaskinen?

5. Ketä sie rakastat?

'Hvem elsker du?

6. Mitä sie pölkkäät?

'Hva er du redd for?

7. Kenheen sie luotat?

'Hvem stoler du på?

8. Miksi sie aijot raavhaana?

'Hva har du tenkt å bli når du blir voksen?
Ei kukhaan.

Ingen.'

Ei mishään.

Ingen steder.'

En kethään.

Ingen.'

En mithään.

Intenting.'

En kenheenkhään

Ingen.'

En miksikhään.

Ikke noe.'

Vi skal se nærmere på hvordan disse kvantorpronomena bøyes, i et eige avsnitt (se 7.6.3).

Videre har kvensk også et dualispronomen, kumpi ('hvem/hvilken av to'), som brukes når det er snakk om bare to individ eller enheter. Dette pronomenet har et fullstendig bøyingsmønster. Det bøyes på samme måte som komparativformer av adjektiv: (sg. nom. : sg. gen. : sg. part. : sg. ill. : sg. ess.) kumpi : kumma/n : kump(p)a/a : kump/haan : kumpa/na, (pl. nom. : pl. gen. : pl. part. : pl. ill. : pl. ess.) kumma/t : kumpp/ii/n kumm/i/tten : kumpp/i/i kump/i/a : kump/hiin : kump/i/na. Vi bruker det som sagt i spørsmål hvor valget står mellom to (9-11).

9. Kumpi halluu lähteet myötä, sie vain Maija?

'Hvem av dere vil være med, du eller Maja?' 
10. Kumman sie valittet, Mikon vain Pekan?

'Hvem velger du, Mikkel eller Peder?'

11. Kummat kengät oon mukavammat, punaiset vain siniset?

'Hvilke sko er bekvemmest, de røde eller de blåe?'

Kvensk har også spørreadverb og spørreadjektiv. Tabell 7.5 gir en oversikt over disse.

Her er noen eksempelsetninger med spørreadjektiv (12) og spørreadverb (13-15):

12. Minkälainen keli sielä oon ulkona?

'Hva slags føre er det der ute?'

13. Minne $(t)$ sie aijot siirttyyt?

'Hvor tenker du å flytte hen?'

14. Koska faari kuoli?

'Når døde far?'

15. Kunka vanhaa muori oon?

'Hvor gammal er mor?'

Tabell 7.5 Spørreadverb og -adjektiv

\begin{tabular}{|l|l|l|l|l|l|}
\hline Pronomen & Sted & Tid & Måte & Årsak & Adjektiv \\
\hline ku-/ko- & & $\begin{array}{l}\text { koska } \\
\text { ('når') }\end{array}$ & $\begin{array}{l}\text { kunka kuinka } \\
\text { ('hvordan') }\end{array}$ & & $\begin{array}{l}\text { kummo(i)nen } \\
\text { kumma(i)nen ('hva } \\
\text { slags') }\end{array}$ \\
\hline mi- & $\begin{array}{l}\text { missä } \\
\text { mistä } \\
\text { mihin(kä) } \\
\text { minne(t) }\end{array}$ & & $\begin{array}{l}\text { millälaila } \\
\text { minkälaihiin } \\
\text { miten(kä) ('på } \\
\text { hvilken måte') }\end{array}$ & $\begin{array}{l}\text { miksi } \\
\text { ('hvorfor') }\end{array}$ & $\begin{array}{l}\text { minkälainen } \\
\text { mimmo(i)nen } \\
\text { ('hva slags') }\end{array}$ \\
\hline
\end{tabular}

\subsection{Relativpronomen}

Relativpronomen brukes til å innleie relativsetninger. Ei relativsetning er alltid ei leddsetning, og den står som modifikator til en del eller frase i den tilhørende oversetninga. Ei relativsetning utgjør altså ikke noen sjølstendig frase, men er del av en annen frase. Den delen av 
oversetninga som relativsetninga bestemmer nærmere, er KORRELATET til relativsetninga. I eksempelsetningene i (1) og (2) nedafor er korrelatet kursivert.

1. Oletko sie kuulu [siitä Vesisaaren papista, joka oon kirjoittannu nämät artikkelit]?

'Har du hørt om den presten fra Vadsø som har skrevet disse artiklene?'

2. Mie tieđän [kaikki, mitä mie tarvittenki tiettäät].

'Jeg veit alt (som) jeg trenger å vite.'

Stundom er det heile oversetninga som utgjør korrelatet til relativpronomenet $(3)$ :

3. Liisa lähti eilen Ruotthiin, minkä sie sikkaristi jo tieđätki.

'Lisa dro til Sverige i går, som du sikkert allerede veit.

Relativpronomenet har samme bøyingsform som det nomenet ville ha hatt som relativpronomenet erstatter. Jamfør (a) med (b) i setningspara (4) $\operatorname{og}(5)$.

4. a. Tuvassa ođotti Pekka, jota [sg. part.] vaimot olthiin lähtenheet noutamhaan.

'I stua venta Peder, som konene hadde gått for å hente.'

b. Tuvassa ođotti Pekka. Vaimot olthiin lähtenheet hakemhaan Pekkaa [sg. part.].

'Peder venta i stua. Konene hadde gått for å hente Peder.'

5. a. Het nähthiin digikartan, missä [sg. iness.] oli koko Raisinvankka.

'De så det digitale kartet, hvor heile Reisadalen vistes.'

b. Het nähthiin digikartan. Digikartassa [sg. iness.] oli koko Raisinvankka.

'De så det digitale kartet. På det digitale kartet vistes heile Reisadalen.'

Kvensk har tre relativpronomen: joka, kuka og mikä. Bøyinga av disse framgår av tabell 7.6. Relativpronomena kuka og mikä bøyes på samme måte som de tilsvarende spørrepronomena kuka og mikä (se 7.3 ovafor). Relativpronomenet joka har fullstendige bøyingsmønster både i entall og flertall, som framstilt i tabellen. 
Tabell 7.6 Bøying av relativpronomen

\begin{tabular}{|c|c|c|c|c|}
\hline \multirow[t]{2}{*}{ Kasus } & \multicolumn{2}{|c|}{ joka } & \multirow{2}{*}{$\frac{\text { kuka }}{\text { Entall/flertall }}$} & \multirow{2}{*}{$\frac{\text { mikä }}{\text { Entall/flertall }}$} \\
\hline & Entall & Flertall & & \\
\hline Nominativ & joka & jokka jotka & kuka / kukka kutka & mikä / mikkä mitkä \\
\hline Genitiv & jonka & joitten & kenen kenenkä & minkä \\
\hline Partitiv & jota & joita & ketä & mitä \\
\hline Essiv & jona & joina & kenenä & minä \\
\hline Translativ & joksi & joiksi & keneksi & miksi \\
\hline Inessiv & jossa & joissa & kenessä & missä \\
\hline Elativ & josta & joista & kenestä & mistä \\
\hline Illativ & johon johonka & joihin & kenheen & mihin mihinkä \\
\hline Adessiv & jolla & joila & kenelä kellä & millä \\
\hline Ablativ & jolta & joilta & keneltä keltä & miltä \\
\hline Allativ & jolle(t) & joile(t) & kenele(t) kelle(t) & mille(t) \\
\hline
\end{tabular}

Oversatt til norsk svarer de tre relativpronomena til subjunksjonen som, et spørrepronomen eller determinativet hvilken, avhengig av bruken.

Relativpronomenet kuka brukes bare om mennesker. Det er sjelden brukt, og i stedet kan vi alltid bruke relativpronomenet joka. Ellers fins det ikke noen klare regler i kvensk for når vi skal bruke joka, og når mikä. Men vi kan gi noen retningslinjer for bruken av dem:

- Når korrelatet er et nomen som betegner et menneske, så bruker vi joka eller kuka $(6,7)$ :

6. Oonko se [tuo vanhaa mies, joka/kuka makkaa tuossa sängyssä]?

'Er det den der gamle mannen som ligger i den senga der?'

7. [Ylisaamelaiset, joila/kellä oli kesäsijat Naavuonossa,] olthiin villissä uskossa. 'Reindriftssamene som hadde sine sommerboplasser i Kvænangen, var falt i vantru.'

Et unntak fra denne regelen er at vi alltid bruker relativpronomenet mikä når korrelatet har en modifikator i superlativ (8):

8. Sivva oli [lujjiin mies, mikä koskhaan oon eläny Raisissa.]

'Sivva var den sterkeste mannen som noen gang har levd i Nordreisa. 
- Når korrelatet er et nomen som betegner et dyr, en ting, et sted eller noe anna livlaust, så kan en velge sjøl om en vil bruke joka eller mikä $(9-11)$ :

9. Het kirjoitethiin alle [semmoisen dokumentin, jossa/missä het luvathiin olla alamaiset kuninkhaale].

'De skreiv under på et dokument der de lovte å undergi seg kongen.'

10. Naakima ensistä [yhđen klasin alle, josta/mistä kajastaa vähän näkköö].

'Vi smyger oss først under et vindu hvorfra det skinner et svakt lys.'

11. Hän kirjoittaa ylös [niitä muisteluksii, joita/mitä ihmiset nyt muistelhaan]. 'Han/Hun skriver ned de fortellingene som folk forteller nå for tida.'

- Når korrelatet er et pronomen eller pro-ord som refererer til en ting, et sted eller noe anna livlaust, så brukes alltid mikä (12-15).

12. Tekkeekö ihminen vain [sitä, mitä histooria tahtoo häneltä]?

'Gjør mennesket bare det historia vil det skal gjøre?'

13. Mutta [tääläki, missä aina oon kylmä,] oon hyvä elläät.

'Men også her, hvor det alltid er kaldt, er det godt å leve.'

14. Se asui [tässä, missä Jounin Jouni nyt assuu].

'Han/Hun bodde der hvor Johan sin Johan bor nå.'

15. Matti vastas taas [sen saman, mitä hän oli vastanut muileki].

'Mats svarte igjen det samme som han hadde svart til de andre også.'

- Når korrelatet består av heile oversetninga, bruker vi relativpronomenet mikä (16):

16. Huomena tullee sađet, mikä kyllä pillaa meiđän reisun.

'Det blir regn i morgen, noe som ødelegger reisa vår.'

Relativsetninger kan også stå foran korrelatet, og noen ganger kan korrelatet mangle heilt. I slike tilfeller bruker man pronomenet $k u k a$ når man refererer til en person (17), ellers bruker man pronomenet mikä (18):

17. [Kuka jääpi tähän, se] jääkhöön, [kuka mennee kävelemhään metthään, se] menkhöön sinne.

'De som bli her, blir her, og de som skal på tur i skogen, går dit.' 
18. (Arvaus:) [Mitä hän löyttää, sen] ottaa hän ja tappaa; mutta [mitä hän ei löyđä], ottaa hän myötä. (Vastaus: "Täitä.")

'(Gåte:) Dem han finner, dem tar han og dreper, men dem han ikke finner, dem tar han med seg. (Svar:) Lus.'

\subsection{Refleksive og resiproke pronomen}

Refleksive og RESIPROKe PRonomen har det til felles at de danner NP-er som har korrelatet sitt i samme setning. Som regel er korrelatet subjekt i setninga.

\subsubsection{Refleksivt pronomen}

Det REFLEKSIVE PRONOMENET i kvensk består av itte etterfulgt av possessivsuffikset (se avsnitt $5.4 \mathrm{om}$ possessivsuffiks). Pronomenet refererer tilbake til subjektet i setninga, det vil si at det har samme person som subjektet, og personen er markert med possessivsuffikset.

Refleksive pronomen bøyes i kasus akkurat som andre nomen. Derimot mangler de tallbøying, det vil si at de bare har entallsformer. De ulike personog kasusformene er framstilt i tabell 7.7.

Det refleksive pronomenet danner en eigen NP som kan fungere som objekt $(1,2)$ eller adverbial $(3,4)$, men som aldri har samme funksjon som det leddet det refererer til, det vil si subjektsfunksjon.

1. $\mathrm{Mie}_{\mathrm{i}}$ en anna juksata itteeni $_{\mathrm{i}} \sim$ itteänni $_{\mathrm{i}} \sim$ ittiänni $_{\mathrm{i}}$.

'Jeg lar meg ikke bli lurt.'

2. Älk(k)ää $\operatorname{antak}(\mathrm{k})$ aa juksata itteen $\ddot{a}_{\mathrm{i}} \sim$ itteänn $\ddot{a}_{\mathrm{i}} \sim$ ittiänn $\ddot{a}_{\mathrm{i}}$. 'Ikke la folk lure dere sjøl.'

3. Älä osta $_{\text {ittelesti }}$ piilii.

'Ikke kjøp bil til deg sjøl.'

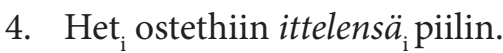

'De kjøpte seg (en) bil.'

Refleksive pronomen opptrer særlig i Porsanger-varieteten, og da som genitivsmodifikator $(5,6)$, som subjekt i partisippkonstruksjon $(7,8)$ og i adposisjonsfraser der de refererer til subjektet i setninga $(9,10)$ : 
5. Hän $n_{\mathrm{i}}$ antoi Stiinale [ittens $\ddot{a}_{\mathrm{i}}$ kuvan]. 'Han/Hun ga bildet sitt til Stina.'

6. Met $_{\mathrm{i}}$ annoima niile [ittemä ${ }_{\mathrm{i}}$ kuvan].

'Vi ga bildet vårt til dem.'

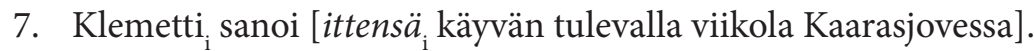
'Klemet sa at han skulle dra til Karasjok til uka'.

8. Pojat ${ }_{\mathrm{i}}$ luulthiin [ittens $\ddot{a}_{\mathrm{i}}$ nähnheen hukan].

'Guttene trudde de hadde sett ulv'.

9. $\mathrm{Mie}_{\mathrm{i}}$ en nähny [itteni $i_{\mathrm{i}}$ eđessä] hukkaa.

'Jeg så ikke noen ulv foran meg.'

10. Etkö sie ${ }_{\mathrm{i}}$ nähny [ittesti $i_{\mathrm{i}}$ eđessä] hukkaa?

'Så du ikke ulven / noen ulv foran deg?'

I de andre varietetene brukes ikke refleksivt pronomen på denne måten. I stedet skriver vi (11-13):

11. Hän antoi Stiinale [oman $_{\mathrm{i}}$ kuvan]. (Jamfør (5) ovafor.)

12. Pojat luulthiin, [ette het $_{\mathrm{i}}$ olthiin nähnheet hukan]. (Jamfør (8) ovafor.)

13. $\mathrm{Mie}_{\mathrm{i}}$ en nähny hukkaa [minun $\mathrm{i}$ e(đ)essä]. (Jamfør (9) ovafor.)

Pronomenet itte ligger også til grunn for adverbet itteksensä ('seg sjøl'), som også alltid opptrer med possessivsuffiks, og som står i samme person som subjektet (14-16).

14. $\mathrm{Mie}_{\mathrm{i}}$ istuin lukemassa ittekseni. 'Jeg sitter og leser for meg sjøl.'

15. Sie $_{\mathrm{i}}$ se vain aina puhut itteksest $i_{\mathrm{i}}$. 'Du prater nå bare alltid for deg sjøl.'

16. Hukka kulki itteksens $\ddot{a}_{\mathrm{i}}$ mettässä. 'Ulven gikk for seg sjøl i skogen.

Ordet itte brukes også i andre funksjoner, men da ikke som refleksivt pronomen (se avsnitt 7.6.2 og 7.7 nedafor). 
Tabell 7.7 Bøying av refleksivt pronomen

\begin{tabular}{|l|l|l|l|l|l|}
\hline Kasus & 1. sg. & 2. sg. & 1. pl. & 2. pl. & 3. sg./3. pl. \\
\hline Nominativ & itte/ni & itte/sti & itte/mä & itte/nä & itte/nsä \\
\hline Genitiv & itte/ni & itte/sti & itte/mä & itte/nä & itte/nsä \\
\hline Partitiv & $\begin{array}{l}\text { itte/e/ni } \\
\text { itte/ä/nni } \\
\text { itti/ä/nni }\end{array}$ & $\begin{array}{l}\text { itte/e/sti } \\
\text { itte/ä/sti } \\
\text { itti/ä/sti }\end{array}$ & $\begin{array}{l}\text { itte/e/mä } \\
\text { itte/ä/mmä } \\
\text { itti/ä/mmä }\end{array}$ & $\begin{array}{l}\text { itte/e/nä } \\
\text { itte/ä/nnä }\end{array}$ & $\begin{array}{l}\text { itte/e/nsä/nnä } \\
\text { itte/ä/nsä } \\
\text { itti/ä/nsä }\end{array}$ \\
\hline Essiv & itte/nä/nni & itte/nä/sti & itte/nä/mmä & itte/nä/nnä & itte/nä/nsä \\
\hline Translativ & itte/kse/nni & itte/kse/sti & itte/kse/mmä & itte/kse/nnä & itte/kse/nsä \\
\hline Inessiv & itte/ssä/nni & itte/ssä/sti & itte/ssä/mmä & itte/ssä/nnä & itte/ssä/nsä \\
\hline Elativ & itte/stä/nni & itte/stä/sti & itte/stä/mmä & itte/stä/nnä & itte/stä/nsä \\
\hline Illativ & itt/hee/ni & itt/hee/sti & itt/hee/mä & itt/hee/nä & itt/hee/nsä \\
\hline Adessiv & itte/lä/nni & itte/lä/sti & itte/lä/mmä & itte/lä/nnä & itte/lä/nsä \\
\hline Ablativ & itte/ltä/nni & itte/ltä/sti & itte/ltä/mmä & itte/Itä/nnä & itte/ltä/nsä \\
\hline Allativ & itte/le/nni & itte/le/sti & itte/le/mmä & itte/le/nnä & itte/le/nsä \\
\hline
\end{tabular}

\subsubsection{Resiproke pronomen}

RESIPROKE PRONOMEN danner en eigen NP som peker til ei kollektiv gruppe som utgjør subjektet i setninga. Gruppa må bestå av minst to individ (1), men det kan være hvor mange som helst $(2,3)$.

Kvensk har to måter å uttrykke resiprositet eller gjensidighet på. Den vanligste måten er å bruke pronomenparet toinen - toinen ('hverandre'), hvor det første toinen alltid står i entall nominativ og det andre toinen bøyes i entallskasus. Den andre måten går ut på å bruke toinen som enkeltpronomen, men i flertall. Denne toiset-varianten har vanlig kasusbøying etter mønster av (i)nennomen. For eksempel:

1. Pekka ja Kreeta rakastuthiin toinen toisheen $\sim$ toishiinsa.

'Peder og Greta blei forelska i hverandre.'

2. Pekka, Kaisa, Matti ja Kreeta muistelhaan toinen toisele $(t) \sim$ toisilensa omista/ittensä reisuista.

'Peder, Kaisa, Mats og Greta forteller hverandre om sine reiser'.

3. Suomalaiset ja kainulaiset ymmärethään toinen toista toisiansa.

'Finner og kvener forstår hverandre.' 
Det resiproke pronomenet toinen har ikke gitt opphav til proadverb eller proadjektiv. Men ordet toinen har også andre funksjoner, og i disse funksjonene er det laga proadverb og -adjektiv basert på toinen. (Se avsnitt 7.7 og 9.3.2.)

\subsection{Kvantorpronomen}

Nesten alle KVANTORPRONOMEN uttrykker ei eller anna form for mengde. I denne grammatikken regner vi som kvantorpronomen alle pronomen som ikke er personlige pronomen, demonstrative pronomen, spørrepronomen, relativpronomen eller refleksive eller resiproke pronomen.

Vi deler kvantorpronomen inn i flere undergrupper, som vist i tabell 7.8.

Tabell 7.8 Typer av kvantorpronomen

\begin{tabular}{|l|l|l|}
\hline Type & Dualis & Entall eller flertall \\
\hline Indefinitt & jompikumpi & joku, muutampi, yksi \\
\hline Universelt & kumpiki, molemat & $\begin{array}{l}\text { jokhainen, kaikki, } \\
\text { itte kukin itte kukanen }\end{array}$ \\
\hline Nektingspronomen & kumpikhaan & yksikhään, kukhaan, mikhään \\
\hline Mengdepronomen & $\begin{array}{l}\text { joku, muutampi, moni, harva, } \\
\text { usheempi useampi usiampi }\end{array}$ \\
\hline $\begin{array}{l}\text { mikä tahansa ('hvilken som } \\
\text { helst')-konstruksjoner }\end{array}$ & $\begin{array}{l}\text { kumpi tahansa } \\
\text { kumpi vain }\end{array}$ & mikä vain
\end{tabular}

\subsubsection{Indefinitte pronomen}

INDEFINITTE PRONOMEN i kvensk er joku ('noen (få)'; en eller annen'), jompikumpi ('en av to'; noen'), muutampi ('en; noen') og yksi ('en'). De kan deles inn i to grupper:

- Pronomena i den første gruppa viser til en referent som vi ikke veit hvem eller hva er. I denne funksjonen bruker vi pronomena joku og jompikumpi. Når det er spørsmål om flere enn to, så bruker vi joku (1-6). Når valget står mellom bare to, så bruker vil dualispronomenet jompikumpi (7-9).

1. Tulleeko sieltä vielä joku?

'Kommer det enda noen der?'

2. Sitte tässä oli [joku teknilinen probleemi].

'Så var det et eller anna teknisk problem her'. 
3. Met olema [jonku vaaran laiđassa].

'Vi er i ei eller anna fjellside.'

4. Eikö sitä olis vaikka trengin paikkaa jossaki eli [jotaki muuta työtä]?

'Fins det ikke engang en drengetjeneste et eller anna sted eller noe anna arbeid?'

5. [Joilaki ihmisillä] oon paljon työtä.

'Noen folk har masse arbeid.'

6. [Joitaki tiettoi] ihmiset saathiin.

'Folk fikk vite noe i hvert fall.'

7. Jompikumpi jääpi kothiin, sie eli mie.

'En av oss blir heime, du eller jeg.'

8. Sie häävyt myyä niistä jommankumman.

'Du må selge en av dem.'

9. Jomppaakumppaa ihminen rakastaa, Jumalaa eli mammonaa.

'Mennesket elsker en av delene, Gud eller mammon.'

Pronomenet jompikumpi er litt spesielt i og med at det egentlig er satt sammen av to pronomen, jompi og kumpi, og begge delene bøyes. Bøyingsformene til joku og jompikumpi er lista opp i tabell 7.9.

Tabell 7.9 Bøying av pronomena joku og jompikumpi

\begin{tabular}{|l|l|l|l|l}
\hline Kasus & Entall & Flertall & Entall & Flertall \\
\hline Nominativ & joku & jokku jotku & jompikumpi & jommatkummat \\
\hline Genitiv & jonku & joittenki & jommankumman & $\begin{array}{l}\text { jomppiinkumppiin } \\
\text { jommittenkummitten }\end{array}$ \\
\hline Partitiv & jotaki & joitaki & jomp(p)aakump(p)aa & $\begin{array}{l}\text { jomppiikumppii } \\
\text { jompiakumpia }\end{array}$ \\
\hline Essiv & jonaki & joinaki & jompanakumpana & jompinakumpina \\
\hline Translativ & joksiki & joiksiki & jommaksikummaksi & jommiksikummiksi \\
\hline Inessiv & jossaki & joissaki & jommassakummassa & jommissakummissa \\
\hline Elativ & jostaki & joistaki & jommastakummasta & jommistakummista \\
\hline Illativ & johonki & joihinki & jomphaankumphaan & jomphiinkumphiin \\
\hline Adessiv & jollaki & joileki & jommalakummala & jommilakummila \\
\hline Ablativ & joltaki & joiltaki & jommaltakummalta & jommiltakummilta \\
\hline Allativ & jolleki & joilleki & jommale(t) & jommile(t)kummile(t) \\
\hline
\end{tabular}


Flertallsformene av pronomenet jompikumpi er nesten ikke i bruk. De brukes bare når pronomenet refererer til noe eller noen som opptrer i par (10, 11):

10. Mie kyllä havaittin, ette [jommissakummissa niistä saapphaista] oli reikä. 'Jeg har nok oppdaga at det var et hol i en/et av disse støvlene/støvelpara.'

11. Kyllä sie hääđyt ottaat [jommatkummat niistä prilliistä].

'Du bør nok ta ei av disse brillene.'

- Den andre typen ubestemte kvantorpronomen viser rett nok til en referent som er kjent, men den blir ikke nevnt i konteksten. I denne funksjonen bruker vi pronomena muutampi ('en; noen') (12-16) og yksi ('en') (17-19). Særlig muutampi er brukt sammen med referenter i flertall $(14,15)$ :

12. [Muutampanna kaunhiina kesäpäivänä] Maija lähti järvele pyythöön.

'På en fin sommerdag dro Maja ut på sjøen for å fiske.'

13. Jussa olis halunu emänäksi [muutaman Alattion tyttären].

'Johan skulle ha ønska seg ei jente fra Alta til kone.'

14. Muutamat tykäthiin oikhein hyvin kalasta, muutamat taas olthiin kylläntynheet siihen.

'Noen av dem er veldig glad i fisk, andre igjen var blitt lei av det.'

15. Lensmanilla oli monta miestä myötä, ja nämät olthiin juuri aresteeraamassa [muutamppii ylisaamelaissii eli lapin ihmissii].

'Lensmannen hadde en del menn med seg, og de holdt nettopp på å arrestere noen reindriftssamer.'

16. Hän urrutteli [muutamppaa tuttuu lauluu], minkä muori oli hänele opettannu.

'Han/Hun nynna på en kjent sang som mor hadde lært han/henne.'

17. Siljola seissoo paljon ihmissii. [Yksi vaimo] heiluttaa aviissii ja muut puhelhaan ympärillä.

'Det står mye folk på gårdsplassen. Ei kvinne vifter med ei avis, og de andre står rundt henne og prater'

18. Ko met tulema kartanon tykö, naakima ensistä [yhđen klasin alle], mistä kajastaa vähäsen näkköö.

'Når vi kommer til gårdsplassen, smyger vi oss først under et vindu hvorfra det skinner et svakt lys.' 
19. Annan Kaisa painaa [yhtä knappii], ja samassa heiđän eđessä seissoo vaimo.

'Anna si Kaisa trykker på en knapp, og straks dukker det opp ei kvinne foran dem.'

Pronomenet $y k s i$ kan også referere til flertallsreferent (20, 21), men det er heller uvanlig:

20. Siljola seisothiin [yhdet studentit].

'Det satt noen studenter på gårdsplassen.'

21. Met naakima raitona [ $y k s i i n$ klassiin alta], mikkä olthiin joksiki korkkeela maasta.

'På rekke og rad sneik vi oss forbi under noen vinduer som var ganske høgt over bakken.'

Pronomenet $y k s i$ bøyes på samme måte som grunntallet $y k s i$ (se avsnitt 8.1). Pronomenet muutampi bøyes stort sett som komparativformer, men er litt uregelmessig. Bøyingsformene er framstilt i tabell 7.10.

Tabell 7.10 Bøying av pronomenet muutampi

\begin{tabular}{l|l|l}
\hline Kasus & Entall & Flertall \\
\hline Nominativ & muutampi & muutamat \\
\hline Genitiv & muutaman & muutami(i)tten \\
\hline Partitiv & muutamppaa muutamaa & muutamppii(ta) muutamia \\
\hline Essiv & muutampanna muutamanna & muutampinna muutaminna \\
\hline Translativ & muutamaksi & muutamiksi \\
\hline Inessiv & muutamassa & muutamissa \\
\hline Elativ & muutamasta & muutamista \\
\hline Illativ & muutamphaan muutamhaan & muutamphiin muutamhiin \\
\hline Adessiv & muutamalla & muutamilla \\
\hline Ablativ & muutamalta & muutamilta \\
\hline Allativ & muutamalle(t) & muutamille(t) \\
\hline
\end{tabular}

I tillegg til å være ubestemt kvantorpronomen brukes muutampi også som mengdepronomen (se avsnitt 7.6.4), og det er ikke alltid klart hvilken av de to bruksområda det dreier seg om. 


\subsubsection{Universelle pronomen}

UNIVERSELLE KVANTORPRONOMEN refererer til heilheta av enten ei gruppe eller ei enhet, eller til hver enkelt del av ei gruppe. Kvensk har følgende universelle pronomen: kaikki ('alle'), koko ('heil'), joka ('hver'), jokhainen ('enhver'), joka ainua ainoa ('hver eneste'), itte kuki itte kukanen ('hver og en'), miki ('hver') og dualispronomena kumpiki ('begge') og molemat ('begge to'). Av disse refererer kaikki, koko og molemat til heilheta av ei gruppe, en ting eller ei skapning. De øvrige refererer til hver enkelt del i ei gruppe.

- Pronomenet kaikki ('alle') bøyes som tostava e-stammer (nomentype 1.1; se avsnitt 5.1.1.1). Setningene i (1-6) er eksempler på bruk av kaikki. Som vi ser av eksempel (1), så brukes nominativ entall av kaikki også når det står som premodifikator til en kjerne i nominativ flertall:

1. [Kaikki nämät miehet] olthiin tulheet tervheinä takaisin.

'Alle disse mennene var kommet tilbake i god behold.'

2. Nyt hän näki [kaiken sen], mitä hän oli ajatellu päivälä.

'Nå så han alt det som han hadde tenkt på (tidligere) på dagen.'

3. Piian se oon ihminen itte, joka oon syypää kaikkheen?

'Kanskje det er mennesket sjøl som er skyldig i alt?'

4. Mie olen sopinu kaikesta Annan Kaisan kans.

'Jeg har avtalt alt med Anna si Kaisa.'

5. Pekka oli vanhiin [kaikista Raisin assuujista].

'Peder var eldst av alle innbyggerne i Nordreisa.'

6. Meilä oon kaikila sama kieli.

'Vi har alle samme språk.'

Det som gjør kaikki litt spesielt, er at vi i stedet for nominativsforma også kan bruke den stivna forma kaikin i subjektsfunksjon (7), eller når korrelatet er subjekt (8):

7. Varhemin puhuthiin kaikin kainuu täälä.

'Før i tida snakka alle kvensk her'. 
8. Met lähđimä kaikin Spaanihaan feeriälle.

'Vi dro alle på ferie til Spania.'

- Pronomenet koko ('heil') er ubøyelig. Det brukes bare som premodifikator i nomenfraser, aldri som sjølstendig frase (9-11):

9. [Koko miestokka] siirtyi lanton rannale. 'Heile mannegjengen flytta seg til tjernkanten.'

10. Met emmä halluu istuut täälä Universiteetin siljola [koko päivää]! 'Vi vil ikke sitte her på universitetsplassen heile dagen.'

11. Sitte mie unheetin [koko assiin]. 'Og så glømte jeg heile saka'

- Dualispronomenet molemat ('begge to') står alltid i flertall og viser til to referenter samtidig (12-14):

12. Kyllä se oon paras, ette tet tuletta molemat. 'Det er nok best at dere kommer begge to.'

13. Sielä oli minun muori ja faari ja [molemat sisaret] ja veli. 'Der var mora mi og faren min og begge søstrene og broren.'

14. Alattiossa oli iso petäjämettä [Alattionjoen molemilla puolila]. 'Det var en stor furuskog i Alta, på begge sidene av Altaelva.'

Tabell 7.11 viser de ulike kasusformene til molemat.

Tabell 7.11 Bøying av pronomenet molemat

\begin{tabular}{l|l}
\hline Kasus & Flertall \\
\hline Nominativ & molemat \\
\hline Genitiv & molemi(i)tten \\
\hline Partitiv & molemppii(ta) molempia \\
\hline Essiv & molempinna \\
\hline Translativ & molemiksi \\
\hline Inessiv & molemissa \\
\hline Elativ & molemista \\
\hline Illativ & molemphiin \\
\hline Adessiv & molemilla \\
\hline Ablativ & molemilta \\
\hline Allativ & molemille(t) \\
\hline
\end{tabular}


Resten av de universelle kvantorpronomena kan vi kalle for DISTRIBUTIVE KVANTORPRONOMEN ettersom de viser til hver enkelt del av referenten for seg. Disse pronomena og referanseorda deres står alltid i entall, og de kan ikke brukes om stofford eller abstrakte begrep. Det dreier seg om følgende pronomen: jokhainen joka(i)nen ('hver'), joka ('enhver'), joka ainua ainoa ('hver eneste'), itte kuki ('hver og en') og kumpiki ('begge').

- Pronomenet jokhainen joka(i)nen ('enhver') bøyes som andre (i)nennomen (nomentype 2.2) $(15,16)$ :

15. [Jokhainen heistä] toivoi, ette sais nähđä omhaiset ja kotipaikan.

'Hver av dem håpa at han/hun skulle få se igjen sine nærmeste og heimplassen sin'.

16. Kohta jokhaisella oli lehmä, lamphaita, jollaki oli kannoiki ja sika.

'Nesten alle hadde ku, sau, og noen hadde også høns og gris.'

- Som premodifikator er det vanligere å bruke det ubøyelige pronomenet joka ('hver') (17-19):

17. Ei olekhaan [joka pojala] ommaa rukkoushuonetta siljola!

'Enhver gutt har jo ikke sitt eige bedehus på gårdsplassen!'

18. Se kävi kohta [joka kesä] meilä niittämässä.

'Han/Hun var med på slåtten hos oss hver sommer.'

19. Se näyttää tukkiivan ittensä vähän [joka paikkhaan].

'Han/Hun ser ut til å trenge seg inn på alle steder'.

- Det sammensatte pronomenet joka ainua ainoa ('hver eneste') $(20,21)$ betyr nesten det samme som jokhainen joka(i)nen og joka. Det er bare siste delen, ordet ainua ainoa, som bøyes, og det er også den delen som bidrar til den forsterka betydninga:

20. Toiset kyllä senthään kuulthiin [joka ainuan sanan].

'De andre hørte nok likevel hvert eneste ord'.

21. Sielähän se oon sitä tyskälaista täynä [joka ainuassa paikassa] ympäri.

'Der er det jo fullt av tyskere på hvert eneste sted rundt omkring.'

- Det sammensatte pronomenet itte kuki ('hver og en') har enda mer utprega distributiv betydning. Det brukes når det er tale om hver del for seg (22-24). 
I samme funksjon kan vi også bruke det sammensatte pronomenet itte kukanen, men det brukes stort sett bare i nominativ entall.

22. Sen saattaa [itte kuki itte kukanen] ajatella, ette kunka se oon.

'En og hver kan tenke seg hvordan det egentlig er.'

23. Se oon ittensä tapa [ittessä kussaki talossa].

'I hvert hus fins det en eigen vane.'

24. Mikkel antoi yhen äpylin [ittele kulleki lapsele].

'Mikkel ga hvert og et av barna et eple.'

Begge delene av pronomenet itte kuki bøyes. I andre delen, ordet kuki, er det den første delen, $k u$-, som bøyes, mens $k i$ blir lagt til ubøyd. Tabell 7.12 viser heile bøyingsmønsteret for itte kuki.

- På samme måte som kukin bøyes også pronomenet miki ('hver'). Også det refererer til ting hver for seg. For eksempel $(25,26)$ :

25. Mettän rannassa heiđän oli pakko mennä yksi mies mihinki suunthaan.

'Ved skogkanten var de nødt til å gå én mann i hver si retning.'

26. Pimmeessä mettässä oli senthään turvalista seisoskella ja kuunnela, mitä mistäki päin kuuluis.

'I den mørke skogen var det likevel trygt å stå og lytte til det som hørtes fra alle kanter'

Tabell 7.12 Bøying av pronomenet itte kuki

\begin{tabular}{|l|l|}
\hline Kasus & Entall \\
\hline Nominativ & itte kuki \\
\hline Genitiv & itten kunki/kenenki \\
\hline Partitiv & $\begin{array}{l}\text { ittee kutaki/ketäki itteä kutaki/ketäki ittiä kutaki/ } \\
\text { ketäki }\end{array}$ \\
\hline Essiv & ittenä kunaki/kenäki \\
\hline Translativ & itteksi kuksiki/keksiki \\
\hline Inessiv & ittessä kussaki/kessäki \\
\hline Elativ & ittestä kustaki/kestäki \\
\hline Illativ & ittheen kuhunki/kehenki \\
\hline Adessiv & ittelä kullaki/kelläki \\
\hline Ablativ & itteltä kultaki/keltäki \\
\hline Allativ & ittele kulleki/kelleki \\
\hline
\end{tabular}


- Dualispronomenet kumpiki ('begge') betyr nesten det samme som molemat. Forskjellen er at mens molemat viser til to referenter i lag, så fokuserer kumpiki mer på at de hver for seg har eller gjør noe til felles (27-29):

27. Mies ja vaimo pittäävät kumpiki anttaat toinen toisele.

'Mann og kone bør begge gi hverandre.'

28. [Kummalaki puolela jokkee] oli korkkee vaaranrinnet suojana.

'Begge sidene av elva var beskytta av ei høg fjellside.'

29. Ihmiset vaihetelthiin tavaraa kummaleki avuksi.

'Folk bytta varer til hjelp for begge partene.'

Pronomenet kumpiki brukes også om parord, og da står det i flertall (30):

30. Nuot sakset pitäis kummatki teroittaat.

'De der saksene burde slipes begge to.'

Som vi ser, er kumpiki satt sammen av to deler, kumpi og ki. Den første delen bøyes som spørrepronomenet kumpi (se avsnitt 7.3), mens ki blir lagt til ubøyd. Heile bøyingsmønsteret framgår av tabell 7.13.

Tabell 7.13 Bøying av pronomenet kumpiki

\begin{tabular}{|l|l|l|}
\hline Kasus & Entall & Flertall \\
\hline Nominativ & kumpiki & kummatki \\
\hline Genitiv & kummanki $(p) a a k i$ & kumppiinki kummittenki \\
\hline Partitiv & kumpanaki & kumppiiki kumpiaki \\
\hline Essiv & kummaksiki & kumpinaki \\
\hline Translativ & kummassaki & kummiksiki \\
\hline Inessiv & kummastaki & kummissaki \\
\hline Elativ & kumphaanki & kummistaki \\
\hline Illativ & kummalaki & kumphiinki \\
\hline Adessiv & kummaltaki & kummilaki \\
\hline Ablativ & kummaleki & kummiltaki \\
\hline Allativ & & kummileki \\
\hline
\end{tabular}




\subsubsection{Nektingspronomen}

Som NeKTINGSPRONOMEN regner vi her pronomen som opptrer bare i nektende eller tvilende setninger. Det fins fire slike pronomen i kvensk: kukhaan ('ingen'), yksikhään ('(ikke) noe(n)'), mikhään ('(ikke) noe(n)') og dualispronomenet kumpikhaan ('ingen av de to'). Pronomenet kukhaan refererer vanligvis til personer $(1-3,8)$. Pronomena yksikhään og mikhään kan referere både til personer $(4,5,13,14)$ og andre skapninger eller ting $(6-12,15)$, avhengig av hva slags setning de opptrer i. For eksempel brukes pronomenet mikhään om personer bare når det fungerer som premodifikator i en substantivfrase (13). Pronomenet kumpikhaan $(14,15)$ refererer alltid til to individ eller enheter.

1. Kukhaan ei halunu heittäät oppimasta kainun kieltä. 'Ingen ville slutte med å lære kvensk.'

2. Ei niistä näyttäny löyttyyvän [kenenkhään merkkii]. 'Det så ikke ut til at det blant dem fantes (rein)merker som hørte til noen som helst.'

3. Mutta ei net silloin senthään kethään tappanheet.

'Men de tok da for all del ikke livet av noen.'

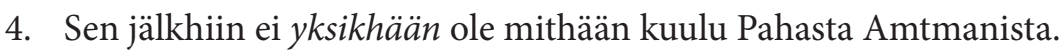

'Etter det har ingen hørt noe om den onde amtmannen.'

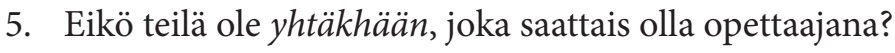

'Har dere ikke noen som kunne jobbe som lærer?'

6. Hän ei löytäny vastausta [yhtheenkhään näistä kysymyksistä].

'Han kom ikke på noe svar på noen av disse spørsmåla.'

7. Heiđän kieli ei ollu [mikhään kieli].

'Språket deres var ikke noe språk.'

8. Pekkaa ei piđätä mikhään eikä kukhaan.

'Det er ikke noe eller noen som stopper Peder.'

9. Tästä ei tule mithään.

'Det blir ikke noe av dette'.

10. Oonko mikhään ihanampi ko Tromssa kaunhiina kesäaamuna?

'Fins det noe nydeligere enn Tromsø på en vakker sommermorgen?' 
11. Ei Iisakki ajatellu tehđä tätä jotaki [milhään konnuuđella]. 'Isak tenkte ikke å gjøre dette som noen skurkestrek.'

12. Emmä met aikonheet mihinkhään.

'Vi tenkte oss ikke noen steder.'

13. Äiji ei ollu [mikhään viisas mies].

'Bestefar var ikke noen klok mann.'

14. Ei kumpikhaan vaimo vaikuttannu hänheen mithään.

'Ingen av de to konene hadde noen innvirkning på han.'

15. [Kumphaankhaan paikhaan] ei kuitenkhaan [yksikhään heistä] olis halunu.

'Ingen av dem skulle ha ønska seg til noen av de to plassene.'

Eksempla viser at nektingspronomena kumpikhaan og yksikhään har klart distributivt innhold. De bøyes på samme måte som henholdsvis spørrepronomenet kumpi og tallordet $y k s i$. Forskjellen er bare at nektingspronomena i tillegg får hekta på seg enklitikonet khAAn. Nektingspronomena kukhaan og mikhään bøyes som vist i tabell 7.14.

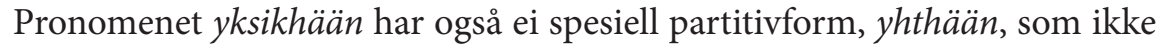
er brukt distributivt, men som forteller at noe(n) ikke fins eller har skjedd i det

Tabell 7.14 Bøying av pronomena kukhaan og mikhään

\begin{tabular}{|l|l|l|}
\hline Kasus & kukhaan & mikhään \\
\hline Nominativ & kenenkhään & minkhään \\
\hline Genitiv & kethään & mithään \\
\hline Partitiv & kenenäkhään & minhään \\
\hline Essiv & keneksikhään & miksikhään \\
\hline Translativ & kenessäkhään & mishään \\
\hline Inessiv & kenestäkhään & misthään \\
\hline Elativ & kenheenkhään & mihinkhään \\
\hline Illativ & keneläkhään kelhään & milhään \\
\hline Adessiv & keneltäkhään kelthään & milthään \\
\hline Ablativ & kenelekhään kelheen & millekhään
\end{tabular}


heile tatt. Det svarer til spørsmåla Kunka paljon? ('Hvor mye?') og Kunka monta? ('Hvor mange?') $(16,17)$ :

16. Mieki ammuin, mutta en tappanu [yhthään ihmistä].

'Også jeg skøyt, men drepte ikke noen mennesker.'

17. Meilä ei ole [yhthään vettä].

'Vi har ikke noe vatn.'

\subsubsection{Mengdepronomen}

Med mengdepronomen spesifiserer vi et ubestemt antall av noe eller noen. Det kan dreie seg om flere eller færre, men ikke bare om én eller alle. Disse pronomena har alle distributiv betydning i den forstand at vi tenker på hvert medlem som atskilt enhet. Mengdepronomen kan altså ikke brukes om stofford eller sammen med abstrakte ord, men bare om referenter som kan telles.

Kvensk har disse mengdepronomena: joku ('noen'), joku harva ('noen få), muutampi ('noen'), moni ('mange, mang en'; i Porsanger også 'noen stykker'), ussee usea usia ('flere'), usheempi useampi usiampi ('flere') samt paljo ('mye; mange') og vähä ('nokså få; lite'). Med pronomena joku, harva og joku harva uttrykker vi at det tross alt er noen få enheter av noe eller noen. Med muutampi, og i Porsanger med moni, forteller vi at det ikke er mange, men likevel flere enn bare noen få. Og så bruker vi moni (i de fleste varietetene), ussee og usheempi med sine varianter når det er snakk om ganske mange enheter. Pronomenet paljo viser til et relativt sett stort antall, og i motsatt ende har vi pronomenet vähä, som betegner et heller lite antall. Bruken av en del av disse mengdepronomena er illustrert i (1-2):

1. Muutamat oon kasvattanheet ohraaki, ei kyllä [monessa talossa] mutta juuri [jossaki harvassa talossa].

'Noen har også dyrka bygg, rett nok ikke på mange gårder, men i hvert fall på noen få:

2. Täälä oon kulkenu [usheita suomalaissii] ja jokku oon jäänheetki. Mutta [paljoita suomalaissii] ei kyllä täältäkhään löyđy.

'Det er flere finner som har ferdes her, og noen er også blitt værende. Men heller ikke her fins det mange av dem.' 
Ofte kan man velge fritt om man vil bruke entalls- eller flertallsformer av disse pronomena uten at det er noen nevneverdig forskjell mellom dem. Jamfør entallsformene i (a) med flertallsformene i (b) i eksempla (3-13):

3. a. Harva tiettää, kuka Perunka oli.

b. Harvat tieđethään, kuka Perunka oli.

'Få veit hvem Beronka var'.

4. a. Mie olen ollu Suomessa [jonku harvan kerran].

b. Mie olen ollu Suomessa [jokku harvat kerrat].

'Jeg har vært i Finland noen få ganger.'

5. a. [Jollaki harvala oli tyhä yksi kläppi].

b. [Joilaki harvoila] oli tyhä yksi kläppi.

'Noen få hadde bare én unge.'

6. a. Muutampi saattoi kohta huonosti ruijaa.

b. Muutamat saatethiin kohta huonosti ruijaa.

'Noen kunne ganske dårlig norsk.'

7. a. [Muutamassa talossa] oli sikaki.

b. [Muutamissa taloissa] oli sikaki.

'På noen gårder var det også gris.'

8. a. Ei hänen rinnale kyllä [moni poika] päässy.

b. Ei hänen rinnale kyllä [monet pojat] pääsheet.

'Det var nok ikke mange gutter som nådde opp til han.'

9. a. [Moni heistä] oli uskovainen lästadiolainen.

b. [Monet heistä] olthiin uskovaiset lästadiolaiset.

'Mange av dem var truende læstadianere.'

10. a. Mie olen käyny Ruottissa [monta kerttaa].

(I Porsanger kan dette bety 'Jeg har vært i Sverige noen ganger.; i de andre varietetene betyr det det samme som b-setninga nedafor.)

b. Mie olen käyny Ruottissa [monet kerrat]. 'Jeg har vært i Sverige mange ganger.'

11. a. Sitä tauttii oon ollu [usheelaki ihmisellä].

b. Se tauti oon ollu [usheilaki ihmisillä].

'Det er flere mennesker som har hatt denne sjukdommen'. 
12. a. [Useampi alattiolainen] saattaa topata verta.

b. [Useammat alattiolaiset] saattava topata verta.

'Flere altaværinger kan stoppe blod.'

13. a. Se olis soma saattaat [usheemppaa kieltä].

b. Se olis soma saattaat [usheemppii kielii].

'Det hadde vært artig å kunne flere språk.'

Men det er likevel ikke alltid slik at entall og flertall er utbyttbare på denne måten. Pronomena kan ha ulik betydning i entall (a) og flertall (b), som for eksempel i (14), der entallsforma (a) forteller at han/hun holdt på med å skrive kanskje flere romaner, men ikke sier noe om hvorvidt han/hun har skrevet dem ferdig, mens flertallsforma i (b) derimot indikerer at han/hun har fullført flere romaner. I eksempel (15) er jokku i (a) indefinitt kvantorpronomen, ikke mengdepronomen. I noen tilfeller er det bare den ene forma som er gangbar. I (16) er det entallsforma (a), og i (17) er det flertallsforma (b).

14. a. Hän kirjoitti [usheetaki rommaanii]. 'Han/Hun skreiv på flere romaner.'

b. Hän kirjoitti [usheitaki rommaaniita]. 'Han/Hun skreiv flere romaner.'

15. a. Niilä pruukas olla [joku lehmä]. 'De brukte å ha noen kyr.'

b. Niilä pruukas olla [jokku lehmät]. 'De brukte å ha ei eller anna ku.'

16. a. [Jonku sanan] Kreeta saattoi ruijaaki.

'Greta kunne noen ord også på norsk.'

b. ${ }^{*}[$ Jokku sanat] Kreeta saattoi ruijaaki.

17. a. ${ }^{\star P}$ Pykejässä oli [jotaki isompaa venettä].

b. Pykejässä oli [joitaki isompia venheitä].

'Det var noen større båter i Børselv.'

La oss se nærmere på de ulike mengdepronomena i tur og orden.

- Mengdepronomena joku ('noen') og muutampi ('noen') har samme bøying som de har som ubestemte kvantorpronomen (se avsnitt 7.6.1). Mengdepronomenet harva ('få) bøyes etter mønster av enstamma nomen med tostava 
vokalstamme på kort $a$ (nomentype 1.1), og mengdepronomenet moni ('mange; noen') bøyes som tostamma nomen med vokalstamme på kort $e$ (nomentype 1.2). Men moni brukes sjelden i flertall. I Varganger har det i tillegg den spesielle forma montaa, som brukes i nektende (18) og tvilende (19) setninger:

18. Mie kyllä en saata [montaa sannaa kiinaa].

'Jeg kan nok ikke mange ord på kinesisk.'

19. Saatatko sie [montaakhaan sannaa kiinaa]?

'Kan du mange ord på kinesisk, da?'

- Pronomenet ussee usea usia ('flere') skiller seg fra de andre pronomena ved at bøyingsstammen inneholder en $h$. Heile bøyingsmønsteret er vist i tabell 7.15.

Tabell 7.15 Bøying av pronomenet ussee usea usia

\begin{tabular}{|c|c|c|}
\hline Kasus & Entall & Flertall \\
\hline Nominativ & ussee usea usia & usheet $\sim$ useat $\sim$ usiat \\
\hline Genitiv & usheen usean usian & usheitten \\
\hline Partitiv & usheeta useaa usiaa & usheita \\
\hline Essiv & usheena useana usiana & usheina \\
\hline Translativ & usheeksi useaksi usiaksi & usheiksi \\
\hline Inessiv & usheessa useassa usiassa & usheissa \\
\hline Elativ & usheesta useasta usiasta & usheista \\
\hline Illativ & usheesseen usehaan usihaan & usheissiin \\
\hline Adessiv & usheela usealla usialla & usheila \\
\hline Ablativ & usheelta usealta usialta & usheilta \\
\hline Allativ & usheele(t) usealle(t) usialle(t) & usheile(t) \\
\hline
\end{tabular}

Pronomenet usheempi useampi usiampi ('flere') er formelt sett komparativforma av pronomenet ussee usea usia ('flere'), og det bøyes også som komparativ (se avsnitt 5.5.1). Men de to pronomena har så å si samme betydning. Begge har også superlativforma usheimat, som bare er i bruk i flertall, og som forteller at det er snakk om flere enn halvparten av gruppa som det blir referert til. Eksempler (20, 21):

20. [Usheimat ihmiset] haluthaan tulla onneliseksi.

'De fleste mennesker vil bli lykkelige.' 
21. Usheimilla oon jotaki probleemii lasten kans.

'De fleste har et eller anna problem med barna sine.'

- Pronomena paljo ('mye; mange') og vähä ('litt; få) står i flertall når de viser til flere referenter (22-24), og da er paljo synonymt med pronomenet moni ('mange') (se eksempel 24). Entallsformer bruker vi når det bare er én referent, eller når referenten er et abstrakt begrep (25-27):

22. [Näin paljoin kalloin] kans mie en tehe mithään. 'Med så mye fisk gjør jeg ingenting.'

23. [Nuoin vähilä tieđoila] ei elämästä pärjää.

'Man klarer seg ikke i livet med så lite kunnskap'

24. [Paljoile ihmisille] / [Monile ihmisille] onni oon elämän tärkkein assii.

'For mange mennesker er lykke det viktigste i livet.'

25. Ei siinä [paljokhaan puhuminen] auttanu.

'Det hjalp heller ikke å snakke mye om det.'

26. Köyhä anttaa vähästäki, rikas ei paljostakhaan.

'Den fattige gir av det lille han har, den rike ingenting, sjøl om han har mye.'

27. Hänelä ei ole [paljoo tiettoo elämästä].

'Han/Hun visste ikke mye om livet.'

Pronomena paljo og vähä bøyes som vanlige enstamma nomen med tostava vokalstamme (nomentype 1.1).

\subsubsection{Spørrepronomena kuka og mikä som kvantorpronomen}

Spørrepronomena kuka ('hvem') og mikä ('hva') finner vi også i ulike konstruksjoner som uttrykker at noe er allment sant $(1,2)$, at noe er likegyldig for noen $(3,4)$, eller at noe skjer uregelmessig og tilfeldig eller er hipp som happ (5-9). Det er konstruksjoner som kuka/mikä tahansa/hyvänsä ('hvem/hva som helst'), kuka/mikä vain ('hvem/hva som helst'), vaikka kuka/mikä ('hvem/hva det enn måtte være'), vähän mikäki/kukaki ('litt hvem/hva som helst'), kuka/mikä koskaki/kunkaki/missäki ('samme hvem/ hva og når/hvor') osv. 
1. [Kuka tahansa/hyvänsä/vain] saattaa oppiit kainun kieltä.

'Hvem som helst kan lære seg kvensk.'

2. [Missä/Mistä tahansa/hyvänsä/vain] saattaa tulla onneliseksi.

'Man kan bli lykkelig hvor / av hva som helst.'

3. Minun mielestä saapi tulla [kuka tahansa/hyvänsä/vain] halluu.

'For min del får de komme som måtte ønske det.'

4. Kyllä sie saat valita [kenen tahansa/hyvänsä/vain] halluut.

'Visst får du velge akkurat hvem du vil.'

5. Sieltä arkusta löytyi [vähän mitäki].

'I kista fantes det litt av hvert.'

6. Kainuu saattaa kyllä kirjoittaat [vähän milläki mallila].

'Kvensk kan skrives litt på hvilken måte som helst.'

7. Het lähđethiin [kuka kuhunki ja koskaki] ja saathiin sitte ruvaksi [mitä mistäki].

'De dro hulter til bulter og når som helst, og de spiste hva som helst hvor enn de fant det.'

8. Minun isä oli seppä ja teki puusta [vaikka mitä].

'Far min var nevenyttig og laga alt mulig av tre.'

9. Mie kyllä rahhaa kiskon [vaikka mistä].

'Penger får jeg nok hvor som helst ifra.'

Spørrepronomena i slike konstruksjoner bøyes på samme måte som i vanlige spørresetninger (se avsnitt 7.3).

\subsection{Pronomenliknende ord}

Det fins ei gruppe ord som kan sies å ha samme funksjon som pronomen, men som også kan klassifiseres som adjektiv. Det er følgende ord som brukes i jamføringskonstruksjoner: sama ('samme'), eri ('annen, ulik'), muu ('annen') og toinen ('annen'). Ordet eri er ubøyelig, mens de andre orda bøyes som andre nomen.

Ordet sama (1-3) uttrykker det motsatte eri, muu og toinen. Orda eri, muu og toinen kan ofte brukes om hverandre $(4,5)$, men ikke alltid (6-11). Ordet eri har også distributiv betydning (8), noe som de andre jamføringsorda mangler. 
1. Eikö se ole kohta [sama kieli] teilä ja heilä? 'Har ikke dere og de nesten samme språk?'

2. Liisassa oon paljon sammaa ko Kreetassaki. 'Lisa likner på mange måter på Greta.'

3. Pekka meni [samoila vaattheila] fästhiin ko kirkkhoonki. 'Peder gikk i de samme klærne både på fest og i kirka.'

4. Liisa oli lähtöisin [eri/muusta paikasta] ko Nilla. 'Lisa var fra et anna sted enn Nils.'

5. Ryssilä oon [eri/muu/toinen usko] ko meilä. 'Russerne har ei anna tru enn oss.'

6. Niin ko [monela muulaki], minula oon usko rakkhautheen. 'Som så mange andre så trur også jeg på kjærligheta.'

7. Het olthiin [eri mieltä] siitä kysymyksestä. 'De var uenige i denne saka.'

8. Mikkä niitten [eri maitten] nimet olthiin? 'Hva het de ulike landa?'

9. [Kaikele muule] net olthiin niin ko kokonhansa sokkeet. 'De var som blinde for alt anna.'

10. Mie en koskhaan rakasta muita ko sinnuu. 'Jeg kommer aldri til å elske noen andre enn deg.'

11. Jos ei tunne [toista ihmistä], se oon paras ettei puhukhaan hänestä mithään. 'Folk man ikke kjenner, bør man heller ikke snakke om.'

Ordet toinen bruker vi også i de to synonyme pronomenkonstruksjonene $y k s i$ - toinen (12) og toinen - toinen ('den ene - den andre') $(13,14)$ :

12. Yksi oli talossa trenkinä ja toinen isäntännä.

'Den ene var tjenestegutt/dreng i huset, og den andre husbond.'

13. [Toisela pojista] oli huonet [joven toisela puolela] ja [toisela pojista] [toisela puolela].

'Den ene gutten hadde huset sitt på den ene sida av elva, og den andre gutten hadde sitt på den andre sida av elva.' 
14. Toisila oon parempi usko tulleevaisuutheen ko toisila.

'For noen faller det lettere å tru på framtida enn for andre.'

Ordet itte ('sjøl') brukes, som vi har sett før, som refleksivpronomen og i ordsambandet itte kuki itte kukanen ('hver og en'). Men det kan også fungere som forsterkende, kontrasterende eller fokuserende ord. Ordet itte har bare entallsformer, og når det står til et subjekt, så er itte i nominativ entall og uten possessivsuffiks (1519). Men når itte viser til et anna ledd i setninga, så kongruerer det med korrelatet, og det har da også possessivsuffiks i samme person som korrelatet (20-23):

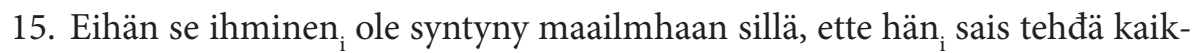
kee mitä hän itte $_{\mathrm{i}}$ halluis.

'Mennesket blei ikke født til denne jorda for at det skal gjøre alt som det sjøl behager.'

16. Mitä maailmala tapattui, siitä het ${ }_{\mathrm{i}}$ ei saanheet tiettoi. Itte $_{\mathrm{i}}$ het $_{\mathrm{i}}$ laitethiin siitä jonkulaisen kuvan.

'Det som skjedde i verden, det fikk de ikke noen opplysninger om. De laga sjøl et slags bilde av det.'

17. $\mathrm{Mie}_{\mathrm{i}}$ en ole ittekhään $n_{\mathrm{i}}$ vielä ko kaksikymmentä vuotta vanhaa.

'Jeg sjøl er heller ikke eldre enn tjue år.'

18. Met $_{i}$ häyđymä tehđä jotaki itte $_{i}$ !

'Vi må gjør noe sjøl.'

19. Isä ${ }_{\mathrm{i}}$ oon itte $_{\mathrm{i}}$ kutonu tuon tröijyn.

'Far har strikka den der trøya sjøl.'

20. Emmä met hevosta kyllä nähnheet juuri ittessäns $\ddot{a}_{\mathrm{i}}$ kirkossa $_{\mathrm{i}}$.

'Vi så nok ikke noen hest akkurat i sjølve kirka'.

21. Sinula itteläst $_{i}$ se paksu niska oon!

'Det er du sjøl som har tjukk nakke.'

22. Het tulthiin eniten siltäalalta, mitä siihen aikhaan käskethiin Kainunmaaksi,

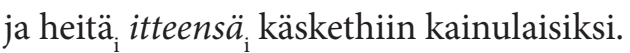

'De kom for det meste fra det området som på den tida kaltes for Kvenland, og de sjøl kaltes for kvener'

23. Niilä ${ }_{i}$ oon tietenki ittelänsä ${ }_{i}$ huonet Joensuussa.

'De har sjølsagt sitt eige hus i Elvebakken.' 



\section{8}

\section{Tallord}

Som i norsk fins det to typer TALLORD i kvensk, GRUNNTALL og ORDENSTALL. Med grunntall angir vi antall på noe, mens ordenstall forteller hvilken plass noe eller noen har i en rekkefølge.

Ordenstall er avleid av grunntall og hører egentlig heime i ordlagingslæra. Vi ser også at bøyingssuffiksa kommer etter avledningssuffiksa i ordenstall: (kolme 'tre' $\rightarrow$ ) (sg. nom. : sg. gen. : sg. part. : pl. part. : pl. gen.) kolma/s ('tredje') : kolma/ne/n, kolma/t/ta, kolma/nss/ii/ta kolma/ns/ila, kolma/nss/ii/tten kolma/ns/i/tten. Det er likevel naturlig å behandle ordenstalla her sammen med grunntalla.

\subsection{Grunntall}

De elementære GRUNNTAlla i kvensk er (1-10) yksi ('én'), kaksi ('to'), kolme ('tre'), nelje neljä ('fire'), viisi ('fem'), kuusi ('seks'), seittemen seittemän ('sju'), kahđeksen kaheksan ('åtte'), yhđeksen yheksän ('ni'), kymmenen ('ti'). Både grunntall og ordenstall har samme tall- og kasusbøying som andre nomen, men blant grunntalla skiller vi mellom ulike bøyingstyper. Bøyingsmønstra for grunntalla fra 1 til 10 er framstilt i tabell $8.1 \mathrm{og}$ tabell 8.2.

Grunntalla fra 11 til 19 dannes ved å kombinere de elementære grunntalla med ordet toista på denne måten: (11) yksitoista, (12) kaksitoista, (13) kolmetoista ... (19) yhđeksentoista yheksäntoista. Det er bare den første delen, altså det elementære grunntallet, som bøyes, mens siste delen, toista, er ubøyd. Vi får da for eksempel slik bøying: (iness. sg.) kah(đ)e/ssa/toista ('tolv'), kolme/ssa/toista ('tretten') . . yhđekse/ssä/toista yheksä/ssä/toista ('nitten').

Grunntalla 20, 30, 40 osv. dannes ved å kombinere de elementære grunntalla med ordet kymmentä på denne måten: (20) kaksikymmentä, 
(30) kolmekymmentä, (40) neljekymmentä neljäkymmentä . . . (90) yhđeksenkymmentä yheksänkymmentä. I disse talla er det begge delene som bøyes, for eksempel: (iness. sg.) kah(đ)e/ssa/kymmene/ssä ('tjue'), kolme/ssa/kymmene/ssä ('tretti') . . yhđekse/ssä/kymmene/ssä yheksä/ssäl kymmene/ssä ('nitti').

Når vi danner tall som 23, 35 eller 78 , så setter vi enerne etter tierne, på denne måten: (23) kaksikymmentä kolme, (35) kolmekymmentä viisi, (78) seittemenkymmentä kahđeksen seittemänkymmentä kaheksan. Også i slike tall bøyes begge elementa, for eksempel: (iness. sg.) kah(đ)e/ssa/kymmene/ssä kolme/ssa ('tjuetre'), kolme/ssa/kymmene/ssä vii(đ)e/ssä ('trettifem'), seittemel ssä/kymmene/ssä kahđekse/ssa seittemä/ssä/kymmene/ssä kaheksa/ssa ('syttiåtte').

100 heter sata på kvensk. Talla 200, 300,400 . . 900 dannes ved å kombinere de elementære grunntalla med sattaa, som er partitiv entall av sata. Vi får da: (200) kaksisattaa, (300) kolmesattaa, (400) nelje neljä sattaa, (900) yhđeksenyheksänsattaa. Også i disse hundretalla bøyes begge delene, for eksempel: (iness. sg.) kah(đ)e/ssa/sa(đ)a/ssa ('to hundre'), kolme/ssa sa(đ)a/ssa ('tre hundre'), nelje/ssä neljä/ssä sa(đ)a/ssa ('fire hundre'), yhđekse/ssä- yheksä/ssäl $s a(d) a / s s a$ ('ni hundre').

Bøyinga av tallet tusen (1 ooo) likner på bøyinga av ordenstall. Det har følgende stammer:

(sg. nom. : sg. gen. : sg. part. : pl. nom. : pl. gen. : pl. part.) tuhat tuhanen: tuhane/n: tuhat/ta: tuhane/t: tuhanss/ii/tten $\sim$ tuhans/i/tten : tuhanss/ii (ta) tuhans/i/a.

I vanlig tale blir grunntalla ofte forkorta, og når man teller, kan det høres slik ut: yks, kaks, kolme, nelje neljä, viis, kuus, seittemen $\sim$ seittemän, kahđeksen kaheksan, yhđeksen yheksän, kymmenen ykstoista, kakstoista osv.

Grunntall har også flertallsbøying. Flertallsformene dannes på samme måte som i andre nomen. Tabell 8.2 viser flertallsbøyinga i noen utvalgte kasus. 

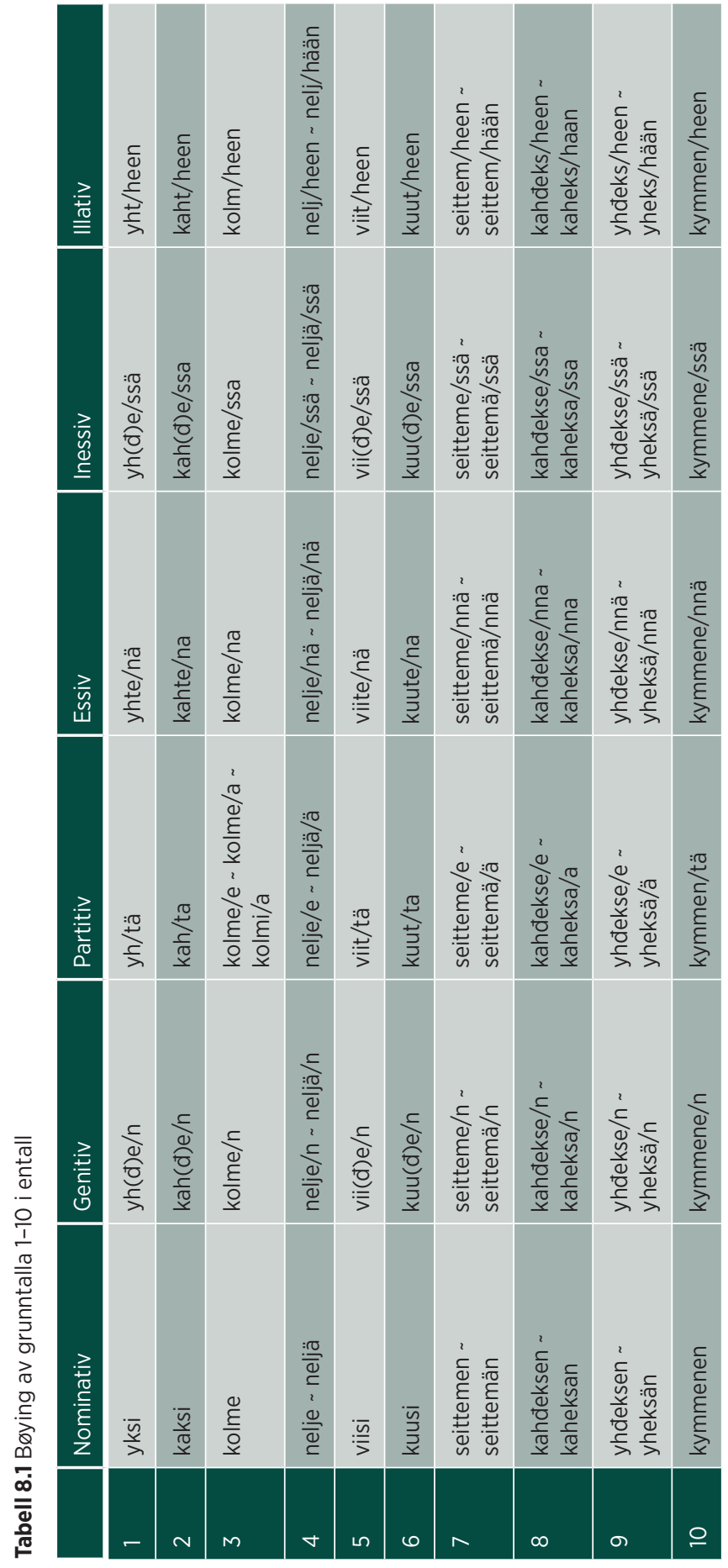
KAPITTEL 8

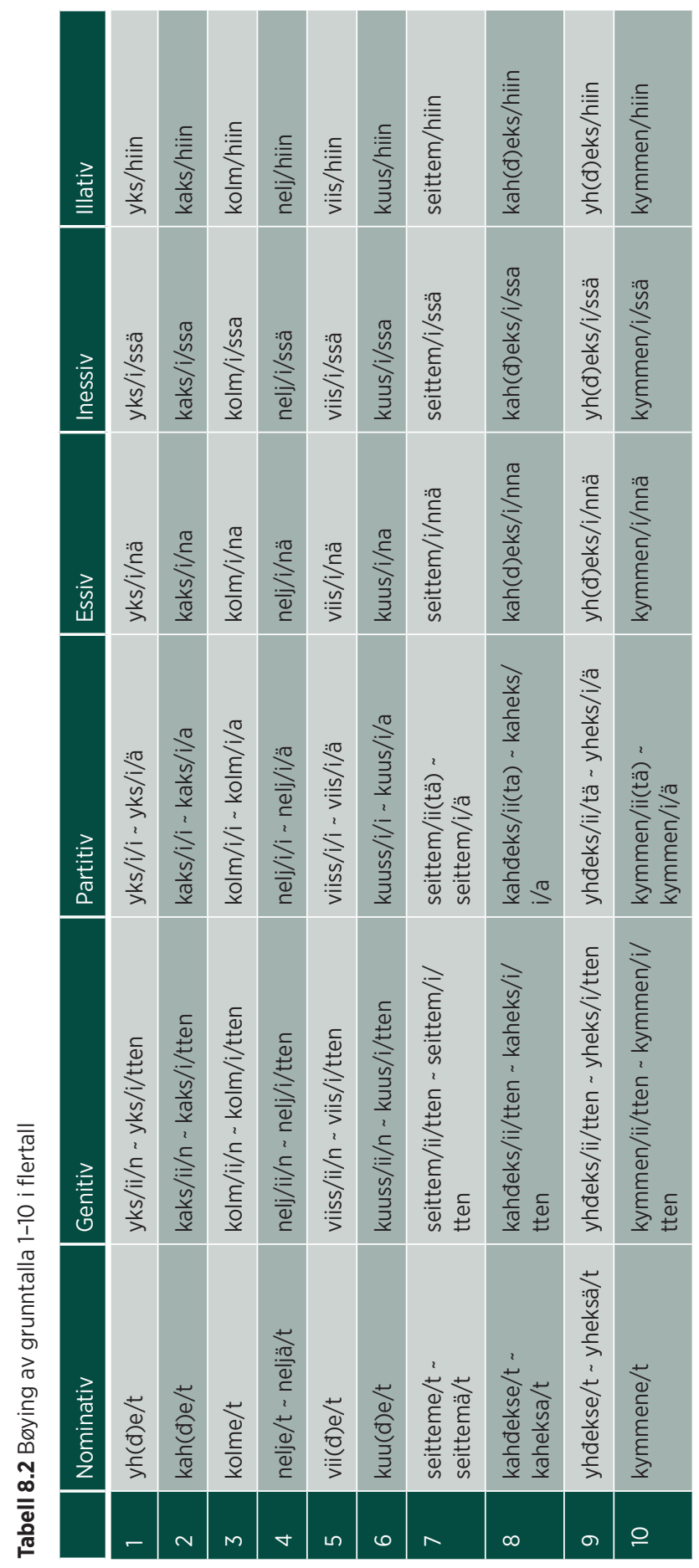




\subsubsection{Grunntall som setnings- og fraseelement}

Det spesielle med grunntall er at de i nominativ entall danner kjernen i sin eigen frase, og det som grunntallet spesifiserer antallet av, står som utfylling $\mathrm{i}$ partitiv entall $(1,2)$. Vi kaller slike fraser for KVANTORfraser (KvaP). En annen spesiell egenskap ved grunntall er at de står i entall nominativ også når de fungerer som objekt i setninga (2).

1. Saarala ja Mikola oon [kymmenen lasta], [kolme tytärtä] ja [seittemen seittemän poik(k)aa].

'Sara og Mikkel har ti barn, tre døtre og sju sønner'

2. Jeesus jakoi kansale [kaksi leip(p)ää] ja [viisi kallaa]. 'Jesus fordelte to brød og fem fisk mellom folket.'

I de andre kasusene fungerer grunntall som foranstilte modifikatorer $\mathrm{i}$ substantivfraser, og de kongruerer da i tall og kasus med substantivet (3-5):

3. Sillä reisula met kävimä [viiđessä maassa] ja [kolmessa pääkaupungissa].

'På den turen var vi innom fem land og tre hovedsteder.'

4. Tänä vuona mie olen ollu jo [viisissä häissä] ja [kaksissa kraviaisissa]. 'Jeg har allerede vært i fem brylluper og to begravelser i år'.

5. Mie ostin kaupasta [vii(đ)et housut] ja [kah(đ)et kengät].

'Jeg kjøpte fem bukser og to par sko på butikken.'

Legg merke til at vi må bruke flertallsformer av grunntall når de står som premodifikator til flertallsord som hä̈̈t ('bryllup'), kraviaiset ('begravelse'), housut ('bukse'), eller når det er snakk om ting som forekommer parvis, for eksempel kengät ('sko').

Årstall danner vi ved å kombinere essivforma av substantivet vuosi ('år'), vuona, med grunntall i nominativ entall (6-8):

6. Suomen kieltä alethiin opettamhaan Tromssassa [vuona 1977] (= vuona yhđeksentoistasattaa seittemenkymmentäseittemen $\sim$ yheksäntoistasattaa seittemenkymmentäseittemän).

'Finskundervisninga i Tromsø blei starta opp i 1977'.

7. Kainun kieli sai viralisen statuksen [vuona 2005] (= vuona kaksituhatta viisi).

'Kvensk språk fikk offisiell status i 2005.' 
8. [Vuona 176o] (= vuona seittementoistasattaa kuusikymmentä) Ruijan ja Tanmarkun kuninkhaana oli Kristian VI.

'I 1760 var det Kristian VI som var konge i Danmark-Norge.'

Tiår og århundre danner vi ved å kombinere grunntall med substantivet luku ('tall'). Alle bøyelige delene av tallordet står da i genitiv, og ordet luku står i adessiv entall (9-11):

9. [170o-luvula] (= seittementoistasađan seittemäntoistasåan luvula) Alattiossa asui enniimitten kainulaissii.

'På 1700-tallet var kvenene i flertall i Alta'.

10. Sammeli siirtyi Pyssyjokheen [1760-luvula] (= seittementoistasadan seittemäntoistasaian kuu(đ)enkymmenen -luvula).

'Samuel flytta til Børselv i 1760-åra.'

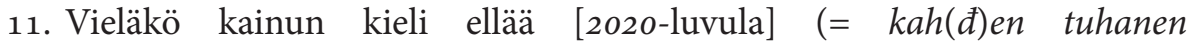
kah(d)en-kymmenen?

'Kommer kvensk fortsatt til å være i live i 2020-åra?'

Når vi snakker om alderen til folk eller noe anna, så står grunntallet i genitiv $(12,13)$ :

12. Meiđän poika kuoli jo [24-vuotisenna/ikhäisennä] (= kah(đ)enkymmennenneljen -neljän vuotisenna/ikhäisennä).

'Sønnen vår døde som 24-åring.'

13. Pekka kuoli vasta [102-vuotisenna/ikhäisennä] $(=s a(d) a n k a h(d) e n$ vuotisenna/ikhäisennä).

'Peder døde først i en alder av 102.'

\subsection{Ordenstall}

Som nevnt er ORDENSTALL avleid av grunntall. Ordenstall er syntaktisk sett adjektiv, og de oppfører seg derfor annleis i setninger enn grunntall.

Ordenstall blir avleid på to måter. I begge tilfella brukes suffikset $-s$ i nominativ entall. Bøyingsmønstra for de to måtene er oppsummert i tabell 8.3.

- I den første avleiingsmåten festes suffikset $n t e:(n)$ ne til vokalstammen, suffikset $t$ (i entall partitiv) til konsonantstammen, og suffikset $n s(s)$ til flertallsstammen. Suffiksa festes til grunntallsstammen på svakest mulig stadium, eller med andre ord den stammen vi får når vi tar bort suffikset $n$ i genitiv entall. Et 
unntak er tallordet kolme ('tre'), der $e$ i stammen blir erstatta med $a$ i ordenstallet, og vi får da kolma/s ('tredje'). Eksempler er (sg. nom. : sg. gen. : sg. part. : sg. ill. : pl. nom. : pl. part) kolme ('tre') : kolme/n $\rightarrow$ kolma/s ('tredje') : kolma/ne/n : kolma/t/ta : kolma/nt/heen : kolma/ne/t : kolma/nss/ii(ta) kolma/ns/i/a, viisi ('fem') : vii(đ)e/n $\rightarrow$ vii(đ)e/s ('femte') : vii(đ)e/ne/n: vii(đ)e/t/tä: vii(đ)e/nt/heen : vii(đ)e/ne/t : viide/nss/ii(tä) viie/ns/i/ä, sata ('hundre') : sa(d)a/n $\rightarrow$ $s a(d) a / s$ ('hundrede') : sa(đ)a/ne/n : sa(đ)a/t/ta : sa(đ)a/nt/heen : sa(d)a/ne/t : sada/nss/ii(ta) sa'a/ns/i/a, tuhat tuhanen ('tusen') : tuhane/ $\rightarrow \rightarrow$ tuhane/s ('tusende') : tuhane/nne/n : tuhane/t/ta : tuhane/nt/heen : tuhane/nne/t : tuhane/nss/ii(ta) tuhane/ns/i/a.

- I den andre avleiingsmåten står $s$ ved lag gjennom heile bøyingsmønsteret, i vokalstammen som se, og i konsonantstammen som s. Vokalstammen står på grunnstadiet eller med andre ord samme stadium som i essiv entall. Eksempler er (sg. nom. : sg. gen. : sg. part. : sg. ill. : pl. nom. : pl. part) kolme ('tre') : kolme/ $n \rightarrow$ kolma/s ('tredje') : kolma/se/n : kolma/s/ta: kolma/s/heen : kolma/se/t : kolma/ss/ii(ta) kolma/s/i/a, viisi ('fem') : vii(d)e/n $\rightarrow$ vii(đ)e/s ('femte') : viite/se/n : vii(đ)e/s/tä : viite/s/heen : viite/se/t : viite/ss/ii(tä) viite/s/i/ä, sata ('hundre') : sa(đ)a/n $\rightarrow$ sa(đ)a/s ('hundrede') : sata/se/n : sa(đ) a/s/ta : sata/s/heen : sata/se/t : sata/ss/ii (ta) $\sim$ sata/s/i/a, tuhat $\sim$ tuhanen ('tusen') : tuhane/n $\rightarrow$ tuhane/s ('tusende') : tuhane/se/n : tuhane/s/ta: tuhane/s/heen : tuhane/se/t : tuhane/ss/ii (ta) tuhane/s/i/a.

Består ordenstallet av flere deler, så festes avleiingssuffikset til alle delene. For eksempel er 25. kah(d)eskymmenesvii(đ)es, 156. er sa(d)asvii(d)eskymmeneskuu(d)es, osv. De ulike delene bøyes også, det vil si at de kongruerer med hverandre (1-3):

1. Pekkakuoli [kolmaskymmenes oktooperikuuta] vuona yhđeksentoistasattaa yhđeksenkymmentäyksi.

'Peder døde den trettiende oktober 1991.'

2. Pekale piđethiin piđot [kah(đ)eskymmenes kolmas] novemperikuuta yhđeksentoistasattaa kahđeksenkymmentäkaksi.

'Peder blei feira den 23. november 1982.'

3. Mie pääsin moolhiin [vii(đ)entenäkymmenentenäkuu(đ)entena] / [viitesenäkymmenesenäkuutesena].

'Jeg kom i mål som den 56. / som nummer 56.' 
Som i grunntalla er ordet toista i ordenstalla fra 11. til 19. ubøyd. Det står allerede i partitiv (jf. grunnforma toinen 'annen'). Eksempler er yksitoista ('elleve') $\rightarrow y h$ (đ)estoista ('ellevte'), kuusitoista ('seksten') $\rightarrow$ kuu( () estoista ('sekstende').

De to første ordenstalla, 1. og 2., kan uttrykkes på to måter: 1. heter ensimäinen eller $y h(d) e s, 2$. heter toinen eller kah(d)es. Men variantene $y h(đ) e s$ og $k a h(đ) e s$ forekommer som regel bare i sammensatte ordenstall, for eksempel i (11.) yh(đ)estoista, (12.) kah(đ)estoista, (20.) kah(đ)eskymmenes. Ellers bruker vi variantene ensimäinen og toinen (4):

4. Pekka oli syntyny [ensimäinen päivä] [toisessa kuussa] (eli fepruaarikuussa).

'Peder blei født på den første dagen i andre måned (det vil si i februar).

- Av pronomenet moni ('mange') er det også avleid et slags ordenstall, og det bruker vi til å spørre om rekkefølge: (sg. nom. : sg. gen. : sg. part. : sg. ill. : pl. nom. : pl. part) moni ('mange') : mone/ $n \rightarrow$ mone/s ('hvilken (i rekkefølgen)') : mone/ne/n / mone/se/n : mone/t/ta / mone/s/ta : mone/nt/heen / mone/s/heen: monelnelt / mone/selt : mone/nss/ii(ta) mone/ns/ila / mone/ss/ii(ta ) mone/s/i/a. Eksempler er $(5,6)$ :

5. Kunka mones sie olit moolissa? Kunka monenet/moneset tet olitta moolissa?

'Hvilken plass kom du i mål på? Hvilken plass kom dere i mål på?'

6. Kunka monentenna/monesenna sie olit moolissa?

'Hvilken plass kom du i mål på?'

Tabell 8.3 viser hvordan ordenstalla bøyes.

I flertall partitiv brukes i Porsanger-varieteten også former med partitivsuffikset $t A$, for eksempel kolmanss/ii/ta / kolmass/ii/ta ('tredje.'), viiđenss/ii/tä / viitess/ii/tä ('femte'), viiđenss/ii/tä/toista / vitess/ii/tä/toista ('femtende'), sadanss/ii/ta / satass/ii/ta ('hundrede'), tuhanenss/ii/ta / tuhaness/ii/ta ('tusende'). 


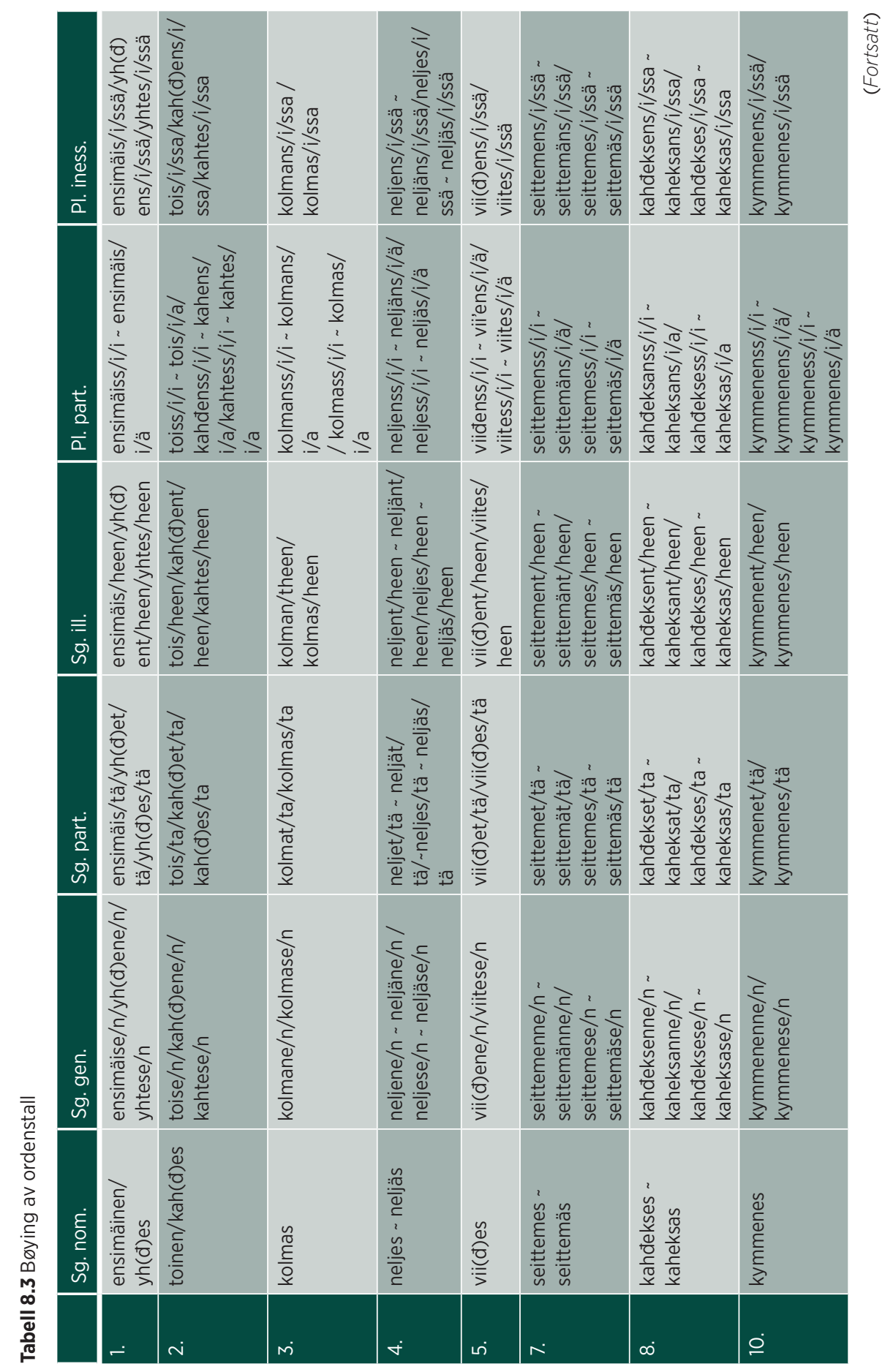




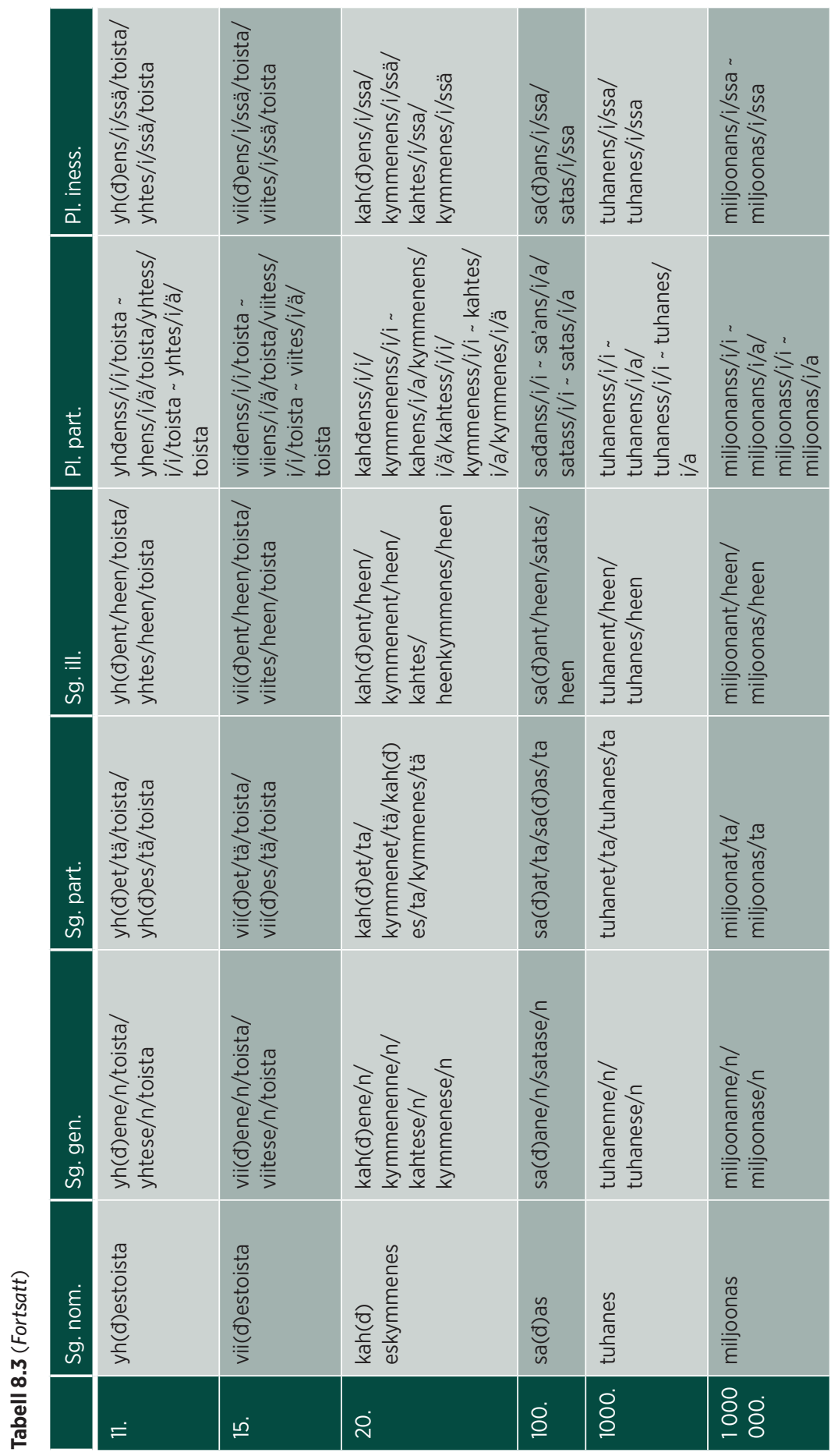




\section{9}

\section{Adverb}

\subsection{Generelt om adverb}

Adverb er en ordklasse som inneholder mange slags ord. De har ingen enhetlige bøyingsmønstre, som for eksempel nomen eller verb, og de fleste adverba bøyes ikke i det heile tatt. Eksempler på slike ubøyelige adverb er irti( $t$ ) ('laus'), halki(t) ('i to, tvers av / gjennom'), poikki(t) ('av, i to, tvers over'), auki(t) ('åpent'), rikki(t) ('sund, i stykker'), rohki ('sikkert; enda til'), nokko ('nok'), äskön ('nylig, nettopp'), eilen ('i går').

Noen av de bøyelige adverba kan vi for eksempel dele inn i følgende grupper:

1. ulkona ('ute'), ulk(k)oo ('utafra'), ul(v)os ('ut'); kaukana ('langt borte'), kauk(k)aa ('langt bortefra'), kau(v)as ('langt bort'); kotona ('heime'), kottoo kotoa ('heimefra'), kothiin kotia ('heim'); siinä ('der'), siitä ('derfra'), sinne(t) ('dit'); sielä ('der'), sieltä ('derfra'); tässä ('her'), tästä ('herfra'), tähän ('hit'); täälä ('her'), täältä ('herfra'), tänne(t) ('hit');

2. alhaala ('nede'), alhaalta ('nedafra'), alhaale ('ned'); sisälä ('inne (i)'), sisältä ('innafra'), sisäle(t) ('inn i'), sishään ('inn i'); vihilä (jf. käyđä vihilä 'bli via'), vihile(t) (jf. mennä vihile 'bli via');

3. päissä ('[være] berusa, full'), päihin ('[bli] berusa, full'); ko(v)ossa ('samla'), kokhoon ('i hop, sammen'), pilassa ('[være] øydelagt'), pilhaan ('[bli] øydelagt'); matkassa ('[være] med'), matkasta ('bort fra, ikke med'), matkhaan ([bli] med'); $y h(đ)$ essä ('[være] sammen'), yhtheen ('[bli] sammen'), tapaturmaa ('ved uhell').

- Det er tydelig at orda i gruppe 1 har ulike bøyingsformer, men disse er likevel mangelfulle. Sjøl om de alle er STEDSADVERB, så inneholder de bøyingsformer som ikke er i lokalkasus, for eksempel ulkona, kauk(k)aa, kotona, kotia 
osv. De inkluderer også bøyingsformer som i moderne kvensk ikke er kasusformer i det heile tatt, for eksempel $u l(v) o s, k a u(v) a s$.

- Stedsadverba i gruppe 2 ser alle ut til å være i lokalkasus, men de skiller seg fra vanlige kasusbøyde ord ved at grunnorda ikke fins som sjølstendig ord i dagens kvensk. Det fins altså ikke noen ord som *alhaa $\sim{ }^{*}$ alas, ${ }^{*}$ sisä eller *vihki. På samme måte mangler også mange av stedsadverba i gruppe 1 et grunnord, ettersom det ikke fins ord som ulko, ${ }^{\star} k a u k a$ eller ${ }^{*}$ sie (det siste fins rett nok som personlig pronomen, men ikke som demonstrativt pronomen).

- Adverba i gruppe 3 har rett nok kjente grunnord, pää ('hode'), koko (heil; ganske; størrelse'), pila ('spøk'), matka ('tur, reise') og yksi ('en'), men vi kan ikke slutte oss til betydninga til disse adverba ut ifra betydninga til grunnorda deres. Vi har her å gjøre med leksikaliserte adverb med særegne betydninger. Betydninga til ordet tapaturmaa ('ved uhell') kan muligens forstås med utgangspunkt i grunnordet tapaturma ('ulykke'), men partitiv i kvensk uttrykker ikke måten noe gjøres på, og tapaturmaa bør derfor også klassifiseres som leksikalisert adverb.

I tillegg til disse gruppene fins det adverb som hopusti ('fort'), visusti ('nøye, nøyaktig'), viikottain ('ukevis'), sađottain ('hundrevis'), vieritysten ('ved sida av hverandre'), rinnatusten ('ved sida av hverandre'), som nok kan forstås ut fra grunnorda sine, men som er avleid med visse AVLEIINGSUFFIKS.

Ei eiga gruppe danner adverb som aldri står aleine, men som krever ei foranstilt utfylling. Det er adverb som käsin ('i retning av'), päin ('mot'), saakka ('inntil; fra av'), asti ('inntil; fra av') og kiini ('inntil'). Disse adverba tar andre adverb eller nomen i lokalkasus som utfylling, og de skiller seg dermed fra adposisjoner, som tar utfyllinger i genitiv eller partitiv. Eksempler er ithään käsin ('austover'), takaisin päin ('bakover'), kottoo saakka ('heimefra'), kotia asti ('inn til heimen'), kiini Raisinvuonhoon saakka ('heilt til Reisadalen').

Ovafor har vi delt inn adverb etter formelle egenskaper. Men ikke alle ord uten eller med mangelfull bøying er adverb. Derfor må vi definere adverb også ut fra hvordan de oppfører seg syntaktisk. Adverb er altså ubøyde ord eller ord med mangelfulle bøyingsmønstre som

- typisk opptrer som modifikator $(1,2)$ eller utfylling $(3,4)$ til verb, men også som modifikator til substantiv (5), adjektiv (6) eller adverb (7), eller som modifikator til ei heil setning (8), og som 
- kan ha sin eigen modifikator eller si eiga utfylling, det vil si at de danner en eigen adverbfrase $[\mathrm{AdvP}](1,2,5,6,7)$.

Eksempler er:

1. Jensi löysi Kiilavaaran pääle [vasta eilen]. 'Jens fant fram opp til Kiilavaara først i går.'

2. Matti heilui siljola [hirmuisesti päissä]. 'Mats sjangla på gårdsplassen forferdelig berusa.'

3. Kaija oon kotona.

'Kaja er heime'.

4. Pekka meni ulos.

'Peder gikk ut.'

5. Jällissä oon [paljon turskaa].

'Det henger mye torsk på hjellen.'

6. Yrkä oli [oikhein kaunis].

'Brudgommen var riktig vakker.'

7. Kläppi lukkee jo [kohta hyvin].

'Ungen leser allerede ganske bra.'

8. Onneksi kaikin pärjäthiin hengen.

'Heldigvis overlevde alle.'

I eksempla ovafor er det også adverb (kotona, ulos) som ikke kan få eigne modifikatorer, men som likevel sjøl står som modifikator til verb. Som adverb kan vi derfor regne alle ord som ikke er nomen, verb eller adposisjoner, og som står som modifikator til verb, substantiv, adjektiv eller heile setninger.

Man bruker å dele adverb inn i grupper etter hvilken betydning de har. Vi kan skille mellom følgende grupper:

- Stedsadverb forteller hvor noen eller noe er eller skjer, hvorfra noe(n) kommer, eller hvor noe(n) beveger seg til.

- Tidsadverb forteller når eller hvor ofte noe er eller skjer.

- Måtesadverb forteller på hvilken måte eller hvordan noe skjer.

- Mengdeadverb forteller hvor mye eller lite det er av noe eller noen, eller i hvilket omfang noe skjer.

- Gradsadverb opptrer som modifikator til adjektiv og adverb, og de forteller i hvilken grad en egenskap gjelder. 
- Lause ADVERB uttrykker talerens holdning til utsagnet i ei setning, for eksempel om utsagnet holdes for sant, eller om det er noe taleren håper på. De kan også knytte setninga til konteksten på annen måte.

De tre første gruppene er adverb som står som modifikator til verb. Den fjerde gruppa, mengdeadverb, står som modifikator til verb eller substantiv. Den femte gruppa, gradsadverb, står som modifikator til adjektiv eller adverb. Den sjette gruppa, lause adverb, står som modifikator til heile setninger.

Vi skal se nærmere på disse gruppene i tur og orden.

\subsection{Stedsadverb}

STEDSADVERB bruker vi i svar på spørsmål som formes med proadverba missä ('hvor') : mistä ('hvorfra') : mihin mihinkä minne( $t$ ) ('hvor (til/hen)').

Karakteristisk for stedsadverb er at de har lokalkasusbøying. Noen av dem forekommer i alle seks lokalkasusformer, noen bare i tre, enten i indre eller ytre lokalkasus.

\subsubsection{Stedsproadverb}

STEDSPROADVERB har et demonstrativt pronomen i botn, og en del av proadverba har derfor former som er identiske med lokalkasusformer til demonstrative pronomen. I tabell 9.1 jamfører vi demonstrative pronomen med tilsvarende proadverb.

Tabell 9.1 Jamføring av pronomen og proadverb

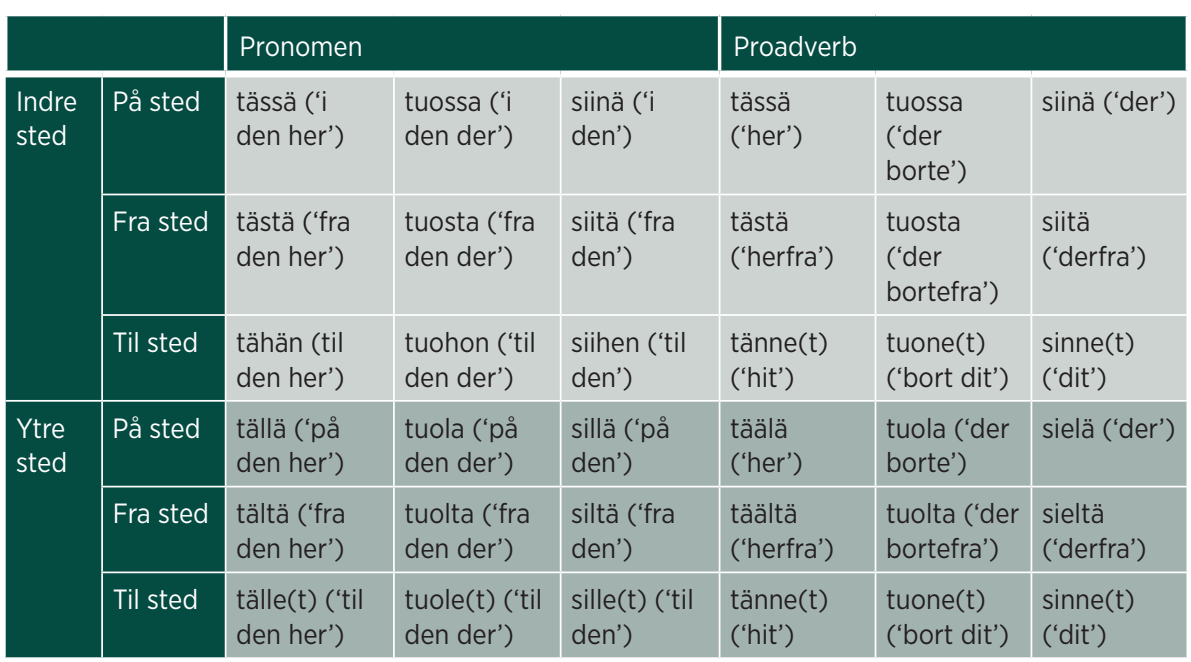


Til tross for disse formelle likhetene så opptrer pronomen og proadverb på ulikt vis, som illustrert $i(1,2)$ :

1. Missä Pekka makkaa? Tuossa. 'Hvor ligger Peder? Der borte.'

2. Kreeta siirtyi tänne.

'Greta flytta hit'.

\author{
Jamfør: Tässä sängyssä. \\ 'I denne senga.' \\ Jamfør: Kreeta siirtyi tähän \\ kaupunkhiin. \\ 'Greta flytta til denne byen.'
}

Når pro-ordet opptrer aleine, så er det et proadverb, men når det fungerer som modifikator til et substantiv, så er det et pronomen.

Stedsproadverb har også komparativformer $(3,4)$ :

3. Mene vähän tuokemaksi, se sie näjet paremin.

'Gå litt lenger bort dit slik at du ser bedre.'

4. Hiljemin Kaisa siirtyi vielä sikemäksi pohjaisheen.

'Seinere flytta Kaisa enda lenger nord.'

Tabell 9.2 gir en oversikt over komparativformer av stedsproadverb.

Tabell 9.2 Komparativ av stedsproadverb

\begin{tabular}{l|l}
\hline Grunnform & Komparativ \\
\hline sielä : sieltä : sinne(t) & sikempännä : sikemp(p)ää : sikemäksi \\
\hline täälä : täältä : tänne(t) & täkempännä : täkemp(p)ää : täkemäksi \\
\hline tuola : tuolta : tuone(t) & tuokempanna : tuokemp(p)aa : tuokemaksi
\end{tabular}

I tillegg har vi sammensatte stedsproadverb med adverbet päin ('mot') eller käsin ('i retning av') som sisteledd. De uttrykker enten omtrentlig sted eller retning: tääläpäin ('her omkring'), sieläpäin ('der omkring'), sieltäpäin ('derfra et sted'), tänne(t)päin ('hitover'), tuone(t)päin ('bortover dit'), sinne(t)päin ('ditover'), tänne(t)käsin ('hitover'), tuone $(t) k a ̈ s i n$ ('bortover dit'), sinne $(t) k a ̈ s i n$ ('ditover').

I nektende svar på spørsmål om sted bruker vi de nektende proadverbformene mishään, misthään, mihinkhään minheen (5-7):

5. Missä? Ei mishään missäkhään.

'Hvor? Ingen steder'.

6. Mistä? Ei misthään mistäkhään.

'Hvorfra? Ikke fra noen steder.' 
7. Mihin? Mihinkä? Minne(t)? Ei mihinkhään minheen.

'Hvor til/hen? Ingen steder.'

Legg merke til at disse nektende formene er identiske med tilsvarende kasusformer av nektingspronomen (se avsnitt 7.6.3). Fordelinga mellom nektende stedsproadverb og nektingspronomen er den samme som mellom stedsproadverb og pronomen generelt: Når ordet opptrer som modifikator til substantiv, har vi med pronomen å gjøre, men når det står aleine, så er det et adverb.

Det fins også et spørrende proadverb, mihinkäsin, som er satt sammen av mihin og adverbet käsin (8):

8. Mie en ymmärä, mihinkäsin mie pitäisin lähteet.

'Jeg skjønner ikke hvor jeg burde gå hen.'

\subsubsection{Relative stedsadverb}

Relative stedsadverb forteller hvor noe eller noen er i forhold til et gitt sted. Vi bruker dem i svar på spørsmål om (1) hvilken retning noe(n) ligger i, kommer fra eller skal til, og (2) hvor talerens sted er i forhold til et gitt sted. Det er ikke alltid vasstette skott mellom disse to funksjonene, og det hender at ett og samme adverb kan brukes i begge funksjonene.

- I den første funksjonen (1) brukes for eksempel følgende adverb: alhaala ('nede, nedafor') : alhaalta ('nedafra') : alhaale(t) ('ned'), ylhäälä ('oppe, oppfor') : ylhäältä ('ovafra') : ylhääle(t) ('opp'), e(đ)essä ('foran') : e(đ)estä ('forfra') : etheen ('framover'), takana ('bakom, bak') : takkaa ('bakfra') : taka( $t$ ) ('bak'), vieressä ('ved sida av') : vierestä ('fra ved sida av, fra sida') : vierheen ('ved sida av, til sida'), vierelä ('ved sida av') : viereltä ('fra ved sida av, fra sida') : vierele(t) ('ved sida av, til sida'), syrjässä ('i utkanten av, ved sida av') : syrjästä ('fra utkanten') : syrjhään ('til utkanten'), sisälä ('inne (i)') : sisältä ('innefra') : sisäle(t) ('inn (i)'), ulkona ('ute') : ulkkoo ulkoa ('utafra') : ulos ('ut'), keskelä ('midt i/på) : keskeltä ('fra midten') : keskele(t) ('midt i'), perässä pörässä ('etter') : perästä pörästä ('fra etter') : perhään pörhään ('til etter'); vasemalla kä(đ)elä / vaseman kä(đ)en puolela ('på venstre side') : vasemalta kä(đ)eltä / vaseman kä(đ)en puolelta ('fra venstre'), oikkeela oikealla oikialla kä (đ)elä / oikkeen oikean oikian kä(đ)en puolela ('på høgre sida') : 
oikkeelta $\sim$ oikealta $\sim$ oikialta kä(đ)eltä / oikkeen $\sim$ oikean $\sim$ oikian kä (đ)en puolelta ('fra høgre'); orjas ('sørover'), pohjas ('nordover'), norttos ('nordover'), vestas ('vestover'), öystäs ('austover'); alaskäsin ('nedover'), alle(t)käsin ('under'), ylöskäsin ('oppover'), ylhääle( $t$ ) käsin ('oppover'), uloskäsin ('utover'), sisäle(t)käsin ('innover'), etheenkäsin ('framover'), taka(t)käsin ('bakover'), perhäänkäsin pörhäänkäsin ('akterut, tilbake'), taka(i)sinkäsin ('bakut, tilbake'), etheenpäin ('framover'), taka(t)päin ('bakover'), ylöspäin ('oppover'), alaspäin ('nedover'), sisäle(t)päin ('innover'), ulospäin ('utover'), norttospäin ('nordover'), öystäspäin ('austover').

Eksempler på hvordan adverb med retningsfunksjon er brukt (1-3):

1. Saha oli alhaala meren rannassa.

'Saga var nedafor på havstranda.'

2. Oli niin lauha, ette lumi katos alhaalta, mutta ylhäälä sitä vielä oli.

'Det var så mildt at snøen forsvant nedafor, men ovafor lå den fortsatt.'

3. Sie häyđyt käänttyyt ensistä vasemalle käđele, ja sitte se huonet oon siinä oikkeela käđelä.

'Du må først snu til venstre, og så er huset der på høgre side.'

- I den andre funksjonen (2) brukes for eksempel følgende adverb: likelä $\sim$ liki(t) ('i nærheta av') : likeltä ('fra nærheta av') : likele(t) liki(t) ('til nærheta av'), lähelä ('i nærheta av') : läheltä ('i nærheta av') : lähele( $t$ ) ('til nærheta av'), kaukana ('langt borte') : kauk(k)aa ('lang bortefra') : kau(v)as ('langt bort'); poissa ('borte') : poi(e)s ('bort'), poi(e)späin ('bortover'), muu( $v$ )ala ('på et anna sted') : muu(v)alta ('fra et anna sted') : muu(v)ale $(t)$ ('til et anna sted'), tois(s)aala ('på et anna sted') : tois(s)aalta ('fra et anna sted') : tois(s)aale( $t$ ) ('til et anna sted'), perilä ('framme') : perile( $t$ ) ('fram'), kotona ('heime') : kottoo kotoa ('heimefra') : kothiin $\sim$ kotia(t) ('heim'), kotisalla ('heime').

Eksempler på hvordan adverb med oppholdsfunksjon er brukt $(4,5)$ :

4. Minun poika assuu kaukana Uslussa, mutta nyt se meinaa siirttyyt taas tähän likele.

'Sønnen/Gutten min bor langt borte i Oslo, men nå tenker han på å flytte til nærheten av meg/oss.' 
5. Ko kauvan oon asunu muuvala, pois kottoo, se oon soma taas tulla kothiin.

'Når man lenge har bodd et anna sted, heimefra, så er det fint å komme heim igjen.'

\subsubsection{Andre stedsadverb}

Noen stedsadverb opptrer aldri aleine, men bare som modifikator i en substantivfrase. Til denne gruppa hører for eksempel lähtö(i)sin, koto(i)sin og poi(e)s ('opprinnelig fra'), som forteller hvor noen kommer fra eller bor. For eksempel:

1. Erkki oon Uslusta lähtö(i)sin koto $(i) \sin \sim$ poi(e)s.

'Erik er fra Oslo.'

Ovafor har vi sett eksempler på sammensatte adverb med adverba päin og käsin som sisteledd. Disse to retningsadverba opptrer også i himmelretninger

(2) og som modifikator til stedssubstantiv (3) og stedsnavn (4). Eksempler:

2. iđästä käsin ('austfra'), ithään käsin ('austover'), läntheen käsin ('vestover'), etelhään käsin ('sørover'), pohja(i)sheen käsin ('nordover')

3. aaphaan käsin ('mot havet'), väylhään käsin ('mot leia'), ranthaan käsin ('mot stranda'), merheen päin ('mot havet')

4. Raisista käsin ('fra Nordreisa'), Raishiin käsin ('i retning av Nordreisa'), Niemenaikkhuun käsin ('i retning av Niemennaiko'), Vesisaarheen käsin ('i retning av Vadsø’), Raishiin päin ('i retning av Nordreisa’)

De usjølstendige adverba kiini( $t$ ) ('heilt; enda') og asti( $t) /$ saakka ('inntil, fram til') likner på adposisjoner. De danner adverbfraser og krever alltid utfylling i form av stedsadverb (5) eller substantivfrase i lokalkasus (6-9). Det vanlige mønsteret er at kiini $(t)$ står først i frasen, etterfulgt av et nomen i elativ $(8,9)$ eller illativ $(7,8)$, av og til også i ablativ eller allativ (6), og så følger enten asti eller saakka:

5. Oletko sie kuoranu minnuu [kiini tänne asti/saakka]?

'Har du fulgt etter meg heilt hit?'

6. Se mies kuoras minnuu [kiini kotisiljolta/kotisiljole saakka/asti]. 'Mannen fulgte etter meg heilt fra/til gårdsplassen heime'. 
7. Mie olen seilanu [kiini Vuorehaan saakka/asti].

'Jeg har seilt heilt til Vardø'

8. Mie olen pyytäny tämän joen [kiini Pitkästäniemestä asti] ja tuone [Seithaan asti].

'Jeg har fiska i denne elva heilt fra Langnes og bort til Seida'

9. Martin oon lähtöisin [kiini eteläpäästä Norjaa].

'Martin er fra den sørlige delen av Norge.'

Adverba kiini(t) og asti(t)/saakka kan også utelates fra setningene (5-9) uten at de blir ufullstendige.

Orda poikki(t) ('av, i to, tvers over') og läpi(t) ('gjennom') brukes også som adposisjoner (se avsnitt 10.1.3 og 10.1.4), men de opptrer også sammen med stedsadverb (11) og nomen i lokalkasus (10, 12):

10. Kyllä sie löyđät sen huonheen, ko menet [tuosta sillasta poikki].

'Du finner nok det huset om du går over den der brua'.

11. Aja vain [sieltä läpi], kyllä sieltä päässee.

'Kjør bare gjennom der, og derifra kommer man nok fram.'

12. Kynttilän näkö loisti [klasista läpi].

'Stearinlyset strålte gjennom vinduet.'

\subsection{Tidsadverb}

TIDSADVERB uttrykker tidspunkt i forhold til et anna tidspunkt (= relativt tidspunkt) (1), de forteller hvor ofte noe skjer, eller hvor lenge noe varer (2), og når en hendelse begynner eller slutter (3). De fungerer aldri som utfyllinger i setninga, men bare som frie adverbial.

1. Eilen mie olin Alattiossa, tääpänä mie olen Tromssassa, mutta huomena mie lähđen Vesisaarheen.

'I går var jeg i Alta, i dag er jeg i Tromsø, men i morgen drar jeg til Vadsø'.

2. Muutamisti mie olen surulinen, mutta usheimitten mie olen iloinen.

'Noen ganger er jeg trist, men oftest er jeg glad.'

3. [Kiini aamusta saakka] ja [ilthaan asti] Liisa tyhä lauleli.

'Lisa småsang heilt fra morgen til kveld.' 


\subsubsection{Relativt tidspunkt}

Følgende adverb uttrykker tidspunkt i forhold til et anna tidspunkt:

tääpänä ('i dag'), eilen ('i går'), huomena ('i morgen'), ylihuomena ('i overmorgen'), toissapäivänä ('i forgårs'), nyt ('nå), ajoissa aijala ('i tide'), varhain ('tidlig'), varhemin ('tidligere'), hiljain ('seint'), hiljemin ('seinere'), ennen ('før'), ensin ('først'), ensistä ('først'), jälkhiin jälkheen ('etterpå), jälemin ('etterpå, seinere'), viimeksi ('til slutt, sist'), e(đ)eltäkäsin e(đ)eltäpäin ('i forvegen, på forhand'), nyky(j)ään nykyaikhaan ('nå til dags'), viimiaikhoin ('i det siste'), vanhaasseen aikhaan ('i gamle dager'), alusta alusti aluksi ('fra først av'), lopulta lopuksi loppuin lopuksi ('til sjuende og sist'), viime(i)n ('endelig, til slutt'), samassa samala samala aik(k)aa ('samtidig'), jo ('allerede'), vielä ('enda'), vasta ('først, ikke før'), äskön ('nylig, nettopp'), hiljan hiljattain ('for ei stund sia'), aik(k)aa ('for lenge sia'), taas ('igjen'), justhiin ('akkurat'), sitte ('siden, så), heti ('snart, straks'), paikala ('umiddelbart, straks'), varsin ('straks'), yhtäaik(k)aa ('samtidig'), yhtäkkii yhtäkkiä ('plutselig'), toiste( $t$ ) ('en gang til, på nytt'), uu(đ)esti ('på nytt'), sitte vasta ('først da').

Her er noen eksempler på hvordan disse adverba er brukt (1-3):

1. Varhemin mie asuin Kaivuonossa, Raishiin mie siiryin hiljan, mutta heti mie taas aion siirtyät takasin Kaivuonhoon.

'Tidligere bodde jeg i Kåfjord, til Nordreisa flytta jeg for ei stund sia, men snart tenker jeg å flytte tilbake til Kåfjord.

2. Jos net kallaa saava, se oon ostaja varsin.

'Viss de får fisk, så fins det straks en kjøper'.

3. Viimiaikhoin oon ollu ihmisillä finit piilit, mutta vanhaassen aikhaan net olthiin huonot.

'I nyere tid har folk hatt gode biler, men i gamle dager var de dårlige.'

\subsubsection{Vedvarende og gjentakende tid}

Følgende adverb uttrykker vedvarende tid eller hvor ofte noe skjer:

aina ('enda, fortsatt'), tasan ('alltid; fortsatt, enda'), iänkaikkisesti ('for evig'), jatku(u)vasti ('fortsatt'), kaikesti ('alltid'), (ei) koskhaan ('aldri'), ylheensä ('generelt, i alminnelighet'), tavalisesti ('vanligvis'), myöthäänsä myötään 
('stadig (vekk)'), yhtenhään ('stadig'), ushein usheen ussein ('ofte'), usseesti $\sim$ useasti usiasti ('ofte'), usheemin useammin usiammasti ('oftere'), usheimitten usseimitten ('oftest'), tihheesti tiheästi tihiästi ('hyppig, støtt'), monesti ('mange ganger, ofte'), joskus ('av og til, iblant'), muutamesti muutamisti ('av og til'), toisinhaan ('av og til'), välilä välhiin välistä ('innimellom, nå og da'), tuoloin tällöin ('i ny og ne'), toisin ai(j)oin ('andre ganger'), aina koskaki ('til enhver tid'), vähitellen ('etter hvert'), harvo(i)n $\sim$ harvakseen $\sim$ harvotellen harvhaan ('sjelden'), harvemin ('mer sjelden'), harviimasti ('mest sjelden'), päivälisesti ('daglig'), vuotisesti ('årlig'), kerran ('en gang'), yh(đ)esti ('én gang'), kah(đ)esti ('to ganger'), kolmesti ('tre ganger'), neljesti neljästi ('fire ganger').

Her er noen eksempler på hvordan disse adverba er brukt (1-3):

1. Meile tullee nyt posti päivälisesti, mutta varhemin se tuli harvotellen. 'Nå får vi post daglig, men før kom den sjelden.'

2. Kranni käy meilä myöthäänsä, ja usheimitten sillä oon kakkoi myötä. 'Naboen kommer stadig på besøk, og oftest har han/hun kaker med seg.'

3. Ei meilä kaikesti ollu kannoi mutta muutamesti kyllä.

'Vi hadde ikke alltid høns, men i hvert fall av og til.'

\subsubsection{Start- og sluttidspunkt}

Start- og sluttidspunkt uttrykkes på samme måte som starten og slutten på ei reise, det vil si med adverba kiini(t) - asti/saakka ('fra - til') (se avsnitt 9.2.3). Men til forskjell fra reisestart og -slutt så er her adverbet, eller i hvert fall ett av dem, påkrevd for at frasen skal være fullstendig $(1-5)$ :

1. Pekka asui kotona [kiini menheesseen vuotheen asti/saakka].

'Peder bodde heime enda til i fjor.'

2. Hän halus assuut kotona [viimisheen asti/saakka].

'Han/Hun ønska å bo heime heilt til det siste.'

3. Hän oon asunu Vesisaaressa [nuoresta saakka/asti].

'Han/Hun har bodd i Vadsø fra han/hun var ung.'

4. Sielä saapi tansata [kiini aamhuun asti/saakka].

'Der får man danse heilt til morgenkvisten.' 
5. Kyllä sielä saapi tansata [aamusta asti/saakka], jos niin halluu. 'Visst får man danse der heilt fra morgenen av, viss man vil.'

Disse adverba kan også danne en frase sammen med påfølgende leddsetning $(6,7)$ :

6. Mie olen pyytäny [siitä asti/saakka, ko lapsena aloin].

'Jeg har fiska heilt sia jeg begynte med det som barn.'

7. Mie kävin Tromssassa joka vuosi [kiini siksi, ko mie heitin] [ siihen asti, ko mie heitin].

'Jeg dro til Tromsø hvert år heilt til jeg slutta.'

\subsection{Måtesadverb}

Som MÅTESADVERB betegner vi her for det første adverb som eksplisitt uttrykker hvilken måte ei handling skjer på $(1,2)$. Disse er oftest avleid med suffikset -sti (1). For det andre tar vi her med adverb som forteller om hvilken fysisk eller psykisk tilstand noe eller noen er i $(3,4)$ :

1. Sie puhut kainun kieltä kaunhiisti.

'Du snakker nydelig kvensk.'

2. Mikkel lähti kothiin rukatuksella.

'Mikkel dro heim i all hast.'

3. Tallin seinät oon kaltossa.

'Stallveggene er på skrå.'

4. Maija joi viinaa ja tuli heti päihin.

'Maja drakk sprit og blei straks full.'

\subsubsection{Adverb på -sti}

Avleiing på -sti er den vanligste måten å lage adverb på. Suffikset er fullt produktivt, og det kan festes til så godt som alle adjektiv og også til visse substantiv. For eksempel:

hyvästi ('bra'), paremasti ('bedre'), hopusti ('fort'), kovasti ('mye'), huonosti ('dårlig'), lujasti ('mye; fast, sterkt, hardt'), keskinäisesti ('seg imellom'), pahasti 
('ille'), finisti ('fint'), helposti ('enkelt, lett'), helpomasti ('lettere'), hienosti ('fint'), hithaasti ('sakte'), hithaamasti ('saktere'), kaunhiisti ('pent'), kevveesti keveästi keviästi ('lett'), kummasti ('merkelig, rart'), kunnolisesti ('ordentlig, skikkelig'), liukkhaasti ('sleipt, glatt'), noppeesti nopeasti nopiasti ('fort'), onnelisesti ('lykkelig', rahalisesti ('pengemessig'), rauhalisesti ('rolig, stille'), rumasti ('stygt'), selvästi ('tydelig'), sievästi ('nett, vakkert'), siivosti ('snilt'), somasti ('artig, trivelig'), taitavasti ('behendig, dyktig'), tarkasti ('nøyaktig'), vaphaasti ('fritt, utvungent; rikelig'), viekkhaasti ('rart, merkelig'), viishaasti ('klokt'), vissisti ('sikkert'), näpsästi ('fort, raskt, hendig'), puhthaasti ('reint'), päivälisesti ('(til) daglig'), ankarasti ('strengt; ivrig'), ruokottomasti ('uskikkelig, uanstendig'), hurskhaasti ('fromt'), pyhästi ('hellig'), laiskasti ('lat, dovent'), lykylisesti ('lykkelig'), hauskasti ('hyggelig, trivelig'), vi(j)attomasti ('uskyldig'), vihaisesti ('sint').

Her er et par eksempler på hvordan disse adverba er brukt $(1,2)$ :

1. Nyt tulet hopusti ja olet siivosti!

'Nå kommer du straks og er snill!'

2. Faarin nimi oli Jakob, mutta met käskimä sen päivälisesti Jaakoksi.

'Faren het Jakob, men til daglig kalte vi han for Jaakko.'

Adverb på -sti har også gradbøying. Det danner komparativ- og superlativformer, som framstilt i tabell 9.3.

Tabell 9.3 Gradbøying av adverb på -sti

\begin{tabular}{|l|l|l|l|}
\hline Adjektiv & $\begin{array}{l}\text { Positiv form av adverb } \\
\text { på -sti }\end{array}$ & $\begin{array}{l}\text { Komparativ form av } \\
\text { adverb på -sti }\end{array}$ & $\begin{array}{l}\text { Superlativ form av } \\
\text { adverb på -sti }\end{array}$ \\
\hline hyvä ('god') & hyvästi ( hyvin) & paremin paremasti & parhaimitten parhaiten \\
\hline siivo ('snill') & siivosti & siivomin siivomasti & siivoimitten siivoiten \\
\hline $\begin{array}{l}\text { kevvee keveä } \\
\text { keviä ('lett') }\end{array}$ & $\begin{array}{l}\text { kevveesti } \sim \text { keveästi } \\
\text { keviästi }\end{array}$ & $\begin{array}{l}\text { kevveemin keveämmästi } \\
\text { keviämmästi }\end{array}$ & kevveimitten kevveiten \\
\hline $\begin{array}{l}\text { hi(đ)as ('sakte') } \\
\text { hithaasti }\end{array}$ & $\begin{array}{l}\text { hithaamin hithaamasti } \\
\text { onnelinen } \\
\text { ('lykkelig') }\end{array}$ & $\begin{array}{l}\text { onnelisesti } \\
\text { onnelisemasti }\end{array}$ & hithaimitten hithaiten \\
\hline
\end{tabular}

Setningene i (3) og (4) viser hvordan komparativ og superlativ form av adverb på sti er brukt: 
3. Hänelä oon paremin paremasti tääpänä ko eilen.

'Han føler seg bedre i dag enn i går.'

4. Matti hihtaa meistä hithaimitten hithaiten.

'Mats går saktest på ski av oss alle.'

\subsubsection{Andre gradsadverb}

Det fins andre gradsadverb, som ikke er avleid på -sti, men som har samme funksjon. Noen av dem er stivna kasusformer, mest av partitiv og uproduktiv instruktiv (1), men vi finner også gradsadverb som går tilbake på andre kasusformer (2). De kan også ha possessivsuffiks festa til seg. I tillegg fins det gradsadverb som er avleid med et anna suffiks enn -sti, men de representerer ikke noen produktiv ordlagingsmåte (3).

1. hiljaa ('stille; sakte'), hätähättää ('så vidt, med nød og neppe'), sallaa ('i smug, i hemmelighet'), tapaturmaa ('ved uhell'), hyvin ('bra'), kovin ('sterkt; svært'), oikhein oikheen ('riktig, rett'), väärin ('galt'), päinvastoin ('tvert imot'), varkhain ('i smug, i hemmelighet'), näin ('sånn her'), nuoin nuin ('sånn der; omtrent'), niin ('slik'), (spørrende adverb) kunka kuinka ('hvordan')

2. rukatuksela ('i all hast'), sattumalla sattumalta ('tilfeldig, tilfeldigvis'), vahingossa vahinkossa ('ved en feiltakelse'), mielelä ('gjerne'), halula ('gjerne'), suunile ('omtrent'), säntilheen ('akkurat'), täsmälheen ('nettopp, akkurat')

3. vaiti ('taust, stille'), ääneti ('lydlaust, stille'), vasiten ('uttrykkelig, spesielt; med vilje'), väkisten ('med makt; nødvendigvis; uunngåelig'), muuto(i)n ('ellers'), samoten ('på samme måte; i like måte')

Ei spesiell gruppe utgjør adverb på -(i)sin, som brukes særlig for å beskrive bevegelsesmåte (4):

4. hihtosin ('på ski'), ajosin ('kjørende, med kjøretøy'), lentosin ('flygende, med fly'), varkhaisin ('i smug')

Eksempla i (5-7) illustrerer bruken av slike adverb:

5. Kunka teiđän trääninki eđistyy?

'Hvordan går det med treninga deres?'

6. Maija laittoi rukatuksela ruokkaa, ja sillä se väkisten paloi.

'Maja laga mat i all hast, og den blei da naturlig nok svidd. 
7. Kyllä mie lähen mielelä lentosin Uslhuun, hihtosin kestää niin kauvon. 'Jeg reiser helst med fly til Oslo, det tar så lang tid på ski.'

\subsubsection{Tilstandsadverb}

Det fins flere typer TILSTANDSADVERB. De kan beskrive hvilken posisjon noen eller noe er i (gruppe 1), hvilken fysisk eller psykisk tilstand noen eller noe er i (gruppe 2), hvor noen eller noe befinner seg i forhold til noe anna (gruppe 3), og også hvor stor gruppe noe eller noen opptrer i (gruppe 4).

Tilstandsadverb står ofte i lokalkasus, vanligvis i påstedskasus eller frastedskasus. Til noen av adverba i gruppe (1) kan vi valgfritt feste possessivsuffiks.

Eksempler på tilstandsadverb i gruppe 1:

- paiko(i)la(nsa) ('på plass') : paiko(i)le(nsa), sijala(nsa) ('på plass') : sijalta(nsa): sijale(nsa), lappheela(nsa) ('på flatsida') : lappheele(nsa), kaltossa ('på skrå) : kaltthoon, kallela ('på skrå') : kallele(t), vinossa ('på skeiva') : vinhoon, viinossa ('på skeiva') : viinthoon, kumossa ('opp ned, om kull') : kumhoon, vinkkelissä ('i vinkel') : vinkkelhiin, pystössä ('loddrett, oppreist') : pysthöön, suorassa ('rett, strak') : suorhaan, poikittain ('på tvers'), jalkasessa ('oppegående') : jalkasheen, jalo(i)la ('på fote') : jalo(i)le(t), nelinkontin ('på alle fire'), nurinniskoin ('over ende'), nurin ('på vranga'), nurinpäin, oikheinpäin oikheenpäin ('rett'), ylöspäin ('oppover'), alaspäin ('nedover').

Setningene i (1-3) er eksempler på hvordan vi bruker disse adverba:

1. Annilta meni polvi sijaltansa, mutta heti Pekan Erkki pani sen taas sijalensa.

'Kneet til Anna gikk ut av ledd, men Peder sin Erik dro det straks i ledd igjen.'

2. Ei se seinä ollu paljon kaltossa, piian millimeetterin eli pari se oli jääny kalthoon.

'Veggen var ikke mye på skrå, kanskje den var havna en millimeter eller to på skrå.'

3. Siinä oli yksi venet kumossa alapuolela tien.

'Det lå en båt opp ned på nersida av vegen.' 
Eksempler på tilstandsadverb i gruppe 2:

- naimisissa ('gift') : naimishiin, päissä ('full, berusa') : päihin, tyrmässä tyrmissä ('bevisstlaus') : tyrmhään tyrmhiin, hengissä ('i live') : henkhiin, palavissa ('svett'), kylmetyksissä ('frossen'), häpheissä ('skamfullt, flaut'), itkheilä ('på gråten'), suunilta ('fra seg'), kuolihaaksi ('i hjel'), umpinensa umpinansa ('lukka, tildekt, ikke åpna'), ummessa ('stengt; tett') : umpheen, pilassa ('øydelagt') : pilhaan, li(v)ossa ('i bløyt') : li(v)osta : likhoon, rikki(t) ('sund, i stykker'), poikki(t) ('av, i to, tvers over'), halki(t) ('i to, tvers igjennom'), auki(t) ('apent'), kiini( $t$ ) ('steng, låst, lukka'), läpi(t) ('gjennom'), kesken ('uferdig'), seka(i)sin ('om hverandre, hulter til bulter'), täynä ('fullt') : täythöön.

Eksempler på hvordan vi bruker disse adverba (4-6):

4. Lamphaita lyöthiin ette menthiin tyrmhiin, mutta vielä net olthiin hengissä.

'Sauene blei slått bevisstlause, men de var fortsatt i live.'

5. Anni oli niin häpheissä, ette oli palavissa.

'Anni var så skamfull at hun svetta'.

6. Minula meni fryysi rikki ja kaikki ruvat pilhaan.

'Fryseren min gikk sund, og all maten blei øydelagt.'

Eksempler på tilstandsverb i gruppe 3:

- $k o(v) o s s a$ ('sammen, samla') : kokhoon, yh(đ)essä ('sammen') : yhtheen, karussa ('på rømmen') : karkhuun, hukassa ('borte; øydelagt') : hukkhaan, korjussa ('[være tatt] vare [på], [være tatt] hand [om]') : korjusta : korjhuun, syrjässä ('i utkanten, avsides') : syrjhään, jäljelä ('[være/bli] igjen’) : jäljele(t), joukossa ('[være] blant [noe(n)]') : joukkhoon, laakissa ('sammen, i lag'), seurassa ([være] med, i') : seurhaan, matkassa ('[være] med') : matkhaan, myötä ('[være] med').

Eksempler på hvordan disse adverba brukes $(7,8)$ :

7. Jos sie otat lapset myötä, se meilä oon taas koko peret kovossa.

'Viss du tar med barna, så får vi samla heile familien.'

8. Pane kaikki tavarat visusti korjhuun, ettei net jouđu hukkhaan.

'Ta godt vare på alle tingene slik at de ikke blir borte.' 
For å uttrykke hvordan to eller flere enheter er relatert i forhold til hverandre bruker vi adverb som er avleid med suffikset tusten tysten, og noen ganger også med suffikset kkain kkäin. Eksempler på slike resiproke adverb: rinnatusten ('ved sida av hverandre'), vieritysten ('ved sida av hverandre'), likitysten ('nær hverandre'), pääletysten ('oppå hverandre'), perätysten pörätysten ('etter hverandre'), käsitysten ('hand i hand'), sölitysten ('i fanget på hverandre'), vastakkain ('mot hverandre, ansikt mot ansikt, front mot front'), rinnakkain ('jamsides, side om side'), peräkkäin pöräkkäin ('etter hverandre'), peräsukkaa pöräsukkaa ('etter hverandre').

For eksempel (9):

9. Pikku-Liisa ja Iso-Liisa tulthiin tänne pörätysten, ja niin het sitte menthiin käsitysten ranthaan.

'Vesle Lisa og Store Lisa kom hit etter hverandre, og så gikk de hand i hand på stranda.'

- Eksempler på tilstandsverb i gruppe 4 er $y k \sin$ ('aleine'), kah(đ)en ('på tomannshand, toene'), kolmen ('tre stykker i lag, på tremannshand'), neljen neljän ('fire stykker i lag'), vii(đ)en ('fem stykker i lag') osv.; molemin ('sammen, begge to'), kaikin ('alle sammen'), erittäin ('for seg, atskilt'), harvassa ('spredt'), ominpäin ('på eiga hand').

Eksempler på hvordan disse adverba er brukt (10-13):

10. Lapset olthiin kotona kolmen.

'Barna var heime tre stykker i lag.'

11. Heti met lähđimä kaikin.

'Snart drar vi alle sammen.'

12. Se oli silloin, ko muori vielä eli ja olima molemin.

'Det var den gangen mor fortsatt var i live og det var oss to.'

13. Sen pittää jokhainen maksaat erittäin.

'Hver enkelt må betale for seg sjøl.'

Adverbet keskenänsä ('seg imellom'), som betegner en resiprok relasjon, skiller seg ut ved at det alltid har festa til seg et possessivsuffiks i samme person som subjektet i setninga (14-16). 
14. Met ${ }_{i}$ olima niin ajatelheet keskenämm $\ddot{a}_{\mathrm{i}^{\circ}}$ 'Vi hadde tenkt det slik oss imellom.'

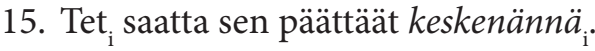
'Dere får avgjøre det dere imellom.'

16. Het ${ }_{\mathrm{i}}$ istuthiin kotona keskenäns $\ddot{a}_{\mathrm{i}}$. 'De satt heime aleine, bare de to.'

\subsection{Mengdeadverb}

Mengdeadverb bruker vi i svar på spørsmål om hvor mye det er av noe, eller hvor stort omfang noe har. Det kan være en stoffmengde, ei tidslengde, en egenskap osv.

Mengdeadverb kan danne en kvantorfrase aleine $(1,2)$, eller de kan danne en kvantorfrase sammen med et substantiv $(3,4)$. I kvantorfraser av sistnevnte type står substantivet i partitiv, og det kommer etter mengdeadverbet.

1. Mie rakastan sinnuu paljon/vähän/hirmusti/liik(k)aa/nokko.

'Jeg elsker deg mye/litt/veldig / for mye / nok.'

2. Het asuit meilä vuosittain.

'De bodde hos oss i årevis.'

3. Meressä oon [paljon/vähän/viljasti/hirmusti/nokko kallaa].

'Det er mye/lite / rikelig med / veldig mye / nok fisk i havet.'

4. Pekka sai komuunilta [säkittäin jauhoo].

'Peder fikk sekkevis av mel av kommunen.'

\subsubsection{Adverb på -sti som mengdeuttrykk}

I tillegg til å være måtesadverb er adverbsuffikset -sti også brukt til å lage adverb som forteller at det er mye av noe, eller at noe har stort omfang. Grunnord i slike adverb er adjektiv som beskriver noe forferdelig eller sterkt (1), eller en annen passende egenskap (2), men det kan også være et banneord (3).

1. hirmusti ('veldig'), hirmusesti ('veldig'), hirveesti hirveästi hirviästi ('forferdelig'), kauheesti kauheasti kauhiasti ('fryktelig'), kamalasti ('forferdelig'), valjusti ('mye'), kovasti ('mye, heftig'), kivasti ('mye'), julmasti ('veldig') 
2. suuresti ('mye'), isosti ('mye'), viljasti ('rikelig'), hyvästi ('bra mye'), mah(đ)ottomasti ('ufattelig/utrulig mye'), loppumattomasti ('uendelig mye'), huomattavasti ('rikelig')

3. pirusti ('djevelsk'), helvetisti ('helvetes mye')

Om bruken av disse adverba se eksempla $(1,3)$ i avsnitt 9.5 ovafor.

\subsubsection{Mye, lite, for mye og passelig mye}

Det er flere adverb vi kan plassere på en skala for relative mengder eller relativt omfang, fra paljon ('mye') til vähän ('lite'), for eksempel: paljon ('mye'), vähän ('lite'), vähä(i)sen ('litt'), pikku(i)sen ('litt'), vaanasti ('snaut'), (ei) olheen olheenkhaan ('(ikke) noe, (ikke) i det heile tatt'), nokko ('nok'), kylliksi ('nok'), liiaksi ('altfor mye'), täysin ('fullstendig, fullt ut'), kokonhansa ('heilt') og adverb på sti: passelisti ('passelig') og soppeevasti sopevasti ('passelig').

- Det vanligste mengdeadverbet med betydninga 'mye' er paljo(n). Det er noe spesielt ved at det også forekommer i den partitivliknende forma paljoo paljoa, som kan brukes i nektende setninger. Det motsatte av paljo(n) er vähä(n) ('lite'), som også har ei partitivliknende form, vähhää. Begge disse to adverba har komparativ- og superlativformer, som framstilt i tabell 9.4.

Tabell 9.4 Gradbøying av adverba paljo(n) og vähä(n)

\begin{tabular}{|l|l|l|}
\hline Positiv & Komparativ & Superlativ \\
\hline $\begin{array}{l}\text { paljon paljo } \\
\text { ('mye') }\end{array}$ & $\begin{array}{l}\text { enämen enämän } \\
\text { enämpi ('mer') }\end{array}$ & $\begin{array}{l}\text { eniten enniiten enintä } \\
\text { enniimitten enimäkseen ('mest') }\end{array}$ \\
\hline $\begin{array}{l}\text { (ei) paljoo paljoa } \\
\text { ('(ikke) mye') }\end{array}$ & $\begin{array}{l}\text { (ei) enämp(p)ää, enämältä } \\
\text { enämästi ('(ikke) mer') }\end{array}$ & \\
\hline $\begin{array}{l}\text { vähän vähä } \\
\text { ('lite') }\end{array}$ & $\begin{array}{l}\text { vähemän vähempi } \\
\text { ('mindre') }\end{array}$ & $\begin{array}{l}\text { vähiten vähhiiten vähhiimitten } \\
\text { ('minst') }\end{array}$ \\
\hline $\begin{array}{l}\text { (ei) vähhää(khään) } \\
\text { ('(ikke) i det heile tatt') }\end{array}$ & $\begin{array}{l}\text { (ei) vähemp(p)ää } \\
\text { ('(ikke) mindre') }\end{array}$ & \\
\hline
\end{tabular}

Eksempla i (1-7) illustrerer bruken av de to adverba:

1. Klassissa oon [paljon lapsii].

'Det er mange barn i klassen.'

2. Ei sielä ole [enämältä kallaa].

'Det er ikke så mye fisk der.' 
3. Vuonosta saa [enniimitten saittaa].

'Det er mest sei man får i fjorden.'

4. Liisa ostaa [vähän vaattheita].

'Lisa kjøper lite klær.'

5. Kreetala oli [vähemän vaattheita].

'Greta har mindre klær.'

6. Priitta rakastaa Mikkoo paljon, mutta minnuu hän rakastaa [vielä emämen].

'Brita elsker Mikkel mye, men meg elsker hun enda mer.'

7. Etkö sie saattais puhuat [vähäsen vähemän]?

'Kan ikke du snakke litt mindre?'

For å beskrive at noe mangler fullstendig, bruker vi orda (ei) vähhääkhään eller (ei) olheen ollenkhaan ('(ikke) noe(n), ingen, (ikke) i det heile tatt') (8, 9). Formelt sett er vähhääkhään partitiv av ordet vähä ('litt, noe'), men ettersom det ikke kongruerer med substantivet i frasen, så regner vi det som adverb (9).

8. Meilä ei ollu [vähhääkhään/olheen/ollenkhaan ruokkaa].

'Vi hadde ingen mat.'

9. Mutta met kyllä tieđämä, ettei Pekan muistelukset olheet [vähhääkhään jouttaaviita puhheita].

'Men vi veit nok at Peders fortellinger ikke var noe unødvendig snakk i det heile tatt.'

Jamfør ellers disse adverba med mengdepronomena paljo og vähä i avsnitt 7.6.4.

- Andre mengdeadverb er for eksempel pikku(i)sen ('(bitte) litt'), vähä(i)sen ('(bitte) litt'), hitu(i)sen ('ørlite'), vaanasti ('snaut'), som alle beskriver liten mengde $(10,11)$.

10. Anna mulle [pikkusen rakkhautta].

'Gi meg bitte litt kjærlighet.' 
11. Heikka antoi mulle [vaanasti rahhaa].

'Henry ga meg snaut med penger.'

- For å uttrykke relativ mengde bruker vi adverba nokko ('nok'), kylliksi ('nok'), lii(j)aksi liik(k)aa ('for mye') og passelisti ('passelig'), soppeevasti sopevasti ('passelig') (12).

12. Pikku-Matila oon [nokko/kylliksi/liiaksi/passelisti/sopevasti vaattheita].

'Vesle Mats har nok / for mye / passelig med / passelig med klær.'

- Sammen med demonstrative pronomen danner adverbet verran $\sim$ verta adverbfrasene sen verran $\sim$ sen verta, tuon verran $\sim$ tuon verta, tämän verran tämän verta ('så pass'), som modifiseres av den etterfølgende ette-setninga (13). En uspesifisert mengde uttrykker vi med adverbfrasen jonku verran jonku verta ('noe, en del') (14).

13. Minula oon [sen verran ruokkaa], ette juuri pärjän̈n.

'Jeg har så pass med mat at jeg akkurat klarer meg.'

14. Oon mulla porroiki [jonku verran].

'Jeg har nok en del rein også.'

Vi kan også bruke substantiv i verran/verta-kvantorfraser, for eksempel venheen verran lauttoi, som betyr 'nok planker til å bygge en båt med'.

- Adverba kokonhansa ('heilt') og täysin ('fullstendig, fullt ut') betegner størst mulig mengde eller omfang. De høver derfor dårlig sammen med substantiv i adverbfraser, men de danner sine eigne fraser som mengdeadverb (15).

15. Mie olin kokonhansa/täysin öksyny tunturhiin.

'Jeg hadde gått meg heilt/fullstendig vill på vidda.'

- Adverbparet kauvo(i)n kauan ('lenge') og (ei) kau(v)aa ('(ikke) lenge') uttrykker tidslengde $(16,17)$.

16. Mie olin kyllä feeriällä kauan, mutten kuitenkhaan [liian kauan].

'Jeg var rett nok lenge på ferie, men likevel ikke for lenge.'

17. Oli meilä kanojaki, mutta ei kyllä [kauaa aikaa].

'Vi hadde nok også høns, men ikke lenge.' 


\subsubsection{Distributiv mengde}

For å uttrykke distributiv mengde bruker vi adverb som er avleid med suffikset (i)ttain (i)ttäin. Dette ordlagingsmønsteret er svært produktivt: Vi kan lage slike adverb av hvilket som helst tallord (1), av ord som kan brukes som måleenhet (2), eller av andre substantiv som uttrykker mengde eller omfang (3). Eksempler:

1. yksittäin ('enkeltvis, individuelt'), kaksittain ('parvis, to i lag'), kolmittain ('tre i lag'), kymmenittäin ('titalls'), sa(đ)o(i)ttain ('hundrevis, hundretalls'), tuhansittain ('tusenvis, tusentalls'), miljoonittain ('miljonvis, miljoner av')

2. meetterittäin ('metervis'), kilomeetterittäin ('kilometervis'), miilo(i)ttain ('milevis'), tiimo(i)ttain ('timevis'), viiko(i)ttain ('ukevis'), vuosittain ('arrevis')

3. jouko(i)ttain ('gruppevis'), tokittain ('flokkevis'), läjittäin ('massevis'), säkittäin ('sekkevis'), tynnyrittäin ('tønnevis'), ämpärittäin ('bøttevis')

Her er noen eksempler på hvordan disse adverba er brukt (4-9):

4. Uuen vuoen aattoiltana nuoret kokkoontuvat kymmenittäin, muutamesti saottain tähän kentäle.

'På nyttårsaften bruker flere titalls ungdommer å samles på denne sletta, noen ganger er det hundrevis av dem.

5. Mies käveli tiimoittain ja miiloittain auttiinta tunturii.

'Mannen gikk timevis og milevis på den øyde vidda.'

6. Skruvi-setälä oon [säkittäin rahhaa].

'Onkel Skrue har sekkevis med penger'.

Eksakt mengde eller omfang uttrykker vi vanligvis med hjelp av objektsadverbial eller adverbial som har objektsform $(7,8)$, eller som kvantorfrase (9).

7. Mie asuin Vesisaaressa vuoen.

'Jeg bodde i Vadsø i ett år.'

8. Met kävelemmä miilan joka päivä.

'Vi går éi mil hver dag.'

9. Maija sai kallaa [tuhanen killoo].

'Maja fikk tusen kilo med fisk.' 


\subsection{Gradsadverb}

GRADSADVERB forteller i hvilken grad noen eller noe har den egenskapen som er uttrykt gjennom et adjektiv eller et adverb. Vi bruker gradsadverb i svar på spørsmål som begynner med kunka kuinka (1-3). Gradsadverb danner ikke noen eigen frase, men fungerer som premodifikator til adjektiv (4) eller adverb $(5,6)$.

1. [Kunka ahkera] Matti on? 'Hvor flittig er Mats?'

2. [Kunka varhain] tet tulitta? 'Hvor tidlig kom dere?'

3. [Kunka paljon] turska maksaa? 'Hvor mye koster torsk(en)?'

4. Matti oon [hirmu / lii(j)an liika / melkhein melkheen / kovin / oikhein / niin ahkera].

'Mats er veldig/altfor/ganske/svært/riktig/så flittig.'

5. Met tulima [hirmu / lii(j)an liika / melkhein melkheen / kovin / oikhein I niin varhain].

'Vi kom veldig/altfor/ganske/svært/riktig/så tidlig.'

6. Turska maksaa [hirmu / lii(j)an liika / melkhein melkheen / kovin / oikhein / niin paljon].

'Torsk(en) koster veldig/altfor/ganske/svært/riktig/så mye.'

Det fins ulike typer av gradsadverb.

\subsubsection{De adjektiviske adverba som uttrykker grad av egenskap}

Den vanligste typen av gradsadverb er adverb som er avleid av adjektiv. Endelsene på disse adverba er identiske med genitivsformer $(1,2)$, og adverba forteller at den egenskapen de beskriver, forekommer i stor grad.

1. Ruoka oli [kauheen $\sim$ kauhean $\sim$ kauhian / hirveen $\sim$ hirveän $\sim$ hirviän / kamalan / hirmun / hirmu(i)sen hyvä ].

'Maten var veldig/forferdelig/fryktelig/uhyre god.' 
2. Mie hihtasin eilen [kauheen $\sim$ kauhean $\sim$ kauhian / hirveen hirveän hirviän / kamalan / hirmun hirmu(i)sen paljon/kau(v)oin].

'Jeg gikk veldig/forferdelig/fryktelig / uhyre mye / lenge på ski i går'.

I samme funksjon kan vi også bruke adverb på -sti (3).

3. Mie nukuin viimi yönä [kauheesti kauheasti kauhiasti / hirmu(i)sesti / mah(d)ottomasti hyvin].

'Jeg sov veldig/uhyre/ufattelig godt i natt.'

Orda hirmu og hirmu(i)nen brukes som gradsadverb også i nominativsform, som for eksempel i hirmu kovat säät ('veldig dårlig vær'), hirmunen hyvä safti ('veldig god saft').

Som vi ser, så har disse gradsadverba i stor grad de samme adjektiva som grunnord som adverba på -sti.

\subsubsection{Andre adverb som uttrykker grad av egenskap}

Eksempler på adverb som uttrykker relativ grad av egenskap, er (stor grad) kovin ('svært'), aivan ('heilt'), ihan ('heilt'), (mindre grad) melkhein melkheen ('ganske'), joksiki ('ganske, rett så), kohta ('ganske'), (tilstrekkelig grad) nokko ('nok'), (for stor grad) lii(j)an liika ('altfor'); (andre) kokonhansa ('heilt'), täysin ('fullstendig'), puolittain ('halvveis'), osittain osaksi ('delvis, til dels'), tuplasti ('dobbelt') $(1,2)$.

1. Kreeta oon [kovin/oikhein/joksiki/siksiki/nokko/lii(j)an kaunis vaimo]. 'Greta er ei svært/riktig/ganske/ganske/tilstrekkelig/altfor vakker kone.'

2. Mie kyllä piän ette se ajatus oon [kokonhansa/täysin hullu]. 'Jeg syns nok at den tanken er heilt/fullstendig gal.' Adverba niin, näin, nuoin nuin noin ('så, så pass') bruker vi for å uttrykke i hvilken grad en egenskap forekommer i forhold til konteksten (3).

3. Mie en tieny, ette sie saatat kainun kieltä [nuoin nuin noin hyvin]. 'Jeg visste ikke at du kunne så godt kvensk.'

\subsubsection{Nøyaktighetsgrad}

Adverb som uttrykker nøyaktighetsgrad, bruker vi for å fortelle om noe som forekommer i en nøyaktig eller unøyaktig mengde eller omfang (1), eller om det har større eller mindre mengde eller omfang jamført med noe anna (2). 
1. justhiin justhiinsa ('nøyaktig'), joksiki ('ganske'), suunile(t) ('omtrent'), nuoin nuin noin ('cirka, omtrent')

2. alle( $t$ ) ('under'), rappeesti $\sim$ rapeasti $\sim$ rapiasti ('drøyt'), yli $(t) \sim$ ylitte ('over'), kohta ('nesten'), liki( $t$ ) ('nært'), melkhein melkheen ('nesten'), enintä enimitten enniimitten ('for de meste, mest, maksimum'), vähhiintä vähintä vähittäin ('i det minste, minst, minimum'), kuitenki kuiten ('i hvert fall'), kork(k)einta kork(k)einthaan ('høgest, i beste fall')

Eksempler på hvordan disse adverba er brukt $(3,4)$ :

3. Kallaa tuli [justhiin/joksiki/suunile $(t) /$ alle $(t) / \mathrm{ylki}(t) /$ rappeesti $\sim$ rapeasti $\sim$ rapiasti/liki(t)/enintä/kuiten/kork(k)einta viisi sattaa killoo].

'Det blei nøyaktig/nærmere/omtrent/under/over/drøyt/nærmere/mest/i hvert fall/i beste fall fem hundre kilo.'

4. Met aijoma olla Raisissa [justhiin/joksiki/suunile $(t) / a l l e(t) / y l i(t) \sim$ ylitte/rappeesti $\sim$ rapeasti $\sim$ rapiasti/liki(t)/enintä/kuiten/kork $(k)$ einta viikon].

'Vi har tenkt å være i Nordreisa

nøyaktig/nærmere/omtrent/under/over/drøyt/nærmere/maksimum/i hvert fall/i beste fall ei uke.'

Som det går fram ovafor, så bruker vi her til dels de samme adverba som vi bruker for å uttrykke grad av egenskap.

\subsection{Lause adverb}

LAUSE ADVERB beskriver ikke bestemte setningsledd, men de knytter setninga til konteksten, kommenterer setninga, eller tilføyer den en eller annen nyanse. Lause adverb danner ikke eigne fraser og har derfor heller ikke eigne modifikatorer. Vi skiller her mellom to grupper av lause adverb, konnektiv og kommentaradverb.

\subsubsection{Konnektiv}

KonNEKTIV viser til tekst eller tale utafor setninga og knytter setninga til disse $(1,2)$ : 
1. Mie olin eilen sairas. Sillä mie en päässy tulemhaan sinun tykö.

'Jeg var sjuk i går. Derfor kunne jeg ikke komme til deg.'

2. Mie olin eilen sairas, mutta kuitenki mie lähđin koulhuun.

'Jeg var sjuk i går, men jeg dro likevel på skolen.'

Eksempler på konnektiv er:

sen takia ('derfor, på grunn av det'), sillä ('derfor'), silti ('likevel'), sentäh(đ)en ('derfor'), nä(j)et ('nemlig'), sitte( $n$ ) ('siden, så, da'), kuitenki kuiten ('likevel'),

(ei) kuitenkhaan ('likevel (ikke)'), senthään ('likevel'), sitte( $n) k i$ ('likevel'), (ei) sitte $(n) k h a ̈ a ̈ n$ ('likevel (ikke)'), muuto(i)n muutosin ('ellers'), taas ('igjen'), tois(s)aaltakäsin ('på den andre sida'), kuulema(n) ('visst nok, som det fortelles'), lopuksi ('til slutt'), lisäksi ('i tillegg')

\subsubsection{Kommentaradverb}

KOMMENTARADVERB beskriver hva slags innstilling taleren eller skriveren har til utsagnet i setninga, det vil si om eller i hvilken grad det er noe han/hun håper på, trur på, oppfatter som mulig osv. (1-4):

1. Ilman sie tulet minun myötä kothiin.

'Du kommer vel heim med meg.'

2. Onneksi sie olet jo tervet.

'Heldigvis er du allerede frisk'.

3. Pekka lähtee kaikisti mielelä koulhuun.

'Peder drar bestandig gjerne på skole.'

4. Mie en vain ymmärä, mitä sie sillä meinasit.

'Jeg forstår bare ikke hva du meinte med det.'

Her er noen flere eksempler på kommentaradverb:

arvattavasti ('formodentlig'), arvatenki ('antakelig'), luultavasti ('trulig'), sikkaristi ('sikkert'), varmasti ('sikkert'), varmastikki ('sikkert'), (ei) varmastikhaan ('sikkert (ikke)'), vishiin vissiin vissisti ('visst'), vissimästi ('sikkert'), (ei) vishiinkhään vissiinkhään ('sikkert (ikke)'), tottavishiin ('ja visst'), (ei) tottavishiinkhään ('for all del ikke'), tuskin ('knapt, nesten ikke, snaut'), toivottavasti ('forhåpentlig'), tietenki ('selvfølgelig'), (ei) tietenkhään ('selvfølgelig (ikke)'), 
piian ('kanskje'), ilman ('vel, uten videre'), erinomhattain ('særlig'), olletiki ('særlig'), erittäinki ('særlig'), eriliikaisesti ('særlig'), tosin ('virkelig, sannelig'), to(đ)esta ('virkelig'), muka ('liksom'), makka ('liksom'), (ei) su(i)nkhaan ('slett ikke, på ingen måte'), onneksi ('heldigvis'), mah(đ)olisesti ('muligens'), melkhein melkheen ('nesten; ganske'), mielelä ('gjerne'), (minun, sinun, hänen, me(iđ)än, te(iđ)än, he(iđ)än) mielestä ('etter min, din, hans/hennes, vår, deres (2. pl.), deres (3. pl.) meining'), oikkeesti oikeasti oikiasti ('riktig'), oikkeesthaan oikeasthaan oikiasthaan ('egentlig'); kyllä ('vel, visst; nok'), nyt ('nå), vain vaan ('bare'), oikhein oikheen ('riktig') 



\section{0}

\section{Adposisjoner: postposisjoner og preposisjoner}

Adposisjoner er enten ubøyelige eller har bare to eller tre kasusformer, og de krever et nomen som utfylling. Adposisjoner danner ADPOSISJONSFraser, som vi forkorter med PP (jf. engelsk Preposition Phrase). I setninga fungerer adposisjonsfraser som adverbialutfyllinger eller frie adverbial. Vi skiller mellom to typer adposisjoner, POSTPOSISJONER og PREPOSISJONER, basert på om utfyllinga står foran eller etter adposisjonen. Preposisjoner står foran utfyllinga si (1), mens postposisjoner følger etter den (2).

1. Lato seissoo [keskelä niittyy].

'Låven står midt i enga.'

2. [Talon takana] oon tyhä mettää.

'Bak huset er det bare skog.'

Et kjennetegn på adposisjoner er at de ikke kan sløyfes uten at setninga blir ugrammatisk $(3,4)$.

3. ${ }^{\star}$ Lato seissoo niittyy.

4. ${ }^{\star}$ Talon oon tyhä mettää.

Adposisjonen er kjernen i adposisjonsfrasen, og den styrer kasusen til utfyllinga. Utfyllinga er et substantiv (eller et pronomen) som står i grammatisk kasus, oftest i genitiv eller partitiv, men stundom også i nominativ. Med andre ord regnes ikke konstruksjonen korsteenista läpi ('gjennom skorsteinen') i setning (5) som adposisjonsfrase ettersom substantivet her står i elativ.

5. Mies laski nuoran toisen pään [korsteenistä läpi].

'Mannen firte den andre enden av tauet ned gjennom skorsteinen.' 
Vi kan endre setninga til (6)

6. Mies laski läpi sitte nuoran toisen pään korsteenista.

Ordet läpi kan også utelates heilt (7):

7. Mies laski sitte korsteenista nuoran toisen pään.

Men om vi derimot skriver (8)

8. Mies laski sitte nuoran toisen pään [korsteenin läpi] [läpi korsteenin].

så er korsteenin läpi läpi korsteenin eksempler på adposisjonsfraser, den første er en postposisjonsfrase, og den andre en preposisjonsfrase.

Et unntak fra det vi nettopp har sagt, er preposisjonen ilman. Den tar utfylling i abessiv, men vi regner den likevel som adposisjon (9).

9. Liisa laukkoi niitylä [ilman kengittä].

'Lisa sprang på enga uten sko.'

Som vi ser i (10), kan vi ikke splitte fraser med ilman uten at setninga blir ugrammatisk. Vi kan altså ikke si

10. ${ }^{\star}$ Liisa laukkoi ilman niitylä kengittä.

Derimot skiller ilman seg fra andre adposisjoner ved at det kan utelates i setninga (11).

11. Liisa laukkoi niitylä kengittä.

Et kjennetegn ved adposisjoner er at de ikke kan ha noen modifikatorer i tillegg til nomenutfyllinga. Man kan altså ikke si (12)

12. ${ }^{*}$ Liisa kiikkus [kiven isolle pääle].

'Lisa klatra stor på en stein / steinen'.

Derimot kan utfyllinga i en adposisjonsfrase sjølsagt ha modifikator (13).

13. Liisa kiikkus [ison kiven pääle].

'Lisa klatra på en stor stein / den store steinen.'

Et anna viktig kjennetegn ved adposisjoner er som nevnt at de styrer hvilken kasus utfyllinga står i. Slik sett er det ikke opplagt å regne konstruksjoner som denne i (14) som adposisjoner.

14. En mie muista, oliko [viittä vuotta jälkheen], ko meiđän äiji kuoli. 
'Jeg husker ikke om det var fem år etter at bestefar vår døde.'

Jamfør (14) med setninga i (15):

15. Se oli [viisi vuotta jälkheen], ko meiđän äiji kuoli.

'Det var fem år etter at bestefar vår døde.'

Konstruksjonen i (14) står i partitiv fordi taleren ikke er sikker på utsagnet, og ikke fordi viittä vuotta er utfylling til postposisjonen jälkheen.

Vi kan dele adposisjoner inn i grupper etter hvilken betydning eller semantisk funksjon de har. Vi skiller mellom

- stedsadposisjoner,

- tidsadposisjoner,

- måtesadposisjoner,

- årsaksadposisjoner,

- mengdeadposisjoner,

- forholdsadposisjoner,

- ugjennomsiktige adposisjoner og

- lause adposisjoner.

Nedafor skal vi i tur og orden greie ut om disse gruppene, og vi skal også se at en og samme adposisjon kan brukes i ulike funksjoner.

\subsection{Stedsadposisjoner}

STEDSADPOSISJONSFRASER uttrykker hvor subjektet eller objektet i setninga befinner seg eller beveger seg, i forhold til det stedet som utfyllinga i adposisjonsfrasen betegner. Stedsadposisjoner er ofte stivna kasusformer, og de forekommer som regel som trekløver bestående av inessiv ('inne i'), elativ ('ut av') og illativ ('inn i, til') eller adessiv ('oppe på, ved'), ablativ ('bort fra') og allativ ('bort til').

Til mange av adposisjonene fins det identiske adverb. (Se avsnitt $9.2 \mathrm{og}$ 9.2.2.)

Vi kan dele stedsadposisjoner inn i flere grupper ut fra hvilke forhold de uttrykker mellom referenten til subjektet eller objektet og stedet som er uttrykt i utfyllinga. Det kan være posisjon (1-4), avstand (5), et mer generelt forhold (6), bevegelsesretning (7) og ferdselsrute eller farlei (8). 
1. Repo oli tehny [laattiin alle] kuopan.

'Reven hadde laga ei grop under golvet.'

2. Erkki assuu [likelä minnuu].

'Erik bor i nærheta av meg.'

3. Kissa oli tarttunu [kivviin välhiin].

'Katten hadde gått seg fast mellom steinene.'

4. Nyt laskeva huonheita [entisten puteettipelloitten pääle].

'Nå bygger de hus på gamle potetåkrer.'

5. Sitte tulima jo [liki Vesisaarta].

'Så kom vi allerede til nærheta av Vadsø.'

6. Met kuljeskelima [ympäri Tromssaa].

'Vi vandra rundt omkring i Tromsø'.

7. Maija oli ajanu jo monta miilaa [Vesisaarta vasten].

'Maja hadde allerede kjørt mange mil mot Vadsø'

8. Sie piđät mennä [poikki meren], jos sinne meinaat päästä.

'Du må dra tvers over havet om du vil komme deg dit.'

\subsubsection{Relativ posisjon}

Det vanlige er at en adposisjonsfrase forteller hvilken posisjon subjektet eller objektet befinner seg i, i forhold til stedet som er uttrykt i utfyllinga, altså for eksempel om den er under, over, foran eller ved sida av. Adposisjoner i denne gruppa har vanligvis også former som uttrykker bevegelse til eller fra. Eksempler på slike adposisjoner er ('hvor': 'hvor fra': 'hvor til') alla ('under') : alta : alle(t), päälä ('på, oppe på) : päältä : pääle(t), e(d)essä ('foran') : e(đ)estä : etheen, takana ('bak') : takkaa : taka(t), vieressä ('ved sida av') : vierestä : vierheen, syrjässä ('i utkanten av/ved sida av') : syrjästä : syrjhään, perässä pörässä ('etter') : perästä pörästä : perhään pörhään, sisälä ('inne') : sisältä : sisäle(t), välissä ('mellom') : välistä : välhiin, välilä : väliltä : välile(t), tykönä ('hos') : tyk$k \ddot{o} \sim$ tyköä : tykö $(t)$ og ympäri( $($ ) ('omkring, rundt'). Disse er alle postposisjoner som tar utfylling i genitiv (1-11).

1. Matti asui siinä [Santatörmän alla].

'Mats bodde der nedafor «Sandbakken»'. 
2. Laiva vajos [meren alle].

'Båten sank ned i havet.'

3. Ruuttapiilit toppaava [tämän törmän pääle].

'Bussene stopper på toppen av denne bakken.'

4. Sammeli kumartui [kuninkhaan etheen].

'Samuel bøyde seg foran kongen.'

5. Lapsi tullee joka yö [meän vierheen].

'Ungen kommer og ligger ved sida av oss hver natt.'

6. Ennen oli täynä puteettipeltoja [huonheen ympärit].

'Før i tida var det fullt med potetåkrer rundt huset.'

7. Se oon iso ja kaunis paikka [mettän sisälä].

'Det er et stort og fint sted inni skogen.'

8. Siinä juoksi vesi [kiven sisältä].

'Der rant det vatn ut fra innsida av en stein.'

9. Hyljet uipi [jäitten välissä].

'Selen svømmer mellom isflaka'

10. Alfi oli tietyössä [Pyssyjoven ja Lemmijoven välilä].

'Alf var på vegarbeid mellom Børselv og Lakselv.'

11. Tule huomena [minun tyköt]!

'Kom til meg i morgen!'

Relativ posisjon uttrykkes også med sammensatte preposisjoner som har puolela, puolelta eller puolele(t) som etterledd, for eksempel ulkopuolela ('utapå, utafor, på utsida'), alapuolela ('nedafor, på nedsida'), ylipuolela ('ovafor, på oversida'), i(đ)änpuolela ('på austsida'), vestapuolela ('på vestsida') (12-14). Disse tar alle utfylling i partitiv.

12. Matti assuu [ylipuolela tietä].

'Mats bor på oversida av vegen.'

13. Zlata siirtyi [iđänpuolele rajjaa].

'Zlata flytta til austsida av grensa'

14. Matti oli lähtösin [lännenpuolelta väylää].

'Mats kom fra vestsida av elva' 


\subsubsection{Avstand, opphold og bevegelse}

Stedsadposisjonsfraser kan også uttrykke avstand $(1-8,13,14)$ og opphold eller bevegelse i forhold til stedet som utfyllinga refererer til (9-12). Til denne gruppa hører adposisjoner som likelä ('nær, i næreheta av') : likeltä : likele(t), liki(t) ('nær, i nærheta av'), likempännä : likemp(p)ää : likemäksi, lähelä ('i nærheta av') : läheltä : lähele(t), keskelä ('midt i / på) : keskeltä : keskele $(t)$, läpi(t) läpitte ('gjennom'), ympäri(t) ('omkring, rundt') og päässä ('på avstand'). Bortsett fra päässä er disse alle preposisjoner. Preposisjonene likelä : likeltä : likele $(t)$, liki( $(t)$, likempännä : likemp(p)ää : likemäksi, lähelä : läheltä : lähele $(t)$, keskelä : keskeltä : keskele $(t)$ tar kun partitivutfylling (1-8), läpi(t) läpitte tar genitivutfylling (9, 10), mens ympäri $(t)$ kan ta både partitiv- og genitivutfylling $(11,12)$. Når utfyllinga til preposisjonen ympäri $(t)$ står i partitiv, så innebærer det at bevegelsen er mer omtrentlig ('rundt omkring'). Når utfyllinga står i genitiv, så vil det si at noen eller noe beveger seg rundt et sted i mer bokstavelig betydning.

1. Kirkkoniemi oon [liki Ryssän rajjaa].

'Kirkenes ligger nær russegrensa.'

2. Mie olisin tykäny assuut [likempännä kotipaikkaa].

'Jeg ville ha likt å bo nærmere heimplassen.'

3. Met meinaama pykätä [lähele Kirkkoniemiä].

'Vi har planer om å bygge nær Kirkenes.'

4. Se häyttyy pittäät kielen [keskelä suuta].

'Man må holde tunga rett i munnen.'

5. Koulun pykäthiin [keskelet kyllää].

'Skolen bygdes midt i bygda.'

6. Mie halluisin assuut [liki meren ranttaa].

'Jeg skulle ønske å bo nær havstranda.'

7. Viimen het tulthiin [likit kotipaikkaa].

'Til slutt kom de til nærheta av heimplassen.'

8. Olavi oon sieltä [liki Ryssän rajjaa].

'Olav kommer fra nærheta av russegrensa.'

9. Kissa haki hiirtä [läpi joka loman].

'Katten leita etter mus igjennom alle romma.' 
10. Turskaa saapi [läpit vuonon] tästä.

'Her får man torsk ut gjennom heile fjorden.'

11. Kissa laukkoi [ympäri siljoo siljon].

'Katten sprang rundt omkring på / rundt gårdsplassen.'

12. Het kuljethiin [ympärit Ruijaa $\sim$ Ruijan].

'De kjørte rundt omkring i Norge. / De kjørte Norge rundt.'

likelä : likeltä : likele $(t)$ er både preposisjon og postposisjon $(13,14)$. Som postposisjon tar det genitivutfylling, som preposisjon tar det partitivutfylling. Det er ingen betydningsforskjell mellom de to bruksmåtene.

13. Älä tule [minun likelet] [likelet minua]!

'Ikke kom nær meg!'

14. Ragna oon lähtöisin [Perunan likeltä] [likeltä Perunaa].

'Ragna kommer fra nærheta av Bergen.'

Postposisjonen päässä : päästä : päähän uttrykker konkret avstand, det vil si hvor langt borte noe er fra noe. Denne postposisjonen tar alltid genitivutfylling (15-17).

15. Pekka assuu tuola [muutaman kilumeetterin päässä].

'Peder bor noen kilometer lenger der borte.'

16. Mie freistasin osata moolhiin [sađan meetterin päästä].

'Jeg forsøkte å treffe målet fra hundre meters avstand.'

17. Maija viskas pallon [kymmenen meetterin päähän].

'Maja kasta ballen ti meter bortover.'

\subsubsection{Retning}

For å uttrykke retning kan vi bruke adposisjonene vasten ('mot'), vasthaan (' $\mathrm{i}$ retning av, mot') og kohti kohdi ('mot'), som alle tar partitivutfylling. To av dem, vasten og vasthaan, er postposisjoner (1-4), mens kohti kohdi er preposisjon $(5,6)$. Forskjellen mellom postposisjonene vasten og vasthaan, som begge kan oversettes med 'mot', er at vasten for det meste brukes om retning bort fra subjektet eller objektet $(1,2)$, mens vasthaan uttrykker retning mot subjektet eller objektet $(3,4)$. Preposisjonen kohti kohdi $(5,6)$ betyr mye det samme som postposisjonen vasthaan. 
1. Minun kotipaikka oon kaheksan kilumeetteriä Yykeänmuotkasta tuone [Tromssaa vasten].

'Heimplassen min ligger åtte kilometer fra Lyngseidet i retning av Tromsø.'

2. Mie olin ajanu jo monta miilaa [Kaarasjokkee vasten].

'Jeg hadde allerede kjørt mange mil mot Karasjok.'

3. Ko tulema kothiin, se tasan koira laukkoo [meitä vasthaan].

'Når vi kommer heim, så kommer alltid hunden springende mot oss.'

4. Karhu hyökkäs vihaisenna [miehii vasthaan].

'Bjørnen gikk sint til angrep mot mennene.'

5. Pyssy oli oikaistu [kohđi heitä].

'Børsa var retta mot dem.

6. Heti lennämä [kohti taivasta].

'Straks flyr vi mot himmelen.'

Ei slags retning uttrykker også preposisjonen poikki( $t$ ) ('på andre sida av, tvers over'), som tar genitivutfylling $(7,8)$. Preposisjonen forteller at noe, fra talerens synsvinkel, ligger på andre sida av noe.

7. Kruunsta oon tuola [poikki joen] (= joven toisela puolela).

'Kronstad ligger der tvers over elva.'

8. Kreeta assuu tuossa [poikki tien] (= toisela puolela tietä).

'Greta bor der tvers over vegen.'

\subsubsection{Ferdselsrute eller farlei}

Følgende adposisjoner uttrykker ferdselsrute eller farlei: läpi $(t)$ läpitte ('gjennom'), poikki( $t$ ) ('tvers over; gjennom'), siu(t) sivvu siutti( $t$ ) ('forbi'), kautta ('gjennom, om, via'), myöten myöđen ('langs'), pitkin ('langs') og yli(t) ylitte ('over'). Av disse er myöten myöđen postposisjon $(1,2)$ og pitkin er preposisjon (3), men begge tar partitivutfylling. Også poikki $(t)$ og $y l i(t) \sim$ ylitte er preposisjoner, men de tar genitivutfylling (4-7). Både $\operatorname{siu}(t) \sim \operatorname{sivvu} \sim \operatorname{siutti}(t)$ og kautta er postposisjoner som tar genitivutfylling $(8-10)$, mens läpi $(t) \sim$ läpitte brukes både som postposisjon og preposisjon, og det tar alltid genitivutfylling $(11,12)$.

1. Posti kulki laivala [merta myöten].

'Posten blei frakta i båt over sjøen.' 
2. Lääkit sanothaan ette pittää [trappui myöđen] käyđä.

'Legene sier at man bør ta trappene.'

3. Siitä se lähti [pitkin tietä] laukkomhaan.

'Der dro han/hun/den/det springende av gårde langs vegen.'

4. Ei saanu viinaa tuua [yli rajan].

'Man fikk ikke ha med seg sprit over grensa'

5. Mie olen kuitenki yhen reisun kesän aikana menny käyen [ylit tunturin]. 'Jeg har i hvert fall gått én tur til fots over vidda i sommer'.

6. Opetuslapset menit [poikkit Kuolheenmeren].

'Disiplene gikk tvers over Dødehavet.'

7. Yhđen puun oli kaađettu [poikki joven].

'Et tre var falt ned tvers over elva.'

8. Rairhoon menthiin [Trollijärven siut].

'På veg til Kviby gikk man forbi Trollvannet.'

9. Pykejästa mennee [Näätämön siutti] tie [ylitte tunturitten] tuone Sotankylhään.

'Fra Bugøynes går det veg forbi Neiden og over vidda dit til Sodankylä.'

10. Net tulit [Inarin kautta] Reisivuonhoon poroila.

'De kom med reinsdyr via Enare til Bugøyfjord.'

11. Net porot kuljit [läpitte kentitten].

'Reinsdyra gikk gjennom marka.'

12. Met menimä [jään läpi].

'Vi gikk gjennom isen.'

\subsubsection{Kasus i stedsadposisjonsfraser}

Som vist ovafor finner vi blant stedsadposisjonene som uttrykker relativ posisjon, mest postposisjoner som tar genitivutfylling. Adposisjoner som uttrykker avstand, er derimot oftest preposisjoner som tar utfylling i partitiv. Hos adposisjonene som uttrykker ferdselsrute eller farlei, finner vi begge disse typene. Men det fins også stedspostposisjoner som tar partitivutfylling, og stedspreposisjoner som tar genitivutfylling. 
Tabell 10.1 oppsummerer hvilken funksjon de ulike stedsadposisjonene har, og hvilken kasus de styrer.

Tabell 10.1 Kasus i stedsadposisjonsfraser

\begin{tabular}{|c|c|c|c|c|}
\hline \multirow[t]{2}{*}{ Funksjon } & \multicolumn{2}{|c|}{ Postposisjoner } & \multicolumn{2}{|c|}{ Preposisjoner } \\
\hline & Genitiv & Partitiv & Genitiv & Partitiv \\
\hline $\begin{array}{l}\text { Relativ } \\
\text { posisjon } \\
(10.1 .1)\end{array}$ & $\begin{array}{l}\text { alla : alta : alle(t), e(đ) } \\
\text { essä : e(đ)estä : } \\
\text { etheen, päälä : päältä : } \\
\text { pääle(t), takana : } \\
\text { takkaa : taka(t), tykönä } \\
\text { : tykköö tyköä : } \\
\text { tykö(t), vieressä : } \\
\text { vierestä : vierheen, } \\
\text { syrjässä : syrjästä : } \\
\text { syrjhään, perässä } \\
\text { pörässä : perästä } \\
\text { pörästä : perhään } \\
\text { pörhään, sisälä : sisältä } \\
\text { : sisäle(t), välissä : } \\
\text { välistä : välhiin, välilä : } \\
\text { väliltä : välile(t), } \\
\text { ympäri(t) }\end{array}$ & & & $\begin{array}{l}\text {-puolela : } \\
\text {-puolelta : } \\
\text {-puolheen }\end{array}$ \\
\hline $\begin{array}{l}\text { Avstand, } \\
\text { opphold og } \\
\text { bevegelse } \\
(10.1 .2)\end{array}$ & $\begin{array}{l}\text { likelä : likeltä : likele(t), } \\
\text { päässä : päästä : } \\
\text { päähän }\end{array}$ & & $\begin{array}{l}\text { läpi(t) läpitte, } \\
\text { ympäri(t) }\end{array}$ & $\begin{array}{l}\text { likelä : likeltä : } \\
\text { likele(t), liki(t), } \\
\text { likempännä : } \\
\text { likemp(p)ää : } \\
\text { likemäksi, lähelä : } \\
\text { läheltä : lähele(t), } \\
\text { keskelä : keskeltä : } \\
\text { keskele(t), ympäri(t) }\end{array}$ \\
\hline $\begin{array}{l}\text { Retning } \\
(10.1 .3)\end{array}$ & & $\begin{array}{l}\text { vasten, } \\
\text { vasthaan }\end{array}$ & poikki(t) & kohti kohđi \\
\hline $\begin{array}{l}\text { Ferdselsrute } \\
\text { eller farlei } \\
\text { (10.1.4) }\end{array}$ & $\begin{array}{l}\text { läpi(t) läpitte, sivvu } \\
\text { siu(t) siutti(t), kautta }\end{array}$ & $\begin{array}{l}\text { myöten } \\
\text { myöđen }\end{array}$ & $\begin{array}{l}\text { läpi(t) läpitte, } \\
\text { poikki(t), yli(t) ylitte }\end{array}$ & pitkin \\
\hline
\end{tabular}

\subsection{Tidsadposisjoner}

Tidsadposisjonene i kvensk er delvis de samme som stedsadposisjonene. Vi deler dem her inn i fire semantiske grupper basert på hva slags tidsforhold de uttrykker. Tidsforholda kan være klokkeslett (1), at hendelsestidspunktet er innafor (2) eller utafor (3) tidsrommet som er uttrykt i utfyllinga, eller at hendelsen varer i heile tidsrommet som er uttrykt i utfyllinga (4). 
1. Vasta neljän aikana pääsimä lähtemhään kotia.

'Vi fikk ikke dratt heim før i firetida'.

2. Sođan alussa met asuima vielä kotona.

'I begynnelsen av krigen bodde vi fortsatt heime.'

3. Sääsket ei vielä kiussaa ennen heinää.

'Myggene er ikke plagsomme enda før høyonna.'

4. Kesän aikana met asuima tunturissa.

'Sommerstid brukte vi å bo på vidda.'

En og samme adposisjon kan stundom brukes i ulike funksjoner, som for eksempel aikana i setningene ovafor $(1,4)$.

\subsubsection{Klokkeslett}

For å uttrykke ulike klokkeslett bruker vi adposisjonene aikana ('klokka'), aikhoin ('-tida'), vaila vaile(t) ('på) og yli(t) ylitte ('over'). Av disse er aikana postposisjon $(1,2)$, mens vaila $\sim$ vaile $(t)$ og yli $(t) \sim$ ylitte er preposisjoner (3, 4), og de tar alle utfylling i genitiv. Eksempler er:

1. Maija tuli kothiin yölä [kello kahđen aikana].

'Maja kom heim klokka to om natta.'

2. Murkina oon [puoli yhđen aikana].

'Det er middag klokka halv ett.'

3. Tooki lähtee [kvartin vaila/vaile $(t)$ kuuđen].

'Toget går kvart på seks.'

4. Perilä se oon [kvartin yli(t)/ylitte kymmenen].

'Det er framme kvart over ti.'

Postposisjonen aikhoin uttrykker omtrentlig klokkeslett, og den tar også genitivutfylling (5).

5. Fruukosti oon [yhđeksän aikhoin].

'Det er frokost i nitida.'

Disse klokkeslettfrasene likner på kvantorfraser (se avsnitt 10.5), og vi kunne ha behandla dem sammen med disse. Men vi har her likevel ønska å samle dem her sammen med de andre adposisjonsfrasene som uttrykker tidsrelasjoner. 


\subsubsection{Tidspunktet er innafor tidsrommet}

For å uttrykke at et tidspunkt ligger innafor tidsrommet som er spesifisert i utfyllinga, bruker vi adposisjoner som alussa ('i begynnelsen av'), kesken ('under, midt i, i løpet av'), keskelä ('midt i') : keskele(t), sisälä ('innafor, i løpet av'), lopula ('i slutten av'). Av disse er alussa, lopula og sisälä postposisjoner som tar genitivutfylling (1-3), mens kesken og keskelä : keskele $(t)$ er preposisjoner, der kesken tar utfylling i genitiv (4) og keskelä : keskele $(t) \mathrm{i}$ partitiv (5).

1. Matti kostui takaisin [päivän alussa].

'Mats kom tilbake ved daggry'.

2. [Soan lopula] met jou'uima evakueeratuksi.

'På slutten av krigen blei vi tvangsevakuert.'

3. Hän häytyi päättäät assiin [vuoden sisälä].

'Han måtte avgjøre saka i løpet av året.'

4. Lapsi nukatti [kesken syömisen].

'Barnet sovna av midt i måltidet.'

5. Se meni [keskele yötä] ennen ko mie sain nukutuksi.

'Det blei midnatt før jeg fikk sove.'

Sammensatte adposisjoner med puolheen som etterledd uttrykker også at et tidspunkt ligger innafor et gitt tidsrom, og de tar utfylling i partitiv $(6,7)$.

6. Lohenpyytö alkaa siinä [loppupuolheen tätä kuuta].

'Laksefisket begynner i siste delen av denne måneden.'

7. Mie nukattin vähän [aamupuolheen yötä].

'Jeg sovna litt på morgenkvisten.'

\subsubsection{Tidspunktet er utafor tidsrommet}

Det fins også adposisjonsfraser som uttrykker at noe skjer før eller etter tids-

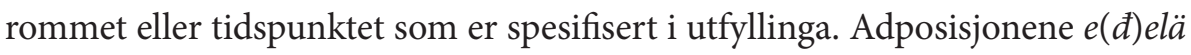
('før'), e(đ)eltä ('i forvegen'), ennen ('før, tidligere’) og vasten ('mot') uttrykker at noe har skjedd før et bestemt tidspunkt, mens jälkheen jälkhiin ('etter'), perästä pörästä ('etter'), päästä ('etter'), siu(t) siutte(t) sivvu ('etter, over'), 
$a i k(k) a a$ ('for ... sia') og taka(i)sin ('for ... sia') uttrykker at noe har skjedd på et tidspunkt som er passert. Av disse er e(đ)elä, perästä pörästä og päästä postposisjoner som tar utfylling i genitiv (1-3). Også vasten er postposisjon, men det tar partitivutfylling $(4,5)$. e(đ)eltä, jälkheen jälkhiin, siu $(t) \sim \operatorname{siutte}(t) \sim$ sivvu og ennen er preposisjoner, der ennen (6) tar utfylling i partitiv, og de andre i genitiv (7-10). Både aik(k)aa og taka(i)sin er postposisjoner, og de skiller seg fra vanlige adposisjoner ved at de alltid tar utfylling i nominativ (11).

1. Koulu loppuu juunikuussa [juhaneksen eelä].

'Skolen slutter i juni før sankthans.'

2. [Lihaviitten vuossiin pörästä] tuli seittemen laihaa vuotta.

'Etter sju feite år kom det sju magre (år).'

3. Siitä hommasta sai palkan vasta [vuođen päästä].

'Man fikk ikke lønn for det arbeidet før etter et år.'

4. Ämmi tuli kothiin [yötä vasten].

'Bestemor kom heim seint på kvelden.'

5. Fepruaarikuussa se mennee jo [näköistä vasten].

'I februar går det allerede mot lysere tider.'

6. Erkki kerkis leipomhaan jo [ennen murkinaa].

'Erik rakk å bake ferdig allerede før middag.'

7. Se oon tapahtunnu jo [eeltä minun].

'Det har skjedd allerede før mi tid.'

8. Lapset tulhaan kothiin [eđeltä joulun].

'Barna kommer heim før jul.'

9. [Jälkhiin juhaneksen] alkkaa jo pimenemhään.

'Etter sankthans begynner det allerede å bli mørkere.'

10. Kello oon jo [sivvu keskipäivän].

'Klokka har allerede passert middag.'

11. Muori kuoli [kuukausi aikkaa/takaisin].

'Mor døde for en måned sia.'

Til denne gruppa hører også postposisjonen ympärillä, som tar utfylling i genitiv (12). 
12. Se tullee etelässä lumi siinä [joulun ympärillä].

'Det kommer snø sørpå rundt juletider.'

\subsubsection{Tidspunktet dekker heile tidsrommet}

Noen adposisjonsfraser dekker heile tidsrommet som er spesifisert i utfyllinga. Eksempler på slike adposisjoner er aikana aikhaan ('i/under'), alla ('under'), päähän ('framover'), välissä ('mellom'), myöten myöđen ('mens, med tida, etter hvert'), ympäri( $t$ ) ('rundt'), läpi(t) läpitte ('gjennom'), yli(t) ylitte ('over') og pitkin ('langs'). Av disse er aikana aikhaan, alla, päähän, välissä og myöten myöđen postposisjoner, der myöten myöđen tar utfylling i partitiv $(5,6)$, og de andre i genitiv $(1-4)$. De andre, det vil si ympäri $(t)$, läpi $(t) \sim$ läpitte, $y l i(t) \sim y l i t t e$ og pitkin er preposisjoner, der pitkin tar utfylling i partitiv (11), og de andre i genitiv ( $7,9,10,11)$. Preposisjonen ympäri $(t)$ avviker litt fra dette mønsteret: Når utfyllinga her er i flertall, så står den i nominativ (8).

1. Se oli raskas työ [meän aikana].

'Det var tungt arbeid i vår tid.'

2. Net tehthiin varkhautta [punnituksen ja mittauksen alla].

'De begikk tyveri under veiinga og målinga'.

3. Tämä laina oon [kolmenkymmenen vuođen päähän].

'Dette lånet gjelder i tretti år framover.'

4. [Kahđen sođan välissä] oli oikhein huono aika.

'Det var ei svært vanskelig tid mellom de to krigene.'

5. Sitä pyssyy häyttyy laađata [sitä myöđen ko sillä ammuthaan].

'Børsa må lades etter hvert som man skyter.'

6. [Aikaa myöten] Annasta tuli paksumpi ette paksumpi.

'Etter hvert som tida gikk, blei Anna tjukkere og tjukkere.'

7. Muori ja faari asuthaan Spaaniassa [ympäri vuođen].

'Mor og far bor i Spania året rundt.'

8. Net pyyethään [ympäri vuoet] sielä meren aavassa.

'De fisker året rundt på storhavet.' 
9. Met olema puhunheet kainuu [läpi aikkain].

'Vi har snakka kvensk oppigjennom tidene.'

10. Laiva seisoi siinä [yli maailmansođan].

'Båten lå der til over krigen.'

11. Verkoila saapi pyytää [pitkin kessää].

'Man får fiske med garn heile sommeren.'

\subsubsection{Kasus i tidsadposisjonsfraser}

Tidsadposisjonene er oppsummert i tabell 10.2. Det er vanskelig å gi noen generelle regler for når en tidsrelasjon er uttrykt gjennom en preposisjon og når som postposisjon, eller regler for hvilken kasus de styrer. De to postposisjonene taka(i)sin og aik(k)aa skiller seg ut ved at de tar utfylling i nominativ. Det samme gjelder preposisjonen ympäri( $t)$, men bare når utfyllinga står i flertall.

Tabell 10.2 Kasus i tidsadposisjoner

\begin{tabular}{|c|c|c|c|c|c|c|}
\hline \multirow[t]{2}{*}{ Funksjon } & \multicolumn{3}{|c|}{ Postposisjoner } & \multicolumn{3}{|c|}{ Preposisjoner } \\
\hline & Genitiv & Partitiv & Nominativ & Genitiv & Partitiv & Nominativ \\
\hline $\begin{array}{l}\text { Klokkeslett } \\
\text { (10.2.1) }\end{array}$ & $\begin{array}{l}\text { aikana, } \\
\text { aikhoin }\end{array}$ & & & $\begin{array}{l}\text { vaila, yli(t) } \\
\text { ylitte }\end{array}$ & & \\
\hline $\begin{array}{l}\text { Tidspunktet } \\
\text { er innafor } \\
\text { tidsrommet } \\
(10.2 .2)\end{array}$ & $\begin{array}{l}\text { alussa, } \\
\text { lopula }\end{array}$ & & & kesken & $\begin{array}{l}\text { keskelä : } \\
\text { keskele(t), } \\
\text {-puolheen }\end{array}$ & \\
\hline $\begin{array}{l}\text { Tidspunktet } \\
\text { er utafor } \\
\text { tidsrommet } \\
\text { 10.2.3) }\end{array}$ & $\begin{array}{l}\text { e(đ)elä, } \\
\text { perästä } \\
\text { pörästä, } \\
\text { päästä, } \\
\text { ympärillä }\end{array}$ & vasten & $\begin{array}{l}\text { taka(i)sin, } \\
\text { aik(k)aa }\end{array}$ & $\begin{array}{l}\text { e(đ)eltä, } \\
\text { jälkheen } \\
\text { jälkhiin, siu(t) } \\
\sim \operatorname{siutte(t)~~} \\
\text { sivvu }\end{array}$ & ennen & \\
\hline $\begin{array}{l}\text { Tidspunktet } \\
\text { dekker heile } \\
\text { tidsrommet } \\
(10.2 .4)\end{array}$ & $\begin{array}{l}\text { aikana } \\
\text { aikhaan, } \\
\text { alla, alusta, } \\
\text { välissä, } \\
\text { päähän, } \\
\text { sisälä }\end{array}$ & $\begin{array}{l}\text { myöten } \\
\text { myöđen }\end{array}$ & & $\begin{array}{l}\text { läpi(t) } \\
\text { läpitte, yli(t) } \\
\text { ylitte, } \\
\text { ympäri(t) } \\
\text { (singulaarissa) }\end{array}$ & pitkin & $\begin{array}{l}\text { ympäri(t) } \\
\text { (pluraalissa) }\end{array}$ \\
\hline
\end{tabular}




\subsection{Måtesadposisjoner}

I tillegg til egentlige MÅTESADPOSISJONER omtaler vi her også såkalte instrumentelle, komitative og abessive adposisjoner. Felles for instrumentelle, komitative og abessive adposisjonsfraser er at de forteller at noen er eller gjør noe sammen med eller med hjelp av noen andre eller noe anna, eller at de er eller gjør noe uten eller uten hjelp av noen andre eller noe anna.

\subsubsection{Instrumentelle adposisjoner}

INSTRUMENTELLE ADPOSISJONSFRASER uttrykker redskapet, grepet eller teknikken som ei handling skjer med hjelp av. Eksempler på slike adposisjoner er avula ('med hjelp av'), kans(a) ('med'), läpi(t) läpitte ('gjennom') ja kautta ('gjennom, om, via'). Disse er alle postposisjoner som tar utfylling i genitiv. Postposisjonene avula og kans(a) forteller hva slags grep eller hjelpemiddel som er brukt for å utføre handlinga (1-3), mens läpi(t) läpitte og kautta betegner grepet eller hjelpemiddelet som er brukt for å oppnå det resultatet eller målet som er uttrykt i setninga (4-8).

1. Kyrre ei halluu kävelä [krykitten avula].

'Kyrre vil ikke gå med krykker.'

2. Jokku tulthiin markkinhaan [porroin kans] ja jokku [hevosten kans].

'Noen kom til markedsplassen/kirkestedet med reinsdyr, og noen med hest.'

3. Taavetti vaihetti ittelensä jauhoo [kalloin kans].

'David bytta til seg mjøl mot fisk.'

4. Ei net kirjoiteta, net puhelhaan tyhä [telefoonin läpit].

'De skriver ikke til hverandre, de snakker bare med hverandre på telefon.'

5. Mikhään ei menesty, jos assiita ei ota [politiikkeriitten läpi].

'Det skjer ikke noe viss man ikke tar opp sakene med politikerne.'

6. Knuutti puhui kuninkhaan kansa [tulkin läpitte].

'Knut snakka med kongen gjennom en tolk.'

7. Vaphaus tuli meile [Ryssän sotilhaitten kautta].

'Friheta kom til oss gjennom russiske soldater.' 
8. Rahhaa saathiin tyhä [raskhaan työn kautta].

'Penger fikk man bare gjennom tungt arbeid.'

\subsubsection{Komitative adposisjoner}

Komitative ADPOSISJONSFRASER forteller hvem eller hva som er med i ei handling. Det er adposisjoner som kans(a) ('sammen med'), myötä ('med'), kesken ('blant'), seurassa ('med, i'), vierheen ('ved sida av'), pääle( $t$ ) ('i tillegg til'). Disse er alle postposisjoner som tar utfylling i genitiv. Postposisjonene kans (a) og myötä er delvis synonyme, men kans(a) betegner mest et resiprokt forhold mellom subjekt eller objekt og utfylling (1-3), mens myötä forteller at subjektet eller objektet følger den eller dem som er uttrykt i utfyllinga $(4,5)$.

1. Lapin ihmiset kauppaava sielä [suomalaisten kansa].

'Samene bruker å drive handel med finlendere der'.

2. Leena meni vihile [sen Pykejän pojan kansa].

'Lena blei via med den gutten fra Bugøynes.'

3. Net oon neppaimet [minun miehen kans].

'De/Han/Hun er søskenbarn til mannen min.'

4. Muori sanoi, ette [sen pojan myötä] sie et saa lähtiit.

'Mor sa at med den gutten får du ikke dra'.

5. Isäntä lähti aaphaan ja otti venheen [ittensä myötä].

'Husbonden dro på havet og tok med seg båten sin.'

Postposisjonsfraser med kesken betegner alltid et resiprokt forhold $(6,7)$.

6. Met puhuima aina suomia, met [lasten kesken].

'Vi snakka alltid finsk oss unger imellom.'

7. [Kranniin kesken] oon sielä niin paljon torraa.

'Det er så mye krangling der mellom naboene.'

Postposisjonen seurassa $(8,9)$ har mye samme betydning som myötä.

8. [Jumalan lapsiin seurassa] Pekala oon hyvä olla.

'Peder trives godt sammen med Guds barn.'

9. Jussa ajoi [markkinaväen seurassa] yli tunturin Inarhiin.

'Johan kjørte sammen med markedsfolka over vidda til Enare.' 
Postposisjonsfrasene med vierheen og pä̈le $(t)$ forteller hva eller hvem som kommer i tillegg til subjektet eller objektet $(10,11)$.

10. Piđimä puoloi [lihan vierheen].

'Vi brukte tyttebær sammen med kjøttet.'

11. Karhuu tappoi vielä yhđen lehmän [niitten kahđen lamphaan pääle]. 'Bjørnen drepte enda ei ku i tillegg til de to sauene.'

\subsubsection{Abessive adposisjonsfraser}

Ordet ilman kunne vi med god grunn ha klassifisert som adverb, og ikke som adposisjon, i og med at det vanligvis opptrer med etterstilt nomen i abessiv (1-3):

1. [Ilman aamukaffitta] mie en kyllä tehe mithään.

'Uten morgenkaffe gjør jeg ingenting.'

2. Eiran faari oli niin köyhä, ette käveli talvelaki [ilman kengittä].

'Far til Eira var så fattig at han gikk uten sko også om vinteren.'

3. Mikkel otti kaapista ruokkaa [ilman luvatta].

'Mikkel tok mat ut av skapet uten lov'.

Ordet ilman kan utelates uten at setningene blir ugrammatiske. I stedet for (1) kan vi altså skrive (4)

4. Aamukaffitta mie en kyllä tehe mithään.

Men ilman kan også brukes med etterstilt utfylling i partitiv (5), og da fungerer ilman uten tvil som preposisjon ettersom vi ikke kan sløyfe det uten at setninga blir ugrammatisk (6).

5. [Ilman aamukaffii] mie en kyllä tehe mithään.

6. ${ }^{\star}$ Aamukaffi mie en kyllä tehe mithään.

Det vanligste er likevel å bruke en abessivfrase, det vil si preposisjonen ilman med utfylling i abessiv.

Ei anna særegenhet ved ilman er at det ofte tar utfylling i form av 3. infinitivsformer $(7,8)$, men også i slike fraser kan vi sløyfe ilman $(9,10)$.

7. Niiltä oon kuolu kolme lasta [ilman kastamatta].

'De har mista tre barn uten at de var blitt døpt.' 
8. Oli niin tiheä ruto, ette ei läpit päässyt [ilman karsimatta].

'Det var så tett småskog at man ikke kom seg fram uten å kviste.'

9. Niiltä oli kuolu kolme lasta kastamatta.

10. Oli niin tiheä ruto, ette ei läpit päässyt karsimatta.

Men det vanlige er likevel å ha med ordet ilman også i slike abessivfraser.

Når utfyllinga til ilman er et demonstrativt pronomen (tämä, tuo, se, nämät, nuot, net), så står det i partitiv (11) ettersom disse pronomena mangler abessivformer.

11. Aamukaffi oon niin tärkkee, ette [ilman sitä] mie en tehe mithään.

'Morgenkaffen er så pass viktig at uten den så gjør jeg ingenting.'

\subsubsection{Egentlige måtesadposisjoner}

Egentlige måtesadposisjoner uttrykker andre måter ei handling kan gjøres på enn instrumentelle (se avsnitt 10.3.1). Eksempler på slike adposisjoner er jälkhiin jälkheen ('etter'), läpi(t) läpitte ('gjennom'), myöten myöđen ('langs'), pääle(t) ('på), päältä ('ut over') og vasto(i)n ('imot'). Av disse er jälkhiin jälkheen, läpi $(t) \sim$ läpitte og pääle $(t)$ postposisjoner som tar utfylling i genitiv (1-9).

1. Heinänteko oon [sen jälkheen kunka heinä oon kasvanu].

'Høyonna blir alt etter som hvordan gresset har grodd.'

2. Suomalaiset kuukauđen nimet oon enämpi [luonnon jälkhiin].

'De finske månedsnavna er mer etter naturens gang.'

3. Mie en maksa verroo [sen tienestin jälkheen mikä mulle oon räknätty].

'Jeg betaler ikke skatt etter den inntekta som er blitt regna ut for meg.'

4. Ei se piđä elläät [lihan jälkhiin], mutta [hengen jälkhiin].

'Vi må ikke leve etter kjødet, men etter ånden'.

5. Kaikki pittää [kellon jälkheen] mennä.

'Alt skal gå etter klokka'.

6. Kyllä mie tiiän, ettei se kaikki menny [sinun mielen jälkheen].

'Jeg veit nok at ikke alt gikk etter ditt ønske.'

7. Ei ihminen halua aivan [piinan läpit] elläät, kitumalla.

'Mennesket vil ikke leve i pine med livet så vidt i behold.' 
8. Et sie tarvitte nyt aivan [kellon päälet] tulla.

'Du behøver nå ikke å komme heilt på slaget.'

9. Se mies oli Suomesta ja sillä se puhui [minän päältä].

'Mannen var fra Finland og brukte derfor ordet minä ('jeg’).'

Myöten myöđen er en postposisjon som tar partitivutfylling (10, 11), og vasto(i)n er en preposisjon som tar partitivutfylling (12).

10. Viimen se sai sen [mieliänsä myöten] tehtyksi.

'Til slutt så fikk han/hun det gjort etter ønsket sitt'.

11. Pekka vajos [polvii myöđen] jänkkhään.

'Peder sank langs opp til knærne ned i myra.'

12. Hän piti lähteet Koutokeinhoon [vastoin ittensä tahtoo].

'Han var nødt til å dra til Kautokeino mot sin vilje.'

\subsubsection{Kasus i måtesadposisjonsfraser}

Nesten alle måtesadposisjonene i kvensk er postposisjoner som tar utfylling i genitiv. Som måtesadposisjon har vi her også regna preposisjonen ilman, som det også er vanlig å bruke med utfylling i abessiv. Men slike abessivfraser fungerer også uten preposisjonen ilman, og i de tilfella kan vi ekskludere det fra adposisjonsklassen.

Tabell 10.3 oppsummerer de ulike måtesadposisjonene og hvilken kasus de styrer.

Tabell 10.3 Kasus i måtesadposisjoner

\begin{tabular}{|c|c|c|c|c|c|}
\hline \multirow[t]{2}{*}{ Funksjon } & \multicolumn{2}{|c|}{ Postposisjoner } & \multicolumn{3}{|c|}{ Preposisjoner } \\
\hline & Genitiv & Partitiv & Genitiv & Partitiv & Abessiv \\
\hline $\begin{array}{l}\text { Instrumentelle } \\
\text { (10.3.1) }\end{array}$ & $\begin{array}{l}\text { avula, kans(a), läpi(t) } \\
\text { läpitte, kautta }\end{array}$ & & & & \\
\hline $\begin{array}{l}\text { Komitative } \\
(10.3 .2)\end{array}$ & $\begin{array}{l}\text { kans(a), myötä, kesken, } \\
\text { seurassa, vierheen, } \\
\text { pääle(t) }\end{array}$ & & & & \\
\hline $\begin{array}{l}\text { Abessive } \\
(10.3 .3)\end{array}$ & & & & ilman & ilman \\
\hline $\begin{array}{l}\text { Egentlige } \\
(10.3 .4)\end{array}$ & $\begin{array}{l}\text { jälkhiin jälkheen, läpi(t), } \\
\text { pääle(t), päältä }\end{array}$ & $\begin{array}{l}\text { myöten } \\
\text { myöđen }\end{array}$ & & vasto(i)n & \\
\hline
\end{tabular}




\section{4 Årsaksadposisjoner}

Årsaksadposisjonsfraser bruker vi i svar på spørsmål om hvorfor (miksi?, minkä tähđen?, millä argumentila?, mitä/ketä vasten?). I denne gruppa finner vi postposisjonene takkii takia ('for, på grunn av'), täh(đ)en ('for, på grunn av'), pääle(t) ('på), kautta ('med, gjennom'), e(đ)estä ('for ... skyld'), som alle tar utfylling i genitiv (1-10), og preposisjonene varten og vasten, som tar utfylling i partitiv (11-14). Postposisjonene takkii takia og tähđen er nesten alltid synonyme og kan byttes ut med hverandre (1-6). Spørrekonstruksjonene minkä takkii takia og minkä täh(đ)en ('av hvilken grunn') brukes som regel på samme vis som spørreadverbet miksi ('hvorfor').

1. [Minkähän takkii/tähđen] net materiäijät tulthiin tänne näin kauvas pohjaisheen?

'Mon tru hvorfor forfedrene våre kom opp hit så langt nord?'

2. [Pommituksen takia] meile ei jääny mithään omaisuutta.

'På grunn av bombinga hadde vi ikke noen eiendom igjen.'

3. Net siirythiin [lasten takia], ko net alkava koulhuun.

'De flytta på grunn av barna, fordi de begynner på skolen.'

4. [Kirkon tähđen] täälä ei ollu ollenkhaan tanssii.

'På grunn av kirka var ikke noe dans her i det heile tatt.'

5. [Ryöväriitten tähđen] mie en ollenkhaan tohđi liikkuut ulkona pimmeelä.

'På grunn av røvere/røverne tør jeg ikke å ferdes ute i mørket i det heile tatt.'

6. Kyllä nyt vanhiimet hävethään [meiđän tähđen].

'Nå skjemmes nok foreldrene på grunn av oss.'

Postposisjonene pääle(t), kautta og e(d)estä betyr mye det samme (7-10).

7. [Tau'in kautta] meile tuli köyhyys.

'På grunn av sjukdommen kom også fattigdommen til oss'.

8. Paljon net oon täälä [kalastuksenki pääle] rustanheet.

'De har her basert seg mye også på fisket.'

9. Ihmiset pajethaan sieltä [hengen eđestä].

'Folk flykter derfra for livet.' 
10. Hän antoi hengen [meiđän eđestä].

'Han/Hun ga sitt liv for oss / for vår skyld.'

Preposisjonene varten og vasten (11-14) er nærmest synonyme, men vasten brukes nesten bare i spørrefrasen mitä vasten (11) og i frasen sitä vasten (12). Ofte er varten også brukt synonymt med postposisjonene takkii takia og tähden $(12,13)$. Men det er ikke alltid de kan brukes om hverandre $(14,15)$.

11. [Mitä vasten] sie minun petit?

'Hvorfor bedro du meg?

12. Mie luulen ette suomen kieli oon säilyny [[sitä vasten] / [sitä varten] / [sen takkii takia] / [sen tähđen] ko sitä kuulthiin seuroissa].

'Jeg trur at finsken har overlevd her fordi man fikk høre det på forsamlingsmøta'

13. Marja lähti [[sitä varten] / [sitä vasten] / [sen takkii takia] / [sen tähđen] että päässee kotia].

'Maria dro av gårde for at hun skulle komme seg heim.'

14. Mie kyllä olen kovonu sienii [syömistä varten].

'Jeg har plukka sopp som matauk.'

15. Siinä oon [öljyä varten] tehty värvi ja pykätty muutaki.

'Det er blitt bygd verft og andre ting der på grunn av olja/oljevirksomheta.'

\subsection{Adposisjoner i kvantorfraser}

Som del av KVANTORFRASER brukes adposisjonene e(d)estä ('for; tilsvarende'), keskelä ('mellom'), kohti kohđi ('for; mot'), vaila vaile( $t$ ) ('under; unna'), välilä ('mellom') og yli(t) ylitte ('over'). Av disse er e(đ)estä og välilä postposisjoner som tar utfylling i genitiv (6-9), kohti kohdi er postposisjon som tar partitivutfylling $(10,11)$, keskelä, vaila vaile $(t)$ og yli $(t)$ er alle preposisjoner, og de tar utfylling i genitiv (1-4), bortsett fra keskelä, som tar partitivutfylling (5).

Preposisjonene $y l i(t) \sim y$ litte og vaila $\sim$ vaile $(t)$ uttrykker relativ mengde, det vil si at det er henholdsvis mer eller mindre av noe enn den mengden som er uttrykt i utfyllinga (1-4). Når nomenet som betegner gjenstanden for mengdejamføringa, er del av kvantorfrasen, så står det i partitiv; jf. substantivet 
korttelii ('mål') i (1). Relativ mengde i kvantorfraser kan også modifiseres med hjelp av et mengdeadverb; jf. vähäsen i (2).

1. Pekka oon [korttelii vaila kahđen meetterin].

'Peder er et kvarter (= ca. $15 \mathrm{~cm}$ ) lågere enn to meter'.

2. Se lohi painoi kuitenki [vähäsen vailet kymmenen kilon].

'Laksen veide i hvert fall litt under ti kilo.'

3. Erkki oli jo viipyny reisussa [yli vuođen].

'Erik hadde allerede vært bortreist i over et år.'

4. Tänne ja Alattihoon tarvittais heinääki [ylitte kymmenen tonnin].

'Her og i Alta skulle folk trenge over ti tonn med høy også.'

Adposisjonene keskelä og välilä tar to parallelle utfyllinger $(5,6)$.

5. Kyllä se maksaa [keskelä kolmee ja neljää tuhatta].

'Den/Det koster nok mellom tre og fire tusen.'

6. Se oon [kymmenen ja kahentoista peninkulman välilä] tämä vuono.

'Denne fjorden er på mellom ti og tolv mil.'

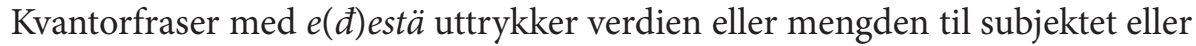
objektet (7-9). Kvantorfraser med kohti kohdi uttrykker hvor stor mengde som trengs for eller som går på et visst antall enheter $(10,11)$.

7. Mie sain kallaa [kymmenen tuhanen kruunun eđestä] yhđessä janturissa. 'Jeg fikk fisk til ti tusen kroner på ett døgn'

8. Ei sillon saanu sokkeriakhaan enämpi ko [kortin eestä].

'Den gangen fikk man heller ikke sukker mer enn tilsvarende (rasjonerings)kortet.'

9. Net myythiin oman talon [miljoonan eestä].

'De solgte huset sitt for en million.'

10. Sitä panthiin [kolmekymmentä kiloa suolaa [tynnyriä kohti]].

'Det gikk tretti kilo salt på ei tønne.'

11. Sanothaan, ette [niin monta kvatraattimeetteriä [itte kutaki henkiä kohti]] pittää olla huonheessa.

'Det sies at det bør være så og så mange kvadratmeter per person i huset / i et hus.' 


\subsection{Forholdsadposisjoner}

FORHOLDSADPOSISJONER utgjør ei ganske stor gruppe av adposisjoner som uttrykker ulike slags forhold mellom subjektet eller objektet og det som er spesifisert i utfyllinga. Det kan dreie seg om at noen er mot eller på samme eller motsatt side av noen andre, at noen eller noe beveger seg mot eller fra noen, eller andre typer relasjoner mellom to eller flere personer eller ting. I denne gruppa finner vi også JAMFøRINGSKONSTRUKSJONER som dannes med hjelp av adposisjoner.

Forholdsadposisjonene er alle postposisjoner. Følgende tar utfylling i genitiv: e(đ)estä ('for; mot'), kautta ('gjennom'), puolela ('på ... side, for') : puolele $(t)$ puolheen, puolelta ('med tanke på, i forhold til'), puolesta ('på vegne av'), sijassa ('i stedet for') : sijhaan, välilä ('mellom'), välissä ('mellom'), takana ('bak') : taka( $t$ ), alla ('under') : alta : alle $(t)$ og yli( $(t) \sim$ ylitte ('over'). Postposisjonene kohthaan ('mot'), vasten ('mot; til') og vasthaan ('mot') tar partitivutfylling. Vi skal se nærmere på dem i tur og orden etter hvilken betydning de har.

- Adposisjonsfraser med puolela : puolele $(t) \sim$ puolheen og vasthaan danner et motsetningspar, og de uttrykker at noen er henholdsvis mot eller for noen (1-6). Adposisjonsfraser med kohthaan likner på vasthaan-fraser, men de modifiserer alltid adjektivfraser $(7,8)$.

1. Net jokka olthiin [Alienden puolela] alethiin panemhaan vasthaan.

'De som var på Aliendes side, begynte å ytre motstand.'

2. Jokku olthiin [tyskäläisenki puolela].

'Noen var også på parti med tyskeren.'

3. Alattiolaiset luulthiin, ette het saava papin [heän puolelet $\sim$ puolheen].

'Altaværingene trudde de skulle få presten med på sitt parti'.

4. Se oli yksi joka oli ollu sođassa [tyskäläistä vasthaan].

'Det var en som hadde vært med i krigen mot tyskerne.'

5. Semmoinen aksuneeraus oon kokonhansa [lakkii vasthaan].

'Ei slik aksjonering er fullstendig mot loven.'

6. Alattiola oon tääpänä jalkapallomatsi [Tromssaa vasthaan].

'Alta har fotballkamp mot Tromsø i dag'. 
7. Ämmi oon siivo [lapsia kohthaan].

'Bestemor er snill mot barna'

8. Natsit olthiin julmat [juutalaissii ja mustilaissii kohthaan].

'Nazistene var grusomme mot jøder og sigøynere'.

- Adposisjonsfraser med vasten forteller hvem eller hva noe er til eller gjøres for (9). De kan også uttrykke at noe er eller skjer mot viljen til noen (10), og da likner de på vasthaan-fraser. Også adposisjonsfraser med e(đ)estä og sijasta likner på hverandre, men mens $e(d) e s t \ddot{a}$-fraser uttrykker at en aktiv aktør gjør noe for noen eller noe $(11,12)$, så uttrykker vi med sijasta-fraser at noen eller noe kommer i stedet for noen andre eller noe anna (13). På liknende vis forteller sijassa-fraser at noen eller noe fungerer i stedet for eller erstatter noen andre eller noe anna $(14,15)$.

9. Mie tehin tämän tröijyn [sinnuu vasten].

'Jeg har laga denne trøya til deg.'

10. Semmoinen puhet oon aivan [minnuu vasten].

'Slik tale er heilt imot meg.'

11. Jotaki sitä pittää tehhä [paikan eestä].

'Noe må gjøres for stedet.'

12. Ole siivo ja vie sille skenkin [minun eđestä].

'Vær snill og ta med deg en gave til han/henne på mine vegne.'

13. Se pakkaa tulemhaan ruijan sana [kainun sijasta].

'Det blir lett til at man bruker et norsk ord i stedet for et kvensk.'

14. Joosef sanoi velimiehile, ette olenko mie sitte [Jumalan sijassa].

'Josef spurte brødrene sine om han var der i stedet for Gud.'

15. Nykyään oon traktorit [hevosten sijassa].

'Nå til dags brukes det traktorer i stedet for hester'.

- Adposisjonsfraser med välilä og välissä (16-19) krever minst to utfyllinger, og setninga forteller om forholdet mellom dem. De to eksempla på välilä-fraser vi har med her $(16,17)$, inngår i en slags eierskapssetninger/-fraser.

16. Siinä oon eroitus [suomen ja lapin välilä].

'Det er forskjell der mellom finsk og samisk'. 
17. [Suomen ja Norjan välilä] oon aina olheet hyvät välit. 'Det har alltid vært et godt forhold mellom Finland og Norge.'

18. Het puhuthiin sitte asian selväksi [heän välissä] het kaksi.

'De avklarte saka seg imellom, de to'

19. Se minun nuorempi sisar, mikä oli [meiđän välissä], oon jo kuolu.

'Den søstera som var yngre enn meg, og som var født mellom oss, er allerede død.'

Postposisjonen välissä brukes også i en slags eierskapskonstruksjon (20), på samme vis som i fraser med postposisjonen takana ('bak') : taka(t) $(21,22)$.

20. Varhemin ei ollu niin paljon rahhaa [ihmisten välissä].

'Før i tida var det ikke så mye penger blant folk.'

21. Se kontrahti jäi [lensmanin taka].

'Den kontrakten blei hos lensmannen.'

22. Muorila oon kaikki meiđän rahat [ittensä takana].

'Mor har alle pengene våre hos seg.'

- Postposisjonene alla ('under') : alta : alle $(t)$ og yli(t) ylitte ('over') (23-29) uttrykker hierarkiske forhold.

23. Ruija oli silloin Tanskan [kuninkhaan alla]. 'Norge var på den tida underlagt danskekongen.'

24. Net meinathiin, ette naisen kuuluu olla [miehen alla].

'De meinte at kvinna skulle være underordna mannen.'

25. Se oon pissiin aika, ko mie olen ollu [toisen ihmisen alla].

'Det er den lengste tida jeg har vært underordna en annen person.'

26. Suomi pääsi pois [Ruottin alta], mutta joutui [venäläisen alle].

'Finland blei fritt fra Sverige, men havna inn under Russland.'

27. Kyllä lästaatiolaisetki kuuluva [saman kirkon allet].

'Visst hører også læstadianere inn under samme kirke'

28. Faarao pani Joosefin koko [Egyptin ylit].

'Faraoen satte Josef som herre over heile Egypt.' 
29. Ei yhđen ihmisen piđä olla [toisen ihmisen yli].

'Et menneske bør ikke være overordna noe anna menneske.'

- Adposisjonsfraser med puolelta og kautta betyr mye det samme, og de brukes i setninger som forteller om opprinnelse $(30,31)$.

30. Hän oon [äitin puolelta] Inkilä mutta [isän puolelta] norjalainen.

'Han/Hun er av Inkilä-slekta gjennom morssida, men norsk gjennom farssida.'

31. Met olema kaikin suomen lähtöä [isän kautta].

'Vi er alle av finsk opphav gjennom farssida.'

- Adposisjonsfraser med puolesta og puolelta spesifiserer under hvilke forhold eller i hvilken forstand eller henseende setninga er sann (32-34). Postposisjonen suhtheen bruker vi når vi jamfører to eller flere ting (35-38).

32. Sođan jälkhiin olthiin mahđolisuuđet huonomat [varroin puolesta], ko tienestit olthiin huonot.

'Etter krigen var mulighetene verre når det gjaldt økonomien ettersom lønnene var så dårlige’'

33. Het pärjäthiin kyllä [vaatheitten puolesta] ja vielä [tervheyđen puolestaki], mutta ei [ruvan puolesta].

'De greide seg med klær og for så vidt med helsa, men ikke når det gjaldt maten.'

34. Nyt oon [elämän puoleltaki] parempi ko tähän oon tullu kalanostaja.

'Når det gjelder livet i si heilhet, så er situasjonen nå blitt bedre ettersom det er kommet fiskeoppkjøpere hit'

35. Meilä oon hyvä elämä täälä [entisen suhtheen].

'Vi har et godt liv her i forhold til før.'

36. Opettaajan työ oon helppo [kalastaajan työn suhtheen].

'Læreryrket er lett jamført med fiskeryrket'.

37. Maija oon kauhian hyvä puhumhaan suomia [sen suhtheen mitä meän tyttäret].

'Maja er fryktelig flink til å snakke finsk sammenlikna med døtrene våre.'

38. Paatsjoela oon paljon hilloja [sen suhtheen mitä meilä täälä].

'Det er mye moltebær i Pasvik sammenlikna med det vi har her.' 


\subsection{Ugjennomsiktige adposisjoner}

Ganske mange adposisjoner har en uklar semantisk motivasjon, og vi kaller dem for ugjennomsiktige eller tilslørte. En del av dem kan sies å være styrt på den måten av at visse verb eller nomen krever en viss type adposisjonsfrase som utfylling, men uten at det kan forklares ut fra betydninga til disse adposisjonene. Ofte er det også slik at slike adposisjonsfraser kan erstattes av en nomenfrase som står i en viss kasus. Men det er ikke alltid tilfellet.

Vi skal her ta for oss ulike typer av slike adposisjoner og hvordan de brukes. Det er her jamt over snakk om postposisjoner som tar utfylling i genitiv.

- alla : alle(t)

Postposisjonen alla : alle(t) ('under') bruker vi for å fortelle at noe holder på å bli gjort, eller begynner å bli gjort (1-4). Det er substantivet i utfyllinga som spesifiserer sjølve gjerninga eller handlinga.

1. Se oon seittemen vuotta aikkaa, ko mie viimeksi olin [operasuunin alla]. 'Det er sju år sia jeg sist gikk gjennom en operasjon / ble operert.'

2. Liisala oli aina [tevon alla] joku artikkeli.

'Lisa har alltid en artikkel under arbeid.'

3. Johaneksen ilmestystä met emmä tohđi ottaat ollenkhaan [selityksen alle].

'Johannes' åpenbaring tør vi ikke å begynne å forklare i det heile tatt.'

4. Sie häyđyt ottaat sen assiin [puhheen alle].

'Du bør ta opp den saka.'

- ympäri(t)

Postposisjonen ympäri(t) ('om; på) brukes særlig i indirekte tale (1-3) og i liknende substantivfraser (4). Men postposisjonen forekommer også i andre setningstyper $(5,6)$.

1. Paulaharju kirjoitti [«Ruijan suomalaisten» eli kainulaisten ympäri]. 'Paulaharju skreiv om finnene i Nord-Norge eller kvenene.'

2. Muistele mulle [sinun perheen ympäri]!

'Fortell meg om familien din!' 
3. Mie en tykkää, ko puhuthaan pahhaa [ihmisten ympäri].

'Jeg liker det ikke når folk snakker stygt om andre'.

4. Kirjassa oon kans muistelus [Ruottin saamelaisten ympärit].

'I boka er det også ei fortelling om svenske samer.'

5. Oletko sie kuulu mithään [Liisan ympäri]?

'Har du hørt noe (nytt) om Lisa?'

6. Anna-Riitta oon tutkinu [kainun kielen ympäri].

'Anna-Riitta har forska på kvensk språk.'

I stedet for adposisjonsfraser med ympäri bruker man vanligvis substantivfraser; jamfør setningene i $(7-11)$, som betyr det samme som dem i (2-6) ovafor. I indirekte tale og for eksempel sammen med verbet kuula bruker vi substantivfraser i elativ (7-10), mens verbet tutkiit brukes i direkte setningstyper med partitivobjekt (11).

7. Muistele mulle [sinun perheestä].

8. Mie en tykkää, ko puhuthaan pahhaa ihmisistä.

9. Kirjassa oon kans muistelus [Ruottin saamelaisista].

10. Oletko sie kuulu mithään Liisasta?

11. Anna-Riitta oon tutkinu [kainun kieltä].

- perässä pörässä, perhään pörhään

Postposisjonene perässä pörässä og perhään pörhään ('etter') er også brukt i abstrakt forstand, som for eksempel i frasene olla, kulkkeet jonku perässä pörässä (‘å være ute etter noe, leite etter noe’) (1), kulkkeet kulkea $(t)$ kulkia, laukkoot laukkoa $(t)$, juosta jonku perässä pörässä ('gå, få til å springe, springe etter noe') (2), kattoot kattoa $(t)$ jonku perhään pörhään ('se etter noen') (3), panna sanan jonku perhään pörhään ('sende bud etter noen')(4).

1. Net hääythiin ennen olla vaarassa [eloitten perässä].

'Før måtte de være på fjellet og vokte på reinsdyrflokken.'

2. Porot laukothiin syksylä [sieniin pörässä].

'På høsten sprang reinsdyra og leita etter sopp.' 
3. Ko lapset tulhaan koulusta, se äiji saapi kattoa [niitten perhään]. 'Når barna kommer fra skolen, får bestefar se etter dem.'

4. Anni pani heti sanan [niitten pörhään]. 'Anni sendte straks bud etter dem.'

- $\operatorname{kans}(\mathrm{a})$

Postposisjonen $\operatorname{kans}(a)$ ('med') bruker vi for eksempel i verbfraser som käy(đ)ä väärin/hyvin jonku kans(a) ('gå dårlig/bra med noe') (1) og tulla hoppu/hätä jonku kans(a) ('bli travelt/hastverk / få det travelt; havne i nød') $(2,3)$.

1. [Matin kans] oon käyny väärin, mutta [Pekan kans] oikhein hyvin. 'Det gikk dårlig med Mats, men veldig bra med Peder.'

2. Vanhaasseen aikhaan ei [kalan kans] tullu koskhaan hätä. 'Før i tida blei det aldri problemer med fisken.'

3. Se tullee aina hoppu [ruvan kans].

'Man får det alltid travelt med maten.'

- päältä

Adpososjonsfraser med päältä ('om') brukes særlig sammen med verb som uttrykker krangling (1-3), eller som modifikator i substantivfraser som betegner krangel (4). Men de forekommer også sammen med andre verb (5).

1. Se oon kumma, ette killaava riielä [marjoitten päältä].

'Det er rart at folk orker å krangle om bær.'

2. Mie freistasin tingata [palkan päältä], ette saisin sen ylös.

'Jeg forsøkte å forhandle om lønna, slik at jeg skulle få mer.'

3. Kovasti net taistelthiin [sen päältä], ette saathiin kylän säilymhään.

'De kjempa hardt for at bygda skulle overleve.'

4. Alattiossa oli riita [sen pađon päältä].

'Det var krangel i Alta om den demningen.'

5. Ei ihminen tarvitte hävetä [oman kielen päältä].

'Folk behøver ikke å skjemmes over sitt eige språk.' 
Sammen med verbet hävetä ('skjemmes') brukes også substantivfraser som står i elativ eller partitiv; jf. setninga i (6), som betyr det samme som (5).

6. Ei ihminen tarvitte hävetä [hänen omasta kielestä] [hänen ommaa kieltä].

- pääle(t)

Postposisjonen pääle $(t)$ brukes sammen med flere typer verb og substantiv. Den brukes også i mange faste fraser, som for eksempel käy(đ) ä jonku pääle(t) ('angripe noen; gå ut over noen') $(1,2)$ og ottaa( $t)$ pääle( $t$ ) ('ta på) (3). Vi ser at de to frasetypene også kan brukes synonymt (jf. (2) og (3)).

1. Heti ryövärit käythiin [sen trengin päälet].

'Røverne heiv seg straks over drengen.'

2. Kova työ alkoi käymhään [kropin pääle].

'Det tunge arbeidet begynte å gå ut over kroppen.'

3. Pimmee aika ottaa niin hirmusesti [ämmin tervheyđen pääle].

'Mørketida tar så forferdelig på helsa til bestemor'.

En annen fast frase er jouttuut joutua(t) / tulla jonku pääle(t) ('få ansvar for') $(4,5)$.

4. Se joutui [palvelijan pääle] kaikki se ruokahoito.

'Tjeneren fikk ansvar for alt matstellet.'

5. Se tuli [mamman pääle] ette passata meän lapsia.

'Mamma fikk ansvar for å passe barna våre.'

Postposisjonen pääle $(t)$ er også vanlig i fraser som forteller at noen er sint på noen. I slike konstruksjoner står adposisjonsfrasen som utfylling til et substantiv $(6,7)$ eller et verb $(8,9)$.

6. Ko niilä oli viha [jonku päälet], se net haethiin kirkonmaan multaa ja panthiin kaffikupphiin.

'Når de sint på noen, så henta de jord fra kirkegården og hadde den opp i en kaffekopp.'

7. Kaisa oon vihassa [minun pääle].

'Kaisa er sint på meg.'

8. Lemmijovessa net suututhiin [meiđän pääle].

'I Lakselv blei de sint på oss.' 
9. Veljet ajatelthiin, ette Joosefi kostaa [heiđän pääle]. 'Brødrene trudde at Josef hevna seg på dem.'

I stedet for pääle $(t)$-fraser kan vi også bruke substantivfraser i slike konstruksjoner; jf. (10-12), som betyr det samme som (7-9).

10. Kaisa oon vihassa minule.

11. Lemmijovessa suututhiin meile.

12. Veljet ajatelthiin, ette Joosefi kostaa heile.

Også verba luottaa( $t$ ) ('stole (på)') $(13,14)$, uskoot uskoa( $t$ ) ('tru') $(15,16)$ og ajatella ('tenke') og unistella ('drømme') (17) tar utfylling i form av en postposisjonsfrase med pä̈le $(t)$.

13. Mie luotin [sinun pääle], mutta kuitenki sie petit minun.

'Jeg stolte på deg, men du bedro meg likevel'.

14. Sivva luotti [ittensä voimiin pääle].

'Sivert stolte på sine eigne krefter.'

15. Se pittää [jumalan päälet] uskoa eikä [ihmisten päälet].

'Man bør tru på en gud, og ikke på menneska.'

16. [Politiikkariitten pääle] mie en usko ennää mithään.

'Jeg trur ikke noe på politikere lenger'.

17. Mie olen ushein ajatellu [sinun pääle] ja unistelluki [sinun pääle].

'Jeg har ofte tenkt på deg og også drømt om deg.'

I stedet for postposisjonsfraser med pääle $(t)$ kan verba i konstruksjonene ovafor også ta et nomen som utfylling. Verba luottaa $(t)$ og uskoot uskoa $(t)$ tar da nomenutfylling i illativ $(18,19)$, verbet ajatella i partitiv (20) og verbet unistella i elativ (20).

18. Mie luotin sinhuun, mutta kuitenki sie petit minun.

'Jeg stolte på deg, men du bedro meg likevel.'

19. Sivva luotti [ittensä voimhiin].

'Sivva stolte på sine eigne krefter.'

20. Mie olen ushein ajatellu sinnuu ja unistelluki sinusta.

'Jeg har ofte tenkt på deg og også drømt om deg.' 
Her er noen flere eksempler på hvordan postposisjonsfraser med pääle $(t)$ brukes (21-23).

21. Mie olen niin paljon kustantannu [tohtorin pääle], ette kyllä oon tullu tyyrhiiksi.

'Jeg har hatt så mye utgifter på doktoren at det er blitt dyrt.'

22. Kauppamiehen piti anttaat jauhoi niitten [korttiin pääle].

'Kjøpmannen måtte gi mjøl for de (rasjonerings)korta'.

23. En mie saanu lainaa [pantin pääle] vaikka pyysin.

'Jeg fikk ikke lån på pantet sjøl om jeg ba om det.'

\subsection{Lause adposisjonsfraser}

Lause adposisjonsfraser uttrykker hva noen syns om saksforholdet i setninga, eller hva eller hvem setninga refererer til. De modifiserer med andre ord ikke et bestemt ledd, men heile setninga, og de fungerer som frie adverbial.

Eksempler på slike adposisjoner er puolesta ('for ... del'), mielestä ('etter ... syn') og jälkheen jälkhiin ('etter, ifølge'). De er alle postposisjoner som tar utfylling i genitiv. Postposisjonsfraser med puolesta forteller etter hvem sitt syn noe er sant (1-3). Postposisjonsfraser med mielestä spesifiserer hva slags syn referenten til nomenet i utfyllinga har på saka $(4,5)$. Stundom kan disse frasene brukes nærmest synonymt (6).

1. [Minun puolesta] ruijan kieli oon sama kevvee puhhuut ko tämä äitinkieli.

'For meg er norsk like lett å snakke som dette morsmålet.'

2. Pojat olthiin luvanheet, ette [heiđän puolesta] sopis kohđata jo tulleevalla viikola.

'Guttene hadde lovt at det passa for dem å komme allerede nå til uka.'

3. [Minun puolesta] saatama lähteet vaikka heti.

'For min del kan vi dra om så med en gang.'

4. [Lästaatiolaisten mielestä] tansi oli kauhee.

'Etter læstadianernes syn var dans noe forferdelig.'

5. Kväänoja ei [minun mielestä] löy’y täältä.

'Etter mitt syn fins det ikke noen som kaller seg for kvener her'. 
6. Ja nokko oon nokko. Kuitenki [heiđän mielestä ja puolesta].

'Og nok er nok. I hvert fall etter deres syn og for deres del.'

For å vise til kjelda til et utsagn bruker vi postposisjonen jälkheen $\sim$ jälkhiin ('etter, ifølge') $(7,8)$.

7. Se Sammeli Kippanen oli [muisteluksen jälkheen] se ensimäinen, joka tuli Pyssyjokheen.

'Etter det som fortelles, var det Samuel Kippanen som var den første som kom til Børselv?'

8. Pekka oli oikhein soma mies [minun muiston jälkhiin].

'Peder var en veldig artig mann, etter det jeg minnes.'

\subsection{Oppsummerende om adposisjoner}

I dette kapitlet har vi sett på i alt 69 ulike adposisjoner, og de fleste av dem har igjen ulike kasusformer, og noen av dem har også parallellformer. Oversikten omfatter likevel ikke alle adposisjoner i kvensk. Vi har også vist at i mange tilfeller så kan en og samme adposisjon opptre i ulike funksjoner, sjøl om det ikke har vært mulig å inkludere alle tenkelige bruksmåter. For eksempel fungerer adposisjonen $y l i(t) \sim y$ litte ('over') som steds-, tids-, mengde- og som forholdsadposisjon. Den fins både som postposisjon og som preposisjon. I noen funksjoner tar den utfylling i genitiv, mens den styrer partitiv i andre funksjoner, på linje med for eksempel ympäri(t).

Som det framgår av tabell 10.4, så er de fleste adposisjonene postposisjoner som tar utfylling i genitiv. Når det er sagt, fins det også mange preposisjoner, og de tar oftest utfylling i partitiv, men det er heller ikke uvanlig med preposisjoner som styrer genitiv. Postposisjoner styrer sjelden partitiv.

Det er bare en handfull eksempler på adposisjoner som styrer nominativ, og de er ikke med i tabellen. Vi har også utelatt den varianten av ilman som styrer abessiv, sjølv om den er vanligere enn varianten med partitivutfylling. 
Tabell 10.4 Adposisjoner - funksjon og struktur

\begin{tabular}{|c|c|c|c|c|}
\hline \multirow[t]{2}{*}{ Funksjon } & \multicolumn{2}{|c|}{ Postposisjoner } & \multicolumn{2}{|c|}{ Preposisjoner } \\
\hline & Genitiv & Partitiv & Genitiv & Partitiv \\
\hline $\begin{array}{l}\text { Stedsadposisjoner } \\
\text { (10.1) }\end{array}$ & $\begin{array}{l}\text { alla : alta : alle(t), e(đ) } \\
\text { essä : e(đ)estä : etheen, } \\
\text { kautta, likelä : likeltä : } \\
\text { likele(t), läpi(t) läpitte, } \\
\text { perässä pörässä : } \\
\text { perästä pörästä : } \\
\text { perhään pörhään, } \\
\text { päälä : päältä : pääle(t), } \\
\text { päässä : päästä : } \\
\text { päähän, sisälä : sisältä : } \\
\text { sishään, sivvu siu(t) } \\
\text { siutti(t), syrjässä : } \\
\text { syrjästä : syrjhään, } \\
\text { takana : takkaa : taka(t), } \\
\text { tykönä : tykköö tyköä : } \\
\text { tykö, vieressä : vierestä : } \\
\text { vierestä, välilä : väliltä : } \\
\text { välile(t), välissä : välistä } \\
\text { : välhiin, ympäri(t) }\end{array}$ & $\begin{array}{l}\text { myöten } \\
\text { myöđen, } \\
\text { vasten, } \\
\text { vasthaan }\end{array}$ & $\begin{array}{l}\text { läpi(t) läpitte, } \\
\text { poikki(t), yli(t) } \\
\text { ylitte, ympäri(t) }\end{array}$ & $\begin{array}{l}\text { keskelä : } \\
\text { keskeltä : } \\
\text { keskele(t), } \\
\text { kohti kohđi, } \\
\text { likelä : likeltä : } \\
\text { likele(t), liki(t), } \\
\text { likempännä : } \\
\text { likemp(p)ää : } \\
\text { likemäksi, } \\
\text { lähelä : läheltä } \\
\text { : lähele(t), } \\
\text { pitkin, } \\
\text { ympäri(t) } \\
\text {-puolela : } \\
\text {-puolelta : } \\
\text {-puolele(t) }\end{array}$ \\
\hline Tidsadposisjoner (10.2) & $\begin{array}{l}\text { aikana, aikhaan, } \\
\text { aikhoin, alussa, e(đ)elä, } \\
\text { lopula, perästä } \\
\text { pörästä, päästä, } \\
\text { ympärillä }\end{array}$ & $\begin{array}{l}\text { myöten } \\
\text { myöđen, } \\
\text { vasten }\end{array}$ & $\begin{array}{l}\text { e(đ)eltä, } \\
\text { jälkheen } \\
\text { jälkhiin, kesken, } \\
\text { läpi(t) läpitte, } \\
\text { siu(t) siutte(t) } \\
\text { sivvu, vaila } \\
\text { vaile(t), yli(t) } \\
\text { ylitte, ympäri(t) } \\
\text { (singulaarissa) }\end{array}$ & $\begin{array}{l}\text { ennen, keskelä } \\
\text { : keskele(t), } \\
\text { pitkin, } \\
\text {-puolheen }\end{array}$ \\
\hline $\begin{array}{l}\text { Måtesadposisjoner } \\
\text { (10.3) }\end{array}$ & $\begin{array}{l}\text { jälkhiin jälkheen, } \\
\text { kans(a), kautta, kesken, } \\
\text { läpi(t) läpitte, myötä, } \\
\text { pääle(t), seurassa, } \\
\text { vierheen }\end{array}$ & $\begin{array}{l}\text { myöten } \\
\text { myöđen }\end{array}$ & & ilman, vasto(i)n \\
\hline $\begin{array}{l}\text { Årsaksadposisjoner } \\
\text { (10.4) }\end{array}$ & $\begin{array}{l}\text { e(đ)estä, kautta, } \\
\text { pääle(t), takkii takia, } \\
\text { täh(đ)en }\end{array}$ & & & varten, vasten \\
\hline $\begin{array}{l}\text { Mengdeadposisjoner } \\
\text { (10.5) }\end{array}$ & e(đ)estä, välilä & kohti kohđi & $\begin{array}{l}\text { vaila vaile(t), } \\
\text { yli(t) ylitte }\end{array}$ & keskelä \\
\hline $\begin{array}{l}\text { Forholdsadposisjoner } \\
(10.6)\end{array}$ & $\begin{array}{l}\text { e(đ)estä, kautta, } \\
\text { puolela : puolele(t), } \\
\text { puolelta, puolesta, } \\
\text { puolheen, sijassa : } \\
\text { sijhaan, välilä, välissä }\end{array}$ & $\begin{array}{l}\text { kohthaan, } \\
\text { vasten, } \\
\text { vasthaan }\end{array}$ & & \\
\hline
\end{tabular}


Tabell 10.4 (Fortsatt)

\begin{tabular}{|c|c|c|c|c|}
\hline \multirow[t]{2}{*}{ Funksjon } & \multicolumn{2}{|c|}{ Postposisjoner } & \multicolumn{2}{|c|}{ Preposisjoner } \\
\hline & Genitiv & Partitiv & Genitiv & Partitiv \\
\hline $\begin{array}{l}\text { Ugjennomsiktige } \\
\text { adposisjoner } \\
\text { (10.7) }\end{array}$ & $\begin{array}{l}\text { alle(t), kans(a), } \\
\text { perhään pörhään, } \\
\text { perässä pörässä, } \\
\text { pääle(t), päältä, } \\
\text { ympäri(t) }\end{array}$ & & & \\
\hline $\begin{array}{l}\text { Lause adposisjoner } \\
(10.8)\end{array}$ & $\begin{array}{l}\text { jälkheen jälkhiin, } \\
\text { mielestä, puolesta }\end{array}$ & & & \\
\hline
\end{tabular}




\section{1}

\section{Junksjoner}

JUNKSJONER er ord som beskriver forhold mellom setningsledd eller fraser. Noen junksjoner har semantisk innhold, mens andre ikke har det. Junksjoner skiller seg fra adverb ved at de har en fast plass i setninga: De står alltid foran den frasen eller den setninga som de forbinder med en annen frase eller setning.

Man bruker å dele junksjoner inn i to grupper basert på om de forbinder to parallelle eller sideordna fraser eller setninger, eller om de binder sammen ei underordna setning med ei overordna setning. Junksjoner i den første gruppa kaller vi her for KONJUNKSJONER, og den andre gruppa kaller vi for SUBJUNKSJONER. Men det fins enda ei tredje, mindre, gruppe av junksjoner, som forbinder oversetninger med leddsetninger. Denne siste gruppa kaller vi for SUPERJUNKSJONER.

Når det gjelder ordstruktur, kan vi skille mellom fire typer junksjoner:

- Simpleksord, som for eksempel ja ('og'), eli elikkä ('eller (med andre ord)'), tahi tai ('eller'), vain vai ('eller'), niin ('slik at'), se ('så), ette että ('at'), nette nettä ('at ikke'), jos ('viss'), ko ('da, når; enn; som'), vaikka ('sjøl om'), mutta ('men').

- Enklitikonet -kä ('og ikke’).

- ORdSAmband som består av to ord som kommer etter hverandre. Av denne typen fins det bare subjunksjoner, og det er disse: niin ette että ('slik at'), sillä ko ('ettersom'), siksi ko ('så lenge at'), siitä ko ('fra av'), niin ko ('slik/så som'), ennen ko ('før, innen'), jälkhiin ko ('etter').

- PARORD, som fungerer på den måten at de står i hver sin frase eller setning som de binder sammen. Det er bare konjunksjoner som opptrer parvis, for eksempel joko - eli elikkä ('enten - eller'), sekä - ja ('både - og'), sekä ette että ('både - og').

Nedafor skal vi se nærmere på hva slags konjunksjoner, subjunksjoner og superjunksjoner som fins i kvensk, og hvordan de brukes. 


\subsection{Konjunksjoner}

Konjunksjoner binder sammen to eller flere parallelle eller sideordna setninger (2-4) eller fraser (1). De sideordna setningene kan være hovedsetninger (2) eller leddsetninger $(3,4)$, men altså ikke slik at den ene er leddsetning og den andre oversetning.

1. Tielä oli jäätä ja lunta.

'Det var is og snø på vegen.'

2. Tielä oli jäätä, ja mie pölkäsin lähteet ajamhaan piililä.

'Det var is på vegen, og jeg var redd for å kjøre bil.'

3. Jos sie lähđet $j a$ Pekkaki lähtee, se mieki lähđen tunturhiin.

'Viss du drar og Peder også drar, så drar også jeg til fjells.'

4. Jos sie lähđet mutta Pekka ei lähđe, niin mie tulen myötä.

'Viss du drar, men Peder ikke drar, så blir jeg med.'

Konjunksjoner kan også stå før leddsetninga og atskilt fra si eiga setning $(5,6)$.

5. Mutta vaikka oli kova sää, se mie kuitenki lähđin tunturhiin.

'Men sjøl om det var dårlig vær, så dro jeg likevel til fjells.'

6. Kyllä mie tieđän, ette sie olet rohkee, mutta ette sie vielä sinneki lähđet, sitä mie en olis uskonu.

'Jeg veit nok at du er modig, men at du til og med vil dra dit, det hadde jeg ikke trudd.'

Med utgangspunkt i betydninga deres kan vi dele konjunksjoner inn i fire grupper:

- Additive Konjunksjoner forbinder fraser eller setninger som alle hører til samme gruppe, og som uttrykker at noen eller noe virkelig fins og er sant. - KonnekTive KONJUNKSJONER binder sammen setninger på det viset at setninga som blir innleid av konjunksjonen, er en logisk følge av den foregående setninga.

- Disjunktive Konjunksjoner uttrykker at det av de to sideordna setningene eller frasene som de forbinder, bare er den ene som gjelder, eller at de to sideordna setningene eller frasene betyr det samme. Resultatet er i begge tilfella bare ett utsagn. 
- Kontrastive KonjunKsjoner forteller at det er ei motsetning mellom de to setningene eller frasene som forbindes.

\subsubsection{Additive konjunksjoner}

Kvensk har følgende ADDITIVE KONJUNKSJONER: simpleksordet ja ('og'), parkonjunksjonen sekä - ja ('både - og') eller sekä - ette että ('både - og') og enklitikonet $-k \ddot{a}$ ('og'). Også konjunksjonen ette kan regnes som additiv når den beskriver at noe forekommer eller skjer i større og større grad. La oss se på dem hver for seg.

- Konjunksjonen ja ('og') kan stå i begynnelsen av ei heilt ny setning (1), eller den kan binde sammen hovedsetninger $(2,3)$ eller leddsetninger $(4)$, eller også to eller flere fraser innafor samme setning $(5,6)$.

1. Se oli harva jää. Ja se oli yksi karhu, mie näin sen, se oli kaukana sielä jäälä. 'Det var skjør is. Og det var en bjørn der, jeg så den, den var der langt borte på isen.'

2. Niilä oon sama murret ko meilä, ja puhuthaan justhiin samhaan laihiin ko met.

'De har samme dialekt som oss, og de prater på akkurat samme måte som vi.'

3. Lapin ihmiset käyvä ja ottava parkin lepästä.

'Samene drar en tur og tar bark av oldra.'

4. Ko oli lämmin sää ja aurinko paistoi, se met lähđimä hihtaamhaan vaarhaan.

'Sia det var varmt vær og sola skinte, så dro vi til fjells på skitur.'

5. Se käypi Suomessa ostamassa lihhaa ja sian fläskii ja makkaroita aina.

'Han/Hun drar alltid til Finland for å handle kjøtt og svineflesk og pølser.'

6. Tie meni Näätämön $j a$ Reisivuonon siutti.

'Vegen gikk forbi Neiden og Bygøyfjorden.'

- Enklitikonet -kä ('og') forekommer i setninger i stedet for ja, og det festes alltid til nektingsverbet. Nektingsverbet bøyes på vanlig måte i person og modus (indikativ og imperativ), og sammen med enklitikonet - $k a ̈$ får det disse formene: (indikativ 1. sg., 2. sg., 3. sg., 1. pl., 2. pl., 3. pl.) enkä, etkä, eikä, 
emmäkä, ettäkä, eikä og (imperativ 2. sg., 3. sg., 2. pl., 3. pl.) äläkä, älk(k)öönkä, älk(k)ääkä, älk(k)öötkä. Det binder sammen to hovedsetninger, der den ene er bekreftende og den andre nektende $(1,2)$. Når det er tale om to eller flere sideordna nektinger, så må alle setningene eller frasene ha med nektingsverbet (3-6).

1. Se kuoli siihen sitte eikä päässy ennää ylös. 'Han/Hun/Den/Det døde der og kom seg ikke opp mer.'

2. Sitä oli niin vähän, enkä mie tieđä, miksi sitä niin vähän oli. 'Det var så lite av det, og jeg veit ikke hvorfor det var så lite av det.'

3. Emmä met ole nähnheet kethään, emmäkä käynheet mishään. 'Vi har ikke sett noen og heller ikke vært noen steder.'

4. Et sie saanu margariinii leivän pääle etkä ostaat tikkui sieltä etkä tupakkaa etkä mithään semmoista.

'Du/Man fikk ikke margarin på brødet, og ikke kjøpt fyrstikker, og ikke tobakk eller noe slikt.'

5. Net ei saata lukkeet eikä kirjoittaat.

'De kan ikke lese eller skrive.'

6. Älkkää menkkää sinne, älkkääkä tehkää synttii.

'[Til flere:] Ikke gå dit, og ikke gjør synd!'

- Parkonjunksjonene sekä - ja og sekä - ette että ('både - og') brukes på akkurat samme måte. De binder sammen to sideordna fraser eller setninger. De to sideordna frasene kan være hvilke som helst av de faste setningsledda $(1-7)$, men det kan også være en forklarende apposisjon (8).

1. Kyllä se kivun pois ottaminen oon sekä hyvä ja paha.

'Det å ta bort smerten er både bra og dårlig.'

2. Se oli sekä Suomen ja Ruottin lappalaisia.

'Det var både finske og svenske samer (der).'

3. Siihen aikhaan oli Yykeässä sekä pappi ja lukkari.

'På den tida var det både prest og klokker i Lyngen.'

4. Sielä oli sekä ruokkaa ja juomaa ja oli viinaa kansa niissä häissä.

'Det var både mat og drikke der, og det var også sprit i det bryllupet / de bryllupa.' 
5. Niitä oli sekä nisujauhot ette krouvit jauhot.

'Det fantes både hvetemjøl og grovt mjøl.'

6. Sielä tuli vettä sekä levveemästi ja kaitasemasti.

'Der kom det vatn både i breide strømmer og i smale sig.'

7. Friiaria tuli sekä etelästä että pohjasesta, öystästä ja västästä.

'Det kom friere både fra sør og fra nord, fra aust og fra vest.

8. Met laskima hevoiset ulos kevväilä juoksemhaan, sekä mie ette kranni.

'Vi slapp hestene ut på våren, både jeg og naboen, slik at de kunne springe rundt.'

- Konjunksjonen ette ('og') bruker vi mellom to identiske verbfraser (9, 10) eller komparativfraser $(11,12)$, og setninga forteller da at hendelsen eller handlinga fortsetter og gjentar seg, eller at det blir mer og mer av noe.

9. Viholinen vain likeni ette likeni.

'Fienden kom bare nærmere og nærmere.'

10. Ääni tielä koveni ette koveni.

'Lyden på vegen auka og auka'.

11. Lapset tulthiin likemäksi ette likemäksi kotipaikkaa.

'Barna kom nærmere og nærmere heimplassen.'

12. Puu kasvoi aina vain korkkeemaksi ette korkkeemaksi.

'Treet vokste bare større og større'.

I stedet for ette kan vi også bruke ja i slike setninger (13).

13. Viholinen vain likeni ja likeni.

'Fienden kom bare nærmere og nærmere.'

\subsubsection{Konnektive konjunksjoner}

Deto KONNEKTIVE KONJUNKSJONENE niinog se('så) forbinderto hovedsetninger. De brukes synonymt og impliserer at setninga som følger etter, er en logisk følge av den foregående setninga (1-3).

1. Ei meilä ollu ruokkaa myötä, niin/se siinä piti pärjätä, siksi ette joku meiđät löytäis.

'Vi hadde ikke mat med oss, så vi måtte klare oss der inntil noen kom og fant oss.' 
2. Viholisetkhaan ei nähnheet pimmeessä, niin/se het olthiin öksynheet niin ko metki.

'Heller ikke fiendene så noe i mørket, så de var gått seg vill slik som vi.'

3. Mie olin pikkuisen sairas yhtenä iltana, niin/se mie panin varhain maata.

'Jeg var litt sjuk en kveld, så jeg la meg tidlig.'

Oftest blir et slikt logisk forhold mellom to setninger uttrykt ved at vi legger til den kausale subjunksjonen ko eller sillä ko ('sia, ettersom') i den første setninga (4-6). Setninga fungerer da som leddsetning til den etterfølgende setninga, og junksjonen regnes som superjunksjon (se avsnitt 11.3).

4. Ko meilä ei ollu ruokkaa myötä, niin/se siinä piti pärjätä, siksi ette joku meiđät löytäis.

'Ettersom vi ikke hadde mat med oss, så måtte vi klare oss der inntil noen kom og fant oss.'

5. Ko viholisetkhaan ei nähnheet pimmeessä, niin/se het olthiin öksynheet niin ko metki.

'Ettersom heller ikke fiendene så noe i mørket, så var også de gått seg vill slik som oss.'

6. Sillä ko mie olin pikkuisen sairas yhtenä iltana, niin/se mie panin varhain maata.

'Ettersom jeg var litt sjuk en kveld, så la jeg meg tidlig.'

\subsubsection{Disjunktive konjunksjoner}

DisJUNKTIVE KONJUNKSJONER forteller enten at det av de to setningene eller frasene som konjunksjonen binder sammen, bare er den ene som gjelder eller er sann, eller at de begge betyr det samme. Denne gruppa av konjunksjoner består av simpleksorda eli(kkä) ('eller'), ta(h)i ('eller') og vai( $n)$ ('eller'), og parkonjunksjonen joko - eli(kkä) ('enten - eller').

- Den disjunktive konjunksjonen eli(kkä) ('eller') brukes på to måter, med inkluderende eller ekskluderende betydning. Når begge frasene eller setningene som bindes sammen, betyr det samme, så er konjunksjonen inkluderende $(1-5)$. Men når den andre frasen eller setninga utelukker den første, så er konjunksjonen ekskluderende (6-9). 
1. Entisheen aikhaan asui yksi noitamies Keisissä eli Muotkassa. 'Tidligere bodde det en trollmann på Keisi eller Muotka (= Kjæs).'

2. Jos öksyy tunturissa, se oon paras, ette kaivaa ittensä lumheen elikkä pittää ittensä sulana.

'Når man går seg vill på vidda, så er det best å grave seg ned i snøen eller med andre ord holde seg varm.'

3. Hilla se oon ensistä semmonen pikkunen ja raaka eli met kuttuma supuksi. 'Molta er først bare lita og umoden, eller moltekart, som vi kaller den for.'

4. Hän ei halluu puhhuut omista assiista eli siitä, minkälainen olo hänele oon. 'Han/Hun vil ikke snakke om sine eigne ting eller hvordan han/hun har det.'

5. Semmoisten huhhuin eli juoruin pääle mie en usko. 'Slike rykter eller sladder trur jeg ikke noe på.'

6. Juntila oli yksi eli kaksi poikkaa, mie en muista tarkoin. 'Johannes hadde en eller to sønner, jeg husker ikke heilt.'

7. Se oon paras, ko sen syöpi vereksennä, paistaa eli keittää sen. 'Den/Det er best å spise når den/det er fersk(t), (og) enten steike eller koke den/det.'

8. Hän häytyi mennä, tahtoi sitte eli ei. 'Han/Hun var nødt til å gå, om han/hun enn ville eller ei'.

9. Matti paranee eli sitte kuolee. 'Mats blir frisk, eller så dør han'

Konjunksjonen eli(kkä) kan også brukes når vi ønsker å presisere eller rette på innholdet i teksten eller talen (10).

10. Yölä sitte tulthiin Pajalhaan Suomessa, elikkä se Pajala oon Ruottin puolela.

'Om natta kom vi da til Pajala i Finland, eller Pajala er jo på svensk side.'

- Konjunksjonen $t a(h) i$ brukes mye på samme måte som eli(kkä), det vil si at de sammenbundne frasene enten er inkluderende eller betyr det samme $(11,12)$, eller at de er ekskluderende, det vil si utelukker hverandre $(13,14)$.

11. Met saatama villastaki punnoot tahi kerttoot lankkaa.

'Vi kan tvinne eller flette garn også av ull. 
12. Se häättyy nuotanki paranttaat, ko se oon lahonu tahi löyhäksi tullu. 'Nota må bøtes ettersom den har råtna eller blitt laus.'

13. Se tarkoittaa, ette siitä oon ihminen tai elläin menny. 'Det betyr at det har gått folk eller dyr der.'

14. Matti ellää tahi kuolee, kyllä met sen sitte näjemä. 'Mats kommer til å leve eller til å dø, det får vi nok se.'

Konjunksjonen $t a(h) i$ kan også innleie en frase eller setning som retter på ordlegginga i det som er sagt forut (15), eller som forteller om omstendighetene ved en hendelse eller ei handling (16).

15. Siinä oli joka kesä työtä nuitten venheitten kans, ko piti piikaroitteat kiini. Tai ei se ollu piikaria siihen aikhaan, mutta siihen porathiin puusta nauloja. 'Hver sommer var det noe arbeid der med de der båtene, når spikerne skulle festes. Eller det var jo ikke spikere på den tida, men det blei bora nagler av tre i den.'

16. Hukka häätyi lähteet juoksemhaan pois, tahi muutoin hän olis mistantannu silmänsä.

'Ulven blei nødt til å springe bort, eller så ville han ha mista øyet sitt.'

- Når vi skal uttrykke et valg mellom to alternativ, så bruker vi parkonjunksjonen joko - eli(kkä) ('enten - eller') (17-19).

17. Priitala oon nyt rahhaa, ja se meinaa joko ostaat talon eli panna rahat pankhoon.

'Brita har penger nå, og hun har planer om enten å kjøpe et hus eller å sette pengene i banken?

18. Et saa koskhaan sitä paikkaa sopimhaan, se oon aina joko liian paljon elikkä liian vähän.

'Du/Man får aldri lappen til å passe, enten så er den for stor, eller så er den for liten.

19. Se piti joko naiđa elikkä net ei saanheetkhaan mennä yhtheen.

'De måtte enten bli gift, eller så fikk de ikke bli/bo sammen.'

Alternativt kan vi bare bruke konjunksjonen eli( $k k \ddot{a})$ ('eller') eller $t a(h) i$ ('eller') aleine, jf. setningene i (20-22), som betyr det samme som (17-19). (Se også ovafor.) 
20. Priitala oon nyt rahhaa, ja se meinaa ostaat talon eli panna rahat pankhoon.

21. Et saa koskhaan sitä paikkaa sopimhaan, se oon aina liian paljon tai liian vähän.

22. Se piti naiđa eli ei saanheetkhaan mennä yhtheen.

- Konjunksjonen vai(n) ('eller') brukes vanligvis bare når valget står mellom to eller flere alternativ $(23-27)$. Det er altså bare det ene alternativet som kan være sant eller bli realisert samtidig.

23. Mie en saata sannoot, oliko hän suomalainen vain ruottalainen.

'Jeg kan ikke si om han var finsk eller svensk.'

24. Mutta oliko se koivunparkki vain oliko se paijunparkki, sitä mie en tieđä. 'Men om det var bjørkebark eller seljebark, det veit jeg ikke'.

25. Niitä saapi Ryssästä, vain mistä net saaađhaan tuohii?

'Dem får man fra Russland, eller hvor er de får never ifra?'

26. Kyllä se näkkee puista, oonko net lihavat vai laihat puut.

'Man ser det nok på trærne om de er feite eller magre'.

27. Lähetkö sie ulkopyythöön, vain jäätkö sie tänne liki kotia?

'Drar du langt ut på havet for å fiske, eller blir du her i nærområdet?'

Konjunksjonen vai(n) kan også innleie ei spørresetning uten at det står noe anna alternativ foran $(28,29)$ :

28. Vain mitä tet pojat meinaatta?

'Eller hva meiner dere gutter?'

29. Vain oonko taivhaassaki kaikki tyyhää?

'Eller er alt tomt også i himmelen?'

\subsubsection{Kontrastive konjunksjoner}

KontRASTIVE KONJUNKSJONER forbinder fraser eller setninger med motsatt betydning. Den vanligste kontrastive konjunksjonen i kvensk er mutta ('men'), i mindre grad brukes også - kä ('men'). Vi skal nedafor ta for oss begge to.

- Konjunksjonen mutta indikerer at setninga eller frasen som den innleier, uttrykker det motsatte av den foregående setninga eller frasen $(1,2)$, eller at 
den tilføyer noe nytt til eller bidrar med et nytt synspunkt på det som står i den første setninga (3-7). Konjunksjonen kan også innleie ei setning som skifter synsvinkel på saka (8-9).

1. Ei se ole kilo- mutta liitterimitta.

'Det var ikke et «kilomål», men et litermål.'

2. Siinä piđethään paijuu, paijun parkkii, ei ittee puuta mutta parkkii.

'Man bruker / Det blir brukt selje, seljebark der, ikke sjølve treet, men barken.'

3. Trolli oon semmonen, mikä ei ole ihminen mutta muu paha.

'Et troll er noe som ikke er menneske, men noe anna ondskapsfullt.'

4. Niissä oon neulat juuri niin ko kuusessa mutta erilaiset.

'De har barnål akkurat som gran, men en annen type.'

5. Kauraa kans freistathaan kyllä täälä kylväät, mutta ei se kassuu.

'Man prøver også å dyrke havre her, men den vokser ikke.'

6. Niilä oon muutamilla yksi ja muutamilla kaksi penikkää. Mutta kolmee mie en ole nähny yhđeläkhään.

'Noen av dem har én og andre to unger. Men tre har jeg ikke sett hos noen.'

7. Hyljet pölkkää ihmistä. Mutta se piti minnuu hylkheenä.

'Selen pleier å være redd for mennesker. Men den selen trudde jeg også var en sel.'

8. Näkkeehän sen, että sielä oon vaarat. Mutta täälä meiđän puolela ei ole muuta, ko aivan jänkkää ja sitte nuita pikkuvaaroi.

9. 'Visst ser man at det er fjell der. Men her på vår side er det ikke anna enn myr og så de der åsene.'

10. Se oli yksi peret ja niilä oli paljon lapsii ja hyvä talo. Mutta oliko niilä saunaa, sitä mie en tieđä.

'Det var en familie der, og de hadde mange barn og et bra hus. Men om de hadde badstue, det veit jeg ikke.'

I nektende mutta-setninger er det vanlig at konjunksjonen smelter i hop med nektingsverbet. De ulike personformene er da som følger: (1. sg., 2. sg., 3. sg., 1. pl., 2. pl., 3. pl.) mutten, muttet, muttei, muttema, muttetta, muttei. Bruken er illustrert i (10-12). 
11. Mie kyllä muistan sen ihmisen, mutten muista sen nimmee.

'Jeg husker nok den personen, men navnet hans/hennes husker jeg ikke.'

12. Se oon soma paikka, muttet sie sinne piililä pääse.

'Det er et fint sted, men du kommer deg ikke dit med bil'.

13. Oon sieläki hillaa, muttema met sitä sieltä plokkaa.

'Det fins molter der også, men vi plukker ikke der'.

- Enklitikonet -kä fins utenom additiv bruk (se ovafor) også som kontrastiv konjunksjon $(13,14)$.

14. Mie ostin sieltä voita enkä margariinii.

'Det var smør jeg handla der, ikke margarin.'

15. Pekka lähti Sappheen eikä taivhaasseen.

'Det var til Sappen Peder dro, ikke til himmelen.'

\subsection{Subjunksjoner}

Subjunksjoner utgjør den største gruppa av junksjoner. De knytter sammen underordna setninger og fraser med sine respektive overordna setninger eller fraser. Underordna setninger eller fraser kan ha ulike funksjoner i setninga. De kan fungere som

- frie adverbial,

- utfyllinger til verb,

- modifikatorer til adverb, adjektiv og substantiv, eller

- jamføringsfraser.

Vi skal gå igjennom subjunksjonene i denne rekkefølgen.

\subsubsection{Subjunksjonssetninger som frie adverbial}

Ei fri adverbialsetning blir alltid knytta til oversetninga si gjennom en subjunksjon. Slike subjunksjoner uttrykker ulike forhold mellom oversetning og leddsetning, og vi deler dem derfor inn i ulike semantiske typer:

- Temporale subjunksjoner, som uttrykker tidsforhold

- Kausale subjunksjoner, som uttrykker årsak

- Kondisjonale SubjunKsjoner, som uttrykker vilkår eller betingelse 
- Konsessive subjunksjoner, som uttrykker alternativ

- Konnektive subjunksjoner, som viser til samtalen eller konteksten

\subsubsection{Temporale subjunksjoner}

Temporale subjunksJoner innleier leddsetninger som forteller når noe skjer. I denne gruppa finner vi simpleksordet ko ('når') og subjuksjonssambanda silloin ko ('da, når'), sitte ko ('da, når så), siitä ko ('fra av'), siksi ko ('inntil'), jälkhiin ko ('etter at'). Vi skal se på dem i tur og orden.

- Ei fri adverbialsetning som innleies av subjunksjonen ko, kan stå etter oversetninga si (1-3), foran den (4-6), og også inni den $(7,8)$.

1. Se oli yhtenä vuona, ko tulthiin hylkheet.

'Det var et år da det kom seler.'

2. Hän oli jo pikkuisen sairas, ko hän meni sinne. 'Han/Hun var allerede litt sjuk da han/hun dro dit.'

3. Nöyrä saapi tulla ottamhaan hänen, ko vissi aika oon kulunu. 'Fanden får komme og hente han/henne når det har gått ei viss tid.'

4. Ko het olit soutanheet pitkän aijan, se tuli vasthaan meriraukka.

'Da de hadde rodd lenge, så kom draugen imot dem.'

5. Ko äiti kerkis sinne, niin lapset olthiin itkheilä, ko olthiin jo vaipunheet matkasta.

'Da mora nådde dit, så var barna på gråten sia de allerede var utslitt av reisa.'

6. Ko oli satanu, hän aina kirjoitti ylös, ja antoi tieđot Kristiaanihaan.

'Når det hadde regna, skreiv han/hun det alltid ned og sendte opplysningene til Kristiania.'

7. Kerta ko Tuomas oli mennyt pois, se ajatteli Matti, eikö hän saattais voittaat tämän ylit.

'En gang da Thomas var bortreist, så funderte Mats på om han ikke kunne overvinne han.'

8. Koko aian, ko oli sota, se met emmä saanheet ostaat saipuata.

'Under heile den tida da det var krig, så fikk vi ikke kjøpt såpe.' 
Noen ganger kan subjunksjonen ko også plasseres inne i leddsetninga, men det er ikke vanlig (9).

9. Tahđoima, ette lapsi ko syntyi, sen piti tulla kastetuksi.

'Vi ville at barnet, når det var født, skulle bli døpt.'

- Subjunksjonen ko opptrer også i temporale subjunksjonssamband sammen med adverba siksi ('til') (10), siitä ('fra av') (11, 12), ennen ('før') (13-16) og jälkheen jälkhiin ('etter') (17-19). Av slike leddsetninger kan særlig de som er innleid av ennen ko og jälkhiin jälkheen ko, stå framfor oversetninga de hører til $(16,18)$.

10. Mie hääđyin ođottaat sykkelin kans, siksi ko isä oli saanu palkan.

'Jeg måtte vente med sykkelen til far hadde fått lønn.'

11. Tenossa kyllä oon saanu aina heiniä, siitä ko mie muistan.

'I Tana har man alltid fått høy, så lenge jeg husker.'

12. Mie olen käyny koulua siitä ko olin seittemän vanhaa.

'Jeg har gått på skole fra da jeg var sju år gammal'.

13. Nyt se ei ole monta vuotta, ennen ko se loppu tullee siihen.

'Nå er det ikke mange år til det blir slutt på det.'

14. Lukkarin tuvassa koulathiin, ennen ko tänne laitethiin koulutuvan.

'Det var i klokkerstua de underviste før de bygde skole her'.

15. Ennen paranttaa Jumala ittensä sään, ennen ko met ihmiset ittemä tavat.

'Før skjer det at Gud bedrer været enn vi mennesker våre eigne vaner.'

16. Ennen ko ilta tuli, olthiinki kaikki seinät valmhiit.

'Før det blei kveld, var alle veggene ferdigbygd.'

17. Mie en ole leiponu jälkhiin ko sairastuin.

'Jeg har ikke bakt etter at jeg blei sjuk.'

18. Jälkheen ko mie olin tullu täyđeksi, se mie lähđin heti kottoo pois.

'Etter at jeg blei voksen, dro jeg heimefra med en gang.'

19. Tämän sillan oon rakentanheet jälkhiin ko met olema tulheet evakoittemasta.

'Denne brua blei bygd etter at vi kom tilbake etter evakueringa'

I stedet for subjunksjonssambandet jälkheen jälkhiin ko kan vi også sette konstruksjonen sen jälkheen jälkhiin ko ('etter at'), der sen jälkheen jälkhiin er en adposisjonsfrase (20). 
20. Sen jälkhiin ko met tulima takaisin evakueerauksesta, se met häyđyimä rakenttaat kaikki uuđesti.

'Etter at vi kom tilbake fra evakueringa, så måtte vi bygge opp alt på nytt.'

Likeens kan vi også regne konstruksjonene sitte ko ('da, når') $(21,22)$ og sillo(i)n ko ('da, når') $(23,24)$ som subjunksjonssamband.

21. Meän puhet loppui, sitte ko tämä mies tuli tähän talhoon.

'Samtalen vår slutta da denne mannen kom inn i dette huset.'

22. Sitte ko olin käny rippikoulun, se mie tahoin vähäsen lentäät ulkona.

'Etter at jeg var blitt konfirmert, så hadde jeg lyst til å være litt ute på vift.'

23. Mie olen ensimäisen kerran käyny alhaala sillon ko olin ristilä.

'Første gangen jeg var der nede [på havstranda], var da jeg blei døpt.'

24. Silloin ko met vielä asuima Tromssassa, meilä oli kissa, minkä nimi oli Raita.

'Den gangen vi fortsatt bodde i Tromsø, hadde vi en katt som het Raita.'

Disse subjunksjonene har samme setningsfunksjon som simpleksordet ko, og orda sitte og sillo(i) $n$ kan også sløyfes i disse setningene. Sjøl om sitte og silloin er adverb, så er det derfor mer naturlig å analysere dem som ANKERORD, som er vanlig når ei subjunksjonssetning fungerer som utfylling til ei oversetning (se avsnitt 11.2.2).

\subsubsection{Kausale subjunksjoner}

KAUSALE SUBJUNKSJONER innleier leddsetninger som spesifiserer årsaka til at noe er eller skjer som beskrevet i oversetninga. Kausale subjunksjoner er ette että ('slik at'), nette nettä ('slik at'), niin ette niin että ('slik at'), ko ('så) og sillä ko ('fordi'). La oss gå igjennom dem én om gangen.

- Subjunksjonen ette $\sim$ että innleier ei etterstilt leddsetning som uttrykker årsak $(1,2)$ eller følge $(3,4)$.

1. Sillä net myyvät sielä etelässä, ette täälä oon hinta halvempi.

'De selger der sørpå fordi prisen er lågere her.'

2. Mie luulen ette hän aikkoo juottaat sen rautahevoisen, ette pärjää huomisheen.

'Jeg trur at han/hun har tenkt å gi den «jernhesten» drikke [= 'fylle bensin på bilen'], slik at den klarer seg til i morgen.' 
3. Sen verran oli kassii ja pöyttii, ette pärjäsimmä.

'Det fantes så pass med kasser og bord at vi klarte oss.'

4. Mie olin net kaffipöönät kuivanu ja polttanu, että net olit pruunit.

'Jeg hadde tørka og brent kaffebønnene sånn at de blei brune.'

I nektende setninger smelter nektingsverbet ofte i hop med subjunksjonen, og vi får da disse verbformene: (1. sg., 2. sg., 3. sg., 1. pl., 2. pl., 3. pl.) etten, ettet, ettei, ettemä, ettettä, ettei. Bruken er illustrert i $(5,6)$.

5. Mutta se alkkaa sitte särkemhään sisäle luuta vasten, ettei ihminen sitä tunnekhaan.

'Men det begynner da å verke innover mot beinet slik at mennesket ikke merker det engang.'

6. Miksi mie kunnioitan tuota miestä niin kauheesti, etten tohđi sannoot sitä, mitä ajattelen?

'Hvorfor har jeg så stor respekt for den der mannen at jeg ikke tør å fortelle hva jeg tenker?'

Subjunksjonen opptrer også som adverbialsetning sammen med preposisjonen ilman ('uten'). I setning (7) angir den manglende årsak.

7. Mie olisin halunu oppiit kainun kieltä, ilman ette kukhaan minnuu siihen käski. 'Jeg skulle ha ønska å lære meg kvensk uten at noen hadde bedt meg om det.'

Subjunksjonen brukes også som innleiing til ei hovedsetning når den skal forklare eller konkludere om noe som er sagt tidligere (8).

8. Lääki neuloi ja pani haavan kiini ja sitte se vasta parani. Ette kyllä se oon hyvä ja huono se kivun pois ottaminen.

'Legen sydde og lukka såret igjen, og først da blei det bedre. Så det er både dårlig og bra, det å ta bort smerten.'

- Også subjunksjonssambandet niin ette niin että ('slik at') innleier ei leddsetning som spesifiserer årsak (9) eller følge $(10,11)$. Men til forskjell fra den simplekse subjunksjonen ette så viser niin ette-setninger i større grad også til måten noe skjer på, eller til andre egenskaper ved handlinga eller tilstanden.

9. Se venet oon soukka, niin ette oon kevveempi mennä vastavirthaan.

'Båten er smal slik at det er lettere å ferdes motstrøms.' 
10. Hän alkoi nauramhaan, niin että tahtoi pakattuut. 'Han/Hun begynte å le så han/hun holdt på å sprekke.'

11. Met veimä sen liinan vetheen, niin että se kulki veđen päälä matkan. 'Vi dro lina ned i vatnet, slik at den fløyt et stykke på vatnet.'

- Subjunksjonen nette nettä brukes mye på samme måte som ette (12-14). Den kan også byttes ut med subjunksjonen niin ette (15).

12. Jotaki net häätyvät kirjottaat nuihin aviishiinki, nettä ihmisillä oon lukemista.

'Noe må jo også de der avisene skrive slik at folk har noe å lese.'

13. Meilä oli niin vähän astioita, mihin kaivethiin ruokaa, nettä met hääyimä oottaat, siksi ko muut syöthiin.

'Vi hadde så dårlig med kar som vi auste maten opp i, at vi måtte vente til de andre hadde spist.'

14. Sielä oon niin vähän kallaa, nettei ollenkhaan kannata lähteetkhään.

'Det er så lite fisk der at det ikke lønner seg å dra (dit) i det heile tatt.'

15. Ko se oli hautunu, nette se oli vähän pehmeempi, se met söimä sen.

'Når den/det var svella slik at den/det var litt mjukere, så spiste vi den/ det.'

- Subjunksjonen ko, som er vanlig i temporale setninger, kan også innleie årsakssetninger (16-19). Vanligvis står da ko-setninga etter oversetninga (1618), men den kan også stå foran (19).

16. Ei se antanu ruokkaa, ko hänelä oli itteläki ruokkaa vaanasti. 'Han/Hun ga ikke (bort) mat sia han/hun sjøl også hadde snaut med mat.'

17. Hän se kyllä oli Suomesta, ko hän suomee puhui. 'Han/Hun var nok fra Finland i og med at han/hun snakka finsk.'

18. Hukkarievula oli jo nälkä, ko ruoka oli loppu. 'Stakkars ulv var sulten fordi det var tomt for mat'.

19. Ko ennen ei ollu tullu käytyksi sielä, ja ko joki oli hänele vielä täysin tuntematon, se hän kokonhansa öksyi.

'Ettersom han/hun ikke hadde vært der før og elva fortsatt var heilt ukjent for han/henne, så gikk han/hun seg fullstendig vill'. 
- Også frie adverbialsetninger som er innleid av subjunksjonssambandet sillä ko, er brukt for å spesifisere årsaka til det som er uttrykt i oversetninga (20-22). Subjunksjonen følger her som regel etter oversetninga.

20. Miehän sen tehny olen, sillä ko ei yksikhään muu ole semmoissii tehny.

'Det er jo jeg som har gjort det ettersom ingen andre har gjort noe slikt før.'

21. Net tykäthiin hirmuisesti hänestä, sillä ko hän oli niin praatikas mies.

'De likte han svært godt fordi han var en så pratsom mann.'

22. Se oon musta maa, sillä ko porroi oon liikkaa.

'Jorda er heilt svart fordi det er for mye rein.'

\subsubsection{Kondisjonale subjunksjoner}

KONDISJONALE SUBJUNKSJONER innleier leddsetninger som setter et vilkår eller en betingelse for det saksforholdet som er uttrykt i oversetninga. Det fins to slike subjunksjoner, jos ('dersom, om, viss') og ko ('dersom, om, viss'). Vi skal se på dem nedafor.

- Den vanligste måten å lage ei vilkårssetning på er å innleie den med subjunksjonen jos. Leddsetninga beskriver da under i hvilke(t) tilfelle(r) oversetninga er eller blir sann. Vi kan også si at saksforholdet som er skildra i oversetninga, er en følge av saksforholdet i jos-setninga.

- Vilkårssetninger med jos kan være plassert i begynnelsen av den komplekse setninga, dsv. foran oversetninga $(1,2)$, eller komme til slutt, det vil si etter oversetninga (3-6). Vanligvis står verbalet både i jos-setninga og i oversetninga i kondisjonalis $(1,6)$. Når subjunksjonen innleier ei nektende leddsetning, så kan nektingsverbet smelte i hop med subjunksjonen, og vi får da følgende former: (1. sg., 2. sg., 3. sg., 1. pl., 2. pl., 3. pl.) jossen, josset, jossei, jossema, jossetta, jossei. Bruken av disse er illustrert i $(4,5)$.

1. Jos hyljet olis tieny, ette mie olin ihminen, ni ei se olis tullu päälet.

'Viss selen hadde visst at jeg var et menneske, så hadde den ikke angrepet meg.'

2. Jos skonto tullee, ni se öksyy sielä.

'Viss skodda kommer, så går han/hun/den/det seg vill der'. 
3. Pekka tullee, jos Maijaki tullee.

'Peder kommer viss også Maja kommer.'

4. Sie jouđut Helvetthiin, josset kadu sinun synttii.

'Du havner i helvete viss du ikke angrer på syndene dine.'

5. Sitä ei päässy naimishiin, jossei ollu käyny rippikouluu.

'Man fikk ikke gifte seg om man ikke var blitt konfirmert.'

6. Mie en kyllä lähtis mihinkhään, jos mulla ei olis rahhaa myötä.

'Jeg skulle nok ikke dra noen steder viss jeg ikke hadde penger på meg.'

- Kondisjonale ko-setninger kan også uttrykke et ønske eller et håp, og verbalet står da alltid i kondisjonalis både i leddsetninga og i oversetninga. Denne typen ko-setning står ofte i begynnelsen av den komplekse setninga (7), men den kan også følge etter oversetninga (8). Det fins også kondisjonale ko-setninger heilt uten oversetning eller hovedsetning (9).

7. Ko ihminen pärjäis päivästä toisheen, niin sitä olis oikhein iloinen.

'Om en bare klarte seg fra dag til dag, så var en oppriktig glad.'

8. Kyllähän ihminen pärjäis, ko tyhä olis nokko meressä kallaa.

'En klarte seg nok, om det bare var nok fisk i havet.'

9. Ko ihminen takois pyssyt vikatheiksi. Ko sottaa ei ennää olis eikä kuuluiskhaan. Ko ihminen olis ymmärtäväisempi, kestäväisempi ja rauhaa rakastavaisempi. Ko maailmasta tulis jotaki uutta! Onnen maailma! Rauhan maailma! Yksi maailma! (Alf Nilsen-Børsskog, Kuosuvaan takana.)

'Bare mennesket smidde børsene om til ljåer. Bare krigen ikke fantes og ikke hørtes om lenger. Bare mennesket var mer forståelsesfull, utholdende og fredelig. Bare verden blei til noe nytt! Lykkens verden! Fredens verden! Én verden!'

\subsubsection{Konsessive subjunksjoner}

Konsessive subjunksjoner innleier leddsetninger som uttrykker et alternativt saksforhold. Kvensk har bare én slik subjunksjon, vaikka ('sjøl om').

Typisk for vaikka-setninger er at saksforholdet som er uttrykt i oversetninga, verken er en forventa eller uventa følge av vaikka-setninga, men at det likevel er noe overraskende. vaikka-setninger kan like godt stå etter $(1-4,7)$ som før $(5,6)$ oversetninga. Når de står før oversetninga, så kan en eventuell 
konjunksjon i oversetninga stå foran subjunksjonen vaikka; jf. konjunksjonen mutta i (5).

1. Mie en ole muutelu asentopaikkoja paljon, vaikka olen orvoksi jääny. 'Jeg har ikke flytta så mye, sjøl om jeg blei foreldrelaus'.

2. Sillä oon hyvä järki, vaikka jo vanhaa mies oonki. 'Han har vettet i behold, sjøl om han er en gammal mann allerede.'

3. Mennee se niinki, ettei saa yhtäkhään kallaa, vaikka oonki ostanu lupakortin. 'Det hender også at man ikke får en eneste fisk, sjøl om man har kjøpt fiskekort.'

4. Hän tyhä puhui meile ruijan kieltä, vaikka met kaikin saatoima kainun kieltä. 'Han/Hun snakka bare norsk til oss, sjøl om vi alle kunne kvensk.'

5. Mutta vaikka oli jo juunikuu, lunta oli vielä hirmunen paljon vaaran laiđoila. 'Men sjøl om det allerede var juni, så var det fortsatt veldig mye snø på fjellsidene.'

Personformene til nektingsverbet $e i$ smelter ofte i hop med subjunksjonen vaikka, og vi får da disse formene: (1. sg., 2. sg., 3. sg., 1. pl., 2. pl., 3. pl.) vaikken, vaikket, vaikkei, vaikkema, vaikketta, vaikkei. Bruken er illustrert i $(6,7)$.

6. Vaikkei meilä ollu sivakoita, se isälä kuitenki oli.

'Sjøl om ikke vi hadde ski, så hadde far det.'

7. Kyllä se visshiin ymmärtäis minun suomen, vaikken mie kirjoittais niin justhiin oikhein.

'Han/Hun skjønner vel finsken min, sjøl om jeg ikke skriver heilt korrekt.'

\subsubsection{Konnektive subjunksjoner}

KonNeKTIVE SUBJUnKSJONER innleier leddsetninger som ikke tilføyer oversetninga noe nytt, men som knytter den til samtalen eller konteksten. De har med andre ord samme funksjon som konnektive adverb (se avsnitt 9.7.1). Kvensk har to konnektive subjunksjoner, niin ko ('som') og jos ('om, viss'), som begge også har andre funksjoner: niin ko brukes også i jamføringskonstruksjoner, og jos brukes som kondisjonal subjunksjon. Men her skal vi ta for oss hvordan de brukes som konnektive subjunksjoner. 
- Den konnektive subjunksjonen niin ko innleier ei leddsetning som knytter oversetninga til samtalen eller konteksten som går forut for oversetninga. Konnektive subjunksjonssetninger kan stå i begynnelsen av den komplekse setninga, eller følge etter oversetninga. Leddsetninga inneholder også et taleverb av typen puhhuut $\sim$ puhua(t) ('snakke'), sannoot $\sim$ sanoa $(t)$ ('si'), kirjoittaa( $t$ ) ('skrive'), muistela ('fortelle').

Ordsambandet niin ko kan også klassifiseres som konnektiv, men ettersom det har en fast plass i begynnelsen av leddsetninga og det ikke kan flyttes aleine uten oversetninga, så regner vi det her som subjunksjon.

niin ko-setninger kan stå foran $(1-3)$ eller etter $(4,5)$ oversetninga.

1. Niin ko mie jo muistelin, net alethiin suomalaiset täälä kulkemhaan heti ko tie tuli.

'Som jeg allerede fortalte, så begynte finlenderne å ferdes her med en gang vegen kom.'

2. Niin ko meän äitiki puhui, kyllä se oon parempi aika nyt. 'Som også mor mi sier, så et det bedre tider nå.'

3. Niin ko Perunka silloin kirjoitti, se oli kamala saarnata vierhaala kielelä ihmisille.

'Som Beronka skreiv den gangen, så var det forferdelig å preke på et språk som var fremmed for folk.'

4. Koko sođassa oli kysymys tyhä vallanhimosta, niin ko Pekkaki assiin ymmärsi. 'Heile krigen handla bare om maktbegjær, slik som også Peder forsto det.'

5. Kyllä kainun kieli vielä ellää, niin ko Alfin kirjatki tođistethaan.

'Kvensk lever da enda, noe også bøkene til Alf vitner om.'

- Den konnektive subjunksjonen jos innleier leddsetninger som refererer til konteksten, enten i tale (6) eller skrift (7), og til hvordan oversetninga skal forstås, men som ellers ikke tilføyer noe til sannhetsgehalten i oversetninga. jos-setninga kan også formuleres som ei slags spørresetning (7).

6. Meilä oli vanhaasseen aikhaan tervahauat, jos tet ymmärättä, mikä semmonen oon.

'I gamle dager hadde vi tjæremiler, viss dere skjønner hva det er.'

7. Jos mie olen assiin oikhein ymmärtänny, tet meinaatta siirttyyt Alattihoon. 'Viss jeg har forstått saka rett, så akter dere å flytte til Alta.' 


\subsubsection{Subjunksjonssetninger som verbalutfyllinger}

Subjunksjoner kan også innleie ei utfyllingssetning eller frase. Utfyllingssetninger har de samme funksjonene som andre utfyllinger i setninga, det vil si at de kan fungere som subjekt, objekt, predikativ eller adverbial i oversetninga.

Utfyllingssetninga kan også ha en nominal representant i oversetninga. Det er vanligvis pronomenet se eller ei bøyingsform av det. For eksempel $(1,2)$ :

1. Se oon kummalinen, ette sieki halusit olla myötä.

'Det er rart at også du ville bli med.'

2. Mie en tieny sitä, ette sieki halusit olla myötä.

'Jeg visste ikke det at du også ville bli med.'

Slike semantisk tomme element i oversetninga kaller vi her for ANKERORD (se avsnitt 2.4.4). Det er mulig å sløyfe ankerordet, men det er vanligvis anbefalt å ha det med.

\subsubsection{Subjunksjonssetninger som subjekt}

Leddsetninger som fungerer som subjekt i oversetninga, innleies med subjunksjonene ette ('at') og ko ('at'). Vi skal se nærmere på disse to.

- Som subjekt står ette-setninger alltid etter oversetninga. Oversetninga er som regel en type predikasjonssetning. ette-setninga kan ha et ankerord i oversetninga (1-3), men den kan også være foruten det (4).

1. Se oon tavalinen, ette tuola mettässä näkkee karfuun.

'Det er vanlig at man ser bjørn der i skogen.'

2. Kyllä se oon juuri tapahtunnu, ette karhu oon pahojansa tehny.

'Det har knapt / så vidt skjedd at bjørnen har gjort hærverk.'

3. Vielä somempi hänestä oli se, ette ämmi oli hänen kansa kotona.

'Det han/hun syntes var enda artigere, var at bestemor var heime sammen med han/henne.'

4. Jos tässä joku sattuis tulla kippeeksi, niin piian olis hyvä, ette meilä olis lääki. 'Viss det hender at noen blir sjuk her, så hadde det kanskje vært bra om vi hadde en lege.'

Når det i oversetninga er et predikativ, så kan vi i stedet for ei ette-setning også ha ei infinitivsfrase som subjekt. Også ei slik infinitivsfrase blir knytta til 
oversetninga med hjelp av subjunksjonen ette. Ei forutsetning for slike konstruksjoner er at ette-frasen har generisk innhold (5-7).

5. Hyvä se oon että päästä valmhiiksi aijala.

'Det er bra å bli ferdig i tide.'

6. Paha se oon että olla köyhänä.

'Det er ille å være fattig.'

7. Se oon soma ette nähhä vielä sinunki.

'Det er artig å treffe også deg enda.'

Sanseverba näyttää ( $t$ ) ('se ut') og tunttuut tuntua(t) ('kjennes, føles') tar vanligvis adverbialutfylling i ablativ (se avsnitt 4.2.3.7). Men i stedet for adverbialutfylling kan de like godt ta et subjekt i form av ei ette-setning (8-10). Slike setninger har vi tidligere regna til setningstypen SANSEOBSERVASJON (se avsnitt 4.3.3, eksempel 15 og 16).

8. Tänä vuona näyttää, ettei tulekhaan hilloja.

'I år ser det ut til at det ikke blir molter.'

9. Näytti, ette kainun kieli kokonhansa kuolee.

'Det så ut til at kvensk skulle dø ut heilt og holdent.'

10. Pekasta tuntui, ette kuolema oli likelä.

'Peder kjente at døden var nær.'

Vi kan jamføre setningene (8), (9) og (10) med tilsvarende setninger med ankerord (11-13):

11. Tänä vuona näyttää siltä, ettei tulekhaan hilloja.

12. Näytti siltä, ette kainun kieli kokonhansa kuolee.

13. Pekasta tuntui siltä, ette kuolema oli likelä.

Det er vanlig å sløyfe ankerordet i slike setninger.

- Også subjunksjonen ko kan innleie ei subjektssetning som korrelat til predikativet i oversetninga (14-17). Det er vanlig i konstruksjonene oon hyväl paha/huono ko ('det er bra/ille/dårlig at'). Adjektivet i slike konstruksjoner kan også stå i komparativ (17). Oversetninga kan være med $(16,17)$ eller uten (14, 15) ankerord. 
14. Oli hyvä, ko tulitta kotia.

'Det var bra at dere kom heim.'

15. Oon paha, ko lapset villiinythään.

'Det er ille at barn blir ustyrlige.'

16. Se oon surkkee, ko kala oon loppunu vuonosta.

'Det er sørgelig at fisken er blitt borte fra fjorden.'

17. Se olis parempi, ko pysyisittä kotona tämmösellä ilmala.

'Det hadde vært best om dere holdt dere heime i dette været.'

\subsubsection{Subjunksjonssetninger som objekt}

Leddsetninger som fungerer som objektsutfylling til verbalet i oversetninga, innleies med subjunksjonene ette että ('at'), jos ('om, viss') og ko ('at, når'). Av disse er det uten tvil ette $\sim$ että-setninger som er vanligst. Men vi skal her kort se på de andre også.

- Når oversetninga er ei indirekte setning, så er det vanlig at den tar ei ette että-setning som objekt (1-7). Ei spørresetning som fungerer som objekt i ei indirekte setning, kan også bli innleid av subjunksjonen ette ( 5 ). Objektssetninga kan ha et ankerord i objektskasus i oversetninga $(6,7)$.

1. Jos hyljet olis tieny, ette se oon ihminen, niin ei se olis pääle tullu.

'Viss selen hadde visst at det var et menneske, så ville den ikke ha gått til angrep'.

2. Mie en usko, ette jäkälästä tullee minkhäänlaista ruokkaa.

'Jeg trur ikke at det blir noe mat av lav'.

3. Saapi sanoa, ette se tuli vaphaus tänne Ryssän sotamiehen kautta.

'Man kan si at friheta kom hit med den russiske soldaten.'

4. Ei kukhaan heistä ajatellu, ette säästeläki se pitäis.

'Ingen av dem tenkte på at en burde spare også.'

5. Sitte sannoo lääki mulle, ette mitä sie aijot tuole käđele tehđä.

'Og så sier legen til meg, hva har du tenkt å gjøre med den handa.'

6. Mie kävelin etumaisena varoittain sitä, etten mie puttois aventhoon.

'Jeg gikk fremst og passa på at jeg ikke skulle dette ned i råka'. 
7. Emmä met hävenheet sitä, että puhuima suomee. 'Vi skjemtes ikke over at vi snakka finsk.'

Det fins også en setningsstruktur der subjunksjonen ette että knytter ei 1. infinitivsfrase som objekt til verbalet i oversetninga. Slike setninger brukes når det er snakk om befalinger eller oppfordringer, eller når ette-frasen forteller hva subjektet $\mathrm{i}$ oversetninga ønsker at noen andre skal gjøre. Verbet $\mathrm{i}$ oversetninga kan være et styringsverb $(8,9)$, men det kan også være et taleverb (10-12).

8. Isäntä käski että kantaa heinät sisäle.

'Husbonden ga ordre om at høyet skulle bæres inn'

9. Mie kielsin että ei lähtiä.

'Jeg forbydde han/henne/den/det å dra.'

10. Mikki sanoi pojile että lähtiä merele hänen kansa.

'Mikke sa til guttene at de måtte bli med han på havet.'

11. Mies huusi että tulla aphuun.

'Mannen ropte at noen skulle komme han til hjelp.'

12. Antti kirjotti mulle että tulla varsin.

'Anders skreiv til meg at han skulle komme straks.'

- Stundom kan også ei jos-setning fungere som objekt. Den har da som regel et ankerord i oversetninga (13), men ankerordet kan også utelates (14).

13. Sitä mie meinasin, jos sie tahtoisit yöttyyt täälä.

'Det var det jeg meinte, om du ville overnatte her'.

14. Sie piđät lähteet kattomhaan, jos niitä miehii löytäis sieltä.

'Du bør gå og se etter om de der mennene er å finne der.'

- Objektssetninger som er innleid av subjunksjonen ko, brukes særlig som utfylling til direkte sanseverb. Ankerordet kan her være med (15) i oversetninga, eller ikke (16).

15. Het ei ollenkhaan nähnheet sitä, ko aamu valkeni.

'De så overhodet ikke at dagen grydde'.

16. Pojat kuulthiin, ko tyttäret tulthiin.

'Guttene hørte at jentene kom.' 


\subsubsection{Subjunksjonssetninger som predikativ}

Leddsetninger som er innleid med ette että, kan også fungere som predikativ. I slike tilfeller presenterer korrelatet i oversetninga en ting eller et saksforhold som leddsetninga avgrenser eller spesifiserer.

Også her finner vi varianter med ankerord i oversetninga $(1,2)$, og sånne uten (3).

1. Ensimäinen toivomus oli se, ette het pärjättäis hengissä kothiin.

'Det første ønsket var at de skulle berge seg heim med livet i behold.'

2. Toinen asia oli se, ette aika kului paremin ko oli jotaki työtä.

'En annen ting var at tida gikk fortere når det fantes noe arbeid.'

3. Ainua asia, mitä het toivothiin, oli ette sota loppuis ja tulis rauha.

'Det eneste de håpa på, var at krigen skulle ta slutt, og at det skulle bli fred.' Av predikativ art er også ette-setninger som bruker ankerord som niin ('slik') eller semmo(i)nen (sådan, slik) $(4,5)$. I slike setninger kan ankerordet vanskelig utelates.

4. Minun äiti oli kans semmonen, ette hän ei uskonu mihinkhään taikuutheen.

'Mor mi var også slik at hun ikke trudde på noe trolldom.'

5. Mutta assiinlaita oli niin, ettei het sinä päivänä halunheet kohđatella meitä. 'Men stoda var slik at de ikke ønska å treffe oss den dagen.'

\subsubsection{Subjunksjonssetninger som adverbialutfylling}

Leddsetninger som er innleid med subjunksjonen ette että, kan også fungere som adverbialutfylling til verbalet i oversetninga. Oversetninga har da vanligvis et ankerord, som står i den lokalkasusen eller annen kasus som verbet styrer (1-6).

1. Sielä puhuthiin siitä / sen ympäri, ette aika oon kauhee.

'Der prata man om at det var ei forferdelig tid.'

2. Hän uskoi siihen / sen pääle, ette parempi aika se kyllä tulis heti. 'Han/Hun trudde på at det snart skulle komme ei bedre tid.'

3. Mie luotin siihen / sen pääle, ettet sie muistelis sitä kelheen. 'Jeg stolte på at du ikke skulle fortelle det til noen.'

4. Ihmiset kiitethiin väärttii siitä, ette heilä oli vielä ruokkaa. 'Folk takka gjestevennen sin for at de fortsatt hadde mat.' 
5. Pojat sovithiin siitä, ette aamula het lähđettäis tunturhiin.

'Guttene blei enige om at de skulle dra til fjells neste morgen.'

6. Minusta näyttää siltä, ette tästä tullee kova talvi.

'For meg ser det ut til at dette blir en hard vinter'.

Legg merke til at vi kan ta bort ankerordet i disse setningene, men da endrer subjunksjonssetninga funksjon; den blir da til objekt (7-9) eller subjekt (10).

7. Sielä puhuthiin, ette aika oon kauhee.

'Der blei det sagt at det var ei forferdelig tid.'

8. Hän uskoi, ette parempi aika se kyllä tulis heti.

'Han/Hun trudde at det snart skulle komme ei bedre tid.'

9. Pojat sovithiin, ette aamula het lähdettäis tunturhiin.

'Guttene avtalte at de skulle dra til fjells neste morgen.'

10. Minusta näyttää, ette tästä tullee kova talvi.

'For meg ser det ut til at dette blir en hard vinter.'

\subsubsection{Subjunksjonssetninger som modifikatorer}

Ovafor har vi sett på subjunksjonssetninger som fungerer som utfyllinger. Men subjunksjoner kan også innleie ei bisetning som fungerer som modifikator til adjektiv, adverb eller substantiv. Det er denne typen subjunksjonssetninger vi skal ta for oss i de følgende to avsnitta.

\subsubsection{Subjunksjonssetninger som modifikator til adverb og adjektiv}

Av subjunksjonssetninger er det kun ette $\sim$ että-setninger som kan fungere som modifikator til adverb og adjektiv. Når de modifiserer adverb, så uttrykker adverbfrasen som regel måte, mengde eller omfang (1-5). Når de modifiserer adjektiv, så forteller de hvor mye av den egenskapen som adjektivet uttrykker, det er snakk om (6-9). I tillegg til subjunksjonssetninga er adverbet og adjektivet i slike konstruksjoner også modifisert av et adverb (niin ('så), liian ('altfor, for'), tarpheeksi ('tiltrekkelig'), nokko ('nok') eller liknende), som avgrenser nærmere mengden eller omfanget av innholdet $\mathrm{i}$ adjektivfrasen. 
1. Kallaa ei jääny sen verran, että olis yhđen vellin tehny.

'Det var ikke så mye fisk igjen at en kunne ha laga ei eneste suppe ut av det.'

2. Kläpit viivythiin niin kauvoin, ette muori häytyi tulla noutamhaan heitä kothiin.

'Ungene drøyde det så lenge at mor måtte komme og hente dem heim.'

3. Kyllä se poika vihhaa viinaa niin paljon, ettei uskala putelhiin koskeekhaan.

'Den gutten avskyr nok sprit så mye at han ikke engang tør å røre flaska'.

4. Ranta oli liian kaukana, ette sinne olis päässy uimala.

'Stranda var for langt unna for at man kunne ha svømt dit.'

5. Laiva oli jo tarpheeksi kaukana, ettei viholinen ennää nähny sitä.

'Båten var allerede tilstrekkelig langt unna for at fienden ikke lenger kunne se den.'

6. Matti oli noitahommista niin vihainen, ette olis piekseny net ihmiset kaikki traasuksi.

'Mats var så sint på heksekunstene at han kunne ha banka de folka sønder og sammen'.

7. Pojat olit niin innostunheet, ette kokonhansa unhotethiin aian.

'Guttene var så ivrige at de glømte heilt av tida'.

8. Mie olen liian vanhaa, ette mie saisin ennää akkaa.

'Jeg er for gammal til at jeg skulle få meg kjerring.'

9. Kyllä liha oli nokko lihava, ette siitä sai hyvän ruvan.

'Kjøttet var feitt nok til at det kunne bli god mat av det.'

Konnektivet sillä blir også modifisert av ei ette-setning (10).

10. En mie tehe työtä sillä, ette minusta tulis rikas, mutta sillä, ette mie tykkään työtelä.

'Jeg arbeider ikke for at jeg skal bli rik, men fordi jeg liker å arbeide.'

\subsubsection{Subjunksjonssetninger som modifikator til substantiv}

Subjunksjonssetninger brukes også som modifikator til substantiv, og de blir da innleid av subjunksjonen ette $\sim$ että eller ko.

- Det er ganske vanlig at subjunksjonssetninger med ette että modifiserer substantiv. Det gjelder spesielt for abstrakte substantiv som forteller om 
sinnstilstand, tanker, tale eller liknende (1-7). De har ofte et ankerord i oversetninga $(1,3,4,6)$, men ikke alltid $(2,5,7)$.

1. Ei kenheen päähän ollu tullu se ajatus, ette miehilä saattais olla nälkä. 'Ingen hadde kommet på den tanken at mennene kunne være sultne.'

2. Heilä tuli eppäilys, ette het olthiin öksynheet. 'De begynte å lure på om de var gått seg vill.'

3. Heile oli jääny usko siihen, ette parempi aika se kyllä tulis heti. 'De hadde fortsatt trua på at det snart skulle komme ei bedre tid.'

4. Maalista tavaraa heilä ei ollu, mutta olihan heilä kuitenki luottamus siihen, ette kyllä sitä löytyis.

'De hadde ikke noe jordisk gods, men festa likevel lit til at de skulle finne noe.'

5. Het ei saanheet tiettoo, ette laivoissa oli siviiliväkkee.

'De fikk ikke noe informasjon om at det var sivile folk i båten.'

6. Se oli kuitenki semmoinen kysymys, ettei siihen löytyny vastausta.

'Det var nok et slikt spørsmål som det ikke fantes noe svar på.'

7. Hän lähätti sanan kaikilet alattiolaisilet, ette het pi’it kokkoontuat hänen tyköt pyssyitten, kirvheitten ja muunlaisten tappamaneuvoitten kansa. 'Han/Hun sendte bud til alle altaværinger om at de måtte samles hos han/ henne med børser, økser og andre drapsvåpen.'

Men ette-setninger brukes også som modifikator til konkrete substantiv (8-11). Slike substantiv må ha et ankerord foran seg, som regel er det semmo(i)nen ('sådan, slik').

8. Ko se oliski ollu semmonen jää, että viholliset oltais hukkunheet. 'Om det bare hadde vært slik is at fiendene hadde drukna'.

9. Mutta se oli semmonen lääkitysihminen, ette se saattoi panna jalan ja luut sijalensa.

'Men han/hun var en slik helbreder at han/hun kunne sette på plass foten og beina'

10. Muutamat tulthiin töihin tänne ja saathiin semmosen työn, ette se oon pysyväinen. 
'Noen kom hit for å jobbe, og de fikk seg slikt arbeid som blei til fast jobb.'

11. Nyt lapset saava kasuta semmosessa aiassa, ette oon tervheet ja saava ellä̈. 'Nå får barna vokse opp i ei tid der de er friske og får leve.'

- Noen ganger kan substantiv også være modifisert av ko-setninger (12-13).

12. Meilä oli vissi aika, ko met pi’imä ollat sisälä.

'Vi hadde et visst tidspunkt når vi måtte komme oss inn.'

13. Muistan vielä sen talven, ko olima feeriällä Spaaniassa.

'Jeg husker enda den vinteren da vi var på ferie i Spania.'

\subsubsection{Jamføringsfraser}

Kvensk har bare én jamføringssubjunksjon i streng forstand, og det er ko ('enn; som'). Sammen med jamføringsordet danner det en jamføringsfrase. Jamføringsfrasen modifiserer korrelatet som fins i oversetninga. Jamføringsordet er enten en komparativfrase $(1,2)$ eller en egentlig jamføringsordfrase $(3,4)$, men det kan også mangle heilt (5).

14. Matti oon vanhempi ko Maija.

'Mats er eldre enn Maja.'

15. Maija lukkee enämen ko Matti.

'Maja leser mer enn Mats.'

16. Pikku-Matti oon sama vanhaa ko Maija.

'Vesle Mats er like gammal som Maja.'

17. Pikku-Matila oon eri faari ko Maijala.

'Vesle Mats har en annen far enn Maja.'

18. Maija oon Pikku-Matile ko sisar.

'Maja er som ei søster for Vesle Mats.'

Vi deler jamføringsfraser inn i tre grupper:

- Komparativfraser

- Ekvivalente forhold

- Illustrerende forhold 


\subsubsection{Komparativfraser}

Vi bruker KOMPARATIVFRASER for å sammenlikne to eller flere ting eller enheter med hverandre. Korrelatet, eller det som blir sammenlikna, står i oversetninga, mens det som korrelatet blir sammenlikna med, er en del av komparativfrasen. Den forteller at korrelatet har mer eller mindre av en gitt egenskap, eller at det forekommer i større eller mindre mengde eller omfang enn det det blir sammenlikna med. Jamføringsordet i ko-fraser er et adjektiv (1-6) eller et adverb (7-9) i komparativform. Adjektivet kan stå aleine (1-4) eller som adjektivmodifikator til et substantiv $(5,6)$.

1. Pekka oon oikhein hyvä opas, parempi ko kukhaan muu, paras kaikista. 'Peder er en veldig god guide, bedre enn noen andre, den beste av alle.'

2. Ulkona oon vielä kylmempi ko varhemin.

'Det er enda kaldere ute enn før.'

3. Se poika oon yhen kuukauen nuorempi ko mie. 'Den gutten er en måned yngre enn meg.'

4. Kesälä saattaa tulla tauti lämpimästä, ja se oon vielä värrempi ko se, mikä kylmästä tullee.

'Om sommeren kan det oppstå en sjukdom på grunn av varmen, og den er enda verre enn den som oppstår på grunn av kulda.'

5. Ei meän vanhiimet ole tulheet sen kummemmasta paikkaa ko mistä tetki tuletta.

'Foreldra våre kommer ikke fra noe merkeligere sted enn det dere kommer fra'.

6. Täälä oon likempi kalanpyytö ko koko Pohjais-Suomessa.

'Her er fisket nærmere enn i heile Nord-Finland.'

7. Näissä kainunleivissä oon fiberii enämen ko sie koskhaan saat niistä fruktiista, mitä sie ylheensä syöt.

'Det er mer fiber i disse kvenbrødene enn du noen gang får fra de der fruktene som du spiser til vanlig.'

8. Eikä minule käyny paremasti ko sinulekhaan.

'Det gikk ikke bedre med meg enn med deg.'

9. Nämät kakot kesti laittaat kauvoimin ko mie uskoinkhaan.

'Det tok lengre tid å lage disse kakene enn jeg hadde trudd.' 
Som komparativfraser regner vi også fraser som forteller at det blir mer og mer av en egenskap (10), eller at noe stadig auker i mengde eller omfang (11). I slike fraser bruker vi konjunksjonen ette:

10. Pakkainen tuli kovemaksi ette kovemaksi.

'Frosten blei hardere og hardere'

11. Matti sai rahhaa enämen ette enämen.

'Mats fikk mer og mer penger.'

\subsubsection{Ekvivalente forhold}

Et ekvivalent forhold innebærer at det enten er eller ikke er like mye av to eller flere ting eller enheter, eller at de enten har eller ikke har samme egenskap (o-3). Ekvivalente forhold kan også uttrykke at saksforholdet i oversetninga er det samme eller ikke det samme som det i jamføringsfrasen (4-7). Som jamføringsord i ekvivalente forhold bruker vi sama ('like'), yhtä ('like') og liikka ('like'), og de står i første delen av jamføringsfrasen som modifikator i en adjektivfrase (0-4) eller en kvantorfrase (5-7).

1. Kuninkhaantyär oli yhtä totinen ko ennenki.

'Kongedattera var like alvorlig som før.'

2. Aviisissa seisoi, ette Alattiosta tullee $y$ htä iso kylä ko Tronjami.

'Det sto i avisa at Alta blir en like stor by som Trondheim.'

3. Liisa oon sama vanhaa ko Matti.

'Lisa er like gammal som Mats.'

4. Uslussa ei ole sama soma assuut ko Tromssassa.

'Det er ikke like fint å bo i Oslo som i Tromsø'.

5. Ilman sinulaki oon sama paljon tiettoo ko sinun opettaajalaki.

'Du har vel like mye kunnskaper som læreren din.'

6. Niitä pölätyksiä saattaa olla liikka paljon ko meitä, vaikka met emmä näe niitä. 'Det er mulig at det fins like mange av disse overnaturlige vesena som det fins av oss, sjøl om vi ikke ser dem.'

7. Se oli tehny kolmessa päivässä työtä liikka monta tiimaa ko nyt viikossa tehhään. 'Han/Hun hadde jobba like mange timer på tre dager som man nå gjør på heile uka. 
Også gradsadverbet niin ('så) brukes i jamføringsfraser for å uttrykke et slags ekvivalent forhold (8-11). Men dersom oversetninga er nektende, så resulterer konstruksjonen i et motsetningsforhold (12-15).

8. Heiđän olo oli niin hyvä ko se kaukana kottoo saattoiki olla.

'Tilværelsen deres var så bra som den kunne være så langt heimefra.'

9. Siinä se velli kiehui niin kypsyksi ko se kerkis kiehumhan.

'Suppa kokte der så ferdig som den rakk å koke.'

10. Het souđethiin niin paljon ko jaksethiin.

'De rodde så mye de orka.'

11. Mie piän asua täälä niin kauan ko poika oon koulussa.

'Jeg må bo her så lenge som sønnen min går på skole.'

12. Eihän täälä ennää ole niin rauhalinen ko ennen oli.

'Det er jo ikke like rolig her som det var før'.

13. Ei silloin ollu niin kallis ko nyt.

'Det var ikke så dyrt den gangen som nå.'

14. Ei se ruokahomma ollu ennen niin kevvee ko nyt.

'Før i tida var ikke matstellet like lett som nå.'

15. Ei se ole niin raskas lukkeet ko sie luulet.

'Det er ikke så tungt å lese som du trur.'

Ekvivalente forhold kan også uttrykkes uten egentlig jamføringsord (16).

16. Se äijä oli paha ko piru.

'Den karen var ond som djevelen.'

\subsubsection{Illustrerende forhold}

Siste delen i jamføringsfraser i illustrerende forhold beskriver første delen i frasen. Som jamføringsord kan vi for eksempel bruke (egentlige jamføringsord) sama ('samme'), muu ('annen') (1-4), (jamføringsadjektiv) samanlainen ('likens, samme slags'), erilainen erisorttinen ('annerledes, forskjellig, ulik'), muunlainen ('annerledes') (5-7), (jamføringsadverb) samoin samoten samhaan laihiin samala tavala ('på samme måte'), eri laila ('på annen måte'), muu(v)ala ('på et anna sted'), muu(v)ale( $t$ ) ('til et anna sted'), muu( $v$ )alta ('fra et anna sted'), muutoin muuten ('ellers') (8-11). 
1. Äiji ei saanu syöđä samassa pöyđässä ko isäntä ja emäntä syöthiin. 'Bestefar fikk ikke spise ved samme bord som husbonden og husmora'

2. Auringolla oon sama vaikutus ko traanila. 'Sol har samme virkning som tran.'

3. Hänelä ei ollut muuta tavaraa ko tarpheeliset vaattheet ja yksi pikku arkku.

'Han hadde ikke mer gods enn nødvendige klær og ei lita kiste.'

4. Ei täälä ollu muuta tietä ko joki talvela.

'Det var ikke annen veg her enn elva om vinteren.'

5. Niilä oli samanlaiset vaattheet ko miesihmisillä.

'De hadde samme slags klær som mannfolka.'

6. Nenetsiilä oli muunlaiset pyytötavat ko meilä Ruijassa.

'Nenetserne hadde andre fangstmetoder en vi her i Norge.'

7. Het praataava vähän erilaista suomia ko met.

'De snakker en litt annen finsk enn vi.'

8. Lappalaiset sanothiin ette talokkhaat oon heiđän väärttit, samoten ko talokkhaat sanothiin, ette lappalaiset oon heiđän väärttit.

'Samene brukte å si at de fastboende var gjestevennene deres, på samme måte som de fastboende brukte å si at samene var deres gjestevenner.'

9. Sykkelillä ei opi ajamhaan muutoin ko ajamalla.

'Man lærer ikke å sykle på annen måte enn ved å sykle'.

10. Ruijan kieltä kirjoitethaan muula laila ko puhuthaan.

'Norsk skrives annerledes enn det snakkes.'

11. Mie en triivastu muuvala ko täälä.

'Jeg trives ikke andre steder enn her'.

Når oversetninga er en predikasjonssetning, så fungerer korrelatet til jamføringsfrasen som subjekt i oversetninga (12-15).

12. Sie olet aivan samanlainen ko Liisa.

'Du er akkurat likedan som Lisa.'

13. Mie olen kokonhansa erilainen ko Pekka.

'Jeg er heilt annerledes enn Peder.' 
14. Se oon erisorttinen ko Tenon kala.

'Det er en annen art enn Tana-fisken.'

15. Suomi oon kokonhansa muunlainen kieli ko nämät skandinaaviset kielet.

'Finsk er et heilt annerledes språk enn disse skandinaviske språka'

På samme vis som de egentlige jamføringsadjektiva fungerer også proadjektiva semmo(i)nen ('slik'), tuomo(i)nen tuoma(i)nen ('sånn der') og tämmö(i)nen $\sim$ tämmä(i)nen ('slik som denne, sånn her') (16-20):

16. Ei ennen ollu semmosia vehkhejäkhään ko nyt.

'Før i tida fantes det heller ikke slikt utstyr som nå.'

17. Ei se ole syytä olla iloinen, ko oon tämmöinen aika ko nyt oon.

'Det er ingen grunn til å være glad i ei slik tid som denne.'

18. Sie nyt olet tuomainen ko sie olet.

'Du er nå engang slik du er.'

19. Elämästä tullee semmonen ko itte sen tekkee.

'Livet blir til det man sjøl gjør ut av det'.

20. Ei se ollu kumma, ette mettäki oli semmoinen ko se oli.

'Det var ikke rart at også skogen var slik den var.'

Jamføringsordet kan også mangle i illustrerende forhold (21-23).

21. Matti kävelee ko karhu.

'Mats går som en bjørn.'

22. Hukka ulvoi ko olis poikansa kađottannu.

'Ulven hylte som om den hadde mista ungen(e) $\sin (\mathrm{e})$.'

23. Liisa oon ko kukkanen kentälä.

'Lisa er som en blomst på marka'

Det er spesielt vanlig å utelate jamføringsordet i nektende setninger (24-26).

24. Tämä ei ollu ollu talossa ko vähän aikkaa.

'Denne/Dette hadde ikke vært i huset mer enn ei kort stund.'

25. Sitä mie en ole kuulu ko ruijaksi.

'Jeg har ikke hørt om det anna enn på norsk'. 
26. Ei siihen panna ko puhasta suolaa.

'Man har ikke anna opp i det/den enn reint salt.'

Vi kan også uttrykke illustrerende forhold med hjelp av subjunksjonssambandet niin ko ('slik som'). Første delen i subjunksjonssambandet, niin, svarer da til jamføringsordet, og det brukes derfor aldri noe anna jamføringsord i setninga. Subjunksjonssambandet kan like godt stå i begynnelsen av den komplekse setninga (27) som etter oversetninga (28-30) eller inni den (31).

27. Niin ko muuvalaki maailmassa, ihmiset elethään tääläki vanhemaksi ette vanhemaksi.

'Som i andre deler av verden lever også her menneskene lenger og lenger'.

28. Met elämä niin ko isot kreevit.

'Vi lever som en greve.'

29. Eihän elämä ennen ollu niin ko nyt.

'Livet før i tida var jo ikke som nå.'

30. Ei ihmiset sielä puhu niin ko met täälä puhuma.

'Folk der snakker ikke som vi snakker her'

31. Oma muori oli hänele, niin ko toisileki ihmisille, rakkhain ihminen maailmassa.

'Hannes/Hennes eiga mor var for han/henne, som for andre mennesker også, det kjæreste mennesket i verden.'

\subsubsection{Oppsummerende om subjunksjoner}

Som vi har sett ovafor, så fins det formmessig bare noen få ulike subjunksjoner i kvensk. Det er ette että, nette nettä, ko, jos og vaikka. I tillegg har vi subjunksjonssamband som bygger på ette- että-subjunksjonen, niin ette että, og sånne som bygger på ko-subjunksjonen, siksi ko, siitä ko, ennen ko, jälkhiin jälkheen ko, sillä ko og niin ko. Men en og samme subjunksjon kan brukes i mange forskjellige funksjoner. Det gjelder særlig subjunksjonen ette $\sim$ että og subjunksjonen ko. De kan nærmest regnes som en slags universalsubjunksjon.

Tabell 11.1 oppsummerer hvilke funksjoner de ulike subjunksjonene har, og hvilke subjunksjonssamband de danner. 
Tabell 11.1 Subjunksjoner og deres funksjon

\begin{tabular}{|c|c|c|c|c|c|}
\hline Funksjon & ette että & nette $\sim$ nettä & ko & jos & vaikka \\
\hline \multicolumn{6}{|l|}{ Fri adverbial } \\
\hline Temporal (11.2.1.1) & & & $\begin{array}{l}\text { ko, siksi ko, siitä ko, } \\
\text { ennen ko, jälkhiin } \\
\text { jälkheen ko }\end{array}$ & & \\
\hline Kausal (11.2.1.2) & $\begin{array}{l}\text { ette } \sim \text { että, } \\
\text { niin ette } \\
\text { niin että }\end{array}$ & $\begin{array}{l}\text { nette } \\
\text { nettä }\end{array}$ & ko, sillä ko & & \\
\hline Kondisjonal (11.2.1.3) & & & ko & jos & \\
\hline Konsessiv (11.2.1.4) & & & & & vaikka \\
\hline Konnektiv (11.2.1.5) & & & niin ko & jos & \\
\hline \multicolumn{6}{|l|}{ Utfylling } \\
\hline Subjekt (11.2.2.1) & ette että & & ko & & \\
\hline Objekt (11.2.2.2) & ette että & & ko & jos & \\
\hline Predikativ (11.2.2.3) & ette että & & & & \\
\hline Adverbial (11.2.2.4) & ette että & & & & \\
\hline \multicolumn{6}{|l|}{ Modifikator } \\
\hline $\begin{array}{l}\text { til adjektiv og adverb } \\
\text { (11.2.3.1) }\end{array}$ & ette että & & & & \\
\hline til substantiv (11.2.3.2) & ette että & & ko & & \\
\hline \multicolumn{6}{|l|}{ Jamføringsfrase } \\
\hline Komparativfrase (11.2.4.1) & & & ko & & \\
\hline Ekvivalent forhold (11.2.4.2) & & & ko & & \\
\hline Illustrerende forhold (11.2.4.3) & & & ko, niin ko & & \\
\hline
\end{tabular}

\subsection{Superjunksjoner}

Superjunksjonene niin ('så, da') og se ('så, da') brukes synonymt, og de forbinder oversetninger som følger etter sine tilhørende leddsetninger, med disse leddsetningene $(1-5)$.

1. Jos hyljet olis tieny, ette se oli ihminen sielä jäälä, niin/se ei se olis pääle tullu.

'Viss selen hadde visst at det var et menneske som var der på isen, så ville den ikke ha gått til angrep.' 
2. Hän sanoi, ette jos hän vielä rikastuis, niin/se saapi nöyrä tulla ottamhaan hänen.

'Han/Hun sa at viss han/hun skulle bli enda rikere, så kunne fanden komme og ta han/henne.'

3. Sielä oon kalanostaja joka haminassa Vesisaaressa ja Pykejässa, ja jos kalan saava, niin/se se oon ostaja varsin.

'Det er fiskekjøpere på hver havn der i Vadsø og på Bugøynes, og viss man får fisk, så fins det straks en kjøper.'

4. Ko nälkä tuli, niin/se varsin sen evhään aina syöthiin.

'Når man blei sulten, så spiste man alltid straks nista.'

5. Mutta jos tehimä jotaki pahhaa, niin/se tiesimä, ette mikä tullee.

'Men om vi gjorde noe galt, så visste vi hva som ville komme.'

Superjunksjonene niin og se bruker vi også når det er ei leddsetning inni oversetninga, og vi ønsker å forbinde siste delen med første delen av oversetninga, det vil si at vi gjentar første delen $(6,7)$.

6. Sielä, missä oon porot, niin/se sielä oon paimenki.

'Der hvor det fins rein, der er det også en gjeter.'

7. Sitä myöten, ko se tie valmistui, niin/se se lyheni se ajo.

'Etter hvert som vegen blei ferdigstilt, så blei kjøringa kortere.' 



\section{Litteraturliste}

Aikio, Marjut. 1981. «Nominien konsonantti- ja vokaalivartaloisuus Raisin murteessa: sosiolingvistinen ja morfologinen tutkimus». Laudaturtutkielma, Suomen kielen laitos, Helsinki: Helsingin yliopisto.

Andreassen, Irene. 2016. «Kven og kainu(lainen)». Kainun institutti - Kvensk institutt. http://www.kvenskinstitutt.no/kvener/kven-og-kainulainen/.

Aronsen, Terje 2001. «Tarvittemmako kväänin kielen stantariseeraamista?» Tutkielmia vähemmistökielistä Jäämereltä Liivinrantaan. Vähemmistökielten tutkimus- ja koulutusverkoston raportti III. Toim. Niina Määttä ja Helena Sulkala. Oulu.

Beronka, Johan. 1922. Syntaktiske iagttagelser fra de finske dialekter $i$ Vadsø og Porsanger. Bd. 1921, nr. 10. Skrifter (Videnskabsselskapet i Kristiania: trykt utg.). Kristiania: I kommisjon hos Jacob Dybwad.

- - - 1925. Iagttagelser fra orddannelses- og formloeren $i$ de finske dialekter $i$ Vadsø og Porsanger. Bd. 1925: no. 1. Skrifter (Det Norske Videnskaps-Akademi i Oslo: trykt utg.). Oslo: I kommission hos Jacob Dybwad.

- - - Norjan suomalaiset. Manuskript A-0098, eske 3, Finnmark fykesbibliotek.

Faarlund, Jan Terje, Svein Lie, og Kjell Ivar Vannebo. 1997. Norsk referansegrammatikk. Oslo: Universitetsforlaget.

Hakulinen, Auli, Maria Vilkuna, Riitta Korhonen, Vesa Koivisto, Tarja Riitta Heinonen, og Irja Alho. 2004. Iso suomen kielioppi. Bd. 950. Suomalaisen kirjallisuuden seuran toimituksia (trykt utg.). Helsinki: Suomalaisen kirjallisuuden seura. http://scripta. kotus.fi/visk/etusivu.php.

Julku, Kösti 1986. Kvenland - Kainuunmaa. Pohjoinen.

Kettunen, Lauri. 1969. Suomen murteet: 3: Murrekartasto. 3., Supistettu p. Suomalaisen Kirjallisuuden Seuran toimituksia 188. Helsinki: Suomalaisen Kirjallisuuden Seura.

Koivulehto, Liisa. «Norjan ja Ruottin kainulaisile yhtheinen kirjakieli». Ruijan Kaiku 6.4.1996.

Lindgren, Anna-Riitta. 1990. «Miten muodot muuttuvat: ruijan murteiden verbintaivutus Raisin, Pyssyjoen ja Annijoen kveeniyhteisöissä». Avhandling (doktorgrad), Tromssa: Tromssan yliopisto.

Lyngen sokneprestembete, 1. nr. 20 1821-1829. Journal for Aarene 1769 og 1770, indsendt, in duplo, til Hds Höyædle Höyærværdighet, Biskopen over Trondhielms Stift Dr Johan Ernst Gunnerus. Avskrift Alf Kiils samlinger, Målselv kommunearkiv.

Nickel, Klaus Peter. 1994. Samisk grammatikk. 2. utg. Karasjok: Davvi girji.

Pajunen, Anneli. 1999. Suomen verbirektiosta: verbin argumenttirakenteen jäsenten valinnasta. Yleisen kielitieteen julkaisuja, Turun yliopisto 1. Turku: Turun yliopisto. 
. 2001. Argumenttirakenne: asiaintilojen luokitus ja verbien käyttäytyminen suomen kielessä. Suomi 187. Helsinki: Suomalaisen Kirjallisuuden Seura.

Rapola, Martti. 1939. «Äännehistoriallinen esimerkkikokoelma Jyykeän murteesta». Virittäjä 43: 473.

Ryymin, Teemu. 2007. «The Making of an Ethnic Identity: From Finns to Kvens». Shaping Ethnic Identities. Ed. Marko Lamberg. Easr-West Books Helsinki.

Skoge, Klaus. 1998. «Infinitiivin illatiivin variaatio kveenimurteissa = Infinitivens kasus illativ i kvendialektane». Hovedoppgave i finsk språk, Tromsø: Universitetet i Tromsø.

Soukka, Maarit. 2006. «Kongruenssi Alf Nilsen-Børsskogin kveenimurteisessa romaanissa Kuosuvaaran takana». Pro gradu-tutkielma, Suomalaisen ja yleisen kielitieteen laitos, Turku: Turun yliopisto.

Trosterud, Trond. 1990. «Binding Relations in Two Finnmark Finnish Dialects: A Comparative Syntactic Study». Hovedoppgave i lingvistikk, Trondheim: Universitetet i Trondheim.

Vilkuna, Maria. 1996. Suomen lauseopin perusteet. Bd. 90. Kotimaisten kielten tutkimuskeskuksen julkaisuja. Helsinki: Edita.

Voronov, Mihail. 2006. «Predikoivat funktiot ensimmäisessä kainunkielisessä romaanissa». Masteroppgave i finsk språk, Tromsø: Universitetet i Tromsø.

\subsection{Utrykt språkmateriale}

Aronsen, Terje. Oversettelsesmanuskripter.

Digitaalinen muoto-opin arkisto (DMA). https://korp.csc.fi/\#?prequery_within=sentence $\&$ cqp $=\% 5 \mathrm{~B} \% 5 \mathrm{D} \&$ corpus $=\mathrm{dma}$

Suomen kielen nauhoitearkisto. Transkriberte kvenske intervjuer fra 1960- og 1970-åra: SKNA 00133:2a, Alta; SKNA 10669:1, Alta; SKNA 10669:2a, Alta, Elvebakken; SKNA 10670:2, Alta, Elvebakken; SKNA 10671:2, Alta, Elvebakken; SKNA 10672:1, Alta; SKNA 10673, Alta; SKNA 10673:1a+b, Alta, Aronnes; SKNA 10698:1a+b, Kvænangen; SKNA 10707:1a+b, Kvænangen; SKNA 10709:1a, Kvænangen; SKNA 10710:2a, Kåfjord; SKNA 10711:2a, Storfjord; SKNA 10712:1a+b, Kåford; SKNA 10717:1a+b, Storfjord; SKNA 10821:2a, Kvænangen; SKNA 10825:1a, Kåfjord; SKNA 10827:1a+b, Storfjord; SKNA 133, Nordreisa; SKNA 1819:1a, Kåfjord, Olderdal; SKNA 4120:4a, Tana, Austertana; SKNA 4125, Vadsø; SKNA 7867:1a+b, Storfjord; SKNA 7872, Nordreisa; SKNA 7878:1, Nordreisa; SKNA 7878:2, Nordreisa; SKNA 9122:1, Nordreisa; SKNA 9229, Nordreisa; SKNA 9433, Vardø; SKNA 9440, Skallelv; SKNA 9442, Skallelv; SKNA 9443:1, Skallelv; SKNA 9670, Sørvaranger; SKNA 9671:1, Sørvaranger; SKNA 9671:2, Sørvaranger; SKNA 9674, Sørvaranger ; SKNA 9675, Sørvaranger; SKNA 9676:1, Sørvaranger; SKNA 9690:1, Sørvaranger; SKNA 9692, Tana; SKNA 9693, Tana; SKNA 9696:1a+b, Tana, Masjok; SKNA 9697:1a+b+c, Tana, 
Louttijoki; SKNA 9698:2, Porsanger, Lakselv; SKNA 9755:1, Nordreisa ; SKNA 9755:2, Nordreisa;

«Ruija-korpuset». Institutt for lingvistiske og nordiske studier, Universitetet i Oslo. http:// www.hf.uio.no/iln/tjenester/kunnskap/sprak/korpus/talesprakskorpus/ruija/.

\subsection{Trykt språkmateriale}

Kapteinin joulut 2002-2006. Ruija-forlaget. Oversatt til kvensk av Terje Aronsen.

Beddari, Olav. 1987. Niin saapi sanoa: «pieni ruijansuomalainen lukukirja». Bd. 23.

Emnehefte (Lokalsamfunnet i skolen) (trykt utg.). Vadsø: Skoledirektøren i Finnmark.

Eriksen, Agnes. 2003. Piu pau paukkuu: kvenske rim og regler m.m. Lakselv: Porsanger kommune, Oppvekstavdelinga.

-——. 2011a. Kummitus ja Tähtipoika: 1. Bd. 1. Tromsø: Ruija forl.

-——. 2011b. Kummitus ja Tähtipoika: 2. Bd. 2. Tromsø: Ruija forl.

-—-. 2014a. Minun kieli: minun aaret 3-4. Lakselv: Porsanger kommune.

-_-. 2014b. Minun kieli: minun aaret 5-6. Lakselv: Porsanger kommune.

Nilsen-Børsskog, Alf. 2004. Kuosuvaaran takana. Bd. 1. Elämän jatko. Indre Billefjord: Iđut.

———. 2007. Aittiruto. Bd. 2. Elämän jatko. Indre Billefjord: Iðut.

- - 2008. Muistoin maila. Indre Billefjord: Iđut.

-_-. 2010a. Korrui tien varrela. Børselv: Kainun Institutti - Kvensk institutt.

-——. 2010b. Poiminttoi. Børselv: Kainun Institutti - Kvensk institutt.

——_. 2010c. Älä unheeta minnuu. Børselv: Kainun Institutti - Kvensk institutt.

-——. 2011. Rauha. Bd. 3. Elämän jatko. Indre Billefjord: Iđut.

-—-. 2013. Merimies muistelee. Indre Billefjord: Iđut.

Qvigstad, Just. 1925. Finske fortcellinger fra Kvonangen og Nord-Reisa. Bd. 47(1924):5.

Tromsø museums årshefter (trykt utg.). Tromsø: Tromsø museum. 



\section{Definisjoner av fagtermer}

I parentes etter termen står synonym til og/eller forkortelse av oppslagsordet. Tegnet > i parentes framfor termer inne i forklaringene symboliserer at den aktuelle termen også har et eige oppslag, som det kan være nyttig å jamføre med. I eksempla er det omtalte fenomenet framheva med kursiv. Stikkordlista opplyser om hvor termene er brukt i denne boka.

o-STAdium (stadium o): Stadium i ( $>$ ) stadieveksling der konsonanten enten er heilt annleis enn på de andre stadia, eller der den er falt bort (> bortfall). o-stadium er bare mulig i vekslinger med plosivene $k, t$ og $p$. For eksempel: (sg. nom. : sg. part. : sg. gen.) luku ('antall, tall') : lukkuu : luvun, der $k k$ og $k$ veksler med $v$, (1. inf. : perf. pts. : ind. pres. 1. sg.) lukkeet ('lese'): lukenu: lujen, der $k k$ og $k$ veksler med $j$, og (sg. nom. : sg. part. : sg. gen.) sota ('krig') : sottaa : sođan soan, der $t$ og $t$ veksler med $d$ i Porsangervarieteten, og med bortfall i de andre varietetene. Jamfør (>) I-stadium og (>) II-stadium.

I-stadium (stadium I): Stadium i (>) stadieveksling som veksler med (>) II-stadium på den måten at det av samme konsonant fins en enkelt/kort forekomst på I-stadiet, og en lang forekomst på II-stadiet. I stadievekslingsparet (sg. nom. : sg. gen.) kukka ('blomst') : kukan er forma kukan på I-stadiet, og i stadievekslingsparet (sg. nom. : sg. part.) kesä ('sommer') : kessää er forma kesä på I-stadiet. Jamfør (>) o-stadium.

II-stadium (stadium II): Stadium i (>) stadieveksling som veksler med (>) I-stadium på den måten at det av samme konsonant fins en enkelt/kort forekomst på I-stadiet, og en lang forekomst på II-stadiet. I stadievekslingsparet (sg. nom. : sg. gen.) kukka ('blomst') : kukan er forma kukka på II-stadiet, 
og i stadievekslingsparet (sg. nom. : sg. part.) kesä ('sommer') : kessää er forma kessää på II-stadiet. Jamfør (>) o-stadium.

1. infinitiv ( $>$ første infinitiv)

2. infinitiv ( $>$ andre infinitiv)

3. infinitiv ( $>$ tredje infinitiv)

Abessiv: (>) Følgekasus som forteller at noe(n) ikke har noe(n), eller at noe(n) mangler. En nomenfrase i abessiv kan opptre sammen med ( $>$ ) preposisjonen ilman ('uten'), men den kan også stå aleine. For eksempel: Mikko lähti Tromsshaan (ilman) vaimotta ('Mikkel drar til Tromsø uten kone’). Abessiv er også vanlig som kasus i $(>)$ 3. infinitiv. For eksempel: Mie en pärjää (ilman) syömättä ja juomatta ('Jeg klarer meg ikke uten å spise og drikke').

Ablativ: (>) Ytre lokalkasus som brukes som $(>)$ frastedskasus i $(>)$ setningstypene $(>)$ BEVEGELSE, (>) FLYTTING og ( $>$ ) EIERSKAPSENDRING, og i $(>)$ predikativ form i $(>)$ setningstypen $(>)$ PREDIKATIV SANS. For eksempel: Liisa tuli torilta ('Lisa kom fra torget'); Viina haissee pahalta ('Brennevin lukter vondt').

ABSTRAKT ORD: Substantiv som ikke refererer til noen konkret enhet, men for eksempel til ei handling, en egenskap eller en idé. For eksempel: lukeminen ('lesing'), uni ('søvn'), rakkhaus ('kjærlighet'), marxismi ('marxisme').

AdDitiv KOnjunksjon: (>) Konjunksjon som forbinder setninger eller fraser som alle hører til samme gruppe, og som alle er sanne. Kvensk har disse additive konjunksjonene: ja ('og'), sekä - ja ('både - og'), sekä - ette että ('både og') og enklitikonet -kä ('og'). I tillegg brukes konjunksjonen ette additivt når den uttrykker at noe skjer mer og mer, eller at det av noe fins mer og mer. For eksempel: Pekka ja Maija naithiin ('Peder og Maja gifta seg'); Lunta pani enämen ette enämen ('Det snødde mer og mer').

Adessiv: (>) Ytre lokalkasus som brukes blant anna i $(>)$ setningstypene STED, EKSISTENS og EIERSKAP. For eksempel: Matti souttaa järvelä ('Mats ror på innsjøen'), Heikala oon soutovenet ('Henry har en robåt'). Adessiv bruker vi også for å uttrykke på hvilken måte noe gjøres. For eksempel: Stiina lähti 
tookila Rovaniemheen ja sieltä sykläämällä Vesisaarheen ('Stina reiste med tog til Rovaniemi og derifra på sykkel til Vadsø’).

Adjektiv: (>) Nomen som forteller om egenskapen ved noen eller noe. For eksempel: kaunis ('pen'), ruma ('stygg'), kolo ('forferdelig'), keltainen ('gul'), iso ('stor'), paksu ('tjukk'). Adjektiv opptrer i (>) adjektivfraser i (>) predikasjonssetninger, og som $(>)$ adjektivmodifikatorer til $(>)$ substantiv.

AdjeKtivfrase (= AP): (>) Frase som har ( $>$ ) adjektivisk funksjon i $(>)$ setninga. For eksempel: Alattio oon oikhein kaunis kaupunki ('Alta er en riktig fin by'); Pekka oon liijan vanhaa ('Peder er for gammal'); Melkhein sađala ihmiselä oli ruttotauti ('Nesten hundre mennesker hadde pesten').

Adjektivmodifikator: (>) Adjektiv som sammen med en (>) kjerne, nærmere bestemt en substantivkjerne, danner en $(>)$ substantivfrase (NP). Det spesielle med adjektivmodifikatorer er at de kongruerer ( $>$ kongruens) med frasekjernen. For eksempel: Pienelä pojala oon isot housut ('Den lille gutten har store bukser').

Adposisjon: Ord som er $(>)$ ubøyelig, eller som bare har to eller tre $(>)$ kasusformer i ( $>$ ) bøyingsmønsteret sitt, og som krever et $(>)$ nomen som $(>)$ utfylling. Adposisjoner danner ( $>$ ) adposisjonsfraser (PP). Det fins to typer adposisjoner: $(>)$ postposisjoner og $(>)$ preposisjoner.

Adposisjonsfrase (= PP; jf. engelsk Prepositional Phrase): (>) Frase som har en $(>)$ adposisjon som $(>)$ kjerne og et $(>)$ nomen som $(>)$ utfylling. I frasen vaaran päälä ('på fjellet') er adposisjonen päälä ('på) og utfyllinga er vaaran (vaara 'fjell'). I frasen tyttären kans ('sammen med dattera') er adposisjonen kans ('(sammen) med') og utfyllinga er tyttären (tyttär 'datter; jente').

Adverb (=Adv): Ord som er (>) ubøyelige, eller som har ( $>$ ) mangelfull bøying, eller ord der ordbetydninga ikke kan direkte avleies fra betydninga til $(>)$ grunnordet. En del adverb kan danne (>) adverbfraser, for eksempel sielä ('der'), silloin ('da'), mielelä ('gjerne'), kotona ('heime'), tääpänä ('i dag'), irti ('laus'), nokko ('nok'), hopusti ('fort'), kaltossa ('på skrå), men vi regner her som adverb også slike ubøyelige ord som ikke kan ha eigne modifikatorer, 
for eksempel kuitenki ('likevel'), kuitenkhaan ('likevel ikke'), tietenki ('selvfølgelig'), tietenkhään ('selvfølgelig (ikke)'), sillä ('derfor'), sitte ('så, siden'), senthään ('likevel'), kuulemma ('som det fortelles'), makka ('liksom'), muka ('liksom').

Adverbirkase (= AdvP): $(>)$ Frase som har et $(>)$ adverb som $(>)$ kjerne. For eksempel justhiin sielä ('nettopp der'), oikhein mielelä ('veldig gjerne') liijan hopusti ('for fort'), pahasti kaltossa 'forferdelig skeivt'.

Adverbial: Adverbial er en type (>) setningsledd. Det fins to hovedtyper adverbial: 1. Adverbial som fungerer som $(>)$ utfylling til $(>)$ verb. Det kan være $(>)$ substantivfraser som står i $(>)$ lokalkasus, eller $(>)$ adverbfraser eller $(>)$ adposisjonsfraser med tilsvarende funksjon. Også en ( $>$ ) verbfrase regnes som adverbial når den i en $(>)$ indirekte eller $(>)$ modifisert setning fungerer som utfylling og det $(>)$ infinitte verbet i verbfrasen står i lokalkasus. For eksempel: Pekka makkaa sängyssä ('Peder ligger i senga'); Mie tulen mielelä sinne ('Jeg kommer gjerne dit.'); Faari kielsi minun lähtemästä uimhaan ('Far forbydde meg å dra for å svømme’). 2. (>) Frie adverbial, som ikke er obligatoriske setningsledd.

Adverbmodifikator: $(>)$ Modifikator som hører til ordklassen $(>)$ adverb. Den kan fungere som $(>)$ fritt adverbial, for eksempel adverbet huomena ('i morgen') i (>) setninga Huomena mie lähđen kothiin ('I morgen drar jeg heim'), og hopusti ('fort') i setninga Lähđe nyt hopusti kothiin! ('Dra nå fort heim!'). Men en adverbmodifikator kan også modifisere (>) adjektiv eller (>) adverb, for eksempel oikhein ('rett, riktig') i setningene Tromssa oon oikhein kaunis kaupunki ('Tromsø er en riktig vakker by') og Mie lähđin kothiin oikhein hopusti ('Jeg drar heim riktig fort').

Agens: Navnet agens brukes om den rolla $(>)$ subjektet har i $(>)$ handlingssetninger. Agens er den aktive aktøren som gjør noe, eller som er årsak til at noe oppstår eller skjer.

AgentKonstruksjon: Konstruksjon som brukes i $(>)$ adjektivisk funksjon som (>) modifikator til ( $>$ ) substantiv eller i (>) predikasjonssetninger. Agentkonstruksjoner består av $(>)$ agentpartisippforma av verbet og et $(>)$ 
subjekt i (>) genitiv. For eksempel: Tämä oon äitin paistama leipä ('Det er mor som har bakt dette brødet / Mor har bakt dette brødet'); Paita oon isän neuloma ('Det er far som har sydd skjorta / Far har sydd denne skjorta').

Agentpartisipp: (>) Partisippform av verb som brukes i ( $>$ ) agentkonstruksjoner. For eksempel: (lukkeet lukea(t) lukia 'lese':) lukema, (pestä 'vaske’:) pesemä.

AgGlutinerende SPRÅK: Kvensk er et såkalt agglutinerende språk. Det betyr at orda er satt sammen av (>) morfem som følger etter hverandre, og som hvert og ett endrer betydninga eller funksjonen til ordet.

Akkusativ: Personlige pronomen har i flertall ei særegen (>) kasusform som kalles for akkusativ (meiđät meät 'oss', teiđät teät 'dere', heiđät heät 'dem'), og som brukes som kasus på (>) totalobjekt.

AKTIV Form: $(>)$ Verbform som kan brukes sammen med et $(>)$ personlig pronomen. Det fins seks aktive verbformer: $(>)$ entall $(>)$ første, $(>)$ andre og $(>)$ tredje person og $(>)$ flertall første, andre og tredje person. Jamfør $(>)$ aktiv og $(>)$ aktiv setning.

Aктіv SETning: Setning som har, eller der vi kan legge til, et synlig $(>)$ subjekt, og der verbalet har (>) aktiv form. Jamfør (>) passiv setning.

Aктіv: $(>)$ Finitt eller $(>)$ infinitt verbform som ikke inneholder noe $(>)$ passivsuffiks. For eksempel: Mie lujen kirjaa ('Jeg leser i ei bok'); Mie olen lukenu kirjaa ('Jeg har lest i ei bok'). Merk likevel at det i tredje person flertall brukes former som er identiske med passivformer. For eksempel: Pojat lujethiin kirjaa ('Guttene leste i ei bok').

Allativ: (>) Ytre lokalkasus som brukes i (>) setningstypene (>) BEVEGELSE, (>) FLYTTING og (>) EIERSKAPSENDRING. For eksempel: Kissä hyppäs pöyđäle ('Katten hoppa opp på bordet'); Muori osti faarile kukkii ('Mor kjøpte blomster til far').

ANDRE INFINITIV (2. infinitiv): ( $>$ ) Infinitt verbform, en av de tre ( $>$ ) infinitivene i kvensk. Andre infinitiv er lite produktiv, og formene kan ofte regnes 
som (>) adverb. Forekommer i to kasus, (>) inessiv og såkalt (>) instruktiv. For eksempel: (käyđä käyvä 'gå en tur':) käytessä : käyđen käyven, (kuula 'høre’:) kuulten, (muistaa(t) 'huske':) muistaissa, (kulkkeet kulkea $(t) \sim$ kulkia 'gå, ferdes':) kulk(k)eissa.

ANDre PERSON: (>) Person som refererer til den eller dem som tales eller skrives til. Andre person finner vi i $(>)$ personbøying av $(>)$ verb, i $(>)$ personlige pronomen og i (>) possessivsuffiks. For eksempel: Sie kassuut heti isoksi ('Du vokser deg snart stor'); Tet rakastatta itteenä ('Dere elsker dere sjøl'). Jamfør $(>)$ første person og $(>)$ tredje person.

ANKerord: (>) Pro-ord i (>) oversetninga som er semantisk tomt, men som har $(>)$ syntaktisk funksjon, og som får sitt innhold av (>) leddsetninga. Ankerord tydeliggjør strukturen i oversetninga og gjør den syntaktisk velforma. For eksempel: Tääpänä näyttää siltä, ette huomena tullee sađet ('I dag ser det ut til at det blir regn i morgen'). Jamfør (>) korrelat.

ANTALL: Setninger av $(>)$ setningstypen ANTALL er $(>)$ kvantorsetninger som uttrykker hvor mange enheter det er av noe eller noen. Som $(>$ ) verbal i slike setninger brukes verbet olla ('være') i (>) tredje person entall. Subjektet er et $(>)$ nomen i $(>)$ partitiv, og den andre utfyllinga er en $(>)$ kvantorfrase. For eksempel: Meitä oli klassissa viisitoista ('Vi var femten i klassen').

Apposisjon: Laust tillegg som forklarer nærmere noe i ei (>) setning, og som har samme funksjon som et anna ledd i setninga. For eksempel: Sie, Maija, olet aivan ihana nainen ('Du, Maja, er ei herlig kvinne'); Knuutila, alattiolaisten sankarilla, oli uskolinen emäntä, Kreeta ('Knut, altaværingenes helt, hadde ei trufast kone, Greta').

AsPeкT: Med aspekt markerer vi om ei handling eller en hendelse er $(>)$ avgrensa eller $(>)$ uavgrensa. I kvensk kommer aspekt vanligvis til uttrykk i (>) objektskasus på den måten at $(>)$ genitiv (entall) og (>) nominativ (flertall) uttrykker avgrensa aspekt, mens (>) partitiv uttrykker uavgrensa aspekt. For eksempel: (avgrensa) Kuningas luki preivin ('Kongen leste brevet'); (avgrensa) Kuningas luki preivit ('Kongen leste breva'); (uavgrensa) Kuningas luki preivii ('Kongen leste i brevet/breva / Kongen holdt på å lese brevet/breva'). 
AspeKtsetning: (>) Modifisert setning som avgrenser ei handling eller en hendelse i tid, det vil si at noe blir begynt eller begynner å skje, at noe er i ferd med å bli gjort eller å skje, eller at noe slutter å bli gjort eller å skje. Som $(>)$ verbal i ei aspektsetning fungerer et $(>)$ aspektverb, for eksempel alk $(k)$ $a a(t)$ ('begynne'), olla ('være'), keritä ('rekke; bli ferdig') og heittää( $t$ ) ('slutte'). Etter verbalet følger en $(>)$ infinitivsfrase med ei $(>)$ 3. infinitivsform som (>) kjerne. For eksempel: Pekka alkoi itkemhään ('Peder begynte å gråte'); Matti oli pesemässä astiita ('Mats holdt på å vaske opp'). Jamfør (>) modalsetning.

AspeKtVerb: $(>)$ Verb som opptrer i (>) aspektsetninger.

Avgrensa HANDling: Handling der begynnelsen og/eller slutten er klart markert. En vanlig måte å uttrykke at ei handling er avgrensa på er å markere $(>)$ objektet med (>) genitiv. For eksempel er handlinga i $(>)$ setninga Mie söin puteetin ('Jeg spiste poteten') avgrensa. En annen måte å uttrykke avgrensa handling på er å bruke (>) aspektverb som signaliserer handlingsslutt. For eksempel: Mie kerkisin syömästä ('Jeg var ferdig med å spise'). Jamfør (>) aspekt og $(>)$ uavgrensa handling.

AvLEIE: Når vi legger et (morfem) til et ord, oftest i slutten av ordet, og resultatet er et nytt ord, så sier vi at vi har avleid et nytt ord.

AvLeIING: Ordlagingsprosess som innebærer at det med hjelp av et $(>)$ avleiingsmorfem blir (>) avleid et nytt ord.

Avleinngsmorfem: (>) Morfem som ord er satt sammen av, og som brukes til å lage nye ord med utgangspunkt i eksisterende ord (> grunnord). Nesten alle avleiingsmorfema i kvensk er (>) avleiingssuffiks, for eksempel (grunnord $\rightarrow$ $(>)$ nomen) puna ('rødfarge') + (i)nen $\rightarrow$ puna(i)nen ('rød'), koiju ('bjørk') + $k k o \rightarrow$ koijukko ('bjørkeskog'); (med verb som grunnord) aja- ('kjøre') + ele $\rightarrow$ ajele- ('kjøre rundt'), aja- $+o \rightarrow$ ajo ('kjøring'). Det fins ett $(>)$ avleiingsprefiks i kvensk, nemlig epä- ('u-'), som festes foran (>) adjektiv, for eksempel tavalinen ('vanlig') + epä- $\rightarrow$ epätavalinen ('uvanlig').

Avleisngsprefiks: (>) Avleiingsmorfem som festes til begynnelsen av et ord. 
Avleisngssuffiks: (>) Avleiingsmorfem som festes til slutten av et ord eller morfem.

BAKRE VOKAL: (>) Vokal som uttales i den bakre delen av munnhula. Kvensk har tre bakre vokaler: /a/, /o/ og /u/. Jamfør (>) fremre vokal og $(>)$ vokalharmoni.

BEKREFTENDE FORM (> bekreftende verbform).

BEKREFTENDE VERBFORM (bekreftende form): (>) Verbform som ikke inneholder ( $>$ ) nektingsverb. Jamfør ( $>$ ) nektende verbform.

BEVEGELSE: Setninger av ( >) setningstypen BEVEGELSE er $(>)$ lokative $(>)$ setninger som forteller at noen eller noe ferdes eller beveger seg fra ett sted til et anna. Som verb i slike setninger bruker vi bevegelsesverb som for eksempel lähteet lähteä( $t) \sim$ lähtiä ('dra (av gårde')), mennä ('dra; gå'), tulla ('komme'), $k \ddot{y} y(đ) \ddot{a}$ ('dra en tur'), kävelä ('spasere, gå) og hih(đ)ata ('gå på ski'). For eksempel: Liisa lähtee Raishiin ('Lisa drar til Nordreisa'); Nilla kävi Kööpenhaminassa ('Nils dro en tur til København').

BITRYKK: (>) Stavelsestrykk som er svakere enn $(>)$ hovedtrykket, men likevel ikke $(>)$ trykksvakt. I ord med fire eller flere stavelser er det den tredje stavelsen og deretter alle oddetallsstavelser som har bitrykk, men likevel aldri den siste stavelsen i ordet. For eksempel har stavelsen ton bitrykk i ordet on-ne-tonta (sg. part. av onneton 'ulykkelig'). Men når en oddetallsstavelse er (>) kort og den etterfølgende stavelsen (>) lang, så kan bitrykket flyttes til partallsstavelsen. For eksempel i ordet pa-rit-to-mal-la ('på/i oddetalls') kan stavelsen mal uttales med bitrykk.

BLANDA BøYING: Et ord har blanda bøying når ulike bøyingsformer ser ut til å høre til ulike (>) bøyingstyper. Det er for eksempel tilfellet ved ordet vanhaa ('gammal'), som har bøyingsformene sg. part. vanhaata, sg. ill. vanhaasseen, pl. part. vanhoita, pl. iness. vanhoissa. (>) Entallsbøyinga følger her mønsteret til $(>)$ lange vokalstammer, mens $(>)$ flertallsbøyinga følger mønsteret til $(>)$ korte vokalstammer. Jamfør (>) mangelfull bøying. 
BORTFALL: Fenomen i $(>)$ stadieveksling der posisjonen til $(>)$ plosiven på $(>)$ o-stadium i et stadievekslingspar er tom. For eksempel i (>) verbet (1. inf. : akt. ind. 1. sg.) maata ('ligge') : makkaan, har vi veksling mellom $k k$ og bortfall, på samme måte som $t$ veksler med bortfall i substantivformene aian (gen. sg.) og aita (nom. sg. 'gjerde; hage').

BydesetNing: $(>)$ Setning der verbet står i bydeform eller $(>)$ imperativ.

Bøyingsmorfem: (>) Morfem som festes til ( $>$ ) stammen i ord, vanligvis ( $>$ ) nomen eller $(>)$ verb. I kvensk er alle bøyingsmorfem $(>)$ suffiks, og de står i en bestemt rekkefølge. Hos nomen skiller vi mellom suffiks for $(>)$ flertall og for de ulike $(>)$ kasusene. Verb kan ha suffiks for $(>)$ preteritum $(>)$ kondisjonalis, $(>)$ imperativ og $(>)$ person; i tillegg kommer suffiksa for de ulike $(>)$ infinitte verbformene. (>) Adverb og (>) adposisjoner som har (>) mangelfull bøying, har bare i liten grad bøyingsmorfem, og som regel bare kasussuffiks.

BøyingsmønsteR: Alle bøyingsformene av et ord. Vanligvis er det bare (>) nomen og $(>)$ verb som har fullstendige bøyingsmønstre. For $(>)$ substantiv innebærer det fullstendig (>) tall- og kasusbøying. For eksempel ser bøyingsmønsteret for substantivet järvi ('innsjø, vatn') slik ut: (entall) järvi : järven : järvee : järveksi : järvenä : järvessä : järvestä : järvheen : järvelä : järveltä : järvele $(t):$ järvettä : (flertall) järvet : järvii : järviksi : järvinä : järvissä : järvistä : järvhiin: järvilä : järviltä: järvile(t) : järvittä : järvine(nsä). Jamfør (>) blanda bøying og (>) mangelfull bøying.

Bøyingstype: (>) Nomen og (>) verb deles inn i bøyingstyper basert på hva slags ( $>$ ) stamme de har, og hvordan $(>)$ bøyingsmorfem blir festa til disse stammene. Jamfør $(>)$ nomentype og $(>)$ verbtype.

Delelig: Et $(>)$ substantiv eller det det står for, er delelig dersom det kan måles, det vil si at vi kan spørre hvor mye som fins av det. Det er to hovedtyper av delelige substantiv: (>) stofford og (>) abstrakte ord. For eksempel: puuro ('graut'), maito ('mjøl'), rakkhaus ('kjærlighet'), viha ('hat'). Men også (>) udelelige ord som kala ('fisk') kan brukes i udelelig betydning. For eksempel: Maija pyysi järvestä kallaa (Maja fanger fisk i innsjøen'). Også alle enheter i (>) 
flertall er delelige. For eksempel: Kađula oli ihmissii ('Det er mennesker på gata'). Et enkelt kjennetegn ved delelige ord er at de kan modifiseres av ordet paljon ('mye; mange'). Jamfør (>) udelelig.

Demonstrativt pronomen: (>) Pronomen som refererer til noen eller noe som går fram av konteksten eller noe utenom konteksten. Har noe uregelmessig, men nesten fullstendig (>) kasusbøying. Demonstrative pronomen i (>) entall er tämä ('denne'), tuo ('den der'), se ('den'), og i (>) flertall er det nämät ('disse'), nuot ('de der'), net ('de'). Jamfør (>) proadjektiv og (>) proadverb.

Diftong: En kombinasjon av to etterfølgende ( $>$ ) vokaler som hører til samme (>) stavelse. Kvensk har følgende diftonger: $a i, e i, o i, u i, y i, o ̈ i, u o, y \ddot{o}, a u, e u, o u$, $\ddot{a} y, \ddot{o} y$.

Diminutiv: $(>)$ Substantiv som er $(>)$ avleid av et anna substantiv med hjelp av et diminutivsuffiks ( $>$ suffiks). Diminutiv betegner noe eller noen som er mindre enn det $(>)$ grunnordet refererer til, og de brukes også som kjælenavn. For eksempel: (poika 'gutt' $\rightarrow$ ) poika(i)nen ('veslegutt'), (piika 'pike' $\rightarrow$ ) piika(i)nen ('lita/ung pike'), (kylä 'bygd' $\rightarrow$ ) kylä(i)nen ('lita bygd'), (kirja 'bok' $\rightarrow)$ kirja(i)nen ('lita bok').

Direkte Setning: $(>)$ Setning som gjengir et saksforhold direkte. Det er den semantiske funksjonen til (>) verbet som avgjør om setninga er direkte eller ikke. For eksempel: Liisa lähti kothiin ('Lisa dro heim'); Kartanolla oon paljon kläppiä ('Det er mange unger på gårdsplassen'); Maijan saunassa haissee pahalta ('Det lukter vondt i badstua til Maja'); Mie rakastan sinnuu ('Jeg elsker deg'). Rakastatko sie minnuu? ('Elsker du meg?'). Jamfør (>) indirekte setning og (>) modifisert setning.

DisjunkTiV Konjunksjon: $(>)$ Konjunksjon som forteller at av to $(>)$ setninger eller $(>)$ fraser som er knytta sammen, så er det bare den ene som gjelder, eller at de begge betyr det samme. For eksempel: Kainun kielessä oon nelje tempusta eli aikahaamuu ('Kvensk har fire tempus eller tidsformer'); Tuletko sie kothiin vain jäätkö sie tänne? ('Kommer du heim, eller blir du her?'). Ordklassen består av (>) simpleksorda eli(kkä) ('eller'), ta(h)i ('eller') og 
vai(n) ('eller'), og parkonjunksjonen joko - eli(kkä) ('enten - eller'). Jamfør (>) ekskluderende og $(>)$ inkluderende konjunksjon.

EGENSKAP: Setninger av $(>)$ setningstypen EGENSKAP er $(>)$ toverdige $(>)$ predikasjonssetninger som forteller om egenskapen ved $(>)$ subjektet i setninga, eller at noen eller noe er av et visst slag. Som $(>)$ verbal i slike setninger bruker vi alltid verbet olla ('være'). ( $>$ ) Predikativet kan bestå av en (>) adjektivfrase eller en (>) substantivfrase. For eksempel: Äiji oon oikhein vanhaa ('Bestefar er riktig gammal'); Alf oli kirjailiija ('Alf var forfatter').

EgENSKAPSNOMEN: $(>)$ Substantiv som er $(>)$ avleid av et $(>)$ adjektiv, og som forteller at noen eller noe har den egenskapen som adjektivet uttrykker. For eksempel: (rikas 'rik' $\rightarrow$ ) rikkhaus ('rikdom'), (rakas 'kjær' $\rightarrow$ ) rakkhaus ('kjærlighet'), (onneton 'ulykkelig' $\rightarrow$ ) onnettommuus ('ulykke').

Egentlig tredje person flertall: $(>)$ Tredje person $(>)$ flertall av $(>)$ verb som i $(>)$ indikativ $(>)$ presens har $(>)$ personsuffikset $v A(t)$, og i indikativ $(>)$ preteritum og i $(>)$ kondisjonalis presens personsuffikset $t$, i motsetning til de identiske formene for $(>)$ passiv, som også kan brukes i tredje person flertall. For eksempel: (1. inf. : akt. ind. pres. 3. pl. : akt. ind. pret. 3 . pl. : akt. ind. kond. 3. pl.) (jakkaa(t) 'dele':) het jak(ka)ava(t): het jaoit: het jakaisit vs. het ja(j)ethaan: het ja(j)ethiin : het ja(j)ettais, (tarvita 'trenge':) het tarvitte $(e) v a(t)$ : het tarvittit : het tarvittisit vs. het tarvithaan: het tarvithiin: het tarvittais.

EIERSKAP: Setninger av $(>)$ setningstypen EIERSKAP er $(>)$ toverdige $(>)$ possessivsetninger som forteller at noen har eller eier noe, eller har kontroll over noe. Verbet olla ('være') fungerer som (>) verbal i slike setninger. For eksempel: Sulla oon vihrinen hamet ('Du har et rødt skjørt'); Pojila oon nälkä ('Guttene er sultne'; ordrett: 'Guttene har sult').

EIERSKAPSKASUs: Anna navn på $(>)$ ytre lokalkasus, det vil si $(>)$ adessiv, $(>)$ ablativ og $(>)$ allativ. Navnet kommer av at disse kasusene brukes i setningstypene ( $>$ ) EIERSKAP og ( $>$ ) INTRANSITIV og $(>)$ TRANSITIV EIERSKAPSENDRING. 
EIERSKAPSPREDIKASJON: Setninger av (>) setningstypen EIERSKAPSPREDIKASJON er $(>)$ predikasjonssetninger som forteller hvem eller hva som eier det subjektet står for. (>) Verbalet i slike setninger er verbet olla ('være'), og $(>)$ predikativet står alltid i (>) genitiv. For eksempel: Tämä talo oon Liisan ('Dette huset er Lisas'); Sie olet minun ('Du er min').

EKSISTENS: Setninger av $(>)$ setningstypen EKSISTENS er $(>)$ lokative $(>)$ setninger som forteller at noen eller noe fins et sted. Som verbal fungerer tilstandsverb som olla ('være'), seissoot seisoa( $t$ ) ('stå'), istuut istua( $t$ ) ('sitte'), maata ('ligge'), assuut asua(t) ('bo') og ellää(t) ('leve'). For eksempel: Mettässä oon paljon reppoi ('Det er mye rev i skogen').

EKSISTENSENDRING:Setningerav (>) setningstypen EKSISTENSENDRING er $(>)$ lokative setninger som forteller at det et sted oppstår noe nytt, eller at noe faller bort eller forsvinner fra et sted. Som verbal fungerer for eksempel syttyyt syttyä $(t)$ ('dukke opp'), sammuut sammua(t) ('slokne'), tulla ('komme'), ittää $(t)$ ('spire, komme til syne'), ilmestyyt ilmestyä(t) ('dukke opp'), hävitä ('forsvinne, bli borte'), tippuut tippua(t) ('dryppe, falle') eller puđota ('ramle, falle'). For eksempel: Katolta tippuu vettä ('Det drypper vatn fra taket').

EKSISTENSPREDIKASJON: Setninger av $(>$ ) setningstypen EKSISTENSPREDIKASJON er $(>)$ predikasjonssetninger som forteller at noe eller noen er av en viss type. Som verbal fungerer verba olla ('være') eller löyttyyt löytyä(t) ('finnes'). For eksempel: Ihmissii oon monenlaissii ('Det fins mange slags mennesker').

EKSKLUDERENDE KONJUNKSJON: (>) Konjunksjon som forbinder to utsagn som utelukker hverandre, det vil si som ikke kan være sanne samtidig. De $(>)$ disjunktive konjunksjonene eli ('eller') og elikkä ('eller') kan brukes ekskluderende, som for eksempel i (>) setninga Matti paranee eli sitte kuolee ('Mats blir frisk, eller så dør han’). Mats kan ikke bli bedre og dø samtidig. Jamfør (>) inkluderende konjunksjon.

EKVIVALENT FORHOLD: En (>) jamføringsfrase uttrykker et ekvivalent forhold når den forteller at to enheter enten har eller ikke har like mye av en egenskap. 
For eksempel er det i (>) setninga Liisa oon sama vanhaa ko Matti ('Lisa er like gammal som Mats') et ekvivalent forhold mellom alderen til Lisa og Mats. Et ekvivalent forhold kan også brukes i en konstruksjon som forteller at saksforholdet i oversetninga er likeens eller annleis enn saksforholdet i jamføringsfrasen. For eksempel: Het soudethiin niin paljon ko het jaksethiin ('De rodde så mye de orka'), som forteller at de rodde like mye som de orka. Jamfør (>) illustrerende forhold.

ELATIV: (>) Indre lokalkasus som forteller at noen eller noe som har vært inni eller nær noe, fjerner seg fra eller løsner fra det (to- eller tredimensjonalt). Kasusen er brukt i ( >) setningstypene ( >) BEVEGELSE, (>) FLYTTING og (>) RESULTAT. For eksempel: Mikko tullee navetasta ('Mikkel kommer ut av/fra føøset'); Kaisa otti maittoo kylmäkaapista ('Kaisa tar mjølka ut av kjøleskapet'); Liisasta tuli opettaaja ('Lisa blei lærer'); Kaisalta lähti rupi ottasta ('Sårskorpa løsna fra panna på Kaisa'). Elativ er også brukt som (>) fritt adverbial, som for eksempel i (>) setninga Tomi työtelee aamusta ilthaan ('Tomi jobber fra morgen til kveld').

ENDRING: Setninger av ( $>$ ) setningstypen ENDRING er $(>)$ predikasjonssetninger som forteller hva noen eller noe resulterer i. Som $(>)$ verbal i slike setninger bruker vi verb som tulla ('komme'), muuttuut muuttua( $t$ ) ('forandre seg'), kasuta ('vokse') og jääđä jäähä ('bli igjen, forbli'). (>) Predikativet i slike setninger står i (>) translativ. For eksempel: Mie tulin hulluksi ('Jeg blei gal'); Aaki kasus isoksi ('Aaki vokste seg stor'). Jamfør setningstypen (>) RESULTAT.

EnkLitikon: (>) Morfem som blir hekta på heilt til slutt i et ord, men som snarere enn å tilføye sjølve ordet ny informasjon forteller hvordan det relaterer seg til andre ord i $(>)$ setninga eller til andre setninger i konteksten. Kvensk har disse enklitikaene: $k O, k h O O n, k i, k h A A n, k \ddot{a}, h A n, p A$ og $p A s$. Betydninga og bruken av dem er forklart i avsnitt 2.3.2. For eksempel: Tuletko kothiin? ('Kommer du heim?'); Kukahan tuolta tullee? ('Hvem er det som kommer der borte, mon tru?'); Miepä muistelen sulle! ('Jeg skal nok fortelle deg!'); Pekkaki rakastaa Liissaa ('Også Peder elsker Lisa').

ENSTAMMA: Et $(>)$ nomen eller et $(>)$ verb kalles for enstamma dersom det bare har én type $(>)$ vokalstamme og ingen $(>)$ konsonantstamme. Legg merke 
til at noen verb har både kort og lang vokalstamme. Vi kaller slike verb for (>) verb med to vokalstammer.

Enstava: $(>)$ Nomen og $(>)$ verb kalles for enstava dersom de bare har én $(>)$ stamme, som består av én (>) stavelse, og slutter på (>) vokal. For eksempel: (nomen:) maa ('jord, land'), pää ('hode; ende'), yö ('natt'), tie ('veg'), (verb:) ui/đa ui/a ('svømme'), syö/đä syy/ä ('spise'), saa/da saa/ha ('fä).

ENTALL (singularis) (= sg.): ( $>$ ) Nomen og $(>)$ verb har to $(>)$ tall: entall og $(>)$ flertall. Entall uttrykker at det er snakk om bare én enhet. Entall ved nomen brukes også når noe ikke kan telles, det vil si når nomenet refererer til noe (>) delelig. Entall ved nomen er den ( $>$ ) umarkerte forma, og det har derfor ikke noe eige suffiks eller anna merke. Entall ved verb kommer derimot til uttrykk gjennom (>) personsuffiks. Jamfør (>) flertall.

ENVERDIG: Et $(>)$ verb er enverdig dersom det krever bare éi ( $>$ ) utfylling for at $(>)$ setninga skal være fullstendig. Som regel er det et $(>)$ subjekt. For eksempel er verbet nukkuut nukkua(t) ('sove') enverdig, og setninga Matti nukkuu ('Mats sover') er ei fullstendig setning. Vi sier også at ei setning er enverdig når $(>)$ hovedverbet i setninga er enverdig. Jamfør $(>)$ nullverdig, $(>)$ toverdig og $(>)$ treverdig.

Essiv: (>) Predikerende kasus som brukes for eksempel i (>) predikativ funksjon i (>) setningstypen MEINING og som (>) rammeadverbial. For eksempel: Pekka pittää Mattii kaunhiina ('Peder synes Mats er pen'); Lapsena Matti halus tulla sontakuskiksi ('Som barn ønska Mats å bli kloakktømmer'). Essiv er ofte brukt i (>) substantivfraser som uttrykker tidspunkt. For eksempel: Tule meile lauvantaina ('Kom til oss på lørdag'); Tulleevanna talvena mie aijon hihđata paljon ('Til vinteren har jeg tenkt å gå mye på ski').

FASTE SETNingSFRAgment: $(>)$ Setningsfragment som allid er satt sammen av de samme orda, og som har ei fast form. For eksempel Hyvvää päivää! ('God dag!); Kiitoksii osasta! ('Takk for laget'); Tervettulemaa! ('Velkommen!); Herraton aika! ('Herregud!'). Jamfør (>) fritt setningsfragment.

FinitT VERbFORM: (>) Verbform som er bøyd i person, og som fungerer som (>) verbal i (>) setninga. For eksempel: Mie menen kotia ('Jeg drar heim'); 
Alattiossa pyyđethään lohta ('I Alta blir det fiska laks'). Jamfør (>) infinitt verbform.

Flerstava: Flerstava kaller vi $(>)$ nomen og $(>)$ verb som bare han én $(>)$ vokalstamme, som har flere enn to $(>)$ stavelser og slutter på $(>)$ kort $(>)$ vokal. For eksempel: koijukko ('bjørkeskog'), emäntä (husmor, kone'), Helsinki ('Helsingfors'), (vares 'kråke':) varekse-, (muistela 'fortelle':) muistele-, (aukaista åpne’: ) aukaise-. Jamfør (>) enstava og (>) tostava.

Flertall (pluralis) (= pl.) Med flertall markerer vi i $(>)$ tallbøyinga at det er snakk om to eller flere enheter. Flertall ved $(>)$ nomen og $(>)$ verb uttrykkes med hjelp av flertallssuffiks. Eksempler på flertallsformer er kukat og kukissa, som henholdsvis er nominativ flertall og inessiv flertall av substantivet kukka ('blomst'), og tulema og tuletta, som henholdsvis er $(>)$ første person flertall og $(>)$ andre person flertall av verbet tulla ('komme'). Jamfør (>) entall.

Flertallsstamme: (>) Stamme i (>) nomen som inneholder flertallssuffikset $-i$. For eksempel ser vi av flertallsformene kuki/ssa (pl. iness.) og $k u k k i / n a$ (pl. ess.) av substantivet kukka ('blomst') at flertallsstammen er kuki- : kukki-.

FLytTe-H (H-flytting): Konsonanten $h$, som plasserer seg mellom (>) stammekonsonant og stammevokal. For eksempel: (illativformer) (poika 'gutt':) poikhaan : poikhiin, (ty(t)är 'jente’:) tyttärheen : tyttärhiin, (pestä 'vaske’:) pesemhään, (maata 'ligge') makkaamhaan, (inne i stammen, genitivsformer) (rikas 'rik':) rikkhaan, (hamet 'kjole':) hamheen.

FLYTTING: Setninger av ( $>$ ) setningstypen FLYTTING er $(>)$ treverdige $(>)$ handlingssetninger som forteller at noen flytter noen eller noe fra ett sted til et anna. Som verb i slike setninger bruker vi for eksempel siirt(t)ää(t) ('flytte'), liikuttaa( $t$ ) ('røre, bevege'), tuođa tuua ('bringe, ha med seg'), vieđä viiä ('føre, ta med seg'), panna ('legge; sette'), nout( $t$ )aa( $t$ ) ('hente'), vettää( $t$ ) ('slepe, dra, trekke'). For eksempel: Kaisa vei muorile kissanpojan ('Kaisa tok med seg kattungen / en kattunge til mor'); Muori pani kissanpojan plakkarhiin ('Mor putta kattungen i lomma'). 
FORHOLDSADPOSISJON: (>) Adposisjon som uttrykker et forhold mellom to skapninger eller ting. For eksempel: Mie tehin tämän tröijyn sinnuu vasten ('Jeg laga denne trøya til deg'); Ruija oli silloin Tanskan kuninkhaan alla ('Norge lå på den tida under danskekongen').

FORMELT SUBJEKT ( $>$ tomt subjekt).

FORTELLENDE SETNING (utsagn): (>) Setning der vi konstaterer eller i hvert fall trur eller antar hvordan et saksforhold er. For eksempel: Mie lähđen kotia ('Jeg drar heim'); Matti söi koko kalan ('Mats spiste heile fisken'). Jamfør (>) spørresetning og $(>)$ bydesetning.

FRAmTID (futurum): (>) Tidsform som uttrykker framtid. I likhet med norsk har ikke kvensk eigne framtidsformer, men framtid blir uttrykt med hjelp av (>) presensformer. For eksempel: Huomena mie lähđen Franskhaan ('I morgen drar jeg til Frankrike').

FRASE: (>) Setninger er satt sammen av fraser. En frase utgjør en enhet, og når vi endrer på ordrekkefølgen i ei setning, så flytter vi alle orda i en frase sammen som enhet. Fraser får navn etter ordklassen til ( $>$ ) kjernen i frasen. For eksempel består den (>) komplekse setninga [Muutamanna aurinkoisenna päivänä] [meiđän Pekka] lähti [oikhein korkkeele vaarale, mikä oon Alattionjoven vestapuolela] ('På en solfylt dag dro vår Peder på et riktig høgt fjell som ligger på vestsida av Altaelva') i tillegg til verbalet av tre (>) substantivfraser. Og disse inneholder igjen fraser. En detaljert fraseanalyse blir da slik: [[Muutamanna $]_{\mathrm{NP}}$

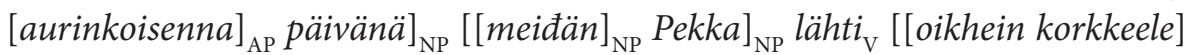
${ }_{\mathrm{AP}}$ vaarale, $\left.\left[\text { mikä }_{\mathrm{NP}} \text { oon }{ }_{\mathrm{V}}[\text { Alattionjoven vestapuolela }]_{\mathrm{NP}}\right]_{\mathrm{SETN}}\right]_{\mathrm{NP}}$.

FRASTEDSKASUS: (>) Lokalkasusene (>) elativ og (>) ablativ kalles for frastedskasus ettersom de vanligvis brukes til å uttrykke at noen eller noe fjerner seg eller blir fjerna fra noen eller noe. For eksempel: Knuutti lähti Alattiosta ('Knut dro fra Alta'); Faari tuli järveltä ('Far kom fra innsjøen').

FREMRE VOKAL: (>) Vokal som blir artikulert i fremre delen av munnhula. Kvensk har disse fremre vokalene: /ä/, /ö/, /y/, /i/ og /e/. Jamfør (>) bakre vokal og $(>)$ vokalharmoni. 
FritT ADVERBIAL: $(>)$ Adverbial som står som $(>)$ modifikator til $(>)$ verbalet eller heile $(>)$ setninga. Forma på frie adverbial retter seg ikke etter hva slags verbal eller setning de modifiserer. Det fins ulike typer av frie adverbial: $(>)$ rammeadverbial, (>) kommentaradverbial og (>) konnektiv. Stundom kan også (>) objektsadverbial fungere som frie adverbial i setninga.

Fritt SETNingsfragment: (>) Setningsfragment som ikke har noen fast struktur eller inneholder bestemte ord. Det kan være deler som er lausrevne fra resten av teksten, så som overskrifter, for eksempel tittelen på originalversjonen av denne boka, Kainun kielen grammatikki ('Kvensk grammatikk'). Men også svar på spørsmål som Koska sie tulet? ('Når kommer du?'), for eksempel Huomena ('I morgen'), regnes som frie setningsfragment. Jamfør (>) fast setningsfragment.

FØLELSE: Setninger av ( $>$ ) setningstypen FØLELSE er $(>)$ følelsessetninger der $(>)$ verbalet består av et følelsesverb så som rakastaa( $t$ ) ('elske'), vihata ('hate'), pöl(j)ätä ('frykte, være red'), tykätä ('like'). For eksempel inneholder den (>) komplekse setninga Pekka vihhaa Maijaa, mutta Maija tykkää Pekasta ('Peder hater Maja, men Maja liker Per') to setninger av typen FØLELSE.

Følelsessetning: (>) Setning som uttrykker at noen føler noe. For eksempel: Mie rakastan sinnuu ('Jeg elsker deg'); Sie inhotat minnuu ('Jeg føler avsky for deg; Du gjør meg kvalm'). (>) Subjektet kan også mangle. For eksempel: Mattii oksettaa ('Mats er kvalm'). Jamfør (>) setningstypene (>) FØLELSE og (>) KAUSATIV FØLELSE.

FøLGEKasus: Med følgekasus markerer vi ledd som uttrykker at noe(n) er med, eller at noe(n) ikke er med eller mangler. Fellesbetegnelse for $(>)$ komitativ, (>) abessiv og $(>)$ instruktiv.

Første INFINITIV (1. infinitiv): (>) Infinitt verbform, en av de tre $(>$ ) infinitivene i kvensk. Første infinitiv er brukt som $(>)$ oppslagsform i ordbøker og ordlister. Den kan stå som $(>)$ modifikator i en annen $(>)$ frase, eller danne en eigen (>) infinitivsfrase. For eksempel: jakkaa(t) ('dele'), maata ('ligge'), kävelä ('spasere, gå), tarvita ('trenge'). Merk at 1. infinitivsformer inneholder et eige $(>)$ suffiks, som må fjernes om en skal finne fram til (>) stammen i (>) verbet. 
FøRSTE PERSON: $(>)$ Finitte $(>)$ verbformer i $(>)$ aktiv og $(>)$ personlige pronomen har seks $(>)$ personer, tre i $(>)$ entall og tre i $(>)$ flertall. Første person refererer til den eller dem som taler eller skriver. For eksempel: Mie lujen kainun kieltä ('Jeg leser kvensk'); Met söimä keskipäivää ('Vi spiste middag').

Generell stadieveksling: (>) Gradveksling som brukes i andre varieteter enn i Porsanger og Nordreisa. Her kan $(>)$ plosivene $k, t$ ja $p$ veksle mellom tre stadier i samme ord (II : I : o) dersom den foregående (>) stavelsen er (>) trykksterk og har $(>)$ kort vokal. Andre ( $>$ ) konsonanter og kombinasjoner av (>) stemt konsonant og plosiv veksler bare mellom to stadier. For eksempel: (1. inf. : akt. perf. pts. : akt. ind. pret. 1. sg.) jakkaa(t) ('dele') : jakanu(t) : jaoin, (sg. nom. : sg. part. : sg. gen.) sika ('gris') : sikkaa : sian, tupa ('hus; stue') : tuppaa: tuvan, liha ('kjøtt') : lihhaa : lihan, (1. inf. : akt. perf. pts. : akt. ind. pres. 3 . sg.) sulata ('smelte, tine') : sulanu(t) : sullaa, (sg. nom. : sg. part. : sg. gen.) ranta 'strand') : rantaa : rannan. Jamfør (>) spesialstadieveksling.

Generisk, upersonlig konstruksjon: (>) Person i ei ( $>$ ) generisk setning. Oftest svarer den til man eller en i tilsvarende norske setninger. For eksempel: Suomessa oppii helposti rakastamhaan saunaa ('Det er lett å bli glad i badstue i Finland'). Jamfør (>) generisk.

Generisk: Ei (>) setning eller en (>) frase er generisk når det ikke går fram hvem det er som handler eller sanser noe, men når det refereres til folk generelt. Eksempler på generiske setninger er Kainun kieltä oppii helposti ('Kvensk lærer man seg lett') og Oon hyvä oppiit kainun kieltä ('Det er bra å lære seg kvensk'). Jamfør (>) generisk, upersonlig konstruksjon.

Genitiv: (>) Grammatisk kasus som har som sin vanligste (>) syntaktiske funksjon å markere (>) totalobjekt i (>) entall. For eksempel: Mie söin äpylin ('Jeg spiste eplet/et eple'). Genitiv kan også markere eierskap eller tilhørighet. For eksempel: Tomin kissan nimi oon Matti ('Tomis katt heter Matt'); Meiđän Matti oon kaunis kissa ('Vår Matti er en pen katt').

Genitivsmodifikator: (>) Premodifikator som står til (>) substantiv, og som står i genitiv. For eksempel: Äitin syđän oon puhđasta kulttaa ('Mors hjerte er av reint gull'); Tromssan reisu oli oikhein onnistunnu ('Turen til Tromsø var 
svært vellykka'); Tromssan universiteetissa opetethaan kainun kieltä ja kulttuurii ('På Universitetet i Tromsø blir det undervist i kvensk språk og kultur').

Gradbøying (komparasjon): Produktiv (>) avleiingstype ved adjektiv som uttrykker om en egenskap forekommer i større eller mindre omfang. For eksempel (> positiv eller grunnform) siivo ('snill') $\rightarrow$ (> komparativ) siivompi ('snillere') $\rightarrow$ (> superlativ) siivoin ('snillest'), (positiv) viisas ('klok') $\rightarrow$ (komparativ) viishaampi ('klokere') $\rightarrow$ (superlativ) viishain ('klokest'). Stundom finner vi gradbøying også ved $(>)$ substantiv og $(>)$ adverb, når de uttrykker forhold mellom to steder eller tidspunkt. Jamfør de to setningspara Venet oon rannassa ('Båten er på stranda') vs. Venet oon rannempanna ('Båten er nærmere stranda') og Pekka lähti päivälä ('Peder dro på dagen') versus Pekka lähti päivemällä ('Peder dro først seinere på dagen').

Gradsadverb: $(>)$ Adverb som ikke danner eigen ( $>$ ) adverbfrase, men som står som ( $>$ ) modifikator til et $(>)$ adjektiv eller et anna ( $>$ ) adverb, og som spesifiserer mengden eller graden av den egenskapen eller den måten som adjektivet eller adverbet uttrykker. Gradsadverb brukes i svar på spørsmål som stilles med hjelp av gradsadverbet kunka kuinka ('hvor'). For eksempel: Kunka siivo Matti oon? Matti oon joksiki siivo ('Hvor snill er Mats? Mats er ganske snill').

GRAMMATISK KASUS: Som grammatiske kasus regner vi (>) nominativ, (>) genitiv og $(>)$ partitiv. Heller enn å bidra med semantisk innhold markerer de hvilken $(>)$ syntaktisk funksjon en $(>)$ frase har i $(>)$ setninga, eller med andre ord om den fungerer som $(>)$ subjekt, $(>)$ objekt eller $(>)$ predikativ.

Grammatisk KorRekT (grammatikalsk): Ei ( $>$ ) setning, en ( $>$ ) frase eller ei $(>)$ ordform er grammatisk korrekt dersom den høres rett ut for morsmålsbrukere. For eksempel er setninga ${ }^{\star}$ Met oletta kotona ikke grammatisk korrekt ettersom det i kvensk må være $(>)$ kongruens mellom ( $>$ ) subjektet og $(>)$ verbalet i setninga. Vi kan altså ikke som i eksempelsetninga kombinere et ( $>$ ) personlig pronomen i (>) første person (>) flertall, met ('vi'), med et verbal i ( $>$ ) andre person flertall, oletta (av olla, 'være'). Når ei setning eller ordform ikke er grammatisk korrekt, markerer vi det med ei stjerne $\left(^{*}\right)$ framfor den. 
GRUnNoRD: Ord som et anna ord er (>) avleid av. For eksempel er liha ('kjøtt') grunnordet til (>) adjektivet lihava ('feit, tjukk'), og det (>) intransitive verbet lähteet $\sim$ lähteä $(t) \sim$ lähtiä ('dra') er grunnordet til $(>)$ transitive verbet lähättää( $t$ ) ('sende'). Jamfør (>) rotmorfem og (>) sammensetning.

GRUNNTALL: Et grunntall er et (>) tallord som brukes i svar på spørsmål om hvor mange (Kunka monta?). Grunntall brukes på samme måte som andre (>) nomen, det vil si at de har både (>) tallbøying og (>) kasusbøying. Eksempler på grunntall er yksi ('én'), viisi ('fem'), kymmenen ('ti'), viisikymmentä ('femti'), viisikymmentä viisi ('femtifem'), sata ('hundre') og tuhat ('tusen'). Jamfør (>) ordenstall.

HANDLERORD (nomina agentis): (>) Substantiv som er avleid av (>) verb med hjelp av (>) suffikset -jA. For eksempel: (tehđä tehhä 'gjøre' $\rightarrow$ ) tekkiijä tekijä ('arbeider, den som gjøre noe'), (opettaa(t) 'lære, undervise') $\rightarrow$ ) opettaaja opettaja ('lærer'), (hih(đ)ata 'gå på ski' $\rightarrow$ ) hihtaaja ('skiløper').

HANDLINGSSETNING: (>) Setning som forteller at (>) subjektet gjør noe eller er årsak til at noe oppstår eller skjer. $(>)$ Verbalet i slike setninger er alltid et $(>)$ transitivt handlingsverb som kan være $(>)$ to- eller $(>)$ treverdig. ( $>$ ) Subjektet er vanligvis et menneske, men det kan også være noe anna som kan tenkes å fungere som $(>)$ agens. Den andre $(>)$ utfyllinga i handlingssetninger er $(>)$ objektet. Sjøl om setninga kan være foruten objekt, så er det alltid mulig å legge til et. Treverdige handlingssetninger har som tredje utfylling et ( $>$ ) adverbial. For eksempel: Kissa söi kalan ('Katten spiste fisken / en fisk'). Repo varasti hiiren kissalta ('Reven stjal musa fra katten').

H-FLYTTING (> flytte-h)

HJelpeverb: Verbet olla ('være') når det brukes i (>) sammensatte verbalformer sammen med ( $>$ ) hovedverbet. For eksempel: Kreeta oli ođottannu Knuuttii koko talven ('Greta hadde venta på Knut heile vinteren'); Matti ei ollu löytäny yhtäkhään hiirtä ('Mats hadde ikke funnet ei eneste mus').

Hovedsetning: (>) Setning som ikke er del av noen anna setning. Jamfør $(>)$ leddsetning og $(>)$ oversetning. 
HoveDtryкk: Det største (>) stavelsestrykket som en $(>)$ stavelse har i et ord. Det ligger alltid på første stavelse i ordet. Jamfør (>) bitrykk og (>) trykksvak stavelse.

Hovedutfylling: Den viktigste $(>)$ utfyllinga til $(>)$ verbalet. Oftest er det $(>)$ subjektet og står først i $(>)$ setninga. Men det kan også være et anna $(>)$ setningsledd. For eksempel i setninga Pekka syö leippää ('Peder spiser brød') er det subjektet Pekka som er hovedutfylling, men i setninga Jussista tuli pappi ('Johan blei prest') er det (>) adverbialet Jussista som er hovedutfylling.

HOVEDVERB: Det verbet i (>) sammensatte verbalformer som bærer betydninga, og som styrer eventuelle $(>)$ utfyllinger. De andre delene i sammensatte verbalformer er $(>)$ hjelpeverb eller $(>)$ nektingsverb. For eksempel er tulla ('komme') hovedverbet i de sammensatte verbalformene en tule ('(jeg) kommer ikke'), en tullu(t) ('(jeg) kom ikke’), olis tultu ('(han/hun/det ville ha kommet').

ILLATIV: (>) Indre lokalkasus som brukes i $(>)$ setninger som forteller at noen eller noe beveger seg eller blir flytta til innsida eller nærheta av noe (to- eller tredimensjonalt). Kasusen brukes særlig i setningstypene BEVEGELSE og FLYTTING. For eksempel: Mikko tullee navetthaan ('Mikkel kommer inn i føset'); Kaisa pannee maiđon kylmäkaapphiin ('Kaisa setter mjølka inn i kjøleskapet'); Kaisale tuli haava otthaan ('Kaisa fikk et sår i panna').

IllativmodifikatoR: (>) Postmodifikator som står til (>) substantiv, og som står i (>) illativ. For eksempel: Matka Kööpenhaminhaan oli oikhein raskas ('Reisa til København var veldig strevsom').

ILLUSTRERENDE FORHOLD: Et ( $>$ ) forhold der den sisten delen i en $(>)$ jamføringsfrase illustrerer den første delen i samme frase. For eksempel: Auringolla oon sama vaikutus ko traanila ('Sol har samme virkning som tran'); Suomalaisila oon muunlainen kieli ko kainulaisila ('Finlenderne har et anna språk enn kvenene'). Jamfør (>) ekvivalent forhold.

IMPERATIV: (>) Modus i verbbøyinga som brukes i (>) bydesetninger. For eksempel: Mene kothiin! ('Dra heim!'); Älkkää lähtekkää yöklubhiin ('[Til flere:] Ikke dra på nattklubb!'). 
INDEFINITT PRONOMEN: (>) Kvantorpronomen som refererer til noen eller noe som er ukjent, eller som ikke skal avsløres. Det er disse pronomena: joku ('noen, en eller annen'), jompikumpi ('en av to; noen'), muutampi ('en; noen') og $y k s i$ ('en'). For eksempel: Met olema jonku vaaran laiđassa ('Vi er i ei eller anna fjellside'); Jussa olis halunu emänäksi muutaman Alattion tyttären ('Johan skulle ha ønska seg ei jente fra Alta til kone’).

InDIKATIV: (>) Umarkert (>) modus i verbbøyinga. Det er en slags grunnmodus som ikke tilfører verbet noen tilleggsinformasjon. For eksempel: Pekka mennee kothiin ('Peder drar heim'); Tet lähđittä yöklubhiin ('Dere dro på nattklubb').

INDIREKTE SETNING: (>) Setning som forteller at noen har sagt, tenkt eller sansa noe. I slike setninger består den ene utfyllinga typisk av ei ( $>$ ) leddsetning eller en $(>)$ verbfrase, men slik er det ikke nødvendigvis alltid. For eksempel: Pekka uskoi, ette oli tullu taivhaasseen ('Peder trudde han var kommet til himmelen'); Liisa haukkui minnuu hulluksi ('Lisa kjefta på meg og kalte meg for gal'); Äiji käski meiđät tulla kothiin ('Bestefar ga oss ordre om å komme heim'); Minusta näyttää, ette mie kuolen heti ('Det virker for meg som om jeg dør snart'). Jamfør (>) direkte setning.

INDIREKTE TALE: Setninger av $(>)$ setningstypen INDIREKTE TALE er $(>)$ indirekte setninger som refererer til en persons utsagn eller tanker. I slike setninger bruker vi ( $>$ ) toverdige taleverb av typen sannoot $\sim \operatorname{sanoa(}($ ) ('si'), muistela ('fortelle'), ilmo(i)ttaa( $t$ ) ('uttrykke; opplyse'), kirjo(i)ttaa( $t$ ) ('skrive'), ajatella ('tenke'), opettaa( $t$ ) ('undervise'), valetella ('lyge'), luvata ('love'), kyssyyt kysyä $(t)$ ('spørre'), lukkeet lukea( $t) \sim$ lukia ('lese') og tutkiit tutkia( $t$ ) ('studere, (ut)forske, undersøke'). Verbet tar et (>) subjekt og et (>) objekt som $(>)$ utfylling. Objektet har som regel form av ei $(>)$ leddsetning. For eksempel: Maija sanoi, ette mie olen kaunis ('Maja sa at jeg var vakker'); Mikko kysyi, halluunko mie naiđa nänen kans ('Mikkel spurte om jeg ville gifte meg med han').

INDRE LOKALKASUS (s-kasus): (>) Lokalkasus som særlig brukes i (>) setningstypene $(>)$ STED, ( $>$ ) EKSISTENS, ( $>$ ) BEVEGELSE og ( $>$ ) FLYTTING. Kvensk har disse indre lokalkasusene: $(>)$ inessiv, $(>)$ elativ og $(>)$ illativ. Jamfør (>) ytre lokalkasus. 
INDRE TILSTAND: Setninger av ( $>$ ) setningstypen INDRE TILSTAND er $(>)$ tilstandssetninger som forteller noe om den indre tilstanden til et levende vesen. Det er alltid verba olla ('være') eller tulla ('komme') som brukes i slike setninger. Sammen med olla står $(>)$ hovedutfyllinga i $(>)$ adessiv, sammen med tulla i $(>)$ allativ. Den andre $(>)$ utfyllinga består av en $(>)$ adjektiv- eller (>) substantivfrase som spesifiserer tilstanden. For eksempel: Minula oon vilu ('Jeg fryser'; ordrett: 'Hos meg er kulde'); Dagnyle tuli kylmä ('Dagny blei kald'; ordrett: 'Til Dagny kom kulde’).

INESSIV: (>) Indre lokalkasus som brukes i (>) setninger som forteller at noen eller noe er på innsida av noe (to- eller tredimensjonalt) eller fast ved noen eller noe. Kasusen brukes i $(>)$ setningstypene $(>)$ BEVEGELSE og $(>)$ FLYTTING. For eksempel: Mikko lypsää navetassa ('Mikkel mjølker i fjøset'); Maito oon kylmäkaapissa ('Mjølka er i kjøleskapet'); Kaisala oon haava ottassa ('Kaisa har et sår i panna').

InessivmodifikatoR: (>) Postmodifikator som står til (>) substantiv, og som står i inessiv. For eksempel: Haava ottassa oon huono assii ('Et sår i panna er en dårlig ting').

INFINITIV: En av de to ( $>$ ) infinitte verbformene. Det fins tre typer infinitiv: $(>)$ første infinitiv, for eksempel mennä ('gå), jakkaat ('dele') og hihđata ('gå på ski'), (>) andre infinitiv, for eksempel kuulten (av kuula 'høre'), nukkuissa (av nukkuut 'sove'), og (>) tredje infinitiv, for eksempel menemässä (av mennä 'gå), jakamasta (av jakkaat 'dele') og hihtaamatta (av hihđata 'gå på ski'). Jamfør (>) partisipp.

INFINITIVSFRASE: $(>)$ Frase som har ei $(>)$ infinitivsform som $(>)$ kjerne. Infinitivsfraser som har en $(>)$ 1. infinitiv som kjerne, fungerer som regel som (>) subjekt eller (>) objekt. For eksempel: Matila oon halu lähteet hiirijahthiin ('Matti har lyst til å dra på musejakt'); Matti halluu lähteet hiirijahthiin ('Matti vil dra på musejakt'). Når kjernen er en (>) 3. infinitivsform, så fungerer frasen som (>) adverbial i (>) setninga. For eksempel: Matti lähti jahtaamhaan hiirii ('Mats dro for å jakte på mus').

INFINITIVSMODIFIKATOR: (>) Modifikator som står til (>) substantiv, og som står i (>) infinitiv. For eksempel: Sinun tapa puhhuut oon soma ('Din måte 
å snakke på er artig'); Hihtaamhaan lähteminen hiljastui ('Avreisa til skituren blei forsinka').

INFINITT VERBFORM: (>) Verbform som ikke bøyes i $(>)$ person, og som ikke kan opptre som $(>)$ verbal i $(>)$ setninga. Vi deler infinitte verbformer inn i to grupper: $(>)$ infinitiver og $(>)$ partisipp. For eksempel: Pekka halluu mennä kothiin ('Peder ønsker å dra heim'); Hän lähti hihtaamalla kothiin ('Han dro heim på ski'); Haukkuuva koira ei pure ('Hunder som bjeffer, biter ikke'; ordrett: 'En bjeffende hund biter ikke').

INKLUDERENDE KONJUNKSJON: (>) Konjunksjon som binder sammen to $(>)$ fraser eller $(>)$ setninger som begge er sanne samtidig. For eksempel kan konjunksjonene eli ('eller') og elikkä ('eller') brukes inkluderende, som i setninga Tämän grammatikin kieltä käskethään kainun kieleksi eli kväänin kieleksi ('Språket i [den kvenske originalutgaven av] denne grammatikken kalles for kainun kieli eller kväänin kieli'). Det vil si at det kvenske navnet på språket er både kainun kieli og kväänin kieli. Jamfør (>) ekskluderende konjunksjon.

InstRuKTIV: Temmelig ( $>$ ) uproduktiv ( $>$ ) følgekasus som uttrykker at noe blir gjort eller skjer sammen med eller med hjelp av noen eller noe. Instruktivformer regnes vanligvis til ( $>$ ) adverba. Eksempler med ( $>$ ) nomen som (>) grunnord er kuivin jaloin ('tørrføtt') og kaksin käsin ('tohendt'). Eksempler med (>) verb som (>) grunnord er kuulten ('i (noens) påhør'), muistaissa ('mens (jeg/du/han/hun/vi/dere/de) husker det').

INTERJEKSJON: (>) Setningsfragment som ikke har noen egentlig betydning i seg sjøl, men som får betydning fra konteksten de brukes i. Eksempler på interjeksjoner er hilsningsord som Hei! ('Hei!'); Mooraa! Moro! ('God morgen!/Morn!') og affektive ord som Oi! ('Oi!'); Voi! ('Huff!'); Ai! ('Nei!'); Hah! ('Ha!').

INTRANSITIV EIERSKAPSENDRING: Setninger av (>) setningstypen INTRANSITIV EIERSKAPSENDRING er $(>)$ toverdige $(>)$ possessive setninger som forteller at noen mister noe eller får noe nytt. Som $(>)$ verbal i slike setninger fungerer verb som synttyyt, syntyä ( $t)$ ('føde; bli født; oppstå), kuola ('dø'), loppuut loppua(t) ('ta slutt'), tulla ('komme'), mennä ('gå'), 
hävitä ('forsvinne'), kasuta ('vokse'). For eksempel: Matile syntyi tytär ('Mats fikk ei datter'); Minulta kuoli poika ('Jeg mista sønnen / en sønn’).

IntRAnsitivt VERB: (>) Verb som ikke kan ta (>) objekt som (>) utfylling. Jamfør (>) transitivt verb.

JAMFøringsfrase: $(>)$ Frase der to eller flere ting eller enheter jamføres med hverandre. For eksempel: Liisa oon kaunhiimpi ko Pekka ('Lisa er penere enn Per'). Jamføringsfraser er også brukt for å uttrykke at egenskapen ved eller mengden av en enhet stadig auker. For eksempel: Pakkainen tuli kovempi ette kovempi ('Frosten blei sterkere og sterkere').

JAMFøRINGSFRASE: $(>)$ Frase der to enheter jamføres med hverandre, og som står som $(>)$ modifikator til $(>)$ korrelatet sitt. Jamføringsfraser dannes alltid med hjelp av (>) subjunksjonen ko ('enn; som'). For eksempel: Maija oon sama vanha ko Liisa ('Maja er like gammal som Lisa'); Kala oon tyyrhiimpi ko liha ('Fisk er dyrere enn kjøtt'); Mikko oon Annele ko veli ('Mikkel er som en bror for Anne').

JunKsJon: (>) Ubøyelig ord som uttrykker hva slags forhold det er mellom to $(>)$ setninger eller $(>)$ fraser. Det fins tre typer av junksjoner: $(>)$ konjunksjoner, $(>)$ subjunksjoner og $(>)$ superjunksjoner.

Kasus: ( $>$ ) Nomen og også en del av de (>) infinitte verbformene bøyes i kasus. Kvensk har 14 ulike kasus: $(>)$ nominativ, $(>)$ genitiv, $(>)$ partitiv, $(>)$ essiv, $(>)$ translativ, $(>)$ inessiv, $(>)$ elativ, $(>)$ illativ, $(>)$ adessiv, $(>)$ ablativ, $(>)$ allativ, $(>)$ abessiv, $(>)$ komitativ og $(>)$ instruktiv. Kasus markerer $(>)$ syntaktiske og semantiske forhold mellom $(>)$ setningsledd med hjelp av eigne $(>)$ kasussuffiks. Et unntak er nominativ, som er ei (>) umarkert form.

Kasusbøying: Et ord har kasusbøying dersom det bøyes i (>) kasus. Kasusbøying finner vi hos $(>)$ nomen og noen $(>)$ infinitte verbformer.

KAsussuffiks: (>) Suffiks som markerer ( $>$ ) kasus. Bortsett fra $(>)$ nominativ har alle kasus sine eigne kasussuffiks. For eksempel: piili ('bil') + kasussuffiks for $(>)$ genitiv $-n>$ piilin, muori ('mor') + kasussuffiks for $(>)$ adessiv (l)la $>$ muorila. 
KAUSAL: Årsaks- eller følgeforhold mellom to saksforhold i ( $>$ ) fraser eller (>) setninger. Et eksempel på et kausalt forhold har vi i setninga: Hinta oon halpa, sillä ko paidat oon tehty lapsityövoimala ('Prisen er låg ettersom skjorta er laga med hjelp av barnearbeid'). Her fungerer den kausale (>) leddsetninga sillä ko paiđat oon tehty lapsityövoimala som (>) fritt adverbial: Den forteller hvorfor saksforholdet er som beskrevet i ( $>$ ) oversetninga Hinta oon halpa.

KAUSATIV FØLELSE: Setninger av (>) setningstypen KAUSATIV FØLELSE er (>) følelsessetninger som har et (>) kausativt følelsesverb som forteller hvilken følelse noe vekker eller forårsaker i $(>)$ objektet. Objektet eller den som erfarer, står alltid i $(>)$ partitiv. Eksempler på kausative følelsesverb er oksettaa( $($ ) ('være kvalm'), iljettää $(t)$ ('føle avsky; gjøre kvalm'), hävettää(t) ('skjemmes'), naurattaa( $t$ ) ('få til å le'), janottaa( $t$ ) ('tørste'). For eksempel: Minnuu iljettää syöđä maksaa ('Jeg avskyr å spise lever'), der det kausative verbet er iljettää $(t)$. Jamfør (>) FØLELSE.

KAUSATIVT FøLELSESVERB: (>) Verb som opptrer i (>) setningstypen KAUSATIV FØLELSE.

KJERNE: Det ordet i en $(>)$ frase som er igjen når $(>)$ utfyllinger og $(>)$ modifikatorer er tatt bort. For eksempel i (>) setninga Pekka oon seppä poika laittamhaan ruokkaa ('Peder er flink gutt til å lage mat') er (>) substantiva Pekka ('Per') og poika ('gutt') kjerne ettersom de står igjen når vi tar bort $(>)$ premodifikatoren seppä ('flink') og (>) postmodifikatoren laittamhaan ruokkaa ('til å lage mat') fra frasen seppä poika laittamhaan ruokkaa. Kjernen i infinitivsfrasen laittamhaan ruokkaa er laittamhaan ettersom det står igjen når vi tar bort substantivet ruokkaa ('mat'), som står som utfylling til verbet laittaat ('lage'). I ( $>$ ) adposisjonsfraser regner vi sjølve ( $>$ ) adposisjonen som kjerne ettersom den styrer kasusen og plasseringa til $(>)$ nomenet det tar som utfylling.

KJERnEKonsonant: (>) Konsonant som er plassert ved første stavelsesgrense. Jamfør (>) kjernekonsonantkombinasjon.

KJERNEKONSONANTKOMBINASJON: Konsonantkombinasjon som er plassert ved første stavelsesgrense. Jamfør (>) kjernekonsonant. 
KOGNISJON: Setninger av (>) setningstypen KOGNISJON uttrykker en bevisst eller kognitiv tilstand. Slike setninger blir danna med hjelp av $(>)$ kog-

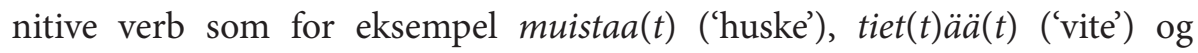
$y m m \ddot{a r} t(t) \ddot{a} \ddot{a}(t)$ ('forstå). (>) Objektet er typisk en $(>)$ verbfrase eller ei $(>)$ leddsetning. To eksempler på setninger av (>) setningstypen KOGNISJON er setninga Mie muistan, ette maapallo oon ymmyräinen ('Jeg husker at jordkloden er rund') og Mie tiedän, ette maapallo oon ymmyräinen ('Jeg veit at jordkloden er rund').

Kognitivt Verb: $(>)$ Verb som brukes i setninger av $(>)$ setningstypen $(>)$ KOGNISJON.

Komitativ: (>) Følgekasus som uttrykker at noen eller noe er med. Komitativ har ikke atskilte former for $(>)$ entall og $(>)$ flertall. I stedet bruker man former som ser ut som flertallsformer, både i entall og flertall. For eksempel: Liisa tuli kylästelemhään miehinensä ('Lisa kom på besøk sammen med mannen sin').

Kommentaradverb: (>) Adverb som forteller om hvordan taleren eller skriveren stiller seg til saksforholdet som er uttrykt i (>) setninga, det vil si om han eller hun ser på det som ønskelig, trulig eller mulig osv. For eksempel: Maapallo oon luultavasti/mahđolisesti/sikkaristi/tuskin tulemassa tyyhään ('Jordkloden holder trulig/muligens/sikkert/neppe på å gå til grunne'). Jamfør (>) kommentaradverbial.

Kommentaradverbial: (>) Fritt adverbial som på et vis kommenterer sannhetsgehalten i ei (>) setning. For eksempel i setninga Maapallo oon luultavasti/ mahđolisesti/sikkaristi/tuskin tulemassa tyyhään ('Jordkloden holder trulig/ muligens/sikkert/neppe på å gå til grunne') fungerer (>) kommentaradverba luultavasti ('trulig'), mahđolisesti ('muligens'), sikkaristi ('sikkert') og tuskin ('neppe') som kommentaradverbial.

KOMPARASJON (> gradbøying)

Komparativ: (>) Adjektiv (og stundom også substantiv) som er (>) avleid av $(>)$ positivforma, og som forteller at noen eller noe har mer eller mindre av en egenskap (eller at noen eller noe er nærmere ett sted enn et anna sted). 
For eksempel: (positiv) siivo ('snill') $\rightarrow$ siivompi ('snillere'), (positiv) viisas ('klok') $\rightarrow$ viishaampi ('klok'), (positiv) ranta ('strand') $\rightarrow$ rannempi ('nærmere stranda'), (positiv) ala- ('ned-') $\rightarrow$ alempi ('nedre').

KompleKs SETNING: $(>)$ Setning som inneholder to eller flere setninger som er satt sammen. Disse delsetningene kan være $(>)$ sideordna, eller de kan være relatert til hverandre som $(>)$ oversetning og $(>)$ leddsetning. For eksempel: Matti lähti Alattihoon, ja Maija lähti Raishiin ('Mats dro til Alta, og Maja dro til Nordreisa'); Matti lähti Alattihoon, sillä ko hänen äiti assuu sielä ('Mats dro til Alta sia mora hans bor der').

Kondisjonal subjunKsjon: (>) Subjunksjon som innleier ei (>) leddsetning som uttrykker et vilkår for det som er beskrevet i (>) oversetninga. Kvensk har to kondisjonale subjunksjoner: jos og ko, som begge betyr 'viss'. For eksempel: Mie lähđen kothiin, jos sie tulet myötä ('Jeg drar heim viss du blir med').

Kondisjonalis: $(>)$ Modus i (>) finitt verbbøying som uttrykker at det er usikkert om verbhandlinga skjer eller ikke. For eksempel: Pekka olis iloinen, jos Matti pärjäis eksaamenissa ('Peder ville være glad om Mats klarte eksamenen’). Kondisjonalis brukes også i høflig tiltale og i ønsker. For eksempel: Olisitko niin siivo, ette aukaisisit klasin? ('Kunne du være så snill å åpne vinduet?'). Kondisjonalis brukes bare i de to (>) tidsformene (>) presens og (>) presens perfektum.

KonGRUENS: Når bøyinga til ledda i ei (>) setning eller elementa i en (>) frase er i samsvar med hverandre, så sier vi at det er kongruens mellom dem, eller at de kongruerer med hverandre. I kvensk er det typisk to typer kongruens: tallog personkongruens mellom $(>)$ subjektet og $(>)$ verbalet i ei setning, og kongruens mellom $(>)$ adjektivmodifikatoren og $(>)$ kjernen i en frase. For eksempel: Mie $_{[1 . \text { sg.] }}$ menen $_{[1 . \text { sg.] }}$ kothiin ('Jeg drar heim'); Kaunhiila ${ }_{\text {[sg. adess.] }}$ pojala $_{\text {[sg. adess] }}$ oon fiinit ${ }_{\text {[pl. nom.] }}$ housut ${ }_{\text {[pl. nom.] }}$ ('Den pene gutten har fine bukser'). En tredje type kongruens er tallkongruens mellom (>) predikativet og (>) korrelatet i ei setning. For eksempel: Kalat ${ }_{[p 1 .]}$ oon verekset ${ }_{\text {[pl.] }}$ ('Fiskene er ferske’).

Konjunksjon: ( $>$ ) Junksjon som binder sammen $(>)$ setninger eller $(>)$ fraser som er $(>)$ sideordna eller på samme nivå. For eksempel: Pekka lähti kothiin 
mutta Maija jäi kafehaan ('Peder dro heim, men Maja blei igjen på kaféen'); Pekka ja Maija olthiin kafeassa ('Peder og Maja var på kafé').

KonNeKTiv Konjunksjon: $(>)$ Konjunksjon som uttrykker at den etterfølgende $(>)$ setninga er en følge av den foregående setninga. For eksempel: Minula oli jalka huono, se/niin mie piđin käyttäät krykkii ('Jeg hadde en vond fot, sånn at jeg måtte jeg gå på krykker’).

Konnektiv subjunksjon: (>) Subjunksjon som innleier ei (>) leddsetning som viser til konteksten eller sammenhengen der noe blir fortalt eller skrevet. Kvensk har to konnektive subjunksjoner, niin ko ('som') og jos ('viss'). For eksempel: Niin ko jo Perunkaki muisteli, kainulaissii oon käsketty kans lantalaisiksi ('Som allerede Beronka fortalte, så er kvenene også blitt kalt for lantalaiset [på kvensk]'); Matila oli viisi lasta, jos mie oikhein muistan ('Mats hadde fem barn, viss jeg husker rett').

KonnekTiv: (>) Adverb som er brukt som (>) fritt adverbial, og som knytter sammen $(>)$ setninger eller setningsdeler. For eksempel: Ensistä menimä saunhaan ja sitte panima maata. Sillä olima niin virkut aamula ('Først gikk vi i badstua, og så la vi oss. Derfor var vi så pigge på morgenen').

Konsessiv SubJunksjon: (>) Subjunksjonen vaikka ('sjøl om'), som innleier ei (>) leddsetning som forteller om et alternativt saksforhold eller et saksforhold som står i motsetning til det som er uttrykt i (>) oversetninga. For eksempel: Matti saattaa kainun kieltä, vaikka kotona hänele puhuthiin tyhä saamee ('Mats kan kvensk sjøl om de heime bare snakker samisk til han').

KonsonAnT: $(>)$ Lyd som oppstår når taleren enten innsnevrer munnhula eller lukker den heilt. En konsonant kan aldri danne kjernen i en (>) stavelse. Kvensk har følgende konsonanter: / / f h j k l m n n p r s [š] t v/. I lånord fins i tillegg konsonantene /b d g/. Jamfør (>) vokal.

KonsonantKombinasjon (konsonantsamband): Kombinasjon av to eller flere $(>)$ konsonanter som følger rett etter hverandre. For eksempel: traani ('tran'), kypsy ('moden'), kurkhuun (sg. ill. av kurkku 'hals, strupe'), pärskiit ('pruste'). 
KONSONANTSAMBAND (> konsonantkombinasjon)

Konsonantstamme: (>) Stamme som slutter på konsonant, og som brukes i (>) nomen eller (>) verb. For eksempel: (lapsi ('barn':) las/ta, (punainen 'rød':) punais/ta, juos/ta ('springe') : juos/thiin.

Kontrakt VERB: (>) Verbtype der en kort $(>)$ vokalstamme veksler med en lang vokalstamme. Vekslinga er av typen $V_{1}: V_{1} V_{1} \sim V_{1} A$. For eksempel: maa/ ta ('ligge') : makkaa/n, pölä/tä ('være redd') : pölk(k) ää/n, halu/ta ('ha lyst til') : halluu/n $\sim$ halua/n.

Kontrastiv KOnJUnKsjon: (>) Konjunksjonen mutta ('men'), som uttrykker at det er ei motsetning mellom to $(>)$ setninger eller to $(>)$ fraser. For eksempel: Pekka ei lähteny kothiin mutta restaurantthiin ('Peder dro ikke heim, men på restaurant'); Mie kyllä muistan sen ihmisen, mutten muista sen nimmee ('Jeg husker nok den personen, men husker ikke navnet hans/ hennes').

Korrelat: (>) Setningsledd som blir nærmere bestemt av et anna ledd i samme eller ei anna (>) setning. Derimot bestemmer korrelatet sjøl ikke forma på noe anna ledd. For eksempel i setningene Minula oon veli. Sen nimi oon Heikka ('Jeg har en bror. Navnet hans er Henry') er ordet veli ('bror') korrelatet til det $(>)$ personlige pronomenet sen ('han'). I den (>) komplekse setninga Minula oon veli, jonka nimi oon Heikka ('Jeg har en bror hvis navn er Henry') er ordet veli ('bror') korrelatet til (>) relativpronomenet jonka ('hvis'). I setningene Oli hyvä ko tulitta kotia ('Det var bra at dere kom heim') og Nilla oli lantalainen ('Nils var kven') er (>) frasene ko tulitta kotia ('at dere kom heim') og Nilla ('Nils') korrelat til henholdsvis (>) predikativa hyvä ('bra') og lantalainen ('kven'). Jamfør (>) ankerord og (>) modifikator.

KORT STAVElse: $(>)$ Stavelse som slutter på $(>)$ kort vokal. For eksempel består orda ta-vu ('stavelse'), pa-ha ('ond'), e-no ('onkel'), ta-ka-na ('bak'), me-ni (av mennä 'gå') og tu-le-ma (av tulla 'komme') bare av korte stavelser, mens det i orda muu-tam-pi ('noen'), kui-ten-ki ('likevel') og mak-kaamas-sa (av maata 'ligge') bare er den siste stavelsen som er kort. Jamfør (>) lang stavelse. 
KORT VOKAL: (>) Vokaler deles inn i korte og $(>)$ lange vokaler basert på den relative lengda deres. En kort vokal uttales altså kortere enn en tilsvarende lang vokal. I skrift markeres kort vokal med enkelt bokstav.

Kort voKalstamme: (>) Stamme som er brukt i (>) nomen, og som i entallsformer slutter på kort vokal. For eksempel: sauna ('badstue') : sauna/na, lapsi ('barn') : lapse/na, kajava ('måse') : kajava/nna, tytär ('datter; jente') : tyttäre/nnä, punainen ('rød') : punaise/nna. Jamfør (>) lang vokalstamme.

Kvalitativ veksling: Type (>) stadieveksling som innebærer at $(>)$ konsonanten på (>) o-stadium er kvalitativt annleis enn på (>) I- og (>) II-stadium. Det er bare $(>)$ plosivene $k, t$ og $p$ som er involvert i kvalitative vekslinger. For eksempel: (1. inf. : akt. ind. 1. sg.) jakkaa(t) ('dele') : ja(j)an, (sg. nom. : gen. sg.) puku ('dress; drakt') : puvun. Jamfør (>) kvantitativ veksling.

Kvantitativ veksling: Type $(>)$ stadieveksling som innebærer at lengda på (>) konsonanten veksler mellom (>) II- og (>) I-stadiet. Alle konsonanter kan gjennomgå kvantitative vekslinger, men bare plosivene $k, t$ og $p$ kan gjennomgå (>) kvalitative vekslinger. Eksempler på kvantitative vekslinger: (sg. nom. : part. sg.) kala ('fisk') : kallaa, kesä ('sommer') : kessää, (1. inf. : akt. ind. 1. sg.) hakata ('hogge') : hakkaan, hypätä ('hoppe') : hyppään.

KvantoR: Ord som uttrykker mengde eller antall. Til kvantorene regner vi alle $(>)$ grunntall, men også $(>)$ kvantorpronomen og $(>)$ mengdeadverb. For eksempel: kaikki ('all, alle'), molemat ('begge'), paljon ('mye; mange'), vähän ('lite; litt'), kivasti ('mye').

Kvantorfrase (KvaP): (>) Frase som har en (>) kvantor som kjerne. Dersom kvantorfrasen i tillegg inneholder et $(>)$ substantiv, så bestemmer kvantoren (>) kasusen til dette substantivet. For eksempel: viisi tytärtä ('fem jenter'), paljon kallaa ('mye fisk'), molemat meistä ('begge vi'). (>) (>) Grunntall danner bare kvantorfraser når de står i $(>)$ nominativ $(>)$ entall; ellers fungerer grunntall som (>) premodifikator til substantiv.

Kvantorpronomen: Til kvantorpronomen regner vi alle (>) pronomen som ikke er $(>)$ personlige pronomen, $(>)$ demonstrative pronomen, 
(>) spørrepronomen, $(>)$ relativpronomen, $(>)$ refleksive pronomen eller $(>)$ resiproke pronomen. Brorparten av kvantorpronomen uttrykker mengde eller antall, for eksempel (ei) kukhaan ('ingen'), jokhainen ('enhver'), kaikki ('alle'), molemat ('begge'), itte kukin ('hver og en').

Kvantorsetning: $(>)$ Toverdig $(>)$ direkte setning som uttrykker antall eller mengde. Ei kvantorsetning har typisk to $(>)$ utfyllinger. Den ene utfyllinga er en $(>)$ kvantorfrase som verken kan klassifiseres som $(>)$ objekt, $(>)$ predikativ eller (>) adverbial (jf. kymmenen ('ti') og liijan paljon ('for mye') i setningene nedafor). Den andre utfyllinga er (>) korrelatet til kvantorfrasen (jf. meitä lapsii ('av oss barn' og kengät ('skoene'). For eksempel: Meitä lapsii oli kymmenen ('Vi var ti barn'); Kengät maksethiin liijan paljon ('Skoene kosta for mye'). Jamfør (>) setningstypene (>) ANTALL og (>) MENGDE.

LANG STAVELSE: $(>)$ Stavelse som inneholder $(>)$ lang vokal eller $(>)$ diftong, eller som slutter på $(>)$ konsonant. For eksempel i ordforma par-haa-la (av paras 'best') er stavelsene par og haa lange. Jamfør (>) kort stavelse.

LANG vOKAL: Etter lengda deres deler vi $(>)$ vokaler inn i ( $>$ ) korte og lange vokaler. Det er to slags lange vokaler: 1 . Enkelt vokal som uttales lenger enn en kort vokal. I skrift markerer vi det med doble bokstaver, som for eksempel aa i ordet kaari ('bue; spant') (jf. kari 'grus; sandgrunne'). 2. (>) Diftong.

LANG VOKALSTAMME: ( $>$ ) Stamme som er brukt i (>) nomen, og som slutter på $(>)$ lang vokal eller $(>)$ diftong. Eksempler på lang vokalstamme finner vi i orda tuorestai ('torsdag'), kauhee ('fryktelig') og (venet 'båt':) venhee-. Jamfør (>) kort vokalstamme.

LAUST ADVERB: (>) Adverb som kommenterer sannhetsgehalten i ei ( $>$ ) setning, i hvilken grad innholdet er ønskelig, hvilken innstilling noen har til saksforholdet i setninga, eller som knytter setninga til konteksten rundt. Lause adverb har ikke eigne $(>)$ modifikatorer. Det fins to typer lause adverb: $(>)$ konnektiv og $(>)$ kommentaradverb.

Leddsetning: Setning som er del av ei anna setning. For eksempel: Mie en lähe nukkumhaan, sillä ko mie en ole vaipunu ('Jeg skal ikke legge meg sia jeg ikke er trøtt'). Jamfør (>) oversetning og (>) hovedsetning. 
LEVENDE: Et (>) subjekt kalles for levende når det refererer til en enhet som handler av eige tildriv, og/eller som føler noe.

L-KAsUs: Alternativ betegnelse for $(>)$ ytre lokalkasus. ( $>$ ) Kasussuffiksa i disse formene inneholder alle $(>)$ konsonanten $l$, derav navnet. Jamfør (>) s-kasus.

LoKALKASUs: (>) Kasus som brukes særlig i ( $>$ ) lokative og ( $>$ ) possessive setninger. Det er vanlig å skille mellom $(>)$ indre lokalkasus (> inessiv, > elativ, > illativ) og ( $>$ ) ytre lokalkasus ( $>$ adessiv, $>$ ablativ, $>$ allativ).

LoKATIV SETNING: $(>)$ Direkte setning som forteller at noen eller noe er et sted eller beveger seg til et sted. Det fins flere lokative (>) setningstyper: (>) STED, (>) BEVEGELSE, $(>)$ EKSISTENS, $(>)$ EKSISTENSENDRING og (>) FLYTTING.

LUKKA KLASSE: Ordtype som ikke får nye medlemmer, det vil si at den ikke er produktiv. Typiske eksempler på lukka klasser er tostava $(>)$ nomen og $(>)$ verb med e-stamme. Jamfør (>) åpen klasse.

LYD: En lyd (og her meiner vi språklyd) oppstår når lufta strømmer gjennom stemmebanda. Kvensk har disse lydene: /a đ e f h i j k l m n y o p r s t u v y ä ö/. I lånord finner vi i tillegg $(>)$ konsonantene /b d g š/. Jamfør (>) vokaler og (>) konsonanter.

MANGelfull Bøying: Vi sier at ord som bare har noen få bøyingsformer, har mangelfull bøying. Det gjelder flere $(>)$ adverb og $(>)$ adposisjoner. For eksempel: (ete- :) e(đ)essä ('foran') : eđestä : etheen : e(đ)elä : e(đ)eltä : e(đ)ele(t), (ala- :) alla ('under') : alta : alle(t), (kumo- 'opp ned':) kumossa:kumhoon.

MEINING: Setninger av (>) setningstypen MEINING uttrykker at noen antar noe, eller at noen syns, trur, håper at noe er eller blir slikt eller slikt. Vanlige meiningsverb er luula ('anta'), uskoot uskoa(t) ('tru'), pittää( $t$ ) ('synes') og toivoot $\sim$ toivoa( $t$ ) ('håpe'). For eksempel: Mie uskon, ette maapallo oon ymmyräinen ('Jeg trur at jordkloden er rund').

MENGDE: Setninger av (>) setningstypen MENGDE er ( $>$ ) kvantorsetninger som forteller for eksempel hvor mye noe koster eller veier, hvor mye 
noen tjener, eller hvor mange år noen fyller. $(>)$ Verbalet i slike setninger består av verb som maksaa(t) ('koste'), tehđä tehhä (her: 'bli'), painaa(t) ('veie'), tienata ('tjene'), täyttää( $t)$ ('fylle'). I tillegg til $(>)$ subjekt tar verbalet en $(>)$ kvantorfrase som (>) utfylling. For eksempel: Maija täyttää heti seittemänkymmentä ('Maja fyller snart sytti'); Lohi maksaa vähän ('Torsk(en) koster lite').

Mengdeadverb: (>) Adverb som brukes i svar på spørsmål om hvor mye (kunka paljon?) og i hvilken grad (mihin määrhään?). Det som spesifiseres, kan være stoffmengde, tidslengde osv. Eksempler på mengdeadverb er paljon ('mye'), vähän ('lite, litt'), vuosittain ('i årevis'), kauheesti kauheasti kauhiasti ('forferdelig (mye)').

Modalsetning: $(>)$ Modifisert setning som har et $(>)$ modalverb som $(>)$ verbal. For eksempel: Sie häyđyt lähteet saunhaan ('Du må dra i badstua'); Met emmä pääse lähtemhään kotia ('Vi får ikke dratt heim / Vi kan ikke dra heim'). Jamfør (>) aspektsetninger.

Modalverb: $(>)$ Verb som brukes i (>) modale setninger, og som krever en $(>)$ infinitivsfrase som $(>)$ utfylling. Et modalverb forteller om hvorvidt saksforholdet i ei $(>)$ setning etter talerens syn eller generelt er sikkert eller usikkert, nødvendig eller mulig, lovlig eller ulovlig, sannsynlig eller usannsynlig osv. Eksempler på modalverb er häyttyyt häytyä $(t)$, häättyyt häätyä $(t)$ ('måtte'), pittää(t) ('skulle, må), jouttuut joutua(t) ('måtte, bli tvunget til'), kannattaa( $t$ ) ('lønne seg'), saađa saaha ('få), aikkoot aikoa( $t$ ) ('akte, ha til hensikt'), meinata ('akte, ha til hensikt, tenke seg'), haluta ('ville, ha lyst til'), saattaa $(t)$ ('kunne'), sattuut sattua( $t$ ) ('falle seg, skje tilfeldigvis) og tait $(t)$ $a a(t)$ ('kunne; tørre').

MODIFIKATOR: (>) Setningsledd som ikke er $(>)$ utfylling. Modifikatorer kan modifisere $(1)$ heile $(>)$ setninga, for eksempel Illala oon juhlapaikan tykönä tanssit ('På kvelden er det dans i festlokalet'), eller (2) en (>) frase i setninga, for eksempel Maija oon kommee nainen ('Maja er ei vakker kvinne').

MODIFISERT SETNING: (>) Verbalet i modifiserte setninger bidrar ikke med ny informasjon til $(>)$ setninga, men modifiserer saksforholdet som er framstilt i setninga, eller bestemmer nærmere tida for når saksforholdet gjelder. 
Det fins tre typer modifiserte setninger: $(>)$ Modale setninger, (>) OON PAKKO-setninger og $(>)$ aspektsetninger.

Modus: Modal bøyingskategori ved (>) verb som har tre medlemmer: $(>)$ indikativ, $(>)$ kondisjonalis og $(>)$ imperativ.

Morfem: Minste betydningsbærende del som ord er satt sammen av. Vi skiller mellom ulike typer morfem: (>) rotmorfem, (>) avleiingsmorfem, (>) bøyingsmorfem, $(>)$ possessivsuffiks og $(>)$ enklitika. Basert på hvor et morfem plasseres i forhold til rotmorfem, skiller vi også mellom $(>)$ prefiks og $(>)$ suffiks. For eksempel i ordforma epäjumalallisissaki (av epäjumalallinen 'ugudelig') utgjør (>) substantivet jumala rotmorfemet, foran rotmorfemet står

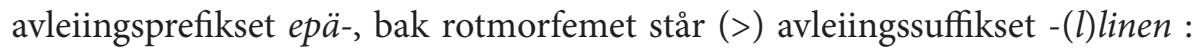
-(l)lise-, som er etterfulgt av (>) flertallssuffikset $-i$, som igjen er etterfulgt av (>) kasussuffikset - i inessiv -ssa, og heilt til slutt følger enklitikonet - $k i$. Morfeminndelinga i dette ordet blir altså slik: epä/jumala/llis/i/ssa/ki.

MorfofONOLOGISK VEKSLING: Veksling der ett og samme ( $>$ ) morfem - et $(>)$ rotmorfem eller et anna morfem - blir realisert på ulike vis avhengig av morfologiske og/eller fonologiske faktorer, slik som hvilken bøyingsform det forekommer i, hvor i ordet det står, hvilken lydomgivelse det står i, eller hvilken (>) stamme det blir festa til. Eksempler på morfofonologiske vekslinger er (>) stadieveksling, $(>)$ vekslinga $t V: s i,(>)$ h-flytting og $(>)$ vokalharmoni.

MÅTESADVERB: (>) Adverb som forteller om måten noe skjer, blir gjort eller oppleves på. For eksempel: hopusti ('fort'), hiljaa ('stille; sakte'), varkhain (' $\mathrm{i}$ smug, i hemmelighet'), näin ('slik, sånn'), hihtosin ('på ski'), mielelä ('gjerne'), alaspäin ('nedover').

NAVNGIVING: Setninger av (>) setningstypen NAVNGIVING inneholder $(>)$ treverdige verb som uttrykker et budskap eller benevner noe, for eksempel verba käskeet käskeä(t) ('kalle, benevne'), kuttuut kuttua(t) ('kalle'), sannoot sanoa $(t)$ ('kalle'), nimittää( $t$ ) ('navngi, kalle') og haukkuut haukkua(t) ('skjelle ut og kalle'). For eksempel: Mie käsken Alarikkii Aakiksi ('Jeg kaller Alarik for Aaki'); Maija haukkui Pekkaa tolloksi ('Maja kjefta på Peder og kalte han for dum'). 
NEKTENDE FORM (> nektende verbform).

NeKtende Setning: $(>)$ Setning der det $(>)$ finitte verbet har $(>)$ nektende form. For eksempel er setninga Mie en lähđe Tromsshaan ('Jeg drar ikke til Tromsø') ei nektende setning.

NeKTENDE VERBFORM (nektende form av verbet): Nektende variant av den $(>$ ) finitte verbforma som består av (>) nektingsverbet ei ('ikke') og (>) nektingsforma eller $(>$ ) perfektum partisipp-forma av verbet. Et eksempel på ei nektende verbform er den ( $>$ ) sammensatte verbalforma en tule i (>) setninga Mie en tule Tromsshaan ('Jeg kommer ikke til Tromsø'). Et anna eksempel er den sammensatte verbalforma ei tultais i setninga Het ei tultais Tromsshaan ('De skulle ikke komme til Tromsø'). I setninga Het ei olheet tulheet Tromshaan ('De var ikke kommet til Tromsø') er preteritum partisipp-forma ei olheet tulheet ei nektende verbform.

NeKTINGSFORM: Den $(>)$ presensforma som $(>)$ hovedverbet har når det står sammen med $(>)$ nektingsverbet i ei $(>)$ nektende setning. For eksempel i $(>)$ setninga Mie en tule Tromsshaan ('Jeg kommer ikke til Tromsø') er tule ei (>) indikativ nektingsform av verbet tulla ('komme'), og i setninga Mie en halluis lähteet Tromsshaan er halluis nektingsform i (>) kondisjonalis av verbet haluta ('ha lyst til, ville').

Nektingspronomen: (>) Pronomen som bare forekommer i (>) nektende eller usikre $(>)$ setninger. Det er fire nektingspronomen i kvensk: kukhaan ('(ikke) noen'), yksikhään ('(ikke) en eneste'), mikhä̈̈n ('(ikke) noe(n)’) og (>) dualispronomenet kumpikhaan ('(ingen) av to').

Nektingsverb: Verbet ei ('ikke'), som brukes i $(>$ ) nektende setninger sammen med $(>)$ nektingsforma eller $(>)$ perfektum partisipp-forma av $(>)$ hovedverbet. Nektingsverbet bøyes ikke i $(>)$ tid eller $(>)$ modus, men det har (>) personbøying: (1. sg. : 2. sg. : 3. sg., 1. pl. : 2. pl. : 3. pl.) en, et, ei, emmä, että, ei.

Nomen: Fellesbetegnelse for $(>)$ substantiv, $(>)$ adjektiv, $(>)$ pronomen og $(>)$ tallord. Felles for orda i disse ordklassene er at de har $(>)$ kasus- og tallbøying. 
Nomentype: $(>)$ Nomen deles inn i nomentyper etter hva slags $(>)$ stamme de har, og hvordan de ulike $(>)$ bøyingssuffiksa festes til disse stammene.

Nomina AGENTis (> handlerord).

Nominativ: (>) Grammatisk kasus som ikke har noe eige (>) suffiks. Med andre ord er nominativsformer (>) umarkerte former. I flertall brukes suffikset $-t$ i stedet for $-i$. Nominativ markerer vanligvis $(>)$ subjekt og $(>)$ predikativ, $\mathrm{i}$ flertall også (>) totalobjekt. Nominativsforma i (>) entall brukes som (>) oppslagsform i ordbøker og lister. For eksempel: (sg. nom. : pl. nom.) poika ('gutt; sønn’) : pojat, ty(t)är ('jente; datter’) : tyttäret, viisas ('klok') : viishaat, vares ('kråke') : varekset, sininen ('blå') : siniset, joka ('hver') : jokka, muutampi ('noen') : muutamat, viisi ('fem') : vii(đ)et.

Nullverdig: Nullverdige ( $>$ ) verb er verb som ikke krever noen ( $>$ ) utfylling, men som kan stå aleine i ei (>) setning. Slike verb er særlig brukt i (>) setningstypen (>) VÆRTILSTAND. Vi sier også at ei setning er nullverdig når $(>)$ hovedverbet i setninga er nullverdig. Jamfør $(>)$ enverdig, $(>)$ toverdig og $(>)$ treverdig.

Numerus ( $>$ tall).

Овјект (= O): (>) Syntaktisk kategori som kommer til uttrykk som $(>)$ utfylling til $(>)$ transitive verb. Objektsutfyllinger finner vi i alle $(>)$ følelses- og ( $>$ ) handlingssetninger. I slike setninger er det $(>)$ nomen som fungerer som objekt, og de står i (>) objektskasus (med verbet tykätä ('like; synes') også i (>) elativ). I (>) indirekte setninger kan objektsutfyllinga også være et nomen, men ofte er det ei $(>)$ leddsetning eller en $(>)$ verbfrase. Verbfraser regnes som objekt når de står i (>) første infinitiv; ellers analyserer vi dem som (>) adverbial. Eksempler på setninger med objekt er: Mie rakastan sinnuu ('Jeg elsker deg'); Amtmani kaatoi mettän ('Amtmannen felte skog'); Mikko maalas talon punaiseksi ('Mikkel malte huset rødt'); Mie muistan sinun ('Jeg husker deg'); Faari kirjoitti, ette hän oon Amerikassa ('Far skreiv at han var i Amerika'); Muori käski faarin tulla kotia ('Mor ba far om å komme heim'); Tet saatta lähtiä kotia ('Dere får dra heim'). 
OBJEKTSADVERBial: (>) Frase som står i (>) objektskasus, men som fungerer som $(>)$ adverbial. Objektsadverbial kan fungere som $(>)$ utfylling eller som (>) fritt adverbial i (>) setninga. For eksempel: Met kävelimmä tietä ('Vi gikk på vegen'); Mie lujin kirjaa koko yön ('Jeg leste i ei bok heile natta'). Når en slik frase består av en (>) kvantorfrase, så kaller vi den i setningsanalysen bare for kvantorfrase.

ОвјектsкAsus: $(>)$ Kasus som brukes på $(>)$ objektet i ei $(>)$ setning. Det kan være $(>)$ partitiv, $(>)$ genitiv eller $(>)$ nominativ.

OON PAKKO-SETNING: (>) Modifisert setning der $(>)$ verbalet består av et $(>)$ verbsamband. Som $(>)$ verbal fungerer verbet olla ('være'), som knytter til seg et $(>)$ substantiv eller et $(>)$ adjektiv. Slike setninger likner på setningstypen EIERSKAP, men i motsetning til denne er $(>)$ subjektet her en $(>)$ infinitivsfrase. For eksempel: Matila oon pakko tulla kothiin ('Mats er nødt til å komme heim'); Meilä oon paha mennä kothiin ('Det er vanskelig for oss å dra heim').

OpPSLAGSFORM: Den forma som står først i oppslaga i ordbøker og ordlister, og som brukes som utgangspunkt i alfabetiske rekkefølger. Som oppslagsform for $(>)$ nomen tjener $(>)$ nominativ $(>)$ entall, og for $(>)$ verb er $\operatorname{det}(>) 1$. infinitiv.

ORDENSTALL: $(>)$ Tallord som er $(>)$ avleid av ( $>$ ) grunntall, og som uttrykker orden eller rekkefølge mellom enheter. Ordenstall danner $(>)$ adjektivfraser og de har fullstendig (>) tall- og kasusbøying. For eksempel: ensimäinen ('første'), viiđes ('femte'), sađas ('hundrede'), tuhanes kahđessađas kuuđeskymmenes viides ('tusentohundreogsekstifemte').

ORDKLASSE: Ord deles inn i ordklasser basert på hvordan de bøyes, og hvilken funksjon de har i $(>)$ setninga. Kvensk har følgende ordklasser: $(>)$ verb, $(>)$ nomen, (>) adverb, (>) adposisjoner og (>) junksjoner. Nomen består av undergruppene $(>)$ substantiv, $(>)$ adjektiv, $(>)$ pronomen og $(>)$ tallord. Jamfør (>) frase.

ORDSAMBAND: Ord som kommer etter hverandre, og som fungerer som enhet i $(>)$ setninga. Det er særlig blant (>) subjunksjoner vi finner ordsamband, 
for eksempel niin ette että ('slik at'), sillä ko ('ettersom'), siksi ko ('så lenge at'), siitä ko ('fra av'), niin ko ('slik/så som'), ennen ko ('før, innen'), jälkhiin ko ('etter'), men de fins også hos adverb, for eksempel tuoloin tällöin ('i ny og ne'), toisin ai(j)oin ('andre ganger'), ennen kaikkee kaikkea kaikkii ('først av alt, framfor alt'). Jamfør (>) enklitikon, (>) parord og (>) simpleksord.

Overgangsstamme: (>) Vokalstamme som brukes som alternativ verbstamme i stedet for den korte stammen i $(>)$ flerstava $(>)$ verb med konsonantstamme og $(>)$ verb med to vokalstammer. For eksempel: (konsonantstamme) (muistel/a ) muistele/a(t) ('fortelle'), (auka(i)s/ta ) auka(i)se/at ('åpne'), (kort og lang vokalstamme) (halli/ta ) hallitte/a(t) ('styre'), (piikaroi/ta ) piikaroitte/a(t) ('spikre'), (pa(j)e/ta ) pakene/a(t) ('rømme'). (>) Kontrakte verb, som også hører til verb med to vokalstammer, har ikke noen alternativ overgangsstamme.

Overgangsverb: (>) Verb som har (>) overgangsstamme. Er vanlig særlig i varietetene i Nord-Troms, men fins også i andre varieteter.

Overordna setning (> oversetning).

Oversetning (overordna setning): (>) Setning som tar ei (>) leddsetning som $(>)$ modifikator eller $(>)$ utfylling. For eksempel i den $(>)$ komplekse setninga Mie näjin, että suorsat olthiin palanheet, vaikka vielä oli kylmä ('Jeg så at stokkendene var kommet tilbake, sjøl om det fortsatt var kaldt') er setninga Mie näjin ('Jeg ser') oversetning til setninga ette suorsat olthiin palanheet ('at stokkendene var kommet tilbake'), som igjen er oversetning til setninga vaikka vielä oli kylmä ('sjøl om det fortsatt var kaldt'). Jamfør (>) leddsetning.

PARORD: To ulike ord som til sammen forbinder to $(>)$ setninger eller $(>)$ fraser. Eksempler på parord er (>) konjunksjonene joko - eli elikkä ('enten- eller'), sekä - ja ('både - og'), sekä - ette että ('både - og'). Et slags parord er også det $(>)$ resiproke parpronomenet toinen - toinen ('hverandre'). Jamfør (>) sammensatt verbalform, (>) ordsamband og $(>)$ sammensetning.

PARTiAlobJEKT: (>) Objekt som står i (>) partitiv. Jamfør (>) totalobjekt. 
PARTISIPP: Ei av de $(>)$ infinitte formene til $(>)$ verb. Det fins tre typer partisipp: (>) perfektum partisipp, $(>)$ presens partisipp og $(>)$ agentpartisipp. Jamfør (>) infinitiv.

PARTISIPPFRASE: $(>)$ Infinitt $(>)$ verbfrase med $(>)$ partisipp som $(>)$ kjerne. For eksempel: Mulla ei tullu otetuksi sitä eksaamenii ('Jeg fikk ikke tatt den eksamenen'); Se näyttää tulleevan kaunis päivä ('Det ser ut til å bli en fin dag').

PARTITIV: (>) Grammatisk kasus som brukes som subjektskasus i (>) setningstypene $(>)$ EKSISTENS og $(>)$ EIERSKAP og som $(>)$ objektskasus i $(>)$ handlingssetninger, i setningstypen ( $>$ ) MEINING og i $(>)$ følelsessetninger. Partitivformer forekommer dessuten i (>) objektsadverbial i ( >) nektende setninger og i (>) utfyllinger i (>) adposisjonsfraser. For eksempel: (kesä 'sommer':) kessää : kessii kesiä, (pieni 'liten':) pientä : pienii pieniä, (ahven 'uer; abbor':) ahventa : ahveniita ahvenia.

PAssiv SETNING: Ei $(>)$ setning er passiv når $(>)$ verbalet har $(>)$ passiv form og det ikke fins noe (>) subjekt. For eksempel: Ensistä poron tapethaan ja sitte vasta keitethään ('Først blir reinsdyret avliva, og først da blir det kokt').

PAssiv: (>) Verbform som brukes uten (>) subjekt i $(>)$ setninger, og som realiseres med eigne $(>)$ suffiks i $(>)$ personbøyinga av verb. Som $(>)$ finitt verbform har passiv fullstendig $(>)$ tids- og $(>)$ modusbøying, som $(>)$ infinitt verbform bare $(>)$ partisippformer. Eksempler på passivformer: (mennä 'gå, dra’:) menhään : menthiin : oon menty : mentäis : olis menty : mentäkhöön. Legg merke til at $(>)$ aktive former i $(>)$ tredje person $(>)$ flertall er til dels identiske med passivformer. Jamfør (>) generisk, upersonlig konstruksjon.

Passivstamme: Den (>) stammen i (>) verbet som passivsuffiks festes til. For eksempel: Til passivstammen men av verbet mennä ('gå, dra') festes passivsuffiksa hä̈̈n/thiin/ty/täis, og resultatet er passivformene menhään, menthiin, menty, mentäis.

PerfeKtum PARTISIPP: ( $>$ ) Partisippform av $(>)$ verb som viser til fortid. Brukes i $(>)$ sammensatte tidsformer og i $(>)$ nektende form av $(>)$ preteritum. For eksempel: (tulla 'komme':) tullu(t) : tultu, (maata 'ligge':) maanu : maattu, 
(jakkaa $(t)$ 'dele':) jakanu( $(t)$ : ja(j)ettu. Perfektum partisipp har fullstendig $(>)$ tall- og kasusbøying. Jamfør (>) presens partisipp og (>) agentpartisipp.

PERSON: $(>)$ Finitte verbformer står alltid i en person. Det fins sju personer. Det er $(>)$ første, $(>)$ andre og $(>)$ tredje person i $(>)$ aktiv bøying i henholdsvis $(>)$ entall og $(>)$ flertall, og i tillegg $(>)$ passive personformer. Personbøyde former fungerer alltid som $(>)$ verbal i $(>)$ setninga. Også ( $>$ ) personlige pronomen og $(>)$ possessivsuffiks står enten i første, andre eller tredje person i entall eller flertall.

Personkongruens: Regel som sier at i $(>)$ aktive $(>)$ setninger skal $(>)$ subjektet og $(>)$ verbalet stå i samme $(>)$ person. For en mer utførlig definisjon se $(>)$ tall- og personkongruens.

Personlig pronomen: $(>)$ Pronomen som refererer til en skapning eller en ting. Personlige pronomen har to $(>)$ tall, $(>)$ entall og $(>)$ flertall, og tre $(>)$ personer, $(>)$ første, $(>)$ andre og $(>)$ tredje. De personlige pronomena i kvensk er mie ('jeg'), sie ('du'), hän/se ('han; hun; den; det'), met ('vi'), tet ('dere'), het/ net ('de'). Legg merke til at i motsetning til norsk så har ikke personlige pronomen i kvensk grammatisk kjønn. Det vil si at pronomena hän og se kan referere til skapninger av både biologisk hankjønn og hunkjønn.

Personsuffiks: De sju personformene til ( $>$ ) verb har hvert sitt personsuffiks. Det er suffiksa for $(>)$ første, $(>)$ andre og $(>)$ tredje person $(>)$ entall og $(>)$ flertall i tillegg til de $(>)$ passive personsuffiksa. Personsuffiksa står etter suffiksa for $(>)$ tid og $(>)$ modus. I $(>)$ presens og $(>)$ preteritum festes personsuffiksa til $(>)$ hovedverbet, i $(>)$ presens perfektum og $(>)$ preteritum perfektum festes de til $(>)$ hjelpeverbet olla ('være'). I (>) nektende verbformer festes personsuffiks til (>) nektingsverbet.

PLosiv: (>) Konsonantene / k, p, t/, som i kvensk er ( $>$ ) ustemte, men som til forskjell fra norsk alltid er uten aspirasjon, også når de står foran vokal i (>) trykksterk stavelse, som for eksempel /p/ i paita ('skjorte').

Positiv: $(>)$ Grunnform som $(>)$ adjektiv har i ( $>$ ) gradbøying. Jamfør $(>)$ komparativ og $(>)$ superlativ. 
Possessiv SETning: (>) Setning som forteller at noen eller noe har, får eller mister noe eller noen. Til possessive setninger regner vi $(>)$ setningstypene $(>)$ EIERSKAP og (>) EIERSKAPSENDRING. For eksempel: Matila oon kallaa ('Mats har fisk'); Multa kuoli poika ('Jeg mista en sønn'). Det fins også (>) treverdige possessive setninger, nemlig setningstypen TRANSITIV EIERSKAPSENDRING. For eksempel: Mie vein kukat Mikole ('Jeg tok blomstene med til Mikkel'); Tomi anttaa Matile kallaa ('Tomi gir fisk til Matti').

Possessivsuffiks: (>) Suffiks som festes til et $(>)$ setningsledd, og som knytter det til (>) subjektet, stundom også til (>) objektet, i (>) setninga. Possessivsuffiks legges etter de andre suffiksa i ordet, bortsett fra enklitika, som alltid kommer sist i ordet. Possessivsuffiks markerer $(>)$ tall, $(>)$ entall og $(>)$ flertall, og tre $(>)$ personer, $(>)$ første, $(>)$ andre og $(>)$ tredje. Suffiksa har disse formene: $-(n) n i$ (1. sg.), -sti (2. sg.), - (m) $m A$ (1. pl.), -ttA (2. pl.) og fellesforma - nsA i tredje person entall og flertall. Possessivsuffiks brukes i $(>)$ komitative kasusformer, $\mathrm{i}$ $(>)$ refleksive pronomen, i $(>)$ agentkonstruksjoner og stundom også i $(>)$ adverb. For eksempel: miehinensä ('mannen sin/hans/hennes / mennene sine/ hans/hennes'), ittelesti ('sjøl', 2. sg. allat.), hänen pesemänsä paita ('skjorta som han/hun har/hadde vaska'), keskenämmä ('oss imellom'). Ellers er ikke possessiv i vanlig bruk.

Postmodifikator: (>) Modifikator som står til nomen, og som er plassert etter $(>)$ kjernen. Det kan være et $(>)$ substantiv i $(>)$ lokalkasus, en $(>)$ adposisjonsfrase, en $(>)$ infinitivsfrase eller ei $(>)$ leddsetning. For eksempel: substantiivi paikkakaasuksessa ('et substantiv i lokalkasus'); vihainen Liisan pääle ('sint på Lisa'); nokko voimaa nostaat kiven ('nok styrke til å løfte steinen / en stein'); mies, joka tiettää kaiken ('mannen / en mann som veit alt').

Postposisjon: (>) Adposisjon som står etter (>) utfyllinga si. For eksempel: Talon takana oon tyhä mettää ('Bak huset er det bare skog'). Jamfør (>) adposisjonsfrase og $(>)$ preposisjon.

Predikasjonssetning: $(>)$ Setning der vanligvis $(>)$ subjektet, men også $(>)$ objektet (i $(>)$ setningstypen TRANSITIV ENDRING) eller ( $>$ ) adverbialet (i setningstypen RESULTAT)) fungerer som korrelat til (>) predikativet, som spesifiserer hva slags egenskap(er) subjektet, objektet eller adverbialet har. 
For eksempel: Taivas oon sininen ('Himmelen er blå'); Anders oon Jaakkoloita ('Anders er av Jakola-slekta'); Pekasta tuli paakari ('Peder blei baker'); Liisa leikkas kynnet lyhykäiseksi ('Lisa klipte neglene korte').

PREDIKATIV SANS: Setninger av (>) setningstypen PREDIKATIV SANS er $(>)$ predikasjonssetninger som uttrykker et sanseinntrykk, det vil si hvordan noe(n) lukter, smaker, høres, ser ut eller føles. (>) Verbalet i slike setninger består av (>) intransitive sanseverb som haista ('lukte'), näyttää $(t)$ ('se ut'), kuuluut kuulua(t) ('høres'), maistuut maistua( $t$ ) ('smake'), tunttuut tuntua( $t$ ) ('kjennes, føles'). (>) Predikativet står i (>) ablativ. For eksempel: Paska haissee pahalta ('Skit lukter vondt'); Pirkon laulu kuuluu kamalalta ('Pirkkos sang høres forferdelig ut'). Jamfør (>) SANSETILSTAND og (>) SANSEOBSERVASJON.

Predikativ: (>) Utfylling i $(>)$ predikasjonssetning som forteller noe om egenskapen(e) til (>) korrelatet.

PREDIKERENDE KASUS: Samlebetegnelse for $(>)$ essiv og $(>)$ translativ, som begge er vanlige kasus til (>) predikativet.

PREFIKS: (>) Morfem som festes foran i $(>)$ rotmorfem eller ( $>$ ) grunnord. Kvensk har bare ett prefiks, epä- ('u-'), som brukes til å lage ord som betyr det motsatte av grunnordet.

Premodifikator: (>) Modifikator som står framfor (>) kjernen. For eksempel: Matti oon kaunis kissa ('Matti er en pen katt'); Kissa näyttää oikhein kaunhiilta ('Katten ser riktig pen ut').

Preposisjon: (>) Adposisjon som står foran (>) utfyllinga si. For eksempel: Lato seissoo keskelä niittyy ('Låven står midt i enga'). Jamfør (>) adposisjonsfrase og $(>)$ postposisjon.

Presens PARTISIPP: (>) Partisippform av (>) verb som viser til samtid eller framtid. Presens partisipp har fullstendig $(>)$ tall- og kasusbøying og har samme funksjon som $(>)$ adjektivi $(>)$ setninga. For eksempel: (tulla 'komme':) tul(le)eva : tultava, (maata 'ligge':) makkaava : maatava, (jakkaa(t) 'dele':) jak(ka)ava: ja(j)ettava. Jamfør (>) perfektum partisipp og (>) agentpartisipp. 
Presens perfeKtum: ( $>$ ) Sammensatt verbform som forteller at noe har skjedd eller blitt gjort før utsagnsøyeblikket i nåtida, og at det som har skjedd, på en eller annen måte er relevant for den nåværende situasjonen. Handlinga eller hendelsen er altså sett fra utsagnsøyeblikkets perspektiv. For eksempel: (tehđä tehhä 'gjøre') olen tehny ('(jeg) har gjort'), en ole tehny ('(jeg) har ikke gjort'), tet olisitta tehnheet ('dere ville ha gjort'), oon tehty ('er gjort'), olis tehty ('ville være gjort'). Jamfør (>) preteritum perfektum.

Presens: (>) Tidsform som brukes i (>) finitt verbbøying når det er spørsmål om nåtid eller framtid. For eksempel: (mennä 'gå, dra') menen : menisin, (jakkaa(t) 'dele':) jakkaa: jakais: jakakhoon, (puhela 'prate':) puhelhaan: puheltais. Jamfør (>) preteritum.

PReteritum PERfEKTUM: ( $>$ ) Sammensatt tidsform som refererer til noe andre har sagt eller skrevet, eller som forteller at noe hadde skjedd eller var blitt gjort før et utsagnsøyeblikk i fortida, og at det som hadde skjedd, på en eller annen måte var relevant for den daværende situasjonen. Handlinga eller hendelsen er altså sett fra utsagnsøyeblikkets perspektiv. Som (>) hjelpeverb bruker vi olla ('være) i preteritum. Med andre ord fins det ingen kondisjonalisformer av preteritum perfektum. Eksempler: (tehđä tehhä 'gjøre':) olin tehny $(t)$ ('(jeg) hadde gjort'), olitta tehnheet ('(dere) hadde gjort'), oli tehty ('var gjort'), ei ollu( $t$ ) tehty ('var ikke gjort').

Preteritum: (>) Tidsform som brukes i (>) finitt verbbøying når det er spørsmål om fortid. For eksempel: (mennä 'gå, dra':) menin, (jakkaa(t) 'dele':) jakoi, (puhela 'prate':) puhelthiin. Det fins inga (>) modusbøying i preteritum, det vil si at preteritumsformer alltid står i $(>)$ indikativ.

Preteritumsstamme: Verbstamme som inneholder preteritumssuffikset $(s) i$. For eksempel ser vi av preteritumsforma tuli/n av ( $>$ ) verbet tulla ('komme') at preteritumsstammen er tuli, og i preteritumsforma makasin av verbet maata ('ligge') er det makasi som er preteritumsstammen.

Privativt AdjeKtiv: (>) Adjektiv som forteller at noen eller noe mangler noe. De er avleid av ( $>$ ) substantiv med ( $>$ ) avleiingssuffikset - $t O n$ : - ttOmA, og av verb med suffikset $-m A t O n$ : $-m A t t O m A$. For eksempel: (onni 'lykke' $\rightarrow$ ) 
onne/ton ('ulykkelig') : onne/ttoma-, (jakkaat 'dele' $\rightarrow$ ) jaka/maton ('udelelig') : jaka/mattoma-.

Proadjektiv: $(>)$ Adjektiv som har som ( $>$ ) grunnord et $(>)$ demonstrativt pronomen eller et $(>)$ spørrepronomen. Vanlige proadjektiv er for eksempel (tämä 'denne' $\rightarrow$ ) tämmö(i)nen ('slik (som denne / den her slags)'), (tuo 'den der' $\rightarrow$ ) tuomo(i)nen ('slik som den der / slik som den der slags'), (se 'den' $\rightarrow$ ) semmo(i)nen ('slik som den / slik som den slags'), (mikä 'hva, hvilken' $\rightarrow$ ) minkälainen ('hva/hvilken slags').

Proadverb: $(>)$ Adverb som har som $(>)$ grunnord et $(>)$ demonstrativt pronomen eller et $(>)$ spørrepronomen. For eksempel: (tämä 'denne' $\rightarrow$ ) täälä ('her'), (tuo 'den der' $\rightarrow$ ) tuola ('der borte'), tuoloin ('da'), (mikä 'hva, hvilken' $\rightarrow$ ) miksi ('hvorfor').

Pronomen: $(>)$ Nomen som brukes i stedet for et anna nomen og stundom også ei heil $(>)$ setning eller $(>)$ frase. Pronomen refererer til et anna ord eller enhet som er omtalt eller går fram et anna sted i konteksten. For eksempel: Tuola tullee äiti. Se oon ollu pyyđössä. ('Der kommer mor. Hun har vært på fiske.); Lomassa istuu mies ja vaimoihminen. Molemat oon kainulaiset. ('Det sitter en mann og ei kvinne på rommet. Begge er kvener.); Liisa tullee huomena kothiin. Se oon soma. ('Lisa kommer heim i morgen. Det er trivelig.')

PRO-ORD: Samlebetegnelse for $(>)$ pronomen, $(>)$ proadjektiv og $(>)$ proadverb.

PÅSTEDSKASUs: (>) Lokalkasus som uttrykker at noen eller noe befinner seg et sted, eller at noen har noe. Det er de to kasusene $(>)$ inessiv og $(>)$ adessiv.

RAMmeAdverbial: $(>)$ Fritt adverbial som spesifiserer hvor, når eller på hvilken måte handlinga eller hendelsen som er uttrykt i (>) kjernesetninga, skjer. For eksempel: Pekka lähtee Alattihoon huomena ('Peder drar til Alta i morgen'); Faari laittaa ruokkaa köökissä ('Far lager mat på kjøkkenet'); Lapsena mie olin oikhein siivo ('Jeg var ordentlig snill som barn').

Refleksivt pronomen: (>) Pronomen som danner en $(>)$ frase som har et $(>)$ korrelat i samme $(>)$ setning. Pronomenet og korrelatet viser begge til 
samme (>) person. Kvensk har bare ett refleksivt pronomen, itte ('sjøl, seg sjøl'), som alltid har festa til seg et (>) possessivsuffiks. For eksempel i setninga Kuningas rakasti tyhä itteänsä ('Kongen elska bare seg sjøl') har det refleksive pronomenet itteä festa til seg possessivsuffikset nsä, som står i (>) tredje person, og det korrelerer med (>) subjektet kuningas ('konge').

Relativpronomen: (>) Pronomen som innleier ei $(>)$ relativsetning. Relativpronomena i kvensk er joka, kuka og mikä. Disse svarer oftest til som på norsk.

ReLATIVSETNing: (>) Leddsetning som står som (>) postmodifikator til enten en $(>)$ frase i $(>)$ oversetninga eller til heile oversetninga. For eksempel i setninga Tässä oon kirja, minkä sie halusit lainata ('Her er boka som du ønska å låne') står leddsetninga minkä sie halusit lainata ('som du ønska å låne') som postmodifikator til substantivet kirja ('kirja'). Relativsetninger blir innleid av (>) relativpronomen, i eksemplet er det mikä ('som').

RESIPROKT PRONOMEN: (>) Pronomen som uttrykker et resiprokt eller gjensidig forhold mellom to eller flere enheter. Kvensk har to resiproke pronomen, flertallspronomenet toiset og parpronomenet toinen toinen, som begge svarer til hverandre på norsk. Korrelatet til disse pronomena i $(>)$ setninga står i $(>)$ flertall, og det har samme $(>)$ person som pronomenet. Personen markeres med $(>)$ possessivsuffiks som festes etter pronomenet. For eksempel: Pekka ja Matti rakastaavat toinen toistansa ('Peder og Mats elsker hverandre'); Met vihhaama toissiima toisiamma ('Vi hater hverandre').

RESULTAT: Setninger av $(>)$ setningstypen RESULTAT er $(>)$ predikasjonssetninger som forteller hva det blir av $(>)$ korrelatet til $(>)$ predikativet. For eksempel: Mikosta tuli varas ('Det blei tjuv av Mikkel'); Meistä tuli krannikset ('Vi blei naboer'). Jamfør setningstypen (>) INTRANSITIV ENDRING.

Rotmorfem: Den minste delen av et ord som har sjølstendig/leksikalsk betydning. I kvensk står rotmorfem alltid i ordbegynnelsen, og deretter følger $(>)$ avleiingssuffiks og $(>)$ bøyingssuffiks. (Et unntak er $(>)$ adjektiv med $(>)$ prefikset epä- ('u-'), for eksempel epätavallinen 'uvanlig.) For eksempel i substantivet ajatus er rotmorfemet aja- ('kjøre'), og i verbet paskanttaat ('skite') er 
rotmorfemet paska ('skit'). Rotmorfemet er ikke alltid synlig i si heilhet. For eksempel består verbet ajela ('kjøre, småkjøre') av rotmorfemet aja, (>) avleiingssuffikset - ele og (>) 1. infinitivssuffikset -(l)A.

SAMMENSATt TIDSFORM: Tidsformene $(>)$ presens perfektum og $(>)$ preteritum perfektum, som er satt sammen av et $(>)$ hjelpeverb og et $(>)$ hovedverb. For eksempel: (pres. perf. : pret. perf.) (mennä 'gå’:) oon menny $(t)$ : oli menny $(t)$, (hakata 'hogge':) olema hakanheet : olima hakanheet.

SAMMENSATT VERBALFORM: ( $>$ ) Verbal som består av et $(>)$ hjelpeverb og/eller et $(>)$ nektingsverb og $(>)$ et hovedverb. For eksempel er alle $(>)$ nektende verbformer og $(>)$ sammensatte tidsformer sammensatte verbalformer. For eksempel: (mennä gå’: ) olen menny $(t)$ ('jeg har gått') : en ole menny $(t)$ ('jeg har ikke gått').

SAmmensetning: Ord som er satt sammen av to ord, og som skrives som enhet uten mellomrom. Eksempler på sammensetninger er nukkumaloma ('soverom'), kesäfeeriä ('sommerferie'), suupuoli ('munnvik'), jalkaneuvo ('fottøy'), pihlajanmarja ('rognebær'), jo(v)ensuu ('elveos, elvemunning'), pikkukoulu ('småskole'), pikkupäissä ('småfull').

SANSEOBSERVASJON:Setningerav( $>$ ) setningstypen SANSEOBSERVASJON er $(>)$ indirekte setninger som uttrykker en sanseobservasjon. ( $>$ ) Verbet kan være (>) transitivt eller (>) intransitivt. For eksempel: Mie kuulin musikkii ('Jeg hørte musikk'); Mie kuulin, ette Matti tuli kotia ('Jeg hørte at Mats kom heim'); Tunttuu ette heti tullee kesä ('Det kjennes at det snart blir sommer'). Jamfør (>) PREDIKATIV SANS og (>) SANSETILSTAND.

SANSETILSTAND: Setninger av ( $>$ ) setningstypen SANSETILSTAND er (>) tilstandssetninger som forteller hvordan det lukter eller ser ut på et sted. I slike setninger bruker vi verba haista ('lukte') og näyttää(t) ('se ut'). For eksempel: Ulkona haissee kevväiltä ('Det lukter vår ute'). Jamfør (>) PREDIKATIV SANS og (>) SANSEOBSERVASJON.

SETNING: Språklig heilhet som inneholder ei (>) finitt verbform som fungerer som $(>)$ verbal som eventuelt knytter til seg $(>)$ utfyllinger, så som $(>)$ subjekt, 
$(>)$ objekt, $(>)$ adverbial eller $(>)$ predikativ. Jamfør $(>)$ frase og $(>)$ setningsfragment.

SETningsfRAgment: Laust ord eller (>) frase som ikke hører til noen annen frase eller $(>)$ setning, men som heller ikke utgjør noen setning sjøl. Det viktigste kjennetegnet ved setningsfragment er at de mangler ( $>$ ) finitt verb. For eksempel: Hei! ('Hei!'); Päivää! ('God dag!'); Voi perkelet! ('For helvete!'); Hah! ('Ha!'); Häh?; ('Hæ?'). Det fins tre typer setningsfragment: (>) frie setningsfragment, $(>)$ faste setningsfragment og $(>)$ interjeksjoner.

SETningsledd: Ei (>) setning er satt sammen av ulike deler eller ledd, som hvert har sin $(>)$ syntaktiske funksjon. Vi skiller mellom to typer setningsledd, $(>)$ utfyllinger og $(>)$ modifikatorer.

SETNINGSMODIFIKATOR: (>) Leddsetning som står som (>) modifikator til ei $(>)$ oversetning eller en del av den. For eksempel: Mies, jota mie rakastin, hylkäs minun ('Mannen som jeg elska, vraka meg'); Hän hylkäs minun, mitä mie hirmuisesti suren ('Han vraka meg, hvilket gjorde meg veldig trist').

Setningstype: $(>)$ Setninger kan deles inn i ulike typer ut fra hva slags $(>)$ verb som fungerer som $(>)$ verbal, og hva slags $(>)$ utfyllinger verbalet tar. Jamfør $(>)$ direkte setninger, $(>)$ indirekte setninger og $(>)$ modifiserende setninger.

SideORdnA SETning: To eller flere delsetninger i ei $(>)$ kompleks setning er sideordna dersom de er på samme nivå, det vil si at ingen av dem fungerer som $(>)$ oversetning til den andre. Sideordning er mulig mellom $(>)$ hovedsetninger og mellom (>) leddsetninger. For eksempel: Matti lähti kothiin ja Pekka jäi pubhiin ('Mats dro heim, og Peder blei igjen på puben'); Pekka sanoi Matile, ette hän jä̈̈pi vielä pubhiin ja juopi pari öölii ('Peder sa til Mats at han blei igjen på puben og drakk et par øl'). I det første eksemplet er det to sideordna hovedsetninger, mens det i det andre eksemplet er to sideordna leddsetninger, som begge har Pekka sanoi Matile ('Peder sa til Mats') som oversetning.

SIMPLEKSORD: Ord som ikke er satt sammen av andre ord, og som fungerer som enkeltord i (>) setninga. For eksempel mutta ('men'). Jamfør (>) enklitikon, $(>)$ ordsamband og $(>)$ parord. 
S-KASUS: Alternativ betegnelse for $(>)$ indre lokalkasus, det vil si $(>)$ inessiv, $(>)$ elativ og $(>)$ illativ. $(>)$ Kasussuffiksa i inessiv, elativ og til dels illativ inneholder $(>)$ konsonanten $s$, derav navnet. Jamfør $(>)$ l-kasus.

Spesialstadieveksling: En av de to typene $(>)$ stadieveksling. Spesialstadieveksling omfatter alle $(>)$ plosiver. Til forskjell fra den $(>)$ generelle stadievekslinga kan her plosivene $k, t, p$ og dessuten $s$ veksle fra $(>)$ I-stadiet til (>) II-stadiet, uavhengig av om den foregående stavelsen er (>) trykksterk eller $(>)$ trykksvak, eller om den er $(>)$ kort eller (>) lang. For eksempel: (sg. nom. : sg. part.) maito ('mjølk') : maittoo, pelko ('frykt, redsel') : pelkkoo, (akt. ind. pres. 1. sg. : akt. ind. pres. 3. sg. av aukaista 'åpne’) aukaisen : aukaissee.

SpøRREADJEKTIV: $(>)$ Adjektiv som er $(>)$ avleid at et $(>)$ spørrepronomen, og som innleier ei $(>)$ spørresetning. For eksempel: kummo(i)nen ('hva slags'), minkälainen ('hva slags').

SpørReAdverb: (>) Adverb som er $(>)$ avleid av et $(>)$ spørrepronomen, og som innleier ei (>) spørresetning. For eksempel: missä ('hvor'), miksi ('hvorfor'), minne ('hvor hen').

SpøRREORD: Ord som innleier ei $(>)$ spørresetning. Til spørreord regner vi $(>)$ spørrepronomen og ord som er $(>)$ avleid av dem, det vil si (>) spørreadverb og (>) spørreadjektiv. For eksempel: mikä ('hva; hvilken'), missä ('hvor'), miksi ('hvorfor'), minkälainen ('hva slags').

Spørrepronomen: (>) Pronomen som innleier ei (>) spørresetning. Kvensk har disse spørrepronomena: kuka ('hvem'), mikä ('hva; hvilken') og kumpi ('hvem/hvilken av to').

SpørRESETNING (spørsmål): Spørresetninger brukes for å spørre (om) noe. Det fins to typer spørresetninger: De som begynner med et $(>)$ spørreord, og de som dannes med hjelp av (>) enklitikonet $k O$. For eksempel: Miksi sie söit koko kalan? ('Hvorfor spiste du heile fisken?'); Söitkö sie koko kalan? ('Spiste du heile fisken?’).

Spørsmål (> spørresetning). 
STADIEVEKSLING: I kvensk kan (>) konsonanter inne i et ord gjennomgå endringer når ordet bøyes. Vi kaller slike endringer for stadieveksling dersom vekslinga er basert på om det etter konsonanten følger en $(>)$ kort eller (>) lang vokal eller vokalkombinasjon, og om $(>)$ stavelsen etter den korte vokalen slutter på konsonant eller ikke. Alle konsonanter har (>) kvantitativ stadieveksling, som betyr at lengda på konsonanten inne i ordet veksler. For eksempel: (sg. nom. : sg. gen.) kukka ('blomst') : kuka/n, (sg. nom. : sg. part.) sana ('ord') : sanna/a. (>) Plosivene $k, t$ og $p$ kan også gjennomgå (>) kvalitativ stadieveksling, og da veksler konsonanten med en annen konsonant, eller den faller heilt bort. For eksempel: (1. inf. : ind. pres. 1. sg.) maata ('ligge') : makkaan, (sg. nom. : sg. gen.) joki ('elv') : joven joen, (1. inf. : ind. pres. 1. sg.) lähteet ('dra') : lähđen lähen, (sg. nom. : sg. gen.) tupa ('hus; stue') : tuvan. Det fins også andre ordinterne konsonantvekslinger i kvensk. Jamfør (>) lengderegel for stemte konsonanter, (>) h-flytting og $(>)$ vekslinga $t V$ : si. Jamfør (>) o-stadium, (>) I-stadium og $(>)$ II-stadium.

Stadium o (> o-stadium).

Stadium I (> I-stadium).

Stadium II (> II-stadium).

Stamme: Den delen av et $(>)$ nomen eller et $(>)$ verb som $(>)$ bøyingssuffiks festes til. Alle nomen og verb har $(>)$ vokalstamme, men bare en del av dem har i tillegg også $(>)$ konsonantstamme. Jamfør (>) flertallsstamme, $(>)$ preteritumsstamme og $(>)$ passivstamme.

StAMmEKOnSONANT: $(>)$ Konsonant eller $(>)$ konsonantkombinasjon som står sist i $(>)$ stammen, og som kan gjennomgå $(>)$ morfonologisk veksling. For eksempel i verbet (1. inf. : akt. ind. pres. 3. sg.) maata ('ligge') : makkaa finner vi stammekonsonanten i forma makkaa; det er kk (som veksler med $(>$ ) bortfall). I nomenet (sg. nom. : sg. gen. : sg. part. : pl. iness.) viisi ('fem') : vii(d) en : viittä : viisissä ser vi at stammekonsonanten veksler mellom $s, A \sim \emptyset$ og $t$.

STAMMEVEKSLING: Kvalitativ veksling som ikke er $(>)$ stadieveksling men veksling mellom sluttkonsonanten i (>) konsonantstammen og konsonantismen i (>) 
vokalstammen. For eksempel: (sg. nom. : sg. gen.) vares ('kråke') : varekse/n, rakas ('kjoer') : rakkhaa/n.

STATUS: Setninger av $(>)$ setningstypen STATUS er $(>)$ toverdige $(>)$ tilstandssetninger der $(>)$ subjektet fungerer som $(>)$ korrelat til et $(>)$ tilstandsadverb. Verbet i slike setninger er olla ('være') eller mennä ('dra, gå), til dels også tulla ('komme'). For eksempel: Ilmapallo meni rikki ('Luftballongen gikk sund'); Mie olin tyrmässä ('Jeg var bevisstløs').

STAVELSE: Rytmisk enhet i ord. Kjernen i en stavelse består av en (>) kort vokal eller en $(>)$ lang vokal eller en $(>)$ diftong. Foran og etter stavelseskjernen kan det stå en eller flere (>) konsonanter, men en kort vokal kan også danne en stavelse aleine. Stavelsesgrensa går foran hver konsonant-vokal-kombinasjon, men også mellom vokaler som ikke danner diftong. For eksempel: a-ja-tel-la ('tenke'), stor-mi ('storm'), kant-ti ('kant'), pirs-kot-taat ('skvette, sprute'), vasta-us ('svar'), au-et-hiin (aueta åpne seg').

STAVELSESTRYKK: Med stavelsestrykk meiner vi hvor mye trykk de ulike $(>)$ stavelsene i et ord har i tale, eller hvor mye styrke som brukes når stavelser uttales. Vi skiller mellom typer stavelsestrykk: (>) hovedtrykk (eller størst trykk), (>) bitrykk (litt mindre trykk) og (>) trykksvak stavelse (enda mindre trykk eller nesten ikke trykk). Det er ikke stavelseslengde som bestemmer trykket, men stavelsesposisjon: Hovedtrykk ligger på den første stavelsen i ordet, og etter det har annenhver stavelse (det vil si alle oddetallsstavelser) bitrykk. Den siste stavelsen i ordet er likevel alltid trykksvak. For eksempel i a-se-nol-la ('overnattingssted') ligger hovedtrykket på den første stavelsen, $a$, mens den tredje stavelsen, nol, har bitrykk og stavelsene se og la er trykksvake. Det er likevel slik at når den tredje (eller femte) stavelsen er (>) kort, så blir det lett til at den uttales som trykksvak, og trykket flyttes i stedet til neste stavelse. For eksempel uttales ordforma pai-not-to-mal-la (av painoton 'trykksvak') uten trykk på stavelsene not og to, mens stavelsen mal har bitrykk.

STED: Setninger av $(>)$ setningstypen STED er $(>)$ lokative $(>)$ setninger som forteller at noen eller noe er på et sted. Som $(>)$ verbal i slike setninger brukes verb som olla ('være'), seissoot seisoa( $t$ ) ('stå'), istuut istua( $t$ ) ('sitte'), maata ('ligge'), assuut asua(t) ('bo') og ellää(t) ('leve'). For eksempel: Knuutti asui 
Alattiossa ('Knut bodde i Alta'); Kissa makkaa penkilä ('Katten ligger på benken'); Mie olen kotona ('Jeg er heime').

Stedsadposisjon: (>) Adposisjon som danner en $(>)$ adposisjonsfrase, og som forteller hvor $(>)$ korrelatet til frasen befinner seg i forhold til ( $>$ ) utfyllinga i frasen. Eksempler på stedsadposisjonsfraser er: kiven alla ('under steinen'), Matin tykö( $t$ ) ('hos Mats'), ympäri( $t$ ) maailmaa ('verden rundt'), poikki( $t$ ) jo(v)en ('tvers over elva').

Stedsadverb: $(>)$ Adverb som spesifiserer hvor noen eller noe er eller skjer, hvorfra noe(n) kommer, eller hvor noe(n) beveger seg til. For eksempel: ulkona ('ute'), kauk(k)aa ('langt borte(fra)'), kotona ('heime'), alas ('ned'), ylös ('opp'), kothiin kotia ('heim'), ul(v)os ('ut'), kau(v)as ('lang bort').

Stedsproadverb: $(>)$ Proadverb som har et $(>)$ demonstrativt pronomen som (>) grunnord. For eksempel: tuola ('der borte'), tässä ('her'), täälä ('her'), siinä ('der'). En del av proadverba er identiske med ( $>$ ) lokalkasusformer av demonstrative pronomen.

STEмT: En stemt lyd oppstår når lufta slipper gjennom strupen og stemmebanda vibrerer. Stemte lyder er alle ( $>$ ) vokaler og $(>)$ konsonantene / j $1 \mathrm{~m} \mathrm{n}$ $\mathrm{n} \mathrm{r} \mathrm{v} /$. I lånord finner vi i tillegg de stemte $(>)$ plosivene $/ \mathrm{b} \mathrm{d} \mathrm{g/.}$

STOFFORD: Substantiv som refererer til et stoff, og som ikke kan telles, bare måles. For eksempel: puuro ('graut'), vesi ('vatn'), kaff ('kaffe'), lumi ('snø'), velli ('suppe'), veri ('blod'), ilma ('luft').

STYRING: Setninger av $(>)$ setningstypen STYRING er $(>)$ indirekte setninger der noen befaler, tillater eller forbyr noen å gjøre noe. Som verb bruker vi for eksempel käskeet käskeä( $(t) \sim$ käskiä ('be; befale'), ant(t)aa(t) ('tillate, gi lov'), kielt(t)ää( $t$ ) ('forby, nekte'). For eksempel: Muori kielsi faarin tulemasta kotia ja käski sen pysyä Amerikassa ('Mor nekta far å komme heim og ba han om å bli værende i Amerika').

Subjekт: $(>)$ Utfylling - vanligvis $(>)$ hovedutfylling - til $(>)$ verbalet eller verbfrasen i $(>)$ setninga. I $(>)$ finitte setninger står subjektet vanligvis i $(>)$ 
nominativeller $(>)$ partitiv, $\mathrm{i}(>)$ verbfraser oftest $\mathrm{i}(>)$ genitiv. Nominativssubjekt kongruerer i $(>)$ tall og $(>)$ person med $(>)$ verbalet.

SubJUNKSJON: (>) Junksjon som forbinder (>) leddsetninga med (>) oversetninga. Eksempler på subjunksjoner er ette ('at'), ko ('da; når; enn; som'), jos ('dersom, viss'), vaikka ('sjøl om'), niin ko ('som'), sillä ko ('ettersom'), jälkhiin ko ('etter').

Substantiv: (>) Nomen som betegner en konkret eller abstrakt enhet. Også navn regnes som substantiv. For eksempel: poika ('gutt'), tuoli ('stol'), piili ('bil'), desemperikuu ('desember'), päivä ('dag'), ilma ('luft; vær'), kaffi ('kaffe'), rakkhaus ('kjærlighet'), Matti ('Mats'), Alattio ('Alta'). Substantiv kan få både $(>)$ premodifikator og (>) postmodifikator.

Substantivfrase (= NP; jf. engelsk Noun Phrase): (>) Frase som har et $(>)$ substantiv (eller et $(>)$ pronomen som står i stedet for et substantiv) som kjerne. For eksempel: Meän Matti studeeraa Tromssan universiteetissa. Sillä oon nyt uusi nimi. Se oon Norjan arktinen universiteetti. ('Vår Mats studerer på Universitetet i Tromsø. Det har nå et nytt navn. Det er Norges arktiske universitet.').

SubSTANTIVMODIFIKATOR: (>) Modifikator som hører til ordklassen substantiv. For eksempel: Matka laivala Pispärkkhiin oli fiini ('Reisa med båten til Spitsbergen var fin').

Suffiks: ( $>$ ) Morfem som festes til slutten av ( $>$ ) rotmorfem eller $(>)$ stamme. Det kan komme flere suffiks etter hverandre. Jamfør (>) prefiks.

SUPERJUNKSJON: (>) Junksjon som forbinder (>) oversetninga som står etter leddsetninga, med denne leddsetninga. De to superjunksjonene i kvensk er niin og se, og de brukes synonymt ('så, da'). for eksempel: Sillä ko mie olin pikkuisen sairas yhtenä iltana, niin/se mie panin varhain maata ('Ettersom jeg var litt sjuk en kveld, så la jeg meg tidlig').

Superlativ: $(>)$ Avleid form som $(>)$ adjektiv - og stundom også $(>)$ substantivhar i $(>)$ gradbøying, og som forteller at noen eller noe har mest av 
en egenskap jamført med andre enheter i samme jamføringsgruppe. For eksempel: (positiv siivo 'snill' $\rightarrow$ ) siivoin ('snillest'), (positiv viisas 'klok' $\rightarrow$ ) viishain ('klokest'), (positiv ranta 'strand' $\rightarrow$ ) rannin ('nærmest stranda'). Jamfør $(>)$ positiv og $(>)$ komparativ.

SYNTAKTISK FUnKSJON: De ulike $(>)$ setningsledda har ulike oppgaver eller funksjoner i $(>)$ setninga, for eksempel $(>)$ subjekt, $(>)$ objekt, $(>)$ predikativ og $(>)$ modifikator.

TALL (numerus): (>) Nomen og $(>)$ verb har former i $(>)$ entall og $(>)$ flertall. For eksempel: (entall) mies ('mann') : (flertall) miehet, (laulaa( $t$ ) 'synge' : ) (entall) laulan : (flertall) laulama.

TALL- OG KASUSBøYING: Et (>) nomen har fullstendig tall- og kasusbøying når det bøyes i alle $(>)$ kasus og i begge $(>)$ tall, det vil si både i $(>)$ entall og $(>)$ flertall.

TALL- OG PERSONKONGRUENS: $(>)$ Subjektet og $(>)$ verbalet kongruerer (> kongruens) som regel i $(>)$ tall og $(>)$ person. Det betyr at subjektet og verbalet i $(>)$ setninga må stå i samme tall, dsv. (>) entall eller $(>)$ flertall, og i samme person, det vil si i $(>)$ første, $(>)$ andre eller $(>)$ tredje person. For eksempel: Mie kävelen ouđassa ('Jeg går en tur i skogen'), men Tet kävelettä oudassa ('Dere går en tur i skogen'), hvor subjektet og verbalet i den første setninga står i første person entall, mens de $\mathrm{i}$ den andre setninga står i andre person flertall. Et unntak er $(>)$ setningstypene $(>)$ EKSISTENS, $(>)$ EKSISTENSENDRING, $(>)$ EIERSKAP, $(>)$ EIERSKAPSENDRING, $(>)$ ANTALL og $(>)$ EKSISTENSPREDIKASJON, som alle mangler kongruens ettersom subjektet her står i $(>)$ partitiv.

TALLBØYING: Egenskap ved (>) nomen som går ut på at de har både $(>)$ entallsog $(>$ ) flertallsformer. For eksempel: (sg. nom.) mies ('mann') : (pl. nom.) miehet, (sg. ess.) miehenä : (pl. ess.) miehinä.

TALLKONGRUENS: Regel som sier at to $(>)$ setningsledd må stå i samme $(>)$ tall, det vil si begge enten i $(>)$ entall eller $(>)$ flertall. Tallkongruens forekommer mellom $(>)$ subjekt og $(>)$ verbal ( $>$ tall- og personkongruens), mellom $(>)$ 
adjektivmodifikator og $(>)$ kjerne i $(>)$ substantivfraser, og også mellom $(>)$ predikativ og $(>)$ korrelat i $(>)$ setningstypene $(>)$ EGENSKAP, ( $>$ ) EKSISTENSPREDIKASJON og $(>)$ RESULTAT.

TALLORD: Det er to typer tallord, $(>)$ grunntall og $(>)$ ordenstall. For eksempel: $y k s i$ ('en'), viisi ('fem'), sa(đ)as ('hundrede'), sa(đ)as vii(đ)eskymmenes ('hundreogfemtiende'). Det er bare grunntall som er egentlige tallord; ordenstall brukes som (>) adjektiv.

Tid (tempus): Bøyingskategori som uttrykker om handlinga eller hendelsen som er uttrykt i (>) verbalet, er samtidig med utsagnsøyeblikket, eller om det er noe som har skjedd eller har begynt før. Det fins to tidsformer i kvensk: $(>)$ presens og $(>)$ preteritum, og i tillegg har vi de to $(>)$ sammensatte tidsformene $(>)$ presens perfektum og $(>)$ preteritum perfektum. Eksempler på tidsformer: (tehđä tehhä 'gjøre') (pres. 3. sg.) tekkee: (pret. 3. sg.) teki : (pres. perf. 3. sg.) oon tehny(t) : (pret. perf. 3. sg.) oli tehny.

Tidsadposisjon: (>) Adposisjon som brukes i ( $>$ ) adposisjonsfraser som uttrykker tid. For eksempel: Sođan alussa met asuima vielä kotona ('I begynnelsen av krigen bodde vi fortsatt heime’); Sääsket ei vielä kiussaa ennen heinää ('Myggene er ikke plagsomme enda før høyonna').

TIDSADVERB: (>) Adverb som uttrykker tidspunktet noe skjer på. For eksempel: Muutamisti mie olen surulinen ('Noen ganger er jeg trist'); Pekka tullee kothiin huomena ('Peder kommer heim i morgen').

TIDSFORM: $(>)$ Finitt verbform som uttrykker $(>)$ tid. Det fins fire tidsformer i kvensk: $(>)$ presens, $(>)$ preteritum, $(>)$ presens perfektum og $(>)$ preteritum perfektum.

TILHØRIGHET: Setninger av (>) setningstypen TILHØRIGHET er (>) predikasjonssetninger som forteller hvilken gruppe eller hvilket område noen eller noe hører til eller er en del av. ( $>$ ) Verbalet i setninger av setningstypen TILHØRIGHET er alltid olla ('være'), og (>) predikativet står i (>) partitiv. For eksempel: Ryssänmaa oon Eurooppaa ('Russland er en del av Europa'); Anders oli Jaakkoloita ('Anders var en av Jakola-slekta'). 
Tilstandsadverb: (>) Adverb som beskriver hvilken posisjon noen eller noe er $\mathrm{i}$, hvilken fysisk eller psykisk tilstand noen eller noe er i, hvor noen eller noe befinner seg i forhold til noe anna, og også i hvor stor gruppe noe eller noen opptrer i. For eksempel: kumossa ('opp ned, om kull'), kumhoon, nurin ('på vranga'), alaspäin ('nedover'), seka(i)sin ('om hverandre, hulter til bulter'), täynä ('fullt'), karussa ('på rømmen'), karkhuun, yksin ('aleine'), kah(đ)en ('på tomannshand, toene'), kaikin ('alle sammen').

Tilstandssetning: (>) Direkte setning som forteller noe om en ytre eller indre tilstand eller ei tilstandsendring. For eksempel: Aurinko paistaa ('Sola skinner'); Oli kova sää ('Det var dårlig vær'); Mettässä haissee kevväiltä ('Det lukter vår i skogen'); Dagnylä oli kylmä ('Dagny fryser').

TiLstedsKasus: $(>)$ Lokalkasus som uttrykker bevegelse til eller mot et sted. Denne gruppa består av de to kasusene $(>)$ illativ og $(>)$ allativ.

Tомт suвJEкт (formelt subjekt): (>) Subjekt som ikke har noen eigen semantisk funksjon i (>) setninga. Det kan typisk også utelates. Det er alltid ordet se som fungerer som tomt subjekt i kvensk, og det svarer som regel til det formelle subjektet det i norsk. For eksempel: Se tuulee ('Det blåser'); Se oli soma kohđata sinun ('Det var hyggelig å treffe deg').

TOSTAmma verb: Et $(>)$ verb er tostamma dersom det har to ulike $(>)$ stammer som $(>)$ bøyingssuffiks festes til. Disse to stammene kan være en $(>)$ vokalstamme og en $(>)$ konsonantstamme, eller to ulike vokalstammer der den ene er kort og den andre er lang. For eksempel: juos- : juokse- : juokse/n (av juos/ta 'springe'), havai- : havaitte- : havaitte/n (av havai/ta ('merke').

Tostava: Et $(>)$ nomen eller et $(>)$ verb kalles for tostava dersom det har en $(>)$ vokalstamme som består av to stavelser, og den siste stavelsen slutter på (>) kort vokal. Hos nomen går det også fram av nominativsforma i (>) entall om ordet er tostava. For eksempel: (sg. nom. : sg. ess.) poika ('gutt') : poika/na, lapsi ('barn') : lapse/na. Tostava verb er slike som i (>) aktive (>) personformer bruker en tostava stamme på (>) kort vokal. For eksempel: (1. inf. : akt. ind. 1. sg.) juos/ta ('springe') : juokse/n, päättä/ät ('bestemme'): päätä/n. 
Tотацовјект: (>) Objekt som i $(>)$ entall står i $(>)$ genitiv, og i flertall i $(>)$ nominativ. (>) Personlige pronomen som fungerer som totalobjekt, har eigne kasusformer, som vi kaller for (>) akkusativ.

TOVERDIG HANDLING: $(>)$ Setninger av $(>)$ setningstypen TOVERDIG HANDLING er $(>)$ handlingssetninger der det $(>)$ transitive verbet har to $(>)$ utfyllinger: et $(>)$ subjekt og et $(>)$ objekt i form av en $(>)$ substantivfrase. For eksempel: Faari laittoi ruokkaa ('Far laga mat'); Maija pyyttää kallaa ('Maja fanger fisk'). Stundom er handlingsresultatet på en måte innbakt i sjølve verbet, og da kan objektet mangle i setninga. For eksempel: Terje laulaa ('Terje synger'). I slike tilfeller er det likevel mulig å tenke seg et objekt. For eksempel: Pappi lauloi virren ('Presten sang en salme').

ToverDIG: Et $(>)$ verb er toverdig dersom det krever to ( $>$ ) utfyllinger for at (>) setninga skal være fullstendig. Vi sier også at ei setning er toverdig når $(>)$ hovedverbet i setninga er toverdig. Jamfør $(>)$ nullverdig, $(>)$ enverdig og $(>)$ treverdig.

TRANSITIV EIERSKAPSENDRING: Setninger av (>) setningstypen TRANSITIV EIERSKAPSENDRING er $(>)$ treverdige $(>)$ handlingssetninger som forteller at noen får eller tar noe fra noen, eller gir, selger eller på annen måte avstår noe til noen. Som $(>)$ verbal i slike setninger bruker vi verb som

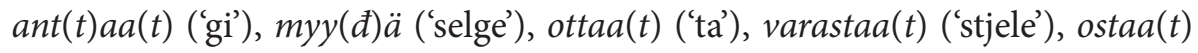
('kjøpe'). For eksempel: Liisa antoi Pekale piilin ('Lisa ga Peder en bil'); Liisa osti Matilta piilin ('Lisa kjøpte en bil fra Mats').

TRANSITIV ENDRING: Setninger av (>) setningstypen TRANSITIV ENDRING er $(>)$ treverdige $(>)$ handlingssetninger som forteller at noe blir endra på et eller anna vis. Som verbal i slike setninger fungerer verb som maalata ('male'), färjätä ('farge') og muuttaa( $t$ ) ('endre'). I tillegg til (>) subjekt tar slike setninger et $(>)$ predikativ som utfylling. Korrelatet til predikativet er $(>)$ objektet i setninga. For eksempel: Skriivari muutti Antin nimen ruijalaiseksi ('Skriveren endra navnet til Antti til norsk').

Transitivt Verb: $(>)$ Verb som kan ta et $(>)$ objekt som $(>)$ utfylling. Transitive verb fungerer som $(>)$ verbal i nesten alle $(>)$ indirekte setninger, 
og av (>) direkte setninger i alle $(>)$ handlingssetninger. Jamfør $(>)$ intransitivt verb.

Translativ: (>) Predikerende kasus som i sin vanligste funksjon er brukt for å markere tilstandsendring. Brukes for eksempel i $(>)$ setningstypene $(>)$ ENDRING, (>) MEINING, (>) NAVNGIVING og i den aspektuelle tulla tehtyksi-konstruksjonen. Translativ er også vanlig i $(>)$ frie adverbial som uttrykker tidspunkt og tidslengde. Eksempelsetninger der $(>)$ predikativet eller det frie adverbialet står i translativ: Aaki kasui isoksi ('Aaki vokste seg stor'); Maalari maalas seinät vihriseksi ('Maleren malte veggene grønne'); Met tulema kothiin jouluiksi ('Vi kommer heim til jul'); Agnes tullee meile viikoksi ('Agnes kommer til oss for ei uke').

Tredje Infinitiv (3. infinitiv): (>) Infinitivsform som dannes med (>) suffikset $-m A$. Tredje infinitiv har fem $(>)$ kasus: $(>)$ inessiv, $(>)$ elativ, $(>)$ illativ, $(>)$ adessiv og $(>)$ abessiv. Inessiv-, elativ- og illativformer brukes særlig i infinitivsfraser i $(>)$ aspektsetninger. Eksempler på tredje infinitivsformer: (maa/ta 'ligge':) makkaa/massa, makkaa/masta, makkaa/mhaan, makkaa/malla, mak$\mathrm{kaa} /$ matta. Jamfør (>) første infinitiv og $(>)$ andre infinitiv.

TREDJE PERSON: Brukes når man refererer til noen eller noe som ikke er direkte involvert i kommunikasjonskonteksten. Tredje person finner vi i den $(>)$ aktive $(>)$ personbøyinga av $(>)$ verb, i $(>)$ possessivsuffiks og i $(>)$ personlige pronomen. For eksempel inneholder ( $>$ ) setninga Het löyđethiin ittensä kirjat ('De fant bøkene sine') tredjepersons flertallspronomenet het, verbforma löyđethiin, som er tredje person flertall av verbet löyttyyt ('finnes') og tredjepersons possessivsuffikset - $n s a$. Jamfør (>) første person og (>) andre person.

TREverdig: Et $(>)$ verb er treverdig dersom det krever tre $(>)$ utfyllinger, som vanligvis er $(>)$ subjekt, $(>)$ objekt og $(>)$ adverbial. Vi sier også at ei $(>)$ setning er treverdig når $(>)$ hovedverbet i setninga er treverdig. Jamfør $(>)$ nullverdig, $(>)$ enverdig og $(>)$ treverdig.

TRIFTONG: Rekke på tre (>) vokaler som sammen danner kjernen i en $(>)$ stavelse og dermed hører til samme stavelse. I skriftspråket forekommer diftong bare i (>) adverbet nuoin ('sånn der, cirka') og i bøyingsformer av pronomenet 
nuot ('de der'), men i talemålet, og da spesielt i Porsanger-varieteten, finner vi triftonger også i andre ordformer, for eksempel i ( >) preteritum av (>) enstava (>) verb; for eksempel vieđä ('bringe, ta med') : viei og tuođa ('bringe, komme med') : tuoi.

TRYKKSTERK STAVELSE: Trykket i ord skifter fra (>) stavelse til stavelse. Vi kaller en stavelse for trykksterk når den uttales med relativt mer styrke enn en (>) trykksvak stavelse. Trykkfordelinga i kvensk er ganske regelmessig: Den første stavelsen er alltid trykksterk, og i ord med fire eller flere stavelser har annenhver stavelse trykk, det vil si alle oddetallsstavelser. Siste stavelse er alltid trykklett. For eksempel i ordet $e$-si-mer-kik-si ('for eksempel') er stavelsene $e$ og mer trykksterke, mens i ordet sa-nas-sa ('i ordet') er det bare den første stavelsen som har trykk. Jamfør (>) stavelsestrykk.

TRYKKSTERK VOKAL: (>) Vokal i (>) trykksterk stavelse. Jamfør (>) stavelsestrykk.

TRYKKSVAK STAVELSE: (>) Stavelse som uttales med relativt mindre styrke enn $(>)$ trykksterk stavelse.

TRYKKSVAK VOKAL: (>) Vokal i (>) trykksvak stavelse. Jamfør (>) stavelsestrykk.

UAVGRENSA HANDLING: Handling uten klart markert begynnelse og/eller slutt. Det er vanlig å uttrykke slike handlinger i $(>)$ transitive setninger med $(>)$ objekt i (>) partitiv. For eksempel går det ikke fram av (>) setninga Mie söin puteettii ('Jeg spiste potet') hvor mye potet som blei spist, og om jeg avslutta spisinga eller ikke. En annen måte å uttrykke uavgrensa handling på er å bruke $(>)$ aspektsetninger med verbet olla ('være') som verbal og der 3. infinitivsfrasen står i (>) inessiv. For eksempel: Mie olin syömässä ('Jeg holdt på å spise'). Jamfør (>) aspekt og (>) avgrensa handling.

UвøуеLIG: Som ikke bøyes i (>) kasus. Fullstendig ubøyelige er for eksempel (>) adjektivet pikku ('liten'), (>) de universelle pronomena koko ('hel') og joka ('hver') og flere adverb, så som rikki(t) ('sund, i stykker'), poikki( $t$ ) ('i to'), eilen ('i går'), vaiti ('taus, stille’), vasiten ('nøyaktig; uttrykkelig'), mielelä ('gjerne'), 
og mange adposisjoner, så som sivvu ('forbi'), kautta ('gjennom, om, via'), kans(a) ('med'), läpitte ('gjennom'). Jamfør (>) mangelfull bøying.

Udelelig: Et (>) substantiv eller det det står for, er udelelig dersom det kan telles, det vil si at vi kan spørre hvor mange det fins av enheten. Brorparten av substantiva er udelelige i $(>)$ entall. For eksempel: Pöyđälä oon viisi kirjaa/ äpylii/kuppii/fattii/kläppii ('Det er fem bøker/epler/kopper/fat/unger på bordet'). Jamfør (>) delelig.

UGJENNOMSIKTIG: Når betydninga til et ord eller en kombinasjon av ord ikke går fram av summen av betydninga til de enkelte delene, så sier vi at ordet er ugjennomsiktig. For eksempel er det tydelig at $(>)$ verbet $o(d) o t t a a(t)$ ('vente') er ( $>$ ) avleid med ( $>$ ) avleiingssuffikset - $t$ t $A$, men det er uklart hva $(>)$ rotmorfemet ${ }^{*} O(d) o$ betyr. Vi kaller derfor avleiinga for ugjennomsiktig. Som ugjennomsiktig regner vi også $(>)$ adposisjoner når betydninga ikke direkte går fram av $(>)$ frasen som de danner sammen med $(>)$ utfyllinga. For eksempel i (>) setninga Mie en ymmärä sen puhheen pääle ('Jeg forstår meg ikke på denne talen') er adposisjonen pääle ('på') i frasen sen puhheen pääle ugjennomsiktig.

UMARKERT FORM: Medlem av bøyingskategori som er uttrykt uten eige $(>)$ suffiks. Eksempler på umarkerte former er $(>)$ entall i nomenbøyinga, og $(>)$ presens og $(>)$ indikativ i verbbøyinga.

Ustemt: Vi kaller en (>) konsonant for ustemt når den uttales uten at stemmebanda vibrerer. Kvensk har følgende ustemte konsonanter: /f h k p s t/. I lånord finner vi også den ustemte konsonanten /š/. Jamfør (>) stemt.

UTFYLLING: Obligatorisk setningsledd som er styrt av (>) verbalet i $(>)$ setninga, og som må være til stede for at setninga skal være fullstendig. For eksempel i setninga Liisa lähtee huomena mielelä Tromsshaan ('Lisa drar gjerne til Tromsø i morgen') er (>) subjektet Liisa og (>) adverbialet Tromsshaan ('til Tromsø') utfyllinger til $(>)$ verbet lähteet $\sim$ lähteä $(t) \sim$ lähtiä. Derimot kan vi utelate (>) adverba huomena ('i morgen') og mielelä ('gjerne'), og setninga Liisa lähtee Tromsshaan ('Lisa drar til Tromsø') er fortsatt ei fullstendig setning. Disse to ledda er altså ikke utfyllinger, men (>) frie adverbial. 
UTSAGN (> fortellende setning).

VALENS: Egenskap ved $(>)$ verb som går ut på at det knytter til seg andre $(>)$ setningsledd i form av (>) utfyllinger. Også (>) adposisjoner har valens i og med at de bestemmer hva slags $(>)$ kasus $(>)$ og posisjon utfyllinga har.

VARIETET: Språk eller dialekt som brukes i et visst område og/eller av ei viss gruppe av språkbrukere. I denne grammatikken bruker vi varietet om de ulike kvenske skriftspråkalternativa som hver og en kan velge blant med utgangspunkt i sitt eige språk eller sin eigen dialekt som vedkommende ønsker å identifisere seg med.

VeKsLINGa $t V: s i$ : (>) Morfofonologisk veksling der $(>)$ stammekonsonanten $t$ blir til $s$ når stammevokalen $e$ eller $A$ faller bort foran $(>)$ suffikset $-i$ i flertall eller preteritum. I nomen med e-stamme finner vi si også i ( >) entall (>) nominativ. For eksempel: hirsi ('tømmer') : hirte/nä: hirs/i/ssä, (huut(t)aa(t) 'skrike,

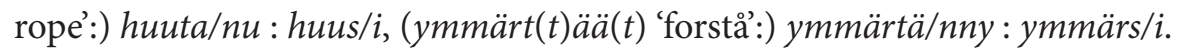

VERB MED TO VOKALSTAMmER: ( $>$ ) Verb som har to ulike ( $>$ ) vokalstammer, en kort og en lang. Eksempler: vali/ta ('velge') : valitte/n, piikaroi/ta ('spikre') : piikaroitte/n, vanhe/ta ('bli eldre') : vanhene/n, maa/ta ('ligge') : makkaa/n.

Verb: Ord av $(>)$ ordklassen verb bøyes i $(>)$ person, $(>)$ tid og $(>)$ modus. Verb har $(>)$ finitte og $(>)$ infinitte former. Det er $(>)$ første infinitiv som brukes som (>) oppslagsform for verb, for eksempel puhhuut puhua( $t$ ) ('snakke'), mennä ('gå, dra'), havaita ('merke'), piikaroita ('spikre'). Men vær oppmerksom på at første infinitiv bare er ei av mange verbale bøyingsformer. Det er $(>)$ stammen som tjener som grunnform i verbbøyinga, og ett og samme verb kan ha flere ulike stammer.

VERBAL: Obligatorisk ( $>$ ) setningsledd i enhver fullstendig ( $>$ ) setning. Består av ei $(>)$ finitt verbform. Verbalet bestemmer hvilke $(>)$ utfyllinger setninga har.

Verbfrase: $(>)$ Frase som har ei $(>)$ infinitt verbform som $(>)$ kjerne. For eksempel: Mie haluan lähtiä huomena kothiin ('Jeg ønsker å dra heim 
i morgen'); Pekka muisti lukia preivin ('Peder huska å lese brevet'); Iisko lupas antaa mulle rahhaa ('Iisko lovte å gi meg penger'); Minun keittämä puuro oli hyvä ('Grauten som jeg hadde laga, var god').

VERBSAMBAND: Konstruksjon som består av (>) verbet olla ('være') og et (>) substantiv, et $(>)$ adjektiv eller en $(>)$ infinitiv, og som danner en semantisk enhet. Eksempler på verbsamband er modifiserende olla olemassakonstruksjoner ('holder på å) og oon pakko/lupa/hyvä/paha/soma-konstruksjoner ('er nødt/lov/bra/ille/hyggelig'). Jamfør (>) sammensatt verbalform.

VERBTyPe: (>) Verb deles inn i ulike verbtyper basert på hva slags (>) stamme de har, og hvordan de ulike $(>)$ bøyingssuffiksa festes til disse stammene.

VOKAL: (>) Lyd som uttales ved at luftstrømmen slippes uhindra fra lungene og ut gjennom munnen. Ved å runde leppene, variere munnåpninga og flytte tunga i munnhula lager vi ulike vokaler. Kvensk har disse vokalene: /a e i o u y ä ö/. Jamfør (>) konsonant.

VOKALHARMONI: Fenomen som går ut på at vokalkvaliteten i (>) rotmorfemet i et ord, det vil si om vokalen(e) er $(>)$ bakre eller $(>)$ fremre, avgjør vokalkvaliteten i (>) suffiksa. Inneholder rotmorfemet bare bakre vokal(er), bruker vi suffiksvarianter med bakre vokal(er). Men dersom rotmorfemet inneholder bare fremre vokal(er), så brukes suffiksvarianter med fremre vokal(er). Suffiks som inneholder de fremre vokalene /i/ eller /e/, kan festes til både rotmorfem med bakre vokal(er) og slike med fremre vokal(er). Legg merke til at det av (>) prefikset epä- ('u-') bare fins én variant med fremre vokaler.

VoKalstamme: (>) Stamme som brukes i ( >) nomen og ( $>$ ) verb, og som slutter på vokal. For eksempel: (talo 'hus':) talo/n, (lapsi 'barn':) lapse/n, (sininen 'blå':) sinise/n, (saapas 'støvel':) saapphaa/n, (juosta 'springe':) juokse/n, maa/ta 'ligge': makkaa/n, havai/ta 'merke': havaitte/n. Jamfør (>) konsonantstamme.

YTRE LOKALKASUS: (1-kasus): Samlebetegnelse for $(>)$ lokalkasusene $(>)$ adessiv, $(>)$ ablativ og $(>)$ allativ. Når de brukes som $(>)$ adverbial i $(>)$ setningstypene $(>)$ STED, (>) EKSISTENS og (>) BEVEGELSE, så markerer de typisk nomenformer som uttrykker utsida heller enn innsida på noe. Den andre 
typiske funksjonen til ytre lokalkasus er at de markerer eierleddet i ( $>$ ) possessive setninger. Derav også den alternative betegnelsen ( $>$ ) eierskapskasus. Etter forma kalles ytre lokalkasus også for (>) 1-kasus. Jamfør (>) indre lokalkasus.

YTRE TILSTAND: Setninger av $(>)$ setningstypen YTRE TILSTAND er $(>)$ tilstandssetninger som forteller om en ytre tilstand, så som vær, temperatur eller liknende, men som ikke inneholder ( $>$ ) værverb, men derimot verbet olla ('være') eller tulla ('komme'). For eksempel: Oli hirmunen tormi ('Det var en forferdelig storm'); Sitte tuli oikhein kaunis ilta ('Så blei det en riktig fin kveld'); Yölä oli kylmä ('Det var kaldt om natta'). Foran verbet kan vi også legge til det (>) tomme subjektet se. For eksempel: Se oli hirmunen tormi ('Det var en forferdelig storm'). Jamfør VÆRTILSTAND.

ÅPEN KLASSE: Ordtype som får stadig nye medlemmer, det vil si utgjør en produktiv klasse eller gruppe. Et eksempel på en åpen klasse er nomen med i-stamme; de fleste nye lånorda havner i denne gruppa. Lånte verb havner som regel i gruppa med (>) kontrakte verb. Jamfør (>) lukka klasse.

ÅRSAKSADPOSISjON: (>) Adposisjon som brukes i svar på spørsmål om hvorfor (Miksi? Minkä takkii takia?). Eksempler på årsaksadposisjoner er takkii takia ('for, på grunn av'), täh(đ)en ('på grunn av'), pääle(t) ('basert på), kautta ('med, gjennom'), e(đ)estä ('for ... skyld'), varten ('for, på grunn av'), vasten ('for, på grunn av'), takkii takia ('for, på grunn av') og tähđen ('for, på grunn av'). 



\section{Stikkordregister}

0-stadium, 70

\section{A}

abessiv, 197, 198

abessiv adposisjon, 362

ablativ, 195

additiv konjunksjon, 384, 385

adessiv, 195

adjektiv, 50, 51, 163

adjektivfrase, 51, 53

adjektivmodifikator, 57

adposisjon, 50, 52, 347

adposisjonsfrase, 52, 347

adverb, 50, 52, 319

adverbfrase, 52, 53

adverbial, 53

adverbmodifikator, 57

agens, 59

agentkonstruksjon, 271

agentpartisipp, 265, 271

agglutinerende språk, 45

akkusativ, 177

aktiv, 209, 228, 236, 239, 243, 244, 268

allativ, 195

andre infinitiv, 258, 260

andre person entall, 217, 250

andre person flertall, 217, 250

ankerord, 59, 60, 396, 403

ANTALL, 110

apposisjon, 57

aspekt, 124

aspektverb, 154 avgrensa handling, 124

avleiingsmorfem, 46

avleiingsuffiks, 320

B

bakre vokal, 39

befaling, 145

bekreftende, 230, 246, 254

BEVEGELSE, 101, 129, 159, 160, 192, 195, 197, 262

bevegelsesverb, 97, 101

bitrykk, 42

bydesetning, 64

bøyingsmorfem, 46

D

delelig, 124

demonstrativt pronomen, 277

demonstrativt pro-ord, 273

diminutiv, 171

direkte setning, 95, 97

disjunktiv konjunksjon, 384, 388

distributivt kvantorpronomen, 295

E

EGENSKAP, 113, 157, 158

egentlig tredje person flertall, 220

EIERSKAP, 107, 109, 110, 126, 132, 133,

$151,152,156,159,161,176,183,195$,

197

EIERSKAPS, 109

EIERSKAPSENDRING, 197 
eierskapskasus, 176

EIERSKAPSPREDIKASJON, 115,

$157,178,179$

EKSISTENS, 103, 108, 116, 130,

$144,156,158,159,160,183,192$,

195,197

EKSISTENSENDRING, 5, 156, 159

EKSISTENSENDRINGS, 105

EKSISTENSPREDIKASJON, 115, 156, 157

ekvivalent forhold, 411

elativ, 192

endringsverb, 117, 125

enklitikon, 46, 383

enstamma, 48, 164, 166, 168, 172, 211, 212

enstava, 211

entall, 174, 177, 178, 192

enverdig, 94

essiv, 189

$\mathbf{F}$

fast setningsfragment, 67,68

finitt verbform, 209

flerstava, 168, 169

flertall, 83, 174, 269

flertallsstamme, 49, 83, 175

flytteverb, 126, 128

FLYTTING, 127, 129, 159, 160, 192, 197

forbud, 145

forholdsadposisjon, 370

fortellende setning, 61

frase, 50

frastedskasus, 102

fremre vokal, 39

fritt adverbial, 55

fritt setningsfragment, 67

FØLELSE, 120

følelsesverb, 120

følgekasus, 176, 197

første infinitiv, 258

første person entall, 217

første person flertall, 217, 249
G

generell stadieveksling, 72

generisk, upersonlig konstruksjon, 59

genitiv, 178

genitivsmodifikator, 57

gi-verb, 125

gradsadverb, 322, 341

grammatisk kasus, 176

grunntall, 51, 309

$\mathbf{H}$

handlingssetning, 122

hendelsesverb, 99

hovedsetning, 93

hovedtrykk, 42

hovedutfylling, 54

hovedverb, 228

II-stadium, 70

I

illativ, 192

illativsmodifikator, 57

illustrerende forhold, 411

imperativ, 210, 249, 250, 253, 254, 256

indefinitt pronomen, 289

indikativ, 210, 222

Indikativ, 239

indirekte setning, 95, 135

INDIREKTE TALE, 142

indre lokalkasus, 103, 192

INDRE TILSTAND, 132

inessiv, 192

infinitiv, 51

infinitivsfrase, 51, 258

infinitivsmodifikator, 57

infinitt verbform, 51, 209

Infinitt verbform, 210

instruktiv, 197

instrumentell adposisjon, 362

instrumentell adposisjonsfrase, 362

interjeksjon, 67, 68 
INTRANSITIV

EIERSKAPSENDRING, 5, 109

INTRANSITIVE ENDRING, 117

intransitivt sanseverb, 119

intransitivt verb, 95

I-stadium, 70

\section{J}

jamføringskonstruksjon, 370

junksjon, 50, 52, 383

junksjonssetning, 53

\section{K}

kausal subjunksjon, 393, 396

KAUSATIV FØLELSE, 60

kausativt følelsesverb, 121

kjerne, 50

kjernekonsonant, 44

kjernekonsonantkombinasjoner, 44

kjernesetning, 55

KOGNISJON, 136

kognitivt verb, 136

komitativ, 197, 198

komitativ adposisjon, 362

komitativ adposisjonsfrase, 363

kommentaradverb, 344

kommentaradverbial, 56

komparativ, 202

komparativfrase, 411, 412

kompleks setning, 93

kondisjonal subjunksjon, 393, 399

kondisjonalis, 210, 242, 243, 244, 246

kongruens, 65

konjunksjon, 53, 383

konnektiv, 56

konnektiv konjunksjon, 384, 387

konnektiv subjunksjon, 394, 401

konsessiv subjunksjon, 394

konsonant, 39

konsonantstamme, 48, 211, 213

kontrakt verb, 214

kontrastiv konjunksjon, 385, 391 korrelat, 58, 60, 273, 283

kort stavelse, 42

kort vokal, 166, 168, 169

kvantor, 51

kvantorfrase, 51, 53, 110, 313, 368

kvantorpronomen, 281, 289

kvantorsetning, 110

kvantorverb, 112

L

lang stavelse, 42

lang vokal, 172

laust adverb, 322, 343

leddsetning, 93

lokalkasus, 176

lokativ setning, 98

lukka klasse, 167

lyd, 39

lydveksling, 69

\section{M}

MEINING, 137, 157, 183, 189, 190

meiningsverb, 137

MENGDE, 111

mengdeadverb, 321, 336

mengdepronomen, 300

modalverb, 148

modifikator, 50, 55, 56

modifisert setning, 148

modus, 210

morfofonologisk veksling, 45, 69

måtesadposisjon, 362

måtesadverb, 321, 330

$\mathbf{N}$

NAVNGIVING, 144, 157, 190

navngivingsverb, 144

nektende, 233, 239, 244, 246, 256

nektende form, 228

nektingsform, 65, 228, 229

nektingspronomen, 281, 298

nektingsverb, 64, 228 
nomen, 51, 163, 169

nominativ, 177

nullverdig, 94

O

objekt, 53

objektsadverbial, 55

objektskasus, 124, 158

oon pakko, 197

OON PAKKO-setning, 152

ordenstall, 51, 52, 309, 314

ordklasse, 50

ordsamband, 383

overgangsstamme, 212

overgangsverb, 212

overordna setning, 93

oversetning, 93

\section{$\mathbf{P}$}

parord, 383

partialobjekt, 124

partisipp, 51

partisippfrase, 51

partitiv, 183

passiv, 209, 229, 237, 239, 243, 246, 253 ,

254, 256, 268

passivkonstruksjon, 59

passivstamme, 49, 216

perfektum partisipp, 236, 237, 265

person, 50, 209

personbøying, 217

personlig pronomen, 275

personsuffiks, 217

plosiv, 40

possessiv setning, 98

possessivsuffiks, 199

postmodifikator, 57

postposisjon, 347

predikasjonssetning, 112

predikativ, 53

PREDIKATIV SANS, 119, 132, 157, 195, 197

predikerende kasus, 176 prefiks, 47

premodifikator, 57

preposisjon, 347

presens, 210, 223, 243, 244, 246

presens partisipp, 265, 268, 269

presens perfektum, 210, 238, 239, 246

preteritum, 83, 210, 230, 233

preteritum perfektum, 210, 238, 239

preteritumsstamme, 83

proadjektiv, 273

proadverb, 273

pronomen, 50, 51, 163, 273

pro-ord, 273

påstedskasus, 103

\section{$\mathbf{R}$}

rammeadverbial, 56

refleksivt pronomen, 286

relativpronomen, 282

relativsetning, 282

relativt stedsadverb, 324

resiprokt pronomen, 286, 288

RESULTAT, 60, 118, 157, 158, 160, 192, 197

rotmorfem, 46

S

sammensatt tidsform, 210

sammensatt verbalform, 228

SANSEOBSERVASJON, 140, 404

SANSETILSTAND, 132, 195, 197

setning, 49, 93, 209

setningsfragment, 67

setningsledd, 50

setningsmodifikat, 57

sideordna setning, 93

simpleksord, 383

s-kasus, 192

spesialstadieveksling, 72

spørreadjektiv, 280

spørreadverb, 280

spørreenklitikon, 46

spørrepronomen, 280 
spørresetninger, 62

stadieveksling, 69

stamme, 48, 211

stammekonsonant, 49, 70

stammeveksling, 70

stammevokal, 49

STATUS, 134, 160

stavelsestrykk, 42

STED, 98, 129, 159, 160, 192, 195, 197, 262

stedsadposisjonsfrase, 349

stedsadverb, 52, 319, 321, 322

stedsproadverb, 322

stemt konsonant, 40, 80

STYRING, 143, 145

styringsverb, 145

subjekt, 53

subjunksjon, 53, 383

substantiv, 50, 51, 163

substantivfrase, 51, 53

substantivmodifikator, 57

suffiks, 46

superjunksjon, 383

superlativ, 203

\section{$\mathrm{T}$}

taleverb, 142

tall- og personkongruens, 66

tallord, 50, 51, 163, 309

ta-verb, 125

temporal subjunksjon, 393, 394

tid, 209, 210

tidsadposisjon, 356

tidsadverb, 52, 321, 327

TILHØRIGHET, 114, 157

tillatelse, 145

tilstandsadverb, 333

tilstandssetning, 129

tilstandsverb, 97

tilstedskasus, 102

tomt subjekt, 60

tostamma, 49, 164, 215 tostava, 166

totalobjekt, 124

toverdig, 94

TOVERDIG HANDLING, 122

TRANSITIV ENDRING, 124

TRANSITIVE EIERSKAPSENDRING, 125

transitivt sanseverb, 140

transitivt verb, 95

translativ, 189, 190

tredje infinitiv, 258, 261

tredje person entall, 217

tredje person flertall, 217

treverdig, 94

trykksterk stavelse, 42

trykksvak stavelse, 42

tulla tehtyksi-konstruksjon, 197

U

uavgrensa handling, 124

umarkert form, 222

universelt kvantorpronomen, 293

ustemt konsonant, 40

utfylling, 54, 94

V

valens, 94

varietet, 25

verb, 50, 211, 213

verbal, 49

verbfrase, 53

verbsamband, 152

verbtype, 211

vokal, 39

vokalstamme, 48, 166, 168, 169, 172, 211

VÆRTILSTAND, 129

værverb, 129

Y

ytre lokalkasus, 103, 195

YTRE TILSTAND, 131

åpen klasse, 167 
